\title{
Enantioselective Carboetherification/Hydrogenation for the Synthesis of Amino Alcohols via a Catalytically Formed Chiral Auxiliary
}

\author{
Luca Buzzetti, ${ }^{\ddagger}$ Mikus Puriňš, ${ }^{\ddagger}$ Phillip D. G. Greenwood, ${ }^{\ddagger}$ and Jerome Waser*
}

Cite This: J. Am. Chem. Soc. 2020, 142, 17334-17339

Read Online

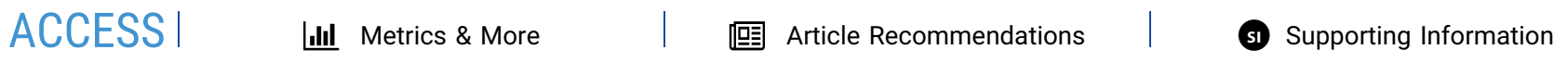

ABSTRACT: Chiral auxiliaries and asymmetric catalysis are the workhorses of enantioselective transformations, but they still remain limited in terms of either efficiency or generality. Herein, we present an alternative strategy for controlling the stereoselectivity of chemical reactions. Asymmetric catalysis is used to install a transient chiral auxiliary starting from achiral precursors, which then directs diastereoselective reactions. We apply this strategy to a palladium-catalyzed carboetherification/ hydrogenation sequence on propargylic amines, providing fast access to enantioenriched chiral amino alcohols, important building blocks for medicinal chemistry and drug discovery. All stereoisomers of the product could be accessed by the choice of ligand and substituent on the propargylic amine, leading to a stereodivergent process.

$\mathrm{C}$ urrently, most enantioselective transformations rely on two strategies: (i) the use of chiral auxiliaries ${ }^{1}$ and (ii) asymmetric catalysis. ${ }^{2}$ The former allows the development of general and robust processes, but requires stoichiometric amounts of enantiopure precursors and multistep procedures. By contrast, asymmetric catalysis relies only on substoichiometric amounts of enantiopure molecules, but it generally requires an intensive optimization at the expense of robustness and generality. To overcome these limitations, we envisioned a catalytic enantioselective method, which would introduce a chiral auxiliary on the substrate from a cheap nonchiral tether in a synthetic useful step (Scheme 1A). This process would require only a catalytic amount of enantiopure species while providing a robust platform for further diastereoselective functionalizations, benefiting from the best aspects of the two traditional strategies. To the best of our knowledge, such an approach has not yet been realized, although different methods for improving asymmetric synthesis have been developed. A seminal work based on the formation of chiral aminals is the "self-reproduction of chirality" reported by Seebach for the stereoselective synthesis of amino acids. In this work, the existing stereocenter on the amino acid first controls the diastereoselective formation of the aminal by condensation with an aldehyde. The latter then shields one face of the enolate. ${ }^{3,4}$ As another example based on an internal chirality transfer, Maulide and co-workers recently reported a redoxneutral coupling of alkenes and aldehydes via a "catch-release" tethering approach (Scheme 1B). ${ }^{5}$ However, the resulting functional group (a ketone) remains in the product. Other researchers have worked on the concept of "transient chiral auxiliaries/tethers", which are easy to install and remove. ${ }^{6-10}$ For example, Beauchemin and co-workers have used chiral aldehydes in substoichiometric amounts for the Cope-type hydroamination of allyl amines (Scheme 1C). ${ }^{11}$ However, the scope of these transformations remains limited, and auxiliaries available from the chiral pool are generally required.

To implement our concept, we considered the palladiumcatalyzed carboetherification of propargylic amines, ${ }^{12}$ based on the use of trifluoroacetaldehyde-derived tethers (Scheme 1D). ${ }^{13-15}$ The stereocenter formed in this step could direct a subsequent functionalization of the double bond, acting de facto as a chiral auxiliary. The rigid nature of the oxazolidine scaffold containing the stereocenter should secure a high level of diasteroselectivity to the following transformations.

Concerning the following diastereoselective functionalization, we found the hydrogenation of the formed double bond particularly attractive. By comparison, the enantioselective hydrogenation of alkyl- or heteroatom-tetrasubstituted olefins is highly challenging, with only few limited catalytic enantioselective systems reported. ${ }^{16-18}$ After removal of the tether molecule, this process would provide amino alcohols, key building blocks in synthetic and medicinal chemistry, which have been the focus of intensive methodology development recently. ${ }^{19-26}$ In particular, the diaryl-substituted amino alcohols obtained using this strategy can be found in antidepressants ${ }^{27,28}$ and have served as intermediates for the synthesis of antimycotic, antibacterials ${ }^{29}$ and antiviral molecules. ${ }^{30,31}$ However, the selective synthesis of one of the four possible stereoisomers of the amino alcohols generally requires multistep processes.

To make this process successful, an enantioselective carboetherification step had to be developed. The reversible

Received: September 1, 2020

Published: October 2, 2020 
Scheme 1. (A) Our Concept: Catalytically Formed Chiral Auxiliaries; (B) Chirality Transfer via Tethering; (C) Transient Chiral Auxiliaries Introduced from Chiral Pool; (D) Implementation for the Stereodivergent Synthesis of Amino Alcohols

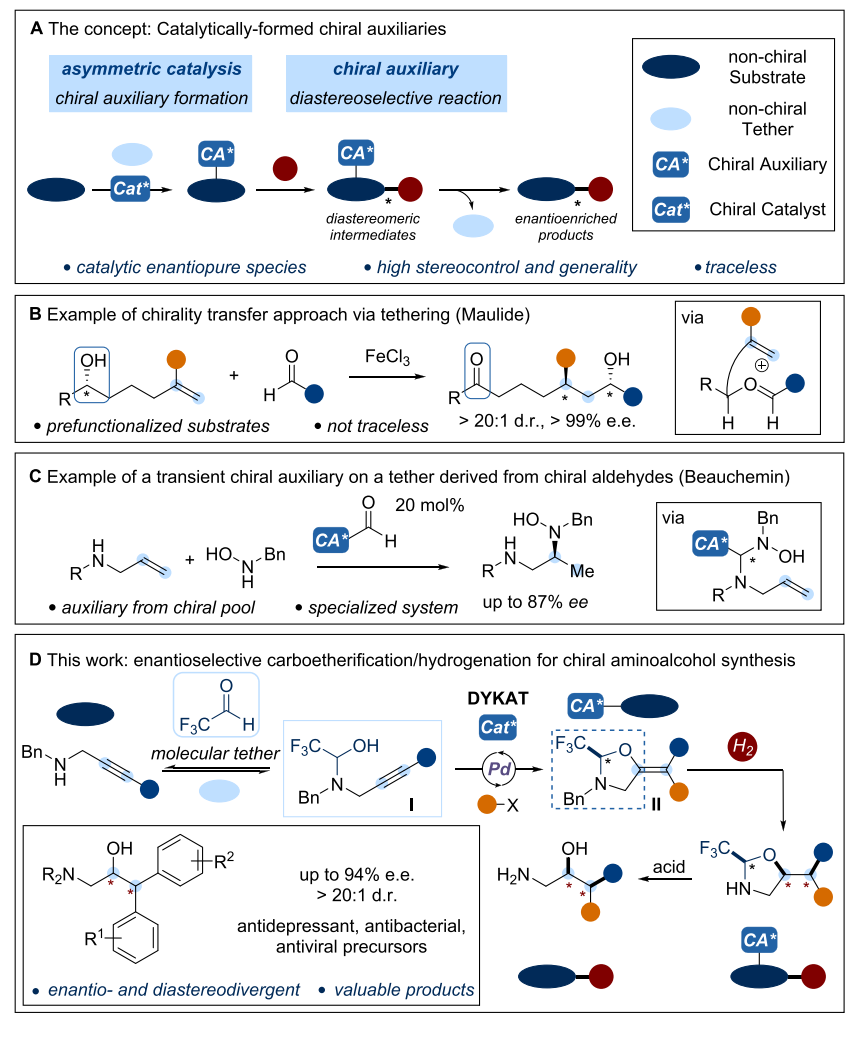

formation of the hemiaminal I from the propargylic amine prevents asymmetric induction at this stage (see Supporting Information (SI), section E for more details). Therefore, a dynamic kinetic asymmetric transformation (DYKAT) needs to take place: in the presence of a chiral catalyst, one enantiomer of I should react preferentially to give oxazolidine II enantioselectively. Although palladium-catalyzed DYKATs have been reported, ${ }^{32}$ the envisaged process is highly challenging, due to the large distance between the chiral metal complex and the stereocenter. To the best of our knowledge, such a DYKAT process has never been realized in the palladium-catalyzed functionalization of alkynes. If successful, the selection of the substitution pattern on the alkyne and on the aryl electrophile, together with the choice of the suitable enantiomer of the chiral ligand on the palladium catalyst would provide a simple enantio- and diastereodivergent access to all four stereoisomers of the amino alcohol. This is especially attractive for medicinal chemistry, as each stereoisomer may have different bioactivity, and the development of stereodivergent methods has been the topic of intensive research in asymmetric catalysis recently. ${ }^{33-35}$

We tested the feasibility of our plan by examining the palladium-catalyzed tethered carboetherification of the readily available propargylic amine $\mathbf{1}$ with iodotoluene $\mathbf{2}$ to access tetrasubstituted olefin $\mathbf{4}$ bearing a chiral oxazolidine fragment (Table 1). 1-Ethoxy trifluoroethanol 3, a commercially available ethyl hemiacetal of trifluoroacetaldehyde, was chosen as the electrophilic molecular tether, and $\mathrm{Pd}_{2}(\mathrm{dba})_{3} \cdot \mathrm{CHCl}_{3}$, as the palladium source. ${ }^{12}$ We first focused on the identification of a suitable ligand that could secure a high level of
Table 1. Optimization Studies

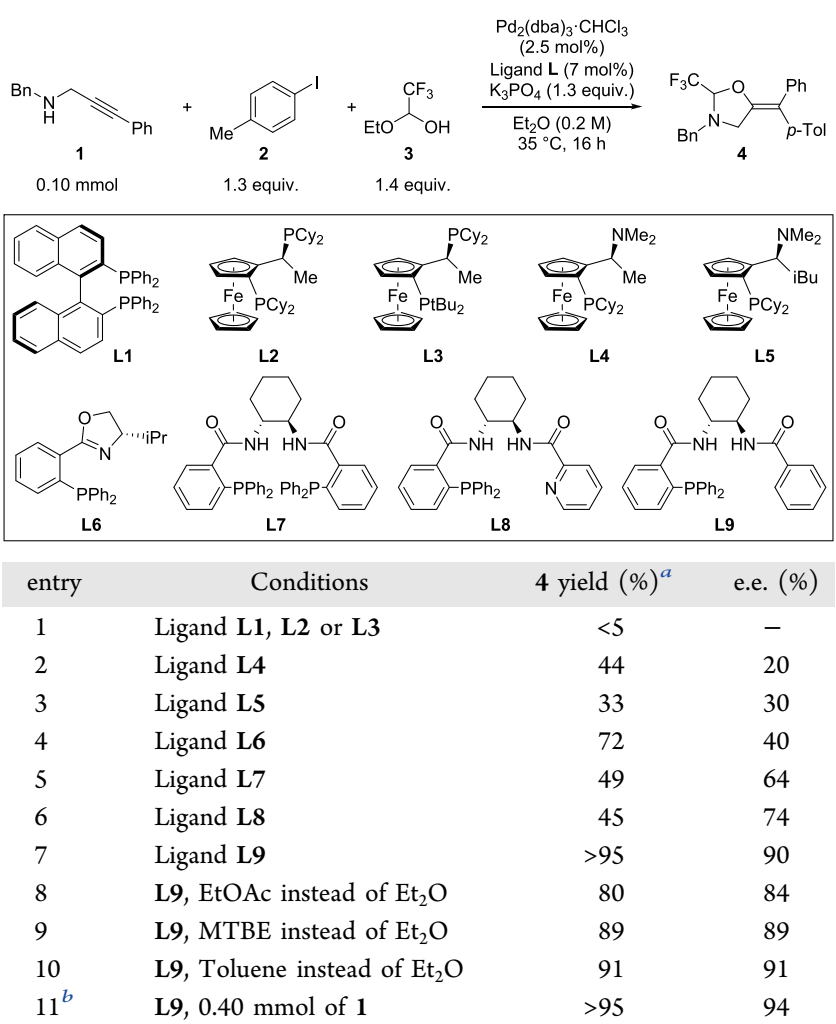

${ }^{a}$ NMR yields. ${ }^{b}$ Reaction performed using $1.25 \mathrm{~mol} \%$ of $\mathrm{Pd}_{2}(\mathrm{dba})_{3}$. $\mathrm{CHCl}_{3}$ and $3.5 \mathrm{~mol} \%$ of $(\mathrm{S}, \mathrm{S})$-ligand.

stereoinduction in the process (for details, see SI, section C). Commonly used bidentate BINAP L1 and Josiphos ligands L2 and L3 were not competent for this reaction (entry 1). The $\mathrm{P}, \mathrm{N}$ ligands L4 and L5, derived from the corresponding Ugi's amines, ${ }^{36}$ delivered 4 in moderate yield and enantiomeric excess (entries 2 and 3), nevertheless demonstrating that a DYKAT was possible. However, higher asymmetric induction could not be achieved with this class of ligands. The P,N ligand S-iPrPhox L6 yielded the desired product in $72 \%$ yield and $40 \%$ e.e. (entry 4). Promising results were obtained evaluating the Trost type ligands, commonly used for palladium catalyzed asymmetric allylation reactions. ${ }^{37,38}$ In particular, the commercially available DACH-phenyl Trost ligand L7 delivered product 4 in $49 \%$ yield and $64 \%$ e.e. (entry 5). Having in mind the previous positive results obtained with $\mathrm{P}, \mathrm{N}$ ligands, we substituted the 2-( $\left.\mathrm{PPh}_{2}\right)$-aryl fragment with a 2-pyridine. ${ }^{39}$ This change increased the e.e. to $74 \%$ (entry 6). Surprisingly, the best results were finally obtained employing the benzamide derived L9 lacking a second strongly coordinating site, which delivered quantitatively 4 with $90 \%$ e.e. (entry 7 ). To the best of our knowledge, ligand L9 has been reported only twice in the literature, ${ }^{40,41}$ and it was not suitable for imparting high stereocontrol, as two strong coordinating sites were required for asymmetric induction. We developed a robust and operationally simple route for accessing both enantiomers of L9 on multigram scale (SI, section B4). Demonstrating the process's robustness, the reaction could be performed in more "industrially preferred" solvents ${ }^{42}$ (ethyl acetate, methyl tertbutyl ether and toluene, entries 8,9 and 10), without loss of yield and enantioselectivity, except for ethyl acetate (entry 8 ). Finally, the reaction could be scaled up to a $0.40 \mathrm{mmol}$ scale, reducing the catalyst and ligand loading to 1.25 and $3.5 \mathrm{~mol} \%$, 
resulting in an improved stereoselectivity of $94 \%$ e.e. (entry $11)$.

The structure of 4, obtained by X-ray single-crystal analysis (Scheme 2A), shows that the trifluoromethyl group is

Scheme 2. (A) X-ray Crystal Structure of the Product 4; (B) Optimized Conditions for the Diastereoselective Hydrogenation
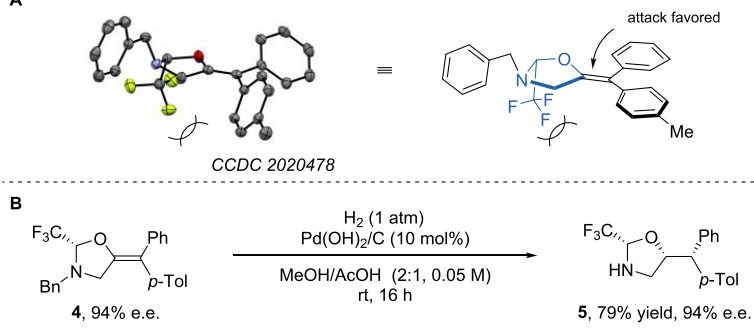

efficiently shielding one of the two enantiotopic faces of the olefin, setting the stage for the stereospecific hydrogenation. Indeed, when we submitted 4 to classical conditions for heterogeneous hydrogenation using Pearlman's catalyst, ${ }^{43}$ the desired hydrogenated product $\mathbf{5}$ was obtained as a single diastereoisomer in $79 \%$ yield and $94 \%$ e.e. (Scheme 2 B). The use of Pearlman's catalyst also allowed simultaneous removal of the benzyl protecting group.

Various aryl propargylic amines were well tolerated in the reaction, regardless of the position of the substituents on the phenyl ring, as well as their electronic and steric properties (Scheme 3, 4, 6-14). The geometry of the olefin can be switched by just exchanging the aryl group on the alkyne and the aryl iodide (4 vs 6 ). The reaction tolerates heterocycles such as pyridine and thiophene on the alkyne, although an erosion of the enantioselectivity was observed (15 and 16). Alkyl propargylic amines delivered products $17-19$ bearing a methyl, a benzyl, and a cyclopropyl group. The reaction could be performed on a $5 \mathrm{mmol}$ scale providing $2.0 \mathrm{~g}$ of 4 (quantitative yield) without erosion of the optical purity. The absolute configuration of the products were assigned by X-ray analysis of 4, confirming in addition that the aryl group coming from the iodide is incorporated in trans position to the oxygen.

The investigation of the scope of the iodoarene showed that numerous synthetically useful functional groups, including ethers, amines, halogens, esters, nitriles or aldehydes, are well tolerated independently from their electronic and steric properties or position on the benzene ring (20-30). 2Iodothiophene and 3-iodopyridine delivered products 31 and

\section{Scheme 3. Scope of the Enantioselective Carboetherification ${ }^{a}$}

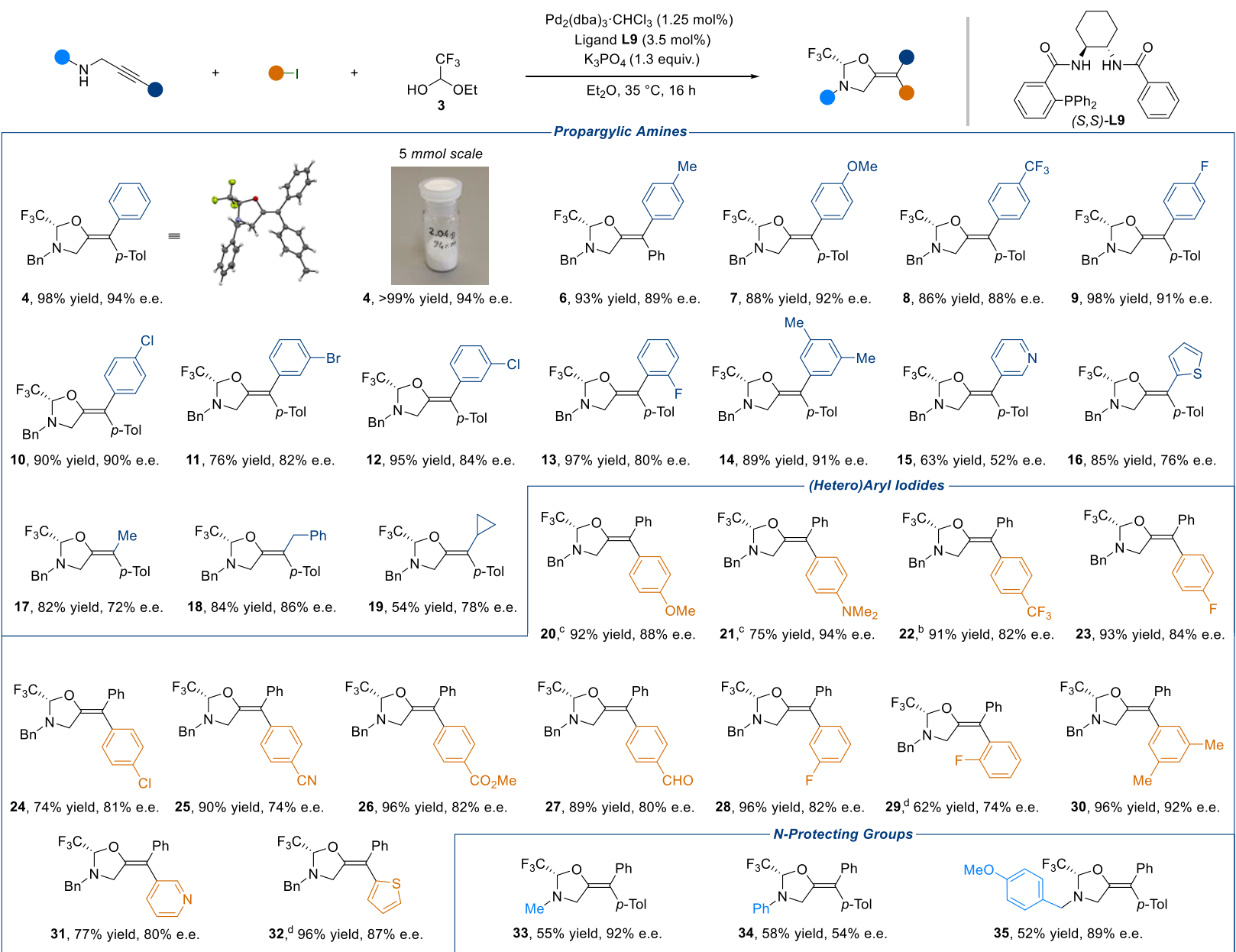

${ }^{a}$ Reactions performed on a $0.40 \mathrm{mmol}$ scale using 1.3 equiv of aryl iodide and 1.4 equiv of 1 -ethoxy trifluoroethanol (3). Isolated yields and HPLC enantiomeric excess are given. ${ }^{b}$ Dichloroethane (DCE) instead of $\mathrm{Et}_{2} \mathrm{O} .{ }^{c}$ Using $2.5 \mathrm{~mol} \%$ of $\mathrm{Pd}_{2}\left(\mathrm{dba}_{3} \cdot \mathrm{CHCl}_{3}\right.$ and $7 \mathrm{~mol} \%$ of ligand. ${ }^{d} \mathrm{DCE}$ at 60 ${ }^{\circ} \mathrm{C}$. 
Scheme 4. Scope of the Stereoselective Hydrogenation ${ }^{a}$

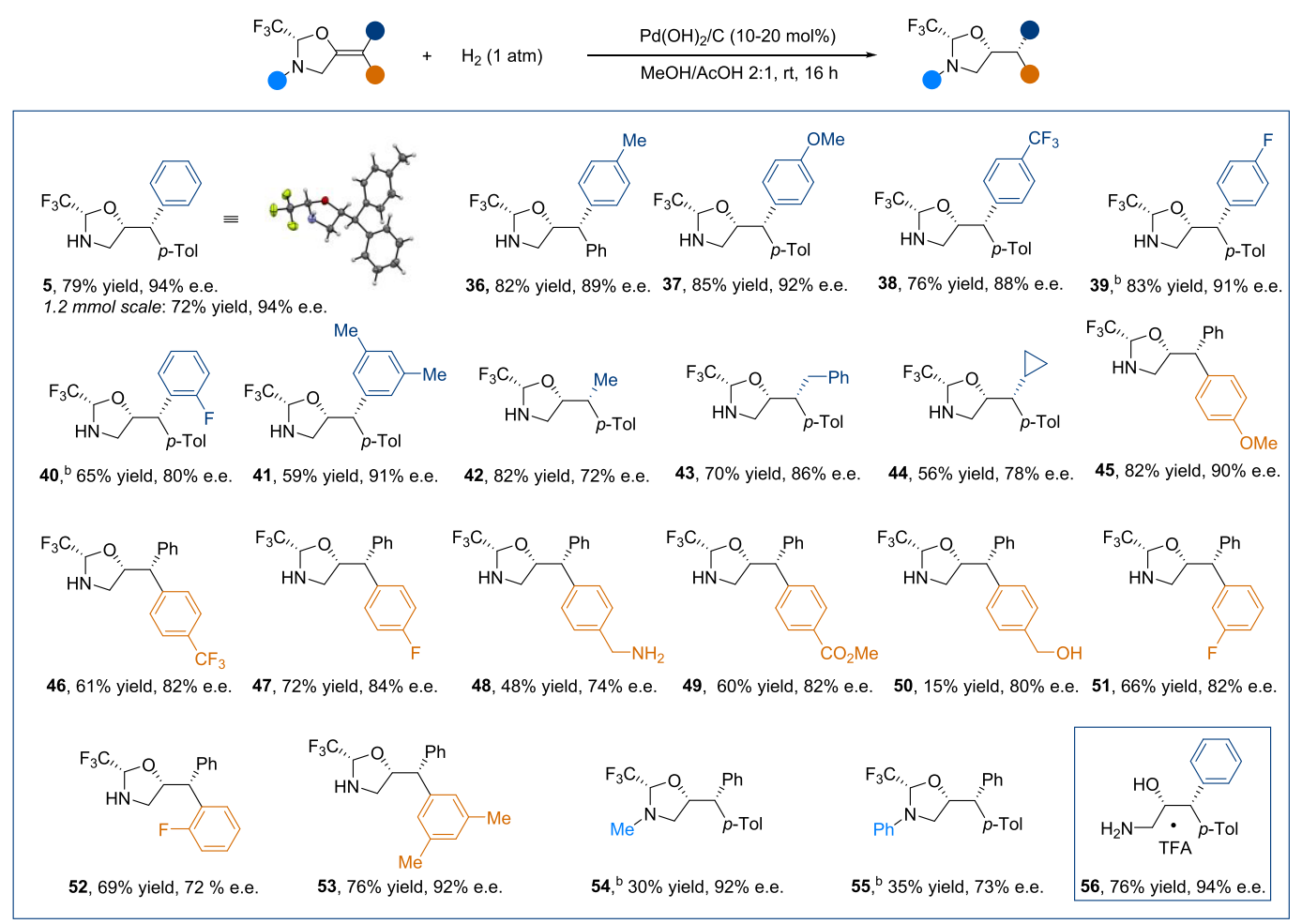

${ }^{a}$ Reactions performed on a $0.2 \mathrm{mmol}$ scale using $\mathrm{Pd}(\mathrm{OH})_{2} / \mathrm{C}(\sim 20 \mathrm{wt} \%)$. Isolated yields and HPLC enantiomeric excess are given. Product 56 was obtained after treating 5 with $\mathrm{TsOH} \cdot \mathrm{H}_{2} \mathrm{O}$ (7 equiv) in a $2: 1 \mathrm{THF} / \mathrm{H}_{2} \mathrm{O}$ mixture at room temperature for 16 h, the trifluoroacetate salt was obtained after purification by reversed phase preparative HPLC. ${ }^{b} \mathrm{Pd} / \mathrm{C}(\sim 5 \mathrm{wt} \%)$ was used instead of $\mathrm{Pd}(\mathrm{OH})_{2} / \mathrm{C}$.

32 in good yields. Finally, $N$-methyl, $N$-phenyl and $N$-paramethoxybenzyl (PMB) propargyl amines delivered products $33-35$ in $52-58 \%$ yield and $54-92 \%$ e.e.

The obtained enantioenriched tetrasubstituted olefins were then submitted to the optimized conditions for the diastereoselective hydrogenation (Scheme 4). Products 36$\mathbf{5 5}$ were all obtained as single diastereoisomers, confirming the robustness of our approach. Scale-up was straightforward and compound 5 could be obtained in $72 \%$ yield on $1.2 \mathrm{mmol}$ scale without erosion of stereoselectivity. Heterocycles and functional groups containing coordinating $\mathrm{N}$ or $\mathrm{S}$ atoms and chlorides were not tolerated in the hydrogenation step (for details, see SI, Section D5). The nitrile and the carbonyl group within 25 and 27 were reduced to the corresponding amine 48 and alcohol 50. ${ }^{44}$ Interestingly, 5, 36, 45, 46, 47 and 54 are precursors of bioactive compounds with antidepressive activity, ${ }^{27,28}$ while the amino alcohols derived from 36 and 47 are intermediates for the synthesis of patented antiviral drugs candidates. ${ }^{30}$ Remarkably, our method provides a high level of asymmetric induction even in the presence of sterically and electronically similar aryl substituents on the olefin, thus overcoming a common obstacle in the development of catalytic asymmetric reactions. Finally, to confirm the traceless nature of our strategy, we performed a mild acidic hydrolysis of the hemiaminal in 5. The enantioenriched amino alcohol 56 was obtained in $76 \%$ yield without loss in optical purity.

We then demonstrated that this strategy provides a simple stereodivergent access to the four possible stereoisomers of chiral diaryl aminoalcohols by a judicious selection of the substrates and the ligands (Scheme 5). Starting from the benzyl propargyl amine 57, a sequence of (i) Sonogashira coupling, (ii) enantioselective carboetherification and (iii)
Scheme 5. Diastereo- and Enantiodivergent Access to Chiral Aminoalcohol Precursors ${ }^{a}$

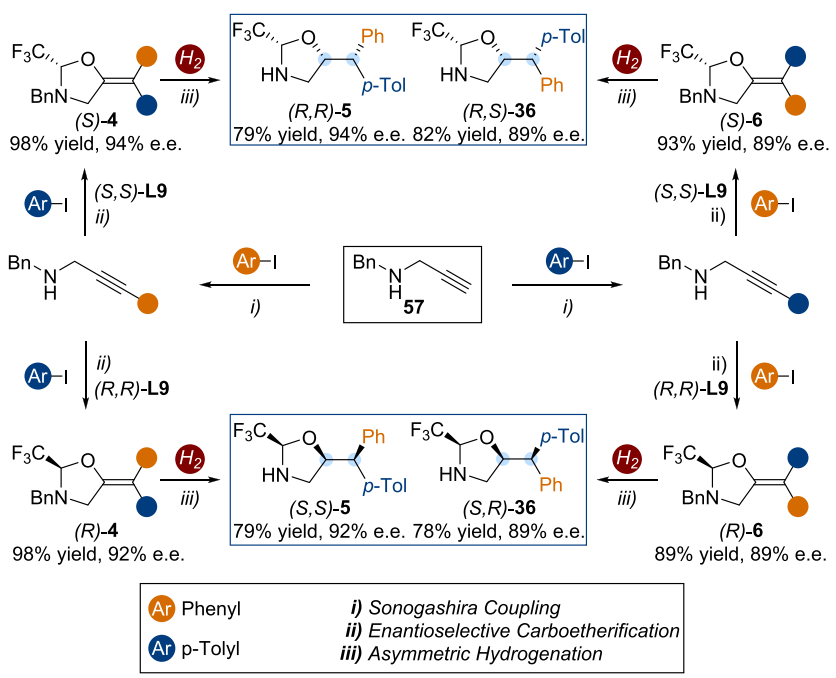

${ }^{a}$ See SI for detailed reaction conditions.

diastereoselective hydrogenation leads to all the stereoisomers of the desired products 5 and 36. Permuting the iodoarenes in the cross-coupling and in the carboetherification steps allows the tuning of the E,Z geometry of the double bond. This selective process, combined with the choice of the enantiomer of the ligand, and the diasteroselectivity of the hydrogenation provide a selective access to the four stereoisomers of the diaryl amino alcohol precursors. 
In summary, we have developed an innovative strategy to control the stereoselectivity of asymmetric transformations. ${ }^{45}$ Our approach first capitalizes on the tools of asymmetric catalysis to forge a chiral oxazolidine from broadly available propargylic amines. This stereogenic element is then used to control the selectivity of the asymmetric hydrogenation of the tetrasubstituted double bond, giving access to valuable chiral amino alcohol precursors. The key for success was the first use of a "truncated" monophosphine Trost-type ligand to induce high enantioselectivity in an unprecedented DYKAT process. Combined with a Sonogashira cross-coupling, our approach gives a stereodivergent access to the four stereoisomers of protected diaryl amino alcohols in high yield and enantioselectivity. New opportunities for the design and development of asymmetric functionalizations of olefins can be expected based on the combination of the enantioselective introduction of a transient chiral auxiliary followed by a diastereoselective transformation. Such processes are currently under investigation in our laboratory.

\section{ASSOCIATED CONTENT}

\section{SI Supporting Information}

The Supporting Information is available free of charge at https://pubs.acs.org/doi/10.1021/jacs.0c09177.

Experimental procedures and characterization data for starting materials, ligands and products; proposed reaction mechanism; copy of HPLC and NMR spectra (PDF)

Crystallographic data for the product 4 (CIF)

Crystallographic data for the product 5 (CIF)

\section{AUTHOR INFORMATION}

\section{Corresponding Author}

Jerome Waser - Laboratory of Catalysis and Organic Synthesis, Ecole Polytechnique Féderale de Lausanne, EPFL, 1015 Lausanne, Switzerland; ○ orcid.org/0000-0002-4570-914X; Email: jerome.waser@epfl.ch

\section{Authors}

Luca Buzzetti - Laboratory of Catalysis and Organic Synthesis, Ecole Polytechnique Féderale de Lausanne, EPFL, 1015 Lausanne, Switzerland

Mikus Puriňš - Laboratory of Catalysis and Organic Synthesis, Ecole Polytechnique Federale de Lausanne, EPFL, 1015 Lausanne, Switzerland

Phillip D. G. Greenwood - Laboratory of Catalysis and Organic Synthesis, Ecole Polytechnique Féderale de Lausanne, EPFL, 1015 Lausanne, Switzerland

Complete contact information is available at: https://pubs.acs.org/10.1021/jacs.0c09177

\section{Author Contributions \\ ${ }^{\ddagger}$ L.B., M.P., and P.D.G.G. contributed equally. \\ Notes}

The authors declare no competing financial interest. Crystallographic data for the product 4 and 5 have been deposited at the Cambridge Crystallographic Data Centre, accession numbers CCDC 2020478 and 2020479, respectively. Raw HPLC, NMR, MS and IR data is available at https:// doi.org/ 10.5281/zenodo.4046256.

\section{ACKNOWLEDGMENTS}

This work is supported by the European Research Council (ERC Consolidator Grant SeleCHEM, No. 771170 and EPFL. We thank Dr. R. Scopelliti from ISIC at EPFL for X-ray analysis. This publication was created as part of NCCR Catalysis, a National Centre of Competence in Research funded by the Swiss National Science Foundation.

\section{ABBREVIATIONS}

Me, Methyl; Bu, Butyl; Pr, Propyl; Cy, Cyclohexyl; Ph, Phenyl; Bn, Benzyl; $p$-Tol, $p$-Tolyl; EtOAc, Ethyl acetate; MTBE, Methyl tertbutyl ether; $\mathrm{Et}_{2} \mathrm{O}$, Diethyl ether; $\mathrm{MeOH}$, Methanol; $\mathrm{AcOH}$, Acetic acid; dba, Dibenzylideneacetone.

\section{REFERENCES}

(1) Gnas, Y.; Glorius, F. Chiral Auxiliaries - Principles and Recent Applications. Synthesis 2006, 2006, 1899-1930.

(2) Noyori, R. Asymmetric Catalysis: Science and Opportunities (Nobel Lecture). Angew. Chem., Int. Ed. 2002, 41, 2008-2022.

(3) Seebach, D.; Boes, M.; Naef, R.; Schweizer, W. B. Alkylation of Amino Acids without Loss of the Optical Activity: Preparation of $\alpha$ Substituted Proline Derivatives. A case of Self-Reproduction of Chirality. J. Am. Chem. Soc. 1983, 105, 5390-5398.

(4) Polt, R.; Seebach, D. Stereoselective Alkylation of Glycine Units in Dipeptide Derivatives: "Chirality Transfer" via a Pivalaldehyde N,N-Acetal Center. J. Am. Chem. Soc. 1989, 111, 2622-2632.

(5) Li, J.; Preinfalk, A.; Maulide, N. Enantioselective Redox-Neutral Coupling of Aldehydes and Alkenes by an Iron-Catalyzed "CatchRelease” Tethering Approach. J. Am. Chem. Soc. 2019, 141, 143-147.

(6) Zhang, F. L.; Hong, K.; Li, T. J.; Park, H.; Yu, J. Q. Functionalization Of $\mathrm{C}(\mathrm{Sp}(3))-\mathrm{H}$ Bonds Using a Transient Directing Group. Science 2016, 351, 252-256.

(7) Xiao, L. J.; Hong, K.; Luo, F.; Hu, L.; Ewing, W. R.; Yeung, K. S.; $\mathrm{Yu}, \mathrm{J}$. Q. Pd-II-Catalyzed Enantioselective C(sp(3))-H Arylation of Cyclobutyl Ketones Using a Chiral Transient Directing Group. Angew. Chem., Int. Ed. 2020, 59, 9594-9600.

(8) Yao, Q. J.; Zhang, S.; Zhan, B. B.; Shi, B. F. Atroposelective Synthesis of Axially Chiral Biaryls by Palladium-Catalyzed Asymmetric C-H Olefination Enabled by a Transient Chiral Auxiliary. Angew. Chem., Int. Ed. 2017, 56, 6617-6621.

(9) Dhawa, U.; Tian, C.; Wdowik, T.; Oliveira, J. C. A.; Hao, J. P.; Ackermann, L. Enantioselective Pallada-Electrocatalyzed C-H Activation by Transient Directing Groups: Expedient Access to Helicenes. Angew. Chem., Int. Ed. 2020, 59, 13451-13457.

(10) Oxtoby, L. J.; Li, Z. Q.; Tran, V.; Erbay, T. G.; Deng, R. H.; Liu, P.; Engle, K. M. A Transient-Directing-Group Strategy Enables Enantioselective Reductive Heck Hydroarylation of Alkenes. Angew. Chem., Int. Ed. 2020, 59, 8885-8890.

(11) MacDonald, M. J.; Schipper, D. J.; Ng, P. J.; Moran, J.; Beauchemin, A. M. A. Catalytic Tethering Strategy: Simple Aldehydes Catalyze Intermolecular Alkene Hydroaminations. J. Am. Chem. Soc. 2011, 133, 20100-20103.

(12) Greenwood, P. D. G.; Grenet, E.; Waser, J. Palladium-Catalyzed Carbo-Oxygenation of Propargylic Amines using in Situ Tether Formation. Chem. - Eur. J. 2019, 25, 3010-3013.

(13) Orcel, U.; Waser, J. Palladium-Catalyzed Vicinal Amino Alcohols Synthesis from Allyl Amines by In Situ Tether Formation and Carboetherification. Angew. Chem., Int. Ed. 2015, 54, 5250-5254.

(14) Orcel, U.; Waser, J. One-Pot Three-Component Synthesis of Vicinal Diamines via In Situ Aminal Formation and Carboamination. Angew. Chem., Int. Ed. 2016, 55, 12881-12885.

(15) Muriel, B.; Orcel, U.; Waser, J. Palladium-Catalyzed Carboamination of Allylic Alcohols Using a TrifluoroacetaldehydeDerived Tether. Org. Lett. 2017, 19, 3548-3551.

(16) Schrems, M. G.; Neumann, E.; Pfaltz, A. Iridium-Catalyzed Asymmetric Hydrogenation of Unfunctionalized Tetrasubstituted Olefins. Angew. Chem., Int. Ed. 2007, 46, 8274-8276. 
(17) Bigler, R.; Mack, K. A.; Shen, J.; Tosatti, P.; Han, C.; Bachmann, S.; Zhang, H. M.; Scalone, M.; Pfaltz, A.; Denmark, S. E.; Hildbrand, S.; Gosselin, F. Asymmetric Hydrogenation of Unfunctionalized Tetrasubstituted Acyclic Olefins. Angew. Chem., Int. Ed. 2020, 59, 2844-2849.

(18) Biosca, M.; Magre, M.; Pàmies, O.; Diéguez, M. Asymmetric Hydrogenation of Disubstituted, Trisubstituted, and Tetrasubstituted Minimally Functionalized Olefins and Cyclic $\beta$-Enamides with Easily Accessible Ir-P,Oxazoline Catalysts. ACS Catal. 2018, 8, 1031610320.

(19) Bergmeier, S. C. The synthesis of vicinal amino alcohols. Tetrahedron 2000, 56, 2561-2576.

(20) Donohoe, T. J.; Callens, C. K. A.; Flores, A.; Lacy, A. R.; Rathi, A. H. Recent Developments in Methodology for the Direct Oxyamination of Olefins. Chem. - Eur. J. 2011, 17, 58-76.

(21) Kurandina, D.; Yadagiri, D.; Rivas, M.; Kavun, A.; Chuentragool, P.; Hayama, K.; Gevorgyan, V. Transition-Metal- and Light-Free Directed Amination of Remote Unactivated C(sp3)-H Bonds of Alcohols. J. Am. Chem. Soc. 2019, 141, 8104-8109.

(22) Wu, F.; Alom, N.-E.; Ariyarathna, J. P.; Naß, J.; Li, W. Regioselective Formal [3+2] Cycloadditions of Urea Substrates with Activated and Unactivated Olefins for Intermolecular Olefin Aminooxygenation. Angew. Chem., Int. Ed. 2019, 58, 11676-11680.

(23) Yang, H.; Zheng, W.-H. Chiral-Organotin-Catalyzed Kinetic Resolution of Vicinal Amino Alcohols. Angew. Chem., Int. Ed. 2019, $58,16177-16180$.

(24) Li, X.; Hall, D. G. Stereodivergent Asymmetric Synthesis of $\alpha, \beta$-Disubstituted $\beta$-Aminoalkylboronic Acid Derivatives via GroupSelective Protodeboronation Enabling Access to the Elusive Anti Isomer. J. Am. Chem. Soc. 2020, 142, 9063-9069.

(25) Schwarz, J. L.; Kleinmans, R.; Paulisch, T. O.; Glorius, F. 1,2Amino Alcohols via $\mathrm{Cr} /$ Photoredox Dual-Catalyzed Addition of $\alpha$ Amino Carbanion Equivalents to Carbonyls. J. Am. Chem. Soc. 2020, $142,2168-2174$.

(26) Nakafuku, K. M.; Zhang, Z.; Wappes, E. A.; Stateman, L. M.; Chen, A. D.; Nagib, D. A. Enantioselective Radical C-H Amination for the Synthesis Of $\beta$-Amino Alcohols. Nat. Chem. 2020, 12, 697704.

(27) Clark, J. A.; Hadley, M. S. Diphenylpropylamines. G.B. Patent No. 1,448,437, 1973.

(28) Clark, J. A.; Clark, M. S. G.; Gardner, D. V.; Gaster, L. M.; Hadley, M. S.; Miller, D.; Shah, A. Substituted 3-Amino-1,1-Diaryl-2Propanols as Potential Antidepressant Agents. J. Med. Chem. 1979, 22, 1373-1379.

(29) Prucher, H.; Uhl, J.; Kurmeier, H. A.; Rudolph, V.; Wahlig, H., Basic Thioethers. U.S. Patent No 4,285,961, 1981.

(30) Jain, R.; Koester, D. C.; Manning, J. R.; Sutton, J. C.; Taft, B. R.; Wan, L.; Zhao, Q. Tricyclic Compounds Useful to Treat Orthomyxovirus Infections. U.S. Patent Application No 16/083,089, 2019.

(31) Hilpert, H.; Kreis, L.; Lerner, C.; Humm, R.; Muser, T.; Kuhn, B., Pyrimidone Derivatives and Their Use in the Treatment, Amelioration or Prevention of a Viral Disease. U.S. Patent No 9,988,390, 2018.

(32) Trost, B. M.; Bunt, R. C.; Lemoine, R. C.; Calkins, T. L. Dynamic kinetic asymmetric transformation of diene monoepoxides: A practical asymmetric synthesis of vinylglycinol, vigabatrin, and ethambutol. J. Am. Chem. Soc. 2000, 122, 5968-5976.

(33) Krautwald, S.; Sarlah, D.; Schafroth, M. A.; Carreira, E. M. Enantio- and Diastereodivergent Dual Catalysis: $\alpha$-Allylation of Branched Aldehydes. Science 2013, 340, 1065-1068.

(34) Lin, L.; Feng, X. Catalytic Strategies for Diastereodivergent Synthesis. Chem. - Eur. J. 2017, 23, 6464-6482.

(35) Kaldre, D.; Klose, I.; Maulide, N. Stereodivergent Synthesis of 1,4-Dicarbonyls by Traceless Charge-Accelerated Sulfonium Rearrangement. Science 2018, 361, 664-667.

(36) Oost, R.; Rong, J.; Minnaard, A. J.; Harutyunyan, S. R. Synthesis of New Derivatives of Copper Complexes of Josiphos
Family Ligands for Applications in Asymmetric Catalysis. Catal. Sci. Technol. 2014, 4, 1997-2005.

(37) Trost, B. M.; Crawley, M. L. Asymmetric transition-metalcatalyzed allylic alkylations: Applications in total synthesis. Chem. Rev. 2003, 103, 2921-2943.

(38) Trost, B. M.; Machacek, M. R.; Aponick, A. Predicting the Stereochemistry of Diphenylphosphino Benzoic Acid (DPPBA)Based Palladium-Catalyzed Asymmetric Allylic Alkylation Reactions: A Working Model. Acc. Chem. Res. 2006, 39, 747-760.

(39) Trost, B. M.; Oslob, J. D. Asymmetric Synthesis of (-)-Anatoxin-a via an Asymmetric Cyclization Using a New Ligand for Pd-Catalyzed Alkylations. J. Am. Chem. Soc. 1999, 121, 30573064.

(40) Trost, B. M.; Breit, B.; Organ, M. G. On the Nature of the Asymmetric Induction in a Palladium Catalyzed Allylic Alkylation. Tetrahedron Lett. 1994, 35, 5817-5820.

(41) Huang, D. S.; Liu, X. Q.; Li, L. J.; Cai, Y. D.; Liu, W. G.; Shi, Y. Enantioselective Bromoaminocyclization of Allyl N-Tosylcarbamates Catalyzed by a Chiral Phosphine-Sc(OTf) ${ }_{3}$ Complex. J. Am. Chem. Soc. 2013, 135, 8101-8104.

(42) Prat, D.; Wells, A.; Hayler, J.; Sneddon, H.; McElroy, C. R.; Abou-Shehada, S.; Dunn, P. J. CHEM21 selection guide of classicaland less classical-solvents. Green Chem. 2016, 18, 288-296.

(43) Pearlman's Catalyst. Comprehensive Organic Name Reactions and Reagents; John Wiley \& Sons, Inc.: 2010. DOI: 10.1002/ 9780470638859.conrr483.

(44) Product 55 was obtained with higher e.e. compared to its precursor 34. The reasons for this surprising result are unclear at this stage. As $\mathbf{3 4}$ was not fully soluble under these conditions, a plausible explanation would be a lower solubility of the racemate salt, leading to a chiral resolution during hydrogenation.

(45) A previous version of this work appeared in a preprint: Buzzetti, L.; Purins, M.; Greenwood, P. D. G.; Waser, J. Enantioselective Carboetherification/Hydrogenation for the Synthesis of Amino Alcohols via a Catalytically-Formed Chiral Auxiliary ChemRxiv, August 25, 2020, ver. 1, DOI: 10.26434/chemrxiv.12855218.v1. 


\title{
"Enantioselective Carboetherification/Hydrogenation for the Synthesis of Amino Alcohols via a Catalytically- Formed Chiral Auxiliary"
}

\author{
Luca Buzzetti $^{1 \dagger}$, Mikus Purins ${ }^{1 \dagger}$, Phillip D. G. Greenwood ${ }^{1 \dagger} \&$ Jerome Waser $^{1 *}$
}

1 Laboratory of Catalysis and Organic Synthesis, Ecole Polytechnique Fédérale de Lausanne, EPFL, SB ISIC LCSO, BCH 1402, 1015 Lausanne (Switzerland)

$†$ These authors contributed equally to this work.

*Correspondence to: jerome.waser@epfl.ch

Raw HPLC, NMR, MS and IR data is available at https://doi.org/ 10.5281/zenodo.4046256 . 


\section{Table of Contents}

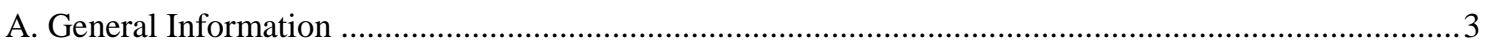

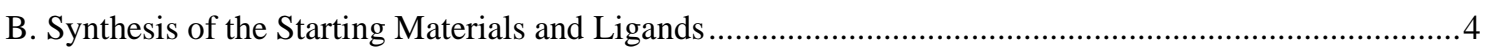

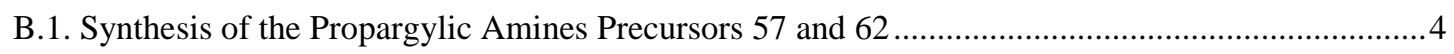

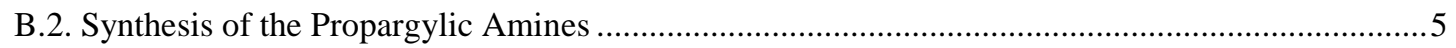

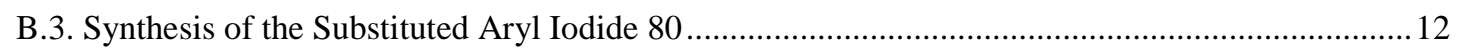

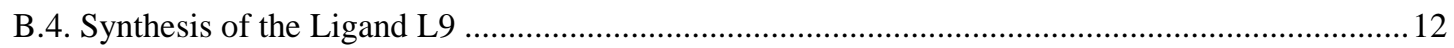

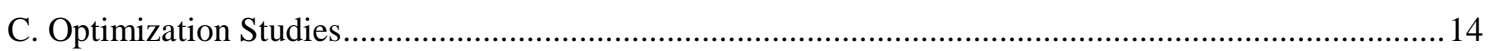

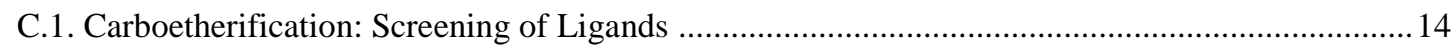

C.2. Carboetherification: Screening of Solvents and Temperatures ......................................................16

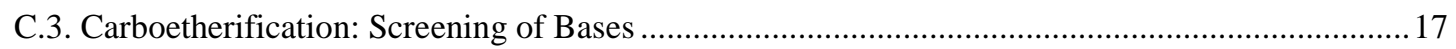

C.4. Carboetherification: Screening of Palladium Sources...............................................................17

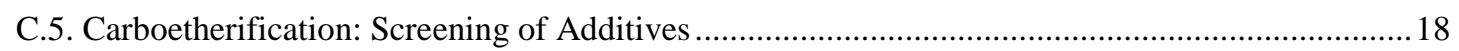

C.5. Asymmetric Hydrogenation: Optimization Studies .................................................................18

D. Stereoselective Carboetherification of Propargylic Amines ........................................................ 19

D.1. General Procedure for the Enantioselective Carboetherification of Propargylic Amines ................19

D.2. Characterization of Products of the Enantioselevtive Carboetherification .....................................19

D.3. General Procedure for the Asymmetric Hydrogenation of the Tetrasubstituted Olefins. ................33

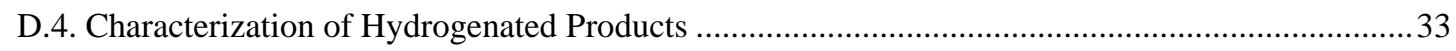

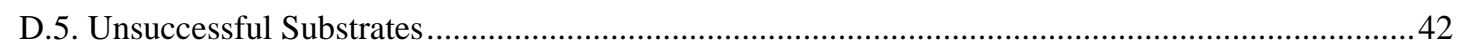

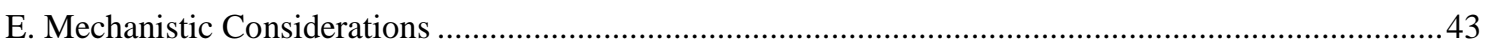

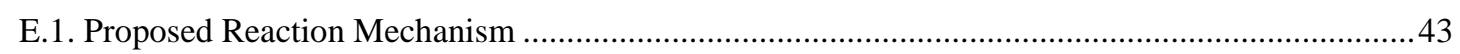

E.2. NMR analysis of the equilibrium between Propargyl Amine 1, Tether 3 and hemiaminal I .........44

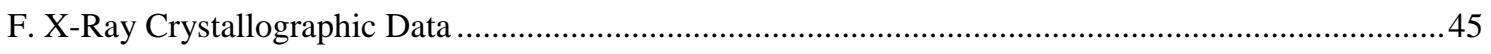

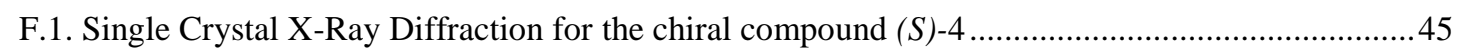

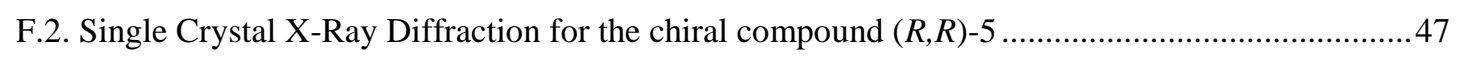

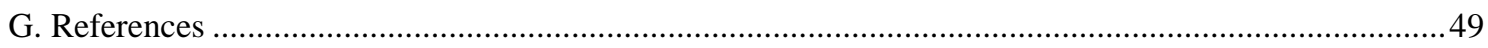

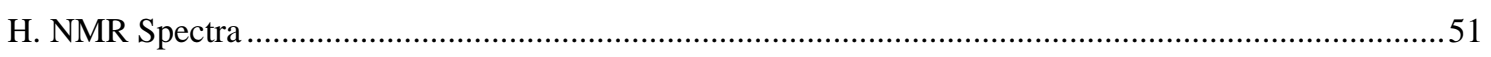

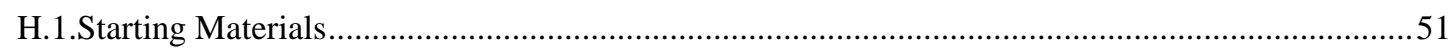

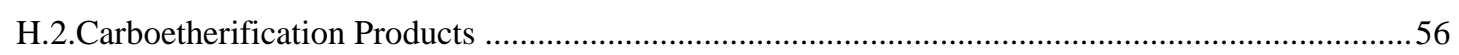

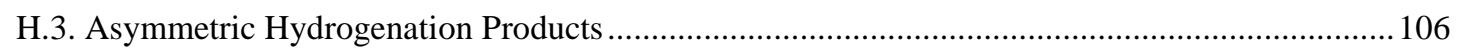

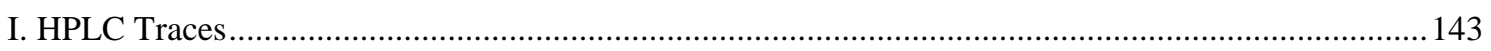

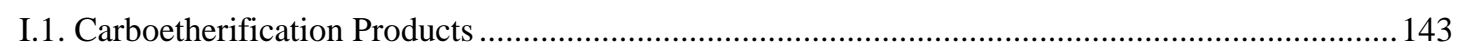

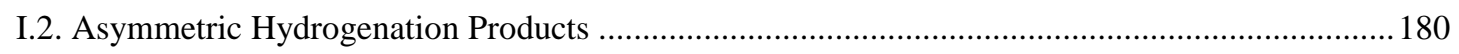




\section{A. General Information}

The NMR spectra were recorded on a Brucker DPX-400 spectrometer at $400 \mathrm{MHz}$ for ${ }^{1} \mathrm{H}, 101 \mathrm{MHz}$ for ${ }^{13} \mathrm{C}, 376 \mathrm{MHz}$ for ${ }^{19} \mathrm{~F}$ and $162 \mathrm{MHz}$ for ${ }^{31} \mathrm{P}$. The chemical shift $(\delta)$ for ${ }^{1} \mathrm{H}$ and ${ }^{13} \mathrm{C}$ are given in ppm relative to residual signals of the solvents (chloroform- $-7.26 \mathrm{ppm}{ }^{1} \mathrm{H}$ NMR and $77.16 \mathrm{ppm}{ }^{13} \mathrm{C}$ NMR; methanold4 $3.31 \mathrm{ppm}{ }^{1} \mathrm{H}$ NMR and $49.0 \mathrm{ppm}{ }^{13} \mathrm{C}$ NMR; dmso-d6 $2.50 \mathrm{ppm}{ }^{1} \mathrm{H}$ NMR and $39.52 \mathrm{ppm}{ }^{13} \mathrm{C}$ NMR). Carbon spectra have been measured using broadband $\left\{{ }^{1} \mathrm{H}\right\}$ decoupling. Coupling constants are given in Hertz. The following abbreviations are used to indicate the multiplicity: s, singlet; d, doublet; q, quartet; m, multiplet; bs, broad signal; app, apparent. Infrared spectra were recorded on a JASCO FT-IR B4100 spectrophotometer with an ATR PRO410-S and a ZnSe prisma and are reported as $\mathrm{cm}^{-1}(\mathrm{w}=$ weak, $\mathrm{m}=$ medium, $\mathrm{s}=$ strong, $\mathrm{br}=$ broad). High resolution mass spectrometric measurements were performed by the mass spectrometry service of ISIC at the EPFL on a MICROMASS (ESI) Q-TOF Ultima API. The raw data obtained from the Q-TOF Waters instrument does not take into account the mass of the electron for the ion, the obtained raw data has been therefore corrected by removing the mass of the electron $(5 \mathrm{mDa})$. The diffraction data for crystal structures were collected by mass spectrometry service of ISIC at the EPFL at low temperature using $\mathrm{Cu}$ (323) or Mo (520) $K_{\text {a }}$ radiation on a Rigaku SuperNova dual system in combination with Atlas type CCD detector. The data reduction and correction were carried out by CrysAlis $^{\text {Pro }}$ (Rigaku Oxford Diffraction, release 1.171.40.68a, 2019). The solutions and refinements were performed by $S H E L X T^{1}$ and $S H E L X L^{2}$, respectively. The crystal structures were refined using full-matrix least-squares based on $F^{2}$ with all non-H atoms defined in anisotropic manner. Hydrogen atoms were placed in calculated positions by means of the "riding" model. Yields of isolated products refer to materials of $>95 \%$ purity as determined by ${ }^{1} \mathrm{H}$ NMR.

The authors are indebted to the team of the research support service of ISIC at EPFL, particularly to the NMR, X-Ray, and the High Resolution Mass Spectrometry Units.

General Procedures. All reactions were set up under a nitrogen atmosphere in oven-dried glassware using standard Schlenk techniques, unless otherwise stated. Synthesis grade solvents were used as purchased; anhydrous solvents (THF, $\mathrm{Et}_{2} \mathrm{O}$, Toluene and DCM) were taken from a commercial SPS solvent dispenser $\left(\mathrm{H}_{2} \mathrm{O}\right.$ content $<10 \mathrm{ppm}$, Karl-Fischer titration). Chromatographic purification of products was accomplished using flash chromatography (FC) on SiliaFlash P60 silica gel (230 - $400 \mathrm{mesh}$ ). For thin layer chromatography (TLC) analysis throughout this work, Pre-coated TLC sheets ALUGRAM ${ }^{\circledR}$ Xtra SIL $\mathrm{G} / \mathrm{UV}_{254}$ were employed, using UV light as the visualizing agent and basic aqueous potassium permanganate $\left(\mathrm{KMnO}_{4}\right)$ stain solutions, and heat as developing agents. Organic solutions were concentrated under reduced pressure on a Büchi rotatory evaporator.

Determination of Enantiomeric Purity: HPLC analysis on chiral stationary phase was performed on a Agilent Acquity instrument using a Daicel CHIRALPAK IA, IB-N5 and IC chiral columns. The exact conditions for the analyses are specified within the characterization section. HPLC traces were compared to racemic samples prepared by running the reactions using racemic ligands. Absolute values of enantiomeric excesses are reported.

Materials. Most of the starting materials used in this study are commercial and were purchased in the highest purity available from Sigma-Aldrich, Fluka, Alfa Aesar, Fluorochem, Enamine and used as received, without further purifications. Tris(dibenzylideneacetone)dipalladium was purchased from Fluorochem and recrystalised in $200 \mathrm{mg}$ portions following a reported procedure. ${ }^{3} \mathrm{Pd}(\mathrm{OH})_{2} / \mathrm{C}$ was purchased from Fluka (humid, Assay: 20\% (Pd), Analysis Number: 320400/1 1192). Pd/C was purchased from Sigma-Aldrich ( 5 wt. \% Pd (dry basis), matrix activated charcoal, wet support. Degussa type E105CA/W, Lot\#MKBJ9424V). Deactivated silica gel was prepared by making a slurry of silica gel (230$400 \mathrm{mesh}$ ) with $5 \% \mathrm{Et}_{3} \mathrm{~N}$ in pentane solution followed by complete removal of solvent by rotary evaporation until obtaining a free flowing powder. The synthesis of 1, 63-65, 68, 71 and 73-78 has already been described by our group. The procedures are taken from the indicated publication ${ }^{4}$ for clarity and to facilitate the reproduction of the results. 


\section{B. Synthesis of the Starting Materials and Ligands}

\section{B.1. Synthesis of the Propargylic Amines Precursors 57 and 62}

$N$-Benzylprop-2-yn-1-amine (57)

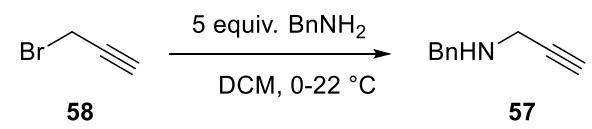

Scheme 1. Synthesis of Benzyl Propargyl amine 57.

To a flame-dried $250 \mathrm{~mL}$ two-necked round-bottom flask, benzylamine (55 mL, $0.50 \mathrm{~mol}, 5.0$ equiv.) and DCM $(60 \mathrm{~mL})$ were added. The mixture was cooled to $0{ }^{\circ} \mathrm{C}$. Then, via an addition funnel, propargyl bromide ( $80 \mathrm{wt} \%$ solution in toluene, $10.8 \mathrm{~mL}, 100 \mathrm{mmol}, 1.0$ equiv.) in DCM (40 mL) was added dropwise over 1 hour. The reaction mixture was allowed to reach room temperature and stirred for $5 \mathrm{~h}$. The reaction mixture was filtered through a plug of silica and concentrated in vacuo to approx. 100 mbar. The mixture was distilled under reduced pressure to give the $N$-benzylprop-2-yn-1-amine $\mathbf{5 7}$ as a colorless oil (7.3 g, $50 \mathrm{mmol}, \sim 90 \%$ purity according to ${ }^{1} \mathrm{H} \mathrm{NMR}\left(\mathrm{T}=50-55^{\circ} \mathrm{C}, 0.35 \mathrm{mbar}\right)$.

${ }^{1} \mathrm{H}$ NMR $(400 \mathrm{MHz}$, Chloroform-d) $\delta 7.41-7.31(\mathrm{~m}, 4 \mathrm{H}, \mathrm{ArH}), 7.31-7.24(\mathrm{~m}, 1 \mathrm{H}, \mathrm{ArH}), 3.90(\mathrm{~s}, 2 \mathrm{H}$, $\left.\mathrm{PhCH}_{2}\right), 3.44\left(\mathrm{~d}, J=2.4 \mathrm{~Hz}, 2 \mathrm{H}, \mathrm{CH}_{2} \mathrm{C} \equiv \mathrm{CH}\right), 2.28(\mathrm{t}, J=2.4 \mathrm{~Hz}, 1 \mathrm{H}, \mathrm{C} \equiv \mathrm{CH}), 1.49(\mathrm{~s}, 1 \mathrm{H}, \mathrm{NH})$.

${ }^{13} \mathrm{C}\left\{{ }^{1} \mathrm{H}\right\}$ NMR $(101 \mathrm{MHz}$, Chloroform- $d$ ) $\delta 139.5,128.52,128.49,127.2,82.2,71.6,52.4,37.4$.

Spectral data were consistent with the values reported in literature. ${ }^{5}$

$N$-Benzyl propynyl trifluoroacetamide (62)

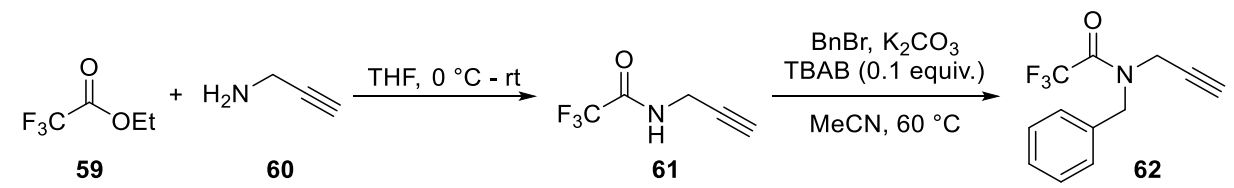

Scheme 2. Synthesis of compound 62.

Following a modified version of a reported procedure. ${ }^{6}$ In a flame dried round-bottom flask, to a solution of ethyl trifluoroacetate $(8.0 \mathrm{~g}, 56 \mathrm{mmol}, 1.2$ equiv. $)$ in THF $(12 \mathrm{~mL})$ at $0{ }^{\circ} \mathrm{C}$ was slowly added propargyl amine $\left(2.6 \mathrm{~g}, 47 \mathrm{mmol}, 1\right.$ equiv.). The reaction mixture was stirred at $0{ }^{\circ} \mathrm{C}$ for 10 minutes; it was then allowed to reach room temperature and stirred for a further 7 hours. The solvent was removed by rotary evaporation and the product was isolated by distillation $\left(90{ }^{\circ} \mathrm{C}\right.$ at 17 mbar $)$ to afford propynyl trifluoroacetamide $\mathbf{6 1}$ as a colourless oil $(5.5 \mathrm{~g}, 37 \mathrm{mmol}, 78 \%$ yield $)$.

${ }^{1} \mathrm{H}$ NMR $(400 \mathrm{MHz}$, Chloroform- $d$ ) $\delta 6.94$ (br. s., $1 \mathrm{H}, \mathrm{NH}), 4.14$ (dd, $J=6.0,2.5 \mathrm{~Hz}, 2 \mathrm{H}, \mathrm{CH}_{2} \mathrm{C} \equiv \mathrm{C}$, ) 2.32 $(\mathrm{q}, J=2.2 \mathrm{~Hz}, 1 \mathrm{H}, \mathrm{C} \equiv \mathrm{CH})$.

${ }^{13} \mathrm{C} \mathrm{NMR}(101 \mathrm{MHz}$, Chloroform- $d$ ) $\delta 157.0$ (q, $J=38.1 \mathrm{~Hz}), 115.5$ (q, $\left.J=287.5 \mathrm{~Hz}\right), 77.0,73.1,29.6$.

${ }^{19} \mathrm{~F}$ NMR (376 MHz, Chloroform- $d$ ) $\delta$-76.3.

Spectra data was consistent with the values reported in literature. ${ }^{6}$

To a mixture of $\mathrm{K}_{2} \mathrm{CO}_{3}$ (8.2 g, 59 mmol, 2 equiv.) and TBAB (0.95 g, 3.0 mmol, 0.1 equiv.) in MeCN (150 $\mathrm{mL}$ ) was added propynyl trifluoroacetamide 61 (4.5 g, $30 \mathrm{mmol}, 1$ equiv.) and benzyl bromide (6.0 g, 33 mmol, 1.1 equiv.) and the reaction mixture was stirred at $60{ }^{\circ} \mathrm{C}$. After 3 hours (progress determined by TLC $\left(\mathrm{SiO}_{2}, 20 \%\right.$ EtOAc in pentane $\left.)\right)$, the mixture was filtered through a plug of Celite, which was washed with $\mathrm{Et}_{2} \mathrm{O}$. The resulting filtrate was concentrated by rotary evaporation. Purification of the crude product by column chromatography $\left(\mathrm{SiO}_{2}, 0-8 \%\right.$ EtOAc in pentane) afforded $\mathrm{N}$-Benzyl propynyl trifluoroacetamide (62) as a colourless oil (5.0 g, $21 \mathrm{mmol}, 71 \%$ yield)

${ }^{1} \mathrm{H}$ NMR $(400 \mathrm{MHz}$, Chloroform- $d ; 1: 1.2$ mixture of rotamers) $\delta 7.46-7.23(\mathrm{~m}, 10 \mathrm{H}, \mathrm{ArH}), 4.79(\mathrm{~s}, 2 \mathrm{H}$, $\left.\mathrm{CH}_{2} \mathrm{Ar}\right), 4.77\left(\mathrm{~s}, 2 \mathrm{H}, \mathrm{CH}_{2} \mathrm{Ar}\right), 4.12\left(\mathrm{~d}, \mathrm{~J}=2.5 \mathrm{~Hz}, 2 \mathrm{H}, \mathrm{CH}_{2} \mathrm{C} \equiv \mathrm{C}\right), 4.06\left(\mathrm{~d}, J=2.4 \mathrm{~Hz}, 2 \mathrm{H}, \mathrm{CH} \mathrm{C}_{2} \mathrm{C}\right), 2.37$ $(\mathrm{t}, J=2.4 \mathrm{~Hz}, 1 \mathrm{H}, \mathrm{C} \equiv \mathrm{CH}), 2.29(\mathrm{t}, J=2.5 \mathrm{~Hz}, 1 \mathrm{H}, \mathrm{C} \equiv \mathrm{CH})$.

${ }^{13} \mathrm{C}\left\{{ }^{1} \mathrm{H}\right\}$ NMR $(101 \mathrm{MHz}$, Chloroform- $d ; 1: 1.2$ mixture of rotamers) $\delta 156.7$ (q, $J=36.5 \mathrm{~Hz}, 2 \times \mathrm{C}=\mathrm{O})$, 134.5, 133.8, 129.1, 129.0, 128.6, 128.6, 128.3, 127.7, 116.4 (q, $J=287.9 \mathrm{~Hz}), 116.3(\mathrm{q}, J=288.1 \mathrm{~Hz})$, 76.6 (overlapping with solvent), 76.5, 73.7, 73.3, 49.7 (q, $J=3.6 \mathrm{~Hz}$ ), 48.7, 35.8 (q, $J=4.2 \mathrm{~Hz}$ ), 34.4.

${ }^{19} \mathrm{~F}$ NMR $(376 \mathrm{MHz}$, Chloroform- $d ; 1: 1.2$ mixture of rotamers) $\delta-68.5,-69.3$.

HRMS (LTQ-Orbitrap) m/z: $[\mathrm{M}+\mathrm{H}]^{+}$Calculated for $\mathrm{C}_{12} \mathrm{H}_{11} \mathrm{~F}_{3} \mathrm{NO}^{+}$242.0787; Found 242.0783. 


\section{B.2. Synthesis of the Propargylic Amines}

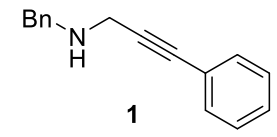

Procedure B2.A<smiles>FC(F)(F)c1ccc(C#CCNCc2ccccc2)cc1</smiles>

Procedure B2.A<smiles>O=S(=O)(C#CCNCc1ccccc1)c1cccc(Br)c1</smiles>

Procedure B2.B<smiles>Cc1cc(C)cc(C#CCNCc2ccccc2)c1</smiles>

Procedure B2.B<smiles>CC#CCNCc1ccccc1</smiles>

Procedure B2.D

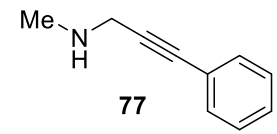

Procedure B2.C<smiles>O=[N+]([O-])c1ccc(C#CCNc2ccccc2)cc1</smiles>

Procedure B2.A<smiles>Fc1ccc(C#CCNCc2ccccc2)cc1</smiles>

Procedure B2.A<smiles>Clc1cccc(C#CCNCc2ccccc2)c1</smiles>

Procedure B2.A<smiles>[X]c1cccnc1</smiles>

Procedure B2.A<smiles>C(C#CCc1ccccc1)#CCc1ccccc1</smiles>

Procedure B2.C

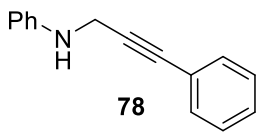

Procedure B2.C<smiles>COc1ccc(C#CCNCc2ccccc2)cc1</smiles>

Procedure B2.A<smiles>Clc1ccc(C#CCNCc2ccccc2)cc1</smiles>

Procedure B2.A<smiles>Fc1ccccc1C#CCNCc1ccccc1</smiles>

Procedure B2.A<smiles>C(#Cc1cccs1)CNCc1ccccc1</smiles>

Procedure B2.B<smiles>C(C#CC1CC1)#CCNCc1ccccc1</smiles>

Procedure B2.C<smiles>CCCCCCC#Cc1ccccc1</smiles>

Procedure B2.C

Scheme 3. The propargylic amines synthesized according to the general procedures reported.

\section{General Procedure B2.A}

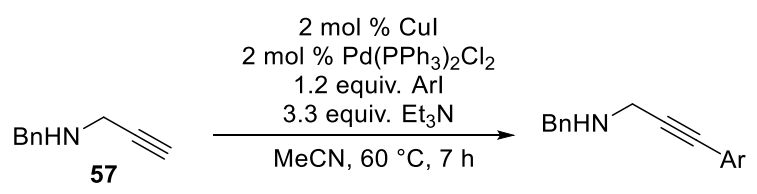

Scheme 4. General Procedure B2.A.

To a flame-dried $100 \mathrm{~mL}$ round bottom flask equipped with a Teflon-coated magnetic stirring bar, $\mathrm{Pd}\left(\mathrm{PPh}_{3}\right)_{2} \mathrm{Cl}_{2}$ (42 mg, $\left.60 \mu \mathrm{mol}, 2 \mathrm{~mol} \%\right)$, CuI (11 mg, $\left.60 \mu \mathrm{mol}, 2 \mathrm{~mol} \%\right), \mathrm{Et}_{3} \mathrm{~N}$ (0.90 g, $1.2 \mathrm{~mL}, 9.0 \mathrm{mmol}$, 3.3 equiv.) and degassed (by bubbling dry $\mathrm{N}_{2}$ for 10 minutes) $\mathrm{MeCN}$ (30 mL) were added. Then, the iodoarene (1.1 equiv.) was added and the mixture was heated to $60{ }^{\circ} \mathrm{C}$ and stirred for 5 minutes. Benzyl propargyl amine 57 (0.39 g, $2.7 \mathrm{mmol}, 1.0$ equiv.) was added and the reaction mixture was stirred for 7 hours at $60{ }^{\circ} \mathrm{C}$. Then, the reaction mixture was cooled down to ambient temperature and concentrated in vacuo. The resulting crude was dissolved in EtOAc $(20 \mathrm{~mL})$, then washed with water $(20 \mathrm{~mL})$ and brine $(20 \mathrm{~mL})$. The organic layer was dried over $\mathrm{Na}_{2} \mathrm{SO}_{4}$, filtered, and concentrated in vacuo. The crude was purified with Biotage flash chromatography system using Buchi FlashPure cartridge with EcoFlex silica $(10 \%-40 \%$ EtOAc in pentane). 


\section{General Procedure B2.B}

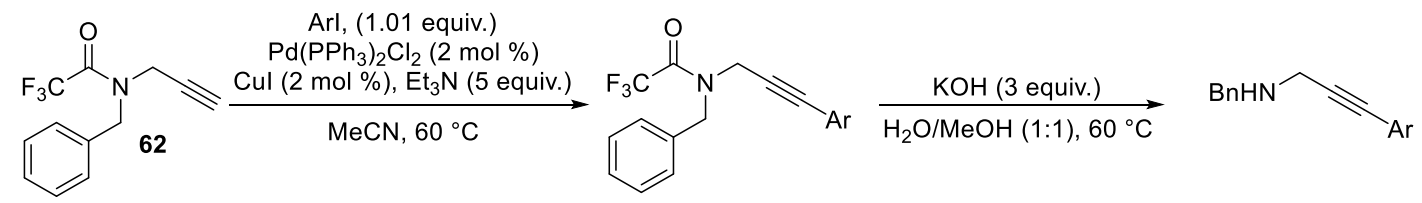

Scheme 5. General Procedure B2.B.

Following a modified version of a reported procedure. ${ }^{7}$ To a solution of $\mathbf{6 2}(0.80 \mathrm{~g}, 3.3 \mathrm{mmol}, 1$ equiv.), ArI (1.01 equiv.) and $\mathrm{Et}_{3} \mathrm{~N}\left(2.3 \mathrm{~mL}, 17 \mathrm{mmol}, 5\right.$ equiv.) in acetonitrile $(30 \mathrm{~mL})$ was added $\mathrm{PdCl}_{2}\left(\mathrm{PPh}_{3}\right)_{2}$ (47 mg, $0.066 \mathrm{mmol}, 2 \mathrm{~mol} \%)$ and $\mathrm{CuI}(13 \mathrm{mg}, 0.066 \mathrm{mmol}, 2 \mathrm{~mol} \%)$ in a single portion. The resulting mixture was stirred for 7 hours at $60{ }^{\circ} \mathrm{C}$. Water $(20 \mathrm{~mL})$ was then added and the reaction mixture extracted with EtOAc $(3 \times 30 \mathrm{~mL})$; the combined organic layers were dried over $\mathrm{MgSO}_{4}$, filtered and concentrated by rotary evaporation. The crude material was purified by flash column chromatography $\left(\mathrm{SiO}_{2}, 0-5 \%\right.$ EtOAc in pentane).

Hydrolysis: following an adapted version of a reported procedure. ${ }^{8}$ To the trifluoroacetamide obtained from the previous step (1 equiv.) was added a solution of $\mathrm{KOH}$ (3.0 equiv.) in water $(15 \mathrm{~mL})$ and methanol (15 $\mathrm{mL}$ ) and the resulting mixture was stirred at $60{ }^{\circ} \mathrm{C}$ for 3 hours. The reaction was then cooled to room temperature and acidified with aq. $\mathrm{HCl}(1.0 \mathrm{M} ; 5 \mathrm{~mL})$ followed by basification with sat. aq. $\mathrm{NaHCO}_{3}(\mathrm{pH}$ >7). The resulting mixture was extracted with $\mathrm{DCM}(3 \times 10 \mathrm{~mL})$, dried over $\mathrm{MgSO}_{4}$, filtered and concentrated by rotary evaporation. The crude material was purified by flash column chromatography $\left(\mathrm{SiO}_{2}, 10-30 \%\right.$ EtOAc in pentane $)$.

\section{General Procedure B2.C}

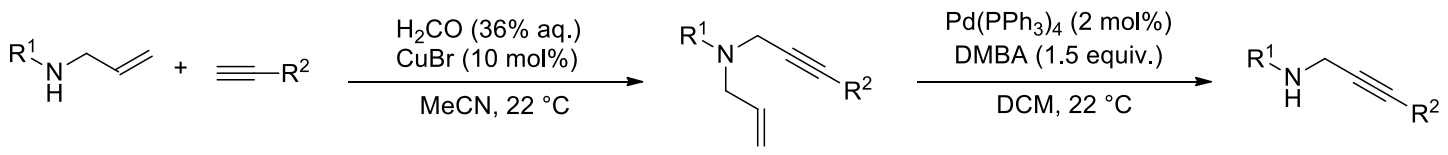

Scheme 6. General Procedure B2.C.

Following an adapted version of a reported procedure. ${ }^{9} \mathrm{To}$ a solution of $\mathrm{CuBr}(0.20 \mathrm{~g}, 1.4 \mathrm{mmol}, 13 \mathrm{~mol} \%)$ in $\mathrm{MeCN}(\mathrm{c}=0.15 \mathrm{M})$ was added allyl amine (1.3 equiv.), formaldehyde ( 3 equiv.) and alkyne (1 equiv.). The reaction mixture was stirred at room temperature for 16 hours after which it was concentrated by rotary evaporation. The residue was diluted with $\mathrm{Et}_{2} \mathrm{O}(20 \mathrm{~mL})$ and washed with aq. $\mathrm{NaOH}$ solution $(5.0 \mathrm{M} ; 3 \mathrm{x}$ $10 \mathrm{~mL}$ ), dried over $\mathrm{MgSO}_{4}$, filtered and concentrated by rotary evaporation. The crude material was purified by flash column chromatography $\left(\mathrm{SiO}_{2}, 0-2 \%\right.$ EtOAc in pentane).

Deallylation: The tertiary amine obtained from the previous step (1 equiv.) was added to a solution of $\mathrm{Pd}\left(\mathrm{PPh}_{3}\right)_{4}(2 \mathrm{~mol} \%)$ and 1,3-dimethylbarbituric acid (1.5 equiv.) in DCM $(\mathrm{c}=0.18 \mathrm{M})$ under an $\mathrm{N}_{2}$ atmosphere. The reaction mixture was stirred at room temperature for 16 hours. The reaction mixture was concentrated to a quarter of its original volume and diluted with ether $(40 \mathrm{~mL})$ and washed with sat. $\mathrm{NaHCO}_{3}(3 \times 15 \mathrm{~mL})$. The organic layer was extracted with aq. $\mathrm{HCl}(1.0 \mathrm{M} ; 3 \times 15 \mathrm{~mL})$ after which the combined aqueous layers and any precipitated solids were basified with $\mathrm{K}_{2} \mathrm{CO}_{3}(\mathrm{pH}>7)$ and extracted with DCM $(3 \times 25 \mathrm{~mL})$. The combined extracts were dried over $\mathrm{MgSO}_{4}$, filtered and concentrated by rotary evaporation. The crude material was purified by flash column chromatography $\left(\mathrm{SiO}_{2}, 20-50 \%\right.$ EtOAc in pentane). 


\section{Procedure B2.D for the Synthesis of 74}

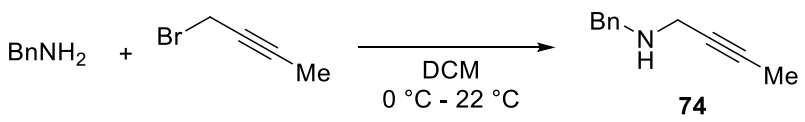

Scheme 7. General Procedure B2.D for the synthesis of $\mathbf{7 4 .}$

A solution of benzyl amine (4-6 equiv.) in DCM $(15 \mathrm{~mL})$ at $0{ }^{\circ} \mathrm{C}$ was stirred vigorously while a solution of bromo-2-butyne $(2.5 \mathrm{~mL}, 27 \mathrm{mmol}, 1$ equiv. $)$ in DCM $(15 \mathrm{~mL})$ was slowly added. The reaction mixture was then warmed to room temperature and stirred for 5 hours. It was then filtered through silica gel, eluting with $40 \%$ EtOAc in pentane and the resulting solution concentrated. Purification was performed by column chromatography $\left(\mathrm{SiO}_{2}, 10-40 \%\right.$ EtOAc in pentane) to afford benzyl butynylamine $\mathbf{7 1}$ as a straw yellow oil $\left(3.4 \mathrm{~g}, 21 \mathrm{mmol}, 74 \%\right.$ yield). Further purification could be achieved by Kugelrohr distillation $\left(86{ }^{\circ} \mathrm{C}\right.$ at $5 \times 10^{-1}$ mbar).

${ }^{1} \mathrm{H}$ NMR (400 MHz, Chloroform- $d$ ) $\delta 7.39-7.21$ (m, 5H, ArH), $3.86\left(\mathrm{~s}, 2 \mathrm{H}, \mathrm{ArCH}_{2}\right), 3.38(\mathrm{q}, J=2.4 \mathrm{~Hz}$,

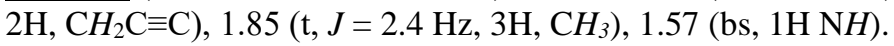

${ }^{13} \mathrm{C}$ NMR $(101 \mathrm{MHz}$, Chloroform- $d$ ) $\delta 139.7,128.4,128.3,127.0,79.1,77.1,52.5,37.8,3.5$.

Spectral data was consistent with the values reported in literature. ${ }^{9}$

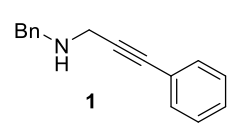

\section{$N$-Benzyl-3-phenylprop-2-yn-1-amine (1)}

Prepared following an up-scaled general procedure B2.A using $N$-benzylprop-2-yn-1amine 57 (2.20 g, $13.5 \mathrm{mmol}, 1.0$ equiv.), iodobenzene (3.1 g, $1.7 \mathrm{~mL}, 15 \mathrm{mmol}, 1.1$ equiv.), $\mathrm{Et}_{3} \mathrm{~N}$ (4.5 g, $6.3 \mathrm{~mL}, 45 \mathrm{mmol}, 3.3$ equiv.), $\mathrm{Pd}\left(\mathrm{PPh}_{3}\right)_{2} \mathrm{Cl}_{2}(211 \mathrm{mg}, 300 \mu \mathrm{mol}, 2 \mathrm{~mol} \%)$ and $\mathrm{CuI}(57$ $\mathrm{mg}, 300 \mu \mathrm{mol}, 2 \mathrm{~mol} \%)$. Purification was performed by Biotage flash column chromatography system with a $120 \mathrm{~g}$ cartridge $\left(\mathrm{SiO}_{2}, 10-40 \%\right.$ EtOAc in pentane) to afford $N$-benzyl-3-phenylprop-2-yn-1-amine (1) as an orange oil $(2.5 \mathrm{~g}, 11 \mathrm{mmol}, 75 \%$ yield $)$.

${ }^{1} \mathrm{H}$ NMR $\left(400 \mathrm{MHz}\right.$, Chloroform-d) $\delta 7.52-7.20(\mathrm{~m}, 9 \mathrm{H}, \mathrm{ArH}), 3.96\left(\mathrm{~s}, 2 \mathrm{H}, \mathrm{PhCH}\right.$ ), $3.66\left(\mathrm{~s}, 2 \mathrm{H}, \mathrm{CH}_{2} \mathrm{C} \equiv \mathrm{C}\right)$, 1.73 (br. s, $1 \mathrm{H}, \mathrm{NH}$ ).

${ }^{13} \mathrm{C}\left\{{ }^{1} \mathrm{H}\right\}$ NMR $(101 \mathrm{MHz}$, Chloroform- $d) \delta 139.5,131.7,128.5(2 \mathrm{C}), 128.3,128.1,127.2,123.2,87.5,83.8$, $52.5,38.3$

Spectral data were consistent with the values reported in literature. ${ }^{9}$

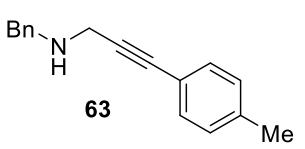

\section{$N$-Benzyl-3-(p-tolyl)prop-2-yn-1-amine (63)}

Prepared following general procedure B2.A using $p$-tolyliodobenzene $(667 \mathrm{mg}$, $3.06 \mathrm{mmol}, 1.1$ equiv.). Purification was performed by Biotage flash column chromatography system with a $25 \mathrm{~g}$ cartridge $\left(\mathrm{SiO}_{2}, 10-40 \%\right.$ EtOAc in pentane) to afford $N$-benzyl-3-(p-tolyl)prop-2-yn-1amine (63) as an orange oil (512 $\mathrm{mg}, 2.13 \mathrm{mmol}$, 79\% yield).

${ }^{1} \mathrm{H}$ NMR $(400 \mathrm{MHz}$, Chloroform-d) $\delta 7.41-7.29(\mathrm{~m}, 6 \mathrm{H}, \mathrm{ArH}), 7.29-7.22(\mathrm{~m}, 1 \mathrm{H}, \mathrm{ArH}), 7.12(\mathrm{~d}, J=7.9$ $\mathrm{Hz}, 2 \mathrm{H}, \mathrm{ArH}$ ), 3.95 (s, 2H, $\mathrm{PhCH}_{2}$ ), 3.65 (s, 2H, CH $\left.\mathrm{C}_{2} \mathrm{C}-\mathrm{C} \equiv \mathrm{C}\right), 2.35$ (s, 3H), 1.68 (br. s., 1H, NH)

${ }^{13} \mathrm{C}\left\{{ }^{1} \mathrm{H}\right\} \mathrm{NMR}\left(101 \mathrm{MHz}, \mathrm{CDCl}_{3}\right) \delta 139.7,138.3,131.7,129.2,128.62,128.59,127.3,120.3,86.7,84.0$, 52.6, 38.4, 21.6.

Spectral data were consistent with the values reported in literature. ${ }^{9}$

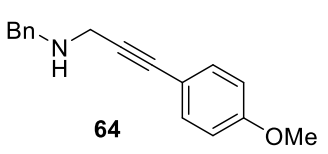

\section{$N$-Benzyl-3-(4-methoxyphenyl)prop-2-yn-1-amine (64)}

Prepared following modified general procedure B2.A using $\mathrm{Pd}\left(\mathrm{PPh}_{3}\right)_{2} \mathrm{Cl}_{2}(90 \mathrm{mg}$, $0.13 \mathrm{mmol}, 5 \mathrm{~mol} \%)$, dppf ( $86 \mathrm{mg}, 0.16 \mathrm{mmol}, 6 \mathrm{~mol} \%), \mathrm{CuI}$ (25 mg, $0.13 \mathrm{mmol}$, $5 \mathrm{~mol} \%)$, DABCO (0.76 g, $6.8 \mathrm{mmol}, 2.6$ equiv.) and 4 -iodo-anisole $(0.79 \mathrm{~g}, 6.4$ mmol, $1.3 \mathrm{mmol}$ ) in DMSO (10 mL; degassed by bubbling $\mathrm{N}_{2}$ ). The crude material was dry-loaded onto $\mathrm{SiO}_{2}$ and purified by column chromatography $\left(\mathrm{SiO}_{2}, 15-30 \%\right.$ EtOAc in pentane) affording $N$-benzyl-3-(4methoxyphenyl)prop-2-yn-1-amine (64) as a light orange solid (0.28 g, $1.1 \mathrm{mmol}, 43 \%$ yield).

${ }^{1} \mathrm{H}$ NMR $(400 \mathrm{MHz}$, Chloroform-d) $\delta 7.42-7.23(\mathrm{~m}, 7 \mathrm{H}, \mathrm{ArH}), 6.87-6.81(\mathrm{~m}, 2 \mathrm{H}, \mathrm{ArH}), 3.95$ (s, 2H,

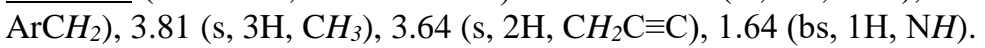

${ }^{13} \mathrm{C}$ NMR $(101 \mathrm{MHz}$, Chloroform- $d$ ) $\delta$ 159.4, 139.6, 133.0, 128.4 (2C), 127.1, 115.3, 113.9, 86.0, 83.5, 55.3, 52.5, 38.3.

Spectral data was consistent with the values reported in literature. ${ }^{10}$ 


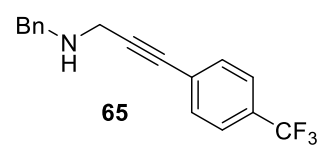

N-Benzyl-3-(4-(trifluoromethyl)phenyl)prop-2-yn-1-amine (65)

Prepared following modified general procedure B2.A using $\mathrm{Pd}\left(\mathrm{PPh}_{3}\right)_{2} \mathrm{Cl}_{2}(90 \mathrm{mg}$, $0.13 \mathrm{mmol}, 5 \mathrm{~mol} \%)$, dppf (86 mg, $0.16 \mathrm{mmol}, 6 \mathrm{~mol} \%)$, CuI (25 mg, $0.13 \mathrm{mmol}$,

$5 \mathrm{~mol} \%)$, DABCO (0.76 g, $6.8 \mathrm{mmol}, 2.6$ equiv.) and 4-trifluro-Iodobenzene (0.92 g, 3.4 mmol, 1.3 equiv.) in DMSO (10 mL; degassed by bubbling $\left.\mathrm{N}_{2}\right)$. The crude material was dryloaded onto $\mathrm{SiO}_{2}$ and purified by column chromatography $\left(\mathrm{SiO}_{2}, 10-20 \%\right.$ EtOAc in pentane) affording $N$ benzyl-3-(4-(trifluoromethyl)phenyl)prop-2-yn-1-amine (65) as a dark orange oil (0.55 g, $1.9 \mathrm{mmol}, 72 \%$ yield)

${ }^{1} \mathrm{H}$ NMR $\left(400 \mathrm{MHz}\right.$, Chloroform-d) $\delta 7.61-7.24(\mathrm{~m}, 9 \mathrm{H}, \mathrm{ArH}), 3.95\left(\mathrm{~s}, 2 \mathrm{H}, \mathrm{ArCH}_{2}\right), 3.67$ (s, 2H, $\left.\mathrm{CH}_{2} \mathrm{C} \equiv \mathrm{C}\right)$, $1.76(\mathrm{bs}, 1 \mathrm{H}, \mathrm{NH})$.

${ }^{13} \mathrm{C}\left\{{ }^{1} \mathrm{H}\right\}$ NMR $(101 \mathrm{MHz}$, Chloroform- $d) \delta 139.3,131.9,129.8(\mathrm{q}, J=32.7 \mathrm{~Hz}), 128.5,128.4,127.2,127.0$, $125.2(\mathrm{q}, J=3.9 \mathrm{~Hz}), 123.91(\mathrm{q}, J=272.2 \mathrm{~Hz}), 90.2,82.5,52.6,38.2$.

${ }^{19} \mathrm{~F}$ NMR (376 MHz, Chloroform- $d$ ) $\delta-63.2$.

Spectral data was consistent with the values reported in literature. ${ }^{10}$

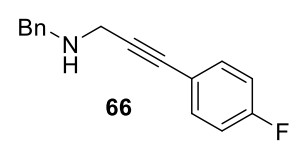

$N$-Benzyl-3-(4-fluorophenyl)prop-2-yn-1-amine (66)

Prepared following general procedure B2.A using 4-fluoroiodobenzene $(0.68 \mathrm{~g}$, $0.35 \mathrm{~mL}, 3.1 \mathrm{mmol}, 1.1$ equiv.). Purification was performed by Biotage flash column chromatography system with a $25 \mathrm{~g}$ cartridge $\left(\mathrm{SiO}_{2}, 10-40 \%\right.$ EtOAc in pentane) to afford $\mathrm{N}$-benzyl-3-(4-fluorophenyl)prop-2-yn-1-amine (66) as an orange oil (512 mg, 2.02 mmol, $79 \%$ yield).

${ }^{1} \mathrm{H}$ NMR $(400 \mathrm{MHz}$, Chloroform- $d$ ) $\delta 7.48-7.30(\mathrm{~m}, 6 \mathrm{H}, \mathrm{ArH}), 7.30-7.22(\mathrm{~m}, 1 \mathrm{H}, \mathrm{ArH}), 7.07-6.91(\mathrm{~m}$, $2 \mathrm{H}, \mathrm{ArH}$ ), 3.95 (s, 2H, $\mathrm{PhCH}_{2}$ ), 3.64 (s, 2H, $\mathrm{CH}_{2} \mathrm{C} \equiv \mathrm{C}$ ), 1.61 (br. s., $1 \mathrm{H}, \mathrm{NH}$ ).

${ }^{13} \mathrm{C}\left\{{ }^{1} \mathrm{H}\right\} \mathrm{NMR}(101 \mathrm{MHz}$, Chloroform- $d) \delta 162.5(\mathrm{~d}, J=249.0 \mathrm{~Hz}), 139.7,133.6(\mathrm{~d}, J=8.3 \mathrm{~Hz}), 128.61$, $128.55,127.3,119.4(\mathrm{~d}, J=3.5 \mathrm{~Hz}), 115.7(\mathrm{~d}, J=22.0 \mathrm{~Hz}), 87.4,82.8,52.7,38.3$.

${ }^{19} \mathrm{~F}$ NMR $(376 \mathrm{MHz}$, Chloroform- $d$ ) $\delta-111.4$ (tt, $J=8.7,5.4 \mathrm{~Hz}$ ).

Spectral data were consistent with the values reported in literature. ${ }^{9}$

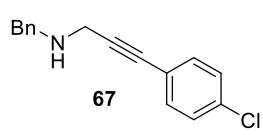

$N$-Benzyl-3-(4-chlorophenyl)prop-2-yn-1-amine (67)

Prepared following general procedure B2.A using 4-chloroiodobenzene (730 mg, 3.06 mmol, 1.1 equiv.). Purification was performed by Biotage flash column chromatography system with a $25 \mathrm{~g}$ cartridge $\left(\mathrm{SiO}_{2}, 10-40 \%\right.$ EtOAc in pentane) to afford $N$-benzyl-3-(4-chlorophenyl)prop-2yn-1-amine 67 as an orange oil (540 mg, $2.08 \mathrm{mmol}$, 77\% yield). ${ }^{1} \mathrm{H}$ NMR (400 MHz, Chloroform- $d$ ) $\delta 7.38-7.28(\mathrm{~m}, 6 \mathrm{H}, \mathrm{ArH}), 7.27-7.19(\mathrm{~m}, 3 \mathrm{H}, \mathrm{ArH}), 3.91(\mathrm{~s}, 2 \mathrm{H}$, $\mathrm{PhCH}_{2}$ ), 3.61 (s, $2 \mathrm{H}, \mathrm{CH}_{2} \mathrm{C} \equiv \mathrm{C}$ ), 2.35 (s, 3H, $\mathrm{CH}_{3}$ ), 1.57 (br. s., $1 \mathrm{H}, \mathrm{NH}$ ).

${ }^{13} \mathrm{C}\left\{{ }^{1} \mathrm{H}\right\}$ NMR $(101 \mathrm{MHz}$, Chloroform- $d) \delta$ 139.6, 134.2, 133.0, 129.1, 128.6, 128.6, 127.3, 121.9, 87.7, 82.8, 52.7, 38.3.

$\underline{\mathrm{IR}}\left(\mathrm{cm}^{-1}\right) 3327(\mathrm{w}), 3031(\mathrm{~m}), 2921(\mathrm{~m}), 2840(\mathrm{~m}), 2104(\mathrm{w}), 1727(\mathrm{~m}), 1487(\mathrm{~s}), 1335(\mathrm{~m}), 1254(\mathrm{~m}), 1166$ (m), $1094(\mathrm{~s})$.

$\underline{\text { HRMS }}\left(\right.$ ESI/QTOF) m/z: $[\mathrm{M}+\mathrm{H}]^{+}$Calculated for $\mathrm{C}_{16} \mathrm{H}_{15} \mathrm{ClN}^{+}$256.0888; Found 256.0890.<smiles>Brc1cccc(C#CCNc2ccccc2)c1</smiles>

\section{$N$-benzyl-3-(3-bromophenyl)prop-2-yn-1-amine (68)}

Prepared following general procedure B2.B using $\mathrm{PdCl}_{2}\left(\mathrm{PPh}_{3}\right)_{2}(47 \mathrm{mg}, 66 \mu \mathrm{mol}$, $2 \mathrm{~mol} \%$ ), CuI (13 mg, $66 \mu \mathrm{mol}, 2 \mathrm{~mol} \%, 57$ (0.80 g, $3.3 \mathrm{mmol}, 1$ equiv.), 1-bromo3-iodobenzene (0.95 g, $3.4 \mathrm{mmol}, 1.01$ equiv.) and $\mathrm{Et}_{3} \mathrm{~N}(2.3 \mathrm{~mL}, 17 \mathrm{mmol}, 5$ equiv.) in acetonitrile $(30 \mathrm{~mL})$. The crude material was purified by flash column chromatography $\left(\mathrm{SiO}_{2}, 0-\right.$ $5 \%$ EtOAc in pentane) affording $N$-benzyl- $N$-(3-(3-bromophenyl)prop-2-yn-1-yl)-2,2,2-trifluoroacetamide as an yellow oil (1.2 g, $3.04 \mathrm{mmol}, 92 \%$ yield).

Hydrolysis: the obtained trifluoroacetamide (1.2 g, $3.0 \mathrm{mmol}, 1$ equiv.) was treated with $\mathrm{KOH}(0.50 \mathrm{~g}, 9.0$ mmol, 3.0 equiv.) in $\mathrm{H}_{2} \mathrm{O}(15 \mathrm{~mL})$ and $\mathrm{MeOH}(15 \mathrm{~mL})$. Purification by column chromatography $\left(\mathrm{SiO}_{2}, 10-\right.$ $30 \%$ EtOAc in pentane) afforded $N$-benzyl-3-(3-bromophenyl)prop-2-yn-1-amine (68) as a light yellow oil (0.80 g, $2.7 \mathrm{mmol}, 88 \%$ yield) 
${ }^{1} \mathrm{H}$ NMR $(400 \mathrm{MHz}$, Chloroform- $d) \delta 7.59(\mathrm{t}, J=1.7 \mathrm{~Hz}, 1 \mathrm{H}, \mathrm{ArH}), 7.45(\mathrm{ddd}, J=8.0,2.1,1.1 \mathrm{~Hz}, 1 \mathrm{H}$, $\mathrm{ArH}), 7.43-7.24(\mathrm{~m}, 6 \mathrm{H}, \mathrm{ArH}), 7.18(\mathrm{t}, J=7.9 \mathrm{~Hz}, 1 \mathrm{H}, \mathrm{ArH}), 3.96\left(\mathrm{~s}, 2 \mathrm{H}, \mathrm{ArCH}_{2}\right), 3.66\left(\mathrm{~s}, 2 \mathrm{H}, \mathrm{CH}_{2} \mathrm{C} \equiv \mathrm{C}\right)$, $2.37(\mathrm{~s}, 1 \mathrm{H}, \mathrm{NH})$.

${ }^{13} \mathrm{C}\left\{{ }^{1} \mathrm{H}\right\} \mathrm{NMR}(101 \mathrm{MHz}$, Chloroform- $d) \delta 138.7,134.4,131.3,130.2,129.7,128.5,128.5,127.4,125.1$, 122.1, 88.4, 82.6, 52.3, 37.9.

HRMS (ESI/QTOF) m/z: [M + H $]^{+}$Calculated for $\mathrm{C}_{16} \mathrm{H}_{15}{ }^{79} \mathrm{BrN}^{+} 300.0382$; Found 300.0384. ${ }^{4}$

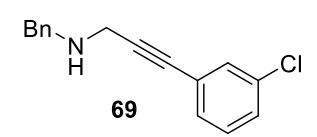

\section{$N$-Benzyl-3-(3-chlorophenyl)prop-2-yn-1-amine (69)}

Prepared following general procedure B2.A using 3-chloroiodobenzene (730 mg, $3.06 \mathrm{mmol}, 1.1$ equiv.). Purification was performed by Biotage flash column chromatography system with a $25 \mathrm{~g}$ cartridge $\left(\mathrm{SiO}_{2}, 10-40 \%\right.$ EtOAc in pentane) to afford $\mathrm{N}$-benzyl-3-(3-chlorophenyl)prop-2yn-1-amine (69)as an orange oil (530 mg, $2.08 \mathrm{mmol}, 77 \%$ yield).

${ }^{1} \mathrm{H}$ NMR $(400 \mathrm{MHz}$, Chloroform-d) $\delta 7.45-7.40(\mathrm{~m}, 1 \mathrm{H}, \mathrm{ArH}), 7.40-7.18(\mathrm{~m}, 8 \mathrm{H}, \mathrm{ArH}), 3.94(\mathrm{~s}, 2 \mathrm{H}$, $\mathrm{PhCH}_{2}$ ), 3.65 (s, 2H, $\mathrm{CH}_{2} \mathrm{C} \equiv \mathrm{C}$ ), 1.60 (br. s., $1 \mathrm{H}$. $\mathrm{NH}$ ).

${ }^{13} \mathrm{C}\left\{{ }^{1} \mathrm{H}\right\} \mathrm{NMR}(101 \mathrm{MHz}$, Chloroform- $d) \delta 139.6,134.2,131.7,129.9,129.6,128.62,128.56,128.5,127.4$, 125.1, 89.1, 82.5, 52.7, 38.3.

$\underline{\text { IR }}\left(\mathrm{cm}^{-1}\right) 3324(\mathrm{~m}), 3030(\mathrm{~m}), 2909(\mathrm{~m}), 2833(\mathrm{~m}), 2357(\mathrm{w}), 1589(\mathrm{~m}), 1560(\mathrm{~m}), 1465(\mathrm{~m})$.

HRMS (ESI/QTOF) m/z: [M+ H] $]^{+}$Calculated for $\mathrm{C}_{16} \mathrm{H}_{15} \mathrm{ClN}^{+} 256.0888$; Found 256.0886.

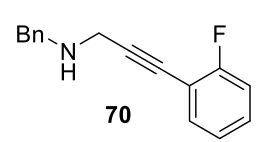

N-Benzyl-3-(2-fluorophenyl)prop-2-yn-1-amine (70)

Prepared following general procedure B2.A using 2-fluoroiodobenzene $(0.80 \mathrm{~g}, 0.42$ $\mathrm{mL}, 3.6 \mathrm{mmol}, 1.2$ equiv.). Purification was performed by Biotage flash column chromatography system with a $25 \mathrm{~g}$ cartridge $\left(\mathrm{SiO}_{2}, 10-40 \%\right.$ EtOAc in pentane) to afford $\mathrm{N}$-benzyl-3-(2-fluorophenyl)prop-2-yn-1-amine (70) as an orange oil (520 mg, $2.17 \mathrm{mmol}, 72 \%$ yield).

${ }^{1} \mathrm{H}$ NMR (400 MHz, Chloroform- $d$ ) $\delta 7.34-7.19(\mathrm{~m}, 5 \mathrm{H}, \mathrm{ArH}), 7.19-7.10(\mathrm{~m}, 2 \mathrm{H}, \mathrm{ArH}), 7.00-6.92(\mathrm{~m}$, $2 \mathrm{H}, \mathrm{ArH}), 3.86\left(\mathrm{~s}, 2 \mathrm{H}, \mathrm{PhCH}_{2}\right), 3.58\left(\mathrm{~s}, 2 \mathrm{H}, \mathrm{CH}_{2} \mathrm{C} \equiv \mathrm{C}\right), 1.48(\mathrm{~s}, 1 \mathrm{H}, \mathrm{NH})$.

${ }^{13} \mathrm{C}\left\{{ }^{1} \mathrm{H}\right\}$ NMR $(101 \mathrm{MHz}$, Chloroform- $d) \delta 163.0(\mathrm{~d}, J=250.9 \mathrm{~Hz}), 139.6,133.7,129.9(\mathrm{~d}, J=7.9 \mathrm{~Hz})$, 128.7, 128.6, 127.3, $124.0(\mathrm{~d}, J=3.7 \mathrm{~Hz}), 115.6(\mathrm{~d}, J=21.0 \mathrm{~Hz}), 111.9$ (d, $J=15.7 \mathrm{~Hz}), 93.2,77.3,52.5$, 38.4 .

${ }^{19} \mathrm{~F}$ NMR $(376 \mathrm{MHz}$, Chloroform- $d$ ) $\delta-110.4(\mathrm{~d}, 1 \mathrm{~F}, J=5.9 \mathrm{~Hz}, \mathrm{Ar} F)$.

$\underline{\mathrm{IR}}\left(\mathrm{cm}^{-1}\right) 3324(\mathrm{~m}), 3032(\mathrm{~m}), 2912(\mathrm{~m}), 2836(\mathrm{~m}), 2104(\mathrm{w}), 1494(\mathrm{~s}), 1451$ (s), $1327(\mathrm{~m}), 1214(\mathrm{~m}), 1107$ $\overline{(\mathrm{m})}$.

$\underline{\text { HRMS }}(\mathrm{ESI} / \mathrm{QTOF}) \mathrm{m} / \mathrm{z}:[\mathrm{M}+\mathrm{H}]^{+}$Calculated for $\mathrm{C}_{16} \mathrm{H}_{15} \mathrm{FN}^{+}$240.1183; Found 240.1184.<smiles>Cc1cc(C#CCNc2ccccc2)cc([N+](=O)[O-])c1</smiles>

\section{$N$-benzyl-3-(3,5-dimethylphenyl)prop-2-yn-1-amine (71)}

Prepared following modified general procedure B2.B using $\mathrm{PdCl}_{2}\left(\mathrm{PPh}_{3}\right)_{2}(0.14 \mathrm{~g}$, $0.20 \mathrm{mmol}, 5 \mathrm{~mol} \%), \mathrm{PPh}_{3}(0.21 \mathrm{~g}, 0.80 \mathrm{mmol}, 20 \mathrm{~mol} \%)$ and $\mathrm{CuI}(76 \mathrm{mg}, 0.40$ mmol, $10 \mathrm{~mol} \%) .57$ (0.97 g, $4.0 \mathrm{mmol}, 1$ equiv.), 1-iodo-3,5-dimethylbenzene (1.1 g, $4.8 \mathrm{mmol}, 1.2$ equiv.) in DMF $(3.3 \mathrm{~mL})$ and $\mathrm{Et}_{3} \mathrm{~N}(10 \mathrm{~mL})$. The crude material was purified by flash column chromatography $\left(\mathrm{SiO}_{2}, 0-5 \%\right.$ EtOAc in pentane) afforded $N$-benzyl$\mathrm{N}$-(3-(3,5-dimethylphenyl)prop-2-ynyl)-trifluoroacetamide as an orange oil (1.2 g, $3.6 \mathrm{mmol}, 90 \%$ yield). Hydrolysis: the obtained trifluoroacetamide $(0.84 \mathrm{~g}, 2.4 \mathrm{mmol}, 1$ equiv.) was treated with $\mathrm{KOH}(0.15 \mathrm{~g}, 2.7$ mmol, 1.3 equiv.) in $\mathrm{H}_{2} \mathrm{O}(5 \mathrm{~mL})$ and $\mathrm{MeOH}(5 \mathrm{~mL})$. Purification by column chromatography $\left(\mathrm{SiO}_{2}, 10-\right.$ $40 \%$ EtOAc in pentane) afforded $\mathrm{N}$-benzyl-3-(3,5-dimethylphenyl)prop-2-ynylamine (71) as an orange oil (0.49 g, $2.0 \mathrm{mmol}, 76 \%$ yield).

${ }^{1} \mathrm{H}$ NMR (400 MHz, Chloroform-d) $\delta 7.42-7.24(\mathrm{~m}, 5 \mathrm{H}, \mathrm{ArH}), 7.08(\mathrm{~m}, 2 \mathrm{H}, \mathrm{ArH}), 6.95(\mathrm{~m}, 1 \mathrm{H}, \mathrm{ArH})$, 3.96 (s, 2H, $\mathrm{ArCH}_{2}$ ), 3.65 (s, 2H, $\mathrm{CH}_{2} \mathrm{C} \equiv \mathrm{C}$ ), 2.29 (s, 6H, $\mathrm{CH}_{3}$ ), 2.09 (bs, 1H, NH).

${ }^{13} \mathrm{C}\left\{{ }^{1} \mathrm{H}\right\}$ NMR $(101 \mathrm{MHz}$, Chloroform- $d) \delta 139.3,137.8,130.0,129.3,128.5,128.4,127.2,122.8,86.5$, 84.2, 52.3, 38.1, 21.1.

Spectral data was consistent with the values reported in literature. ${ }^{11}$ 


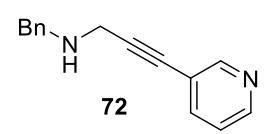

$N$-Benzyl-3-(pyridin-3-yl)prop-2-yn-1-amine (72)

Prepared following general procedure B2.A using 3-bromopyridine $(0.48 \mathrm{~g}, 0.30 \mathrm{~mL}$, $3.06 \mathrm{mmol}, 1.1$ equiv.). Purification was performed by two sequential runs of Biotage

flash column chromatography system with a $25 \mathrm{~g}$ cartridge $\left(\mathrm{SiO}_{2}, 0-10 \% \mathrm{MeOH}\right.$ in DCM) to afford $N$-benzyl-3-(pyridin-3-yl)prop-2-yn-1-amine (72) as a dark orange oil (401 mg, $1.80 \mathrm{mmol}$, $60 \%$ yield). The material was used without further purification.

${ }^{1} \mathrm{H}$ NMR (400 MHz, DMSO-d6) $\delta 8.62$ (br. s, 1H, HetArH), 8.55 (br. s, 1H, HetArH), 7.84 (dt, $J=7.9,1.9$ $\mathrm{Hz}, 1 \mathrm{H}, \mathrm{HetArH}), 7.45-7.29(\mathrm{~m}, 5 \mathrm{H}$, HetArH and $\mathrm{ArH}), 7.26-7.19$ (m, 1H, ArH), $3.82\left(\mathrm{~s}, 2 \mathrm{H}, \mathrm{PhCH}_{2}\right)$, $3.56\left(\mathrm{~s}, 2 \mathrm{H}, \mathrm{CH}_{2} \mathrm{C} \equiv \mathrm{C}\right)$.

${ }^{13} \mathrm{C}\left\{{ }^{1} \mathrm{H}\right\}$ NMR $(101 \mathrm{MHz}, \mathrm{DMSO}-d 6) \delta 151.6,148.6,140.1,138.5,128.1,128.1,126.7,123.6,119.8,92.3$, 79.8, 51.5, 37.4.

IR $\left(\mathrm{cm}^{-1}\right) 3649(\mathrm{~m}), 3276(\mathrm{~m}), 3032(\mathrm{~m}), 2914(\mathrm{~m}), 2831(\mathrm{~m}), 2233(\mathrm{w}), 1663(\mathrm{~m}), 1465(\mathrm{~m}), 1112(\mathrm{~m})$.

$\underline{\text { HRMS }}$ (ESI/QTOF) m/z: [M+ H] ${ }^{+}$Calculated for $\mathrm{C}_{15} \mathrm{H}_{15} \mathrm{~N}_{2}{ }^{+} 223.1230$; Found 223.1232 .

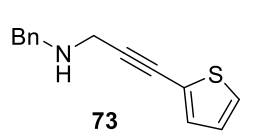

\section{$N$-benzyl-3-(thiophen-2-yl)prop-2-yn-1-amine (73)}

Prepared following general procedure B2.B using $\mathrm{PdCl}_{2}\left(\mathrm{PPh}_{3}\right)_{2}(36 \mathrm{mg}, 51 \mu \mathrm{mol}, 2$ mol\%), CuI (12 mg, $66 \mu \mathrm{mol}, 3 \mathrm{~mol} \%), 57$ (0.50 g, $2.0 \mathrm{mmol}, 1$ equiv.), $2-$ iodothiophene $(0.43 \mathrm{~g}, 2.0 \mathrm{mmol}, 1.01$ equiv. $)$ and $\mathrm{Et}_{3} \mathrm{~N}(1.4 \mathrm{~mL}, 10 \mathrm{mmol}, 5$ equiv. $)$ in acetonitrile $(30 \mathrm{~mL})$. The The crude material was purified by flash column chromatography $\left(\mathrm{SiO}_{2}, 0-5 \%\right.$ EtOAc in pentane) afforded $N$-benzyl-2,2,2-trifluoro- $N$-(3-(thiophen-2-yl)prop-2-yn-1-yl)acetamide as an yellow oil ( $0.58 \mathrm{~g}, 1.8 \mathrm{mmol}, 88 \%$ yield).

Hydrolysis: the obtained trifluoroacetamide $(0.58 \mathrm{~g}, 1.8 \mathrm{mmol}, 1$ equiv. $)$ was treated with $\mathrm{KOH}(0.30 \mathrm{~g}, 5.4$ mmol, 3.0 equiv.) in $\mathrm{H}_{2} \mathrm{O}(9 \mathrm{~mL})$ and $\mathrm{MeOH}(9 \mathrm{~mL})$. Purification by column chromatography $\left(\mathrm{SiO}_{2}, 10-\right.$ $30 \%$ EtOAc in pentane) afforded $\mathrm{N}$-benzyl-3-(3-bromophenyl)prop-2-yn-1-amine (73) as an orange amorphous solid $(0.38 \mathrm{~g}, 1.7 \mathrm{mmol}, 93 \%$ yield $)$.

${ }^{1}$ H NMR (400 MHz, Chloroform- $d$ ) $\delta 7.40-7.27(\mathrm{~m}, 5 \mathrm{H}, \mathrm{ArH}), 7.24(\mathrm{dd}, J=5.2,1.2 \mathrm{~Hz}, 1 \mathrm{H}, \mathrm{ArH}), 7.20$ $(\mathrm{dd}, J=3.6,1.1 \mathrm{~Hz}, 1 \mathrm{H}, \mathrm{Ar} H), 6.97(\mathrm{dd}, J=5.2,3.6 \mathrm{~Hz}, 1 \mathrm{H}, \mathrm{Ar} H), 3.95\left(\mathrm{~s}, 2 \mathrm{H}, \operatorname{ArCH}_{2}\right), 3.68(\mathrm{~s}, 2 \mathrm{H}$, $\left.\mathrm{CH}_{2} \mathrm{C} \equiv \mathrm{C}\right), 3.00(\mathrm{~s}, 1 \mathrm{H} \mathrm{NH})$.

${ }^{13} \mathrm{C}\left\{{ }^{1} \mathrm{H}\right\}$ NMR $(101 \mathrm{MHz}$, Chloroform- $d) \delta 138.8,131.8,128.5,128.5,127.3,126.9,126.8,123.1,91.0$, 77.3, 52.3, 38.2.

HRMS (ESI/QTOF) m/z: [M + H] $]^{+}$Calculated for $\mathrm{C}_{14} \mathrm{H}_{14} \mathrm{NS}^{+} 228.0841$; Found 228.0844. ${ }^{4}$

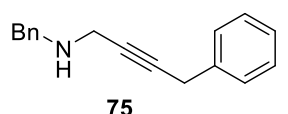

$N$-Benzyl 4-phenyl-but-2-ynylamine (75)

Prepared following general procedure B2.C using $\mathrm{CuBr}(0.18 \mathrm{~g}, 1.3 \mathrm{mmol}, 12 \mathrm{~mol} \%)$, allyl benzylamine (1.9 g, $13 \mathrm{mmol}, 1.3$ equiv), formaldehyde $(2.5 \mathrm{~mL}, 33 \mathrm{mmol} 36 \%$ aq. solution, 3.1 equiv) and phenylpropyne (1.2 g, $10 \mathrm{mmol}, 1$ equiv.) in MeCN (60 mL). Purification of the crude product by column chromatography $\left(\mathrm{SiO}_{2}, 0-2 \%\right.$ EtOAc in pentane) to afford $N$-allyl- $N$-benzyl4-phenyl-but-2-ynylamine as a colourless oil (2.6 g, $9.3 \mathrm{mmol}, 89 \%$ yield).

Deallylation: the obtained tertiary amine $(1.0 \mathrm{~g}, 3.6 \mathrm{mmol}, 1$ equiv. $)$ was treated with $\mathrm{Pd}\left(\mathrm{PPh}_{3}\right)_{4}(84 \mathrm{mg}, 73$ $\mu \mathrm{mol}, 2 \mathrm{~mol} \%)$ and 1,3-dimethylbarbituric acid (0.85 g, $5.5 \mathrm{mmol}, 1.5$ equiv.) in DCM (22 mL). Purification by flash column chromatography $\left(\mathrm{SiO}_{2}, 20-30 \%\right.$ EtOAc in pentane) to afford $N$-benzyl-4phenyl-but-2-ynylamine (75) as a straw coloured oil (0.76 g, $3.0 \mathrm{mmol}, 83 \%$ yield)

${ }^{1} \mathrm{H}$ NMR $\left(400 \mathrm{MHz}\right.$, Chloroform-d) $\delta 7.41-7.20(\mathrm{~m}, 10 \mathrm{H}, \mathrm{ArH}), 3.90\left(\mathrm{~s}, 2 \mathrm{H}, \mathrm{ArCH}_{2} \mathrm{~N}\right), 3.65(\mathrm{t}, J=2.3$ $\mathrm{Hz}, 2 \mathrm{H}, \mathrm{C} \equiv \mathrm{CCH}_{2} \mathrm{Ph}$ ), 3.48 (t, $J=2.3 \mathrm{~Hz}, 2 \mathrm{H}, \mathrm{NCH}_{2} \mathrm{C} \equiv \mathrm{C}$ ), 1.65 (br. s., $1 \mathrm{H}, \mathrm{NH}$ ).

${ }^{13} \mathrm{C}\left\{{ }^{1} \mathrm{H}\right\}$ NMR $(101 \mathrm{MHz}$, Chloroform- $d$ ) $\delta 139.5,137.0,128.5,128.4$ (2C), 127.9, 127.1, 126.6, 81.4, 80.2, 52.5, 37.9, 25.2.

Spectral data was consistent with the values reported in literature. ${ }^{11}$

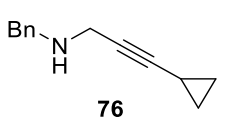

\section{$N$-Benzyl 4-phenyl-but-2-ynylamine (76)}

Prepared following general procedure B2.C using $\mathrm{CuBr}(0.36 \mathrm{~g}, 2.5 \mathrm{mmol}, 12 \mathrm{~mol} \%)$, allyl benzylamine ( $3.9 \mathrm{~mL}, 25 \mathrm{mmol}, 1.3$ equiv), formaldehyde ( $36 \%$ aq. solution; 5.0 $\mathrm{mL}, 65 \mathrm{mmol}, 3.3$ equiv.) and ethynylcyclopropane $(1.7 \mathrm{~mL}, 20 \mathrm{mmol}, 1$ equiv.) in $\mathrm{MeCN}(130 \mathrm{~mL})$. Purification of the crude material by column chromatography $\left(\mathrm{SiO}_{2}, 0-2 \%\right.$ EtOAc in pentane) afforded $N$-allyl- $N$-benzyl 3-cyclopropyl-prop-2-ynylamine as a colourless oil (4.0 g, $18 \mathrm{mmol}$, $89 \%$ yield). 


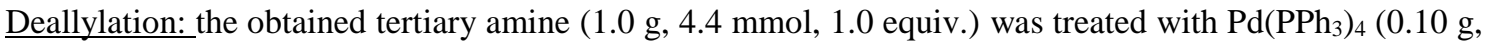
$89 \mu \mathrm{mol}, 2 \mathrm{~mol} \%)$ and 1,3-dimethylbarbituric acid (1.0 g, $6.7 \mathrm{mmol}, 1.5$ equiv.) in DCM (22 mL). The crude material was purified by column chromatography $\left(\mathrm{SiO}_{3}, 20-30 \%\right.$ EtOAc in pentane) to afford $\mathrm{N}$ benzyl 3-cyclopropyl-prop-2-ynylamine (76) as a lightly straw coloured oil (0.82 g, 4.4 mmol, 99\% yield). ${ }^{1} \mathrm{H}$ NMR (400 MHz, Chloroform- $d$ ) $\delta 7.45-7.19(\mathrm{~m}, 5 \mathrm{H}, \mathrm{ArH}), 3.84\left(\mathrm{~s}, 2 \mathrm{H}, \mathrm{ArCH}_{2}\right), 3.37(\mathrm{~d}, J=2.0 \mathrm{~Hz}$, $\left.2 \mathrm{H}, \mathrm{CH}_{2} \mathrm{C} \equiv \mathrm{C}\right), 1.50(\mathrm{bs}, 1 \mathrm{H}, \mathrm{NH}), 1.25$ (dddd, $\left.J=10.1,8.6,5.0,2.5 \mathrm{~Hz}, 1 \mathrm{H}, \mathrm{CH}\left(\mathrm{CH}_{2}\right)_{2}\right), 0.80-0.63(\mathrm{~m}$, $\left.\left.4 \mathrm{H}, \mathrm{CH}\left(\mathrm{CH}_{2}\right)_{2}\right)\right)$.

${ }^{13} \mathrm{C}\left\{{ }^{1} \mathrm{H}\right\}$ NMR (101 MHz, Chloroform- $d$ ) $\delta 139.7,128.4$ (2C), 127.0, 87.0, 73.3, 52.5, 37.9, 8.1, -0.5.

Spectral data was consistent with the values reported in literature. ${ }^{9}$

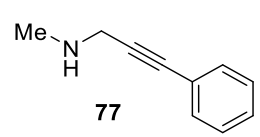

\section{$N$-methyl-3-phenylprop-2-yn-1-amine (77)}

Prepared following general procedure B2.C using $\mathrm{CuBr}(0.20 \mathrm{~g}, 1.4 \mathrm{mmol}, 13 \mathrm{~mol} \%)$, allyl methylamine $(0.98 \mathrm{~g}, 14 \mathrm{mmol}, 1.3$ equiv.), formaldehyde $(2.5 \mathrm{~mL}, 33 \mathrm{mmol} 36 \%$ aq. solution, 3 equiv.) and phenylpropyne (1.2 g, $11 \mathrm{mmol}, 1$ equiv.) in $\mathrm{MeCN}(70 \mathrm{~mL})$. Purification of the crude product by column chromatography $\left(\mathrm{SiO}_{2}, 0-2 \%\right.$ EtOAc in pentane) to afford $N$ allyl-N-benzyl-4-phenyl-but-2-ynylamine as a colourless oil ( $1.8 \mathrm{~g}, 9.7 \mathrm{mmol}, 88 \%$ yield $)$.

Deallylation: the obtained tertiary amine (1.0 g, $3.6 \mathrm{mmol}, 1$ equiv.), $\mathrm{Pd}\left(\mathrm{PPh}_{3}\right)_{4}(0.37 \mathrm{~g}, 0.32 \mathrm{~mol}, 6 \mathrm{~mol} \%)$ and 1,3-dimethylbarbituric acid (1.7 g, $11 \mathrm{mmol}, 2$ equiv.) in DCM (50 mL). Purification by flash column chromatography $\left(\mathrm{SiO}_{2}, 20-50 \%\right.$ EtOAc in pentane) to afford $N$-methyl-3-phenylprop-2-yn-1-amine (77) as an orange viscous oil $(0.46 \mathrm{~g}, 3.1 \mathrm{mmol}, 58 \%$ yield $)$.

${ }^{1} \mathrm{H}$ NMR $(400 \mathrm{MHz}$, Chloroform- $d) \delta 7.49-7.41(\mathrm{~m}, 2 \mathrm{H}, \mathrm{ArH}), 7.33(\mathrm{~m}, 3 \mathrm{H}, \mathrm{ArH}), 3.68(\mathrm{~s}, 2 \mathrm{H}$, $\left.\mathrm{NCH}_{2} \mathrm{C} \equiv \mathrm{C}\right), 3.16(\mathrm{~s}, 1 \mathrm{H}, \mathrm{NH}), 2.59\left(\mathrm{~s}, 3 \mathrm{H}, \mathrm{CH}_{3}\right)$.

${ }^{13} \mathrm{C}\left\{{ }^{1} \mathrm{H}\right\}$ NMR $(101 \mathrm{MHz}$, Chloroform- $d) \delta 131.7,128.3,128.1,123.0,86.5,84.1,40.5,34.9$.

Spectral data was consistent with the values reported in literature. ${ }^{9}$

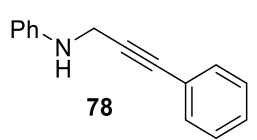

\section{$N$-(3-phenylprop-2-yn-1-yl)aniline (78)}

Prepared following modified general procedure B2.A using phenyl propargylamine ${ }^{12}$ (400 mg, $3.05 \mathrm{mmol}, 1.0$ equiv.), iodobenzene (684 mg, $3.35 \mathrm{mmol}, 1.1$ equiv.), $\mathrm{PdCl}_{2}\left(\mathrm{PPh}_{3}\right)_{2}(43 \mathrm{mg}, 0.061 \mathrm{mmol}, 2 \mathrm{~mol} \%), \mathrm{CuI}(6 \mathrm{mg}, 0.03 \mathrm{mmol}, 1 \mathrm{~mol} \%)$ and $\mathrm{Et}_{3} \mathrm{~N}$ (0.31 g, $0.43 \mathrm{~mL}, 3.0 \mathrm{mmol}, 1.0$ equiv.). Purification by flash column chromatography $\left(\mathrm{SiO}_{2}, 2-6 \%\right.$ EtOAc in pentane) afforded $N$-(3-phenylprop-2-yn-1-yl)aniline (78) as an orange solid (0.43 g, $1.9 \mathrm{mmol}, 63 \%$ yield).

${ }^{1}$ H NMR (400 MHz, Chloroform-d) $\delta 7.44-7.36(\mathrm{~m}, 2 \mathrm{H}, \mathrm{ArH}), 7.35$ - 7.27 (m, 3H, ArH), 7.27 - 7.20 (m, $3 \mathrm{H}, \mathrm{ArH}), 6.86-6.73(\mathrm{~m}, 3 \mathrm{H}, \mathrm{ArH}$ and $\mathrm{NH}), 4.17\left(\mathrm{~s}, 2 \mathrm{H}, \mathrm{CH}_{2}\right)$.

${ }^{13} \mathrm{C}\left\{{ }^{1} \mathrm{H}\right\}$ NMR $(101 \mathrm{MHz}$, Chloroform- $d) \delta 146.9,131.9,129.4,128.4$ (2C), 123.0, 119.0, 114.1, 86.2, 83.7, 35.0 .

Spectral data was consistent with the values reported in literature. ${ }^{12}$

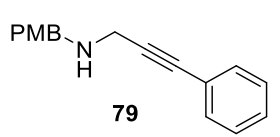

\section{$N$-(4-methoxybenzyl)-3-phenylprop-2-yn-1-amine (79)}

Prepared following general procedure B2.C using $\mathrm{CuBr}(0.22 \mathrm{~g}, 1.5 \mathrm{mmol}, 13 \mathrm{~mol} \%)$, $\mathrm{N}$-(4-methoxybenzyl)prop-2-en-1-amine ${ }^{13} \quad(2.7 \mathrm{~g}, 15.0 \mathrm{mmol}, 1.3$ equiv.), formaldehyde $(2.8 \mathrm{~mL}, 36.0 \mathrm{mmol} 36 \%$ aq. solution, 3 equiv.) and phenylpropyne (1.2 g, $12.0 \mathrm{mmol}, 1$ equiv.) in $\mathrm{MeCN}(80 \mathrm{~mL})$. Purification of the crude product by column chromatography $\left(\mathrm{SiO}_{2}, 0-2 \%\right.$ EtOAc in pentane) afforded $N$-benzyl- $N$-(3-(4-methoxyphenyl)prop-2-yn-1yl)prop-2-en-1-amine as a pale yellow oil (3.40 g, $11.7 \mathrm{mmol}, 97 \%$ yield).

Deallylation: the obtained tertiary amine $\left(3.40 \mathrm{~g}, 11.7 \mathrm{mmol}, 1\right.$ equiv.) was treated with $\mathrm{Pd}\left(\mathrm{PPh}_{3}\right)_{4}(0.270$ g, $0.233 \mathrm{~mol}, 2 \mathrm{~mol} \%)$ and 1,3-dimethylbarbituric acid (2.70 g, $17.5 \mathrm{mmol}, 1.5$ equiv.) in DCM (58 mL). Purification by flash column chromatography $\left(\mathrm{SiO}_{2}, 20-50 \%\right.$ EtOAc in pentane) to afford $\mathrm{N}$-(4methoxybenzyl)-3-phenylprop-2-yn-1-amine (79) as an orange viscous oil (2.3 g, $9.3 \mathrm{mmol}, 80 \%$ yield).

${ }^{1} \mathrm{H}$ NMR (400 MHz, Chloroform- $d$ ) $\delta 7.49-7.41(\mathrm{~m}, 2 \mathrm{H}, \mathrm{ArH}), 7.34-7.28(\mathrm{~m}, 5 \mathrm{H}, \mathrm{ArH}), 6.93-6.85$ (m, $\overline{2 \mathrm{H}, \mathrm{ArH}}), 3.89\left(\mathrm{~s}, 2 \mathrm{H}, \mathrm{ArCH}_{2} \mathrm{~N}\right), 3.81\left(\mathrm{~s}, 3 \mathrm{H}, \mathrm{OCH}_{3}\right), 3.64$ (s, $\left.2 \mathrm{H}, \mathrm{NCH}_{2} \mathrm{C} \equiv \mathrm{C}\right) 1.54$ (br. s., $\left.1 \mathrm{H}, \mathrm{NH}\right)$.

${ }^{13} \mathrm{C}\left\{{ }^{1} \mathrm{H}\right\} \mathrm{NMR}(101 \mathrm{MHz}$, Chloroform- $d) \delta 158.9,131.8$ (2c), 129.8, 128.4, 128.1, 123.4, 114.0, 87.8, 83.8, 55.4, 52.0, 38.2.

Spectral data was consistent with the values reported in literature. ${ }^{9}$ 


\section{B.3. Synthesis of the Substituted Aryl Iodide 80}

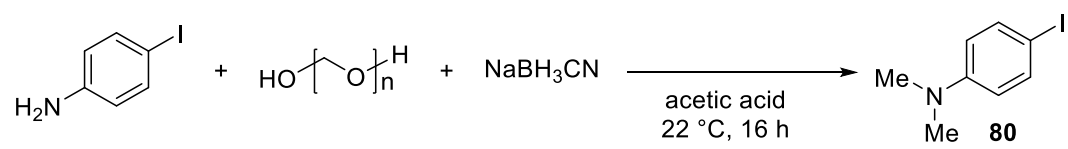

Scheme 8. Synthesis of aryl iodide $\mathbf{8 0}$.

In accordance to a reported procedure, ${ }^{14} 4$-iodoaniline $(4.00 \mathrm{~g}, 18.5 \mathrm{mmol}, 1$ equiv.) was dissolved in acetic acid $(120 \mathrm{~mL})$ and degassed. To the solution was added paraformaldehyde $(6.00 \mathrm{~g}, 194 \mathrm{mmol}, 10.5$ equiv.) and slowly sodium cyanoborohydride $(5.5 \mathrm{~g}, 87 \mathrm{mmol}, 4.7$ equiv.). The reaction mixture was stirred at room temperature for $12 \mathrm{~h}$. Then, the mixture was cooled and neutralized by adding $1 \mathrm{M} \mathrm{NaOH}$ solution and pure $\mathrm{NaOH}$ until basicity $(\mathrm{pH}>9)$. The suspension was extracted with DCM $(3 \times 150 \mathrm{~mL})$. The combined organic layers were washed with brine and dried over sodium sulfate. After filtration, the solvent was removed in vacuum affording the product 80 as a grey solid $(4.13 \mathrm{~g}, 16.7 \mathrm{mmol}, 91 \%)$

${ }^{1} \mathrm{H}$ NMR $(400 \mathrm{MHz}$, Chloroform- $d$ ) $\delta 7.47(\mathrm{~d}, J=9.1 \mathrm{~Hz}, 2 \mathrm{H}, \mathrm{Ar} H), 6.49(\mathrm{~d}, J=9.1 \mathrm{~Hz}, 2 \mathrm{H}, \operatorname{Ar} H), 2.92$ $\left(\mathrm{s}, 6 \mathrm{H}, \mathrm{N}\left(\mathrm{CH}_{3}\right)_{2}\right)$.

${ }^{13} \mathrm{C}\left\{{ }^{1} \mathrm{H}\right\}$ NMR $(101 \mathrm{MHz}$, Chloroform- $d$ ) $\delta 150.1,137.7,114.9,77.6,40.5$.

Spectral data was consistent with the values reported in literature. ${ }^{14}$

\section{B.4. Synthesis of the Ligand L9}

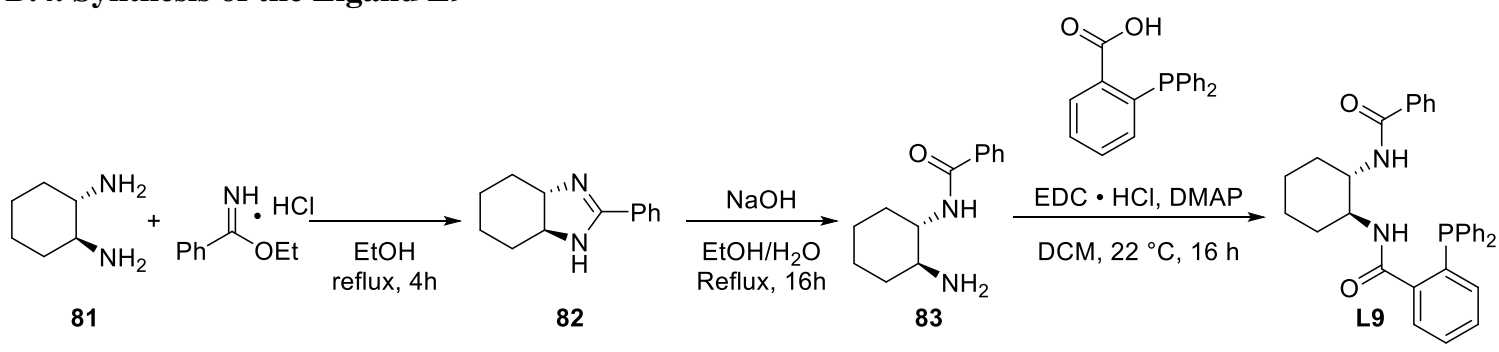

Scheme 9. Synthesis of ligand $\mathbf{L 9}$.

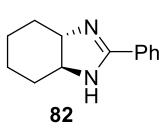

(3aS,7aS)-2-phenyl-3a,4,5,6,7,7a-hexahydro-1H-benzo[d]imidazole (82)

In accordance with a reported procedure,,$^{15}$ ethyl benzimidate hydrochloride $(3.3 \mathrm{~g}, 18 \mathrm{mmol}$, 1.2 equiv.) in ethanol $(15 \mathrm{~mL})$ was stirred at room temperature under nitrogen and $(1 S, 2 S)$ cyclohexane-1,2-diamine ( $1.70 \mathrm{~g}, 15.0 \mathrm{mmol}, 1.0$ equiv.) was added to the solution in one portion. The solution was heated to reflux and stirred for 4 hours. $1 \mathrm{M} \mathrm{NaOH}(50 \mathrm{~mL})$ was then added and the mixture was extracted with 5\% $\mathrm{MeOH}$ in DCM. The organic layer was dried over sodium sulfate and concentrated to afford the crude product, which was purified by silica gel chromatography (gradient from DCM to DCM/MeOH/NH 3 100:10:1) to obtain the product as a white solid $(2.50 \mathrm{~g}, 12.5 \mathrm{mmol}, 83 \%)$. $[\alpha] \mathrm{D}^{20}=-132.8\left(\mathrm{c}=0.51, \mathrm{CHCl}_{3}\right)$.

${ }^{1} \mathrm{H}$ NMR $(400 \mathrm{MHz}$, Chloroform- $d$ ) $\delta 7.84-7.74(\mathrm{~m}, 2 \mathrm{H}, \operatorname{Ar} H), 7.40(\mathrm{~m}, 3 \mathrm{H}, \operatorname{Ar} H), 5.50-4.50$ (bs, $1 \mathrm{H}$, $\mathrm{NH}), 3.12\left(\mathrm{~m}, 2 \mathrm{H}, \mathrm{NCHCH}_{2}\right.$ and $\left.\mathrm{NHCHCH}_{2}\right), 2.36-2.25\left(\mathrm{~m}, 2 \mathrm{H}, \mathrm{NCHCH}_{2}\right), 1.92-1.79(\mathrm{~m}, 2 \mathrm{H}$, $\mathrm{NHCHCH}_{2}$ ), $1.62-1.49$ (m, 2H, $\left.-\mathrm{CH}_{2} \mathrm{CH}_{2} \mathrm{CH}_{2}-\right), 1.45-1.28$ (m, $2 \mathrm{H},-\mathrm{CH}_{2} \mathrm{CH}_{2} \mathrm{CH}_{2}-$ ).

${ }^{13} \mathrm{C}\left\{{ }^{1} \mathrm{H}\right\}$ NMR (101 MHz, Chloroform- $d$ ) $\delta$ 165.5, 131.0, 130.7, 128.6, 126.7, 69.8, 31.1, 25.2.

Spectral data was consistent with the values reported in literature. ${ }^{15}$

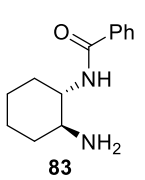

\section{$\mathbf{N}$-((1S,2S)-2-aminocyclohexyl)benzamide (83)}

In accordance with a reported procedure, ${ }^{15}$ to compound $\mathbf{8 3}(2.30 \mathrm{~g}, 11.5 \mathrm{mmol})$ was added 19 $\mathrm{mL} 5 \% \mathrm{NaOH}$ and $42 \mathrm{~mL} \mathrm{EtOH} / \mathrm{H}_{2} \mathrm{O}(2: 1)$ and the solution was heated to reflux for 16 hours. After cooling to room temperature, the ethanol was removed in vacuum, and the crude product was extracted with DCM. The product was purified by silica column chromatography (gradient from DCM to DCM/MeOH/NH 3 100:10:1) to provide the desired product as a white solid. (1.6 g, $7.3 \mathrm{mmol}$, $64 \%)$.

$[\alpha] \mathrm{D}^{20}=-16.5\left(\mathrm{c}=0.51, \mathrm{CHCl}_{3}\right)$.

${ }^{1}$ H NMR $(400 \mathrm{MHz}$, Chloroform- $d$ ) $\delta 7.82-7.76(\mathrm{~m}, 2 \mathrm{H}, \operatorname{Ar} H), 7.54-7.39(\mathrm{~m}, 3 \mathrm{H}, \operatorname{Ar} H), 6.12(\mathrm{~d}, J=8.4$ $\mathrm{Hz}, 1 \mathrm{H}, \mathrm{N} H), 3.71$ (dddd, $\left.J=11.9,9.9,8.3,4.1 \mathrm{~Hz}, 1 \mathrm{H}, \mathrm{NHCHCH}_{2}\right), 2.49(\mathrm{td}, J=10.2,3.9 \mathrm{~Hz}, 1 \mathrm{H}$, 
$\mathrm{NH}_{2} \mathrm{CHCH}_{2}$ ), $2.14\left(\mathrm{ddd}, J=12.7,4.0,2.1 \mathrm{~Hz}, 1 \mathrm{H}, \mathrm{NHCHCH}_{\mathrm{a}} \mathrm{H}_{\mathrm{b}}\right), 2.08-1.98\left(\mathrm{~m}, 1 \mathrm{H}, \mathrm{NHCHCH}_{\mathrm{a}} H_{b}\right), 1.76$ $\left(\mathrm{dq}, J=9.7,2.7 \mathrm{~Hz}, 2 \mathrm{H}, \mathrm{NH}_{2} \mathrm{CHCH}_{2}\right), 1.54-1.12\left(\mathrm{~m}, 6 \mathrm{H}, \mathrm{NH}_{2}\right.$ and $\left.2 \mathrm{x}-\mathrm{CH}_{2} \mathrm{CH}_{2} \mathrm{CH}_{2}-\right)$.

${ }^{13} \mathrm{C}\left\{{ }^{1} \mathrm{H}\right\} \mathrm{NMR}(101 \mathrm{MHz}$, Chloroform-d) $\delta 167.9,134.9,131.5,128.7,127.0,56.8,55.8,35.9,32.7,25.3$, 25.2 .

Spectral data was consistent with the values reported in literature. ${ }^{15}$

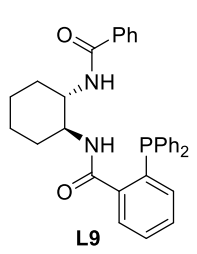

N-((1S,2S)-2-benzamidocyclohexyl)-2-(diphenylphosphino)benzamide (L9)

To a stirred solution of 2-(diphenylphosphino)benzoic acid (1.5 g, $5.0 \mathrm{mmol}, 1.1$ equiv.) and DMAP (280 mg, $2.30 \mathrm{mmol}, 0.5$ equiv.) in DCM $(20 \mathrm{~mL})$ was added EDC $\mathrm{HCl}$ (966 $\mathrm{mg}, 5.00 \mathrm{mmol}, 1.1$ equiv.) at $0{ }^{\circ} \mathrm{C}$. The mixture was stirred for few minutes and allowed to reach room temperature. Then, compound $\mathbf{8 3}(1.0 \mathrm{~g}, 4.6 \mathrm{mmol}, 1$ equiv.) was added followed by $8 \mathrm{~mL}$ of DCM. The resulting mixture was stirred at room temperature for 16 hours. The mixture was then quenched with $1 \mathrm{M} \mathrm{HCl}(50 \mathrm{~mL})$ and extracted with DCM $(2 \times 50 \mathrm{~mL})$. The combined organic layers were washed with brine and dried over sodium sulfate. The solvent was removed in vacuum and the crude mixture was purified by column chromatography (pentane/EtOAc up to 1:1) and recrystallized from boiling acetonitrile to obtain the desired compound L9 as a white solid $(1.4 \mathrm{~g}, 60 \%)$.

$[\alpha] \mathrm{D}^{20}=+21.3\left(\mathrm{c}=0.5, \mathrm{CHCl}_{3},>99 \%\right.$ e.e. $)$.

${ }^{1} \mathrm{H}$ NMR $(400 \mathrm{MHz}$, Chloroform- $d) \delta 7.84-7.76(\mathrm{~m}, 2 \mathrm{H}, \mathrm{ArH}), 7.51-7.12(\mathrm{~m}, 16 \mathrm{H}, \operatorname{Ar} H), 7.09(\mathrm{~d}, J=$ $7.6 \mathrm{~Hz}, 1 \mathrm{H}, \mathrm{NH}), 6.90-6.83(\mathrm{~m}, 1 \mathrm{H}, \mathrm{ArH}), 6.19(\mathrm{~d}, J=8.4 \mathrm{~Hz}, 1 \mathrm{H}, \mathrm{NH}), 3.96$ (tdd, $J=11.8,8.4,3.9 \mathrm{~Hz}$, $\left.1 \mathrm{H}, \mathrm{NHCHCH}_{2}\right), 3.83\left(\mathrm{dtd}, J=10.8,7.4,3.9 \mathrm{~Hz}, 1 \mathrm{H}, \mathrm{NHCHCH}_{2}\right), 2.21(\mathrm{dd}, J=14.8,7.6 \mathrm{~Hz}, 1 \mathrm{H}$, $\left.\mathrm{NHCHCH}_{\mathrm{a}} \mathrm{H}_{\mathrm{b}}\right), 1.86\left(\mathrm{dd}, J=12.9,3.6 \mathrm{~Hz}, 1 \mathrm{H}, \mathrm{NHCHCH}_{\mathrm{a}} H_{b}\right), 1.80-1.67\left(\mathrm{~m}, 2 \mathrm{H}, \mathrm{NHCHCH}_{\mathrm{a}} \mathrm{H}_{\mathrm{b}}\right.$ and $\mathrm{NHCHCH}_{\mathrm{a}} \mathrm{H}_{b}$ ), 1.29 (q, $\left.J=12.7,10.9 \mathrm{~Hz}, 3 \mathrm{H},-\mathrm{CH}_{2} \mathrm{CH}_{2} \mathrm{CH}_{2}-\right), 1.15-1.00$ (m, $1 \mathrm{H},-\mathrm{CH}_{2} \mathrm{CH}_{2} \mathrm{CH}_{2}-$ ).

${ }^{13} \mathrm{C}\left\{{ }^{1} \mathrm{H}\right\}$ NMR $(101 \mathrm{MHz}$, Chloroform- $d) \delta 170.2,167.7,141.2,141.0,137.4,137.3,137.2,136.1,135.9$, $134.5,134.3,134.07,134.05,133.87,133.85,131.3,130.4,129.0,128.9,128.84,128.76,128.7,128.6$, $128.5,127.7,127.6,127.3,55.5,53.3,32.5,32,0,25.0,24.7 .^{\mathrm{a}}$

${ }^{31} \mathrm{P}$ NMR $(162 \mathrm{MHz}$, Chloroform- $d) \delta-10.97$.

HRMS (ESI/QTOF) m/z: [M+ H] $]^{+}$Calculated for $\mathrm{C}_{32} \mathrm{H}_{32} \mathrm{~N}_{2} \mathrm{O}_{2} \mathrm{P}^{+}$507.2196; Found 507.2201.

$\underline{\text { IR }}\left(\mathrm{cm}^{-1}\right) 3279(\mathrm{~m}), 3064(\mathrm{~m}), 2935(\mathrm{~m}), 2860(\mathrm{~m}), 1634$ (s), 1545 (s), 1334 (m).

The $(R, R)$-L9 ligand and the rac-L9 were prepared using the same route starting from $(R, R)$-cyclohexane1,2-diamine and racemic cyclohexane-1,2-diamine respectively. 


\section{Optimization Studies}

\section{C.1. Carboetherification: Screening of Ligands}

The optimization reactions were conducted on a $0.1 \mathrm{mmol}$ scale (relative to the propargylic amine). Reactions were performed in $6 \mathrm{~mL}$ conical microwave vials equipped with Teflon-coated magnetic stirring bars. The vials were loaded with the palladium source, the base and the ligand. Part of the solvent (300 $\mu \mathrm{L})$ was added and the mixture was stirred at the specified temperature for 10 minutes. Propargylic amine, tether, and the remaining solvent $(200 \mu \mathrm{L})$ were then added and the reaction mixture was stirred for 16 hours. The crude mixture was filtered through a plug of deactivated silica eluting with $10 \mathrm{~mL}$ of pentane/EtOAc 9:1. The solvent was removed and yields were determined by ${ }^{1} \mathrm{HNMR}$ analysis of the crude mixture using 1 equiv. of trichloroethylene as the internal standard (IS). The enantiomeric excess was determined by HPLC analysis of a pure sample of product obtained by preparative TLC purification (pentane/EtOAc 100:3). HPLC method: Daicel Chiralpak IB N-5 column, 99:1 hexane/IPA, flow rate 1 $\mathrm{mL} / \mathrm{min}$. : $\tau_{1}=7.0 \mathrm{~min} \tau_{2}=8.5 \mathrm{~min}$.

The ligands used in the optimization studies are commercially available or synthesized following reported procedures (L4-L5, ${ }^{16} \mathbf{L 1 6},{ }^{17} \mathbf{L 8},{ }^{18} \mathbf{L 1 7},{ }^{19} \mathbf{L 1 8},{ }^{20} \mathbf{L 1 9},{ }^{21} \mathbf{L 2 0},{ }^{19} \mathbf{L 2 1},{ }^{20} \mathbf{L 2 2}^{21}{ }^{21} \mathbf{L 2 3}^{20}$ ).

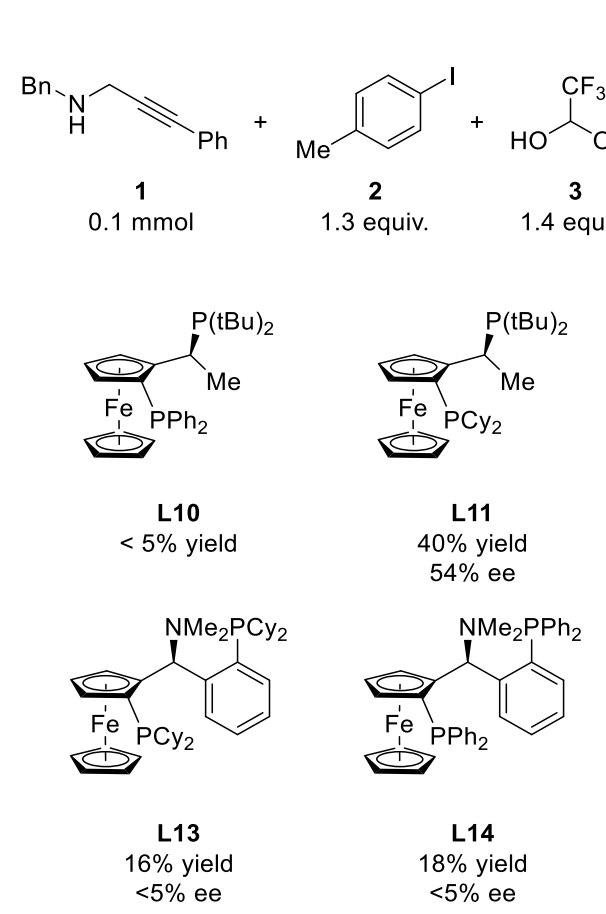

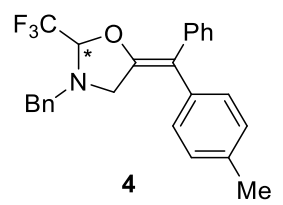
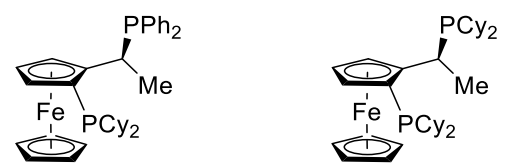

L12

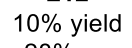

$28 \%$ ee

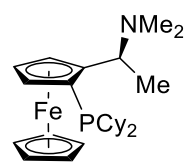

L4

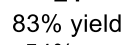

$54 \%$ ee
L2

$15 \%$ yield

$58 \%$ ee

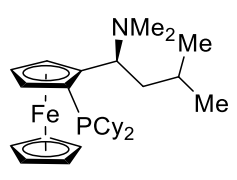

L5

$97 \%$ yield

$42 \%$ ee

Scheme 10. Screen 1 Evaluation of the JosiPhos and TaniaPhos type ligands and the corresponding P,N ligands. 


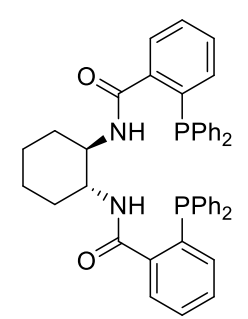

L7

$66 \%$ yield

$66 \%$ ee

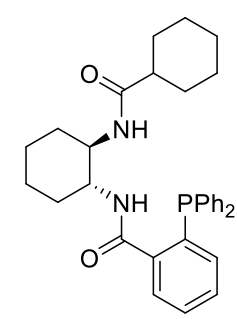

L17

$64 \%$ yield $78 \%$ ee

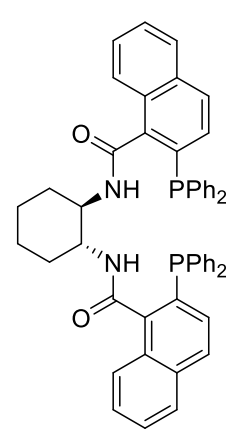

L15

$<5 \%$ yield

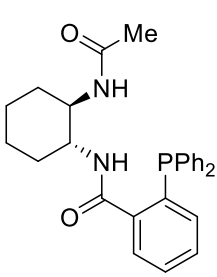

L18

$82 \%$ yield

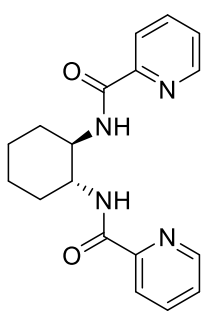

L16

$<5 \%$ yield

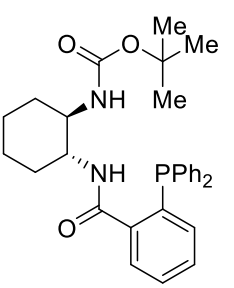

L19

$29 \%$ yield $56 \%$ ee

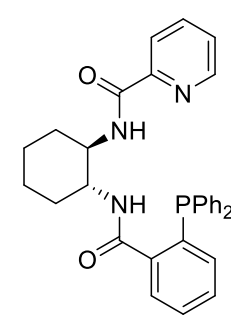

L8

$60 \%$ yield $79 \%$ ee

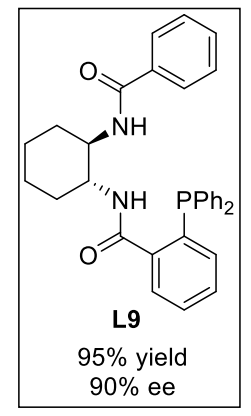

Scheme 11. Screen 2 Evaluation of the Trost type ligands and analogs.

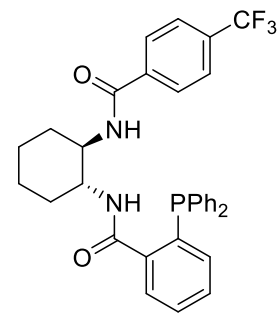

L20

$92 \%$ yield

$90 \%$ ee

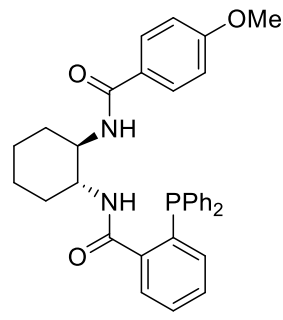

L21

$96 \%$ yield

$88 \%$ ee

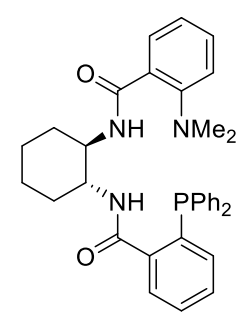

L22

$26 \%$ yield

$60 \%$ ee

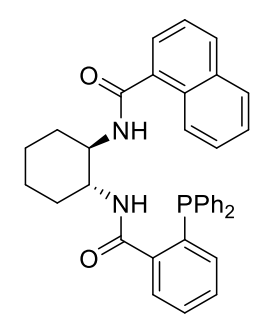

L23

$79 \%$ yield

$84 \%$ ee

Scheme 12. Screen 3 Variations on the benzoyl amide 
C.2. Carboetherification: Screening of Solvents and Temperatures

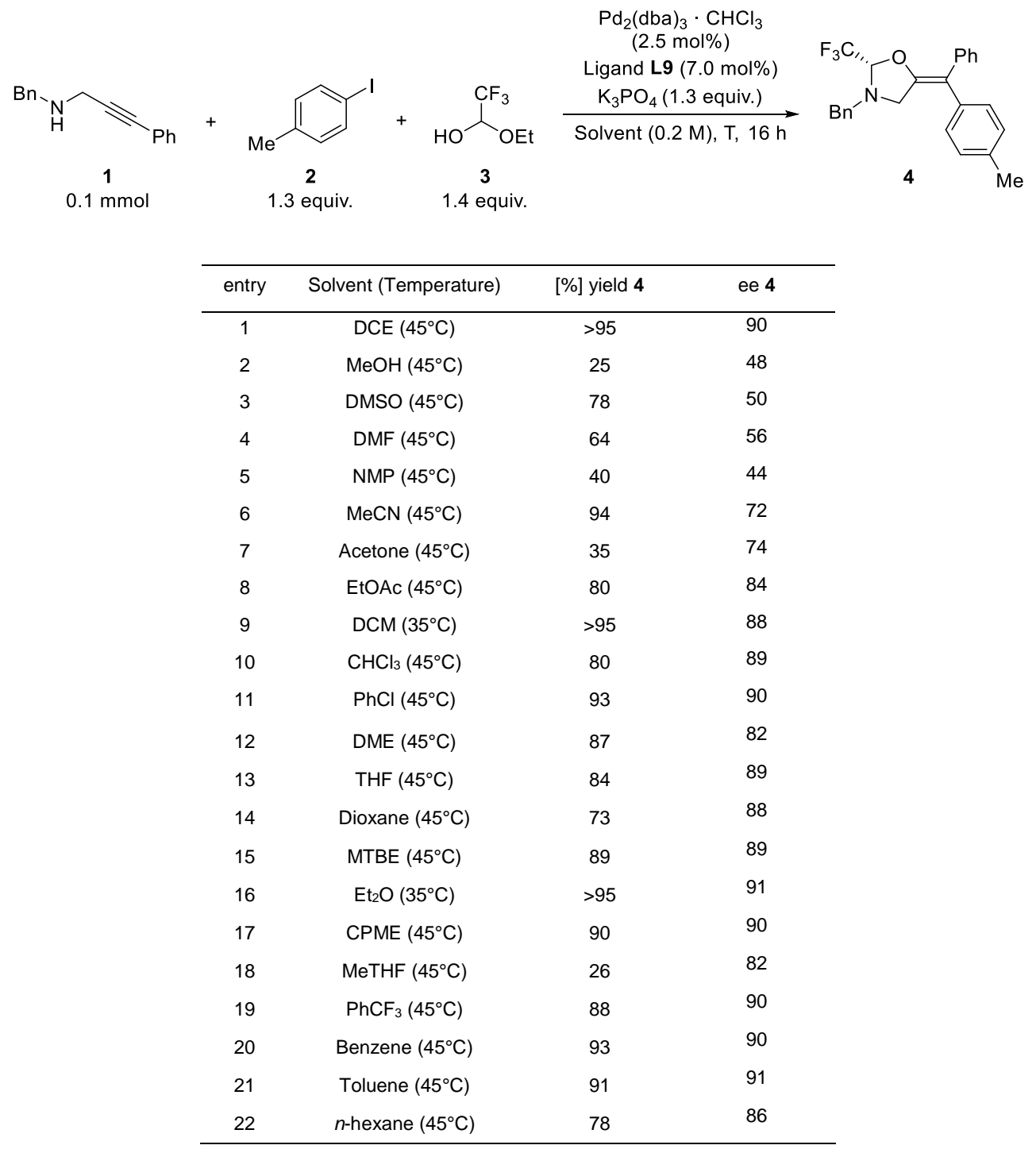




\section{C.3. Carboetherification: Screening of Bases}

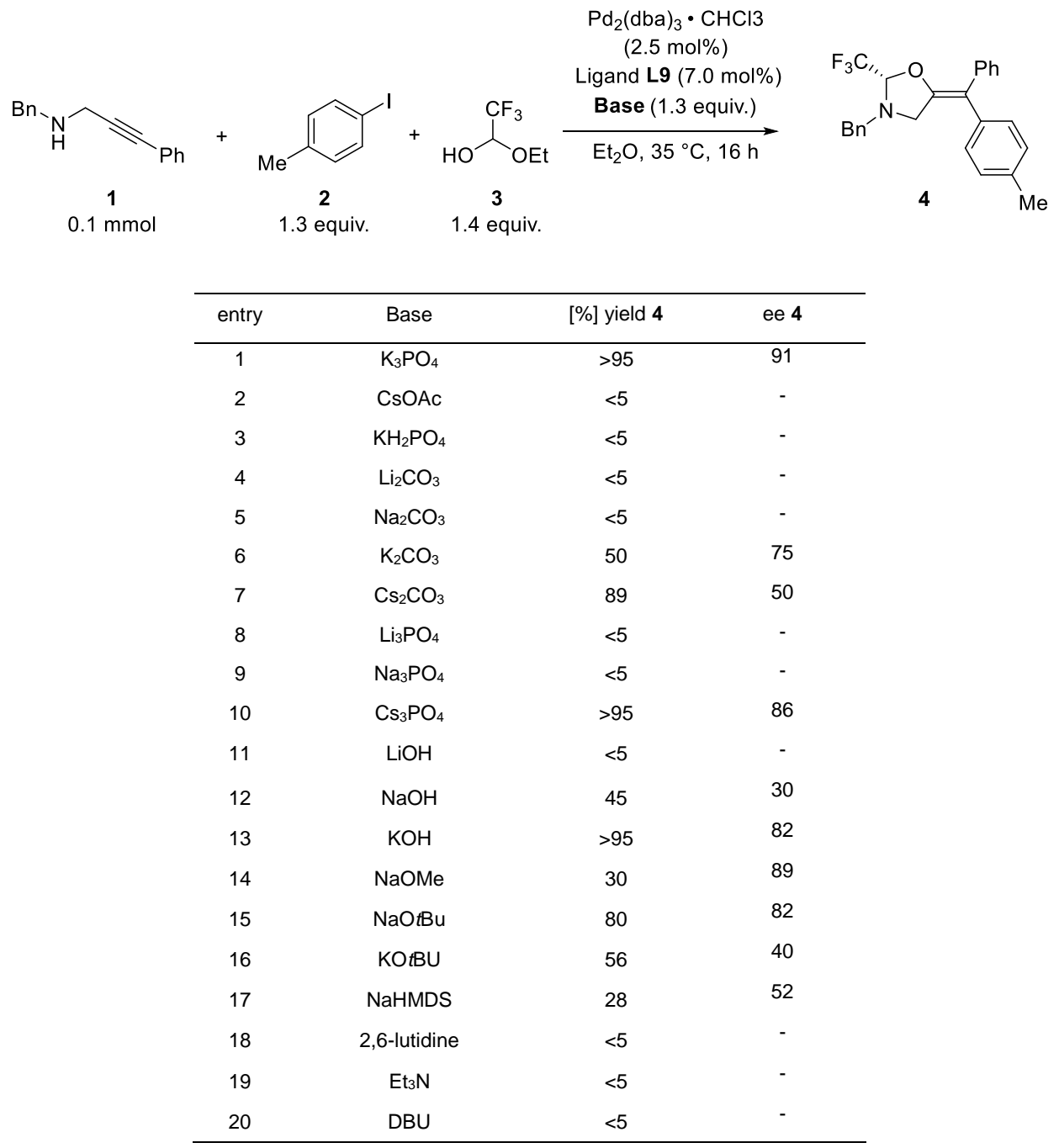

\section{C.4. Carboetherification: Screening of Palladium Sources}

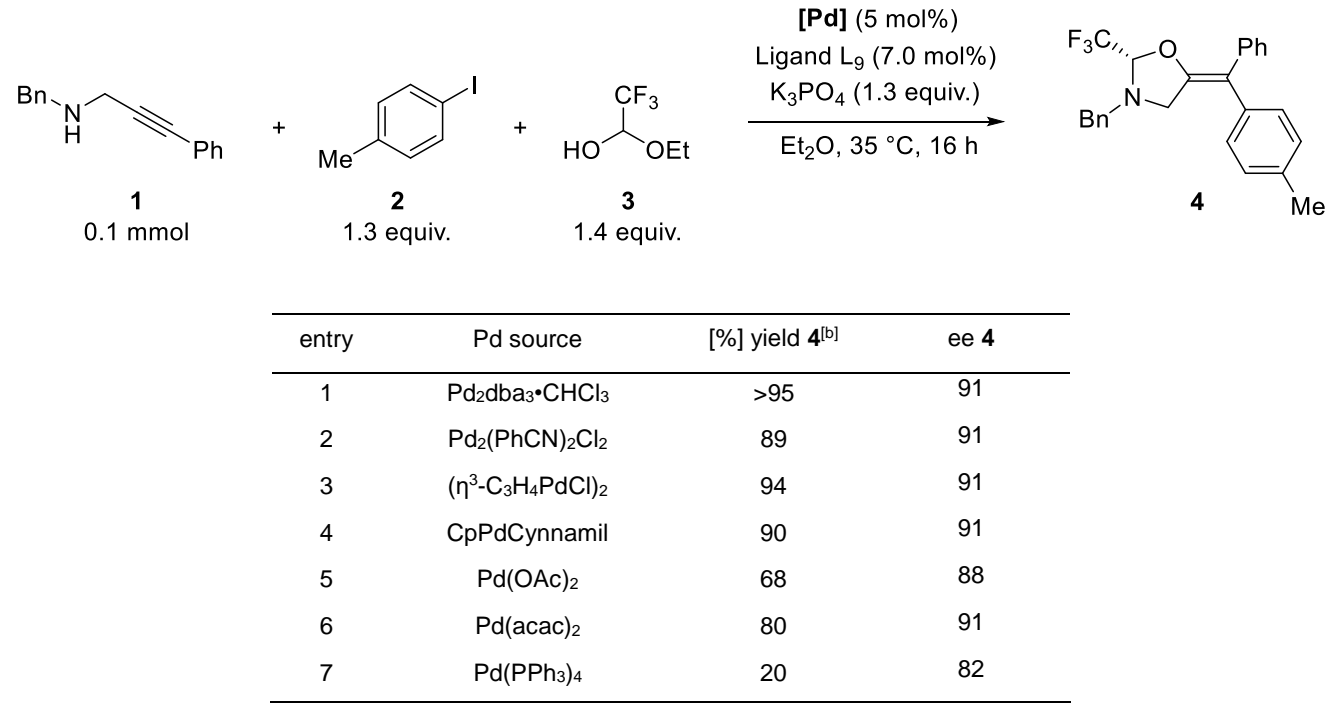




\section{C.5. Carboetherification: Screening of Additives}

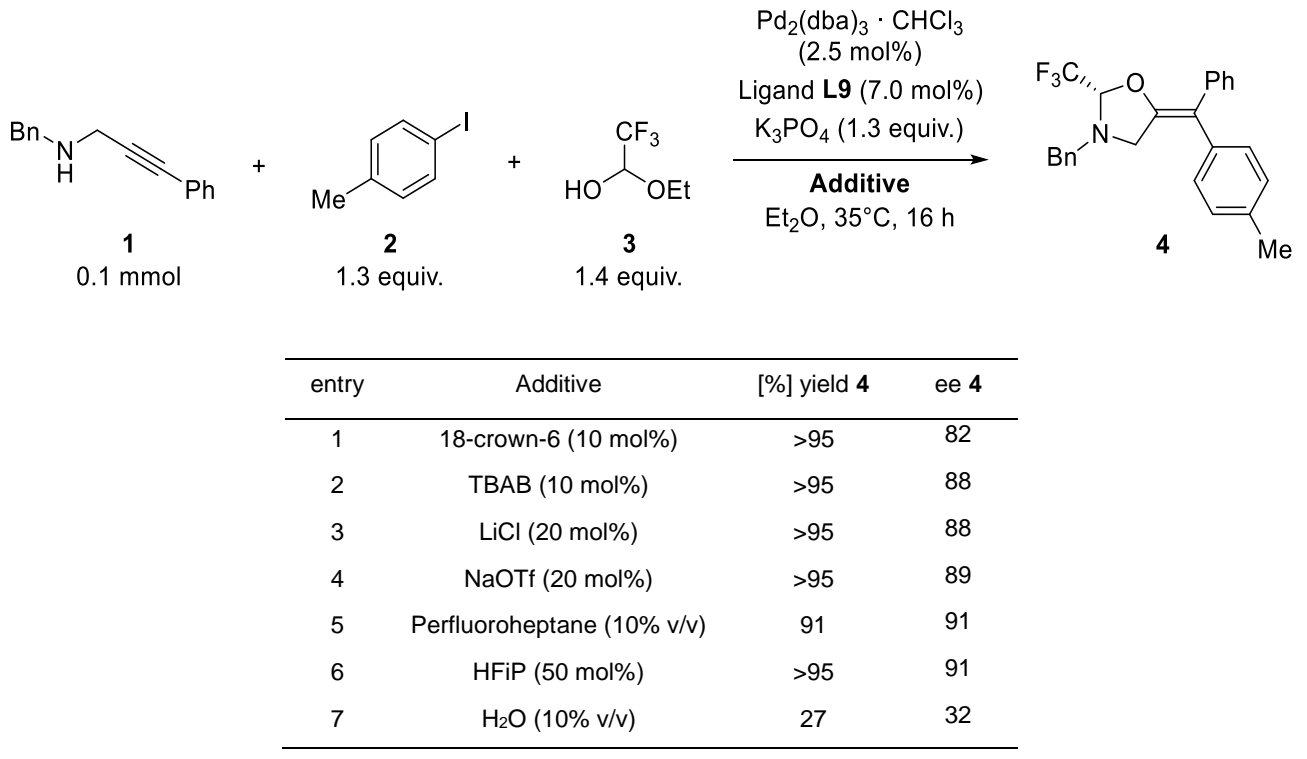

\section{C.5. Asymmetric Hydrogenation: Optimization Studies}

The optimization reactions were performed in $25 \mathrm{~mL}$ round-bottom flask equipped with Teflon-coated magnetic stir bars. The flasks were loaded with the palladium catalyst and the olefin substrate closed with a septum, and purged with nitrogen. The solvent mixture was added and the suspension was stirred under a nitrogen flow for 10 minutes. Then, a balloon of hydrogen was connected to the flask with a needle and the reaction was stirred for $16 \mathrm{~h}$ at room temperature. The crude mixture was degassed bubbling nitrogen for 10 minutes and filtered through a plug of celite eluting with $10 \mathrm{~mL}$ of $\mathrm{MeOH}$. The crude extract was washed with saturated $\mathrm{NaHCO}_{3}$ and extracted with DCM $(3 \times 20 \mathrm{~mL})$. The combined organic layers were dried over sodium sulfate, filtered and concentrated in vacuum. Yields were determined by ${ }^{1} \mathrm{HNMR}$ analysis of the crude mixture using 1 equiv. of trichloroethylene as the internal standard (IS). The enantiomeric excess was determined by HPLC analysis of a pure sample obtained by preparative TLC purification (pentane/EtOAc 100:15). HPLC method: Daicel Chiralpak IA column, 95:5 hexane/IPA, flow rate $1 \mathrm{~mL} / \mathrm{min} . \tau_{1}=8.2 \mathrm{~min}, \tau_{2}=12.5 \mathrm{~min}$.

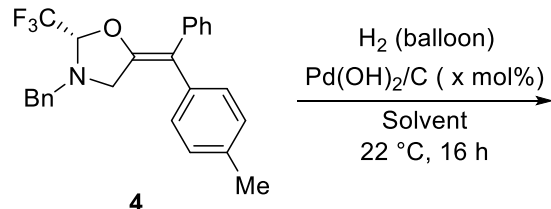

4

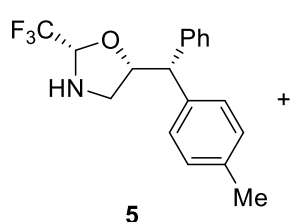

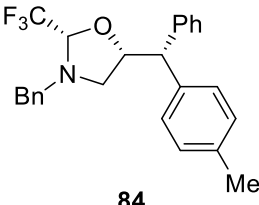

84

\begin{tabular}{cccccc}
\hline entry & Scale (mmol) & Solvent & [Pd] loading & [\%] yield $\mathbf{5}$ & [\%] yield 84 \\
\hline 1 & 0.1 & MeOH/EtOAc (2:1) & 10 & 28 & 8 \\
2 & 0.2 & MeOH/EtOAc (2:1) & 20 & 23 & 70 \\
3 & 0.1 & MeOH/AcOH (2:1) & 20 & 77 & - \\
4 & 0.1 & MeOH/AcOH (2:1) & 10 & 77 & - \\
5 & 0.2 & MeOH/AcOH (2:1) & 10 & $80(91 \% \text { ee) })^{\mathrm{a}}$ & -
\end{tabular}

a: ee starting material: $91 \%$ 


\section{Stereoselective Carboetherification of Propargylic Amines}

\section{D.1. General Procedure for the Enantioselective Carboetherification of Propargylic Amines}

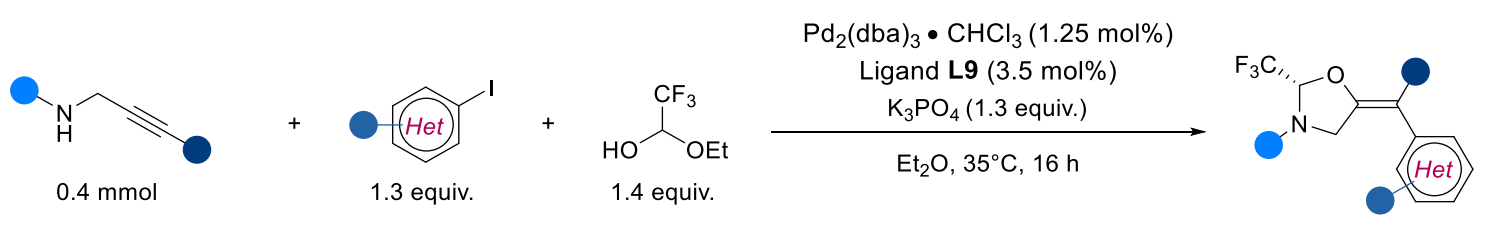

Scheme 13. Enantioselevtive Carboetherification of Propargylic Amines

An oven-dried $8 \mathrm{~mL}$ microwave vial equipped with a Teflon coated stirring bar was charged with $\mathrm{Pd}_{2}(\mathrm{dba})_{3}$ - $\mathrm{CHCl}_{3}(5.2 \mathrm{mg}, 5.0 \mu \mathrm{mol}, 1.25 \mathrm{~mol} \%)$, the ligand $(7.2 \mathrm{mg}, 14 \mu \mathrm{mol}, 3.5 \mathrm{~mol} \%)$ and $\mathrm{K}_{3} \mathrm{PO}_{4}(0.11 \mathrm{~g}, 0.52$ mmol, 1.3 equiv.). The vial was then sealed, purged with $\mathrm{N}_{2}$ and placed in a heating metal block. $1.5 \mathrm{~mL}$ of $\mathrm{Et}_{2} \mathrm{O}$ were added and the suspension was stirred at $35^{\circ} \mathrm{C}$ for 10 minutes. Propargylic amine $(0.40 \mathrm{mmol}$, 1.0 equiv) and 1-ethoxy-2,2,2-trifluoroethanol (85\% in $\mathrm{EtOH}, 76 \mathrm{uL}, 0.56 \mathrm{mmol} 1.4$ equiv.) were added followed by the aryl iodide ( $0.52 \mathrm{mmol}, 1.3$ equiv.) and the remaining $0.5 \mathrm{~mL}$ of $\mathrm{Et}_{2} \mathrm{O}$ to rinse the wall of the vial. The resulting suspension was stirred at $35{ }^{\circ} \mathrm{C}$ for 16 hours. Next, the reaction mixture was filtered through a plug of deactivated silica gel eluting with $15 \mathrm{~mL}$ of pentane/EtOAc 9:1 and concentrated in vacuo. The crude material was purified by flash column chromatography on silica gel to afford the corresponding product.

\section{D.2. Characterization of Products of the Enantioselevtive Carboetherification}

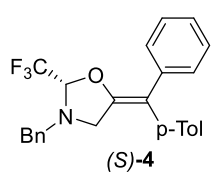

(S,E)-3-Benzyl-5-(phenyl(p-tolyl)methylene)-2-(trifluoromethyl)oxazolidine $((S)-4)$

Prepared according to the general procedure D1 using N-benzyl-3-phenylprop-2-yn-1amine (76 $\mu \mathrm{L}, 0.40 \mathrm{mmol}, 1.0$ equiv.) and 1-iodo-4-methylbenzene (113 mg, $0.520 \mathrm{mmol}$, 1.3 equiv). The crude material was purified by flash column chromatography (pentane/EtOAc gradient 100:0 to 100:3) to give the corresponding olefin $(S)$-4 (161 mg, $0.393 \mathrm{mmol}, 98 \%$ yield) as a white solid (m.p. $118^{\circ} \mathrm{C}$ ). The enantiomeric excess was determined to be $94 \%$ by HPLC analysis on a Daicel Chiralpak IB N-5 column: 99:1 hexane/IPA, flow rate $1 \mathrm{~mL} / \mathrm{min}, \lambda=254$ $\mathrm{nm}: \tau_{\text {Minor }}=6.9 \mathrm{~min} \tau_{\text {Major }}=8.4 \mathrm{~min}$. Absolute configuration was determined by X-Ray diffraction analysis of a single crystal of $(S)-4$ (details in section F).

$[\alpha] \mathrm{D}^{20}=+67.5\left(\mathrm{c}=0.37, \mathrm{CHCl}_{3}, 94 \%\right.$ ee $)$.

${ }^{1} \mathrm{H}$ NMR $(400 \mathrm{MHz}$, Chloroform- $d) \delta 7.39-7.26(\mathrm{~m}, 9 \mathrm{H}, \mathrm{ArH}), 7.22-7.16(\mathrm{~m}, 1 \mathrm{H}, \mathrm{ArH}), 7.14(\mathrm{~d}, J=7.8$ $\mathrm{Hz}, 2 \mathrm{H}, \mathrm{ArH}), 7.05(\mathrm{~d}, J=8.1 \mathrm{~Hz}, 2 \mathrm{H}, \mathrm{ArH}), 5.13\left(\mathrm{q}, J=5.3 \mathrm{~Hz}, 1 \mathrm{H}, \mathrm{CHCF}_{3}\right), 3.99(\mathrm{~d}, J=13.3 \mathrm{~Hz}, 1 \mathrm{H}$, $\left.\mathrm{PhCH}_{a} \mathrm{H}_{b}\right), 3.94\left(\mathrm{~d}, J=16.0 \mathrm{~Hz}, 1 \mathrm{H}, \mathrm{NCH}_{a} \mathrm{H}_{b} \mathrm{C}=\mathrm{C}\right), 3.89$ (d, $\left.J=13.2 \mathrm{~Hz}, 1 \mathrm{H}, \mathrm{PhCH}_{a} H_{b}\right), 3.54$ (d, $J=16.0$ $\left.\mathrm{Hz}, 1 \mathrm{H}, \mathrm{NCH}_{\mathrm{a}} H_{b} \mathrm{C}=\mathrm{C}\right)$ ), $2.35\left(\mathrm{~s}, 3 \mathrm{H}, \mathrm{CH}_{3}\right)$.

${ }^{13} \mathrm{C}\left\{{ }^{1} \mathrm{H}\right\}$ NMR $(101 \mathrm{MHz}$, Chloroform- $d) \delta 148.4,138.8,137.2,137.1,136.7,130.0,129.4,129.1,128.8$ (2C), 128.04, 128.02, 126.3, $122.9\left(\mathrm{q}, J_{C-F}=283.9 \mathrm{~Hz}\right), 112.9,94.00\left(\mathrm{q}, J_{C-F}=34.4 \mathrm{~Hz}\right), 60.5,54.9,21.3$. ${ }^{19} \mathrm{~F}$ NMR $(376 \mathrm{MHz}$, Chloroform- $d$ ) $\delta-80.3$.

IR $\left(\mathrm{cm}^{-1}\right) 3031(\mathrm{w}), 1665(\mathrm{w}), 1503(\mathrm{w}), 1451(\mathrm{w}), 1293(\mathrm{~m}), 1175(\mathrm{~s}), 1153(\mathrm{~s})$.

$\underline{\text { HRMS }}$ (ESI/QTOF) m/z: [M+ H] $]^{+}$Calculated for $\mathrm{C}_{25} \mathrm{H}_{23} \mathrm{~F}_{3} \mathrm{NO}^{+} 410.1726$; Found 410.1728 .

5 mmol scale reaction. The model reaction was repeated on $5 \mathrm{mmol}$ scale. An oven dried $50 \mathrm{~mL}$ roundbottom flask equipped with a Teflon stir bar was charged with $\mathrm{Pd}_{2}(\mathrm{dba})_{3} \cdot \mathrm{CHCl}_{3}(65 \mathrm{mg}, 63 \mu \mathrm{mol}, 1.25$ mol\%), the ligand (90 mg, $0.18 \mathrm{mmol}, 3.5 \mathrm{~mol} \%$ ) and $\mathrm{K}_{3} \mathrm{PO}_{4}(1.38 \mathrm{~g}, 6.50 \mathrm{mmol}, 1.3 \mathrm{equiv}$.). The flask was then purged with $\mathrm{N}_{2}$ and placed in a heating metal block. $20 \mathrm{~mL}$ of $\mathrm{Et}_{2} \mathrm{O}$ were added and the suspension was stirred at $35^{\circ} \mathrm{C}$ for 10 minutes N-benzyl-3-phenylprop-2-yn-1-amine (1.11 g, $5.00 \mathrm{mmol}, 1.0$ equiv) and 1-ethoxy-2,2,2-trifluoroethanol ( $85 \%$ in EtOH, $0.96 \mathrm{~mL}, 7.0 \mathrm{mmol}, 1.4$ equiv.) were added followed by 1-iodo-4-methylbenzene ( $1.42 \mathrm{~g}, 6.50 \mathrm{mmol}, 1.3$ equiv.) and the remaining $5 \mathrm{~mL}$ of $\mathrm{Et}_{2} \mathrm{O}$ to rinse the wall. The resulting suspension was stirred at $35{ }^{\circ} \mathrm{C}$ for 16 hours. Then, the reaction mixture was filtered through a plug of deactivated silica gel eluting with $50 \mathrm{~mL}$ of pentane/EtOAc 9:1 and concentrated in vacuo and analyzed by ${ }^{1} \mathrm{H}$ NMR with an internal standard (trichloroethylene, 0.1 equiv., NMR yield: >99\%). The crude material was purified by flash column chromatography (pentane/EtOAc gradient 100:0 to 100:3) to give the corresponding product $(S)-4(2.04 \mathrm{~g}, 4.98 \mathrm{mmol}$, >99\% yield) as a white solid. The enantiomeric 
excess was determined to be $94 \%$ by HPLC analysis on a Daicel Chiralpak IB N-5 column: 99:1 hexane $/ \mathrm{IPA}$, flow rate $1 \mathrm{~mL} / \mathrm{min}, \lambda=254 \mathrm{~nm}: \tau_{\text {Minor }}=6.9 \mathrm{~min} \tau_{\text {Major }}=8.6 \mathrm{~min}$.

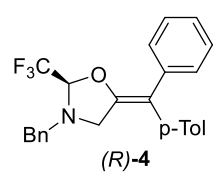

$(R, E)-3-B e n z y l-5-(p h e n y l(p-t o l y l) m e t h y l e n e)-2-(t r i f l u o r o m e t h y l) o x a z o l i d i n e ~((R)-4)$

Prepared according to the general procedure D1 using N-benzyl-3-phenylprop-2-yn-1amine (76 $\mu \mathrm{L}, 0.40 \mathrm{mmol}, 1.0$ equiv.), 1-iodo-4-methylbenzene (113 mg, $0.520 \mathrm{mmol}, 1.3$ equiv) and the $(R, R)$-L9 ligand. The crude material was purified by flash column chromatography (pentane/EtOAc gradient 100:0 to 100:3) to give the corresponding olefin 3 (160 mg, $0.390 \mathrm{mmol}, 98 \%$ yield) as a white solid. The enantiomeric excess was determined to be 92\% by HPLC analysis on a Daicel Chiralpak IB N-5 column: 99:1 hexane/IPA, flow rate $1 \mathrm{~mL} / \mathrm{min}, \lambda=$ $254 \mathrm{~nm}: \tau_{\text {Major }}=7.0 \mathrm{~min} \tau_{\text {Minor }}=8.6 \mathrm{~min} .[\alpha] \mathrm{D}^{20}=-52.3\left(\mathrm{c}=0.50, \mathrm{CHCl}_{3}, 92 \%\right.$ ee $)$. Absolute configuration determined in comparison to compound $(S)-4$.

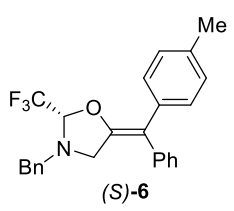

(S,Z)-3-Benzyl-5-(phenyl(p-tolyl)methylene)-2-(trifluoromethyl)oxazolidine

$((S)-$ 6))

Prepared according to the general procedure D1 using N-benzyl-3-(p-tolyl)prop-2-yn-1amine (94 mg, $0.40 \mathrm{mmol}, 1.0$ equiv.) and iodobenzene (108 mg, $58 \mu \mathrm{l}, 0.520 \mathrm{mmol}$, 1.3 equiv.). The crude material was purified by flash column chromatography (pentane/EtOAc gradient 100:0 to 97:3) to give the corresponding olefin $(S)$-6 (152 mg, $0.372 \mathrm{mmol}, 93 \%$ yield) as colorless oil. The enantiomeric excess was determined to be $89 \%$ by HPLC analysis on a Daicel Chiralpak IB N-5 column: 99:1 hexane/IPA, flow rate $1 \mathrm{~mL} / \mathrm{min}, \lambda=254 \mathrm{~nm}$ : $\tau_{\text {Minor }}=$ $7.0 \mathrm{~min}, \tau_{\mathrm{Major}}=8.1 \mathrm{~min}$. Absolute configuration determined in comparison to compound $(S)-\mathbf{4}$.

$[\alpha] \mathrm{D}^{20}=45.6\left(\mathrm{c}=0.55, \mathrm{CHCl}_{3}, 89 \%\right.$ ee $)$.

${ }^{1} \mathrm{H}$ NMR (400 MHz, Chloroform-d) $\delta 7.36-7.28(\mathrm{~m}, 7 \mathrm{H}, \mathrm{ArH}), 7.27-7.21(\mathrm{~m}, 3 \mathrm{H}, \mathrm{ArH}), 7.18-7.13(\mathrm{~m}$, $2 \mathrm{H}, \mathrm{ArH}), 7.10(\mathrm{~d}, J=8.0 \mathrm{~Hz}, 2 \mathrm{H}, \mathrm{ArH}), 5.11\left(\mathrm{q}, J=5.3 \mathrm{~Hz}, 1 \mathrm{H}, \mathrm{CHCF}_{3}\right), 4.03-3.83\left(\mathrm{~m}, 3 \mathrm{H}, \mathrm{PhCH}_{2}\right.$ and $\left.\mathrm{NCH}_{a} \mathrm{H}_{\mathrm{b}} \mathrm{C}=\mathrm{C}\right), 3.52\left(\mathrm{~d}, J=15.7 \mathrm{~Hz}, 1 \mathrm{H}, \mathrm{NCH}_{\mathrm{a}} \mathrm{H}_{b} \mathrm{C}=\mathrm{C}\right), 2.33\left(\mathrm{~s}, 3 \mathrm{H}, \mathrm{ArCH}_{3}\right)$.

${ }^{13} \mathrm{C}\left\{{ }^{1} \mathrm{H}\right\}$ NMR (101 MHz, Chloroform-d) $\delta 148.1,140.3,137.1,136.1,135.8,130.2,129.0,128.81,128.77$ (2C), 128.7, 128.0, 127.0, 122.9 (q, $J=284.0 \mathrm{~Hz}), 113.0,93.9(\mathrm{q}, J=34.3 \mathrm{~Hz}), 60.5,54.8,21.3$.

${ }^{19} \mathrm{~F}$ NMR $(376 \mathrm{MHz}$, Chloroform- $d$ ) $\delta-80.4(\mathrm{~d}, 3 \mathrm{~F}, J=5.3 \mathrm{~Hz})$.

$\underline{\text { IR }\left(\mathrm{cm}^{-1}\right)} 3024(\mathrm{w}), 3023(\mathrm{w}), 1664(\mathrm{w}), 1505(\mathrm{w}), 1295(\mathrm{~m}), 1214(\mathrm{~m}), 1154(\mathrm{~m})$.

HRMS (ESI/QTOF) m/z: [M + Na] ${ }^{+}$Calculated for $\mathrm{C}_{25} \mathrm{H}_{22} \mathrm{~F}_{3} \mathrm{NNaO}^{+} 432.1546$; Found 432.1547 .

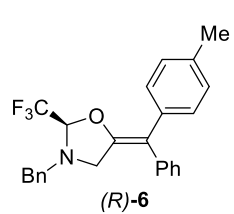

(R,Z)-3-Benzyl-5-(phenyl(p-tolyl)methylene)-2-(trifluoromethyl)oxazolidine

$((\boldsymbol{R})-$ 6)

Prepared according to the general procedure D1 using N-benzyl-3-(p-tolyl)prop-2-yn-1amine (94 mg, $0.40 \mathrm{mmol}, 1.0$ equiv.), iodobenzene (108 mg, $58 \mu 1,0.520 \mathrm{mmol}$, 1.3 equiv.) and the $(R, R)$-L9 ligand. The crude material was purified by flash column chromatography (pentane/EtOAc gradient 100:0 to $97: 3$ ) to give the corresponding olefin $(R)$-6. (142 mg, $0.347 \mathrm{mmol}, 87 \%$ yield) as colorless oil. The enantiomeric excess was determined to be $89 \%$ by HPLC analysis on a Daicel Chiralpak IB N-5 column: 99:1 hexane/IPA, flow rate $1 \mathrm{~mL} / \mathrm{min}$, $\lambda=254 \mathrm{~nm}: \tau_{\text {Major }}=7.6 \mathrm{~min}, \tau_{\text {Minor }}=9.0 \mathrm{~min} .[\alpha] \mathrm{D}^{20}=-45.1\left(\mathrm{c}=0.58, \mathrm{CHCl}_{3}, 89 \%\right.$ ee $)$. Absolute configuration determined in comparison to compound $(S)-4$.

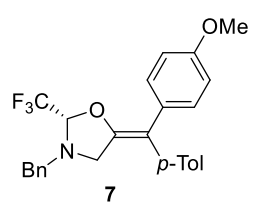

\section{(trifluoromethyl)oxazolidine (7)}

(S,Z)-3-Benzyl-5-((4-methoxyphenyl)(p-tolyl)methylene)-2-

Prepared according to the general procedure D1 using N-benzyl-3-(4(methoxy)phenyl)prop-2-yn-1-amine (101 mg, $0.400 \mathrm{mmol}, 1.0$ equiv.) and $p$ iodotoluene (113 mg, $0.520 \mathrm{mmol}, 1.3$ equiv.). The crude material was purified by flash column chromatography (pentane/EtOAc gradient 100:0 to 97:3) to give the corresponding olefin 7 (154 mg, $0.352 \mathrm{mmol}, 88 \%$ yield) as amorphous white solid. The enantiomeric excess was determined to be $92 \%$ by HPLC analysis on a Daicel Chiralpak IB N-5 column: 99:1 hexane $/ \mathrm{IPA}$, flow rate $1 \mathrm{~mL} / \mathrm{min}, \lambda=254 \mathrm{~nm}$ : $\tau_{\text {Minor }}=10.9 \mathrm{~min}, \tau_{\text {Major }}=22.6 \mathrm{~min}$. Absolute configuration determined in comparison to compound $(S)-\mathbf{4}$.

$[\alpha] \mathrm{D}^{20}=54.5\left(\mathrm{c}=0.52, \mathrm{CHCl}_{3}, 92 \%\right.$ ee $)$. 
${ }^{1} \mathrm{H}$ NMR $(400 \mathrm{MHz}$, Chloroform-d) $\delta 7.36-7.27$ (m, 7H, ArH), $7.16-7.09$ (m, 2H, ArH), $7.07-7.00$ (m, $\overline{2 \mathrm{H}, \mathrm{ArH}}), 6.87-6.78(\mathrm{~m}, 2 \mathrm{H}, \mathrm{ArH}), 5.10\left(\mathrm{q}, J=5.3 \mathrm{~Hz}, 1 \mathrm{H}, \mathrm{CHCF}_{3}\right), 4.03-3.85\left(\mathrm{~m}, 3 \mathrm{H}, \mathrm{PhCH}_{2}\right.$ and $\left.\mathrm{NCH}_{a} \mathrm{H}_{\mathrm{b}} \mathrm{C}=\mathrm{C}\right), 3.80\left(\mathrm{~s}, 3 \mathrm{H}, \mathrm{OCH}_{3}\right), 3.52\left(\mathrm{dd}, J=15.7,0.9 \mathrm{~Hz}, 1 \mathrm{H}, \mathrm{NCH}_{\mathrm{a}} H_{b} \mathrm{C}=\mathrm{C}\right), 2.34\left(\mathrm{~s}, 3 \mathrm{H}, \mathrm{ArCH}_{3}\right)$.

${ }^{13} \mathrm{C}\left\{{ }^{1} \mathrm{H}\right\}$ NMR (101 MHz, Chloroform-d) $\delta 158.0,147.3,147.3,137.4,137.1,136.7,131.4,130.2,130.0$, 129.4, 128.8, 128.0, 122.9 (q, $J=283.9 \mathrm{~Hz}), 113.5,112.5,93.8$ (q, $J=34.2 \mathrm{~Hz}), 60.5,55.4,54.8,21.3$.

${ }^{19} \mathrm{~F} \mathrm{NMR}(376 \mathrm{MHz}$, Chloroform- $d) \delta-80.3(\mathrm{~d}, 3 \mathrm{~F}, J=5.3 \mathrm{~Hz})$.

$\underline{\mathrm{IR}}\left(\mathrm{cm}^{-1}\right) 2941(\mathrm{w}), 2835(\mathrm{w}), 1664(\mathrm{~m}), 1607(\mathrm{~m}), 1512(\mathrm{~m}), 1293(\mathrm{~m}), 1247(\mathrm{~m}), 1176(\mathrm{~s}), 1155(\mathrm{~s}), 1033$ $(\mathrm{m})$.

$\underline{\text { HRMS }}(\text { ESI/QTOF) m/z: [M + Na }]^{+}$Calculated for $\mathrm{C}_{26} \mathrm{H}_{24} \mathrm{~F}_{3} \mathrm{NNaO}_{2}{ }^{+} 462.1651$; Found 462.1661 .

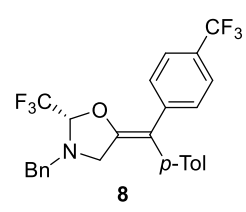

(trifluoromethyl)oxazolidine (8)

(S,Z)-3-Benzyl-5-(p-tolyl(4-(trifluoromethyl)phenyl)methylene)-2-

Prepared according to the general procedure D1 using N-benzyl-3-(4(trifluoromethyl)phenyl)prop-2-yn-1-amine (116 mg, $0.400 \mathrm{mmol}, 1.0$ equiv.) and $p$ iodotoluene (113 mg, $0.520 \mathrm{mmol}, 1.3$ equiv.). The crude material was purified by flash column chromatography (pentane/EtOAc gradient 100:0 to $97: 3$ ) to give the corresponding olefin 8 (165 mg, $0.346 \mathrm{mmol}, 86 \%$ yield) as colorless oil. The enantiomeric excess was determined to be $88 \%$ by HPLC analysis on a Daicel Chiralpak IB N-5 column: 99:1 hexane/IPA, flow rate $1 \mathrm{~mL} / \mathrm{min}, \lambda=254 \mathrm{~nm}: \tau_{\text {Minor }}=6.8 \mathrm{~min}, \tau_{\text {Major }}=9.5 \mathrm{~min}$. Absolute configuration determined in comparison to compound $(S)-4$.

$[\alpha] \mathrm{D}^{20}=37.9\left(\mathrm{c}=0.51, \mathrm{CHCl}_{3}, 88 \%\right.$ ee $)$.

${ }^{1} \mathrm{H}$ NMR $(400 \mathrm{MHz}$, Chloroform-d) $\delta 7.51(\mathrm{~d}, J=8.5 \mathrm{~Hz}, 2 \mathrm{H}, \mathrm{ArH}), 7.46(\mathrm{~d}, J=8.5 \mathrm{~Hz}, 2 \mathrm{H}, \mathrm{ArH}), 7.36-$ $7.27(\mathrm{~m}, 5 \mathrm{H}, \mathrm{ArH}), 7.15(\mathrm{~d}, J=8.0 \mathrm{~Hz}, 2 \mathrm{H}, \mathrm{ArH}), 7.02(\mathrm{~d}, J=8.0 \mathrm{~Hz}, 2 \mathrm{H}, \mathrm{ArH}), 5.17(\mathrm{q}, J=5.2 \mathrm{~Hz}, 1 \mathrm{H}$, $\left.\mathrm{CHCF}_{3}\right), 3.99\left(\mathrm{~d}, J=13.3 \mathrm{~Hz}, 1 \mathrm{H}, \mathrm{PhCH}_{a} \mathrm{H}_{\mathrm{b}}\right), 3.95\left(\mathrm{~d}, J=16.2 \mathrm{~Hz}, 1 \mathrm{H}, \mathrm{NCH}_{a} \mathrm{H}_{\mathrm{b}} \mathrm{C}=\mathrm{C}\right), 3.90(\mathrm{~d}, J=13.3$ $\left.\mathrm{Hz}, 1 \mathrm{H}, \mathrm{PhCH}_{\mathrm{a}} H_{b}\right), 3.54\left(\mathrm{~d}, J=16.2 \mathrm{~Hz}, 1 \mathrm{H}, \mathrm{NCH}_{\mathrm{a}} \mathrm{H}_{b} \mathrm{C}=\mathrm{C}\right), 2.36\left(\mathrm{~s}, 3 \mathrm{H}, \mathrm{ArCH}_{3}\right)$.

${ }^{13} \mathrm{C}\left\{{ }^{1} \mathrm{H}\right\}$ NMR (101 MHz, Chloroform-d) $\delta 150.2,142.4,137.3,138.8,136.3,130.0,129.7,129.1,128.83$, $128.78,128.2,127.9(\mathrm{q}, J=32.0 \mathrm{~Hz}), 124.9(\mathrm{q}, J=3.7 \mathrm{~Hz}), 124.5(\mathrm{q}, J=272 \mathrm{~Hz}), 122.7(\mathrm{q}, J=284.0 \mathrm{~Hz})$ 111.7, 94.4 (q $J=34.4 \mathrm{~Hz}), 60.6,55.1,21.3$.

${ }^{19} \mathrm{~F}$ NMR $\left(376 \mathrm{MHz}\right.$, Chloroform- $d$ ) $\delta-62.4\left(\mathrm{~s}, 3 \mathrm{~F}, \mathrm{ArCF}_{3}\right),-80.4\left(\mathrm{~d}, 3 \mathrm{~F}, J=5.2 \mathrm{~Hz}, \mathrm{CHCF}_{3}\right)$.

$\underline{\mathrm{IR}}\left(\mathrm{cm}^{-1}\right) 2979(\mathrm{~m}), 2901(\mathrm{~m}), 1662(\mathrm{~m}), 1616(\mathrm{~m}), 1516(\mathrm{~m}), 1329(\mathrm{~s}), 1157$ (s), 1122 (s), $1075(\mathrm{~m})$.

HRMS (ESI/QTOF) m/z: [M+H] ${ }^{+}$Calculated for $\mathrm{C}_{26} \mathrm{H}_{22} \mathrm{~F}_{6} \mathrm{NO}^{+} 478.1600$; Found 478.1607.

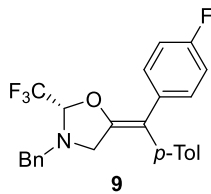

\section{(trifluoromethyl)oxazolidine (9)}

$(S, Z)-3-B e n z y l-5-((4-f l u o r o p h e n y l)(p$-tolyl)methylene)-2-

Prepared according to the general procedure D1 using N-benzyl-3-(4(fluoro)phenyl)prop-2-yn-1-amine (96 mg, $0.40 \mathrm{mmol}, 1.0$ equiv.) and $p$-iodotoluene (113 mg, $0.520 \mathrm{mmol}, 1.3$ equiv.). The crude material was purified by flash column chromatography (pentane/EtOAc gradient 100:0 to 97:3) to give the corresponding olefin 9 (168 mg, $0.392 \mathrm{mmol}, 98 \%$ yield) as amorphous white solid. The enantiomeric excess was determined to be $91 \%$ by HPLC analysis on a Daicel Chiralpak IB N-5 column: 99:1 hexane/IPA, flow rate $1 \mathrm{~mL} / \mathrm{min}, \lambda$ $=254 \mathrm{~nm}: \tau_{\text {Minor }}=6.5 \mathrm{~min}, \tau_{\text {Major }}=8.2 \mathrm{~min}$. Absolute configuration determined in comparison to compound (S)-4.

$[\alpha] \mathrm{D}^{20}=56.3\left(\mathrm{c}=0.50, \mathrm{CHCl}_{3}, 91 \%\right.$ ee $)$.

${ }^{1} \mathrm{H}$ NMR (400 MHz, Chloroform-d) $\delta 7.36-7.27(\mathrm{~m}, 7 \mathrm{H}, \mathrm{ArH}), 7.13(\mathrm{~d}, J=7.8 \mathrm{~Hz}, 2 \mathrm{H}, \mathrm{ArH}), 7.06-6.99$ $(\mathrm{m}, 2 \mathrm{H}, \mathrm{ArH}), 6.99-6.92(\mathrm{~m}, 2 \mathrm{H}, \mathrm{ArH}), 5.12\left(\mathrm{q}, J=5.3 \mathrm{~Hz}, 1 \mathrm{H}, \mathrm{CHCF}_{3}\right), 4.02-3.83\left(\mathrm{~m}, 3 \mathrm{H}, \mathrm{PhCH}_{2}\right.$ and $\left.\mathrm{NCH}_{a} \mathrm{H}_{\mathrm{b}} \mathrm{C}=\mathrm{C}\right), 3.52\left(\mathrm{dd}, J=15.8,1.0 \mathrm{~Hz}, 1 \mathrm{H}, \mathrm{NCH}_{\mathrm{a}} H_{b} \mathrm{C}=\mathrm{C}\right), 2.35\left(\mathrm{~s}, 3 \mathrm{H}, \mathrm{ArCH}_{3}\right)$.

${ }^{13} \mathrm{C}\left\{{ }^{1} \mathrm{H}\right\}$ NMR (101 MHz, Chloroform-d) $\delta 161.3(\mathrm{~d}, J=245.8 \mathrm{~Hz}), 148.25,148.24,137.0$ (2C), 136.9, $134.8(\mathrm{~d}, J=3.2 \mathrm{~Hz}), 130.7,130.6,129.9,129.5,128.79,128.76,122.82(\mathrm{~d}, J=284.0 \mathrm{~Hz}), 114.9(\mathrm{~d}, J=$ $21.2 \mathrm{~Hz}), 94.0(\mathrm{q}, J=34.2 \mathrm{~Hz}), 60.5,54.8,21.3$.

${ }^{19} \mathrm{~F}$ NMR $\left(376 \mathrm{MHz}\right.$, Chloroform- $d$ ) $\delta-80.4\left(\mathrm{~d}, 3 \mathrm{~F}, J=5.3 \mathrm{~Hz}, \mathrm{CHCF}_{3}\right),-116.2(\mathrm{tt}, 1 \mathrm{~F}, J=8.8,5.5 \mathrm{~Hz}$, $\operatorname{Ar} F)$.

$\underline{\text { IR }}\left(\mathrm{cm}^{-1}\right) 2979(\mathrm{~m}), 2908(\mathrm{~m}), 1665(\mathrm{w}), 1508(\mathrm{~m}), 1402(\mathrm{~m}), 1229(\mathrm{~s}), 1154(\mathrm{~s}), 1066(\mathrm{~s})$.

$\underline{\text { HRMS }}$ (ESI/QTOF) m/z: $[\mathrm{M}+\mathrm{H}]^{+}$Calculated for $\mathrm{C}_{25} \mathrm{H}_{22} \mathrm{~F}_{4} \mathrm{NO}^{+} 428.1632$; Found 428.1627 . 


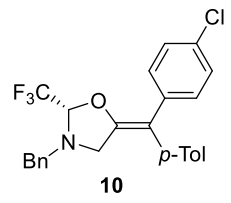

\section{(trifluoromethyl)oxazolidine (10)}

$(S, Z)-3-B e n z y l-5-((4-c h l o r o p h e n y l)(p-t o l y l) m e t h y l e n e)-2-$

Prepared according to the general procedure D1 using N-benzyl-3-(4(chloro)phenyl)prop-2-yn-1-amine (102 $\mathrm{mg}, 0.400 \mathrm{mmol}, 1.0$ equiv.) and $p$-iodotoluene (113 mg, $0.520 \mathrm{mmol}, 1.3$ equiv.). The crude material was purified by flash column chromatography (pentane/EtOAc gradient 100:0 to 97:3) to give the corresponding olefin 10 (159 mg, $0.360 \mathrm{mmol}, 90 \%$ yield) as colorless oil. The enantiomeric excess was determined to be $90 \%$ by HPLC analysis on a Daicel Chiralpak IB N-5 column: 99:1 hexane/IPA, flow rate $1 \mathrm{~mL} / \mathrm{min}, \lambda=254$ $\mathrm{nm}$ : $\tau_{\text {Minor }}=6.9 \mathrm{~min}, \tau_{\text {Major }}=9.1 \mathrm{~min}$. Absolute configuration determined in comparison to compound $(S)$ 4.

$[\alpha] \mathrm{D}^{20}=34.7\left(\mathrm{c}=0.38, \mathrm{CHCl}_{3}, 90 \%\right.$ ee $)$.

${ }^{1} \mathrm{H}$ NMR $(400 \mathrm{MHz}$, Chloroform-d) $\delta 7.36-7.20(\mathrm{~m}, 9 \mathrm{H}, \operatorname{Ar} H), 7.14(\mathrm{~d}, J=7.9 \mathrm{~Hz}, 2 \mathrm{H}, \operatorname{Ar} H), 7.01(\mathrm{~d}, J$ $=7.9 \mathrm{~Hz}, 2 \mathrm{H}, \mathrm{Ar} H), 5.14\left(\mathrm{q}, J=5.3 \mathrm{~Hz}, 1 \mathrm{H}, \mathrm{CHCF}_{3}\right), 4.03-3.81\left(\mathrm{~m}, 3 \mathrm{H}, \mathrm{PhCH}_{2}\right.$ and $\left.\mathrm{NCH}_{a} \mathrm{H}_{\mathrm{b}} \mathrm{C}=\mathrm{C}\right), 3.52$ (dd, $\left.J=15.9,0.9 \mathrm{~Hz}, 1 \mathrm{H}, \mathrm{NCH}_{\mathrm{a}} \mathrm{H}_{b} \mathrm{C}=\mathrm{C}\right), 2.35$ (s, 3H, $\mathrm{ArCH}_{3}$ ).

${ }^{13} \mathrm{C}\left\{{ }^{1} \mathrm{H}\right\}$ NMR (101 MHz, Chloroform-d) $\delta 148.9,137.3,137.0,136.9,136.7,131.9,130.3,130.0,129.6$, 128.80, 128.76, 128.2, 128.1, 122.8 (q, $J=283.9 \mathrm{~Hz}), 111.8,91.2(\mathrm{q}, J=34.4 \mathrm{~Hz}), 60.5,55.0,21.3$.

${ }^{19} \mathrm{~F}$ NMR $(376 \mathrm{MHz}$, Chloroform- $d$ ) $\delta-80.4(\mathrm{~d}, 3 \mathrm{~F}, J=5.3 \mathrm{~Hz})$.

IR $\left(\mathrm{cm}^{-1}\right) 2928(\mathrm{~m}), 2855(\mathrm{~m}), 1664(\mathrm{~m}), 1496(\mathrm{~m}), 1292(\mathrm{~m}), 1177(\mathrm{~s}), 1154(\mathrm{~s}), 1096(\mathrm{~m})$.

HRMS (ESI/QTOF) m/z: [M+ H] $]^{+}$Calculated for $\mathrm{C}_{25} \mathrm{H}_{22} \mathrm{ClF}_{3} \mathrm{NO}^{+} 444.1337$; Found 444.1332 .

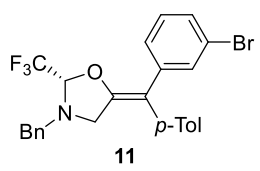

$(S, Z)-3-B e n z y l-5-((3-b r o m o p h e n y l)(p-t o l y l) m e t h y l e n e)-2-$

\section{(trifluoromethyl)oxazolidine (11)}

Prepared according to the general procedure D1 using N-benzyl-3-(3bromophenyl)prop-2-yn-1-amine (120 mg, $0.400 \mathrm{mmol}, 1.0$ equiv.) and $p$-iodotoluene (113 $\mathrm{mg}, 0.520 \mathrm{mmol}, 1.3$ equiv.). The crude material was purified by flash column chromatography (pentane/EtOAc gradient 100:0 to 97:3) to give the corresponding olefin 11 (149 mg, $0.304 \mathrm{mmol}, 76 \%$ yield) as colorless oil. The enantiomeric excess was determined to be $82 \%$ by HPLC analysis on a Daicel Chiralpak IB N-5 column: $99: 1$ hexane/IPA, flow rate $1 \mathrm{~mL} / \mathrm{min}, \lambda=254 \mathrm{~nm}: \tau_{\text {Minor }}=$ $8.4 \mathrm{~min}, \tau_{\mathrm{Minor}}=10.4 \mathrm{~min}$. Absolute configuration determined in comparison to compound $(S)-\mathbf{4}$.

$[\alpha] \mathrm{D}^{20}=21.4\left(\mathrm{c}=0.64, \mathrm{CHCl}_{3}, 82 \%\right.$ ee $)$.

${ }^{1} \mathrm{H}$ NMR $(400 \mathrm{MHz}$, Chloroform-d) $\delta 7.49(\mathrm{t}, J=1.7 \mathrm{~Hz}, 1 \mathrm{H}, \mathrm{Ar} H), 7.36-7.26(\mathrm{~m}, 7 \mathrm{H}, \mathrm{ArH}), 7.17-7.09$ $(\mathrm{m}, 3 \mathrm{H}, \mathrm{Ar} H), 7.01(\mathrm{~d}, J=8.0 \mathrm{~Hz}, 2 \mathrm{H}, o-\mathrm{Me}-\mathrm{Ar} H), 5.15\left(\mathrm{q}, J=5.3 \mathrm{~Hz}, 1 \mathrm{H}, \mathrm{CHCF}_{3}\right), 4.01-3.81(\mathrm{~m}, 3 \mathrm{H}$, $\mathrm{PhCH}_{2}$ and $\left.\mathrm{NCH}_{a} \mathrm{H}_{\mathrm{b}} \mathrm{C}=\mathrm{C}\right), 3.50\left(\mathrm{~d}, J=16.1 \mathrm{~Hz}, 1 \mathrm{H}, \mathrm{NCH}_{\mathrm{a}} H_{b} \mathrm{C}=\mathrm{C}\right), 2.35\left(\mathrm{~s}, 3 \mathrm{H}, \mathrm{ArCH}_{3}\right)$.

${ }^{13} \mathrm{C}\left\{{ }^{1} \mathrm{H}\right\}$ NMR (101 MHz, Chloroform-d) $\delta 149.5,140.9,137.1,136.9,136.4,131.9,130.0,129.6,129.5$, $129.2,128.81,128.78,128.1,127.7,122.7(\mathrm{q}, J=284.1 \mathrm{~Hz}), 122.3,111.6,94.2(\mathrm{q}, J=34.5 \mathrm{~Hz}), 60.6$,

55.0, 21.3.

${ }^{19} \mathrm{~F}$ NMR $(376 \mathrm{MHz}$, Chloroform- $d$ ) $\delta-80.3(\mathrm{~d}, 3 \mathrm{~F}, J=5.3 \mathrm{~Hz})$.

$\underline{\mathrm{IR}}\left(\mathrm{cm}^{-1}\right) 2927(\mathrm{w}), 2850(\mathrm{w}), 1664$ (m), 1593 (m), 1480 (m), 1465 (m), 1292 (m), 1179 (s), 1154 (s), 1082 (m).

HRMS (ESI/QTOF) m/z: [M + H] ${ }^{+}$Calculated for $\mathrm{C}_{25} \mathrm{H}_{22}{ }^{79} \mathrm{BrF}_{3} \mathrm{NO}^{+}$488.0831; Found 488.0830.

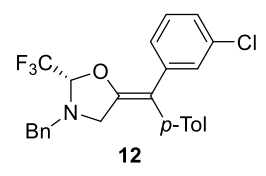

(S,Z)-3-Benzyl-5-((3-chlorophenyl)(p-tolyl)methylene)-2(trifluoromethyl)oxazolidine (12)

Prepared according to the general procedure D1 using N-benzyl-3-(3chlorophenyl)prop-2-yn-1-amine (102 mg, $0.400 \mathrm{mmol}, 1.0$ equiv.) and $p$-iodotoluene (113 $\mathrm{mg}, 0.520 \mathrm{mmol}, 1.3$ equiv.). The crude material was purified by flash column chromatography (pentane/EtOAc gradient 100:0 to 97:3) to give the corresponding olefin $12(168 \mathrm{mg}$, $0.380 \mathrm{mmol}, 95 \%$ yield) as amorphous white solid. The enantiomeric excess was determined to be $84 \%$ by HPLC analysis on a Daicel Chiralpak IB N-5 column: 99:1 hexane/IPA, flow rate $1 \mathrm{~mL} / \mathrm{min}, \lambda=254 \mathrm{~nm}$ : $\tau_{\text {Minor }}=8.2 \mathrm{~min}, \tau_{\text {Major }}=10.5 \mathrm{~min}$. Absolute configuration determined in comparison to compound $(S)-4$. $[\alpha] \mathrm{D}^{20}=33.0\left(\mathrm{c}=0.48, \mathrm{CHCl}_{3}, 84 \%\right.$ ee $)$.

${ }^{1} \mathrm{H}$ NMR $(400 \mathrm{MHz}$, Chloroform-d) $\delta 7.36-7.27(\mathrm{~m}, 6 \mathrm{H}, \operatorname{Ar} H), 7.25-7.16(\mathrm{~m}, 2 \mathrm{H}, \operatorname{Ar} H), 7.17-7.10(\mathrm{~m}$, $3 \mathrm{H}, \mathrm{ArH}), 7.04-6.97(\mathrm{~m}, 2 \mathrm{H}, \mathrm{ArH}), 5.16\left(\mathrm{q}, J=5.3 \mathrm{~Hz}, 1 \mathrm{H}, \mathrm{CHCF}_{3}\right), 4.01-3.80\left(\mathrm{~m}, 3 \mathrm{H}, \mathrm{PhCH}_{2}\right.$ and $\left.\mathrm{NCH}_{a} \mathrm{H}_{\mathrm{b}} \mathrm{C}=\mathrm{C}\right), 3.50\left(\mathrm{dd}, J=16.0,1.0 \mathrm{~Hz}, 1 \mathrm{H}, \mathrm{NCH}_{\mathrm{a}} H_{b} \mathrm{C}=\mathrm{C}\right), 2.35\left(\mathrm{~s}, 3 \mathrm{H}, \mathrm{ArCH}_{3}\right)$. 
${ }^{13} \mathrm{C}\left\{{ }^{1} \mathrm{H}\right\}$ NMR (101 MHz, Chloroform-d) $\delta 149.4,140.6,137.1,136.9,136.4,134.0,130.0,129.6,129.2$, 129.0, 128.80, 128.78, 128.1, 127.2, 126.3, 122.7 (q, $J=284.0 \mathrm{~Hz}), 111.7,94.3$ (q, $J=34.2 \mathrm{~Hz}), 60.6,55.0$, 21.3.

${ }^{19} \mathrm{~F}$ NMR $(376 \mathrm{MHz}$, Chloroform- $d) \delta-80.3(\mathrm{~d}, 3 \mathrm{~F}, J=5.3 \mathrm{~Hz})$.

IR $\left(\mathrm{cm}^{-1}\right) 2842(\mathrm{w}), 1665(\mathrm{~m}), 1589$ (m), 1467 (w), 1293 (m), 1179 (s), 1154 (s), 1014 (m).

HRMS (ESI/QTOF) m/z: [M+ H] $]^{+}$Calculated for $\mathrm{C}_{25} \mathrm{H}_{22} \mathrm{ClF}_{3} \mathrm{NO}^{+} 444.1337$; Found 444.1337.

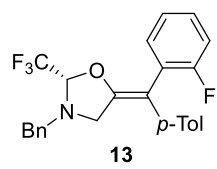

\section{(trifluoromethyl)oxazolidine (13)}

(S,Z)-3-benzyl-5-((2-fluorophenyl)(p-tolyl)methylene)-2-

Prepared according to the general procedure D1 using N-benzyl-3-(2-fluorophenyl)prop2-yn-1-amine (96 mg, $0.40 \mathrm{mmol}, 1.0$ equiv.) and $p$-iodotoluene (113 $\mathrm{mg}, 0.520 \mathrm{mmol}$, 1.3 equiv.). The crude material was purified by flash column chromatography (pentane/EtOAc gradient 100:0 to 97:3) to give the corresponding olefin 13 (165 mg, $0.380 \mathrm{mmol}, 97 \%$ yield) as amorphous white solid. The enantiomeric excess was determined to be $80 \%$ by HPLC analysis on a Daicel Chiralpak IB N-5 column: 99:1 hexane/IPA, flow rate $1 \mathrm{~mL} / \mathrm{min}, \lambda=254 \mathrm{~nm}$ : $\tau_{\text {Minor }}=6.6 \mathrm{~min}$, $\tau_{\text {Minor }}=7.4$ min. Absolute configuration determined in comparison to compound $(S)-4$.

$[\alpha] \mathrm{D}^{20}=6.2\left(\mathrm{c}=0.54, \mathrm{CHCl}_{3}, 80 \%\right.$ ee $)$.

${ }^{1} \mathrm{H}$ NMR (400 MHz, Chloroform-d) $\delta 7.41-7.27(\mathrm{~m}, 5 \mathrm{H}, \mathrm{ArH}), 7.26-7.16(\mathrm{~m}, 2 \mathrm{H}, \mathrm{ArH}), 7.13-7.03(\mathrm{~m}$, $4 \mathrm{H}, \operatorname{Ar} H), 7.04-6.94(\mathrm{~m}, 2 \mathrm{H}, \operatorname{Ar} H), 5.00\left(\mathrm{q}, J=5.3 \mathrm{~Hz}, 1 \mathrm{H}, \mathrm{CHCF}_{3}\right), 4.12(\mathrm{dd}, J=15.6,1.1 \mathrm{~Hz}, 1 \mathrm{H}$, $\left.\mathrm{NCH}_{a} \mathrm{H}_{\mathrm{b}} \mathrm{C}=\mathrm{C}\right), 3.99\left(\mathrm{~d}, J=13.3 \mathrm{~Hz}, 1 \mathrm{H}, \mathrm{PhCH}_{\mathrm{a}} \mathrm{H}_{\mathrm{b}}\right), 3.91\left(\mathrm{~d}, J=13.3 \mathrm{~Hz}, 1 \mathrm{H}, \mathrm{PhCH}_{\mathrm{a}} H_{b}\right), 3.72(\mathrm{dd}, J=15.6$, $\left.1.3 \mathrm{~Hz}, 1 \mathrm{H}, \mathrm{NCH}_{\mathrm{a}} \mathrm{H}_{b} \mathrm{C}=\mathrm{C}\right), 2.32\left(\mathrm{~s}, 3 \mathrm{H}, \mathrm{ArCH}_{3}\right)$.

${ }^{13} \mathrm{C}\left\{{ }^{1} \mathrm{H}\right\}$ NMR $(101 \mathrm{MHz}$, Chloroform-d) $\delta 160.4(\mathrm{~d}, J=248.0 \mathrm{~Hz}), 149.5,136.7(\mathrm{~d}, J=57.4 \mathrm{~Hz}), 136.6$, $133.2(\mathrm{~d}, J=3.8 \mathrm{~Hz}), 129.2,128.9,128.82,128.79,128.6,128.0,126.6(\mathrm{~d}, J=15.8 \mathrm{~Hz}), 124.1,123.91(\mathrm{~d}$, $J=3.5 \mathrm{~Hz}), 122.7(\mathrm{q}, J=283.9 \mathrm{~Hz}), 115.8(\mathrm{~d}, J=22.5 \mathrm{~Hz}), 107.8,93.2(\mathrm{q}, J=34.3 \mathrm{~Hz}), 60.5,54.0,21.3$. ${ }^{19} \mathrm{~F}$ NMR $\left(376 \mathrm{MHz}\right.$, Chloroform- $d$ ) $\delta-80.2\left(\mathrm{~d}, 3 \mathrm{~F}, J=5.3 \mathrm{~Hz}, \mathrm{CHCF}_{3}\right),-112.63--112.82(\mathrm{~m}, 1 \mathrm{~F}, \mathrm{Ar} F)$. $\underline{\mathrm{IR}}\left(\mathrm{cm}^{-1}\right) 2927(\mathrm{w}), 2858(\mathrm{w}), 1675(\mathrm{~m}), 1492(\mathrm{~m}), 1452$ (m), $1294(\mathrm{~m}), 1223(\mathrm{~m}), 1176(\mathrm{~s}), 1155$ (s), 1021 $(\mathrm{m})$.

$\underline{\text { HRMS }}$ (ESI/QTOF) m/z: [M + H] $]^{+}$Calculated for $\mathrm{C}_{25} \mathrm{H}_{22} \mathrm{~F}_{4} \mathrm{NO}^{+} 428.1632$; Found 428.1640 .

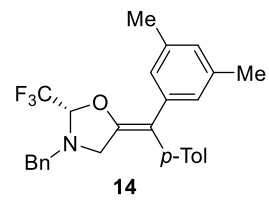

(trifluoromethyl)oxazolidine (14)

$(S, Z)-3-B e n z y l-5-((3,5-d i m e t h y l p h e n y l)(p-t o l y l) m e t h y l e n e)-2-$

Prepared according to the general procedure D1 using N-benzyl-3-(3,5dimethylphenyl)prop-2-yn-1-amine (100 mg, $0.400 \mathrm{mmol}, \quad 1.0$ equiv.) and $p$ iodotoluene (113 mg, $0.520 \mathrm{mmol}, 1.3$ equiv.). The crude material was purified by flash column chromatography (pentane/EtOAc gradient 100:0 to 97:3) to give the corresponding olefin 14 (155 mg, $0.356 \mathrm{mmol}, 89 \%$ yield) as colorless oil. The enantiomeric excess was determined to be $91 \%$ by HPLC analysis on a Daicel Chiralpak IB N-5 column: 99:1 hexane/IPA, flow rate $1 \mathrm{~mL} / \mathrm{min}, \lambda=254 \mathrm{~nm}: \tau_{\text {Minor }}=5.8 \mathrm{~min}, \tau_{\text {Major }}=7.2 \mathrm{~min}$. Absolute configuration determined in comparison to compound $(S)-4$.

$[\alpha] \mathrm{D}^{20}=56.7\left(\mathrm{c}=0.52, \mathrm{CHCl}_{3}, 91 \%\right.$ ee $)$.

${ }^{1} \mathrm{H}$ NMR (400 MHz, Chloroform-d) $\delta 7.36$ - 7.32 (m, 4H, ArH), $7.32-7.27$ (m, 1H, ArH), 7.11 (d, $J=7.8$ $\mathrm{Hz}, 2 \mathrm{H}, \operatorname{Ar} H), 7.05-6.99(\mathrm{~m}, 2 \mathrm{H}, \operatorname{ArH}), 6.96(\mathrm{~s}, 2 \mathrm{H}, \operatorname{Ar} H), 6.84(\mathrm{~s}, 1 \mathrm{H}, \operatorname{ArH}), 5.09$ (q, J = 5.3 Hz, 1H, $\left.\mathrm{CHCF}_{3}\right), 4.04-3.81\left(\mathrm{~m}, 3 \mathrm{H}, \mathrm{PhCH}_{2}\right.$ and $\left.\mathrm{NCH}_{a} \mathrm{H}_{\mathrm{b}} \mathrm{C}=\mathrm{C}\right), 3.53\left(\mathrm{dd}, J=15.7,0.9 \mathrm{~Hz}, 1 \mathrm{H}, \mathrm{NCH}_{\mathrm{a}} H_{b} \mathrm{C}=\mathrm{C}\right), 2.34$ (s, $\left.3 \mathrm{H}, \mathrm{ArCH}_{3}\right), 2.26\left(\mathrm{~s}, 6 \mathrm{H}, 2 \times \mathrm{ArCH}_{3}\right)$.

${ }^{13} \mathrm{C}\left\{{ }^{1} \mathrm{H}\right\}$ NMR (101 MHz, Chloroform-d) $\delta 148.1,138.7,137.4$ (2C), 137.2, 136.5, 129.9, 129.3, 128.8 (2C), 128.2, 128.0, 127.0, $122.9(\mathrm{q}, J=284.1 \mathrm{~Hz}), 113.2,93.8(\mathrm{q}, J=34.2 \mathrm{~Hz}), 60.5,54.8,21.6,21.3$. ${ }^{19} \mathrm{~F} \mathrm{NMR}(376 \mathrm{MHz}$, Chloroform- $d) \delta-80.3(\mathrm{~d}, 3 \mathrm{~F}, J=5.3 \mathrm{~Hz})$.

IR $\left(\mathrm{cm}^{-1}\right) 2925(\mathrm{~m}), 2865(\mathrm{w}), 1664(\mathrm{~m}), 1600(\mathrm{~m}), 1506(\mathrm{~m}), 1453(\mathrm{~m}), 1295(\mathrm{~m}), 1154(\mathrm{~s}), 1077$ (m). HRMS (ESI/QTOF) m/z: [M + Na] ${ }^{+}$Calculated for $\mathrm{C}_{27} \mathrm{H}_{26} \mathrm{~F}_{3} \mathrm{NNaO}^{+} 460.1859$; Found 460.1863.

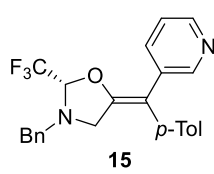

(15)

(S,Z)-3-benzyl-5-(pyridin-3-yl(p-tolyl)methylene)-2-(trifluoromethyl)oxazolidine

Prepared according to the general procedure D1 using N-benzyl-3-(pyridin-3-yl)prop-2yn-1-amine (89 mg, $0.40 \mathrm{mmol}, 1.0$ equiv.) and $p$-iodotoluene (113 mg, $0.520 \mathrm{mmol}$, 
1.3 equiv.). The crude material was purified by flash column chromatography (pentane/EtOAc gradient 90:10 to 60:40) to give the corresponding olefin 15 (103 mg, $0.251 \mathrm{mmol}, 63 \%$ yield) as orange oil. The enantiomeric excess was determined to be $52 \%$ by HPLC analysis on a Daicel Chiralpak IB N-5 column: 90:10 hexane/IPA, flow rate $1 \mathrm{~mL} / \mathrm{min}, \lambda=254 \mathrm{~nm}: \tau_{\text {minor }}=10.4 \mathrm{~min}, \tau_{\text {Major }}=11.2 \mathrm{~min}$. Absolute configuration determined in comparison to compound $(S)-4$.

$[\alpha] \mathrm{D}^{20}=18.5\left(\mathrm{c}=0.80, \mathrm{CHCl}_{3}, 52 \%\right.$ ee $)$.

${ }^{1} \mathrm{H}$ NMR (400 MHz, Chloroform-d) $\delta 8.57$ (br. s, $1 \mathrm{H}$, HetArH), 8.38 (br. s, $1 \mathrm{H}, \operatorname{HetArH}$ ), 7.66 (dt, $J=8.1$, $1.9 \mathrm{~Hz}, 1 \mathrm{H}, \operatorname{Het} \operatorname{Ar} H), 7.37-7.25(\mathrm{~m}, 5 \mathrm{H}, \operatorname{Ar} H), 7.21(\mathrm{dd}, J=8.1,4.7 \mathrm{~Hz}, 1 \mathrm{H}, \operatorname{HetAr} H), 7.15(\mathrm{~d}, J=7.8$ $\mathrm{Hz}, 2 \mathrm{H}, \mathrm{ArH}), 7.06-6.99(\mathrm{~m}, 2 \mathrm{H}, \mathrm{Ar} H), 5.17\left(\mathrm{q}, J=5.3 \mathrm{~Hz}, 1 \mathrm{H}, \mathrm{CHCF}_{3}\right), 4.03-3.93\left(\mathrm{~m}, 2 \mathrm{H}, \mathrm{NCH}_{a} \mathrm{H}_{\mathrm{b}} \mathrm{C}=\mathrm{C}\right.$ and $\left.\mathrm{PhCH}_{\mathrm{a}} \mathrm{H}_{\mathrm{b}}\right), 3.90\left(\mathrm{~d}, J=13.3 \mathrm{~Hz}, 1 \mathrm{H}, \mathrm{PhCH}_{\mathrm{a}} H_{b}\right), 3.54\left(\mathrm{dd}, J=16.1,1.4 \mathrm{~Hz}, 1 \mathrm{H}, \mathrm{NCH}_{\mathrm{a}} H_{b} \mathrm{C}=\mathrm{C}\right), 2.35(\mathrm{~s}$, $3 \mathrm{H}, \mathrm{ArCH}_{3}$ ).

${ }^{13} \mathrm{C}\left\{{ }^{1} \mathrm{H}\right\}$ NMR (101 MHz, Chloroform-d) $\delta 150.6,149.8,146.6,137.3,136.8,136.3,135.7,129.9,129.7$, $128.83,128.78,128.2,126.4,123.2,122.7$ (q, $J=283.9 \mathrm{~Hz}), 109.5,94.3$ (q, $J=34.5 \mathrm{~Hz}), 60.5,54.9,21.3$. ${ }^{19} \mathrm{~F} \mathrm{NMR}(376 \mathrm{MHz}$, Chloroform- $d) \delta-80.3(\mathrm{~d}, 3 \mathrm{~F}, J=5.3 \mathrm{~Hz})$.

IR $\left(\mathrm{cm}^{-1}\right) 3035(\mathrm{~m}), 1664(\mathrm{~m}), 1569(\mathrm{~m}), 1515(\mathrm{~m}), 1412(\mathrm{~m}), 1292(\mathrm{~m}), 1155(\mathrm{~s}), 1076(\mathrm{~m})$.

$\underline{\text { HRMS }}(E S I / Q T O F) ~ m / z: ~[M+H]^{+}$Calculated for $\mathrm{C}_{24} \mathrm{H}_{22} \mathrm{~F}_{3} \mathrm{~N}_{2} \mathrm{O}^{+} 411.1679$; Found 411.1679.

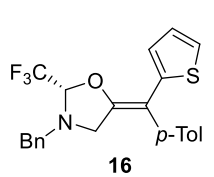

(S,Z)-3-Benzyl-5-(thiophen-2-yl(p-tolyl)methylene)-2-(trifluoromethyl)oxazolidine (16)

Prepared according to the general procedure D1 using N-benzyl-3-(thiophen-2-yl)prop-2yn-1-amine (91 mg, $0.40 \mathrm{mmol}, 1.0$ equiv.) and $p$-iodotoluene $(113 \mathrm{mg}, 0.520 \mathrm{mmol}$, 1.3 equiv.). The crude material was purified by flash column chromatography (pentane/EtOAc gradient 100:0 to 97:3) to give the corresponding olefin 16 (142 mg, 0.340 mmol, 85\% yield) as brown oil. The enantiomeric excess was determined to be $76 \%$ by HPLC analysis on a Daicel Chiralpak IB N-5 column: 99:1 hexane/IPA, flow rate $1 \mathrm{~mL} / \mathrm{min}, \lambda=254 \mathrm{~nm}: \tau_{\text {Minor }}=8.3 \mathrm{~min}$, $\tau_{\text {Major }}=13.9$ min. Absolute configuration determined in comparison to compound $(S)$-4.

$[\alpha] \mathrm{D}^{20}=9.4\left(\mathrm{c}=0.68, \mathrm{CHCl}_{3}, 76 \%\right.$ ee $)$.

${ }^{1}$ H NMR (400 MHz, Chloroform-d) $\delta 7.35-7.26(\mathrm{~m}, 5 \mathrm{H}, \mathrm{ArH}), 7.24-7.13(\mathrm{~m}, 5 \mathrm{H}, \mathrm{ArH}), 6.94(\mathrm{dd}, J=$ $5.1,3.7 \mathrm{~Hz}, 1 \mathrm{H}, \operatorname{HetAr} H), 6.79(\mathrm{dd}, J=3.7,1.0 \mathrm{~Hz}, 1 \mathrm{H}, \operatorname{HetAr} H), 5.26\left(\mathrm{q}, J=5.3 \mathrm{~Hz}, 1 \mathrm{H}, \mathrm{CHCF}_{3}\right), 4.02-$ $3.82\left(\mathrm{~m}, 3 \mathrm{H}, \mathrm{PhCH}_{2}\right.$ and $\left.\mathrm{NCH}_{a} \mathrm{H}_{\mathrm{b}} \mathrm{C}=\mathrm{C}\right), 3.39\left(\mathrm{dd}, J=16.1,0.9 \mathrm{~Hz}, 1 \mathrm{H}, \mathrm{NCH}_{\mathrm{a}} H_{b} \mathrm{C}=\mathrm{C}\right), 2.38\left(\mathrm{~s}, 3 \mathrm{H}, \mathrm{ArCH}_{3}\right)$. ${ }^{13} \mathrm{C}\left\{{ }^{1} \mathrm{H}\right\}$ NMR (101 MHz, Chloroform-d) $\delta 147.0,142.2,137.5,137.0,135.6,130.2,129.6,128.8,128.7$, 128.0, 126.5, 125.3, 124.5, 122.7 (q, $J=283.7 \mathrm{~Hz}), 108.3,94.7$ (q, $J=34.5), 60.6,54.6,21.4$.

${ }^{19} \mathrm{~F}$ NMR $(376 \mathrm{MHz}$, Chloroform- $d) \delta-80.5(\mathrm{~d}, 3 \mathrm{~F}, J=5.3 \mathrm{~Hz})$.

$\underline{\mathrm{IR}}\left(\mathrm{cm}^{-1}\right) 2937(\mathrm{~m}), 2834(\mathrm{~m}), 1663(\mathrm{~m}), 1512(\mathrm{~m}), 1453(\mathrm{~m}), 1294(\mathrm{~m}), 1223$ (s), 1170 (s), $1153(\mathrm{~s}), 1077$ (m).

$\underline{\text { HRMS }}(\mathrm{ESI} / \mathrm{QTOF}) \mathrm{m} / \mathrm{z}:[\mathrm{M}+\mathrm{H}]^{+}$Calculated for $\mathrm{C}_{23} \mathrm{H}_{21} \mathrm{~F}_{3} \mathrm{NOS}^{+}$416.1290; Found 416.1289.

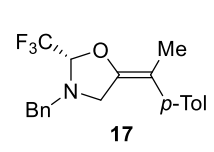

(S,E)-3-Benzyl-5-(1-(p-tolyl)ethylidene)-2-(trifluoromethyl)oxazolidine (17)

Prepared according to the general procedure D1 using $N$-benzylbut-2-yn-1-amine (64 mg, $0.40 \mathrm{mmol}, 1.0$ equiv.) and $p$-iodotoluene $(113 \mathrm{mg}, 0.520 \mathrm{mmol}, 1.3$ equiv.). The crude material was purified by flash column chromatography (pentane/EtOAc gradient 100:0 to 97:3) to give the corresponding olefin 17 (114 $\mathrm{mg}, 0.328 \mathrm{mmol}, 82 \%$ yield) as amorphous white solid. The enantiomeric excess was determined to be $72 \%$ by HPLC analysis on a Daicel Chiralpak IB N-5 column: 99:1 hexane/IPA, flow rate $1 \mathrm{~mL} / \mathrm{min}, \lambda=254 \mathrm{~nm}: \tau_{\text {Minor }}=5.5 \mathrm{~min}, \tau_{\text {Major }}=6.4 \mathrm{~min}$. . Absolute configuration determined in comparison to compound $(S)-4$.

$[\alpha] \mathrm{D}^{20}=27.5\left(\mathrm{c}=0.54, \mathrm{CHCl}_{3}, 72 \%\right.$ ee $)$

${ }^{1} \mathrm{H}$ NMR (400 MHz, Chloroform-d) $\delta 7.35-7.26(\mathrm{~m}, 5 \mathrm{H}, \mathrm{ArH}), 7.10(\mathrm{~d}, J=8.0 \mathrm{~Hz}, 2 \mathrm{H}, m-\mathrm{Me}-\mathrm{Ar} H), 7.07$ $-7.02(\mathrm{~m}, 2 \mathrm{H}, o-\mathrm{Me}-\mathrm{Ar} H), 4.96\left(\mathrm{q}, J=5.3 \mathrm{~Hz}, 1 \mathrm{H}, \mathrm{CHCF}_{3}\right), 3.97\left(\mathrm{~d}, J=14.9 \mathrm{~Hz}, 1 \mathrm{H}, \mathrm{NCH}_{a} \mathrm{H}_{\mathrm{b}} \mathrm{C}=\mathrm{C}\right), 3.92$ $\left(\mathrm{d}, J=13.3 \mathrm{~Hz}, 1 \mathrm{H}, \mathrm{PhCH}_{a} \mathrm{H}_{\mathrm{b}}\right), 3.81\left(\mathrm{~d}, J=13.3 \mathrm{~Hz}, 1 \mathrm{H}, \mathrm{PhCH}_{\mathrm{a}} H_{b}\right), 3.45(\mathrm{dt}, J=14.9,1.3 \mathrm{~Hz}, 1 \mathrm{H}$, $\left.\mathrm{NCH}_{\mathrm{a}} \mathrm{H}_{b} \mathrm{C}=\mathrm{C}\right), 2.32\left(\mathrm{~s}, 3 \mathrm{H}, \mathrm{ArCH}_{3}\right), 2.07\left(\mathrm{t}, J=1.7 \mathrm{~Hz}, 3 \mathrm{H}, \mathrm{C}-\mathrm{CCH}_{3}\right)$.

${ }^{13} \mathrm{C}\left\{{ }^{1} \mathrm{H}\right\}$ NMR $(101 \mathrm{MHz}$, Chloroform-d) $\delta$ 146.9, 138.3, 137.3, 136.0, 129.1, 128.7 (2C), 127.9, 127.4, $123.0(\mathrm{q}, J=283.9 \mathrm{~Hz}), 107.6,94.6(\mathrm{q}, J=34.0 \mathrm{~Hz}), 60.3,53.3,21.2$, 16.6.

${ }^{19} \mathrm{~F}$ NMR $(376 \mathrm{MHz}$, Chloroform- $\left.d)\right) \delta-80.6(\mathrm{~d}, 3 \mathrm{~F}, J=5.3 \mathrm{~Hz})$. 
$\underline{\text { IR }}\left(\mathrm{cm}^{-1}\right) 2979(\mathrm{~s}), 2910(\mathrm{~m}), 1689(\mathrm{w}), 1508(\mathrm{w}), 1451(\mathrm{~m}), 1386(\mathrm{~m}), 1292(\mathrm{~m}), 1233(\mathrm{~m}), 1157(\mathrm{~s}), 1067$ $\underline{(\mathrm{s})}$.

$\underline{\text { HRMS }}(\mathrm{ESI} / \mathrm{QTOF} \text { ) m/z: [M + H] }]^{+}$Calculated for $\mathrm{C}_{20} \mathrm{H}_{21} \mathrm{~F}_{3} \mathrm{NO}^{+}$348.1570; Found 348.1567.

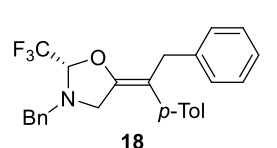

(S,E)-3-Benzyl-5-(2-phenyl-1-(p-tolyl)ethylidene)-2-(trifluoromethyl)oxazolidine (18)

Prepared according to the general procedure D1 using $N$-benzyl-4-phenylbut-2-yn-1amine (94 mg, $0.40 \mathrm{mmol}, 1.0$ equiv.) and $p$-iodotoluene (113 mg, $0.520 \mathrm{mmol}$, 1.3 equiv.). The crude material was purified by flash column chromatography (pentane/EtOAc gradient 100:0 to 97:3) to give the corresponding olefin 18 (142 mg, $0.336 \mathrm{mmol}, 84 \%$ yield) as amorphous white solid. The enantiomeric excess was determined to be $86 \%$ by HPLC analysis on a Daicel Chiralpak IB N5 column: 99:1 hexane/IPA, flow rate $1 \mathrm{~mL} / \mathrm{min}, \lambda=254 \mathrm{~nm}: \tau_{\text {Minor }}=6.3 \mathrm{~min}, \tau_{\text {Major }}=6.9 \mathrm{~min}$. Absolute configuration determined in comparison to compound $(S)-4$.

$[\alpha] \mathrm{D}^{20}=21.4\left(\mathrm{c}=0.39, \mathrm{CHCl}_{3}, 86 \%\right.$ ee $)$.

${ }^{1} \mathrm{H}$ NMR (400 MHz, Chloroform-d) $\delta 7.39-7.28(\mathrm{~m}, 5 \mathrm{H}, \mathrm{ArH}), 7.25-7.18(\mathrm{~m}, 2 \mathrm{H}, \mathrm{ArH}), 7.18-7.10(\mathrm{~m}$, $3 \mathrm{H}, \mathrm{ArH}), 7.03(\mathrm{~d}, J=8.0 \mathrm{~Hz}, 2 \mathrm{H}, m-\mathrm{Me}-\mathrm{ArH}), 6.95(\mathrm{~d}, J=8.0 \mathrm{~Hz}, 2 \mathrm{H}, o-\mathrm{Me}-\mathrm{ArH}), 5.02(\mathrm{q}, J=5.3 \mathrm{~Hz}$, $\left.1 \mathrm{H}, \mathrm{CHCF}_{3}\right), 4.03-3.94\left(\mathrm{~m}, 2 \mathrm{H}, \mathrm{NCH}_{a} \mathrm{H}_{\mathrm{b}} \mathrm{C}=\mathrm{C}\right.$ and $\left.\mathrm{PhCHaH}_{\mathrm{b}} \mathrm{N}\right), 3.94-3.73\left(\mathrm{~m}, 3 \mathrm{H}, \mathrm{PhCHaH}_{b} \mathrm{~N}\right.$ and $\left.\mathrm{C}=\mathrm{CCH}_{2} \mathrm{Ph}\right), 3.47\left(\mathrm{~d}, J=15.2 \mathrm{~Hz}, 1 \mathrm{H}, \mathrm{NCHaH}_{b} \mathrm{C}=\mathrm{C}\right), 2.28\left(\mathrm{~s}, 3 \mathrm{H}, \mathrm{ArCH}_{3}\right)$.

${ }^{13} \mathrm{C}\left\{{ }^{1} \mathrm{H}\right\}$ NMR (101 MHz, Chloroform-d) $\delta 148.0,140.5,137.2,136.8,136.2,129.1,128.74,128.71,128.6$, $128.4,128.3,128.2,127.9,123.0(\mathrm{q}, J=283.9 \mathrm{~Hz}), 111.4,92.8(\mathrm{q}, J=34.1 \mathrm{~Hz}), 60.4,53.3,37.2,21.2$.

${ }^{19} \mathrm{~F}$ NMR $(376 \mathrm{MHz}$, Chloroform- $d$ ) $\delta-80.5(\mathrm{~d}, 3 \mathrm{~F}, J=5.3 \mathrm{~Hz})$.

$\underline{\mathrm{IR}}\left(\mathrm{cm}^{-1}\right) 2927(\mathrm{~m}), 2851(\mathrm{~m}), 1690(\mathrm{~m}), 1504(\mathrm{~m}), 1452$ (m), 1293 (m), 1173 (s), 1154 (s), 1025 (m).

HRMS (ESI/QTOF) m/z: [M + H] $]^{+}$Calculated for $\mathrm{C}_{26} \mathrm{H}_{25} \mathrm{~F}_{3} \mathrm{NO}^{+} 424.1883$; Found 424.1886.

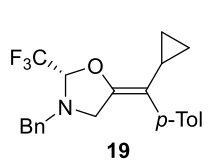
(19)

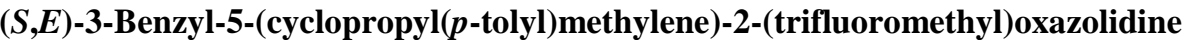

Prepared according to the general procedure D1 using $N$-benzyl-3-cyclopropylprop-2-yn-

1-amine (74 mg, $0.40 \mathrm{mmol}, 1.0$ equiv.) and $p$-iodotoluene (113 mg, $0.520 \mathrm{mmol}$, 1.3 equiv.). The crude material was purified by flash column chromatography (pentane/EtOAc gradient 100:0 to $97: 3)$ to give the corresponding olefin 19 (80 mg, $0.22 \mathrm{mmol}, 54 \%$ yield) as amorphous white solid. The enantiomeric excess was determined to be $78 \%$ by HPLC analysis on a Daicel Chiralpak IB N5 column: $99: 1$ hexane/IPA, flow rate $1 \mathrm{~mL} / \mathrm{min}, \lambda=254 \mathrm{~nm}: \tau_{\text {Minor }}=5.0 \mathrm{~min}, \tau_{\text {Major }}=5.8 \mathrm{~min} .[\alpha] \mathrm{D}^{20}=$ $22.6\left(\mathrm{c}=0.53, \mathrm{CHCl}_{3}, 78 \%\right.$ ee). Absolute configuration determined in comparison to compound $(S)$-4.

${ }^{1} \mathrm{H}$ NMR (400 MHz, Chloroform-d) $\delta 7.33-7.24(\mathrm{~m}, 5 \mathrm{H}, \mathrm{ArH}), 7.07$ (d, J=7.9 Hz, 2H, ArH), 6.95 (d, J $=7.9 \mathrm{~Hz}, 2 \mathrm{H}, \mathrm{Me}-\mathrm{ArH}), 5.02\left(\mathrm{q}, J=5.3 \mathrm{~Hz}, 1 \mathrm{H}, \mathrm{CHCF}_{3}\right), 3.95\left(\mathrm{~d}, J=13.3 \mathrm{~Hz}, 1 \mathrm{H}, \mathrm{PhCH}_{a} \mathrm{H}_{\mathrm{b}}\right), 3.81(\mathrm{~d}, J$ $\left.=13.3 \mathrm{~Hz}, 1 \mathrm{H}, \mathrm{PhCH}_{\mathrm{a}} H_{b}\right), 3.71\left(\mathrm{~d}, J=15.2 \mathrm{~Hz}, 1 \mathrm{H}, \mathrm{NCH}_{\mathrm{a}} \mathrm{H}_{\mathrm{b}} \mathrm{C}=\mathrm{C}\right), 3.21\left(\mathrm{~d}, J=15.2 \mathrm{~Hz}, 1 \mathrm{H}, \mathrm{NCH}_{\mathrm{a}} H_{b} \mathrm{C}=\mathrm{C}\right)$, $2.31\left(\mathrm{~s}, 3 \mathrm{H}, \mathrm{ArCH}_{3}\right), 2.01-1.88\left(\mathrm{~m}, 1 \mathrm{H}, \mathrm{CH}\left(\mathrm{CH}_{2}\right) \mathrm{CH}_{2}\right), 0.68-0.58\left(\mathrm{~m}, 2 \mathrm{H}, \mathrm{CH}\left(\mathrm{CH}_{2}\right) \mathrm{CH}_{2}\right), 0.37-0.18$ $\left(\mathrm{m}, 2 \mathrm{H}, \mathrm{CH}\left(\mathrm{CH}_{2}\right) \mathrm{CH}_{2}\right)$.

${ }^{13} \mathrm{C}\left\{{ }^{1} \mathrm{H}\right\}$ NMR $(101 \mathrm{MHz}$, Chloroform-d) $\delta 147.6,137.4,136.5,134.5,129.7,129.0,128.69,128.67,127.8$, $123.0(\mathrm{q}, J=284.0 \mathrm{~Hz}), 112.7,93.2(\mathrm{q}, J=34.0 \mathrm{~Hz}), 60.4,53.5,21.3,11.6,4.8,4.4$.

${ }^{19} \mathrm{~F}$ NMR $(376 \mathrm{MHz}$, Chloroform- $d) \delta-80.5$ (d, 3F, $\left.J=5.3 \mathrm{~Hz}\right)$.

IR $\left(\mathrm{cm}^{-1}\right) 3022(\mathrm{w}), 2946(\mathrm{w}), 2863(\mathrm{w}), 1665$ (w), $1523(\mathrm{w}), 1425(\mathrm{w}), 1216(\mathrm{~m})$.

HRMS (ESI/QTOF) m/z: [M + H] $]^{+}$Calculated for $\mathrm{C}_{22} \mathrm{H}_{23} \mathrm{~F}_{3} \mathrm{NO}^{+}$374.1726; Found 374.1725.

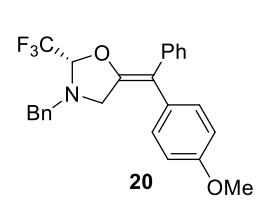

\section{(trifluoromethyl)oxazolidine (20)}

(S,E)-3-Benzyl-5-((4-methoxyphenyl)(phenyl)methylene)-2-

Prepared according to the general procedure D1 using N-benzyl-3-phenylprop-2-yn-1amine (76 $\mu \mathrm{L}, 0.40 \mathrm{mmol}, 1.0$ equiv.) and 4-iodoanisole (122 mg, $0.520 \mathrm{mmol}, 1.3$ equiv). $2.5 \mathrm{~mol} \%$ of $\mathrm{Pd}_{2}(\mathrm{dba})_{3} \cdot \mathrm{CHCl}_{3}(10.4 \mathrm{mg}, 10.0 \mu \mathrm{mol})$ and $7 \mathrm{~mol} \%$ of ligand (14.2 $\mathrm{mg}, 28.0 \mu \mathrm{mol})$ were used. The crude material was purified by flash column chromatography (pentane/EtOAc gradient 100:0 to 100:3) to give the corresponding olefin $\mathbf{2 0}$ (156 mg, 92\% yield) as a white solid. The enantiomeric excess was determined to be $88 \%$ by HPLC analysis on a Daicel Chiralpak IB N-5 column: 99:1 hexane/IPA, flow rate $1 \mathrm{~mL} / \mathrm{min}, \lambda=254 \mathrm{~nm}: \tau_{\text {Minor }}=9.9 \mathrm{~min}, \tau_{\text {Major }}=14.7 \mathrm{~min}$. Absolute configuration determined in comparison to compound $(S)-\mathbf{4}$. 
$[\alpha] \mathrm{D}^{20}=+63.5\left(\mathrm{c}=0.48, \mathrm{CHCl}_{3}, 88 \%\right.$ ee $)$.

${ }^{1} \mathrm{H}$ NMR (400 MHz, Chloroform- $d$ ) $\delta 7.40-7.25(\mathrm{~m}, 9 \mathrm{H}, \mathrm{ArH}), 7.22-7.15(\mathrm{~m}, 1 \mathrm{H}, \mathrm{Ar} H), 7.08(\mathrm{~d}, J=8.7$ $\mathrm{Hz}, 2 \mathrm{H}, \mathrm{ArH}), 6.86(\mathrm{~d}, J=8.7 \mathrm{~Hz}, 2 \mathrm{H}, \mathrm{ArH}), 5.13\left(\mathrm{q}, J=5.3 \mathrm{~Hz}, 1 \mathrm{H}, \mathrm{CHCF}_{3}\right), 4.00(\mathrm{~d}, J=13.3 \mathrm{~Hz}, 1 \mathrm{H}$, $\left.\mathrm{PhCH}_{a} \mathrm{H}_{\mathrm{b}}\right), 3.96-3.85\left(\mathrm{~m}, 2 \mathrm{H}, \mathrm{PhCH}_{a} H_{\mathrm{b}}\right.$ and $\left.\mathrm{NCH}_{\mathrm{a}} \mathrm{H}_{b} \mathrm{C}=\mathrm{C}\right), 3.81\left(\mathrm{~s}, 3 \mathrm{H}, \mathrm{OCH}_{3}\right), 3.52(\mathrm{dd}, J=15.6,1.5$ $\left.\mathrm{Hz}, 1 \mathrm{H}, \mathrm{NCH}_{\mathrm{a}} H_{b} \mathrm{C}=\mathrm{C}\right)$.

${ }^{13} \mathrm{C}\left\{{ }^{1} \mathrm{H}\right\}$ NMR $(101 \mathrm{MHz}$, Chloroform- $d) \delta 158.6,148.4,138.9,137.1,132.4,131.3,129.0,128.77,128.76$, $128.0(2 \mathrm{C}), 126.3,122.9$ (q, $J=284.0 \mathrm{~Hz}), 114.1,112.5,94.0(\mathrm{q}, J=34.4 \mathrm{~Hz}), 60.5,55.4,54.9$.

${ }^{19} \mathrm{~F}$ NMR $(376 \mathrm{MHz}$, Chloroform- $d) \delta-80.3(\mathrm{~d}, J=4.9 \mathrm{~Hz})$.

$\underline{\mathrm{IR}}\left(\mathrm{cm}^{-1}\right) 3032(\mathrm{w}), 2943(\mathrm{w}), 2841$ (w), $1665(\mathrm{~m}), 1606$ (m), 1506 (m), $1453(\mathrm{~m}), 1292(\mathrm{~m}), 1246(\mathrm{~s}), 1173$ (s), $1153(\mathrm{~s})$.

HRMS (ESI/QTOF) m/z: [M + H] ${ }^{+}$Calculated for $\mathrm{C}_{25} \mathrm{H}_{23} \mathrm{~F}_{3} \mathrm{NO}_{2}{ }^{+}$426.1675; Found 426.1678.

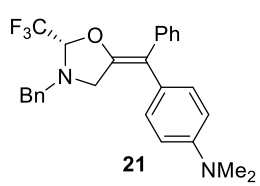

(S,E)-4-((3-Benzyl-2-(trifluoromethyl)oxazolidin-5-ylidene)(phenyl)methyl)$N, N$-dimethylaniline (21)

Prepared according to the modified general procedure D1 using N-benzyl-3phenylprop-2-yn-1-amine (76 $\mu \mathrm{L}, 0.40 \mathrm{mmol}, 1.0$ equiv.) and 4-iodo-N,Ndimethylaniline (128 mg, $0.520 \mathrm{mmol}, 1.3$ equiv). $2.5 \mathrm{~mol} \%$ of $\mathrm{Pd}_{2}(\mathrm{dba})_{3} \cdot \mathrm{CHCl}_{3}$ $(10.4 \mathrm{mg}, 10.0 \mu \mathrm{mol})$ and $7 \mathrm{~mol} \%$ of ligand $(14.2 \mathrm{mg}, 28.0 \mu \mathrm{mol})$ were used. The crude material was purified by flash column chromatography (pentane/EtOAc gradient 100:0 to 100:5) to give the corresponding olefin 21 (132 mg, $0.301 \mathrm{mmol}, 75 \%$ yield) as a pale yellow solid. The enantiomeric excess was determined to be $94 \%$ by HPLC analysis on a Daicel Chiralpak IB N-5 column: 99:1 hexane/IPA, flow rate $1 \mathrm{~mL} / \mathrm{min}, \lambda=254 \mathrm{~nm}: \tau_{\text {Minor }}=9.9 \mathrm{~min}, \tau_{\text {Major }}=14.6 \mathrm{~min}$.). Absolute configuration determined in comparison to compound $(S)-4$.

$[\alpha] \mathrm{D}^{20}=+79.1\left(\mathrm{c}=0.64, \mathrm{CHCl}_{3}, 94 \%\right.$ ee

${ }^{1} \mathrm{H}$ NMR (400 MHz, Chloroform-d) $\delta 7.42-7.27(\mathrm{~m}, 9 \mathrm{H}, \mathrm{ArH}), 7.20-7.14(\mathrm{~m}, 1 \mathrm{H}, \mathrm{ArH}), 7.05-6.94(\mathrm{~m}$, $2 \mathrm{H}, \mathrm{ArH}), 6.73-6.64(\mathrm{~m}, 2 \mathrm{H}, \mathrm{ArH}), 5.10\left(\mathrm{q}, J=5.3 \mathrm{~Hz}, 1 \mathrm{H}, \mathrm{CHCF}_{3}\right), 4.03-3.92\left(\mathrm{~m}, 2 \mathrm{H}, \mathrm{PhCH}_{a} \mathrm{H}_{\mathrm{b}}\right.$ and $\left.\mathrm{NCH}_{a} \mathrm{H}_{\mathrm{b}} \mathrm{C}=\mathrm{C}\right), 3.89\left(\mathrm{~d}, J=13.4 \mathrm{~Hz}, 1 \mathrm{H}, \mathrm{PhCH}_{a} H_{b}\right), 3.57\left(\mathrm{dd}, J=15.7,1.3 \mathrm{~Hz}, 1 \mathrm{H}, \mathrm{NCH}_{\mathrm{a}} H_{b} \mathrm{C}=\mathrm{C}\right), 2.96(\mathrm{~s}$, $\left.6 \mathrm{H}, \mathrm{N}\left(\mathrm{CH}_{3}\right)_{2}\right)$.

${ }^{13} \mathrm{C}\left\{{ }^{1} \mathrm{H}\right\}$ NMR (101 MHz, Chloroform-d) 149.4, 148.0, 139.3, 137.2, 130.9, 129.1, 128.8, 128.5, 128.00, 127.96, 126.2, 125.6, $122.9(\mathrm{q}, J=284.2 \mathrm{~Hz}), 112.9,112.5,93.8(\mathrm{q}, J=34.1 \mathrm{~Hz}), 60.5,54.9,40.6$.

${ }^{19} \mathrm{~F}\left\{{ }^{1} \mathrm{H}\right\} \mathrm{NMR}(376 \mathrm{MHz}$, Chloroform- $d) \delta-80.3$.

$\underline{\mathrm{IR}}\left(\mathrm{cm}^{-1}\right) 3030(\mathrm{w}), 2924(\mathrm{w}), 2855(\mathrm{w}), 2809(\mathrm{w}), 1662(\mathrm{w}), 1611(\mathrm{~m}), 1522(\mathrm{~m}), 1452(\mathrm{w}), 1351(\mathrm{~m})$, $1295(\mathrm{~m}), 1223(\mathrm{~m}), 1151(\mathrm{~s})$.

HRMS (ESI/QTOF) m/z: [M + H] $]^{+}$Calculated for $\mathrm{C}_{26} \mathrm{H}_{26} \mathrm{~F}_{3} \mathrm{~N}_{2} \mathrm{O}^{+}$439.1992; Found 439.1992.

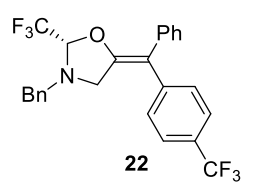

\section{(trifluoromethyl)oxazolidine (22)}

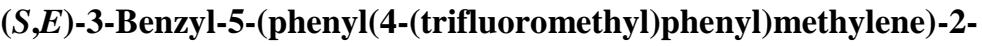

Prepared according to the general procedure D1 using N-benzyl-3-phenylprop-2-yn-1amine $(76 \mu \mathrm{L}, 0.40 \mathrm{mmol}, 1.0$ equiv.) and 4-iodobenzotrifluoride $(76 \mu \mathrm{L}, 0.52 \mathrm{mmol}$, 1.3 equiv). The crude material was purified by flash column chromatography (pentane/EtOAc gradient 100:0 to 100:3) to give the corresponding olefin 22 (168 $\mathrm{mg}, 0.363 \mathrm{mmol}, 91 \%$ yield) as a colorless oil. The enantiomeric excess was determined to be $82 \%$ by HPLC analysis on a Daicel Chiralpak IB N-5 column: 99:1 hexane/IPA, flow rate $1 \mathrm{~mL} / \mathrm{min}, \lambda=254 \mathrm{~nm}: \tau_{\text {Minor }}=10.7$ min, $\tau_{\text {Major }}=$ $12.1 \mathrm{~min}$. Absolute configuration determined in comparison to compound $(S)$-4.

$[\alpha] \mathrm{D}^{20}=+47.8\left(\mathrm{c}=0.77, \mathrm{CHCl}_{3}, 82 \%\right.$ ee $)$.

${ }^{1} \mathrm{H}$ NMR $(400 \mathrm{MHz}$, Chloroform- $d$ ) $\delta 7.58(\mathrm{~d}, J=8.1 \mathrm{~Hz}, 2 \mathrm{H}, \mathrm{ArH}), 7.40-7.17(\mathrm{~m}, 12 \mathrm{H}, \operatorname{ArH}), 5.16(\mathrm{q}, J$ $\left.=5.2 \mathrm{~Hz}, 1 \mathrm{H}, \mathrm{CHCF}_{3}\right), 4.01\left(\mathrm{~d}, J=13.3 \mathrm{~Hz}, 1 \mathrm{H}, \mathrm{PhCH}_{a} \mathrm{H}_{\mathrm{b}}\right), 3.99-3.93\left(\mathrm{~m}, 1 \mathrm{H}, \mathrm{NCH}_{\mathrm{a}} \mathrm{H}_{b} \mathrm{C}=\mathrm{C}\right), 3.91(\mathrm{~d}, J$ $\left.=13.3 \mathrm{~Hz}, 1 \mathrm{H}, \mathrm{PhCH}_{a} H_{b}\right), 3.54\left(\mathrm{dd}, J=15.8,1.4 \mathrm{~Hz}, 1 \mathrm{H}, \mathrm{NCH}_{\mathrm{a}} H_{b} \mathrm{C}=\mathrm{C}\right)$.

${ }^{13} \mathrm{C}\left\{{ }^{1} \mathrm{H}\right\}$ NMR $(101 \mathrm{MHz}$, Chloroform- $d) \delta 149.4,144.0,138.0,136.7,130.4,129.3(\mathrm{q}, J=32.2 \mathrm{~Hz})$, $129.2,128.9,128.8,128.3,128.2,126.8,125.7$ (q, $J=3.8 \mathrm{~Hz}), 124.3$ (q, $J=275.6 \mathrm{~Hz}) 122.73(\mathrm{q}, J=283.9$ $\mathrm{Hz}), 112.2,94.1$ (q, $J=34.5 \mathrm{~Hz}), 60.5,54.8$.

${ }^{19} \mathrm{~F}\left\{{ }^{1} \mathrm{H}\right\}$ NMR (377 MHz, Chloroform- $d$ ) $\delta-62.5,-80.3$.

$\underline{\text { IR }\left(\mathrm{cm}^{-1}\right)} 3042(\mathrm{w}), 2929(\mathrm{w}), 1664(\mathrm{~m}), 1610(\mathrm{w}), 1404$ (w), 1328 (s), 1293 (m), 1158 (s), 1130 (s), 1073 $(\mathrm{m})$. 
$\underline{\text { HRMS }}(\mathrm{ESI} / \mathrm{QTOF}) \mathrm{m} / \mathrm{z}:[\mathrm{M}+\mathrm{H}]^{+}$Calculated for $\mathrm{C}_{25} \mathrm{H}_{20} \mathrm{~F}_{6} \mathrm{NO}^{+} 464.1444$; Found 464.1447 .

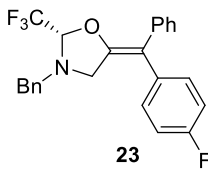

(trifluoromethyl)oxazolidine (23)

(S,E)-3-Benzyl-5-((4-fluorophenyl)(phenyl)methylene)-2-

Prepared according to the general procedure D1 using N-benzyl-3-phenylprop-2-yn-1amine (76 $\mu \mathrm{L}, 0.40 \mathrm{mmol}, 1.0$ equiv.) and 4-fluoroiodobenzene $(60 \mu \mathrm{L}, 0.52 \mathrm{mmol}, 1.3$ equiv). The crude material was purified by flash column chromatography (pentane/EtOAc gradient 100:0 to 100:3) to give the corresponding olefin 23 (154 mg, $0.373 \mathrm{mmol}, 93 \%$ yield) as a colorless oil. The enantiomeric excess was determined to be $84 \%$ by HPLC analysis on a Daicel Chiralpak IB N-5 column: 99:1 hexane/IPA, flow rate $1 \mathrm{~mL} / \mathrm{min}, \lambda=254 \mathrm{~nm}: \tau_{\text {Minor }}=10.0$ min, $\tau_{\text {Major }}=$ $11.9 \mathrm{~min}$. Absolute configuration determined in comparison to compound $(S)-\mathbf{4}$.

$[\alpha] \mathrm{D}^{20}=+45.5\left(\mathrm{c}=0.41, \mathrm{CHCl}_{3}, 84 \%\right.$ ee $)$.

${ }^{1} \mathrm{H}$ NMR (400 MHz, Chloroform- $d$ ) $\delta 7.41-7.25(\mathrm{~m}, 9 \mathrm{H}, \mathrm{ArH}), 7.24-7.17(\mathrm{~m}, 1 \mathrm{H}, \mathrm{ArH}), 7.16-7.10(\mathrm{~m}$, $2 \mathrm{H}, \mathrm{ArH}), 7.02(\mathrm{td}, J=8.3,1.5 \mathrm{~Hz}, 2 \mathrm{H}, \mathrm{ArH}), 5.18-5.12\left(\mathrm{~m}, 1 \mathrm{H}, \mathrm{CHCF}_{3}\right), 4.00(\mathrm{~d}, J=13.4 \mathrm{~Hz}, 1 \mathrm{H}$, $\left.\mathrm{PhCH}_{a} \mathrm{H}_{\mathrm{b}}\right), 3.95-3.85\left(\mathrm{~m}, 2 \mathrm{H}, \mathrm{PhCH}_{a} H_{b}\right.$ and $\left.\mathrm{NCH}_{\mathrm{a}} \mathrm{H}_{b} \mathrm{C}=\mathrm{C}\right), 3.49\left(\mathrm{~d}, J=15.4 \mathrm{~Hz}, 1 \mathrm{H}, \mathrm{NCH}_{\mathrm{a}} H_{b} \mathrm{C}=\mathrm{C}\right)$.

${ }^{13} \mathrm{C}\left\{{ }^{1} \mathrm{H}\right\}$ NMR $(101 \mathrm{MHz}$, Chloroform- $d$ ) $\delta 162.0(\mathrm{~d}, J=246.3 \mathrm{~Hz}), 148.8,138.4,136.9,136.0(\mathrm{~d}, J=3.4$ $\mathrm{Hz}), 131.8(\mathrm{~d}, J=8.0 \mathrm{~Hz}), 128.9,128.82,128.76,128.14,128.12,126.5,122.8(\mathrm{q}, J=283.9 \mathrm{~Hz}), 115.7$ $(\mathrm{d}, J=21.3 \mathrm{~Hz}), 112.0,94.1(\mathrm{q}, J=34.4 \mathrm{~Hz}), 60.5,54.9$.

${ }^{19} \mathrm{~F}$ NMR $(376 \mathrm{MHz}$, Chloroform- $d$ ) $\delta-80.3(\mathrm{~d}, J=4.2 \mathrm{~Hz}),-115.2$.

$\underline{\mathrm{IR}}\left(\mathrm{cm}^{-1}\right) 3034(\mathrm{w}), 2929(\mathrm{w}), 2103(\mathrm{w}), 1665(\mathrm{~m}), 1602(\mathrm{~m}), 1503(\mathrm{~m}), 1293(\mathrm{~m}), 1226(\mathrm{~m}), 1176(\mathrm{~s}), 1153$ (s).

$\underline{\text { HRMS }}$ (ESI/QTOF) m/z: [M + H $]^{+}$Calculated for $\mathrm{C}_{24} \mathrm{H}_{20} \mathrm{~F}_{4} \mathrm{NO}^{+}$414.1476; Found 414.1476.

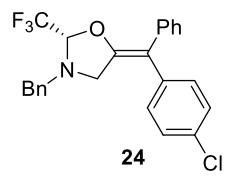

$(S, E)-3-B e n z y l-5-((4-c h l o r o p h e n y l)(p h e n y l) m e t h y l e n e)-2-$ (trifluoromethyl)oxazolidine (24)

Prepared according to the general procedure D1 using N-benzyl-3-phenylprop-2-yn-1amine ( $76 \mu \mathrm{L}, 0.40 \mathrm{mmol}, 1.0$ equiv.) and 1-chloro-4-iodobenzene (124 mg, $0.520 \mathrm{mmol}$, 1.3 equiv.). The crude material was purified by flash column chromatography (pentane/EtOAc gradient 100:0 to 100:3) to give the corresponding olefin 24 (128 $\mathrm{mg}, 0.298 \mathrm{mmol}, 74 \%$ yield) as a pale yellow oil. The enantiomeric excess was determined to be $81 \%$ by HPLC analysis on a Daicel Chiralpak IB N-5 column: 99:1 hexane/IPA, flow rate $1 \mathrm{~mL} / \mathrm{min}, \lambda=254 \mathrm{~nm}: \tau_{\text {Minor }}=10.4 \mathrm{~min}$, $\tau_{\text {Major }}=11.9$ min. Absolute configuration determined in comparison to compound $(S)$-4.

$[\alpha] \mathrm{D}^{20}=+55.1\left(\mathrm{c}=0.49, \mathrm{CHCl}_{3}, 81 \%\right.$ ee $)$.

${ }^{1} \mathrm{H}$ NMR $(400 \mathrm{MHz}$, Chloroform- $d) \delta 7.39-7.26(\mathrm{~m}, 11 \mathrm{H}, \operatorname{Ar} H), 7.23-7.17(\mathrm{~m}, 1 \mathrm{H}, \operatorname{Ar} H), 7.09(\mathrm{~d}, J=$ $8.4 \mathrm{~Hz}, 2 \mathrm{H}, \mathrm{ArH}), 5.14\left(\mathrm{q}, J=5.3 \mathrm{~Hz}, 1 \mathrm{H}, \mathrm{CHCF}_{3}\right), 4.00\left(\mathrm{~d}, J=13.3 \mathrm{~Hz}, 1 \mathrm{H}, \mathrm{PhCH}_{a} \mathrm{H}_{\mathrm{b}}\right), 3.96-3.85(\mathrm{~m}$, $2 \mathrm{H}, \mathrm{PhCH}_{a} H_{b}$ and $\left.\mathrm{NCH}_{a} \mathrm{H}_{\mathrm{b}} \mathrm{C}=\mathrm{C}\right), 3.51\left(\mathrm{dd}, J=15.8,1.5 \mathrm{~Hz}, 1 \mathrm{H}, \mathrm{NCH}_{a} H_{b} \mathrm{C}=\mathrm{C}\right)$.

${ }^{13} \mathrm{C}\left\{{ }^{1} \mathrm{H}\right\}$ NMR $(101 \mathrm{MHz}$, Chloroform- $d) \delta 148.9,138.6,138.2,136.8,133.0,131.5,129.03,128.97$, $128.84,128.75,128.18,128.15,126.6,122.8$ (q, $J=283.8 \mathrm{~Hz}), 112.0,94.1$ (q, $J=34.5 \mathrm{~Hz}), 60.5,54.8$.

${ }^{19} \mathrm{~F}\left\{{ }^{1} \mathrm{H}\right\}$ NMR $(376 \mathrm{MHz}$, Chloroform- $d$ ) $\delta-80.3$.

$\underline{\text { IR }}\left(\mathrm{cm}^{-1}\right) 3062(\mathrm{w}), 3032(\mathrm{w}), 2845(\mathrm{w}), 1664(\mathrm{~m}), 1598(\mathrm{w}), 1494(\mathrm{~m}), 1293(\mathrm{~m}), 1176$ (s), 1153 (s).

HRMS (ESI/QTOF) m/z: [M + H] $]^{+}$Calculated for $\mathrm{C}_{24} \mathrm{H}_{20} \mathrm{ClF}_{3} \mathrm{NO}^{+} 430.1180$; Found 430.1182 .

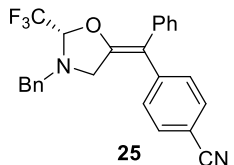

ylidene)(phenyl)methyl)benzonitrile (25)

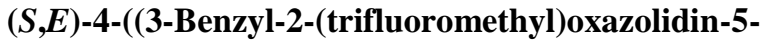

Prepared according to the general procedure D1 using N-benzyl-3-phenylprop-2-yn-1amine $(76 \mu \mathrm{L}, 0.40 \mathrm{mmol}, 1.0$ equiv.) and 4-iodobenzonitrile $(119 \mathrm{mg}, 0.520 \mathrm{mmol}, 1.3$ equiv). The crude material was purified by flash column chromatography (pentane/EtOAc gradient 100:0 to 100:10) to give the corresponding olefin 25 (152 mg, $0.362 \mathrm{mmol}, 90 \%$ yield) as a white foam. The enantiomeric excess was determined to be $74 \%$ by HPLC analysis on a Daicel Chiralpak IA column: 95:5 hexane/IPA, flow rate $1 \mathrm{~mL} / \mathrm{min}, \lambda=254 \mathrm{~nm}: \tau_{\text {Major }}=6.8 \mathrm{~min}, \tau_{\text {Minor }}=7.5 \mathrm{~min}$. Absolute configuration determined in comparison to compound $(S)-4$.

$[\alpha] \mathrm{D}^{20}=+50.3\left(\mathrm{c}=0.52, \mathrm{CHCl}_{3}, 74 \%\right.$ ee $)$. 
${ }^{1}$ H NMR $(400 \mathrm{MHz}$, Chloroform- $d$ ) $\delta 7.60(\mathrm{~d}, J=8.4 \mathrm{~Hz}, 2 \mathrm{H}, \operatorname{Ar} H), 7.38-7.21(\mathrm{~m}, 12 \mathrm{H}, \operatorname{Ar} H), 5.16(\mathrm{q}, J$ $\left.=5.1 \mathrm{~Hz}, 1 \mathrm{H}, \mathrm{CHCF}_{3}\right), 4.02\left(\mathrm{~d}, J=13.3 \mathrm{~Hz}, 1 \mathrm{H}, \mathrm{PhCH}_{a} \mathrm{H}_{\mathrm{b}}\right), 3.97\left(\mathrm{~d}, J=15.9 \mathrm{~Hz}, 1 \mathrm{H}, \mathrm{NCH}_{a} \mathrm{H}_{\mathrm{b}} \mathrm{C}=\mathrm{C}\right), 3.90$ $\left(\mathrm{d}, J=13.3 \mathrm{~Hz}, 1 \mathrm{H}, \mathrm{PhCH}_{a} H_{b}\right), 3.55\left(\mathrm{~d}, J=15.9,1 \mathrm{H}, \mathrm{NCH}_{a} H_{b} \mathrm{C}=\mathrm{C}\right)$.

${ }^{13} \mathrm{C}\left\{{ }^{1} \mathrm{H}\right\}$ NMR $(101 \mathrm{MHz}$, Chloroform- $d$ ) $\delta$ 149.9, 145.3, 137.6, 136.6, 132.5, 130.6, 129.3, 128.9, 128.7, $128.4,128.3,127.1,122.7(\mathrm{q}, J=283.9 \mathrm{~Hz}), 118.9,112.3,110.7,94.1(\mathrm{q}, J=34.6 \mathrm{~Hz}) 60.4,54.7$.

${ }^{19} \mathrm{~F}\left\{{ }^{1} \mathrm{H}\right\}$ NMR $(376 \mathrm{MHz}$, Chloroform- $d$ ) $\delta-80.3$.

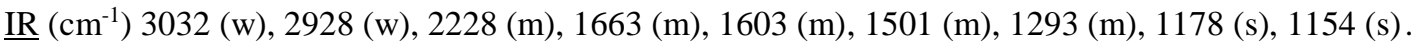

HRMS (ESI/QTOF) m/z: [M + H] $]^{+}$Calculated for $\mathrm{C}_{25} \mathrm{H}_{20} \mathrm{~F}_{3} \mathrm{~N}_{2} \mathrm{O}^{+} 421.1522$; Found 421.1529.

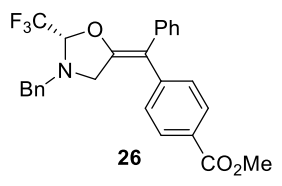

$(S, E)$-Methyl-4-((3-benzyl-2-(trifluoromethyl)oxazolidin-5ylidene)(phenyl)methyl)benzoate (26)

Prepared according to the general procedure D1 using N-benzyl-3-phenylprop-2-yn1-amine ( $76 \mu \mathrm{L}, 0.40 \mathrm{mmol}, 1.0$ equiv.) and methyl 4-iodobenzoate (136 mg, 0.520 mmol, 1.3 equiv). The crude material was purified by flash column chromatography (pentane/EtOAc gradient 100:0 to 100:10) to give the corresponding olefin 26 (175 mg, $0.386 \mathrm{mmol}, 96 \%$ yield) as a white foam. The enantiomeric excess was determined to be $82 \%$ by HPLC analysis on a Daicel IA column: 95:5 hexane $/ \mathrm{IPA}$, flow rate $1 \mathrm{~mL} / \mathrm{min}, \lambda=254 \mathrm{~nm}$ : $\tau_{\text {Major }}=6.2 \mathrm{~min}, \tau_{\text {Minor }}=7.1 \mathrm{~min}$. Absolute configuration determined in comparison to compound $(S)-4$.

$[\alpha] \mathrm{D}^{20}=+49.8\left(\mathrm{c}=0.76, \mathrm{CHCl}_{3}, 82 \%\right.$ ee $)$.

$\underline{{ }^{1} \mathrm{H} N M R}(400 \mathrm{MHz}$, Chloroform- $d) \delta 7.98(\mathrm{~d}, J=8.4 \mathrm{~Hz}, 2 \mathrm{H}, \operatorname{Ar} H), 7.37-7.27(\mathrm{~m}, 9 \mathrm{H}, \operatorname{Ar} H), 7.21(\mathrm{~d}, J$ $=8.4 \mathrm{~Hz}, 3 \mathrm{H}, \mathrm{Ar} H), 5.15\left(\mathrm{q}, J=5.2 \mathrm{~Hz}, 1 \mathrm{H}, \mathrm{CHCF}_{3}\right), 4.00\left(\mathrm{~d}, J=13.3 \mathrm{~Hz}, 1 \mathrm{H}, \mathrm{PhCH}_{a} \mathrm{H}_{\mathrm{b}}\right), 3.95(\mathrm{~d}, J=$ $\left.15.8,1 \mathrm{H}, \mathrm{NCH}_{a} \mathrm{H}_{\mathrm{b}} \mathrm{C}=\mathrm{C}\right), 3.91\left(\mathrm{~m}, 4 \mathrm{H}, \mathrm{OCH}_{3}\right.$ and $\left.\mathrm{PhCH}_{a} H_{\mathrm{b}}\right), 3.55\left(\mathrm{dd}, J=15.8,1.3 \mathrm{~Hz}, 1 \mathrm{H}, \mathrm{NCH}_{\mathrm{a}} H_{b} \mathrm{C}=\mathrm{C}\right)$.

${ }^{13} \mathrm{C}\left\{{ }^{1} \mathrm{H}\right\}$ NMR $(101 \mathrm{MHz}$, Chloroform- $d$ ) $\delta 167.0,149.3,145.2,138.0,136.8,130.1,130.0,129.2,128.85$, $128.79,128.76,128.22,128.17,126.8,122.70$ (q, $J=284.1 \mathrm{~Hz}), 112.7,94.1$ (q, $J=34.5 \mathrm{~Hz}), 60.5,54.8$, 52.3 .

${ }^{19} \mathrm{~F}\left\{{ }^{1} \mathrm{H}\right\}$ NMR $(376 \mathrm{MHz}$, Chloroform- $d$ ) $\delta-80.3$.

IR $\left(\mathrm{cm}^{-1}\right) 3029(\mathrm{w}), 2951$ (w), 1721 (s), 1664 (m), 1604 (m), 1444 (m), 1284 (s), 1181 (s), 1153 (s), 1112 (m).

HRMS (ESI/QTOF) m/z: [M + H] $]^{+}$Calculated for $\mathrm{C}_{26} \mathrm{H}_{23} \mathrm{~F}_{3} \mathrm{NO}_{3}{ }^{+}$454.1625; Found 454.1624.

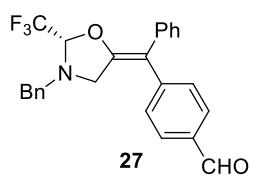

\section{ylidene)(phenyl)methyl)benzaldehyde (27)}

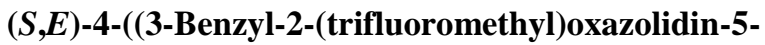
Prepared according to the general procedure D1 using N-benzyl-3-phenylprop-2-yn-1amine ( $76 \mu \mathrm{L}, 0.40 \mathrm{mmol}, 1.0$ equiv.) and 4-iodobenzaldehyde $(121 \mathrm{mg}, 0.520 \mathrm{mmol}$, 1.3 equiv). The crude material was purified by flash column chromatography (pentane/EtOAc gradient 100:0 to 100:10) to give the corresponding olefin 27 (150 mg, $0.354 \mathrm{mmol}, 89 \%$ yield) as a white foam. The enantiomeric excess was determined to be $80 \%$ by HPLC analysis on a Daicel IA column: 95:5 hexane/IPA, flow rate $1 \mathrm{~mL} / \mathrm{min}, \lambda=254 \mathrm{~nm}$ : $\tau_{\text {Major }}=6.8 \mathrm{~min}, \tau_{\text {Minor }}=7.5 \mathrm{~min}$. Absolute configuration determined in comparison to compound $(S)-4$.

$[\alpha] \mathrm{D}^{20}=+66.3\left(\mathrm{c}=0.45, \mathrm{CHCl}_{3}, 80 \%\right.$ ee $)$.

${ }^{1} \mathrm{H}$ NMR $(400 \mathrm{MHz}$, Chloroform- $d$ ) $\delta 10.00(\mathrm{~s}, 1 \mathrm{H}, \mathrm{CHO}), 7.83(\mathrm{~d}, J=8.2 \mathrm{~Hz}, 2 \mathrm{H}, \mathrm{Ar} H), 7.49-7.07$ (m, $12 \mathrm{H}, \mathrm{Ar} H), 5.16\left(\mathrm{q}, J=5.2 \mathrm{~Hz}, 1 \mathrm{H}, \mathrm{CHCF}_{3}\right), 4.09-3.94\left(\mathrm{~m}, 2 \mathrm{H}, \mathrm{PhCH}_{a} \mathrm{H}_{\mathrm{b}}\right.$ and $\left.\mathrm{NCH}_{a} \mathrm{H}_{\mathrm{b}} \mathrm{C}=\mathrm{C}\right), 3.91(\mathrm{~d}, J$ $\left.=13.3 \mathrm{~Hz}, 1 \mathrm{H}, \mathrm{PhCH}_{a} H_{b}\right), 3.59\left(\mathrm{dd}, J=15.8,1.4 \mathrm{~Hz}, 1 \mathrm{H}, \mathrm{NCH}_{\mathrm{a}} H_{b} \mathrm{C}=\mathrm{C}\right)$.

${ }^{13} \mathrm{C}\left\{{ }^{1} \mathrm{H}\right\}$ NMR (101 MHz, Chloroform- $d$ ) $\delta 191.8,149.7,146.9,137.9,136.7,135.0,130.6,130.1,129.3$, $128.9,128.8,128.3,128.2,126.9,122.7(\mathrm{q}, J=285.6 \mathrm{~Hz}), 112.8,94.0(\mathrm{q}, J=34.5 \mathrm{~Hz}), 60.5,54.7$.

${ }^{19} \mathrm{~F}\left\{{ }^{1} \mathrm{H}\right\}$ NMR $(376 \mathrm{MHz}$, Chloroform- $d$ ) $\delta-80.3$.

IR $\left(\mathrm{cm}^{-1}\right) 3031(\mathrm{w}), 2840(\mathrm{w}), 1700(\mathrm{~s}), 1663(\mathrm{~m}), 1602(\mathrm{~m}), 1295$ (m), $1174(\mathrm{~s}), 1156(\mathrm{~s})$.

HRMS (ESI/QTOF) m/z: [M + H] $]^{+}$Calculated for $\mathrm{C}_{25} \mathrm{H}_{21} \mathrm{~F}_{3} \mathrm{NO}_{2}{ }^{+}$424.1519; Found 424.1522.

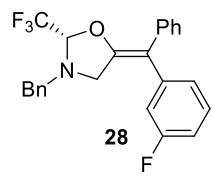

(trifluoromethyl)oxazolidine (28)

(S,E)-3-Benzyl-5-((3-fluorophenyl)(phenyl)methylene)-2- 
1.3 equiv). The crude material was purified by flash column chromatography (pentane/EtOAc gradient 100:0 to 100:3) to give the corresponding olefin 28 (158 mg, $0.382 \mathrm{mmol}, 96 \%$ yield) as a colorless oil. The enantiomeric excess was determined to be $82 \%$ by HPLC analysis on a Daicel Chiralpak IB N-5 column: 99:1 hexane/IPA, flow rate $1 \mathrm{~mL} / \mathrm{min}, \lambda=254 \mathrm{~nm}: \tau_{\text {Minor }}=8.5 \mathrm{~min}, \tau_{\text {Major }}=10.5 \mathrm{~min}$. Absolute configuration determined in comparison to compound $(S)-4$.

$[\alpha] \mathrm{D}^{20}=+47.3\left(\mathrm{c}=0.69, \mathrm{CHCl}_{3}, 82 \%\right.$ ee $)$.

${ }^{1} \mathrm{H}$ NMR $(400 \mathrm{MHz}$, Chloroform-d) $\delta 7.41-7.26(\mathrm{~m}, 10 \mathrm{H}, \mathrm{ArH}), 7.24-7.17(\mathrm{~m}, 1 \mathrm{H}, \mathrm{ArH}), 7.02-6.91$ $(\mathrm{m}, 2 \mathrm{H}, \mathrm{Ar} H), 6.86(\mathrm{ddd}, J=9.8,2.5,1.6 \mathrm{~Hz}, 1 \mathrm{H}, \mathrm{Ar} H), 5.15\left(\mathrm{q}, J=5.2 \mathrm{~Hz}, 1 \mathrm{H}, \mathrm{CHCF}_{3}\right), 4.00(\mathrm{~d}, J=13.3$ $\left.\mathrm{Hz}, 1 \mathrm{H}, \mathrm{PhCH}_{a} \mathrm{H}_{\mathrm{b}}\right), 3.95\left(\mathrm{~d}, J=16.0 \mathrm{~Hz}, 1 \mathrm{H}, \mathrm{NCH}_{a} \mathrm{H}_{\mathrm{b}} \mathrm{C}=\mathrm{C}\right), 3.90\left(\mathrm{~d}, J=13.3 \mathrm{~Hz}, 1 \mathrm{H}, \mathrm{PhCH}_{\mathrm{a}} H_{b}\right), 3.55$ (dt, $\left.J=16.0,1.4 \mathrm{~Hz}, 1 \mathrm{H}, \mathrm{NCH}_{a} H_{b} \mathrm{C}=\mathrm{C}\right)$.

${ }^{13} \mathrm{C}\left\{{ }^{1} \mathrm{H}\right\}$ NMR (101 MHz, Chloroform- $\left.d\right) \delta 163.0(\mathrm{~d}, J=246.6 \mathrm{~Hz}), 149.1,142.4(\mathrm{~d}, J=7.8 \mathrm{~Hz}), 138.1$, $136.8,130.2(\mathrm{~d}, J=8.5 \mathrm{~Hz}), 129.0,128.83,128.78,128.19,128.14,126.7,125.87(\mathrm{~d}, J=2.9 \mathrm{~Hz}), 122.8$ $(\mathrm{q}, J=283.8 \mathrm{~Hz}), 117.1(\mathrm{~d}, J=21.0 \mathrm{~Hz}), 114.1(\mathrm{~d}, J=21.0 \mathrm{~Hz}), 112.2(\mathrm{~d}, J=2.0 \mathrm{~Hz}), 94.1(\mathrm{q}, J=34.4$ $\mathrm{Hz}), 60.5,54.8$.

${ }^{19} \mathrm{~F}\left\{{ }^{1} \mathrm{H}\right\}$ NMR $(376 \mathrm{MHz}$, Chloroform- $d$ ) $\delta-80.3,-112.9$.

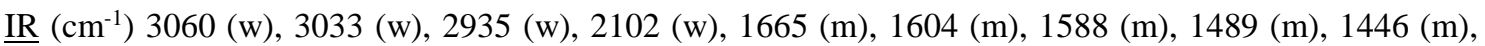
$1293(\mathrm{~m}), 1228(\mathrm{~m}), 1175(\mathrm{~s}), 1151$ (s).

HRMS (ESI/QTOF) m/z: [M+H] $]^{+}$Calculated for $\mathrm{C}_{24} \mathrm{H}_{20} \mathrm{~F}_{4} \mathrm{NO}^{+}$414.1476; Found 414.1480.

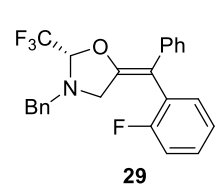

(S,E)-3-Benzyl-5-((2-fluorophenyl)(phenyl)methylene)-2(trifluoromethyl)oxazolidine (29)

Prepared according to the general procedure D1 using N-benzyl-3-phenylprop-2-yn-1amine ( $76 \mu \mathrm{L}, 0.40 \mathrm{mmol}, 1.0$ equiv.) and 2-iodofluorobenzene $(61 \mu \mathrm{L}, 0.52 \mathrm{mmol}, 1.3$ equiv). The reaction was conducted at $60^{\circ} \mathrm{C}$ using 1,2-dichloroethane as the solvent. The crude material was purified by flash column chromatography (pentane/EtOAc gradient 100:0 to 100:3) to give the corresponding olefin 29 which was further purified using a chiral preparative HPLC (103 mg, $0.249 \mathrm{mmol}, 62 \%$ yield) as a colorless oil (Chiral prep method: Daicel Chiralpak IB N-5 column: 99:1 hexane/IPA, flow rate $15 \mathrm{~mL} / \mathrm{min}$ ). The enantiomeric excess was determined to be $74 \%$ by HPLC analysis on a Daicel Chiralpak IB N-5 column: 99:1 hexane $/ \mathrm{IPA}$, flow rate $1 \mathrm{~mL} / \mathrm{min}, \lambda=254 \mathrm{~nm}: \tau_{\text {Minor }}=7.3 \mathrm{~min}$, $\tau_{\text {Major }}=8.5 \mathrm{~min}$. The e.e. was no affected by the preparative chiral HPLC purification. Absolute configuration determined in comparison to compound $(S)-4$.

$[\alpha] \mathrm{D}^{20}=+60.9\left(\mathrm{c}=0.32, \mathrm{CHCl}_{3}, 74 \%\right.$ ee $)$.

${ }^{1} \mathrm{H}$ NMR $(400 \mathrm{MHz}$, Chloroform-d) $\delta 7.43-7.26(\mathrm{~m}, 10 \mathrm{H}, \operatorname{Ar} H), 7.21-7.06(\mathrm{~m}, 4 \mathrm{H}, \operatorname{Ar} H), 5.19(\mathrm{q}, J=$ $\left.5.4 \mathrm{~Hz}, 1 \mathrm{H}, \mathrm{CHCF}_{3}\right), 3.98\left(\mathrm{~d}, J=13.2 \mathrm{~Hz}, 1 \mathrm{H}, \mathrm{PhCH}_{a} \mathrm{H}_{\mathrm{b}}\right), 3.90\left(\mathrm{~d}, J=13.3 \mathrm{~Hz}, 1 \mathrm{H}, \mathrm{PhCH}_{a} H_{b}\right), 3.85(\mathrm{~d}, J$ $\left.=16.1 \mathrm{~Hz}, 1 \mathrm{H}, \mathrm{NCH}_{a} \mathrm{H}_{\mathrm{b}} \mathrm{C}=\mathrm{C}\right), 3.43\left(\mathrm{dd}, J=16.0,1.4 \mathrm{~Hz}, 1 \mathrm{H}, \mathrm{NCH}_{\mathrm{a}} H_{b} \mathrm{C}=\mathrm{C}\right)$.

${ }^{13} \mathrm{C}\left\{{ }^{1} \mathrm{H}\right\}$ NMR $(101 \mathrm{MHz}$, Chloroform- $d) \delta 160.5(\mathrm{~d}, J=246.1 \mathrm{~Hz}), 149.8,137.7,137.0,132.9(\mathrm{~d}, J=3.2$ $\mathrm{Hz}), 129.5(\mathrm{~d}, J=8.0 \mathrm{~Hz}), 128.9,128.8,128.4,128.2,128.1,127.1(\mathrm{~d}, J=16.4 \mathrm{~Hz}), 126.5,124.6(\mathrm{~d}, J=$ $3.6 \mathrm{~Hz}), 122.74(\mathrm{q}, J=283.8 \mathrm{~Hz}), 116.2(\mathrm{~d}, J=22.5 \mathrm{~Hz}), 106.0,94.8(\mathrm{q}, J=34.5 \mathrm{~Hz}), 60.7,55.1$.

${ }^{19} \mathrm{~F}$ NMR $(376 \mathrm{MHz}$, Chloroform- $d$ ) $\delta-80.3(\mathrm{~d}, J=5.4 \mathrm{~Hz}),-113.7--115.9(\mathrm{~m})$.

$\underline{\text { IR }}\left(\mathrm{cm}^{-1}\right) 3064(\mathrm{w}), 3031(\mathrm{w}), 1668(\mathrm{~m}), 1491(\mathrm{~m}), 1451(\mathrm{~m}), 1294(\mathrm{~m}), 1179(\mathrm{~s}), 1155(\mathrm{~s})$.

HRMS (ESI/QTOF) m/z: $[\mathrm{M}+\mathrm{H}]^{+}$Calculated for $\mathrm{C}_{24} \mathrm{H}_{20} \mathrm{~F}_{4} \mathrm{NO}^{+}$414.1476; Found 414.1482.

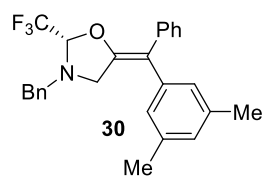
(trifluoromethyl)oxazolidine (30)

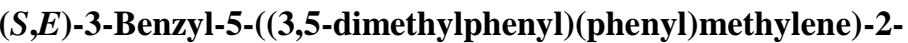

Prepared according to the general procedure D1 using N-benzyl-3-phenylprop-2-yn1-amine (76 $\mu \mathrm{L}, 0.40 \mathrm{mmol}, 1.0$ equiv.) and 1-iodo-3,5-dimethylbenzene (121 mg, $0.520 \mathrm{mmol}, 1.3$ equiv). The crude material was purified by flash column chromatography (pentane/EtOAc gradient 100:0 to 100:3) to give the corresponding olefin 30 (162 mg, $0.383 \mathrm{mmol}, 96 \%$ yield) as a colorless oil. The enantiomeric excess was determined to be $92 \%$ by HPLC analysis on a Daicel Chiralpak IB N-5 column: 99:1 hexane/IPA, flow rate $1 \mathrm{~mL} / \mathrm{min}, \lambda=254 \mathrm{~nm}: \tau_{\text {Minor }}=$ $5.0 \mathrm{~min}, \tau_{\mathrm{Major}}=6.2 \mathrm{~min}$. Absolute configuration determined in comparison to compound $(S)-4$.

$[\alpha] \mathrm{D}^{20}=+53.5\left(\mathrm{c}=0.57, \mathrm{CHCl}_{3}, 92 \%\right.$ ee $)$.

${ }^{1} \mathrm{H}$ NMR $(400 \mathrm{MHz}$, Chloroform-d) $\delta 7.42-7.26(\mathrm{~m}, 9 \mathrm{H}, \mathrm{ArH}), 7.22-7.14(\mathrm{~m}, 1 \mathrm{H}, \mathrm{ArH}), 6.90(\mathrm{~s}, 1 \mathrm{H}$, $\operatorname{ArH}), 6.78(\mathrm{~d}, J=1.6 \mathrm{~Hz}, 2 \mathrm{H}, \mathrm{ArH}), 5.13\left(\mathrm{q}, J=5.3 \mathrm{~Hz}, 1 \mathrm{H}, \mathrm{CHCF}_{3}\right), 3.99$ (d, $J=13.3 \mathrm{~Hz}, 1 \mathrm{H}, \mathrm{PhCH}_{a} \mathrm{H}_{\mathrm{b}}$ ), 
$3.95-3.86\left(\mathrm{~m}, 2 \mathrm{H}, \mathrm{PhCH}_{a} H_{b}\right.$ and $\left.\mathrm{NCH}_{a} \mathrm{H}_{\mathrm{b}} \mathrm{C}=\mathrm{C}\right), 3.53\left(\mathrm{dd}, J=15.9,1.5 \mathrm{~Hz}, 1 \mathrm{H}, \mathrm{NCH}_{a} H_{b} \mathrm{C}=\mathrm{C}\right), 2.28(\mathrm{~s}$, $\left.6 \mathrm{H}, 2 \times \mathrm{ArCH}_{3}\right)$.

${ }^{13} \mathrm{C}\left\{{ }^{1} \mathrm{H}\right\} \mathrm{NMR}(101 \mathrm{MHz}$, Chloroform- $d) \delta 148.4,140.0,138.8,138.1,137.1,129.03,128.83,128.75(2 \mathrm{C})$, 128.03 (2C), 127.97, 126.3, 122.8 (q, $J=283.9 \mathrm{~Hz}), 113.1,94.2$ (q, $J=34.2 \mathrm{~Hz}), 60.6,54.8,21.4$.

${ }^{19} \mathrm{~F}\left\{{ }^{1} \mathrm{H}\right\}$ NMR $(376 \mathrm{MHz}$, Chloroform- $d$ ) $\delta-80.3$.

$\underline{\mathrm{IR}}\left(\mathrm{cm}^{-1}\right) 3028(\mathrm{w}), 2925(\mathrm{w}), 2862(\mathrm{w}), 1665(\mathrm{~m}), 1600(\mathrm{w}), 1491(\mathrm{w}), 1453(\mathrm{w}), 1294(\mathrm{~m}), 1174(\mathrm{~s}), 1152$ (s).

$\underline{\text { HRMS }}$ (ESI/QTOF) m/z: [M + H] $]^{+}$Calculated for $\mathrm{C}_{26} \mathrm{H}_{25} \mathrm{~F}_{3} \mathrm{NO}^{+} 424.1883$; Found 424.1885.<smiles>FC(F)(F)C1CC(=C(c2ccccc2)c2cccnc2)N(Cc2ccccc2)C1</smiles>
(31)

(S,E)-3-Benzyl-5-(phenyl(pyridin-3-yl)methylene)-2-(trifluoromethyl)oxazolidine Prepared according to the general procedure D1 using N-benzyl-3-phenylprop-2-yn-1amine $(76 \mu \mathrm{L}, 0.40 \mathrm{mmol}, 1.0$ equiv.) and 3-iodopyridine (107 $\mathrm{mg}, 0.520 \mathrm{mmol}, 1.3$ equiv). The reaction was conducted at $60{ }^{\circ} \mathrm{C}$ using 1,2-dichloroethane as the solvent. The crude material was purified by flash column chromatography (pentane/EtOAc gradient 100:0 to 50:50) to give the corresponding olefin 31 (122 mg, $0.308 \mathrm{mmol}, 77 \%$ yield) as an orange solid. The enantiomeric excess was determined to be $80 \%$ by HPLC analysis on a Daicel Chiralpak IB N-5 column: 90:10 hexane/IPA, flow rate $1 \mathrm{~mL} / \mathrm{min}, \lambda=254 \mathrm{~nm}: \tau_{\text {Minor }}=10.6 \mathrm{~min}, \tau_{\text {Major }}=19.8 \mathrm{~min}$. Absolute configuration determined in comparison to compound $(S)-4$.

$[\alpha] \mathrm{D}^{20}=+47.3\left(\mathrm{c}=0.55, \mathrm{CHCl}_{3}, 80 \%\right.$ ee $)$.

${ }^{1} \mathrm{H}$ NMR $(400 \mathrm{MHz}$, Chloroform- $d$ ) $\delta 8.49(\mathrm{~m}, 2 \mathrm{H}, \mathrm{ArH}), 7.45(\mathrm{dt}, J=7.9,1.9 \mathrm{~Hz}, 1 \mathrm{H}, \mathrm{ArH}), 7.39-7.12$ $(\mathrm{m}, 11 \mathrm{H}, \mathrm{ArH}), 5.17\left(\mathrm{q}, J=5.2 \mathrm{~Hz}, 1 \mathrm{H}, \mathrm{CHCF}_{3}\right), 4.01\left(\mathrm{~d}, J=13.3 \mathrm{~Hz}, 1 \mathrm{H}, \mathrm{PhCH}_{a} \mathrm{H}_{\mathrm{b}}\right), 3.97-3.85(\mathrm{~m}, 2 \mathrm{H}$, $\mathrm{PhCH}_{a} H_{b}$ and $\left.\mathrm{NCH}_{a} \mathrm{H}_{\mathrm{b}} \mathrm{C}=\mathrm{C}\right), 3.55\left(\mathrm{dd}, J=15.7,1.4 \mathrm{~Hz}, 1 \mathrm{H}, \mathrm{NCH}_{a} H_{b} \mathrm{C}=\mathrm{C}\right)$.

${ }^{13} \mathrm{C}\left\{{ }^{1} \mathrm{H}\right\} \mathrm{NMR}(101 \mathrm{MHz}$, Chloroform- $d) \delta 150.8,149.7,148.4,137.8,137.7,136.7,136.0,129.1,128.9$, 128.8, 128.3, 128.2, 126.8, 123.7, 122.7 (q, $J=283.8 \mathrm{~Hz}), 109.8,94.2$ (q, $J=34.5 \mathrm{~Hz}), 60.5,54.8$.

${ }^{19} \mathrm{~F}\left\{{ }^{1} \mathrm{H}\right\}$ NMR $(376 \mathrm{MHz}$, Chloroform- $d) \delta-80.3$.

$\underline{\text { IR }}\left(\mathrm{cm}^{-1}\right) 3345(\mathrm{w}), 3033$ (w), $2970(\mathrm{w}), 1663$ (m), $1488(\mathrm{w}), 1451(\mathrm{w}), 1409(\mathrm{w}), 1292(\mathrm{~m}), 1173(\mathrm{~s}), 1152$ (s).

$\underline{\text { HRMS }}$ (ESI/QTOF) m/z: [M + H] $]^{+}$Calculated for $\mathrm{C}_{23} \mathrm{H}_{20} \mathrm{~F}_{3} \mathrm{~N}_{2} \mathrm{O}^{+}$397.1522; Found 397.1524.

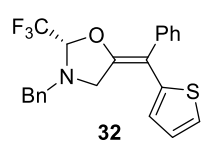

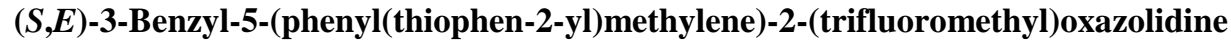
(32)

Prepared according to the general procedure D1 using N-benzyl-3-phenylprop-2-yn-1amine ( $76 \mu \mathrm{L}, 0.40 \mathrm{mmol}, 1.0$ equiv.) and 2-iodothiophene ( $57 \mu \mathrm{L}, 0.52 \mathrm{mmol}, 1.3$ equiv).

The reaction was conducted at $60 \mathrm{C}$ using DCE as the solvent. The crude material was purified by flash column chromatography (pentane/EtOAc gradient 100:0 to 100:3) to give the corresponding olefin 32 (154 $\mathrm{mg}, 0.384 \mathrm{mmol}, 96 \%$ yield) as a brown solid. The enantiomeric excess was determined to be $87 \%$ by HPLC analysis on a Daicel IB N-5 column: 99:1 hexane/IPA, flow rate $1 \mathrm{~mL} / \mathrm{min}, \lambda=254 \mathrm{~nm}: \tau_{\text {Minor }}=9.1$ $\min , \tau_{\text {Major }}=10.2 \mathrm{~min}$.). Absolute configuration determined in comparison to compound $(S)-4$.

$[\alpha] \mathrm{D}^{20}=+46.9\left(\mathrm{c}=0.65, \mathrm{CHCl}_{3}, 87 \%\right.$ ee

${ }^{1}$ H NMR $(400 \mathrm{MHz}$, Chloroform-d) $\delta 7.44-7.29(\mathrm{~m}, 9 \mathrm{H}, \mathrm{ArH}), 7.28-7.23(\mathrm{~m}, 2 \mathrm{H}, \mathrm{ArH}), 6.97(\mathrm{dd}, J=$ $5.2,3.5 \mathrm{~Hz}, 1 \mathrm{H}, \mathrm{Ar} H), 6.76(\mathrm{dd}, J=3.6,1.2 \mathrm{~Hz}, 1 \mathrm{H}, \mathrm{Ar} H), 5.11\left(\mathrm{q}, J=5.3 \mathrm{~Hz}, 1 \mathrm{H}, \mathrm{CHCF}_{3}\right), 4.12(\mathrm{dd}, J=$ 16.1, $\left.1.0 \mathrm{~Hz}, 1 \mathrm{H}, \mathrm{NCH}_{a} \mathrm{H}_{\mathrm{b}} \mathrm{C}=\mathrm{C}\right), 4.01\left(\mathrm{~d}, J=13.3 \mathrm{~Hz}, 1 \mathrm{H}, \mathrm{PhCH}_{a} \mathrm{H}_{\mathrm{b}}\right), 3.94\left(\mathrm{~d}, J=13.3 \mathrm{~Hz}, 1 \mathrm{H}, \mathrm{PhCH}_{a} H_{b}\right)$, $3.80\left(\mathrm{dd}, J=16.1,1.4 \mathrm{~Hz}, 1 \mathrm{H}, \mathrm{NCH}_{a} H_{b} \mathrm{C}=\mathrm{C}\right)$.

${ }^{13} \mathrm{C}\left\{{ }^{1} \mathrm{H}\right\}$ NMR $(101 \mathrm{MHz}$, Chloroform- $d) \delta 149.8,142.3,138.3,136.9,129.1,128.8,128.2(2 \mathrm{C}), 128.1$, 127.1, 126.98, 126.91, 125.1, $122.7(\mathrm{q}, J=283.6 \mathrm{~Hz}), 107.1,94.1$ (q, $J=34.5 \mathrm{~Hz}), 60.7,55.2$.

${ }^{19} \mathrm{~F}\left\{{ }^{1} \mathrm{H}\right\}$ NMR (376 MHz, Chloroform- $d$ ) $\delta$-80.4.

$\underline{\mathrm{IR}}\left(\mathrm{cm}^{-1}\right) 3064(\mathrm{w}), 3031(\mathrm{w}), 2935(\mathrm{w}), 2848(\mathrm{w}), 1658(\mathrm{~m}), 1493(\mathrm{w}), 1449(\mathrm{w}), 1293$ (m), $1226(\mathrm{~m})$, $1175(\mathrm{~s}), 1150(\mathrm{~s})$.

$\underline{\text { HRMS }}\left(\right.$ ESI/QTOF) m/z: $[\mathrm{M}+\mathrm{H}]^{+}$Calculated for $\mathrm{C}_{22} \mathrm{H}_{19} \mathrm{~F}_{3} \mathrm{NOS}^{+} 402.1134$; Found 402.1134 . 


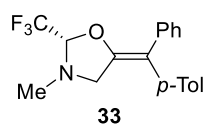

(S,E)-3-Methyl-5-(phenyl(p-tolyl)methylene)-2-(trifluoromethyl)oxazolidine (33)

Prepared according to the general procedure D1 using $N$-methyl-3-phenylprop-2-yn-1amine $(58 \mathrm{mg}, 0.40 \mathrm{mmol}, 1.0$ equiv.) and $p$-iodotoluene $(113 \mathrm{mg}, 0.520 \mathrm{mmol}$, 1.3 equiv.). The crude material was purified by flash column chromatography (pentane/EtOAc gradient 100:0 to 97:3) to give the corresponding olefin 33 (74 $\mathrm{mg}, 0.22 \mathrm{mmol}, 55 \%$ yield) as colorless oil. The enantiomeric excess was determined to be $92 \%$ by HPLC analysis on a Daicel Chiralpak IA column: 99.75:0.25 hexane $/ \mathrm{IPA}$, flow rate $1 \mathrm{~mL} / \mathrm{min}, \lambda=254 \mathrm{~nm}: \tau_{\text {Minor }}=5.1 \mathrm{~min}, \tau_{\text {Major }}=$ $5.4 \mathrm{~min}$. Absolute configuration determined in comparison to compound $(S)-\mathbf{4}$.

$[\alpha] \mathrm{D}^{20}=30.0\left(\mathrm{c}=0.50, \mathrm{CHCl}_{3}, 92 \%\right.$ ee $)$.

${ }^{1} \mathrm{H}$ NMR $(400 \mathrm{MHz}$, Chloroform-d) $\delta 7.41-7.34(\mathrm{~m}, 2 \mathrm{H}, \mathrm{ArH}), 7.32-7.26(\mathrm{~m}, 2 \mathrm{H}, \mathrm{ArH}), 7.21-7.12(\mathrm{~m}$, $3 \mathrm{H}, \operatorname{Ar} H), 7.09-7.01(\mathrm{~m}, 2 \mathrm{H}, \operatorname{Ar} H), 4.90\left(\mathrm{q}, J=5.0 \mathrm{~Hz}, 1 \mathrm{H}, \mathrm{CHCF}_{3}\right), 3.93(\mathrm{~d}, J=15.1 \mathrm{~Hz}, 1 \mathrm{H}$, $\left.\mathrm{NCH}_{a} \mathrm{H}_{\mathrm{b}} \mathrm{C}=\mathrm{C}\right), 3.43\left(\mathrm{~d}, J=15.1 \mathrm{~Hz}, 1 \mathrm{H}, \mathrm{NCH}_{\mathrm{a}} H_{b} \mathrm{C}=\mathrm{C}\right), 2.60\left(\mathrm{~s}, 3 \mathrm{H}, \mathrm{NCH}_{3}\right), 2.37\left(\mathrm{~s}, 3 \mathrm{H}, \mathrm{ArCH}_{3}\right)$.

${ }^{13} \mathrm{C}\left\{{ }^{1} \mathrm{H}\right\} \mathrm{NMR}(101 \mathrm{MHz}$, Chloroform-d $) \delta 148.2,138.6,137.2,136.8,130.0,129.4,129.1,128.1,126.4$, $122.8(\mathrm{q}, J=283.4 \mathrm{~Hz}), 113.0,95.7(\mathrm{q}, J=34.2 \mathrm{~Hz}), 56.8,43.4,21.3$.

${ }^{19} \mathrm{~F}$ NMR $(376 \mathrm{MHz}$, Chloroform-d) $\delta-80.8(\mathrm{~d}, J=4.8 \mathrm{~Hz})$.

$\underline{\mathrm{IR}}\left(\mathrm{cm}^{-1}\right) 2910(\mathrm{w}), 1660(\mathrm{~m}), 1605(\mathrm{~m}), 1451(\mathrm{~m}), 1401(\mathrm{~m}), 1284(\mathrm{~s}), 1155$ (s), 1064 (s). HRMS (APCI/QTOF) m/z: [M + H] ${ }^{+}$Calculated for $\mathrm{C}_{19} \mathrm{H}_{19} \mathrm{~F}_{3} \mathrm{NO}^{+}$334.1413; Found 334.1410.

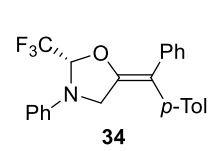

(S,E)-3-Phenyl-5-(phenyl(p-tolyl)methylene)-2-(trifluoromethyl)oxazolidine (34)

Prepared according to the general procedure D1 using $N$-(3-phenylprop-2-yn-1-yl)aniline ( $83 \mathrm{mg}, 0.40 \mathrm{mmol}, 1.0$ equiv.) and $p$-iodotoluene (113 $\mathrm{mg}, 0.520 \mathrm{mmol}, 1.3$ equiv.). The crude material was purified by flash column chromatography (pentane/EtOAc gradient 100:0 to 97:3) to give the corresponding olefin 34 (91 mg, $0.23 \mathrm{mmol}, 58 \%$ yield) as amorphous white solid. The enantiomeric excess was determined to be $54 \%$ by HPLC analysis on a Daicel Chiralpak IB N5 column: 99:1 hexane/IPA, flow rate $1 \mathrm{~mL} / \mathrm{min}, \lambda=254 \mathrm{~nm}: \tau_{\text {Minor }}=6.2 \mathrm{~min}, \tau_{\text {Minor }}=11.6 \mathrm{~min}$. Absolute configuration determined in comparison to compound $(S)-\mathbf{4}$.

$[\alpha] \mathrm{D}^{20}=68.0\left(\mathrm{c}=0.69, \mathrm{CHCl}_{3}, 54 \%\right.$ ee $)$.

${ }^{1} \mathrm{H}$ NMR (400 MHz, Chloroform-d) $\delta 7.42-7.36(\mathrm{~m}, 2 \mathrm{H}, \mathrm{ArH}), 7.34-7.27$ (m, 4H, ArH), $7.25-7.17$ (m, $3 \mathrm{H}, \operatorname{ArH}), 7.17-7.10(\mathrm{~m}, 2 \mathrm{H}, \mathrm{ArH}), 6.97-6.89(\mathrm{~m}, 1 \mathrm{H}, \mathrm{ArH}), 6.79-6.67$ (m, 2H, ArH), 5.90 (q, $J=4.1$ $\left.\mathrm{Hz}, 1 \mathrm{H}, \mathrm{CHCF}_{3}\right), 4.35\left(\mathrm{~d}, J=14.0 \mathrm{~Hz}, 1 \mathrm{H}, \mathrm{NCH}_{a} \mathrm{H}_{\mathrm{b}} \mathrm{C}=\mathrm{C}\right), 4.21\left(\mathrm{~d}, J=14.0 \mathrm{~Hz}, 1 \mathrm{H}, \mathrm{NCH}_{a} H_{b} \mathrm{C}=\mathrm{C}\right), 2.41$ (s, 3H, $\left.\mathrm{ArCH}_{3}\right)$.

${ }^{13} \mathrm{C}\left\{{ }^{1} \mathrm{H}\right\} \mathrm{NMR}(101 \mathrm{MHz}$, Chloroform-d $) \delta 147.1,144.6,138.2,137.2,136.6,123.0,129.64,129.62,129.1$, $128.2,126.7,123.3(\mathrm{q}, J=287.4 \mathrm{~Hz}), 120.4,114.0,113.7,88.2(\mathrm{q}, J=35.4 \mathrm{~Hz}), 50.2,21.4$.

${ }^{19} \mathrm{~F}$ NMR (376 MHz, Chloroform-d) $\delta-80.5(\mathrm{~d}, J=4.1 \mathrm{~Hz})$.

$\underline{\mathrm{IR}}\left(\mathrm{cm}^{-1}\right) 3051(\mathrm{~m}), 2926(\mathrm{w}), 1674(\mathrm{~m}), 1602(\mathrm{~m}), 1503(\mathrm{~s}), 1358(\mathrm{~m}), 1317(\mathrm{~m}), 1183(\mathrm{~s}), 1155(\mathrm{~s}), 1077$ (m).

HRMS (APCI/QTOF) m/z: [M + H] ${ }^{+}$Calculated for $\mathrm{C}_{24} \mathrm{H}_{21} \mathrm{~F}_{3} \mathrm{NO}^{+}$396.1570; Found 396.1562.

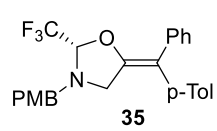

\section{(trifluoromethyl)oxazolidine (35)}

(S,E)-3-(4-Methoxybenzyl)-5-(phenyl(p-tolyl)methylene)-2-

Prepared according to the general procedure D1 using N-(4-methoxybenzyl)-3phenylprop-2-yn-1-amine (101 mg, $0.400 \mathrm{mmol}, 1.0$ equiv.) and 1-iodo-4-methylbenzene

(113 $\mathrm{mg}, 0.520 \mathrm{mmol}, 1.3$ equiv). The crude material was purified by flash column chromatography (pentane/EtOAc gradient 100:0 to 100:3) to give the corresponding olefin 35 (92 mg, $0.21 \mathrm{mmol}, 52 \%$ yield) as a colorless oil. The enantiomeric excess was determined to be $89 \%$ by HPLC analysis on a Daicel Chiralpak IB N-5 column: 99:1 hexane/IPA, flow rate $1 \mathrm{~mL} / \mathrm{min}, \lambda=254 \mathrm{~nm}: \tau_{\text {Minor }}=9.4 \mathrm{~min}, \tau_{\text {Major }}=13.1$ min. Absolute configuration determined in comparison to compound $(S)$-4.

$[\alpha] \mathrm{D}^{20}=+55.0\left(\mathrm{c}=0.60, \mathrm{CHCl}_{3}, 89 \%\right.$ ee $)$.

${ }^{1} \mathrm{H}$ NMR $(400 \mathrm{MHz}$, Chloroform- $d$ ) $\delta 7.40-7.34(\mathrm{~m}, 2 \mathrm{H}, \mathrm{ArH}), 7.32-7.22(\mathrm{~m}, 4 \mathrm{H}, \mathrm{ArH}), 7.21-7.09(\mathrm{~m}$, $3 \mathrm{H}), 7.07-7.00(\mathrm{~m}, 2 \mathrm{H}, \mathrm{ArH}), 6.90-6.83(\mathrm{~m}, 2 \mathrm{H}, \mathrm{ArH}), 5.11\left(\mathrm{q}, J=5.4 \mathrm{~Hz}, 1 \mathrm{H}, \mathrm{CHCF}_{3}\right), 3.94-3.81(\mathrm{~m}$, $3 \mathrm{H}, \mathrm{ArCH}_{2}$ and $\left.\mathrm{NCH}_{a} \mathrm{H}_{\mathrm{b}} \mathrm{C}=\mathrm{C}\right), 3.80\left(\mathrm{~s}, 3 \mathrm{H}, \mathrm{OCH}_{3}\right), 3.53\left(\mathrm{dd}, J=15.9,1.4 \mathrm{~Hz}, 1 \mathrm{H}, \mathrm{NCH}_{a} H_{b} \mathrm{C}=\mathrm{C}\right), 2.35(\mathrm{~s}$, $\left.3 \mathrm{H}, \mathrm{ArCH}_{3}\right)$. 
${ }^{13} \mathrm{C}\left\{{ }^{1} \mathrm{H}\right\}$ NMR (101 MHz, Chloroform- $d$ ) $\delta 159.4,148.5,138.8,137.2,136.7,130.09,130.05,129.4$, $129.06,129.04,128.0,126.3,122.9(\mathrm{q}, J=284.1 \mathrm{~Hz}), 114.12,112.8,93.8(\mathrm{q}, J=34.2 \mathrm{~Hz}), 59.9,55.4,54.8$, 21.3 .

${ }^{19} \mathrm{~F}\left\{{ }^{1} \mathrm{H}\right\}$ NMR $(376 \mathrm{MHz}$, Chloroform- $d$ ) $\delta-80.3$.

$\underline{\mathrm{IR}}\left(\mathrm{cm}^{-1}\right) 3024(\mathrm{w}), 2931$ (w), 2844 (w), 1665 (m), 1609 (m), $1514(\mathrm{~m}), 1454(\mathrm{~m}), 1295(\mathrm{~m}), 1250(\mathrm{~s}), 1175$ (s), $1153(\mathrm{~s})$.

HRMS (ESI/QTOF) m/z: [M + H] $]^{+}$Calculated for $\mathrm{C}_{26} \mathrm{H}_{25} \mathrm{~F}_{3} \mathrm{NO}_{2}{ }^{+}$440.1832; Found 440.1842. 


\section{D.3. General Procedure for the Asymmetric Hydrogenation of the Tetrasubstituted Olefins.}
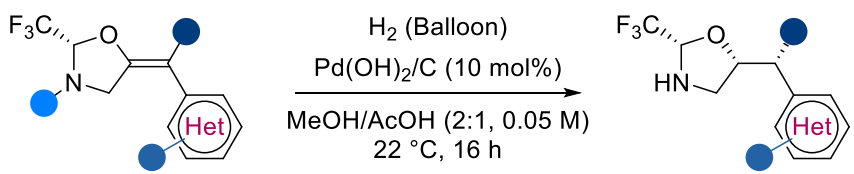

$0.2 \mathrm{mmol}$

Scheme 14. Palladium-catalyzed asymmetric hydrogenation of tetrasubstituted olefins.

An oven-dried $25 \mathrm{~mL}$ round-bottom flask equipped with a Teflon coated stirring bar was charged with $\mathrm{Pd}(\mathrm{OH})_{2} / \mathrm{C}(10 \mathrm{~mol} \%, 14 \mathrm{mg})$ and the tetrasubstituted olefin $(0.20 \mathrm{mmol})$. The flask was sealed and evacuated and back-filled with $\mathrm{N}_{2}$ three times. $\mathrm{MeOH}(2.7 \mathrm{~mL})$ and $\mathrm{AcOH}(1.3 \mathrm{~mL})$ were added and the suspension was stirred at room temperature for 10 minutes under a nitrogen flow. Then, a hydrogen balloon was connected to the flask through a needle and the mixture was vigorously stirred at room temperature for 16 hours. Then, the reaction mixture was degassed by bubbling nitrogen for 10 minutes and filtered through a plug of celite eluting with $10 \mathrm{~mL}$ of $\mathrm{MeOH}$. The crude extract was washed with saturated $\mathrm{NaHCO}_{3}$ and extracted with DCM $(3 \times 25 \mathrm{~mL})$. The combined organic layer was dried over sodium sulfate, filtered and concentrated in vacuum. The crude material was purified by flash column chromatography on silica gel to afford the corresponding product as a single diastereoisomer.

\section{D.4. Characterization of Hydrogenated Products}

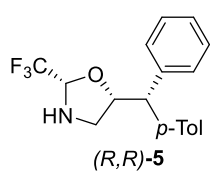

\section{(2S,5R)-5-((R)-Phenyl(p-tolyl)methyl)-2-(trifluoromethyl)oxazolidine $((R, R)-5)$}

Prepared according to the general procedure D5 using $(S)-4(82 \mathrm{mg}, 0.20 \mathrm{mmol}, 1.0$ equiv., 94\% ee) and $\mathrm{Pd}(\mathrm{OH})_{2} / \mathrm{C}(10 \mathrm{~mol} \%, 14 \mathrm{mg})$. The crude material was purified by flash column chromatography (pentane/EtOAc gradient 100:0 to 85:15) to give the corresponding product $(R, R)-5(51 \mathrm{mg}, 0.16 \mathrm{mmol}, 79 \%$ yield $)$ as a pale yellow solid (m.p. $72{ }^{\circ} \mathrm{C}$ ).. The enantiomeric excess was determined to be $94 \%$ by HPLC analysis on a Daicel Chiralpak IA column: $95: 5$ hexane/IPA, flow rate $1 \mathrm{~mL} / \mathrm{min}, \lambda=210 \mathrm{~nm}: \tau_{\text {Major }}=8.2 \mathrm{~min}, \tau_{\text {Minor }}=12.5 \mathrm{~min}$. Absolute and relative configuration were determined by X-Ray diffraction analysis of a single crystal of $(R, R)-\mathbf{5}$ (Details in section F)

$[\alpha] \mathrm{D}^{20}=+6.9\left(\mathrm{c}=0.36, \mathrm{CHCl}_{3}, 94 \%\right.$ ee $)$.

${ }^{1}$ H NMR $(400 \mathrm{MHz}$, Chloroform- $d$ ) $\delta 7.34-7.18(\mathrm{~m}, 7 \mathrm{H}, \operatorname{Ar} H), 7.12(\mathrm{~d}, J=7.9 \mathrm{~Hz}, 2 \mathrm{H}, \operatorname{Ar} H), 4.97(\mathrm{dq}, J$ $\left.=8.2,5.6 \mathrm{~Hz}, 1 \mathrm{H}, \mathrm{CHCF}_{3}\right), 4.62(\mathrm{td}, J=9.4,5.5 \mathrm{~Hz}, 1 \mathrm{H}, \mathrm{OCH}), 3.97\left(\mathrm{~d}, J=9.5 \mathrm{~Hz}, 1 \mathrm{H}, \mathrm{Ar}^{1} \mathrm{Ar}^{2} \mathrm{CH}\right), 3.15$ (dt, $\left.J=12.3,6.2 \mathrm{~Hz}, 1 \mathrm{H}, \mathrm{NCH}_{a} \mathrm{H}_{\mathrm{b}}\right), 2.80\left(\mathrm{q}, J=11.0 \mathrm{~Hz}, 1 \mathrm{H}, \mathrm{NCH}_{\mathrm{a}} H_{b}\right), 2.72-2.58$ (br. s., $\left.1 \mathrm{H}, \mathrm{NH}\right), 2.31$ (s, $\left.3 \mathrm{H}, \mathrm{CH}_{3}\right)$.

${ }^{13} \mathrm{C}\left\{{ }^{1} \mathrm{H}\right\}$ NMR $(101 \mathrm{MHz}$, Chloroform- $d$ ) $\delta$ 141.5, 139.2, 136.3, 129.3, 128.9, 128.3, 128.2, 127.1, 123.4 $(\mathrm{q}, J=282.9 \mathrm{~Hz}), 88.4(\mathrm{q}, J=33.9 \mathrm{~Hz}), 82.2,55.3,50.7,21.2$.

${ }^{19} \mathrm{~F}\left\{{ }^{1} \mathrm{H}\right\}$ NMR $(376 \mathrm{MHz}$, Chloroform- $d$ ) $\delta$-81.0.

IR $\left(\mathrm{cm}^{-1}\right) 3351(\mathrm{w}), 3024$ (w), 2925 (m), 2861 (w), 1523 (w), 1454 (w), 1290 (m), 1166 (s), 1150 (s).

HRMS (ESI/QTOF) m/z: [M + H] $]^{+}$Calculated for $\mathrm{C}_{18} \mathrm{H}_{19} \mathrm{~F}_{3} \mathrm{NO}^{+}$322.1413; Found 322.1413 .

1.2 mmol scale reduction. The model reduction was repeated on $1.2 \mathrm{mmol}$ scale. An oven dried $50 \mathrm{~mL}$ round-bottom flask equipped with a Teflon stir bar was charged with $\mathrm{Pd}(\mathrm{OH})_{2} / \mathrm{C}(10 \mathrm{~mol} \%, 86 \mathrm{mg}$, $0.12 \mathrm{mmol}$ ) and olefin $(S)-4$ (500 mg, $1.22 \mathrm{mmol}, 1.0$ equiv.). $\mathrm{MeOH}(16 \mathrm{~mL})$ and $\mathrm{AcOH}(8 \mathrm{~mL})$ were added and the suspension was stirred at $22{ }^{\circ} \mathrm{C}$ for 10 minutes under a nitrogen flow. Then, a hydrogen balloon was connected to the flask through a needle and the mixture was vigorously stirred at $22{ }^{\circ} \mathrm{C}$ for 16 hours. Then, the reaction mixture was degassed by bubbling nitrogen for 10 minutes and filtered through a plug of celite eluting with $20 \mathrm{~mL}$ of $\mathrm{MeOH}$. The crude extract was washed with saturated $\mathrm{NaHCO}_{3}$ and extracted with DCM $(3 \times 50 \mathrm{~mL})$. The combined organic layer was dried over sodium sulfate, filtered and concentrated in vасио. The crude material was purified by flash column chromatography (pentane/EtOAc gradient 100:0 to $85: 15)$ to give the corresponding product $(R, R)-\mathbf{5}(284 \mathrm{mg}, 0.884 \mathrm{mmol}, 72 \%$ yield) as a colorless oil, which solidified upon vigorous scratching with a spatula. The enantiomeric excess was determined to be $94 \%$ by HPLC analysis on a Daicel Chiralpak IA column: 95:5 hexane/IPA, flow rate 1 $\mathrm{mL} / \mathrm{min}, \lambda=210 \mathrm{~nm}: \tau_{\text {Major }}=8.2 \mathrm{~min}, \tau_{\text {Minor }}=12.6 \mathrm{~min}$. 


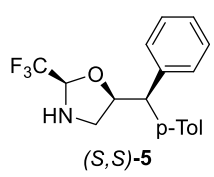

(2R,5S)-5-((S)-Phenyl(p-tolyl)methyl)-2-(trifluoromethyl)oxazolidine ((S,S)-5)

Prepared according to the general procedure D5 using $(R)-4(82 \mathrm{mg}, 0.20 \mathrm{mmol}, 1.0$ equiv., 92\% ee) and $\mathrm{Pd}(\mathrm{OH})_{2} / \mathrm{C}(10 \mathrm{~mol} \%, 14 \mathrm{mg})$. The crude material was purified by flash column chromatography (pentane/EtOAc gradient 100:0 to 85:15) to give the corresponding product $(S, S)-5(51 \mathrm{mg}, 0.16 \mathrm{mmol}, 79 \%$ yield) as a pale yellow solid. The enantiomeric excess was determined to be $92 \%$ by HPLC analysis on a Daicel Chiralpak IA column: 95:5 hexane/IPA, flow rate $1 \mathrm{~mL} / \mathrm{min}, \lambda=210 \mathrm{~nm}: \tau_{\text {Minor }}=7.8 \mathrm{~min}, \tau_{\text {Major }}=11.6 \mathrm{~min} .[\alpha] \mathrm{D}^{20}=-2.0(\mathrm{c}=0.50$, $\mathrm{CHCl}_{3}, 92 \%$ ee). Absolute configuration was determined in comparison to compound $(R, R)-\mathbf{5}$.

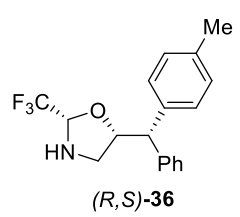

(2S,5R)-5-((S)-Phenyl( $p$-tolyl)methyl)-2-(trifluoromethyl)oxazolidine ((R,S)-36)

Prepared according to the general procedure D5 using $(S)-6(82 \mathrm{mg}, 0.20 \mathrm{mmol}$, 1.0 equiv., $89 \%$ ee $)$ and $\mathrm{Pd}(\mathrm{OH})_{2} / \mathrm{C}(20 \mathrm{~mol} \%, 28 \mathrm{mg})$. The crude material was purified by flash column chromatography (pentane/EtOAc gradient 100:0 to 85:15) to give the corresponding product $(R, S)-\mathbf{3 6}(52 \mathrm{mg}, 0.16 \mathrm{mmol}, 82 \%$ yield) as colorless oil. The enantiomeric excess was determined to be $89 \%$ by HPLC analysis on a Daicel Chiralpak IA column: 95:5 hexane/IPA, flow rate $1 \mathrm{~mL} / \mathrm{min}, \lambda=210 \mathrm{~nm}: \tau_{\text {Major }}=7.7 \mathrm{~min}, \tau_{\text {Minor }}=11.0 \mathrm{~min}$. Absolute configuration was determined in comparison to compound $(R, R)-\mathbf{5}$.

$[\alpha] \mathrm{D}^{20}=-0.5\left(\mathrm{c}=0.64, \mathrm{CHCl}_{3}, 89 \%\right.$ ee $)$.

${ }^{1} \mathrm{H}$ NMR $(400 \mathrm{MHz}$, Chloroform- $d$ ) $\delta 7.36-7.27(\mathrm{~m}, 4 \mathrm{H}, \operatorname{Ar} H), 7.23-7.16(\mathrm{~m}, 1 \mathrm{H}, \mathrm{Ar} H), 7.16-7.05(\mathrm{~m}$, $4 \mathrm{H}, \mathrm{Ar} H), 4.98\left(\mathrm{q}, J=5.5 \mathrm{~Hz}, 1 \mathrm{H}, \mathrm{CHCF}_{3}\right), 4.61(\mathrm{ddd}, J=11.5,9.6,5.6 \mathrm{~Hz}, 1 \mathrm{H}, \mathrm{OCH}), 3.96(\mathrm{~d}, J=9.6$ $\left.\mathrm{Hz}, 1 \mathrm{H}, \operatorname{Ar}^{1} \mathrm{Ar}^{2} \mathrm{CH}\right)$ ), $3.16\left(\mathrm{dd}, J=11.5,5.6 \mathrm{~Hz}, 1 \mathrm{H}, \mathrm{NCH}_{a} \mathrm{H}_{\mathrm{b}}\right), 2.81\left(\mathrm{t}, J=11.5 \mathrm{~Hz}, 1 \mathrm{H}, \mathrm{NCH}_{\mathrm{a}} H_{b}\right), 2.66$ (br. s, $1 \mathrm{H}, \mathrm{NH}), 2.31$ (s, $\left.3 \mathrm{H}, \mathrm{CH}_{3}\right)$.

${ }^{13} \mathrm{C}\left\{{ }^{1} \mathrm{H}\right\}$ NMR (101 MHz, Chloroform- $d$ ) $\delta$ 142.4, 138.4, 136.8, 129.6, 128.5, 128.3, 128.2, 126.7, 123.4 $(\mathrm{q}, J=283.0 \mathrm{~Hz}), 88.4(\mathrm{q}, J=33.9 \mathrm{~Hz}), 81.1,55.2,50.8,21.2$.

${ }^{19} \mathrm{~F}$ NMR $(376 \mathrm{MHz}$, Chloroform- $d$ ) $\delta-81.1(\mathrm{~d}, 3 \mathrm{~F}, J=5.5 \mathrm{~Hz})$.

IR $\left(\mathrm{cm}^{-1}\right) 3354(\mathrm{w}), 2927$ (w), $1508(\mathrm{~m}), 1453(\mathrm{w}), 1328(\mathrm{~m}), 1290(\mathrm{~m}), 1168(\mathrm{~s}), 1150(\mathrm{~s})$.

HRMS (ESI/QTOF) m/z: $[\mathrm{M}+\mathrm{H}]^{+}$Calculated for $\mathrm{C}_{18} \mathrm{H}_{19} \mathrm{~F}_{3} \mathrm{NO}^{+}$322.1413; Found 322.1417 .

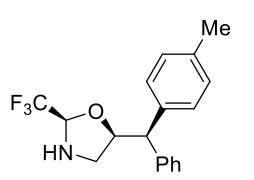

$(S, R)-36$

\section{(2R,5S)-5-((R)-Phenyl( $p$-tolyl)methyl)-2-(trifluoromethyl)oxazolidine ( $(S, R)$-36)}

Prepared according to the general procedure D3 using $(R)-6(82 \mathrm{mg}, 0.20 \mathrm{mmol}$, 1.0 equiv., $89 \%$ ee) and $\mathrm{Pd}(\mathrm{OH})_{2} / \mathrm{C}(20 \mathrm{~mol} \%, 28 \mathrm{mg})$. The crude material was purified by flash column chromatography (pentane/EtOAc gradient 100:0 to 85:15) to give the corresponding product $(S, R)-\mathbf{3 6}(50 \mathrm{mg}, 0.16 \mathrm{mmol}, 78 \%$ yield) as colorless oil. The enantiomeric excess was determined to be $89 \%$ by HPLC analysis on a Daicel Chiralpak IA column: $95: 5$ hexane/IPA, flow rate $1 \mathrm{~mL} / \mathrm{min}, \lambda=210 \mathrm{~nm}: \tau_{\text {Minor }}=7.7 \mathrm{~min}, \tau_{\text {Major }}=10.9 \mathrm{~min} .[\alpha] \mathrm{D}^{20}=$ $2.7\left(\mathrm{c}=0.50, \mathrm{CHCl}_{3}, 89 \%\right.$ ee). Absolute configuration was determined in comparison to compound $(R, R)$ 5.

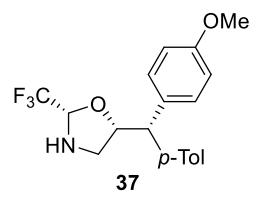

\section{(2S,5R)-5-((S)-(4-Methoxyphenyl)(p-tolyl)methyl)-2-(trifluoromethyl)oxazolidine} (37)

Prepared according to the general procedure D5 using 7 ( $88 \mathrm{mg}, 0.20 \mathrm{mmol}$, 1.0 equiv., $92 \%$ ee $)$ and $\mathrm{Pd}(\mathrm{OH})_{2} / \mathrm{C}(20 \mathrm{~mol} \%, 28 \mathrm{mg})$. The crude material was purified by flash column chromatography (pentane/EtOAc gradient 100:0 to 85:15) to give the corresponding product 37 (60 mg, $0.17 \mathrm{mmol}, 85 \%$ yield) as colorless oil The enantiomeric excess was determined to be $92 \%$ by HPLC analysis on a Daicel Chiralpak IA column: 95:5 hexane/IPA, flow rate 1 $\mathrm{mL} / \mathrm{min}, \lambda=210 \mathrm{~nm}$ : $\tau_{\text {Major }}=10.2 \mathrm{~min}, \tau_{\text {Minor }}=15.7 \mathrm{~min}$. Absolute configuration was determined in comparison to compound $(R, R)-\mathbf{5}$.

$[\alpha] \mathrm{D}^{20}=-0.8\left(\mathrm{c}=0.44, \mathrm{CHCl}_{3}, 92 \%\right.$ ee $)$.

${ }^{1}$ H NMR $(400 \mathrm{MHz}$, Chloroform- $d$ ) $\delta 7.21(\mathrm{~d}, J=8.1 \mathrm{~Hz}, 2 \mathrm{H}, \operatorname{Ar} H), 7.17-7.12(\mathrm{~m}, 2 \mathrm{H}, \operatorname{Ar} H), 7.11(\mathrm{~d}, J$ $=8.0 \mathrm{~Hz}, 2 \mathrm{H}, \operatorname{Ar} H), 6.87-6.78(\mathrm{~m}, 2 \mathrm{H}, \operatorname{Ar} H), 4.97\left(\mathrm{q}, J=5.6 \mathrm{~Hz}, 1 \mathrm{H}, \mathrm{CHCF}_{3}\right), 4.56(\mathrm{dt}, J=9.6,5.2 \mathrm{~Hz}$, $1 \mathrm{H}, \mathrm{OCH}), 3.91\left(\mathrm{~d}, J=9.6 \mathrm{~Hz}, 1 \mathrm{H}, \mathrm{Ar}^{1} \mathrm{Ar}^{2} \mathrm{CH}\right)$ ), $3.77\left(\mathrm{~s}, 3 \mathrm{H}, \mathrm{OCH}_{3}\right), 3.15(\mathrm{dd}, J=11.6,5.2 \mathrm{~Hz}, 1 \mathrm{H}$, $\mathrm{NCH}_{a} \mathrm{H}_{\mathrm{b}}$ ), 2.81 (dd, $\left.1 \mathrm{H}, J=11.6,9.6, \mathrm{NCH}_{\mathrm{a}} H_{b}\right), 2.67$ (br. s, $\left.1 \mathrm{H}, \mathrm{NH}\right), 2.30$ (s, 3H, $\mathrm{ArCH}_{3}$ ).

${ }^{13} \mathrm{C}\left\{{ }^{1} \mathrm{H}\right\}$ NMR $(101 \mathrm{MHz}$, Chloroform- $d$ ) $\delta$ 158.6, 139.5, 136.2, 133.7, 129.28, 129.25, 128.1, 123.5 (q, $J$ $=282.9 \mathrm{~Hz}), 114.3,88.4(\mathrm{q}, J=33.9 \mathrm{~Hz}), 82.4,55.4,54.4,50.8,21.2$. 
${ }^{19} \mathrm{~F} \mathrm{NMR}(376 \mathrm{MHz}$, Chloroform- $d) \delta-81.1(\mathrm{~d}, 3 \mathrm{~F}, J=5.6 \mathrm{~Hz})$.

$\underline{\text { IR }}\left(\mathrm{cm}^{-1}\right) 3349(\mathrm{~m}), 3010(\mathrm{~m}), 2926(\mathrm{~m}), 2839(\mathrm{w}), 1612(\mathrm{~m}), 1513(\mathrm{~s}), 1456(\mathrm{~m}), 1293(\mathrm{~m}), 1254(\mathrm{~s}), 1171$ (s), $1150(\mathrm{~s}), 1038(\mathrm{~m})$.

HRMS (ESI/QTOF) m/z: [M+ H] $]^{+}$Calculated for $\mathrm{C}_{19} \mathrm{H}_{21} \mathrm{~F}_{3} \mathrm{NO}_{2}{ }^{+}$352.1519; Found 352.1515.

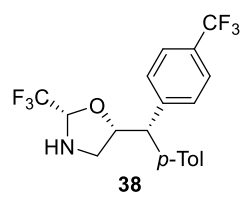

$((2 S, 5 R)-5-((S)-p-T o l y l(4-(t r i f l u o r o m e t h y l) p h e n y l) m e t h y l)-2-$ (trifluoromethyl)oxazolidine (38)

Prepared according to the general procedure D5 using 8 (95 mg, $0.20 \mathrm{mmol}, 1.0$ equiv., $88 \%$ ee $)$ and $\mathrm{Pd}(\mathrm{OH})_{2} / \mathrm{C}(20 \mathrm{~mol} \%, 28 \mathrm{mg})$. The crude material was purified by flash column chromatography (pentane/EtOAc gradient 100:0 to 85:15) to give the corresponding product 38 (59 $\mathrm{mg}, 0.15 \mathrm{mmol} 76 \%$ yield) as colorless oil. The enantiomeric excess was determined to be $88 \%$ by HPLC analysis on a Daicel Chiralpak IA column: $95: 5$ hexane $/ \mathrm{IPA}$, flow rate $1 \mathrm{~mL} / \mathrm{min}, \lambda=210 \mathrm{~nm}: \tau_{\text {Major }}=9.3 \mathrm{~min}, \tau_{\text {Minor }}=11.8 \mathrm{~min}$. Absolute configuration was determined in comparison to compound $(R, R)-\mathbf{5}$.

$[\alpha] \mathrm{D}^{20}=0.9\left(\mathrm{c}=0.88, \mathrm{CHCl}_{3}, 88 \%\right.$ ee $)$.

${ }^{1} \mathrm{H}$ NMR $(400 \mathrm{MHz}$, Chloroform- $d) \delta 7.55(\mathrm{~d}, J=8.1 \mathrm{~Hz}, 2 \mathrm{H}, \operatorname{Ar} H), 7.37(\mathrm{~d}, J=8.1 \mathrm{~Hz}, 2 \mathrm{H}, \operatorname{Ar} H), 7.19$ $(\mathrm{d}, J=8.0 \mathrm{~Hz}, 2 \mathrm{H}, \mathrm{Ar} H), 7.13(\mathrm{~d}, J=8.0 \mathrm{~Hz}, 2 \mathrm{H}, \mathrm{Ar} H), 4.98\left(\mathrm{q}, J=5.3 \mathrm{~Hz}, 1 \mathrm{H}, \mathrm{CHCF}_{3}\right), 4.62(\mathrm{ddd}, J=$ $11.5,9.1,5.6 \mathrm{~Hz}, 1 \mathrm{H}, \mathrm{OCH}), 4.04\left(\mathrm{~d}, J=9.1 \mathrm{~Hz}, 1 \mathrm{H}, \mathrm{Ar}^{1} \mathrm{Ar}^{2} \mathrm{CH}\right), 3.17$ (dd, $\left.J=11.5,5.6 \mathrm{~Hz}, 1 \mathrm{H}, \mathrm{NCH}_{a} \mathrm{H}_{\mathrm{b}}\right)$, $2.78\left(\mathrm{t}, J=11.5 \mathrm{~Hz}, 1 \mathrm{H}, \mathrm{NCH}_{\mathrm{a}} H_{b}\right), 2.68$ (br. s, $\left.1 \mathrm{H}, \mathrm{NH}\right), 2.31$ (s, 3H, $\left.\mathrm{CH}_{3}\right)$.

${ }^{13} \mathrm{C}\left\{{ }^{1} \mathrm{H}\right\}$ NMR $(101 \mathrm{MHz}$, Chloroform- $d) \delta 145.6,138.0,136.8,129.5,129.4(\mathrm{q}, J=32.5 \mathrm{~Hz}) 128.7,128.3$, $125.9(\mathrm{q}, J=3.7 \mathrm{~Hz}), 124.2(\mathrm{q}, J=271.9 \mathrm{~Hz}), 123.3(\mathrm{q}, J=282.8 \mathrm{~Hz}), 88.4(\mathrm{q}, J=34.0 \mathrm{~Hz}), 81.6,55.0$, $50.5,21.2$

${ }^{19} \mathrm{~F}$ NMR $\left(376 \mathrm{MHz}\right.$, Chloroform- $d$ ) $\delta-62.6\left(\mathrm{~s}, 3 \mathrm{~F}, \mathrm{ArCF}_{3}\right),-81.0\left(\mathrm{~d}, 3 \mathrm{~F}, J=5.3 \mathrm{~Hz}, \mathrm{CHC} F_{3}\right)$.

IR $\left(\mathrm{cm}^{-1}\right) 3351(\mathrm{w}), 3017(\mathrm{w}), 2932$ (w), 1620 (w), 1516 (w), 1421 (w), 1328 (s), 1165 (s), 1125 (s), 1074 (m).

$\underline{\text { HRMS }}$ (ESI/QTOF) m/z: [M + H $]^{+}$Calculated for $\mathrm{C}_{19} \mathrm{H}_{18} \mathrm{~F}_{6} \mathrm{NO}^{+} 390.1287$; Found 390.1298.

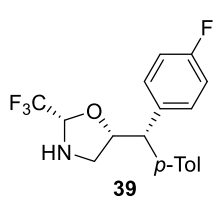

(2S,5R)-5-((S)-(4-Fluorophenyl)(p-tolyl)methyl)-2-(trifluoromethyl)oxazolidine (39)

Prepared according to the general procedure D5 using 9 (85 mg, $0.20 \mathrm{mmol}, 1.0$ equiv., $91 \%$ ee) and $\mathrm{Pd} / \mathrm{C}(20 \mathrm{~mol} \%, 85 \mathrm{mg})$. The crude material was purified by flash column chromatography (pentane/EtOAc gradient 100:0 to $85: 15$ ) to give the corresponding product 39 (52 $\mathrm{mg}, 0.16 \mathrm{mmol}, 83 \%$ yield) as colorless oil. The enantiomeric excess was determined to be $91 \%$ by HPLC analysis on a Daicel Chiralpak IA column: 95:5 hexane/IPA, flow rate 1 $\mathrm{mL} / \mathrm{min}, \lambda=210 \mathrm{~nm}: \tau_{\text {Major }}=9.7 \mathrm{~min}, \tau_{\text {Minor }}=12.8 \mathrm{~min}$. Absolute configuration was determined in comparison to compound $(R, R)-5$.

$[\alpha] \mathrm{D}^{20}=1.5\left(\mathrm{c}=0.92, \mathrm{CHCl}_{3}, 91 \%\right.$ ee $)$.

${ }^{1} \mathrm{H}$ NMR $(400 \mathrm{MHz}$, Chloroform- $d) \delta 7.24-7.15(\mathrm{~m}, 4 \mathrm{H}, \mathrm{ArH}), 7.15-7.08(\mathrm{~m}, 2 \mathrm{H}, \mathrm{ArH}), 7.02-6.94(\mathrm{~m}$, $\overline{2 \mathrm{H}, \mathrm{ArH})}, 4.97\left(\mathrm{q}, J=5.5 \mathrm{~Hz}, 1 \mathrm{H}, \mathrm{CHCF}_{3}\right), 4.57(\mathrm{td}, J=9.3,5.5 \mathrm{~Hz}, 1 \mathrm{H}, \mathrm{OCH}), 3.96(\mathrm{~d}, J=9.3 \mathrm{~Hz}, 1 \mathrm{H}$, $\operatorname{Ar}^{1} \mathrm{Ar}^{2} \mathrm{CH}$ ), 3.15 (ddd, $J=12.3,5.5,1.5 \mathrm{~Hz}, 1 \mathrm{H}, \mathrm{NCH}_{a} \mathrm{H}_{\mathrm{b}}$ ), $), 2.78$ (ddd, $J=12.3,9.3,1.5 \mathrm{~Hz}, 1 \mathrm{H}, \mathrm{NCH}_{a} H_{b}$ ), $2.30\left(\mathrm{~s}, 3 \mathrm{H}, \mathrm{ArCH}_{3}\right)$.

${ }^{13} \mathrm{C}\left\{{ }^{1} \mathrm{H}\right\}$ NMR $(101 \mathrm{MHz}$, Chloroform- $d) \delta 161.9(\mathrm{~d}, J=245.8 \mathrm{~Hz}), 138.9,137.4(\mathrm{~d}, J=3.5 \mathrm{~Hz}), 136.5$, $129.8(\mathrm{~d}, J=7.8 \mathrm{~Hz}), 129.4,128.2,123.4(\mathrm{q}, J=282.8 \mathrm{~Hz}), 115.8(\mathrm{~d}, J=21.2 \mathrm{~Hz}), 88.4(\mathrm{q}, J=33.8 \mathrm{~Hz})$, 82.1, 54.4, 50.6, 21.2.

${ }^{19} \mathrm{~F}$ NMR (376 MHz, Chloroform- $d$ ) $\delta{ }^{19} \mathrm{~F}$ NMR (376 MHz, Chloroform-d) $\delta-81.0$ (d, 3F, $J=5.5 \mathrm{~Hz}$, $\left.\mathrm{CHCF}_{3}\right),-115.7$ (tt, $\left.1 \mathrm{~F}, J=8.3,5.4 \mathrm{~Hz}, \mathrm{Ar} F\right)$.

$\underline{\mathrm{IR}}\left(\mathrm{cm}^{-1}\right) 3350(\mathrm{w}), 3016(\mathrm{w}), 2925(\mathrm{w}), 1611(\mathrm{w}), 1512(\mathrm{~m}), 1329(\mathrm{~m}), 1291(\mathrm{~m}), 1226(\mathrm{~m}), 1168(\mathrm{~s}), 1137$ (s).

HRMS (ESI/QTOF) m/z: [M+ H] $]^{+}$Calculated for $\mathrm{C}_{19} \mathrm{H}_{21} \mathrm{~F}_{3} \mathrm{NO}^{+}$336.1570; Found 336.1576.

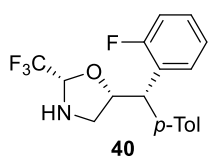

(2S,5R)-5-((S)-(2-Fluorophenyl)(p-tolyl)methyl)-2-(trifluoromethyl)oxazolidine (40)

Prepared according to the general procedure D5 using $13(85 \mathrm{mg}, 0.20 \mathrm{mmol}, 1.0$ equiv., $80 \%$ ee $)$ and $\mathrm{Pd} / \mathrm{C}(20 \mathrm{~mol} \%, 85 \mathrm{mg})$. The crude material was purified by flash column chromatography (pentane/EtOAc gradient 100:0 to $85: 15$ ) to give the corresponding product 40 (44 mg, $0.13 \mathrm{mmol}, 65 \%$ yield) as colorless oil. The enantiomeric excess was determined to be $80 \%$ by HPLC analysis on a Daicel Chiralpak IA column: 95:5 hexane/IPA, flow rate 1 
$\mathrm{mL} / \mathrm{min}, \lambda=230 \mathrm{~nm}: \tau_{\text {Major }}=9.0 \mathrm{~min}, \tau_{\text {Minor }}=13.8 \mathrm{~min}$. Absolute configuration was determined in comparison to compound $(R, R)-5$.

$[\alpha] \mathrm{D}^{20}=8.1\left(\mathrm{c}=0.74, \mathrm{CHCl}_{3}, 80 \%\right.$ ee $)$.

${ }^{1} \mathrm{H}$ NMR $(400 \mathrm{MHz}$, Chloroform- $d) \delta 7.29(\mathrm{td}, J=7.5,1.8 \mathrm{~Hz}, 1 \mathrm{H}, \mathrm{ArH}), 7.27-7.16(\mathrm{~m}, 3 \mathrm{H}, \mathrm{ArH}), 7.15$ $-7.05(\mathrm{~m}, 3 \mathrm{H}, \mathrm{Ar} H), 7.02(\mathrm{ddd}, J=10.5,8.2,1.3 \mathrm{~Hz}, 1 \mathrm{H}, \mathrm{ArH}), 4.98\left(\mathrm{q}, J=5.6 \mathrm{~Hz}, 1 \mathrm{H}, \mathrm{CHCF}_{3}\right), 4.68$ $(\mathrm{dtd}, J=9.2,6.8,5.9,3.1 \mathrm{~Hz}, 1 \mathrm{H}, \mathrm{OCH}), 4.28\left(\mathrm{~d}, J=9.4 \mathrm{~Hz}, 1 \mathrm{H}, \operatorname{Ar}^{1} \mathrm{Ar}^{2} \mathrm{CH}\right), 3.22(\mathrm{dd}, J=12.2,5.1 \mathrm{~Hz}$, $\left.1 \mathrm{H}, \mathrm{NCH}_{a} \mathrm{H}_{\mathrm{b}}\right), 2.80\left(\mathrm{dd}, J=12.2,9.3 \mathrm{~Hz}, 1 \mathrm{H}, \mathrm{NCH}_{\mathrm{a}} H_{b}\right), 2.30\left(\mathrm{~s}, 3 \mathrm{H}, \mathrm{Ar}^{1} \mathrm{CH}_{3}\right)$.

${ }^{13} \mathrm{C}\left\{{ }^{1} \mathrm{H}\right\}$ NMR $(101 \mathrm{MHz}$, Chloroform- $d) \delta 160.5(\mathrm{~d}, J=245.9 \mathrm{~Hz}), 138.1,136.6,129.8(\mathrm{~d}, J=4.5 \mathrm{~Hz})$, $129.3,128.7(\mathrm{~d}, J=8.4 \mathrm{~Hz}), 128.7(\mathrm{~d}, J=15.0 \mathrm{~Hz}), 128.3,124.54(\mathrm{~d}, J=3.5 \mathrm{~Hz}), 123.4(\mathrm{~d}, J=283.0 \mathrm{~Hz})$, $116.1(\mathrm{~d}, J=23.0 \mathrm{~Hz}), 88.5(\mathrm{q}, J=34.1 \mathrm{~Hz}), 81.7(\mathrm{~d}, J=2.8 \mathrm{~Hz}), 50.4,48.7,21.2$.

${ }^{19} \mathrm{~F}$ NMR $\left(376 \mathrm{MHz}\right.$, Chloroform- $d$ ) $\delta-81.0\left(\mathrm{~d}, 3 \mathrm{~F}, J=5.6 \mathrm{~Hz}, \mathrm{CHCF}_{3}\right),-115.9(\mathrm{dt}, 1 \mathrm{~F}, J=12.1,6.5 \mathrm{~Hz}$, $\mathrm{Ar} F)$.

$\underline{\mathrm{IR}}\left(\mathrm{cm}^{-1}\right) 3356(\mathrm{w}), 3039(\mathrm{w}), 2929(\mathrm{w}), 1496(\mathrm{~m}), 1454(\mathrm{~m}), 1290(\mathrm{~m}), 1225(\mathrm{~m}), 1169(\mathrm{~s})$.

HRMS (ESI/QTOF) m/z: [M+ H] $]^{+}$Calculated for $\mathrm{C}_{18} \mathrm{H}_{18} \mathrm{~F}_{4} \mathrm{NO}^{+}$340.1319; Found 340.1318.

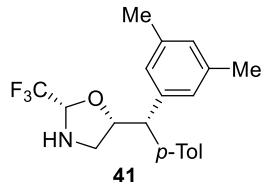

give the corresponding product 41 (41 mg $0.12 \mathrm{mmol}, 59 \%$ yield) as colorless oil. The enantiomeric excess was determined to be $91 \%$ by HPLC analysis on a Daicel Chiralpak IA column: 95:5 hexane/IPA, flow rate $1 \mathrm{~mL} / \mathrm{min}, \lambda=230 \mathrm{~nm}: \tau_{\text {Major }}=5.8 \mathrm{~min}, \tau_{\text {Minor }}=8.9 \mathrm{~min}$. Absolute configuration was determined in comparison to compound $(R, R)-5$.

$[\alpha] \mathrm{D}^{20}=5.9\left(\mathrm{c}=0.62, \mathrm{CHCl}_{3}, 91 \%\right.$ ee $)$.

${ }^{1} \mathrm{H}$ NMR $(400 \mathrm{MHz}$, Chloroform- $d) \delta 7.22(\mathrm{~d}, J=8.0 \mathrm{~Hz}, 2 \mathrm{H}, \operatorname{Ar} H), 7.11(\mathrm{~d}, J=8.0 \mathrm{~Hz}, 2 \mathrm{H}, \operatorname{Ar} H), 6.84$ $(\mathrm{s}, 1 \mathrm{H}, \mathrm{ArH}), 6.84(\mathrm{~s}, 2 \mathrm{H}, \mathrm{ArH}), 4.98\left(\mathrm{q}, J=5.6 \mathrm{~Hz}, 1 \mathrm{H}, \mathrm{CHCF}_{3}\right), 4.62(\mathrm{td}, J=9.7,5.6 \mathrm{~Hz}, 1 \mathrm{H}, \mathrm{OCH}), 3.87$ $\left(\mathrm{d}, J=9.7 \mathrm{~Hz}, 1 \mathrm{H}, \mathrm{Ar}^{1} \mathrm{Ar}^{2} \mathrm{CH}\right)$ ), $3.19\left(\mathrm{ddd}, J=12.2,5.5,1.0 \mathrm{~Hz}, 1 \mathrm{H}, \mathrm{NCH}_{a} \mathrm{H}_{\mathrm{b}}\right), 2.80(\mathrm{dd}, J=12.2,9.7 \mathrm{~Hz}$, $1 \mathrm{H}, \mathrm{NCH}_{\mathrm{a}} \mathrm{H}_{b}, 2.79$ (br. s, $\left.1 \mathrm{H}, \mathrm{NH}\right), 2.29$ (s, 3H, $\left.\mathrm{Ar}^{2} \mathrm{CH}_{3}\right), 2.27$ (s, 6H, $\left.\mathrm{Ar}^{1} \mathrm{CH}_{3}\right)$.

${ }^{13} \mathrm{C}\left\{{ }^{1} \mathrm{H}\right\}$ NMR $(101 \mathrm{MHz}$, Chloroform- $d) \delta 141.3,139.3,138.3,136.2,129.3,128.8,128.1,126.1,123.3$ $(\mathrm{q}, J=283.0 \mathrm{~Hz}), 88.2(\mathrm{q}, J=33.9 \mathrm{~Hz}), 82.3,55.2,50.6,21.5,21.2$.

${ }^{19} \mathrm{~F}$ NMR $(376 \mathrm{MHz}$, Chloroform- $d) \delta-81.8(\mathrm{~d}, 3 \mathrm{~F}, J=5.6 \mathrm{~Hz})$.

$\underline{\text { IR }}\left(\mathrm{cm}^{-1}\right) 3353(\mathrm{~m}), 3018(\mathrm{~m}), 2923(\mathrm{~m}), 1606(\mathrm{~m}), 1515(\mathrm{~m}), 1456(\mathrm{~m}), 1290$ (m), 1168 (s), 1043 (m). HRMS (ESI/QTOF) m/z: [M + H] $]^{+}$Calculated for $\mathrm{C}_{20} \mathrm{H}_{23} \mathrm{~F}_{3} \mathrm{NO}^{+}$350.1726; Found 350.1733.

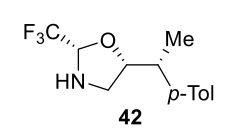

\section{(2S,5R)-5-((R)-1-(p-Tolyl)ethyl)-2-(trifluoromethyl)oxazolidine (42)}

Prepared according to the general procedure D5 using 17 (70 mg, $0.20 \mathrm{mmol}, 1.0$ equiv., $72 \%$ ee) and $\mathrm{Pd}(\mathrm{OH})_{2} / \mathrm{C}(10 \mathrm{~mol} \%, 14 \mathrm{mg})$. The crude material was purified by flash column chromatography (pentane/EtOAc gradient 100:0 to $85: 15$ ) to give the corresponding product 42 (43 mg, $0.16 \mathrm{mmol}, 82 \%$ yield) as colorless oil. The enantiomeric excess was determined to be $72 \%$ by HPLC analysis on a Daicel Chiralpak IA column: 95:5 hexane/IPA, flow rate 1 $\mathrm{mL} / \mathrm{min}, \lambda=210 \mathrm{~nm}: \tau_{\text {Major }}=7.7 \mathrm{~min}, \tau_{\text {Minor }}=9.3 \mathrm{~min}$. Absolute configuration was determined in comparison to compound $(R, R)-5$.

$[\alpha] \mathrm{D}^{20}=2.7\left(\mathrm{c}=0.43, \mathrm{CHCl}_{3}, 72 \%\right.$ ee $)$.

${ }^{1} \mathrm{H}$ NMR $\left(400 \mathrm{MHz}\right.$, Chloroform- $d$ ) $\delta 7.14(\mathrm{~s}, 4 \mathrm{H}, \mathrm{ArH}), 4.87\left(\mathrm{q}, J=5.6 \mathrm{~Hz}, 1 \mathrm{H}, \mathrm{CHCF}_{3}\right), 3.93(\mathrm{td}, J=8.8$, $5.6 \mathrm{~Hz}, 1 \mathrm{H}, \mathrm{OCH}), 3.32\left(\mathrm{dd}, J=11.4,5.6 \mathrm{~Hz}, 1 \mathrm{H}, \mathrm{NCH}_{a} \mathrm{H}_{\mathrm{b}}\right), 2.94-2.79\left(\mathrm{~m}, 2 \mathrm{H}, \mathrm{NCH}_{\mathrm{a}} \mathrm{H}_{b}\right.$ and $\left.\mathrm{ArCHCH}_{3}\right)$, 2.67 (br. s, $1 \mathrm{H}, \mathrm{NH}), 2.33$ (s, 3H, $\left.\mathrm{ArCH}_{3}\right), 1.24$ (d, $\left.J=7.1 \mathrm{~Hz}, 3 \mathrm{H}, \mathrm{ArCHCH}_{3}\right)$.

${ }^{13} \mathrm{C}\left\{{ }^{1} \mathrm{H}\right\}$ NMR $(101 \mathrm{MHz}$, Chloroform- $d) \delta 140.6,136.4,129.3,127.5,123.5(\mathrm{q}, J=282.9 \mathrm{~Hz}), 87.9(\mathrm{q}, J$ $=33.8 \mathrm{~Hz}$ ), 84.7, 49.4, 42.9, 21.2, 16.9 .

${ }^{19} \mathrm{~F}$ NMR $(376 \mathrm{MHz}$, Chloroform- $d$ ) $\delta-81.1(\mathrm{~d}, 3 \mathrm{~F}, J=5.6 \mathrm{~Hz})$.

$\underline{\text { IR }\left(\mathrm{cm}^{-1}\right)} 3348(\mathrm{w}), 2928(\mathrm{w}), 2887(\mathrm{w}), 1514(\mathrm{~m}), 1456$ (m), 1291 (m), 1166 (s).

HRMS (ESI/QTOF) m/z: [M+H] $]^{+}$Calculated for $\mathrm{C}_{13} \mathrm{H}_{17} \mathrm{~F}_{3} \mathrm{NO}^{+} 260.1257$; Found 260.1259. 


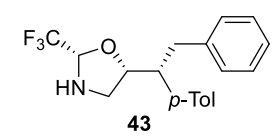

(2S,5R)-5-((R)-2-Phenyl-1-(p-tolyl)ethyl)-2-(trifluoromethyl)oxazolidine (43)

Prepared according to the general procedure D5 using 18 (85 $\mathrm{mg}, 0.20 \mathrm{mmol}$, 1.0 equiv., $86 \%$ ee) and $\mathrm{Pd}(\mathrm{OH})_{2} / \mathrm{C}(20 \mathrm{~mol} \%$, $28 \mathrm{mg})$. The crude material was purified by flash column chromatography (pentane/EtOAc gradient 100:0 to 85:15) to give the corresponding product $\mathbf{4 3}(47 \mathrm{mg}, 0.14 \mathrm{mmol}, 70 \%$ yield) as colorless oil. The enantiomeric excess was determined to be $86 \%$ by HPLC analysis on a Daicel Chiralpak IA column: 95:5 hexane/IPA, flow rate $1 \mathrm{~mL} / \mathrm{min}, \lambda=210 \mathrm{~nm}: \tau_{\text {Major }}=7.1 \mathrm{~min}, \tau_{\text {Minor }}=11.4 \mathrm{~min}$. Absolute configuration was determined in comparison to compound $(R, R)-5$.

$[\alpha] \mathrm{D}^{20}=-49.3\left(\mathrm{c}=0.74, \mathrm{CHCl}_{3}, 86 \%\right.$ ee $)$.

${ }^{1} \mathrm{H}$ NMR $(400 \mathrm{MHz}$, Chloroform- $d) \delta 7.23-7.17(\mathrm{~m}, 2 \mathrm{H}, \mathrm{ArH}), 7.17-7.11(\mathrm{~m}, 1 \mathrm{H}, \mathrm{ArH}), 7.11-7.02(\mathrm{~m}$, $6 \mathrm{H}, \mathrm{ArH}), 4.84\left(\mathrm{q}, J=5.5 \mathrm{~Hz}, 1 \mathrm{H}, \mathrm{CHCF}_{3}\right), 4.04(\mathrm{dt}, J=9.5,5.6 \mathrm{~Hz}, 1 \mathrm{H}, \mathrm{OCH}), 3.20(\mathrm{dd}, J=12.0,5.5 \mathrm{~Hz}$, $\left.1 \mathrm{H}, \mathrm{NCH}_{a} \mathrm{H}_{\mathrm{b}}\right), 3.11-2.91\left(\mathrm{~m}, 3 \mathrm{H}, \mathrm{PhCH}_{2} \mathrm{CH}\right.$ and $\left.\mathrm{PhCH}_{2} \mathrm{CH}\right), 2.75\left(\mathrm{t}, J=12.0,9.5 \mathrm{~Hz}, 1 \mathrm{H}, \mathrm{NCH}_{\mathrm{a}} H_{b}\right), 2.46$ (br. s, $1 \mathrm{H}, \mathrm{NH}), 2.30$ (s, 3H, $\left.\mathrm{ArCH}_{3}\right)$.

${ }^{13} \mathrm{C}\left\{{ }^{1} \mathrm{H}\right\}$ NMR $(101 \mathrm{MHz}$, Chloroform- $d) \delta 139.7,137.6,136.4,129.2,129.1,128.6,128.4,126.2,123.3$ $(\mathrm{q}, J=282.8 \mathrm{~Hz}), 87.5(\mathrm{q}, J=33.9 \mathrm{~Hz}), 82.5,50.4,49.1,38.5,21.2$.

${ }^{19} \mathrm{~F}$ NMR $\left(376 \mathrm{MHz}\right.$, Chloroform- $d$ ) $\delta-80.8\left(\mathrm{~d}, 3 \mathrm{~F}, J=5.4 \mathrm{~Hz}, \mathrm{CHCF}_{3}\right)$.

IR $\left(\mathrm{cm}^{-1}\right) 3349(\mathrm{w}), 3027(\mathrm{w}), 2927$ (w), $1508(\mathrm{~m}), 1451(\mathrm{~m}), 1292(\mathrm{~m}), 1165$ (s), $1115(\mathrm{~s})$.

HRMS (ESI/QTOF) m/z: [M+H] $]^{+}$Calculated for $\mathrm{C}_{19} \mathrm{H}_{21} \mathrm{~F}_{3} \mathrm{NO}^{+}$336.1570; Found 336.1575.

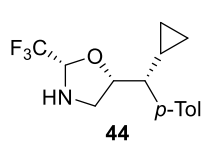

\section{(2S,5R)-5-((R)-Cyclopropyl(p-tolyl)methyl)-2-(trifluoromethyl)oxazolidine (44)}

Prepared according to the general procedure D5 using $19(75 \mathrm{mg}, 0.20 \mathrm{mmol}, 1.0$ equiv., $78 \%$ ee) and $\mathrm{Pd}(\mathrm{OH})_{2} / \mathrm{C}(20 \mathrm{~mol} \%, 28 \mathrm{mg})$. The crude material was purified by flash column chromatography (pentane/EtOAc gradient 100:0 to $85: 15$ ) to give the corresponding product 44 (32 mg, $0.11 \mathrm{mmol}, 56 \%$ yield) as colorless oil. The enantiomeric excess was determined to be $78 \%$ by HPLC analysis on a Daicel Chiralpak IA column: 95:5 hexane/IPA, flow rate 1 $\left.\mathrm{mL} / \mathrm{min}, \lambda=210 \mathrm{~nm}: \tau_{\text {Major }}=7.1 \mathrm{~min}, \tau_{\text {Minor }}=9.2 \mathrm{~min}.\right)$. Absolute configuration was determined in comparison to compound $(R, R)-5$.

$[\alpha] \mathrm{D}^{20}=-21.6\left(\mathrm{c}=0.57, \mathrm{CHCl}_{3}, 78 \%\right.$ ee

${ }^{1} \mathrm{H}$ NMR $\left(400 \mathrm{MHz}\right.$, Chloroform- $d$ ) $\delta 7.14(\mathrm{~s}, 4 \mathrm{H}, \mathrm{ArH}), 4.85$ (q, $\left.J=5.6 \mathrm{~Hz}, 1 \mathrm{H}, \mathrm{CHCF}_{3}\right), 4.10(\mathrm{td}, J=8.9$, $5.5 \mathrm{~Hz}, 1 \mathrm{H}, \mathrm{OCH}), 3.45\left(\mathrm{ddd}, J=12.0,5.5,1.4 \mathrm{~Hz}, 1 \mathrm{H}, \mathrm{NCH}_{a} \mathrm{H}_{\mathrm{b}}\right), 2.96\left(\mathrm{dd}, J=12.0,8.9 \mathrm{~Hz}, 1 \mathrm{H}, \mathrm{NCH}_{\mathrm{a}} H_{b}\right)$, $2.33\left(\mathrm{~s}, 3 \mathrm{H}, \mathrm{ArCH}_{3}\right), 1.93(\mathrm{dd}, J=10.1,8.3 \mathrm{~Hz}, 1 \mathrm{H}, \mathrm{Ar}(\mathrm{CyPr}) \mathrm{CH}), 1.04(\mathrm{dtt}, J=10.1,8.1,4.8 \mathrm{~Hz}, 1 \mathrm{H}$, $\left.\mathrm{CH}\left(\mathrm{CH}_{\mathrm{a}} \mathrm{H}_{\mathrm{b}}\right) \mathrm{CH}_{\mathrm{a}} \mathrm{H}_{\mathrm{b}}\right), 0.65$ (dddd, $\left.J=9.2,8.1,5.8,4.5 \mathrm{~Hz}, 1 \mathrm{H}, \mathrm{CH}\left(\mathrm{CH}_{a} \mathrm{H}_{\mathrm{b}}\right) \mathrm{CH}_{\mathrm{a}} \mathrm{H}_{\mathrm{b}}\right), 0.44$ (dddd, $J=9.2,8.1$, $\left.5.6,4.5 \mathrm{~Hz}, 1 \mathrm{H}, \mathrm{CH}\left(\mathrm{CH}_{\mathrm{a}} \mathrm{H}_{\mathrm{b}}\right) \mathrm{CH}_{a} \mathrm{H}_{\mathrm{b}}\right), 0.33\left(\mathrm{ddt}, J=9.2,5.6,4.8 \mathrm{~Hz}, 1 \mathrm{H}, \mathrm{CH}\left(\mathrm{CH}_{\mathrm{a}} H_{b}\right) \mathrm{CH}_{\mathrm{a}} \mathrm{H}_{\mathrm{b}}\right), 0.06(\mathrm{ddt}, J=$ 9.2, 5.8, $\left.4.8 \mathrm{~Hz}, 1 \mathrm{H}, \mathrm{CH}\left(\mathrm{CH}_{\mathrm{a}} \mathrm{H}_{\mathrm{b}}\right) \mathrm{CH}_{\mathrm{a}} \mathrm{H}_{b}\right)$.

${ }^{13} \mathrm{C}\left\{{ }^{1} \mathrm{H}\right\}$ NMR $(101 \mathrm{MHz}$, Chloroform- $d) \delta 139.4,136.3,129.2,128.1,123.4(\mathrm{q}, J=282.8 \mathrm{~Hz}), 87.6(\mathrm{q}, J$ $=33.8 \mathrm{~Hz}), 84.3,53.6,49.6,21.2,13.4,6.3,3.3$.

${ }^{19} \mathrm{~F}$ NMR $\left(376 \mathrm{MHz}\right.$, Chloroform- $d$ ) $\delta-81.1\left(\mathrm{~d}, 3 \mathrm{~F}, J=5.5 \mathrm{~Hz}, \mathrm{CHCF}_{3}\right)$.

$\underline{\text { IR }}\left(\mathrm{cm}^{-1}\right) 3343(\mathrm{w}), 3010(\mathrm{w}), 2927(\mathrm{w}), 2897(\mathrm{w}), 1515(\mathrm{~m}), 1327(\mathrm{~m}), 1291(\mathrm{~m}), 1167$ (s), $1116(\mathrm{~m})$.

HRMS (ESI/QTOF) m/z: [M+H] $]^{+}$Calculated for $\mathrm{C}_{15} \mathrm{H}_{19} \mathrm{~F}_{3} \mathrm{NO}^{+}$286.1413; Found 286.1416.

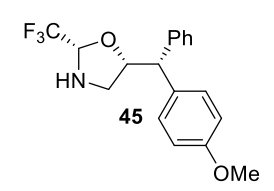

\section{(trifluoromethyl)oxazolidine (45)}

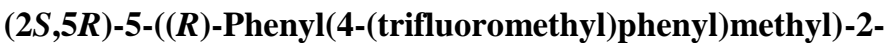

Prepared according to the general procedure D5 using 20 (85 mg, $0.20 \mathrm{mmol}$, 1.0 equiv., $88 \%$ ee $)$ and $\mathrm{Pd}(\mathrm{OH})_{2} / \mathrm{C}(10 \mathrm{~mol} \%, 14 \mathrm{mg})$. The crude material was purified determined to be $90 \%$ by HPLC analysis on a Daicel Chiralpak IA column: 95:5 hexane/IPA, flow rate 1 $\mathrm{mL} / \mathrm{min}, \lambda=210 \mathrm{~nm}$ : $\tau_{\text {Major }}=12.6 \mathrm{~min}, \tau_{\text {Minor }}=20.2 \mathrm{~min}$.). Absolute configuration was determined in comparison to compound $(R, R)-5$.

$[\alpha] \mathrm{D}^{20}=+13.0\left(\mathrm{c}=0.32, \mathrm{CHCl}_{3}, 90 \%\right.$ ee

${ }^{1} \mathrm{H}$ NMR $(400 \mathrm{MHz}$, Chloroform- $d$ ) $\delta 7.34-7.20(\mathrm{~m}, 7 \mathrm{H}, \mathrm{ArH}), 6.88-6.82(\mathrm{~m}, 2 \mathrm{H}, \mathrm{ArH}), 4.98$ (br. s., $1 \mathrm{H}$, $\left.\mathrm{CHCF}_{3}\right), 4.58(\mathrm{td}, J=9.3,5.5 \mathrm{~Hz}, 1 \mathrm{H}, \mathrm{OCH}), 3.95\left(\mathrm{~d}, J=9.4 \mathrm{~Hz}, 1 \mathrm{H}, \mathrm{Ar}^{1} \mathrm{Ar}^{2} \mathrm{CH}\right), 3.77\left(\mathrm{~s}, 3 \mathrm{H}, \mathrm{OCH}_{3}\right), 3.14$ (br.s., $1 \mathrm{H}, \mathrm{NCH}_{a} \mathrm{H}_{\mathrm{b}}$ ), 2.79 (br. s., $1 \mathrm{H}, \mathrm{NCH}_{a} H_{b}$ ), 2.65 (br. s., $1 \mathrm{H}, \mathrm{NH}$ ).

${ }^{13} \mathrm{C}\left\{{ }^{1} \mathrm{H}\right\}$ NMR $(101 \mathrm{MHz}$, Chloroform- $d) \delta 158.4,141.7,134.3,129.4,128.9,128.3,127.1,123.5$ (q, $J=$ $282.9 \mathrm{~Hz}), 113.9,88.4(\mathrm{q}, J=33.8 \mathrm{~Hz}), 82.3,55.3,54.8,50.7$. 
${ }^{19} \mathrm{~F}\left\{{ }^{1} \mathrm{H}\right\}$ NMR (376 MHz, Chloroform- $d$ ) $\delta$-81.0.

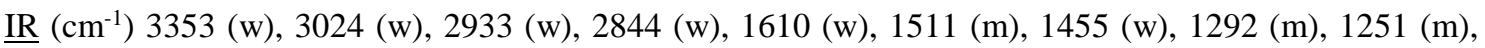
$1171(\mathrm{~s}), 1152(\mathrm{~s})$.

$\underline{\text { HRMS }}$ (ESI/QTOF) m/z: [M + Na] ${ }^{+}$Calculated for $\mathrm{C}_{18} \mathrm{H}_{18} \mathrm{~F}_{3} \mathrm{NNaO}_{2}{ }^{+}$360.1182; Found 360.1184.

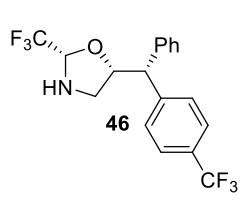

\section{(trifluoromethyl)oxazolidine (46)}

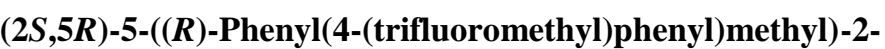

Prepared according to the general procedure D5 using 22 (93 $\mathrm{mg}, 0.20 \mathrm{mmol}$, 1.0 equiv., $82 \%$ ee $)$ and $\mathrm{Pd}(\mathrm{OH})_{2} / \mathrm{C}(10 \mathrm{~mol} \%, 14 \mathrm{mg})$. The crude material was purified by flash column chromatography (pentane/EtOAc gradient 100:0 to 85:15) to give the corresponding product 46 (46 mg, $0.12 \mathrm{mmol}, 61 \%$ yield) as colorless oil. The enantiomeric excess was determined to be $82 \%$ by HPLC analysis on a Daicel Chiralpak IA column: 95:5 hexane/IPA, flow rate 1 $\mathrm{mL} / \mathrm{min}, \lambda=210 \mathrm{~nm}: \tau_{\text {Major }}=12.0 \mathrm{~min}, \tau_{\text {Minor }}=14.2 \mathrm{~min}$. Absolute configuration was determined in comparison to compound $(R, R)-5$.

$[\alpha] \mathrm{D}^{20}=+5.0\left(\mathrm{c}=0.30, \mathrm{CHCl}_{3}, 82 \% \mathrm{ee}\right)$.

${ }^{1} \mathrm{H}$ NMR $(400 \mathrm{MHz}$, Chloroform- $d) \delta 7.54(\mathrm{~d}, J=8.1 \mathrm{~Hz}, 2 \mathrm{H}, \mathrm{Ar} H), 7.44(\mathrm{~d}, J=8.1 \mathrm{~Hz}, 2 \mathrm{H}, \operatorname{Ar} H), 7.34-$ $7.27(\mathrm{~m}, 2 \mathrm{H}, \mathrm{ArH}), 7.27-7.19(\mathrm{~m}, 3 \mathrm{H}, \mathrm{ArH}), 4.98\left(\mathrm{dq}, J=8.5,5.6 \mathrm{~Hz}, 1 \mathrm{H}, \mathrm{CHCF}_{3}\right), 4.62(\mathrm{td}, J=9.3,5.5$ $\mathrm{Hz}, 1 \mathrm{H}, \mathrm{OCH}), 4.03$ (d, $J=9.6 \mathrm{~Hz}, 1 \mathrm{H}, \mathrm{Ar}^{1} \mathrm{Ar}^{2} \mathrm{CH}$ ), 3.17 (dddd, $J=13.0,7.2,5.6,1.5 \mathrm{~Hz}, 1 \mathrm{H}, \mathrm{NCH}_{a} \mathrm{H}_{\mathrm{b}}$ ), $2.89-2.75\left(\mathrm{~m}, 1 \mathrm{H}, \mathrm{NCH}_{a} H_{b}\right), 2.66$ (br.s., $\left.1 \mathrm{H}, \mathrm{NH}\right)$.

${ }^{13} \mathrm{C}\left\{{ }^{1} \mathrm{H}\right\}$ NMR $(101 \mathrm{MHz}$, Chloroform- $d) \delta 146.1,140.4,129.2,129.0(\mathrm{q}, J=32.2 \mathrm{~Hz}) 128.8,128.4,127.6$, $125.5(\mathrm{q}, J=3.7 \mathrm{~Hz}), 124.3(\mathrm{q}, J=271.6 \mathrm{~Hz}), 123.3(\mathrm{q}, J=281.5 \mathrm{~Hz}), 88.6(\mathrm{q}, J=34.0 \mathrm{~Hz}), 81.6,55.5$, 50.7.

${ }^{19} \mathrm{~F}\left\{{ }^{1} \mathrm{H}\right\}$ NMR $(376 \mathrm{MHz}$, Chloroform- $d$ ) $\delta-62.5,-81.1$.

$\underline{\text { IR }}\left(\mathrm{cm}^{-1}\right) 2928(\mathrm{w}), 1613(\mathrm{w}), 1495(\mathrm{w}), 1455(\mathrm{w}), 1329$ (s), $1292(\mathrm{~m}), 1167$ (s), 1136 (s).

HRMS (ESI/QTOF) m/z: [M+ H] $]^{+}$Calculated for $\mathrm{C}_{18} \mathrm{H}_{16} \mathrm{~F}_{6} \mathrm{NO}^{+} 376.1131$; Found 376.1141 .

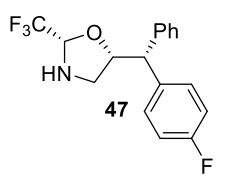

(2S,5R)-5-((R)-(4-Fluorophenyl)(phenyl)methyl)-2-(trifluoromethyl)oxazolidine (47)

Prepared according to the general procedure D5 using 23 (83 mg, 0.20 mmol, 1.0 equiv., $84 \%$ ee) and $\mathrm{Pd}(\mathrm{OH})_{2} / \mathrm{C}(10 \mathrm{~mol} \%, 14 \mathrm{mg})$. The crude material was purified by flash column chromatography (pentane/EtOAc gradient 100:0 to $85: 15$ ) to give the corresponding product 47 (47 mg, $0.14 \mathrm{mmol}, 72 \%$ yield) as colorless oil. The enantiomeric excess was determined to be $84 \%$ by HPLC analysis on a Daicel Chiralpak IA column: 95:5 hexane/IPA, flow rate 1 $\mathrm{mL} / \mathrm{min}, \lambda=210 \mathrm{~nm}: \tau_{\text {Major }}=10.7 \mathrm{~min}, \tau_{\text {Minor }}=14.2 \mathrm{~min}$. Absolute configuration was determined in comparison to compound $(R, R)-5$.

$[\alpha] \mathrm{D}^{20}=+8.1\left(\mathrm{c}=0.37, \mathrm{CHCl}_{3}, 84 \%\right.$ ee $)$.

${ }^{1} \mathrm{H}$ NMR $(400 \mathrm{MHz}$, Chloroform- $d) \delta 7.39-7.19(\mathrm{~m}, 7 \mathrm{H}, \mathrm{ArH}), 6.99(\mathrm{t}, J=8.7 \mathrm{~Hz}, 2 \mathrm{H}, \operatorname{Ar} H), 4.99(\mathrm{dq}, J$ $\left.=8.5,5.6 \mathrm{~Hz}, 1 \mathrm{H}, \mathrm{CHCF}_{3}\right), 4.58(\mathrm{td}, J=9.2,5.5 \mathrm{~Hz}, 1 \mathrm{H}, \mathrm{OCH}), 3.98\left(\mathrm{~d}, J=9.4 \mathrm{~Hz}, 1 \mathrm{H}, \mathrm{Ar}^{1} \mathrm{Ar}^{2} \mathrm{CH}\right), 3.22$ $-3.11\left(\mathrm{~m}, 1 \mathrm{H}, \mathrm{NCH}_{a} \mathrm{H}_{\mathrm{b}}\right), 2.87-2.72\left(\mathrm{~m}, 1 \mathrm{H}, \mathrm{NCH}_{a} H_{b}\right), 2.65$ (br. s., $\left.1 \mathrm{H}, \mathrm{N} H\right)$.

${ }^{13} \mathrm{C}\left\{{ }^{1} \mathrm{H}\right\}$ NMR $(101 \mathrm{MHz}$, Chloroform- $d) \delta 161.7(\mathrm{~d}, J=244.9 \mathrm{~Hz}), 141.2,137.8(\mathrm{~d}, J=3.3 \mathrm{~Hz}), 130.0(\mathrm{~d}$, $J=8.0 \mathrm{~Hz}$ ), 129.0, 128.3, 127.3, 123.4 (q, $J=282.9 \mathrm{~Hz}), 115.3(\mathrm{~d}, J=21.2 \mathrm{~Hz}), 88.5$ (q, $J=34.1 \mathrm{~Hz}), 82.1$, $54.8,50.7$.

${ }^{19} \mathrm{~F}\left\{{ }^{1} \mathrm{H}\right\}$ NMR $(376 \mathrm{MHz}$, Chloroform- $d$ ) $\delta-81.1,-116.6$.

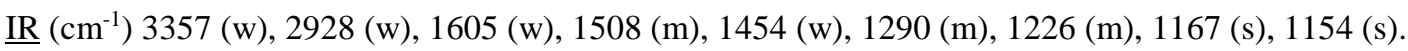

HRMS (ESI/QTOF) m/z: [M+ H] $]^{+}$Calculated for $\mathrm{C}_{17} \mathrm{H}_{16} \mathrm{~F}_{4} \mathrm{NO}^{+} 326.1163$; Found 326.1164.

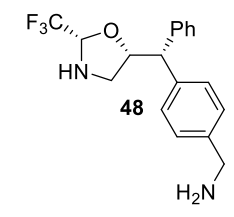

(4-((R)-Phenyl((2S,5R)-2-(trifluoromethyl)oxazolidin-5yl)methyl)phenyl)methanamine (48)

Prepared according to the general procedure D5 using 25 (84 mg, $0.20 \mathrm{mmol}, 1.0$ equiv., $73 \%$ ee) and $\mathrm{Pd}(\mathrm{OH})_{2} / \mathrm{C}(10 \mathrm{~mol} \%, 14 \mathrm{mg})$. The crude material was purified by flash column chromatography (DCM/MeOH gradient 100:0 to 90:10) to give the corresponding product 48 (32 mg, $95 \mu \mathrm{mol}, 48 \%$ yield) as colorless oil. The enantiomeric excess was determined to be $74 \%$ by HPLC analysis on a Daicel Chiralpak IC column: 85:15 hexane/IPA, flow rate 1 $\mathrm{mL} / \mathrm{min}, \lambda=210 \mathrm{~nm}: \tau_{\text {Major }}=17.4 \mathrm{~min}, \tau_{\text {Minor }}=24.7 \mathrm{~min}$. Absolute configuration was determined in comparison to compound $(R, R)-5$. 
$[\alpha] \mathrm{D}^{20}=+10.1\left(\mathrm{c}=0.33, \mathrm{CHCl}_{3}, 74 \%\right.$ ee $)$.

${ }^{1} \mathrm{H}$ NMR (400 MHz, Chloroform- $d$ ) ${ }^{1} \mathrm{H}$ NMR (400 MHz, Chloroform- $d$ ) $\delta 7.38-7.09$ (m, 9H, ArH), 4.90 $\left(\mathrm{q}, J=5.6 \mathrm{~Hz}, 1 \mathrm{H}, \mathrm{CHCF}_{3}\right), 4.59(\mathrm{td}, J=9.4,5.5 \mathrm{~Hz}, 1 \mathrm{H}, \mathrm{OCH}), 3.96\left(\mathrm{dd}, J=9.6,3.3 \mathrm{~Hz}, 1 \mathrm{H}, \mathrm{Ar}^{1} \mathrm{Ar}^{2} \mathrm{CH}\right)$, $3.79\left(\mathrm{~d}, J=3.9 \mathrm{~Hz}, 2 \mathrm{H}, \mathrm{ArCH}_{2} \mathrm{NH}_{2}\right), 3.23-2.84\left(\mathrm{~m}, 4 \mathrm{H}, \mathrm{NCH}_{a} \mathrm{H}_{\mathrm{b}}, \mathrm{NCH}_{a} H_{b}\right.$ and $\left.\mathrm{NH}_{2}\right), 2.84-2.70$ (br. s., $1 \mathrm{H}, \mathrm{N} H)$.

${ }^{13} \mathrm{C}\left\{{ }^{1} \mathrm{H}\right\}$ NMR $(101 \mathrm{MHz}$, Chloroform- $d) \delta 141.3,141.2,128.9,128.6,128.3,127.8,127.7,127.2,123.4$ $(\mathrm{q}, J=282.9 \mathrm{~Hz}), 88.4(\mathrm{q}, J=34.0 \mathrm{~Hz}), 82.1,55.4,50.7,45.6$.

${ }^{19} \mathrm{~F}\left\{{ }^{1} \mathrm{H}\right\}$ NMR (376 MHz, Chloroform- $d$ ) $\delta-81.0$.

$\underline{\text { IR }}\left(\mathrm{cm}^{-1}\right) 3354(\mathrm{w}), 3027(\mathrm{~m}), 2928(\mathrm{~m}), 2865(\mathrm{~m}), 1602(\mathrm{w}), 1505(\mathrm{~m}), 1455(\mathrm{w}), 1291(\mathrm{~m}), 1151(\mathrm{~s}), 1092$ (m).

$\underline{\text { HRMS }}$ (APCI/QTOF) m/z: [M + H] ${ }^{+}$Calculated for $\mathrm{C}_{18} \mathrm{H}_{20} \mathrm{~F}_{3} \mathrm{~N}_{2} \mathrm{O}^{+} 337.1522$; Found 337.1518.

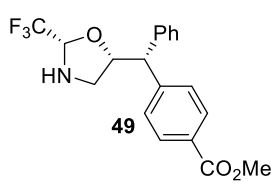
yl)methyl)benzoate (49)

Methyl-4-((R)-phenyl((2S,5R)-2-(trifluoromethyl)oxazolidin-5-

Prepared according to the general procedure D5 using 26 (91 $\mathrm{mg}, 0.20 \mathrm{mmol}$, 1.0 equiv., $82 \%$ ee) and $\mathrm{Pd}(\mathrm{OH})_{2} / \mathrm{C}(10 \mathrm{~mol} \%, 14 \mathrm{mg})$. The crude material was

to give the corresponding product 49 (44 mg, $0.12 \mathrm{mmol}, 60 \%$ yield) as colorless oil. The enantiomeric excess was determined to be $82 \%$ by HPLC analysis on a Daicel Chiralpak IA column: 90:10 hexane/IPA, flow rate $1 \mathrm{~mL} / \mathrm{min}, \lambda=210 \mathrm{~nm}: \tau_{\text {Major }}=13.4 \mathrm{~min}, \tau_{\text {Minor }}=19.6 \mathrm{~min}$. Absolute configuration was determined in comparison to compound $(R, R)-5$.

$[\alpha] \mathrm{D}^{20}=+6.8\left(\mathrm{c}=0.39, \mathrm{CHCl}_{3}, 82 \%\right.$ ee $)$.

${ }^{1} \mathrm{H}$ NMR $(400 \mathrm{MHz}$, Chloroform- $d) \delta 7.97(\mathrm{~d}, J=8.4 \mathrm{~Hz}, 2 \mathrm{H}, \mathrm{ArH}), 7.41(\mathrm{~d}, J=8.3 \mathrm{~Hz}, 2 \mathrm{H}, \operatorname{Ar} H), 7.35-$ $7.19(\mathrm{~m}, 5 \mathrm{H}, \mathrm{Ar} H), 4.99\left(\mathrm{dq}, J=7.9,5.6 \mathrm{~Hz}, 1 \mathrm{H}, \mathrm{CHCF}_{3}\right), 4.64(\mathrm{td}, J=9.3,5.5 \mathrm{~Hz}, 1 \mathrm{H}, \mathrm{OCH}), 4.05(\mathrm{~d}, J$ $\left.=9.5 \mathrm{~Hz}, 1 \mathrm{H}, \mathrm{Ar}^{1} \mathrm{Ar}^{2} \mathrm{CH}\right), 3.88\left(\mathrm{~s}, 3 \mathrm{H}, \mathrm{COOCH}_{3}\right), 3.22-3.12\left(\mathrm{~m}, 1 \mathrm{H}, \mathrm{NCH}_{a} \mathrm{H}_{\mathrm{b}}\right), 2.82(\mathrm{q}, J=10.9 \mathrm{~Hz}, 1 \mathrm{H}$, $\mathrm{NCH}_{a} H_{b}$ ), 2.68 (br. s., $1 \mathrm{H}, \mathrm{NH}$ ).

${ }^{13} \mathrm{C}\left\{{ }^{1} \mathrm{H}\right\}$ NMR $(101 \mathrm{MHz}$, Chloroform- $d) \delta 167.1,147.3,140.6,129.9,129.1,128.6,128.5,128.4,127.5$, $123.4(\mathrm{q}, J=282.8 \mathrm{~Hz}), 88.5(\mathrm{q}, J=34.0 \mathrm{~Hz}), 81.6,55.6,52.2,50.7$.

${ }^{19} \mathrm{~F}\left\{{ }^{1} \mathrm{H}\right\}$ NMR $(376 \mathrm{MHz}$, Chloroform- $d) \delta-81.1$.

$\underline{\mathrm{IR}}\left(\mathrm{cm}^{-1}\right) 3349$ (w), 2953 (w), 1718 (s), 1607 (w), 1444 (m), 1286 (s), 1169 (s), 1151 (s).

HRMS (ESI/QTOF) m/z: [M+ H] ${ }^{+}$Calculated for $\mathrm{C}_{19} \mathrm{H}_{19} \mathrm{~F}_{3} \mathrm{NO}_{3}{ }^{+}$366.1312; Found 366.1320.

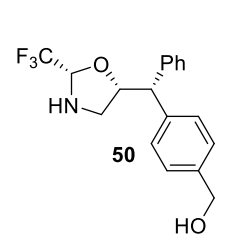

((4-((R)-Phenyl((2S,5R)-2-(trifluoromethyl)oxazolidin-5-yl)methyl)phenyl)methanol (50)

Prepared according to the general procedure D5 using 27 ( $85 \mathrm{mg}, 0.20 \mathrm{mmol}, 1.0$ equiv., $80 \%$ ee) and $\mathrm{Pd}(\mathrm{OH})_{2} / \mathrm{C}(10 \mathrm{~mol} \%, 14 \mathrm{mg})$. The crude material was purified by flash column chromatography (pentane/EtOAc gradient 100:0 to 60:40) to give the corresponding product $\mathbf{5 0}(10 \mathrm{mg}, 30 \mu \mathrm{mol}, 15 \%$ yield $)$ as colorless oil. The enantiomeric excess was determined to be $80 \%$ by HPLC analysis on a Daicel Chiralpak IA column: 80:20 hexane/IPA, flow rate $1 \mathrm{~mL} / \mathrm{min}, \lambda=210 \mathrm{~nm}$ : $\tau_{\text {Major }}=9.1 \mathrm{~min}, \tau_{\text {Minor }}=13.0 \mathrm{~min}$. Absolute configuration was determined in comparison to compound $(R, R)-5$.

$[\alpha] \mathrm{D}^{20}=+9.4\left(\mathrm{c}=0.39, \mathrm{CHCl}_{3}, 80 \%\right.$ ee $)$.

${ }^{1} \mathrm{H}$ NMR $(400 \mathrm{MHz}$, Chloroform- $d) \delta 7.37-7.19(\mathrm{~m}, 9 \mathrm{H}, \mathrm{ArH}), 4.97\left(\mathrm{q}, J=5.7 \mathrm{~Hz}, 1 \mathrm{H}, \mathrm{CHCF}_{3}\right), 4.64(\mathrm{~m}$, $3 \mathrm{H}, \mathrm{OCH}$ and $\left.\mathrm{ArCH}_{2} \mathrm{OH}\right), 3.99\left(\mathrm{~d}, J=9.5 \mathrm{~Hz}, 1 \mathrm{H}, \mathrm{Ar}^{1} \mathrm{Ar}^{2} \mathrm{CH}\right), 3.16\left(\mathrm{dd}, J=12.2,5.4 \mathrm{~Hz}, 1 \mathrm{H}, \mathrm{NCH}_{a} \mathrm{H}_{\mathrm{b}}\right)$, 2.81 (br. s., $1 \mathrm{H}, \mathrm{NCH}_{a} H_{b}$ ), 2.66 (br. s., $1 \mathrm{H}, \mathrm{NH}$ ).

${ }^{13} \mathrm{C}\left\{{ }^{1} \mathrm{H}\right\}$ NMR $(101 \mathrm{MHz}$, Chloroform- $d) \delta 141.7,141.2,139.3,129.0,128.6,128.3,127.3,127.2,123.4$ $(\mathrm{q}, J=282.8 \mathrm{~Hz}), 88.4(\mathrm{q}, J=34.2 \mathrm{~Hz}), 82.0,65.3,55.4,50.7$.

${ }^{19} \mathrm{~F}\left\{{ }^{1} \mathrm{H}\right\}$ NMR (376 MHz, Chloroform- $d$ ) $\delta-81.1$.

$\underline{\mathrm{IR}}\left(\mathrm{cm}^{-1}\right) 3339(\mathrm{~m}), 2925(\mathrm{~m}), 1596(\mathrm{w}), 1454(\mathrm{~m}), 1291(\mathrm{~m}), 1151(\mathrm{~s})$.

HRMS (ESI/QTOF) m/z: [M+ H] $]^{+}$Calculated for $\mathrm{C}_{18} \mathrm{H}_{19} \mathrm{~F}_{3} \mathrm{NO}_{2}{ }^{+}$338.1362; Found 338.1372. 


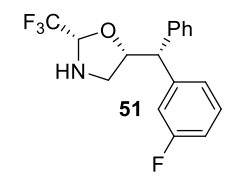

(2S,5R)-5-((R)-(3-Fluorophenyl)(phenyl)methyl)-2-(trifluoromethyl)oxazolidine (51)

Prepared according to the general procedure D5 using 28 (83 mg, $0.20 \mathrm{mmol}, 1.0$ equiv., $82 \%$ ee) and $\mathrm{Pd}(\mathrm{OH})_{2} / \mathrm{C}(10 \mathrm{~mol} \%, 14 \mathrm{mg})$. The crude material was purified by flash column chromatography (pentane/EtOAc gradient 100:0 to 80:15) to give the corresponding product $\mathbf{5 1}$ (43 mg, $0.14 \mathrm{mmol}, 66 \%$ yield) as colorless oil. The enantiomeric excess was determined to be $82 \%$ by HPLC analysis on a Daicel Chiralpak IA column: $95: 5$ hexane $/ \mathrm{IPA}$, flow rate $1 \mathrm{~mL} / \mathrm{min}, \lambda=210 \mathrm{~nm}: \tau_{\text {Major }}=9.2 \mathrm{~min}, \tau_{\text {Minor }}=13.4 \mathrm{~min}$. Absolute configuration was determined in comparison to compound $(R, R)-5$.

$[\alpha] \mathrm{D}^{20}=+3.3\left(\mathrm{c}=0.25, \mathrm{CHCl}_{3}, 82 \%\right.$ ee $)$.

${ }^{1} \mathrm{H}$ NMR $(400 \mathrm{MHz}$, Chloroform- $d) \delta 7.39-7.19(\mathrm{~m}, 6 \mathrm{H}, \mathrm{ArH}), 7.11(\mathrm{dt}, J=7.8,1.2 \mathrm{~Hz}, 1 \mathrm{H}, \mathrm{ArH}), 7.05$ $(\mathrm{dt}, J=10.3,2.2 \mathrm{~Hz}, 1 \mathrm{H}, \operatorname{Ar} H), 6.90(\mathrm{tdd}, J=8.3,2.6,1.0 \mathrm{~Hz}, 1 \mathrm{H}, \operatorname{Ar} H), 5.00(\mathrm{dq}, J=8.4,5.6 \mathrm{~Hz}, 1 \mathrm{H}$, $\left.\mathrm{CHCF}_{3}\right), 4.59$ (td, $\left.J=9.3,5.5 \mathrm{~Hz}, 1 \mathrm{H}, \mathrm{OCH}\right), 3.99\left(\mathrm{~d}, J=9.5 \mathrm{~Hz}, 1 \mathrm{H}, \mathrm{Ar}^{1} \mathrm{Ar}^{2} \mathrm{CH}\right), 3.25-3.05$ (br. s, $1 \mathrm{H}$, $\mathrm{NCH}_{a} \mathrm{H}_{\mathrm{b}}$ ), $2.89-2.74$ (br. s, $1 \mathrm{H}, \mathrm{NCH}_{a} H_{b}$ ), 2.66 (br. s., $1 \mathrm{H}, \mathrm{NH}$ ).

${ }^{13} \mathrm{C}\left\{{ }^{1} \mathrm{H}\right\}$ NMR $(101 \mathrm{MHz}$, Chloroform- $d) \delta 162.9(\mathrm{~d}, J=245.4 \mathrm{~Hz}), 144.6(\mathrm{~d}, J=7.0 \mathrm{~Hz}), 140.7,129.9(\mathrm{~d}$, $J=8.3 \mathrm{~Hz}), 129.1,128.4,127.5,124.2(\mathrm{~d}, J=2.8 \mathrm{~Hz}), 123.4(\mathrm{q}, J=282.9 \mathrm{~Hz}), 115.4(\mathrm{~d}, J=21.9 \mathrm{~Hz})$, $113.7(\mathrm{~d}, J=21.1 \mathrm{~Hz}), 88.5(\mathrm{q}, J=34.0 \mathrm{~Hz}), 81.8,55.3(\mathrm{~d}, J=1.8 \mathrm{~Hz}), 50.7$.

${ }^{19} \mathrm{~F}\left\{{ }^{1} \mathrm{H}\right\}$ NMR $(376 \mathrm{MHz}$, Chloroform- $d$ ) $\delta-81.1,-113.2$.

$\underline{\mathrm{IR}}\left(\mathrm{cm}^{-1}\right) 3354(\mathrm{w}), 2925(\mathrm{w}), 1597(\mathrm{~m}), 1493(\mathrm{~m}), 1451(\mathrm{~m}), 1291(\mathrm{~m}), 1168(\mathrm{~s}), 1151(\mathrm{~s})$.

HRMS (APCI/QTOF) m/z: [M+ H] $]^{+}$Calculated for $\mathrm{C}_{17} \mathrm{H}_{16} \mathrm{~F}_{4} \mathrm{NO}^{+} 326.1163$; Found 326.1163 .

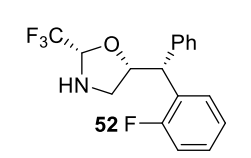

(2S,5R)-5-((R)-(2-Fluorophenyl)(phenyl)methyl)-2-(trifluoromethyl)oxazolidine (52) Prepared according to the general procedure D5 using 29 (83 mg, $0.20 \mathrm{mmol}, 1.0$ equiv., $74 \%$ ee $)$ and $\mathrm{Pd}(\mathrm{OH})_{2} / \mathrm{C}(10 \mathrm{~mol} \%, 14 \mathrm{mg})$. The crude material was purified by flash column chromatography (pentane/EtOAc gradient 100:0 to 80:15) to give the corresponding product 52 (45 mg, $0.14 \mathrm{mmol}, 69 \%$ yield) as colorless oil. The enantiomeric excess was determined to be $72 \%$ by HPLC analysis on a Daicel Chiralpak IA column: 95:5 hexane/IPA, flow rate 1 $\mathrm{mL} / \mathrm{min}, \lambda=254 \mathrm{~nm}: \tau_{\text {Major }}=8.1 \mathrm{~min}, \tau_{\text {Minor }}=14.0 \mathrm{~min}$. Absolute configuration was determined in comparison to compound $(R, R)-5$.

$[\alpha] \mathrm{D}^{20}=-12.8\left(\mathrm{c}=0.26, \mathrm{CHCl}_{3}, 72 \%\right.$ ee $)$.

${ }^{1} \mathrm{H}$ NMR $(400 \mathrm{MHz}$, Chloroform- $d) \delta 7.45(\mathrm{td}, J=7.6,1.9 \mathrm{~Hz}, 1 \mathrm{H}, \mathrm{Ar} H), 7.33-7.15(\mathrm{~m}, 6 \mathrm{H}, \mathrm{Ar} H), 7.12$ $(\mathrm{td}, J=7.5,1.4 \mathrm{~Hz}, 1 \mathrm{H}, \mathrm{Ar} H), 7.01$ (ddd, $J=10.5,8.0,1.4 \mathrm{~Hz}, 1 \mathrm{H}, \mathrm{Ar} H), 4.97$ (br. s., $\left.1 \mathrm{H}, \mathrm{CHCF}_{3}\right), 4.71$ (td, $J=9.1,5.5 \mathrm{~Hz}, 1 \mathrm{H}, \mathrm{OCH}), 4.34\left(\mathrm{~d}, J=9.2 \mathrm{~Hz}, 1 \mathrm{H}, \mathrm{Ar}^{1} \mathrm{Ar}^{2} \mathrm{CH}\right), 3.18$ (br. s, $1 \mathrm{H}, \mathrm{NCH}_{a} \mathrm{H}_{\mathrm{b}}$ ), 2.85 (br. s, $1 \mathrm{H}, \mathrm{NCH}_{a} H_{b}$ ), 2.66 (br. s., $1 \mathrm{H}, \mathrm{NH}$ ).

${ }^{13} \mathrm{C}\left\{{ }^{1} \mathrm{H}\right\}$ NMR (101 MHz, Chloroform- $\left.d\right) \delta 160.9(\mathrm{~d}, J=245.8 \mathrm{~Hz}), 140.5,129.3(\mathrm{~d}, J=4.3 \mathrm{~Hz}), 129.0$, 128.9, 128.4, 128.3, 127.3, $124.2(\mathrm{~d}, J=3.5 \mathrm{~Hz}), 123.3(\mathrm{q}, J=282.8 \mathrm{~Hz}), 115.7$ (d, $J=22.6 \mathrm{~Hz}), 88.4$ (q, $J=34.0 \mathrm{~Hz}), 80.9,50.6,48.5(\mathrm{~d}, J=2.1 \mathrm{~Hz})$.

${ }^{19} \mathrm{~F}\left\{{ }^{1} \mathrm{H}\right\}$ NMR (376 MHz, Chloroform- $d$ ) $\delta-81.1,-117.2$.

$\underline{\text { IR }}\left(\mathrm{cm}^{-1}\right) 3067(\mathrm{w}), 3025(\mathrm{w}), 2945(\mathrm{w}), 2891(\mathrm{w}), 2109(\mathrm{w}), 1715(\mathrm{w}), 1592(\mathrm{w}), 1494(\mathrm{~m}), 1455(\mathrm{~m}), 1291$ (m), $1226(\mathrm{~m}), 1167(\mathrm{~s}), 1153(\mathrm{~s})$.

HRMS (ESI/QTOF) m/z: $[\mathrm{M}+\mathrm{H}]^{+} \mathrm{C}_{17} \mathrm{H}_{16} \mathrm{~F}_{4} \mathrm{NO}^{+}$326.1163; Found 326.1163 .

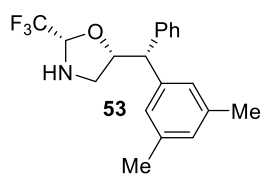

\section{(trifluoromethyl)oxazolidine (53)}

$(2 S, 5 R)-5-((R)-(3,5-D i m e t h y l p h e n y l)(p h e n y l) m e t h y l)-2-$

Prepared according to the general procedure D5 using $30(85 \mathrm{mg}, 0.20 \mathrm{mmol}$, 1.0 equiv., $92 \%$ ee) and $\mathrm{Pd}(\mathrm{OH})_{2} / \mathrm{C}(10 \mathrm{~mol} \%, 14 \mathrm{mg})$. The crude material was purified by flash column chromatography (pentane/EtOAc gradient 100:0 to 80:15) to give the corresponding product $53(51 \mathrm{mg}, 0.15 \mathrm{mmol}, 76 \%$ yield) as colorless oil. The enantiomeric excess was determined to be $92 \%$ by HPLC analysis on a Daicel Chiralpak IA column: 95:5 hexane/IPA, flow rate $1 \mathrm{~mL} / \mathrm{min}, \lambda=210 \mathrm{~nm}$ : $\tau_{\text {Major }}=6.8 \mathrm{~min}, \tau_{\text {Minor }}=8.3 \mathrm{~min}$. Absolute configuration was determined in comparison to compound $(R, R)-\mathbf{5}$.

$[\alpha] \mathrm{D}^{20}=-2.1\left(\mathrm{c}=0.47, \mathrm{CHCl}_{3}, 92 \%\right.$ ee $)$.

${ }^{1} \mathrm{H}$ NMR $(400 \mathrm{MHz}$, Chloroform- $d$ ) $\delta 7.35-7.17(\mathrm{~m}, 5 \mathrm{H}, \mathrm{ArH}), 6.95(\mathrm{~s}, 2 \mathrm{H}, \mathrm{ArH}), 6.85(\mathrm{~s}, 1 \mathrm{H}, \mathrm{ArH}), 4.97$ $\left(\mathrm{dq}, J=8.5,5.6 \mathrm{~Hz}, 1 \mathrm{H}, \mathrm{CHCF}_{3}\right), 4.63(\mathrm{td}, J=9.3,5.5 \mathrm{~Hz}, 1 \mathrm{H}, \mathrm{OCH}), 3.91\left(\mathrm{~d}, J=9.4 \mathrm{~Hz}, 1 \mathrm{H}, \mathrm{Ar}^{1} \mathrm{Ar}^{2} \mathrm{CH}\right)$, $3.21-3.09\left(\mathrm{~m}, 1 \mathrm{H}, \mathrm{NCH}_{a} \mathrm{H}_{\mathrm{b}}\right), 2.85-2.71\left(\mathrm{~m}, 1 \mathrm{H}, \mathrm{NCH}_{a} H_{b}\right), 2.63$ (br. s., $\left.1 \mathrm{H}, \mathrm{NH}\right), 2.28\left(\mathrm{~s}, 6 \mathrm{H}, \mathrm{ArCH}_{3}\right)$. ${ }^{13} \mathrm{C}\left\{{ }^{1} \mathrm{H}\right\}$ NMR $(101 \mathrm{MHz}$, Chloroform- $d) \delta 141.9,141.6,137.9,128.9,128.6,128.3,127.0,126.2,123.4$ $(\mathrm{q}, J=283.1 \mathrm{~Hz}), 88.4(\mathrm{q}, J=33.9 \mathrm{~Hz}), 82.1,55.6,50.7,21.6$. 
${ }^{19} \mathrm{~F}\left\{{ }^{1} \mathrm{H}\right\}$ NMR $(376 \mathrm{MHz}$, Chloroform- $d$ ) $\delta$-81.0.

IR $\left(\mathrm{cm}^{-1}\right) 3355(\mathrm{w}), 3028(\mathrm{w}), 2923(\mathrm{w}), 1603(\mathrm{w}), 1492(\mathrm{w}), 1455(\mathrm{w}), 1292(\mathrm{~m}), 1167(\mathrm{~s})$.

HRMS (ESI/QTOF) m/z: [M+ H] $]^{+}$Calculated for $\mathrm{C}_{19} \mathrm{H}_{21} \mathrm{~F}_{3} \mathrm{NO}^{+}$336.1570; Found 336.1564 .

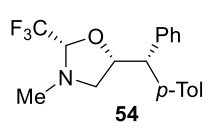

(2S,5R)-3-Methyl-5-((R)-phenyl(p-tolyl)methyl)-2-(trifluoromethyl)oxazolidine (54)

Prepared according to the general procedure D5 using $\mathbf{3 3}$ (33 mg, $0.10 \mathrm{mmol}, 1.0$ equiv., $92 \%$ ee) and $\mathrm{Pd} / \mathrm{C}(20 \mathrm{~mol} \%, 43 \mathrm{mg})$ in $\mathrm{MeOH}(1.3 \mathrm{~mL})$ and $\mathrm{AcOH}(0.7 \mathrm{~mL})$. The crude material was purified by flash column chromatography (pentane/EtOAc gradient 100:0 to 97:3) to give the corresponding product $\mathbf{5 4}(10 \mathrm{mg}, 0.030 \mathrm{mmol}, 30 \%$ yield $)$ as colorless oil. The enantiomeric excess was determined to be $92 \%$ by HPLC analysis on a Daicel Chiralpak IB N-5 column: 99:1 hexane/IPA, flow rate $1 \mathrm{~mL} / \mathrm{min}, \lambda=210 \mathrm{~nm}: \tau_{\text {Major }}=5.2 \mathrm{~min}, \tau_{\text {Minor }}=6.1 \mathrm{~min}$. Absolute configuration was determined in comparison to compound $(R, R)-\mathbf{5}$.

$[\alpha] \mathrm{D}^{20}=10.3\left(\mathrm{c}=0.50, \mathrm{CHCl}_{3}, 92 \%\right.$ ee $)$.

${ }^{1}$ H NMR $(400 \mathrm{MHz}$, Chloroform- $d$ ) $\delta 7.33-7.27(\mathrm{~m}, 2 \mathrm{H}, \operatorname{Ar} H), 7.25-7.20(\mathrm{~m}, 5 \mathrm{H}, \operatorname{Ar} H), 7.11(\mathrm{~d}, J=8.0$ $\mathrm{Hz}, 2 \mathrm{H}, \mathrm{Ar} H), 4.86(\mathrm{ddd}, J=9.9,8.1,5.8 \mathrm{~Hz}, 1 \mathrm{H}, \mathrm{OCH}), 4.51\left(\mathrm{q}, J=5.3 \mathrm{~Hz}, 1 \mathrm{H}, \mathrm{CHCF}_{3}\right), 3.98(\mathrm{~d}, J=9.9$ $\mathrm{Hz}, 1 \mathrm{H}, \operatorname{Ar}^{1} \mathrm{Ar}^{2} \mathrm{CH}$ ), 3.02 (ddd, $J=11.7,8.1,1.3 \mathrm{~Hz}, 1 \mathrm{H}, \mathrm{NCH}_{a} \mathrm{H}_{\mathrm{b}}$ ), 2.77 (ddd, $J=11.7,5.8,1.2 \mathrm{~Hz}, 1 \mathrm{H}$, $\mathrm{NCH}_{a} H_{b}$ ), 2.58 (s, $\left.3 \mathrm{H}, \mathrm{NCH}_{3}\right), 2.30$ (s, 3H, $\mathrm{ArCH}_{3}$ ).

${ }^{13} \mathrm{C}\left\{{ }^{1} \mathrm{H}\right\}$ NMR (101 MHz, Chloroform- $d$ ) $\delta$ 141.6, 139.2, 136.3, 129.3, 128.9, 128.4, 128.2, 127.0, 123.4 $(\mathrm{q}, J=283.2 \mathrm{~Hz}), 94.7(\mathrm{q}, J=33.6 \mathrm{~Hz}), 79.6,58.7,55.3,43.3,21.2$.

${ }^{19} \mathrm{~F}$ NMR $\left(376 \mathrm{MHz}\right.$, Chloroform- $d$ ) $\delta-80.4\left(\mathrm{~d}, 3 \mathrm{~F}, J=5.2 \mathrm{~Hz}, \mathrm{CHC}_{3}\right)$.

IR $\left(\mathrm{cm}^{-1}\right) 3023(\mathrm{w}), 2924(\mathrm{~m}), 2867$ (w), $1510(\mathrm{w}), 1459(\mathrm{~m}), 1294(\mathrm{~m}), 1161$ (s), $1068(\mathrm{~m})$.

HRMS (ESI/QTOF) m/z: [M + H] $]^{+}$Calculated for $\mathrm{C}_{19} \mathrm{H}_{21} \mathrm{~F}_{3} \mathrm{NO}^{+}$336.1570; Found 336.1576.

$\mathrm{Ph}^{\mathrm{F}_{3} \mathrm{C} / \overbrace{55}} \overbrace{p \text {-Tol }}^{\mathrm{Ph}}$

(2S,5R)-3-Phenyl-5-((R)-phenyl(p-tolyl)methyl)-2-(trifluoromethyl)oxazolidine (55)

Prepared according to the general procedure D5 using 34 (40 mg, 0.10 mmol, 1.0 equiv., $54 \%$ ee) and $\mathrm{Pd} / \mathrm{C}(20 \mathrm{~mol} \%, 43 \mathrm{mg})$ in $\mathrm{MeOH}(1.3 \mathrm{~mL})$ and $\mathrm{AcOH}(0.7 \mathrm{~mL})$. The crude material was purified by flash column chromatography (pentane/EtOAc gradient 100:0 to 97:3) to give the corresponding product 55 (14 mg, $0.035 \mathrm{mmol}, 35 \%$ yield) as colorless oil. The enantiomeric excess was determined to be $73 \%$ by HPLC analysis on a Daicel Chiralpak IB N-5 column: 99:1 hexane/IPA, flow rate $1 \mathrm{~mL} / \mathrm{min}, \lambda=210 \mathrm{~nm}: \tau_{\text {Major }}=8.1 \mathrm{~min}, \tau_{\text {Minor }}=11.8 \mathrm{~min}$. Absolute configuration was determined in comparison to compound $(R, R)-5$. The olefin 34 was recovered (17 mg, $0.043 \mathrm{mmol}, 43 \%, 24 \%$ e.e.).

$[\alpha] \mathrm{D}^{20}=-23.7\left(\mathrm{c}=0.50, \mathrm{CHCl}_{3}, 73 \%\right.$ ee $)$.

${ }^{1} \mathrm{H}$ NMR $(400 \mathrm{MHz}$, Chloroform-d) $7.37-7.30(\mathrm{~m}, 2 \mathrm{H}, \mathrm{ArH}), 7.30-7.26(\mathrm{~m}, 3 \mathrm{H}, \mathrm{ArH}), 7.26-7.21(\mathrm{~m}$, $4 \mathrm{H}, \operatorname{Ar} H), 7.13(\mathrm{~d}, J=8.0 \mathrm{~Hz}, 2 \mathrm{H}, \operatorname{Ar} H), 6.88(\mathrm{tt}, J=7.3,1.1 \mathrm{~Hz}, 1 \mathrm{H}, \operatorname{Ar} H), 6.77-6.70(\mathrm{~m}, 2 \mathrm{H}, \operatorname{Ar} H)$, $5.58\left(\mathrm{q}, J=4.5 \mathrm{~Hz}, 1 \mathrm{H}, \mathrm{CHCF}_{3}\right), 4.88(\mathrm{td}, J=9.9,6.1 \mathrm{~Hz}, 1 \mathrm{H}, \mathrm{OCH}), 4.11\left(\mathrm{~d}, J=9.9 \mathrm{~Hz}, 1 \mathrm{H}, \operatorname{Ar}^{1} \mathrm{Ar}^{2} \mathrm{CH}\right)$, $3.74\left(\mathrm{ddd}, J=10.8,6.1,1.4 \mathrm{~Hz}, 1 \mathrm{H}, \mathrm{NCH}_{a} \mathrm{H}_{\mathrm{b}}\right), 3.33\left(\mathrm{dd}, J=10.8,9.9 \mathrm{~Hz}, 1 \mathrm{H}, \mathrm{NCH}_{a} H_{b}\right), 2.31(\mathrm{~s}, 3 \mathrm{H}$, $\left.\mathrm{ArCH}_{3}\right)$.

${ }^{13} \mathrm{C}\left\{{ }^{1} \mathrm{H}\right\}$ NMR $(101 \mathrm{MHz}$, Chloroform- $d) \delta 145.3,141.2,138.6,136.5,129.5,129.4,129.1,128.3,128.2$, $127.3,123.7(\mathrm{q}, J=286.8 \mathrm{~Hz}), 120.2,114.5,87.5(\mathrm{q}, J=34.5 \mathrm{~Hz}), 80.5,55.4,52.3,21.2$.

${ }^{19} \mathrm{~F}$ NMR $\left(376 \mathrm{MHz}\right.$, Chloroform- $d$ ) $\delta-79.6\left(\mathrm{~d}, 3 \mathrm{~F} . J=4.6 \mathrm{~Hz}, \mathrm{CHC} F_{3}\right)$.

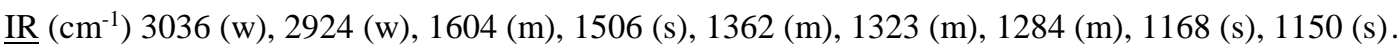

HRMS (ESI/QTOF) m/z: [M+H] $]^{+}$Calculated for $\mathrm{C}_{24} \mathrm{H}_{23} \mathrm{~F}_{3} \mathrm{NO}^{+}$398.1726; Found 398.1723.

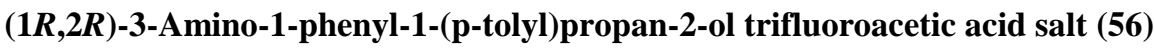
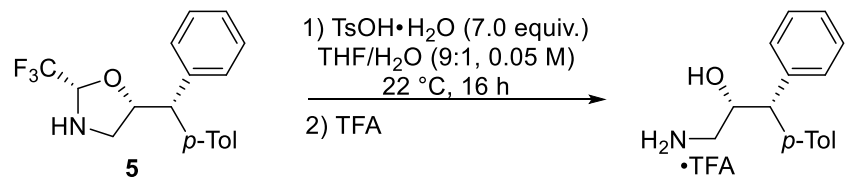

$56,76 \%$

Scheme 15. Acidic hydrolysis of the hemiaminal, synthesis of $\mathbf{5 6}$

In $5 \mathrm{~mL}$ round bottom flask 5 (53 $\mathrm{mg}, 0.20 \mathrm{mmol}$, 94\% ee) was dissolved in a mixture of THF (3.6 mL) and $\mathrm{H}_{2} \mathrm{O}(0.4 \mathrm{~mL})$. Tosylsulfonic acid $(266 \mathrm{mg}, 1.40 \mathrm{mmol}, 7.0$ equiv) was added and the mixture was stirred at room temperature for 16 hours. The reaction was diluted with DCM $(5 \mathrm{~mL})$ and quenched by 
adding $1 \mathrm{M} \mathrm{NaOH}(4 \mathrm{~mL})$. The layers were separated and the aqueous layer was extracted with DCM $(2 \mathrm{x}$ $5 \mathrm{~mL}$ ). The combined organic layers were washed with brine, dried over $\mathrm{Na}_{2} \mathrm{SO}_{4}$, filtered and concentrated. The crude material was purified by preparative RP-HPLC on an Agilent 1260 HPLC system with a G2260A 1260 Prep ALS Autosampler, a G1361a 1260 Prep Pump, a G1365C 1260 MWD detector and a G1364B 1260 FC-PS collector, coupled with a Waters XBridge semi-preparative C18 column (19 x $150 \mathrm{~mm}, 5 \mu \mathrm{m})$. Water (solvent A) and water:acetonitrile 5:95 (solvent B), each containing 0.1\% TFA, were used as the mobile phase at a flow rate of $20 \mathrm{~mL}$.min-1. The following method was used: $100 \%$ A to $100 \% \mathrm{~B}$ in 20 minutes. The desired product $(1 R, 2 R)$-3-amino-1-phenyl-1-(p-tolyl)propan-2-ol trifluoroacetic acid salt $\mathbf{5 6}$ was obtained as gummy solid $(56 \mathrm{mg}, 0.15 \mathrm{mmol}, 76 \%)$. The enantiomeric excess was determined to be 94\% by HPLC analysis on a Daicel Chiralpak IA column: $80: 20$ hexane/IPA, flow rate $1 \mathrm{~mL} / \mathrm{min}, \lambda=210$ $\mathrm{nm}: \tau_{\text {Major }}=8.2 \mathrm{~min}, \tau_{\text {Minor }}=11.4 \mathrm{~min}$. Absolute configuration was determined in comparison to compound $(R, R)-5$.

$[\alpha] \mathrm{D}^{20}=-28.3\left(\mathrm{c}=0.50, \mathrm{CHCl}_{3}, 94 \%\right.$ ee $)$.

${ }^{1} \mathrm{H}$ NMR $(400 \mathrm{MHz}$, Methanol-d4) $\delta 7.35-7.26(\mathrm{~m}, 6 \mathrm{H}, \mathrm{ArH}), 7.24-7.17(\mathrm{~m}, 1 \mathrm{H}, \mathrm{ArH}), 7.17-7.08(\mathrm{~m}$, $2 \mathrm{H}, \operatorname{Ar} H), 4.53(\mathrm{td}, J=9.8,3.0 \mathrm{~Hz}, 1 \mathrm{H}, \mathrm{HOCH}), 3.90\left(\mathrm{~d}, J=9.4 \mathrm{~Hz}, 1 \mathrm{H}, \operatorname{Ar}^{1} \mathrm{Ar}^{2} \mathrm{CH}\right), 2.85(\mathrm{dd}, J=12.8$, $\left.2.9 \mathrm{~Hz}, 1 \mathrm{H}, \mathrm{H}_{2} \mathrm{NCH}_{a} \mathrm{H}_{\mathrm{b}}\right), 2.75\left(\mathrm{dd}, J=12.8,9.9 \mathrm{~Hz}, 1 \mathrm{H}, \mathrm{H}_{2} \mathrm{NCH}_{\mathrm{a}} H_{b}\right), 2.29\left(\mathrm{~s}, 3 \mathrm{H}, \mathrm{ArCH}_{3}\right)$.

${ }^{13} \mathrm{C}\left\{{ }^{1} \mathrm{H}\right\} \mathrm{NMR}(101 \mathrm{MHz}$, Methanol-d4) $\delta 162.7$ (q, $J=34.9 \mathrm{~Hz}), 143.1,139.5,137.4,130.2,129.9,129.6$, 129.2, 128.0, 118.1 (q, $J=292.3 \mathrm{~Hz}), 71.1,57.8,45.3,21.0$.

${ }^{19} \mathrm{~F}$ NMR $(376 \mathrm{MHz}$, Methanol- $d 4) \delta-77.0\left(\mathrm{~s}, 3 \mathrm{~F},{ }^{-} \mathrm{OOCCF}_{3}\right)$.

$\underline{\mathrm{IR}}\left(\mathrm{cm}^{-1}\right) 3031(\mathrm{~m}), 2922(\mathrm{~m}), 1679(\mathrm{~s}), 1518(\mathrm{~m}), 1200$ (s), 1137 (s).

HRMS (ESI/QTOF) m/z: $[\mathrm{M}+\mathrm{H}]^{+}$Calculated for $\mathrm{C}_{16} \mathrm{H}_{20} \mathrm{NO}^{+} 242.1539$; Found 242.1542 .

\section{D.5. Unsuccessful Substrates}

Unreactive propargylic amines, aryl iodides and failed hydrogenations are reported in the following scheme. Yields are reported in the case of low conversions.

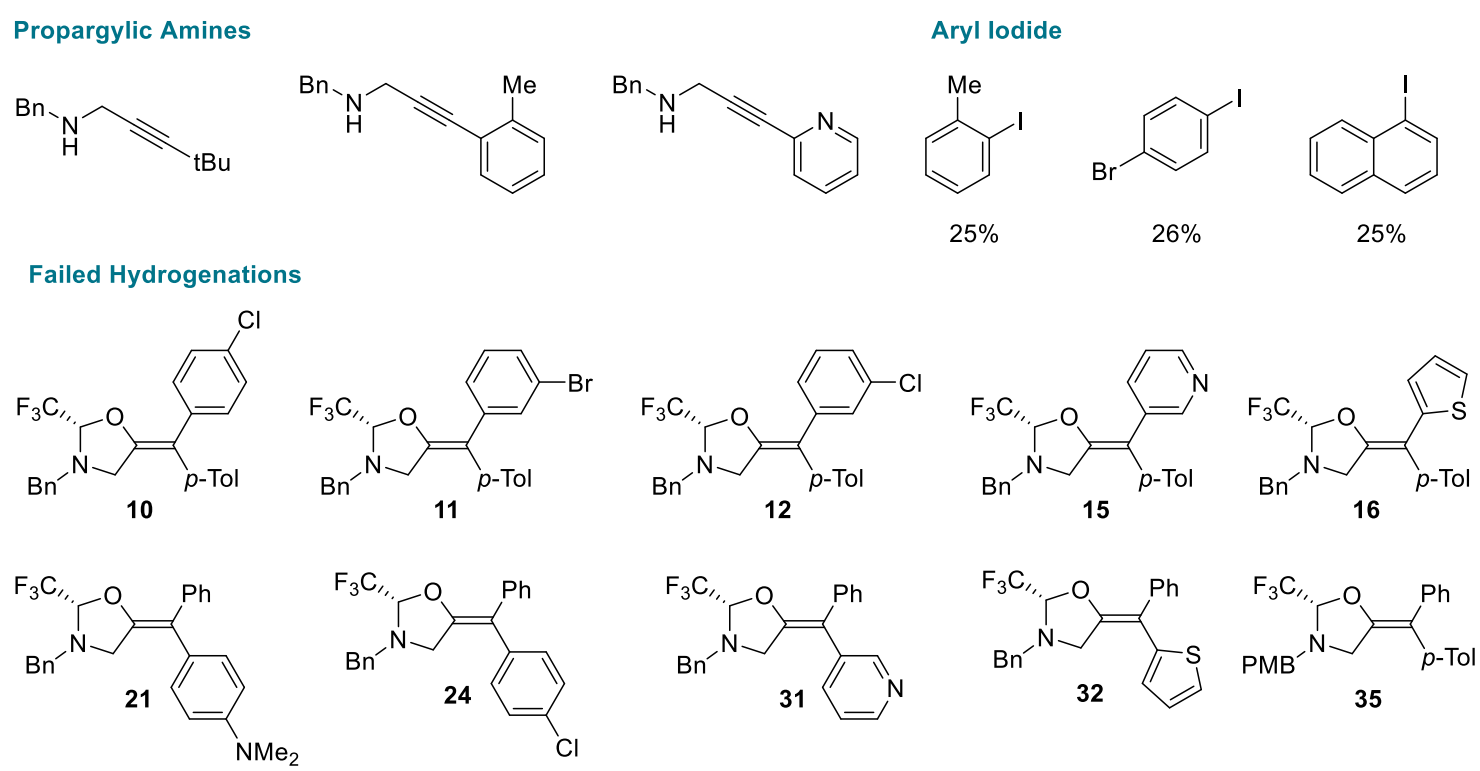

Scheme 16. Unsuccessful substrates and scope limitations. 


\section{E. Mechanistic Considerations}

\section{E.1. Proposed Reaction Mechanism}

In the proposed reaction mechanism, the propargyl amine $\mathbf{1}$ condenses with the ethoxy trifluoroethanol $\mathbf{3}$ to give hemiaminal I. Then a ligand exchange onto the ArPdX species, obtained by oxidative addition of the $\operatorname{Pd}(0)$ catalyst with the aryl iodide, would provide the diastereomeric complexes IV. After a transoxypalladation step, (based on the observed geometry of the products ${ }^{\mathrm{a}}$ ), the vinyl paladium species $\mathbf{V}$ could be obtained. Finally, a reductive elimination step would regenerate $\operatorname{Pd}(0)$ and provide the desired products II.

The origin of the asymmetric induction can be explained considering that the propargyl amine $\mathbf{1}$ and ethoxy trifluoroethanol $\mathbf{3}$ are in equilibrium with the hemiaminal I. This equilibrium provide the source of the racemization of the stereocenter in $\alpha$ to the $\mathrm{CF}_{3}$-group. This racemization pathway is key for the development of a dynamic kinetic asymmetric transformation (DYKAT). In the presence of a chiral palladium complex, the two enantiomers of IV undergoes coordination, oxopalladation and reductive elimination with different kinetics $\left(\mathrm{K}_{1(\mathrm{~S})} \neq \mathrm{K}_{1(\mathrm{R})}, \mathrm{K}_{2(\mathrm{~S})} \neq \mathrm{K}_{2(\mathrm{R})}, \mathrm{k}_{3(\mathrm{~S})} \neq \mathrm{k}_{3(\mathrm{R})}\right)$ leading to the enantioenriched product II. Most likely, coordination proceed in a reversible fashion while the oxypalladation and/or the reductive elimination are irreversible thus constituting the enantiodeterming steps.

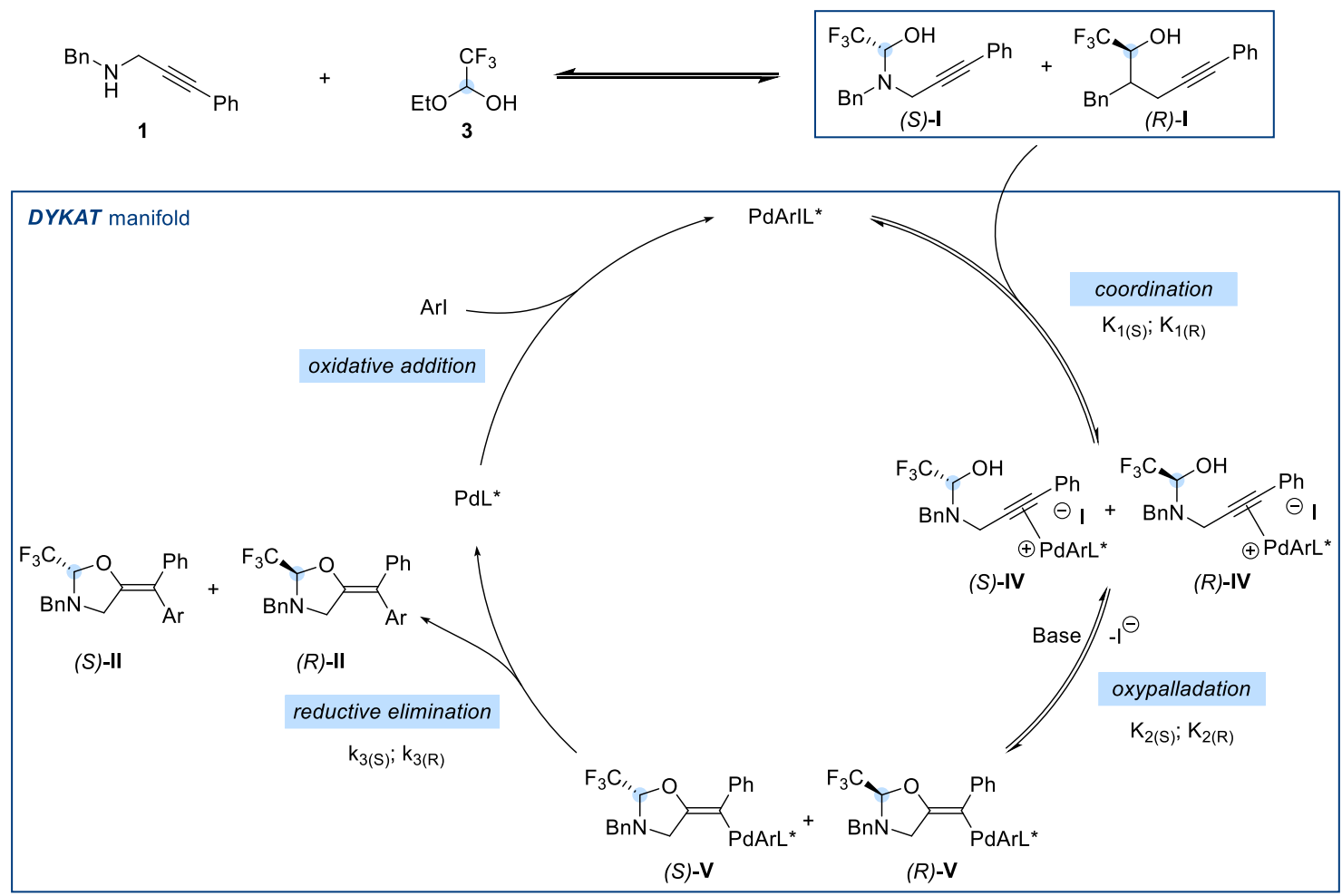

Scheme 17. Proposed reaction mechanism. 


\section{E.2. NMR analysis of the equilibrium between Propargyl Amine 1, Tether 3 and hemiaminal I}<smiles>C(#Cc1ccccc1)CNCc1ccccc1</smiles>

1<smiles>CCOC(O)C(F)(F)F</smiles>

3

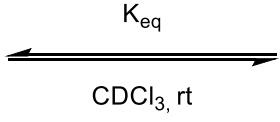

$\mathrm{CDCl}_{3}, \mathrm{rt}$<smiles>OC(C#CCN(Cc1ccccc1)C(F)(F)F)C(F)(F)F</smiles>

Scheme 18. Equilibrium between 1,3 and $\mathbf{I}$.

An NMR tube $(180 \times 5 \mathrm{~mm})$ was charged with propargylic amine $1(21.5 \mu \mathrm{L}, 22.0 \mathrm{mg}, 0.10 \mathrm{mmol}, 1.0$ equiv $)$ and 1-ethoxy-2,2,2-trifluoroethanol 3 (85\% in EtOH, $19 \mathrm{uL}, 0.14 \mathrm{mmol}, 1.4$ equiv.) and $\mathrm{CDCl}_{3}(1.0 \mathrm{~mL})$. ${ }^{1} \mathrm{H}$ NMR spectra was obtained using the following acquisition parameters: pulse program zg30, TD 65536, NS 16, D1 $1.00000000 \mathrm{~s}$, TE $298.0 \mathrm{~K}$.

The integral ratio between the $\mathrm{CHCF}_{3}$ protons of the heminal $\mathbf{I}$ and $\mathbf{3}$ was found to be 1.00:2.41. By simple calculation:

$$
\left\{\begin{array}{c}
{[3]+[\mathbf{I}]=140 \mu M} \\
{[3]=2.41 \cdot[\mathbf{I}]}
\end{array}\right.
$$

This corresponds to approx. $41 \%$ conversion of the propargyl amine $\mathbf{1}$ to the hemiaminal $\mathbf{I}$.

IH NMR ( $400 \mathrm{MHz}, \mathrm{CB} Q \mathrm{G} 1$

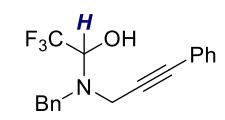

$$
\text { EtO } \overbrace{H}^{\mathrm{CF}_{3}}
$$
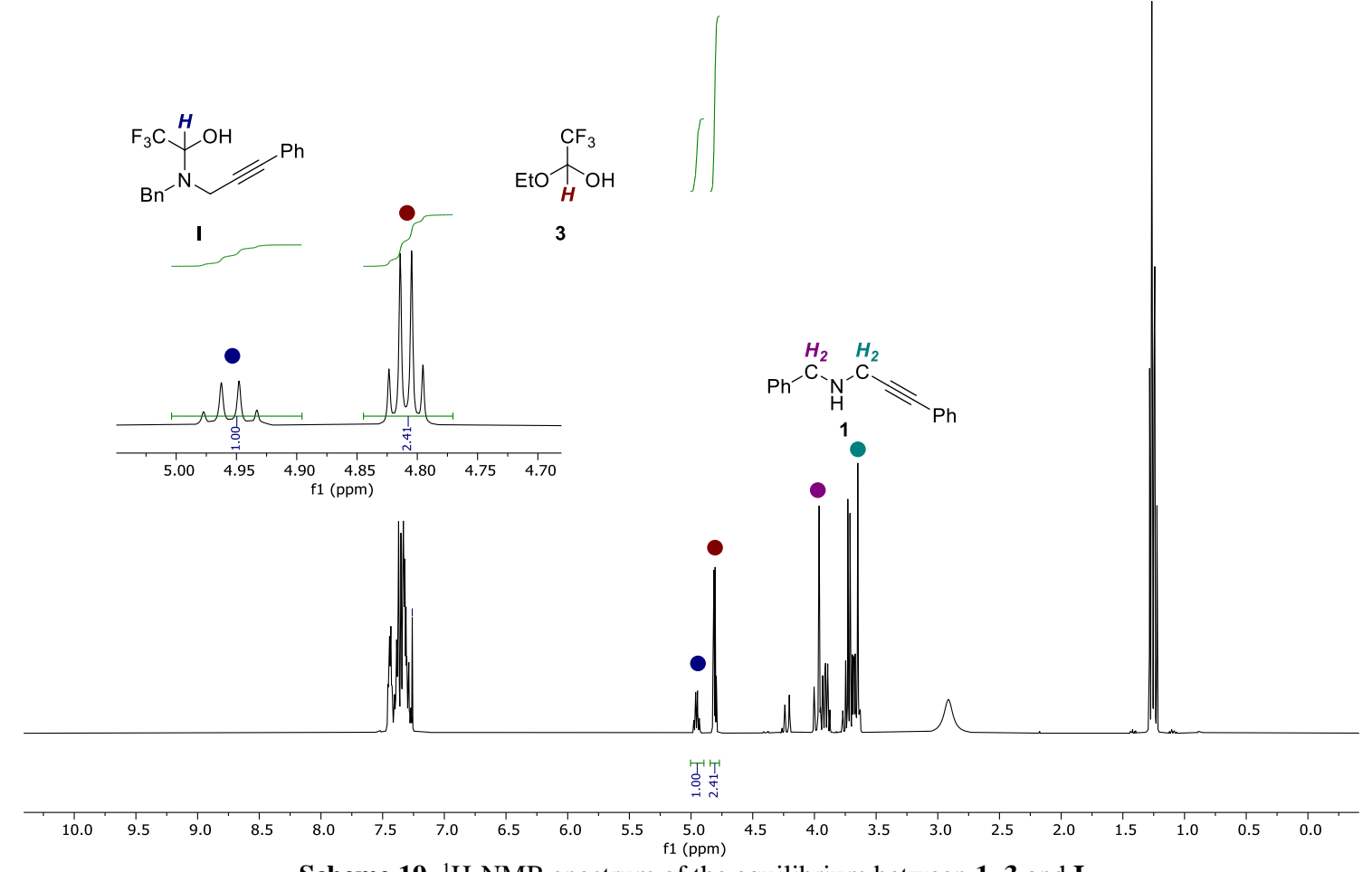

Scheme 19. ${ }^{1} \mathrm{H}-\mathrm{NMR}$ spectrum of the equilibrium between $\mathbf{1}, \mathbf{3}$ and $\mathbf{I}$ 


\section{F. X-Ray Crystallographic Data}

\section{F.1. Single Crystal X-Ray Diffraction for the chiral compound (S)-4}

Crystals of the compound (S)-4 were obtained by slow evaporation of a diethyl ether solution.

Data acquisition: Single clear pale colourless needle crystals of $(S)-4$ were used as supplied. A suitable crystal with dimensions $0.78 \times 0.13 \times 0.07 \mathrm{~mm}^{3}$ was selected and mounted on a SuperNova, Dual, $\mathrm{Cu}$ at home/near, Atlas diffractometer. The crystal was kept at a steady $T=140.01(10) \mathrm{K}$ during data collection. The structure was solved with the ShelXT (Sheldrick, 2015) solution program using dual methods and by using Olex 2 as the graphical interface. The model was refined with ShelXL 2018/3 (Sheldrick, 2015) using full matrix least squares minimisation on $\boldsymbol{F}^{2}$
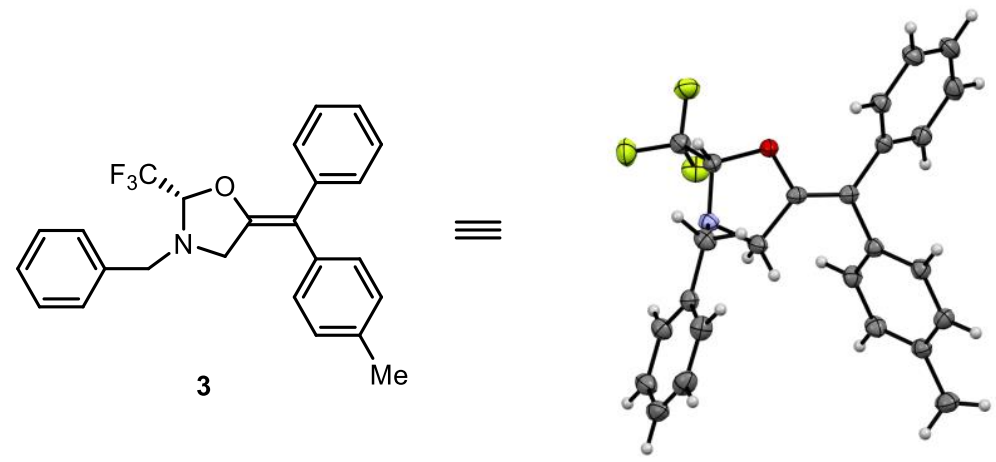

Scheme 20: Crystal data and structure refinement for (S)-4. CCDC 2020478 


\begin{tabular}{|c|c|}
\hline Formula & $\mathrm{C}_{25} \mathrm{H}_{22} \mathrm{~F}_{3} \mathrm{NO}$ \\
\hline$D_{\text {calc. }} / \mathrm{g} \mathrm{cm}^{-3}$ & 1.354 \\
\hline$\mu / \mathrm{mm}^{-1}$ & 0.843 \\
\hline Formula Weight & 409.43 \\
\hline Colour & clear pale colourless \\
\hline Shape & needle \\
\hline Size $/ \mathrm{mm}^{3}$ & $0.78 \times 0.13 \times 0.07$ \\
\hline$T / \mathrm{K}$ & $140.01(10)$ \\
\hline Crystal System & orthorhombic \\
\hline Flack Parameter & $0.02(5)$ \\
\hline Hooft Parameter & $0.04(4)$ \\
\hline Space Group & $P 2_{1} 2_{1} 2_{1}$ \\
\hline$a / \AA ̊$ & $5.80938(12)$ \\
\hline$b / \AA$ & $17.8312(3)$ \\
\hline$c / \AA$ & $19.3852(4)$ \\
\hline$\left.\alpha\right|^{\circ}$ & 90 \\
\hline$\beta /^{\circ}$ & 90 \\
\hline$\gamma /^{\circ}$ & 90 \\
\hline $\mathrm{V} / \AA^{3}$ & $2008.09(7)$ \\
\hline$Z^{\prime}$ & 4 \\
\hline$Z^{\prime}$ & 1 \\
\hline Wavelength/Å & 1.54184 \\
\hline Radiation type & $\mathrm{Cu} \mathrm{K} \alpha$ \\
\hline$\Theta_{\min } /^{\circ}$ & 3.368 \\
\hline$\Theta_{\max } /^{\circ}$ & 72.663 \\
\hline Measured Refl's. & 14345 \\
\hline Ind't Refl's & 3929 \\
\hline Refl's with $\mathrm{I}>2 \sigma(\mathrm{I})$ & 3826 \\
\hline Rint & 0.0255 \\
\hline Parameters & 273 \\
\hline Restraints & 0 \\
\hline Largest Peak & 0.180 \\
\hline Deepest Hole & -0.155 \\
\hline GooF & 1.048 \\
\hline$w R_{2}$ (all data) & 0.0761 \\
\hline$w R_{2}$ & 0.0750 \\
\hline$R_{1}$ (all data) & 0.0301 \\
\hline$R_{1}$ & 0.0291 \\
\hline
\end{tabular}




\section{F.2. Single Crystal X-Ray Diffraction for the chiral compound $(R, R)-5$}

Crystals of the compound $(R, R)-\mathbf{5}$ were obtained by slow evaporation of an hexane/diethyl ether (10:1) solution.

Data Acquisition: Single clear pale colourless prism crystals of $(R, R)-\mathbf{5}$ were used as supplied. A suitable crystal with dimensions $0.23 \times 0.17 \times 0.09 \mathrm{~mm}^{3}$ was selected and mounted on a SuperNova, Dual, $\mathrm{Cu}$ at home/near, AtlasS2 diffractometer. The crystal was kept at a steady $T=140.00(10) \mathrm{K}$ during data collection. The structure was solved with the ShelXT (Sheldrick, 2015) solution program using dual methods and by using Olex2 (Dolomanov et al., 2009) as the graphical interface. The model was refined with ShelXL 2018/3 (Sheldrick, 2015) using full matrix least squares minimisation on $\boldsymbol{F}^{2}$.
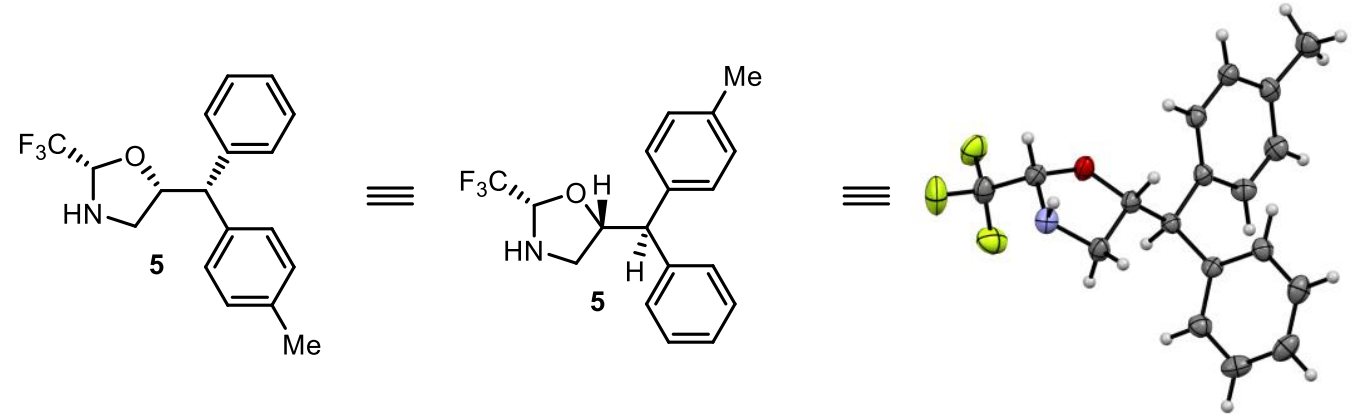

Scheme 21: Crystal data and structure refinement for 5. CCDC2020479 


\begin{tabular}{|c|c|}
\hline Formula & $\mathrm{C}_{18} \mathrm{H}_{18} \mathrm{~F}_{3} \mathrm{NO}$ \\
\hline$D_{\text {calc. }} / \mathrm{g} \mathrm{cm}^{-3}$ & 1.357 \\
\hline$\mu / \mathrm{mm}^{-1}$ & 0.916 \\
\hline Formula Weight & 321.33 \\
\hline Colour & clear pale colourless \\
\hline Shape & prism \\
\hline Size $/ \mathrm{mm}^{3}$ & $0.23 \times 0.17 \times 0.09$ \\
\hline$T / \mathrm{K}$ & $140.00(10)$ \\
\hline Crystal System & orthorhombic \\
\hline Flack Parameter & $0.01(7)$ \\
\hline Hooft Parameter & $0.05(5)$ \\
\hline Space Group & $P 2{ }_{1} 2{ }_{1}{ }_{1}$ \\
\hline$a / \AA ̊$ & $5.83034(13)$ \\
\hline$b / \AA$ & $8.00767(18)$ \\
\hline$c / \AA$ & $33.6790(7)$ \\
\hline$\alpha /^{\circ}$ & 90 \\
\hline$\beta /^{\circ}$ & 90 \\
\hline$\left.\gamma\right|^{\circ}$ & 90 \\
\hline $\mathrm{V} / \AA^{3}$ & $1572.38(6)$ \\
\hline$Z$ & 4 \\
\hline$Z^{\prime}$ & 1 \\
\hline Wavelength/Å & 1.54184 \\
\hline Radiation type & $\mathrm{Cu} \mathrm{K} \alpha$ \\
\hline$\Theta_{\min } /^{\circ}$ & 5.253 \\
\hline$\left.\Theta_{\max }\right|^{\circ}$ & 72.678 \\
\hline Measured Refl's. & 3094 \\
\hline Ind't Refl's & 3094 \\
\hline Refl's with I > $2 \sigma(\mathrm{I})$ & 2974 \\
\hline Rint & . \\
\hline Parameters & 218 \\
\hline Restraints & 0 \\
\hline Largest Peak & 0.336 \\
\hline Deepest Hole & -0.220 \\
\hline GooF & 1.120 \\
\hline$w R_{2}$ (all data) & 0.1374 \\
\hline$w R_{2}$ & 0.1360 \\
\hline$R_{1}$ (all data) & 0.0468 \\
\hline$R_{1}$ & 0.0454 \\
\hline
\end{tabular}




\section{G. References}

1. Sheldrick, G. M., SHELXT - Integrated space-group and crystal-structure determination. Acta Cryst A 2015, 71, 3-8.

2. Sheldrick, G. M., Crystal structure refinement with SHELXL. Acta Cryst C 2015, 71, 3-8.

3. Zalesskiy, S. S.; Ananikov, V. P., $\mathrm{Pd}_{2}(\mathrm{dba})_{3}$ as a Precursor of Soluble Metal Complexes and Nanoparticles: Determination of Palladium Active Species for Catalysis and Synthesis. Organometallics 2012, 31, 2302-2309.

4. Greenwood, P. D. G.; Waser, J., Palladium-Catalyzed Carboxy-Alkynylation of Propargylic Amines Using Carbonate Salts as Carbon Dioxide Source: Palladium-Catalyzed Carboxy-Alkynylation of Propargylic Amines Using Carbonate Salts as Carbon Dioxide Source. Eur. J. Org. Chem. 2019, 2019, 5183-5186.

5. Althuon, D.; Rönicke, F.; Fürniss, D.; Quan, J.; Wellhöfer, I.; Jung, N.; Schepers, U.; Bräse, S., Functionalized triazolopeptoids - a novel class for mitochondrial targeted delivery. Org. Biomol. Chem. 2015, 13, 4226-4230.

6. Hashmi, A. S. K.; Häffner, T.; Yang, W.; Pankajakshan, S.; Schäfer, S.; Schultes, L.; Rominger, F.; Frey, W., Gold catalysis: Non-spirocyclic intermediates in the conversion of furanynes by the formal insertion of an alkyne into an aryl-alkyl C-C single bond. Chem. Eur. J. 2012, 18, 10480-10486.

7. Kundu, N. G.; Chaudhuri, G., Heteroannulation through copper catalysis : a novel and highly regioand stereoselective cyclisation of alkynes leading to (E) -2- ( 2-arylvinyl ) quinazolinones. Tetrahedron Lett. 2001, 42, 2883-2886.

8. Reis, O.; Koyuncu, H.; Esiringu, I.; Sahin, Y.; Gulcan, O. H., A New Method for the Synthesis of Rasagiline. U.S. Patent No US 8,901,352 B2, 2014.

9. Shao, Y.; Zhang, F.; Zhang, J.; Zhou, X., Lanthanide-Catalyzed Reversible Alkynyl Exchange by Carbon-Carbon Single-Bond Cleavage Assisted by a Secondary Amino Group. Angew. Chem. Int. Ed. 2016, 55, 11485-11489.

10. García-Domínguez, P.; Fehr, L.; Rusconi, G.; Nevado, C., Palladium-catalyzed incorporation of atmospheric CO2: Efficient synthesis of functionalized oxazolidinones. Chem. Sci. 2016, 7, 39143918.

11. Greenwood, P. D. G.; Grenet, E.; Waser, J., Palladium-Catalyzed Carbo-Oxygenation of Propargylic Amines using in Situ Tether Formation. Chem. Eur. J. 2019, 25, 3010-3013. 
12. Xu, H.-H.; Zhang, X.-H.; Zhang, X.-G., Copper-Catalyzed Tandem Sulfuration/Annulation of Propargylamines with Sulfur via C-N Bond Cleavage. J. Org. Chem. 2019, 84, 7894-7900.

13. Chavan, S.; Pathak, A.; Pawar, K., Synthesis of 3-Ethyl-4-methyl-1,5-dihydro-2H-pyrrol-2-one by Novel Palladium(II)-Catalyzed Cyclization and Ring-Closing Metathesis. Synthesis 2015, 47, 955960.

14. Nauth, A. M.; Otto, N.; Opatz, T., $\alpha$-Cyanation of Aromatic Tertiary Amines using Ferricyanide as a Non-Toxic Cyanide Source. Adv. Synth. Catal. 2015, 357, 3424-3428.

15. Suez, G.; Bloch, V.; Nisnevich, G.; Gandelman, M., Design and Development of Bioinspired GuanineBased Organic Catalyst for Asymmetric Catalysis. Eur. J. Org. Chem. 2012, 2012, 2118-2122.

16. Oost, R.; Rong, J.; Minnaard, A. J.; Harutyunyan, S. R., Synthesis of New Derivatives of Copper Complexes of Josiphos Family Ligands for Applications in Asymmetric Catalysis. Catal. Sci. Technol. 2014, 4, 1997-2005.

17. Conlon, D. A.; Yasuda, N., Practical Synthesis of Chiral N,N'-Bis(2'-pyridinecarboxamide)-1,2cyclohexane Ligands. Adv. Synth. Catal., 2001, 343, 137-138.

18. Trost, B. M.; Oslob, J. D., Asymmetric Synthesis of (-)-Anatoxin-a via an Asymmetric Cyclization Using a New Ligand for Pd-Catalyzed Alkylations. J. Am. Chem. Soc. 1999, 121, 3057-3064.

19. Opačak, S.; Kokan, Z.; Glasovac, Z.; Perić, B.; Kirin, S.I., "Backdoor Induction” of Chirality: Trans1,2-cyclohexanediamine as Key Building Block for Asymmetric Hydrogenation Catalysts. Eur. J. Org. Chem., 2019, 2019, 2115-2128.

20. Liu, W.; Pan, H.; Tian, H.; Shi, Y., Enantioselective 6-exo-Bromoaminocyclization of Homoallylic NTosylcarbamates Catalyzed by a Novel Monophosphine-Sc(OTf)3 Complex Org. Lett., 2015, 17, 3956-3959.

21. Kim, Y. K.; Lee, S. J.; Ahn, K. H., New Hybrid Ligands with a trans-1,2-Diaminocyclohexane Backbone: Competing Chelation Modes in Palladium-Catalyzed Enantioselective Allylic Alkylation J. Org. Chem. 2000, 65, 7807-7813. 


\section{H. NMR Spectra}

\section{H.1.Starting Materials}

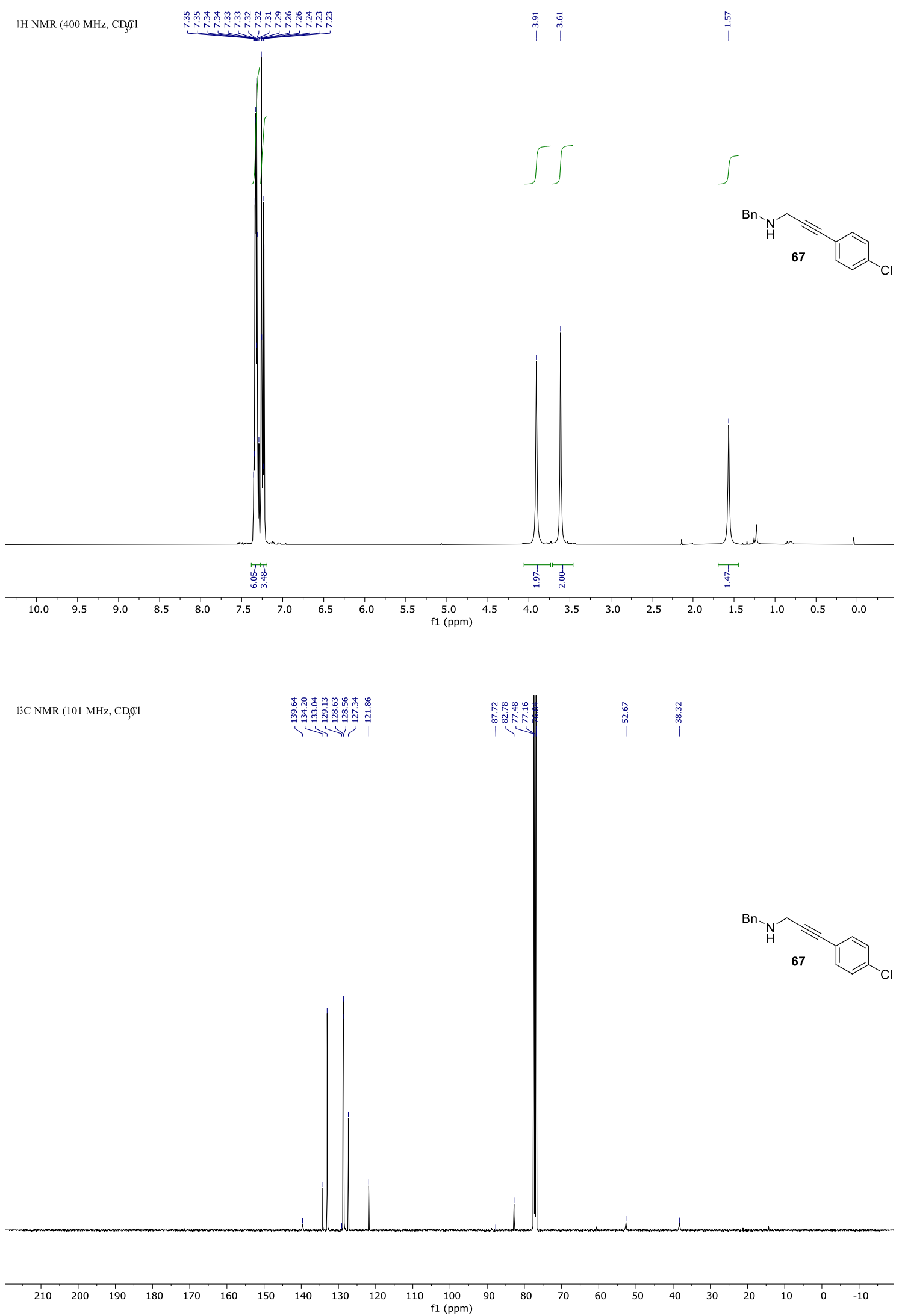



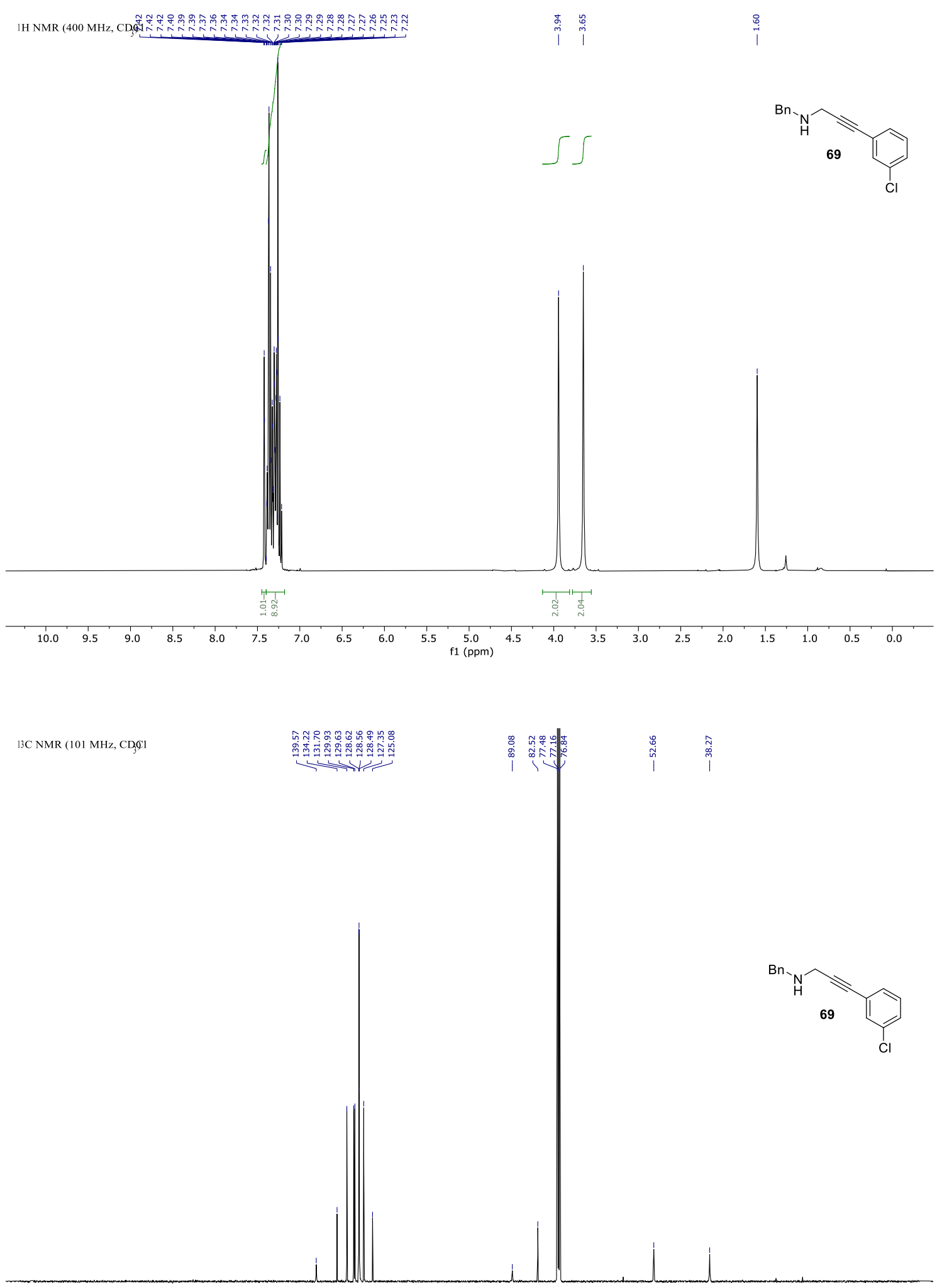

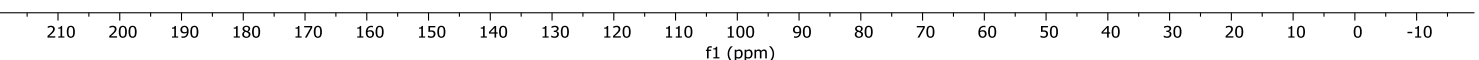




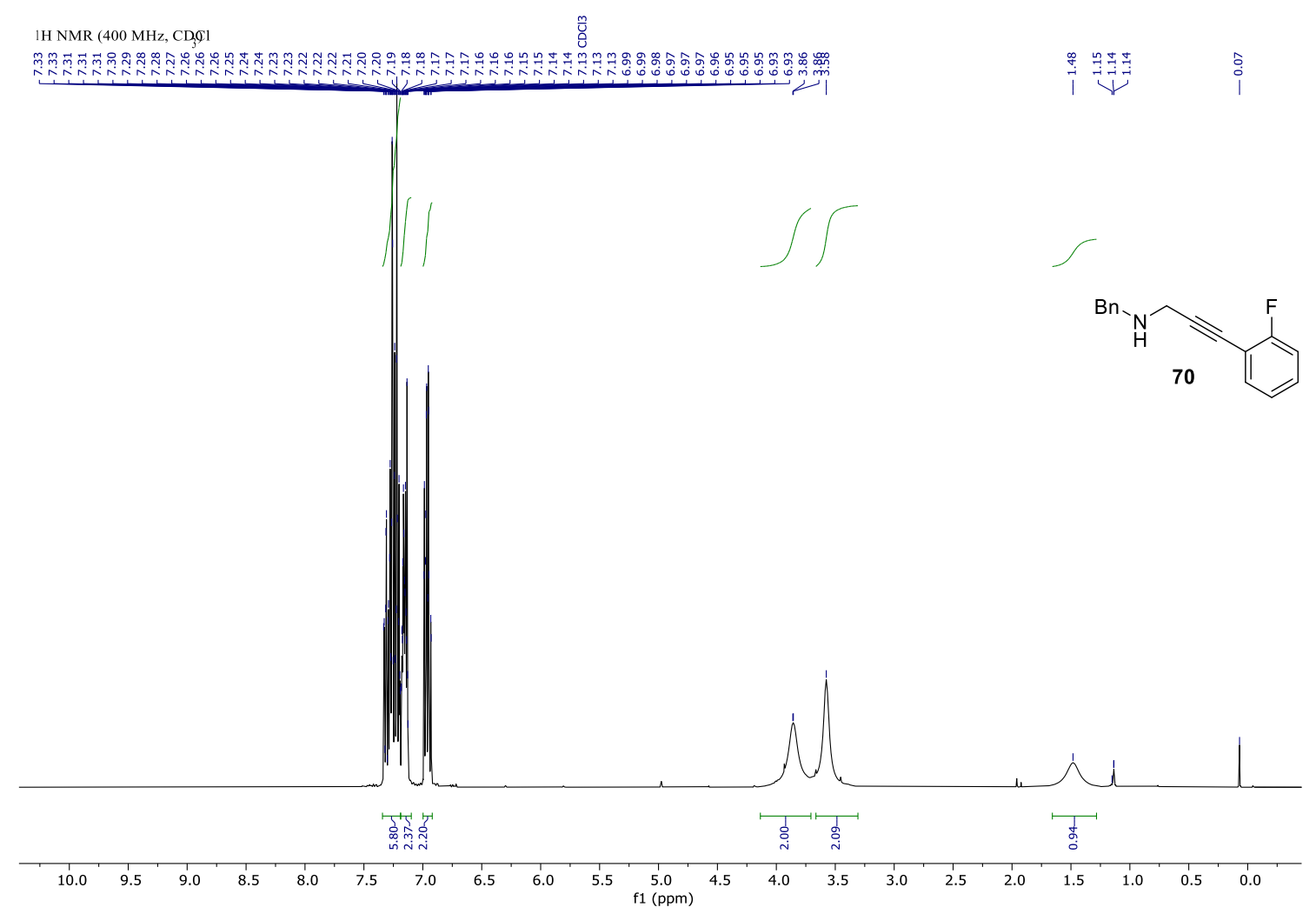

13C NMR (101 MHz, CD,91

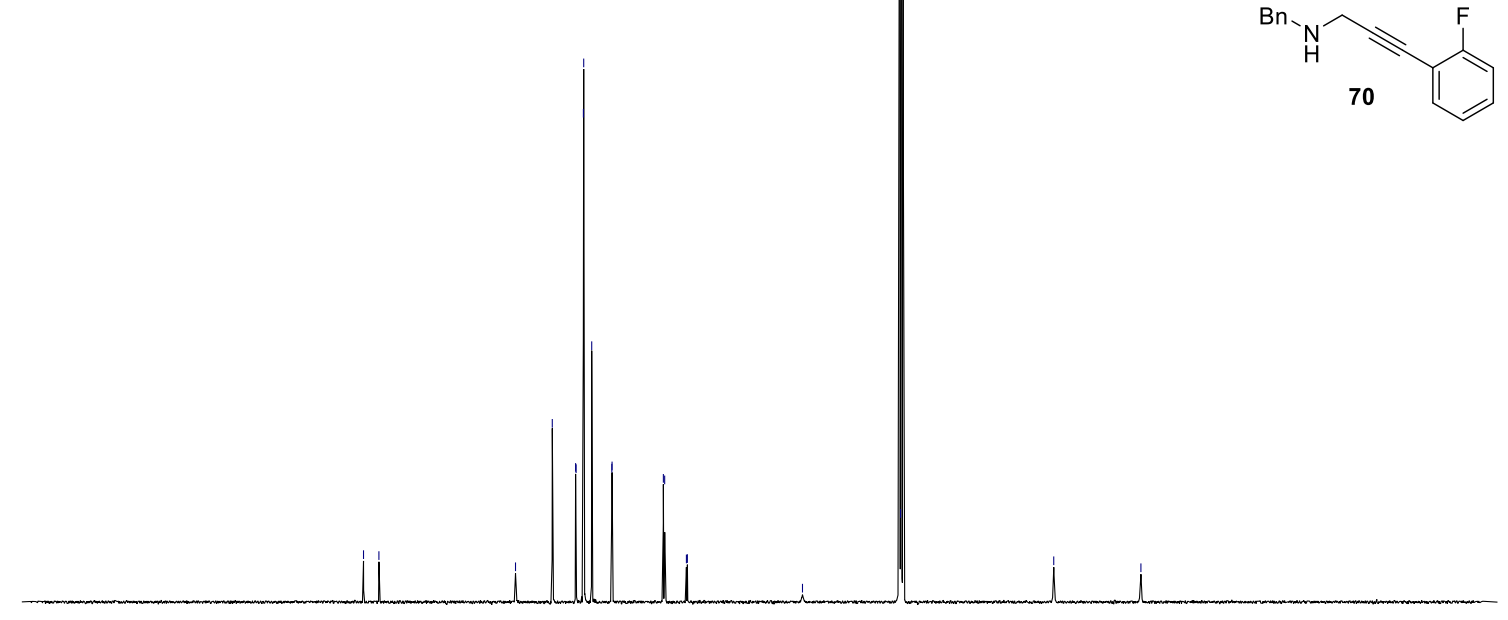

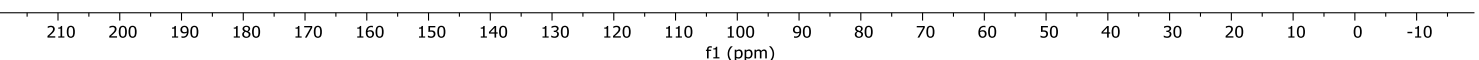



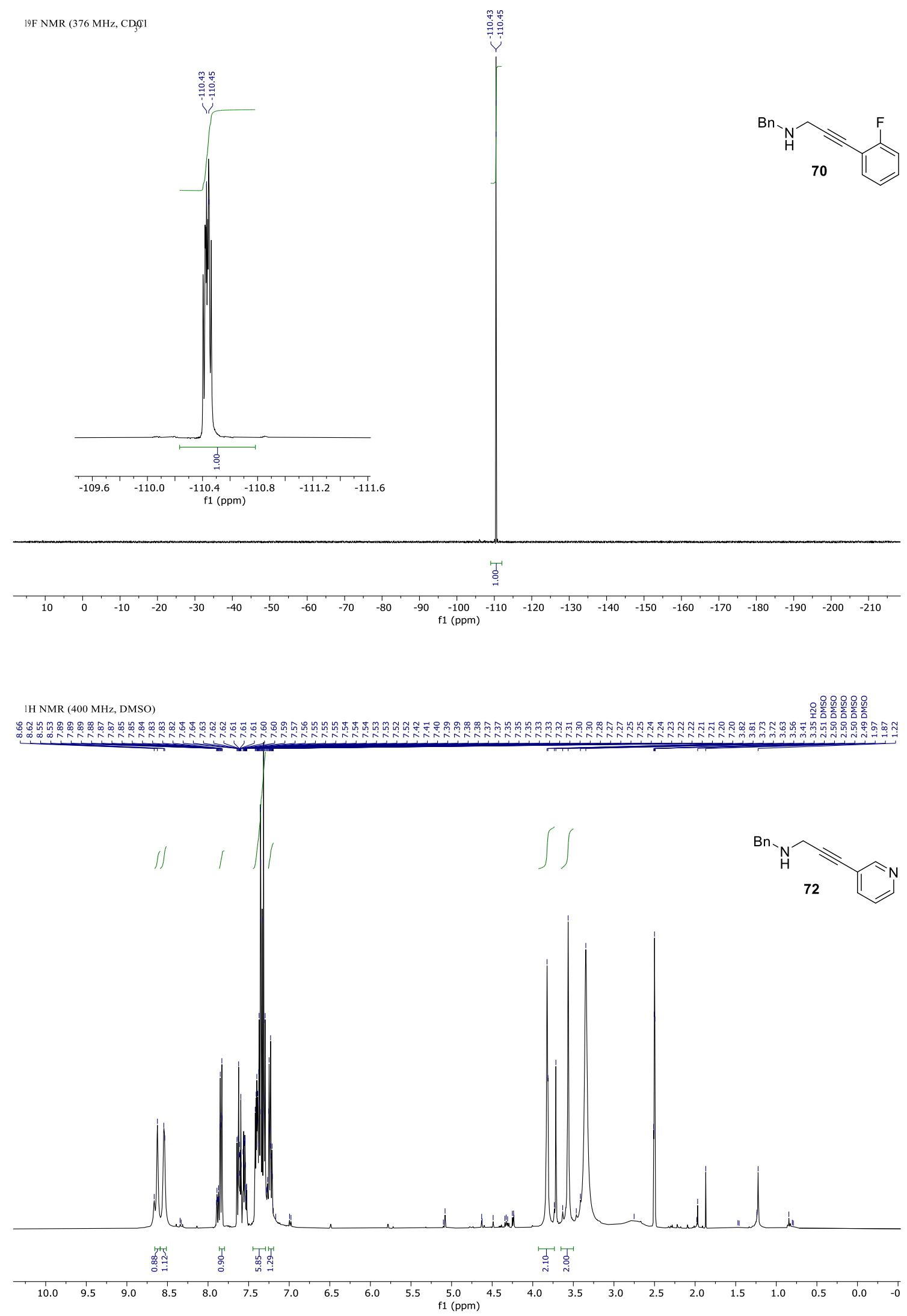


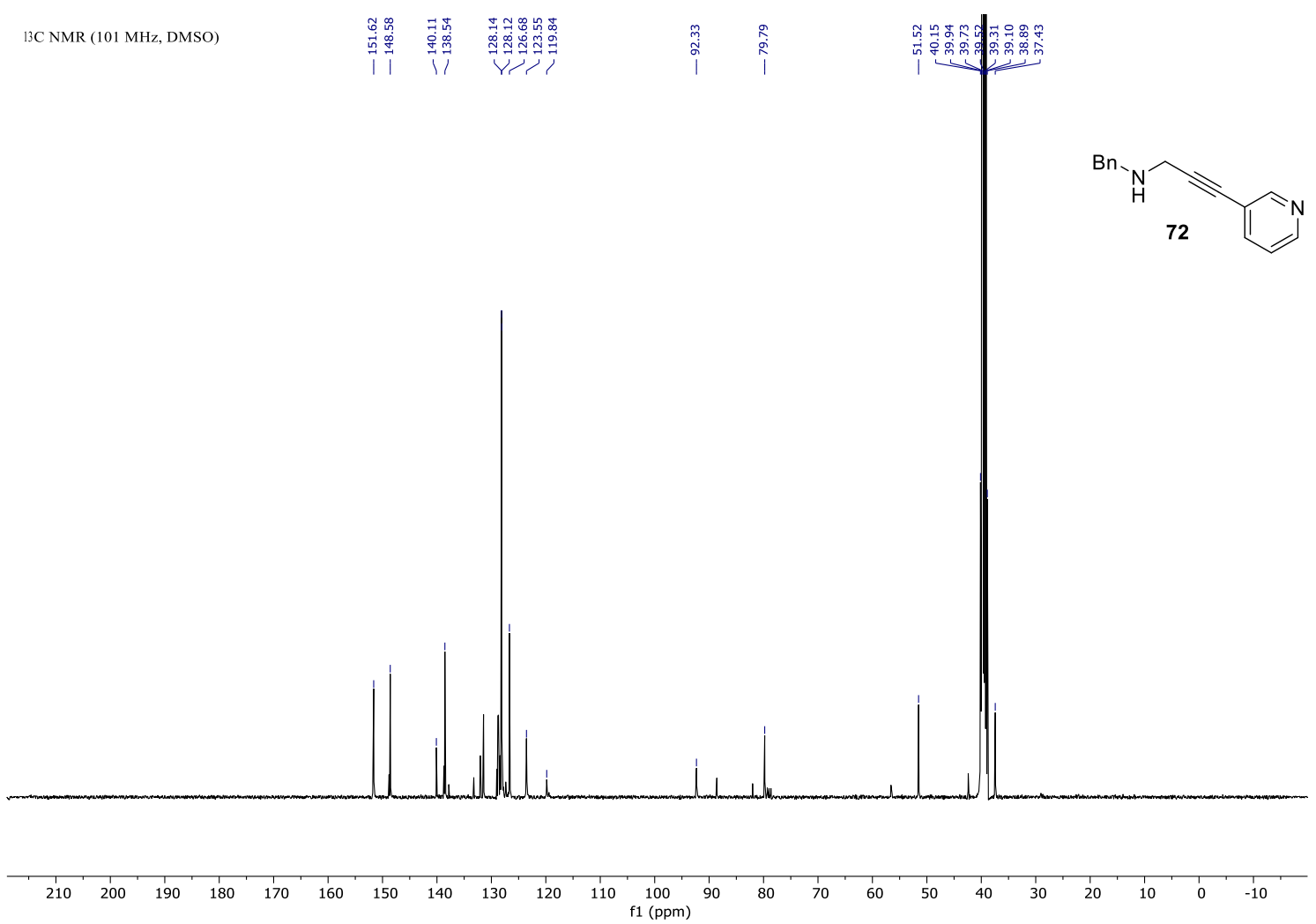




\section{H.2.Carboetherification Products}

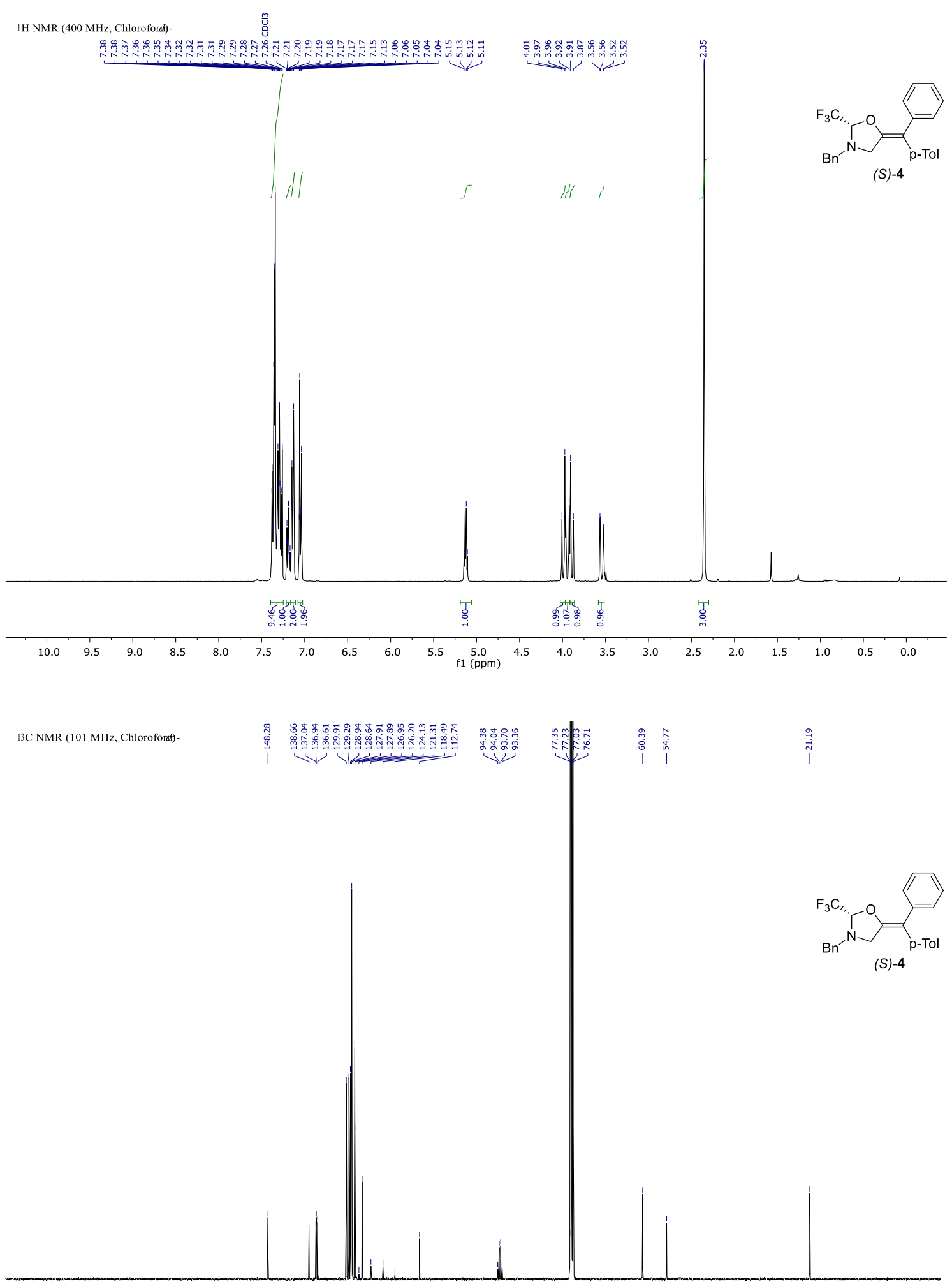

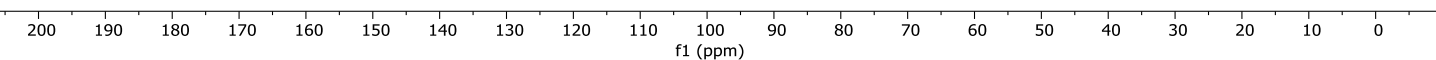




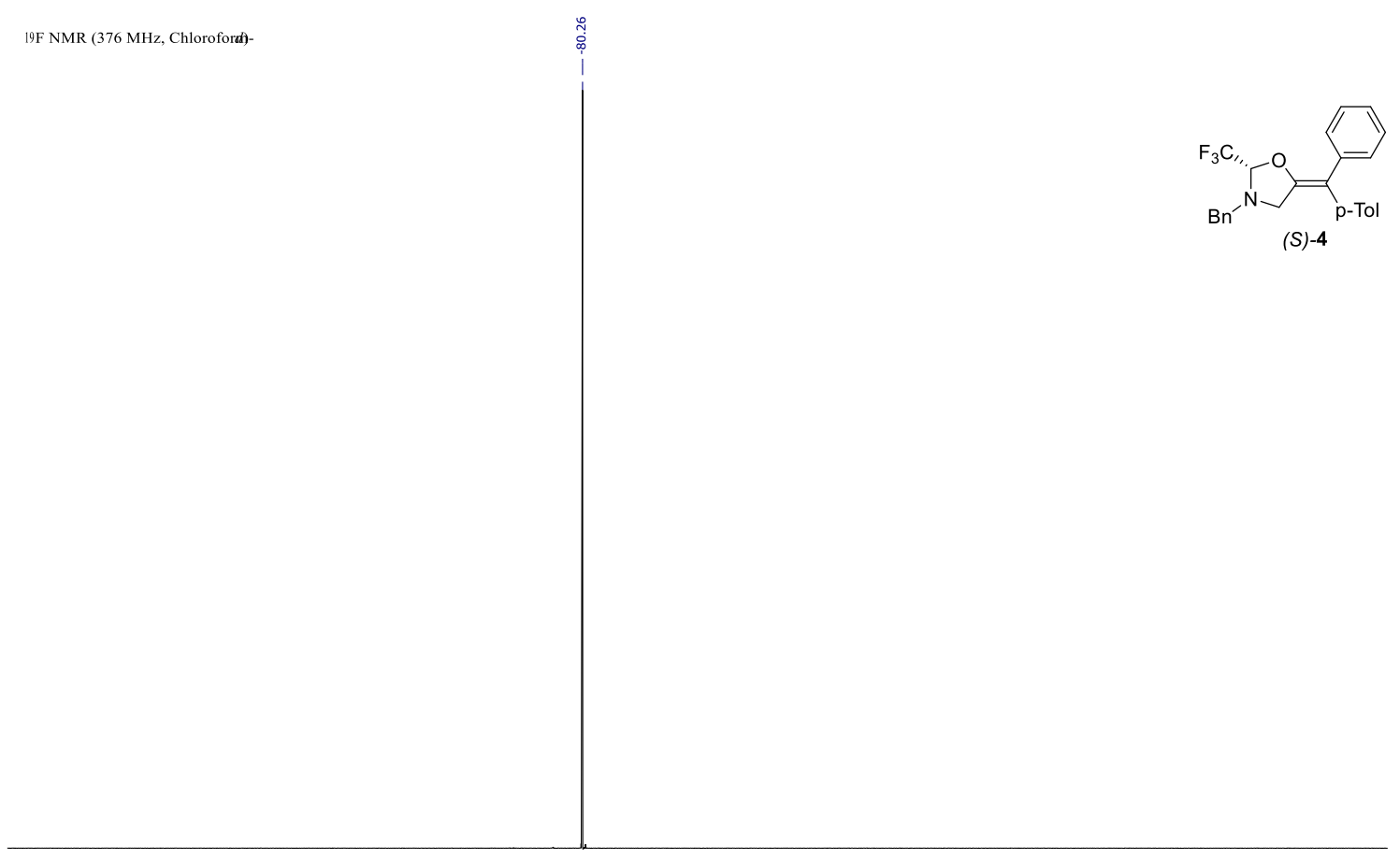

$\begin{array}{llllllllllllllllllllllll}1 & 0 & 0 & -10 & -20 & -30 & -40 & -50 & -60 & -70 & -80 & -90 & -100 & -110 & -120 & -130 & -140 & -150 & -160 & -170 & -180 & -190 & -200 & -210\end{array}$

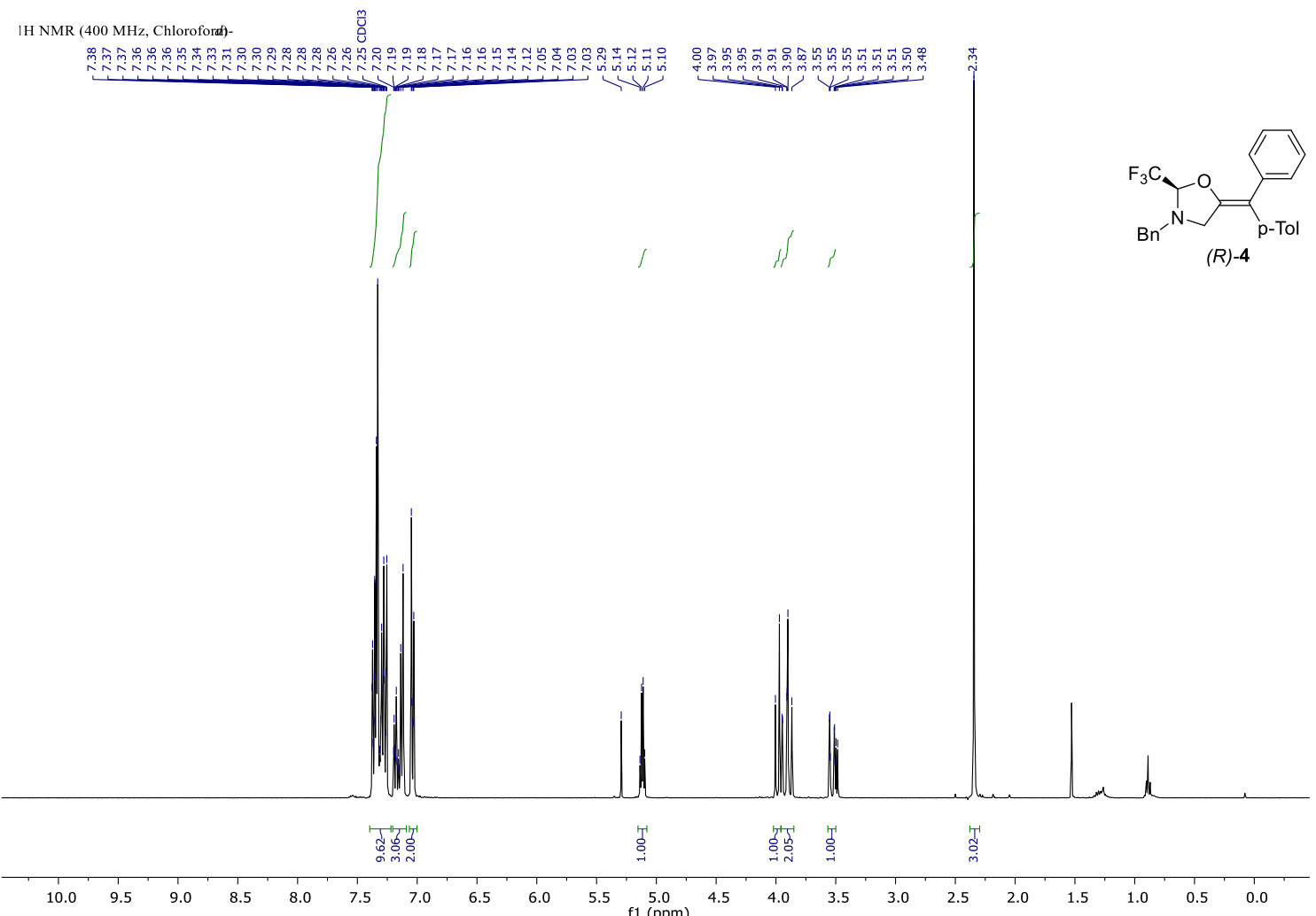




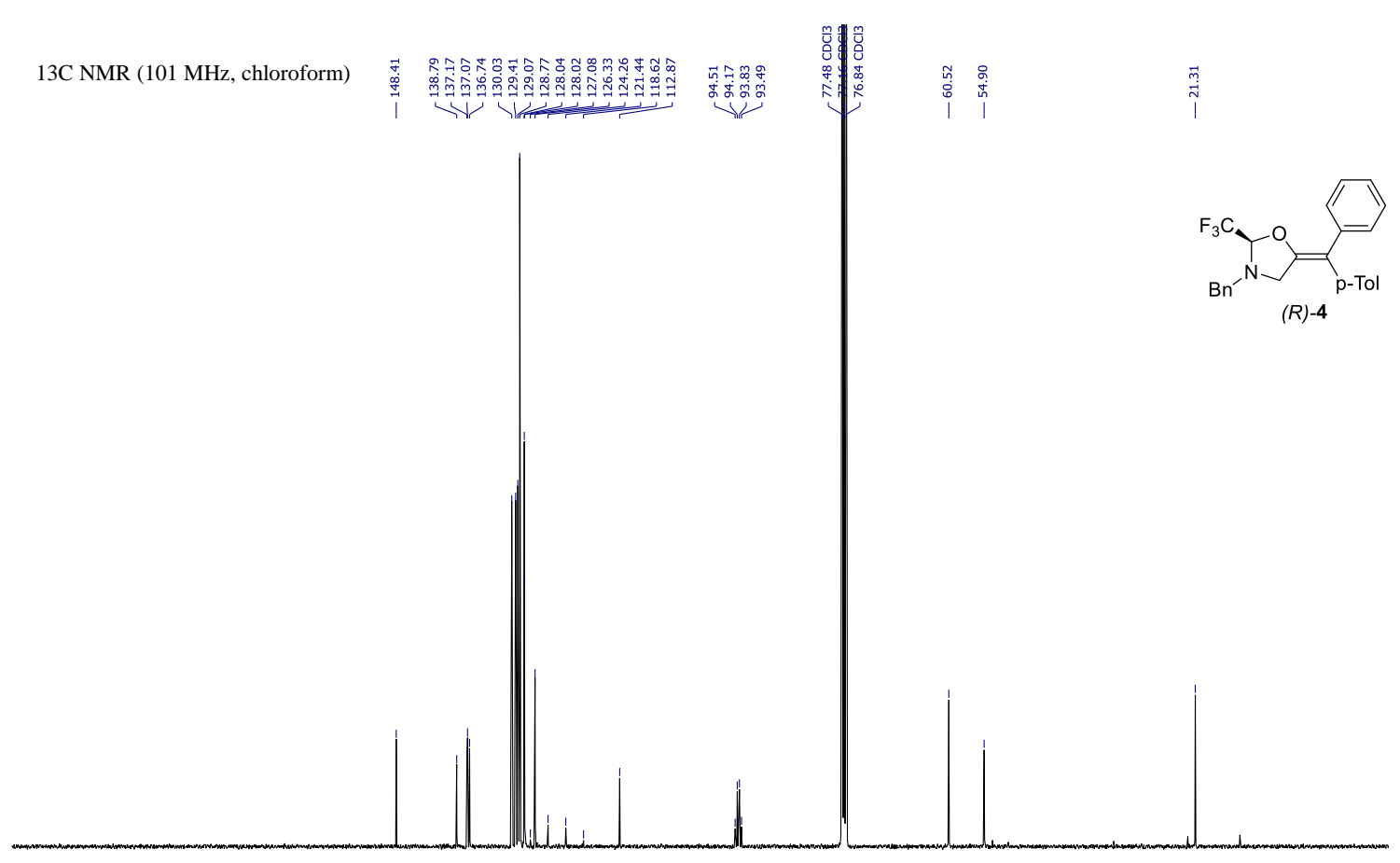

$\begin{array}{llllllllllllllllllllll} & 1 \\ 200 & 190 & 180 & 170 & 160 & 150 & 140 & 130 & 120 & 110 & 100 & 90 & 80 & 70 & 60 & 50 & 40 & 30 & 20 & 10 & 0\end{array}$

19F NMR (376 MHz, Chloroford)-

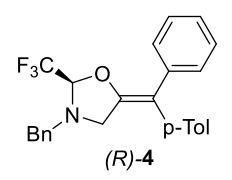

$\begin{array}{lllllllllllllllllllllllll}10 & 0 & -10 & -20 & -30 & -40 & -50 & -60 & -70 & -80 & -90 & -100 & -110 & -120 & -130 & -140 & -150 & -160 & -170 & -180 & -190 & -200 & -210\end{array}$ 

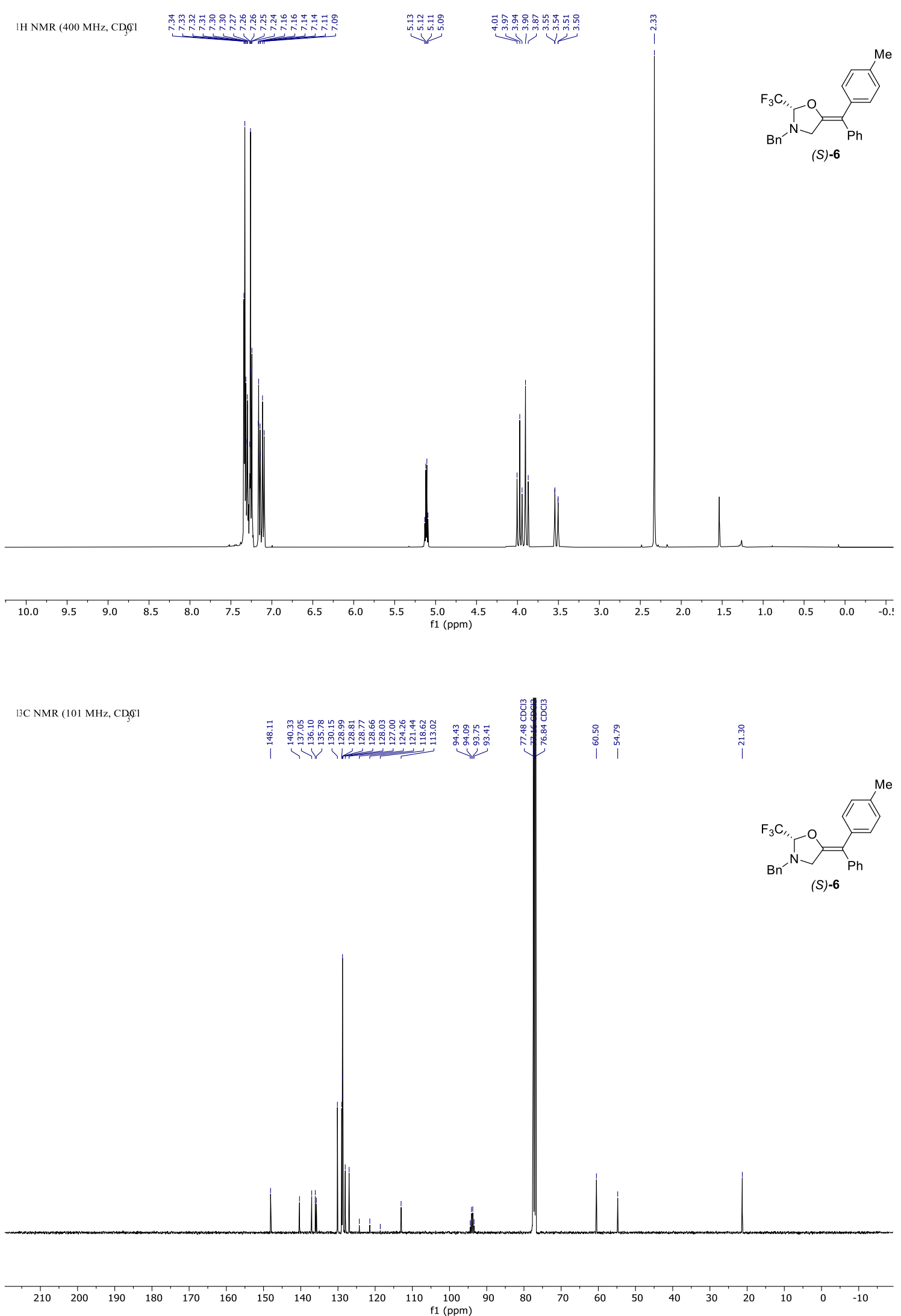


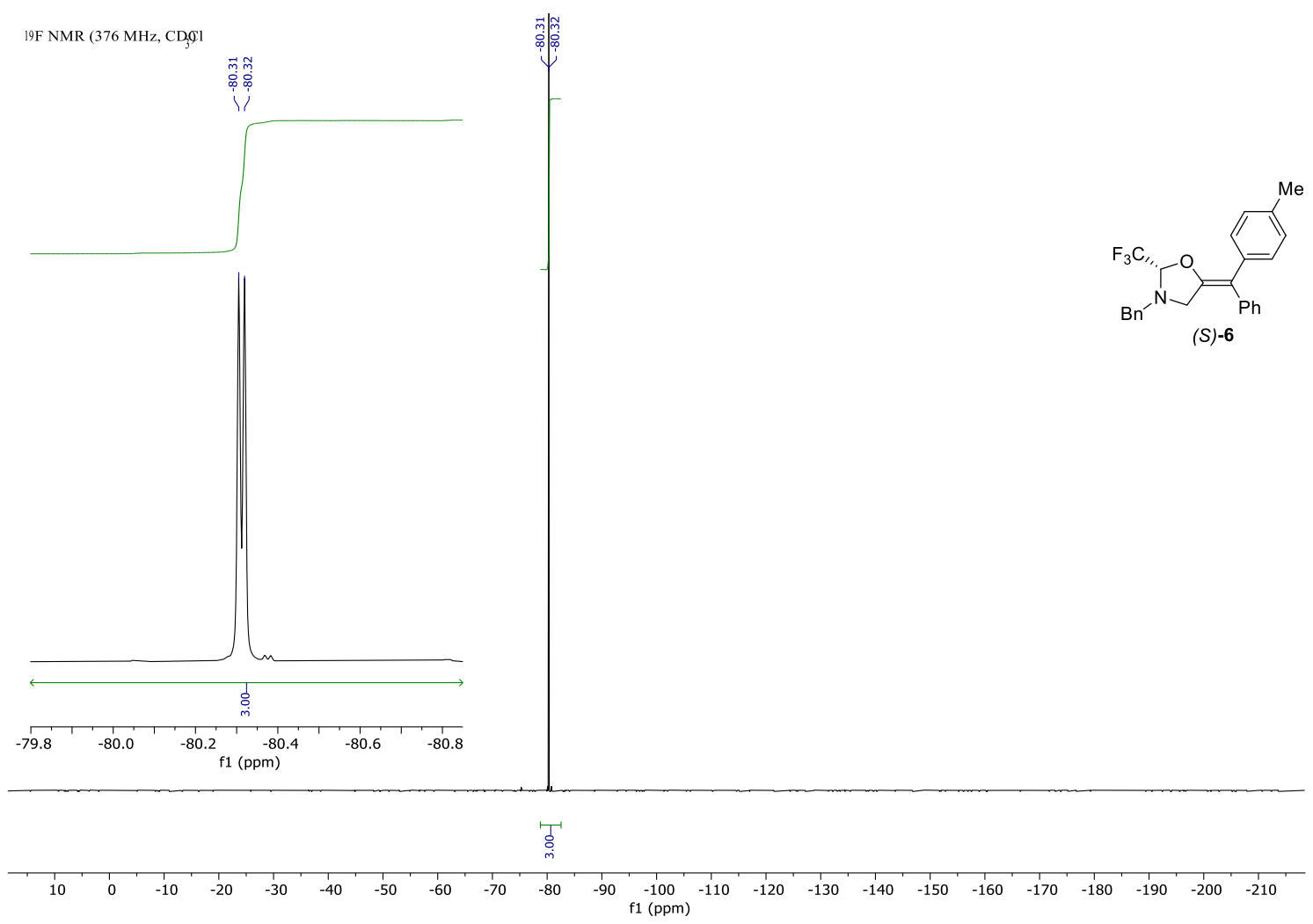

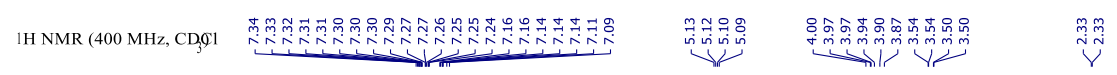

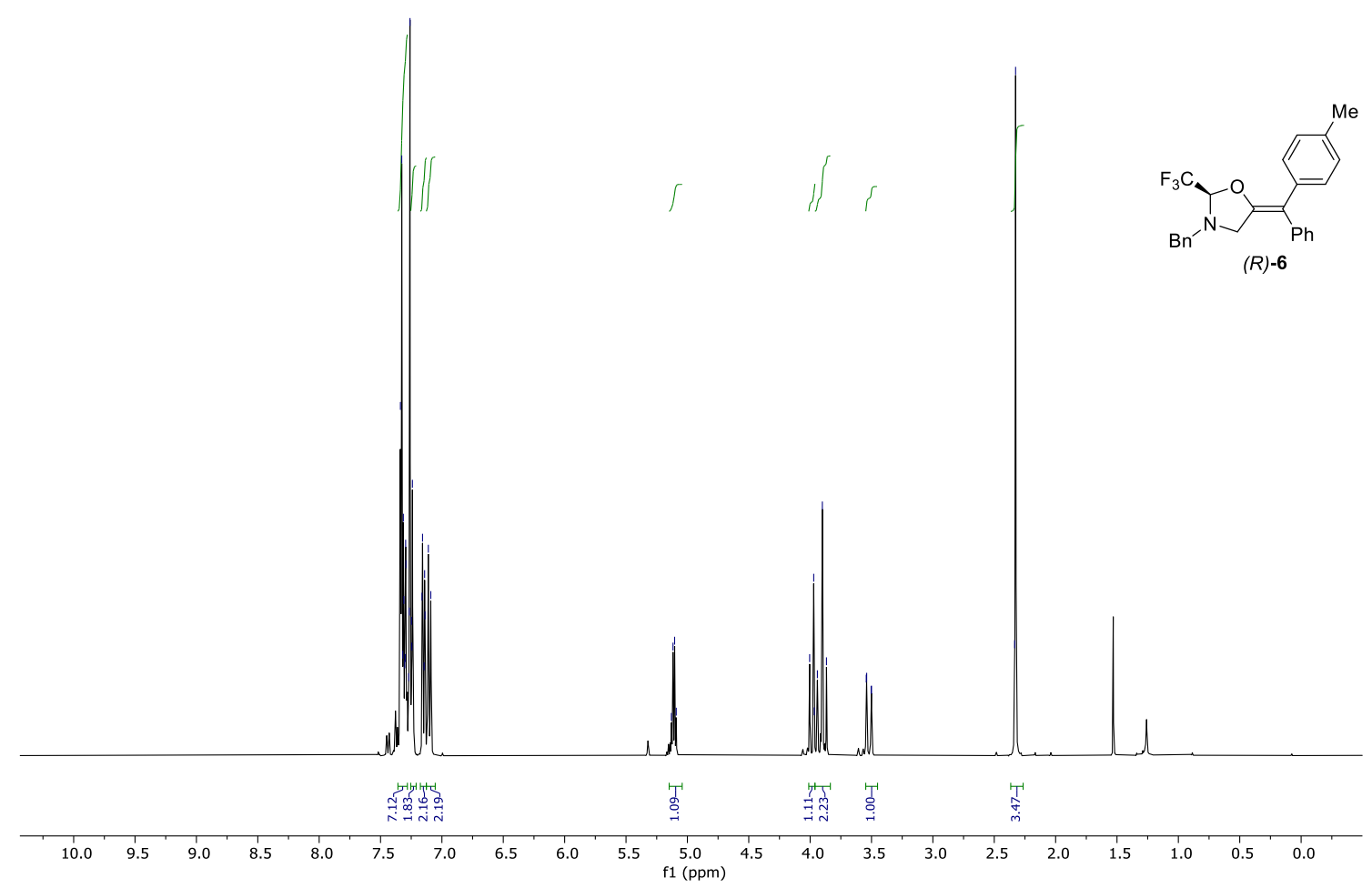



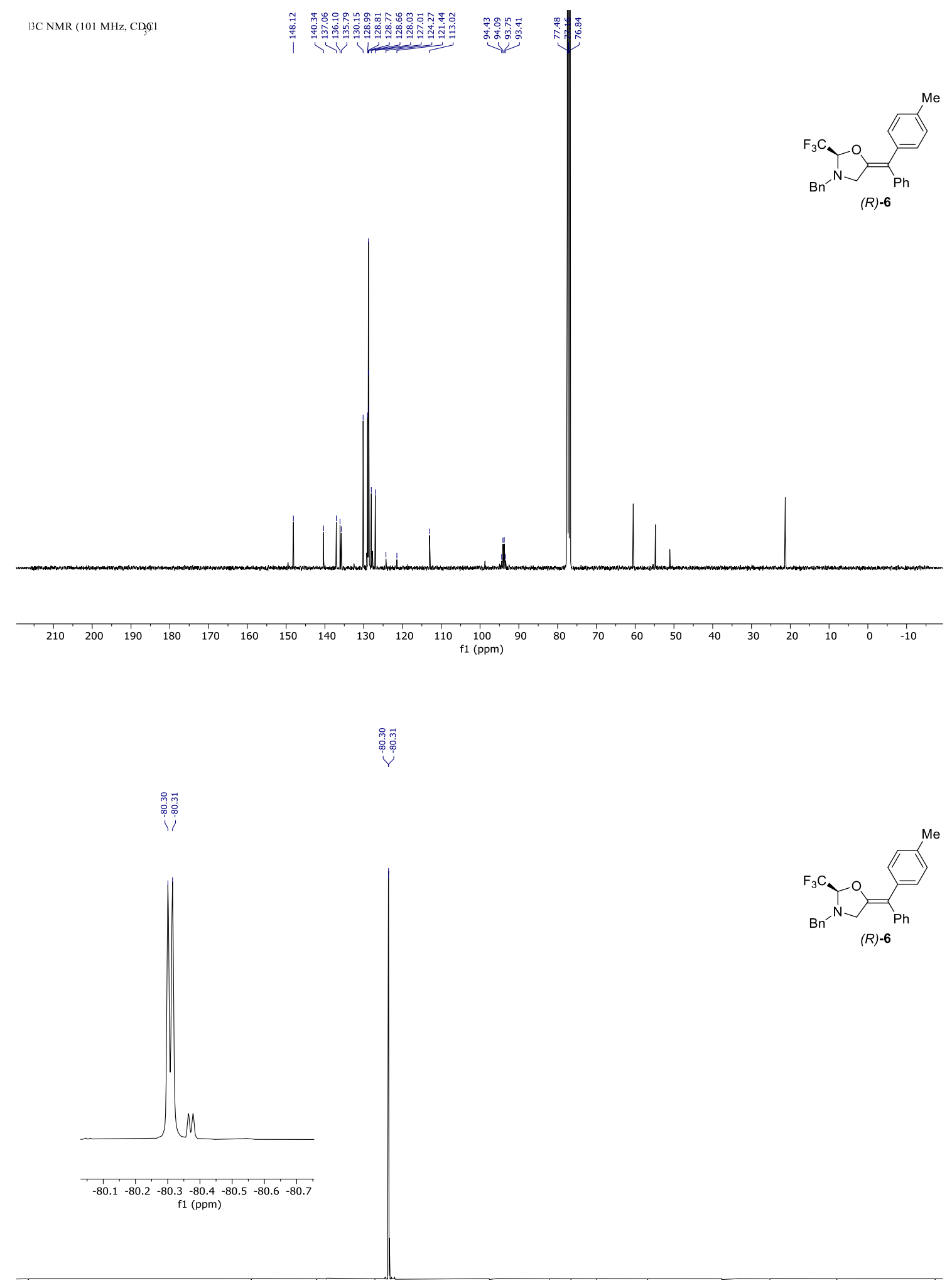

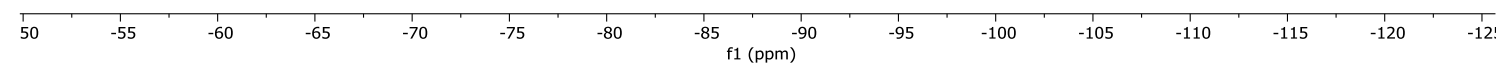



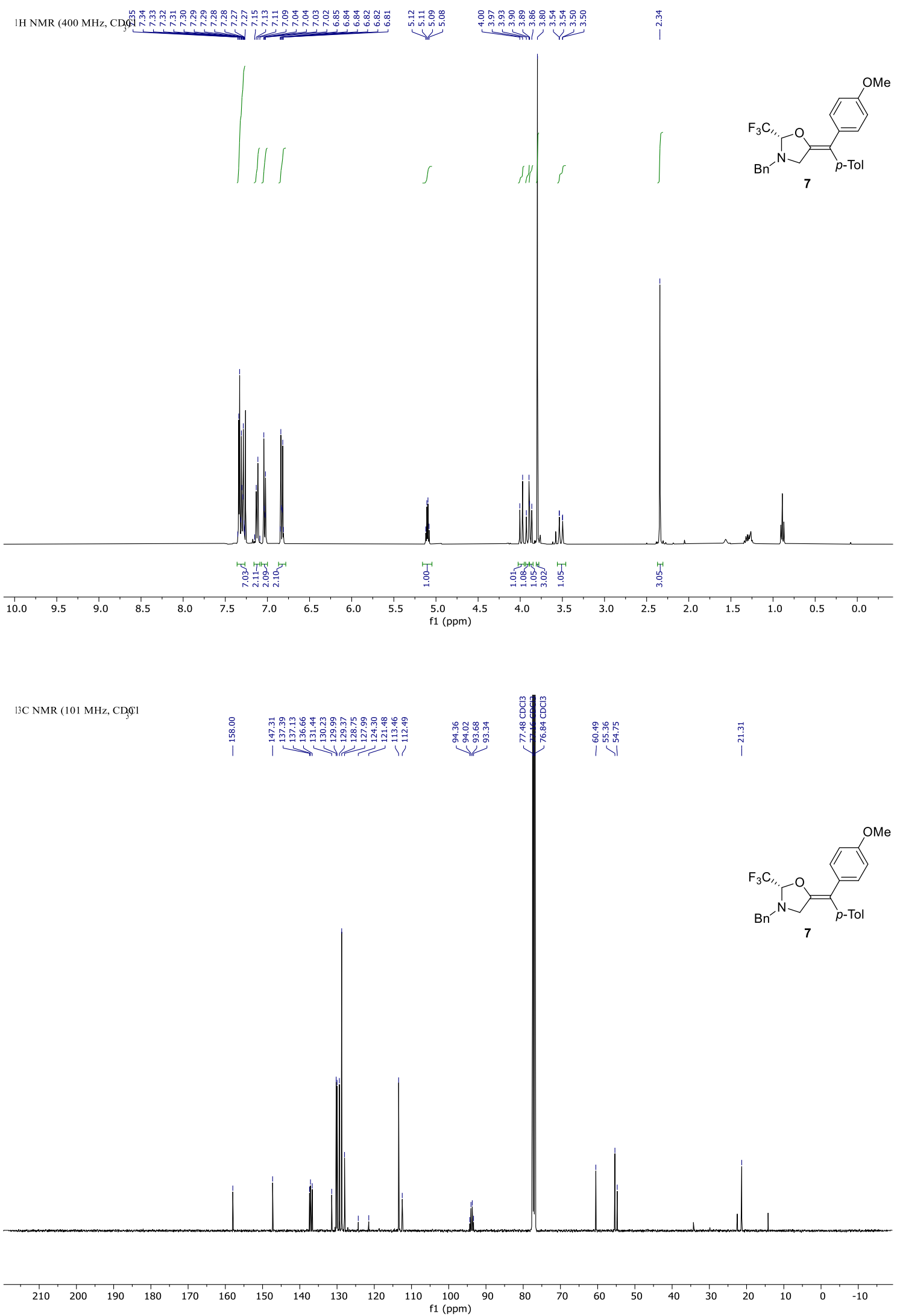


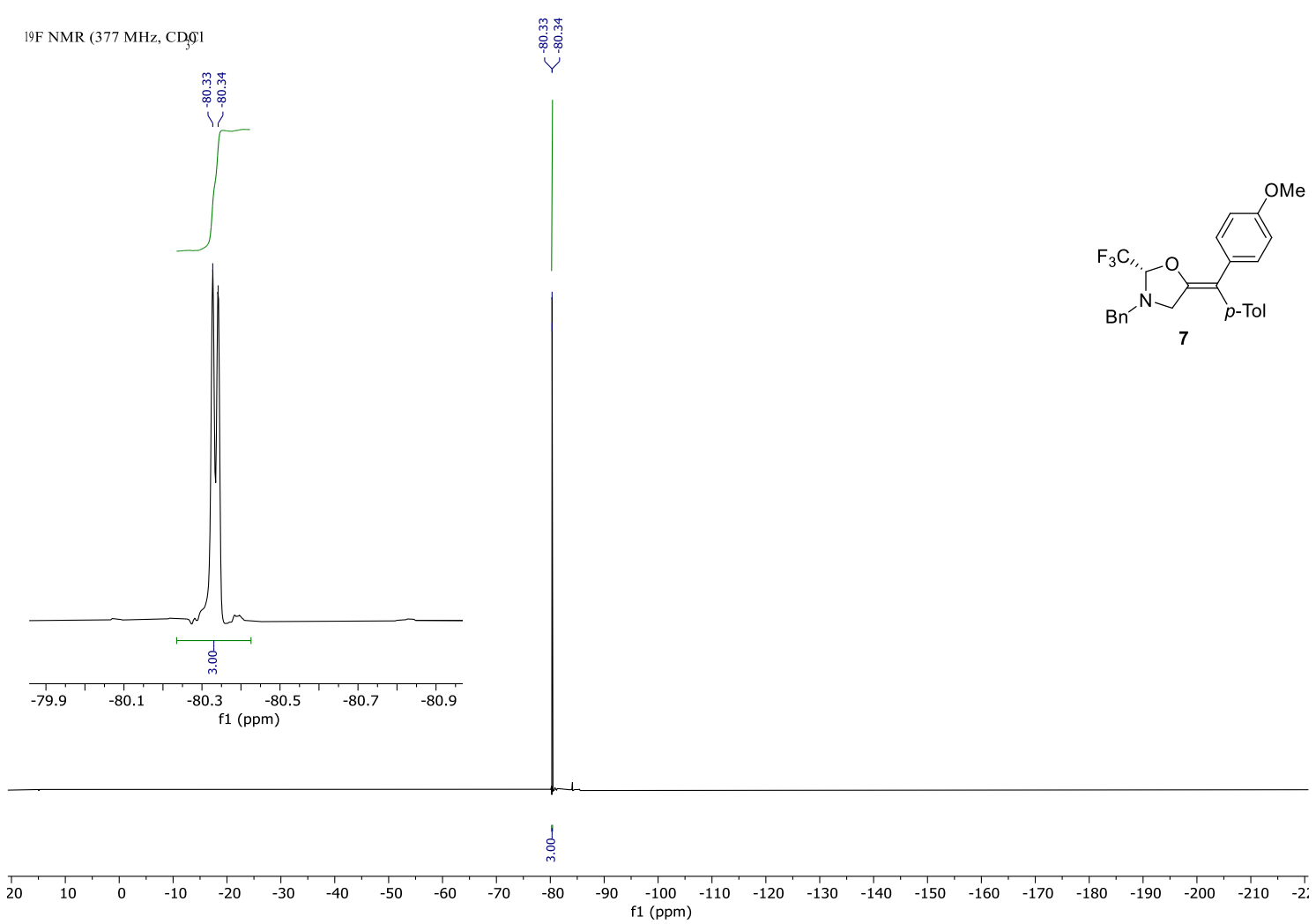

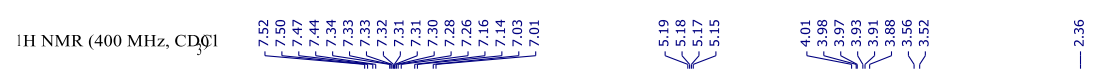

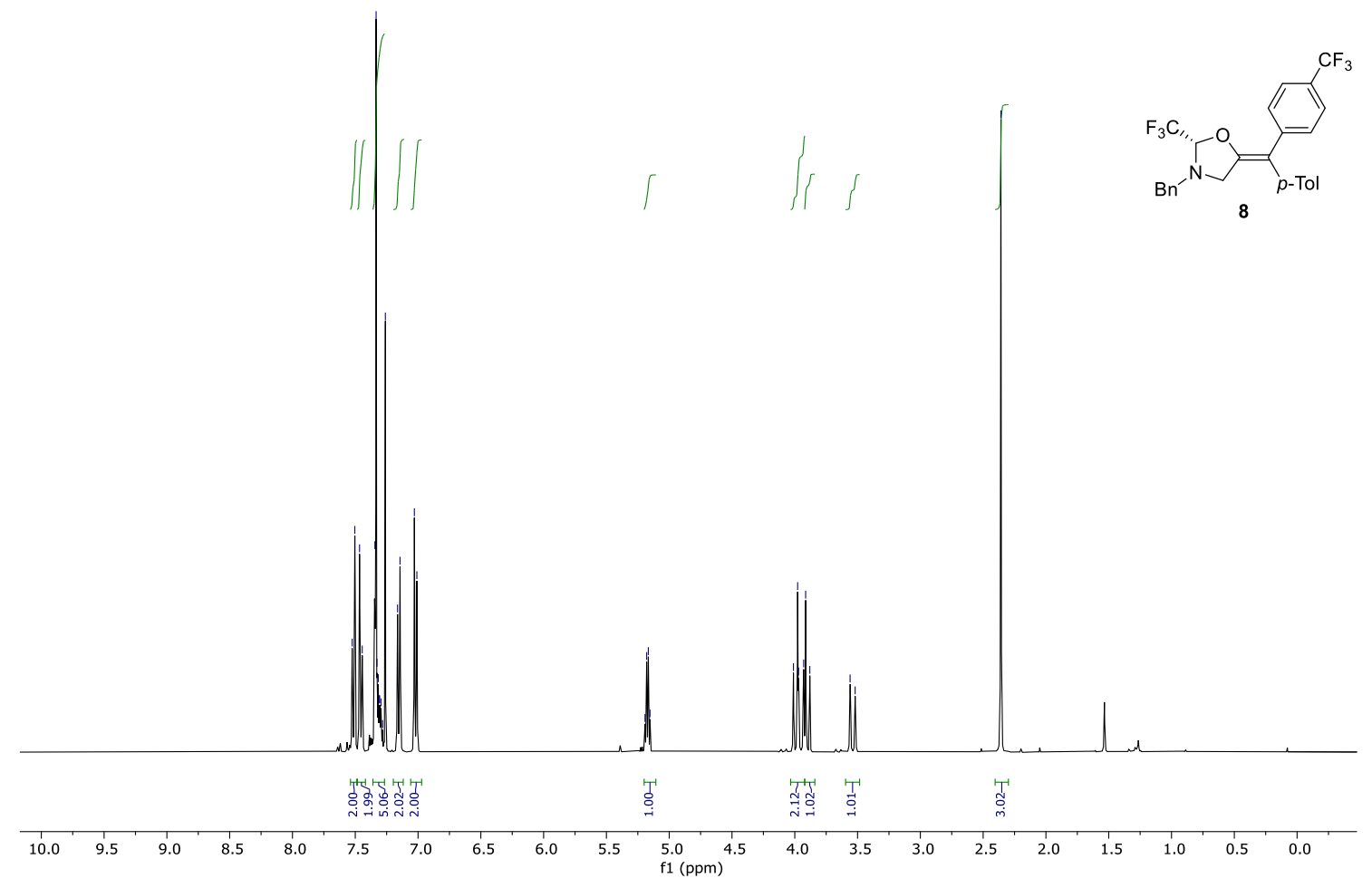



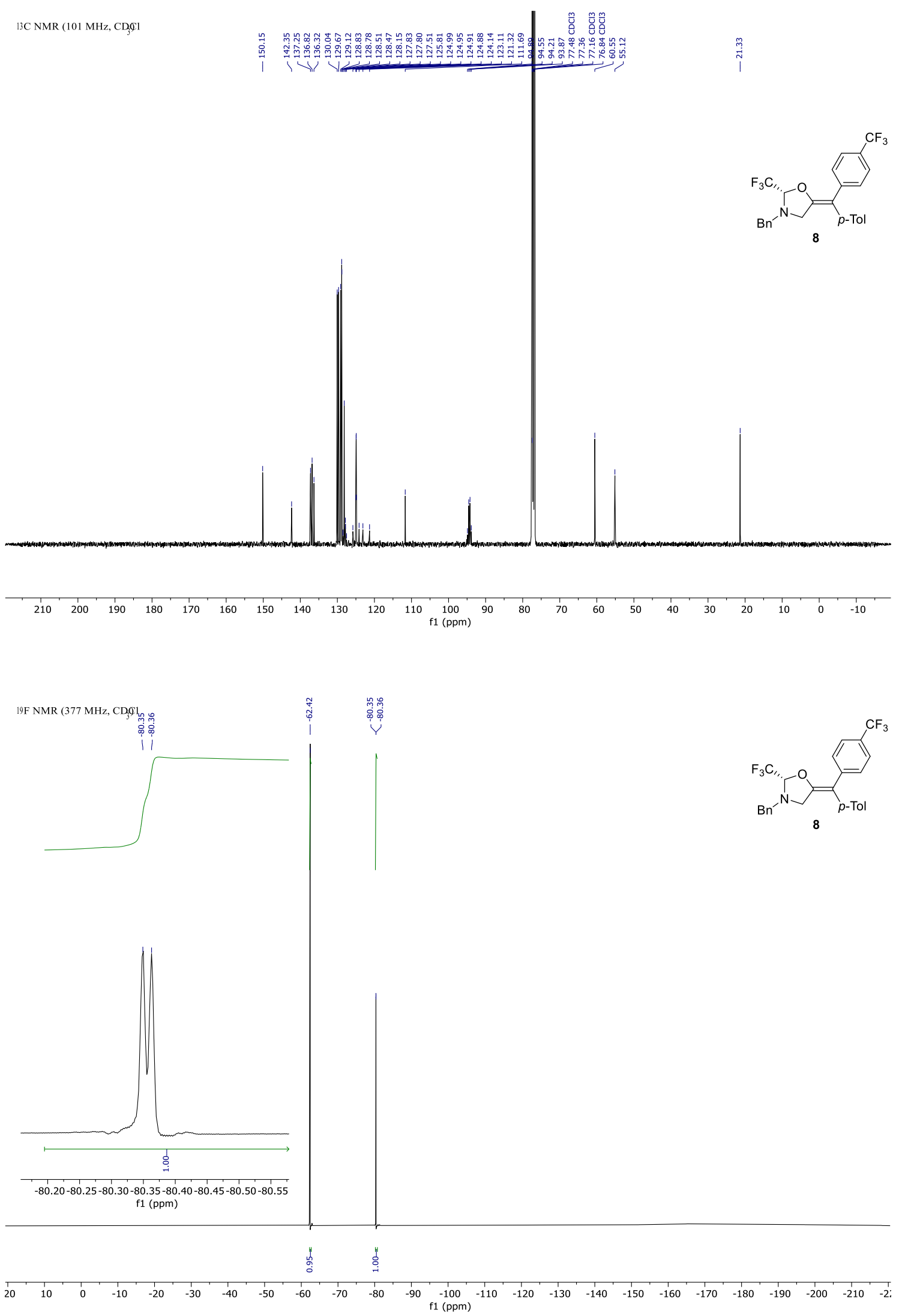


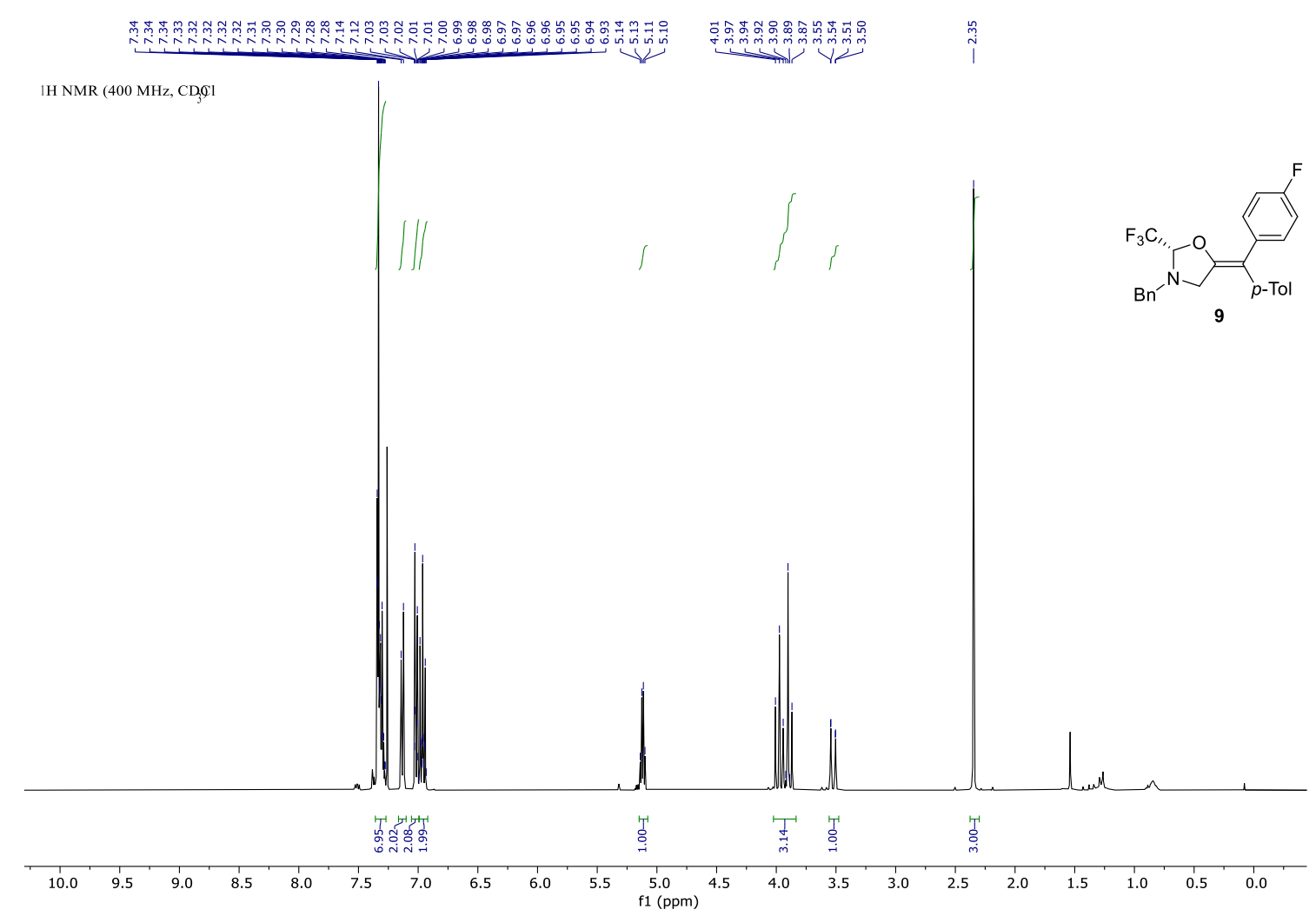

$13 \mathrm{C} \mathrm{NMR}(101 \mathrm{MHz}, \mathrm{CD}, \mathrm{Cl}$
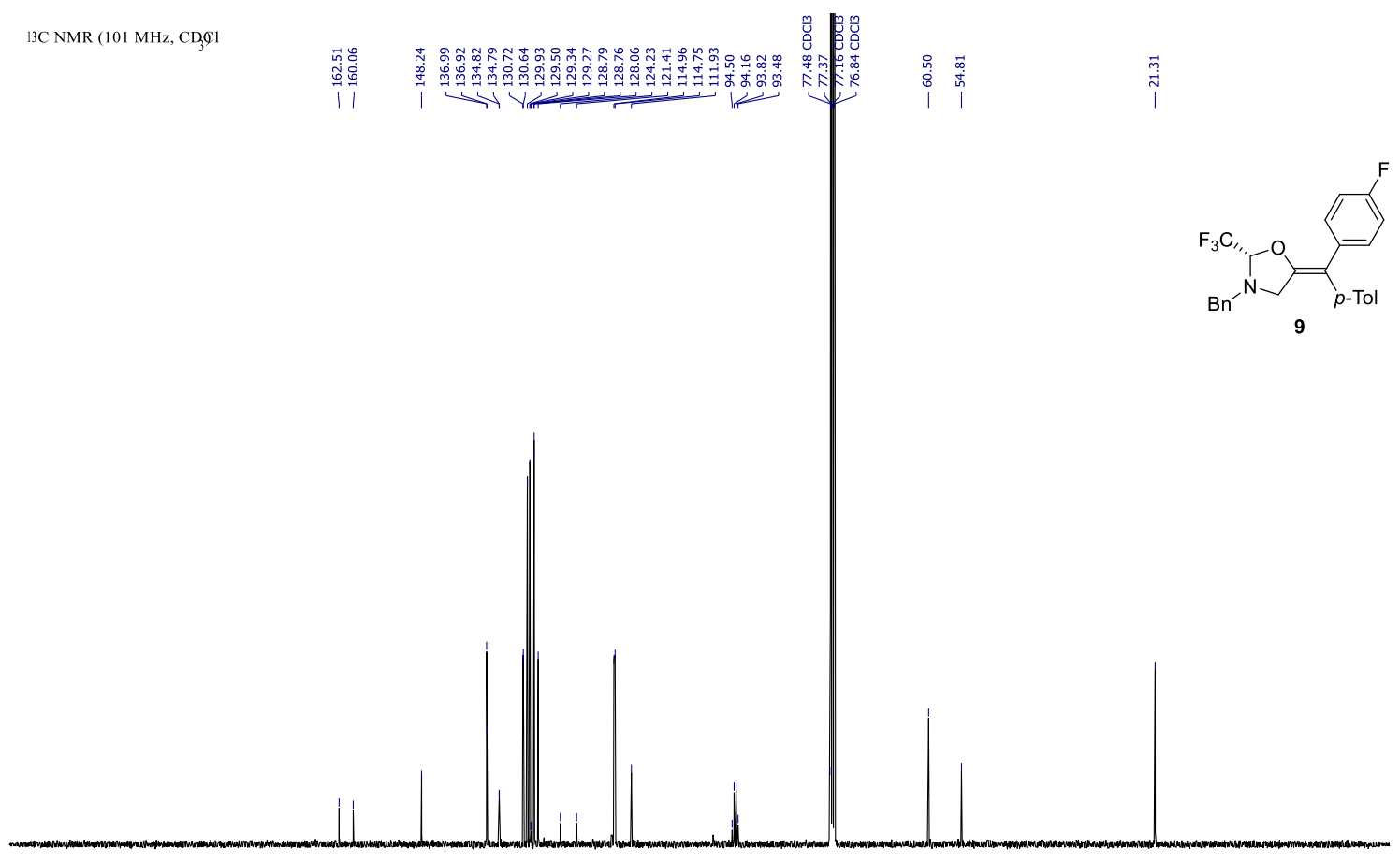

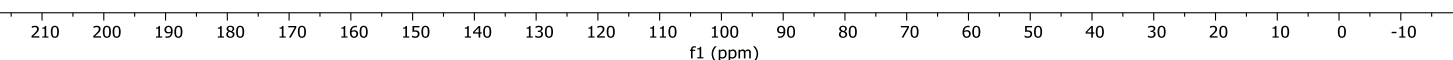




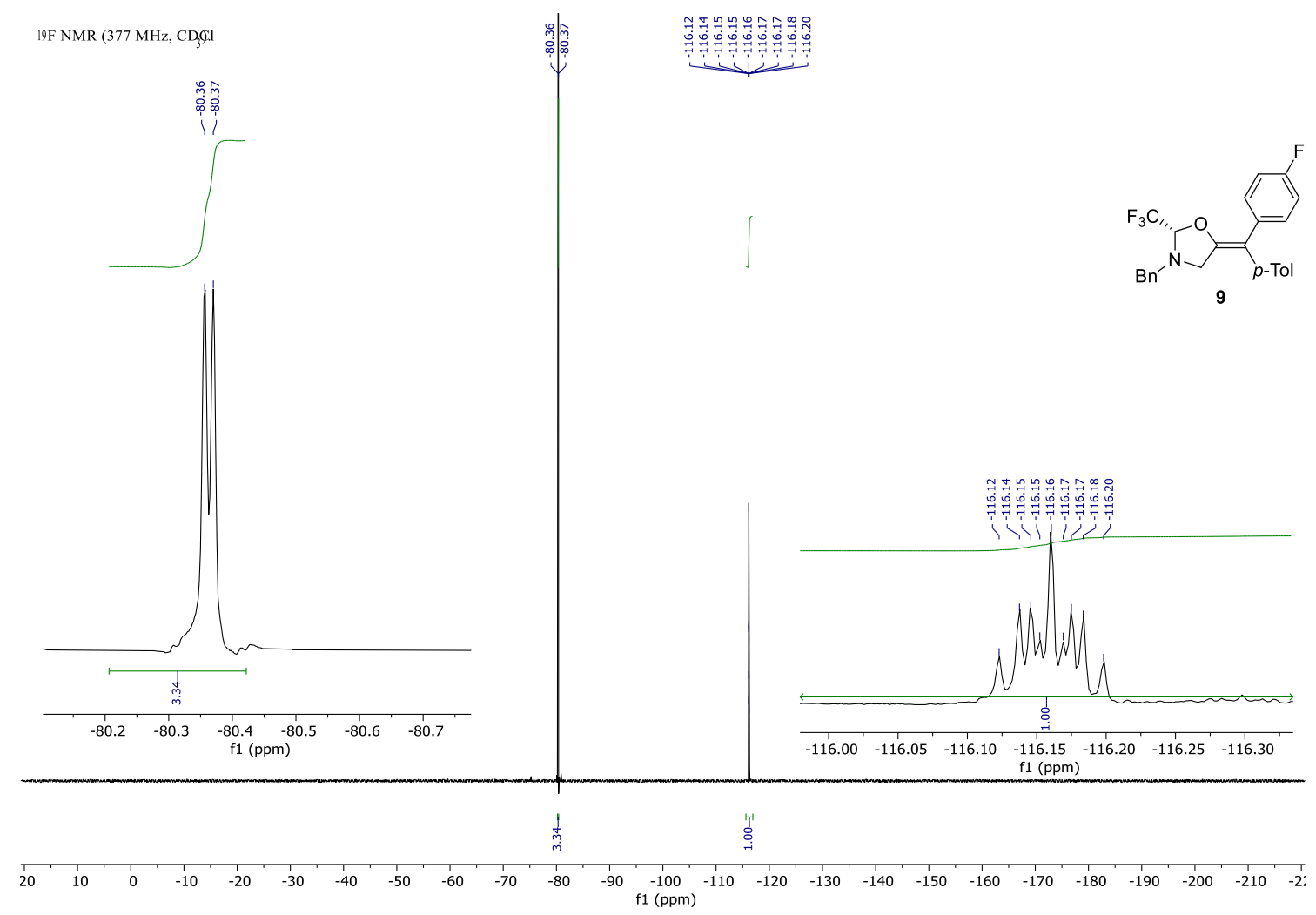

$1 \mathrm{HMR}(400 \mathrm{MHz}, \mathrm{CD}$

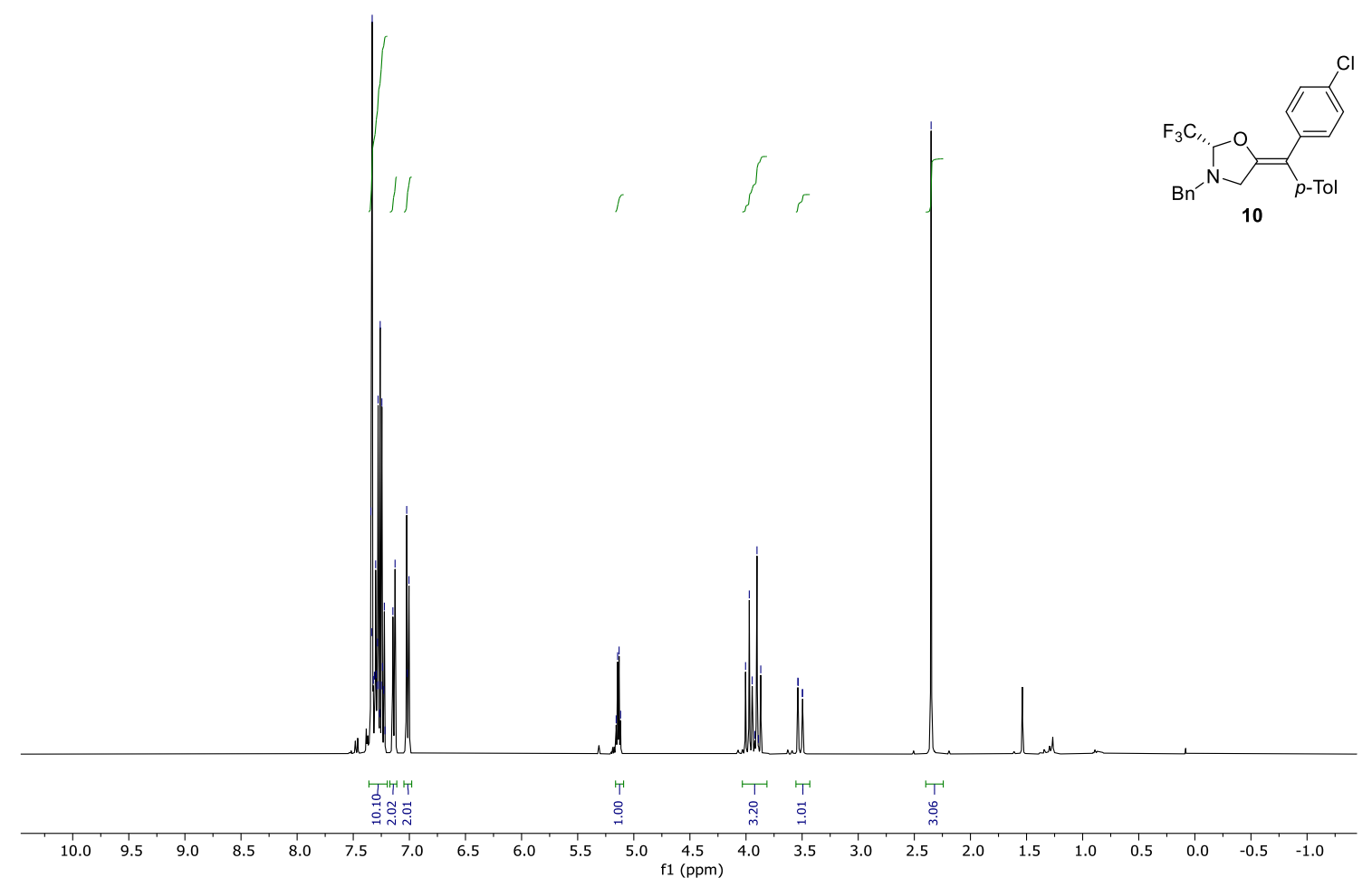



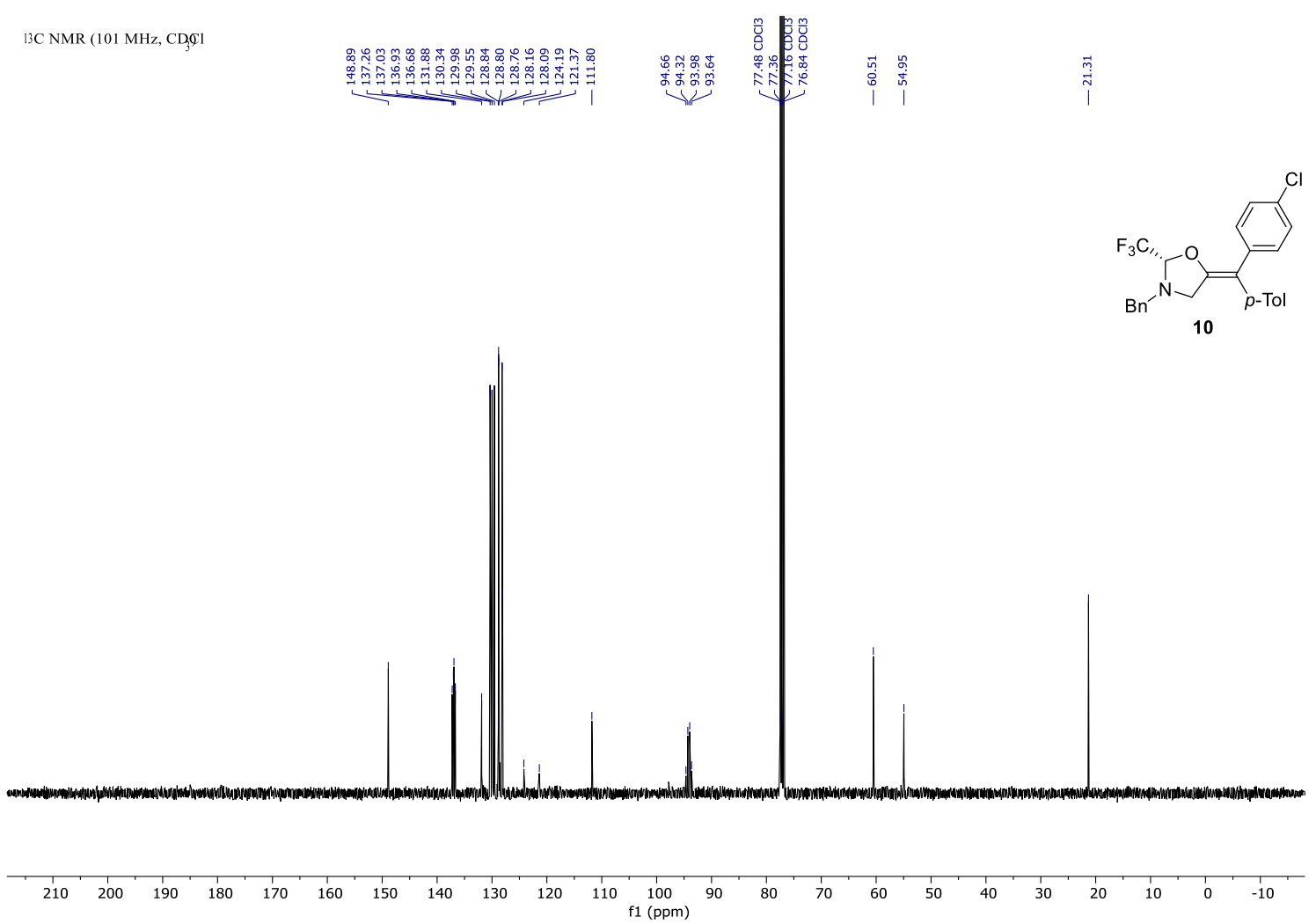

19F NMR (377 MHz, CD, 91

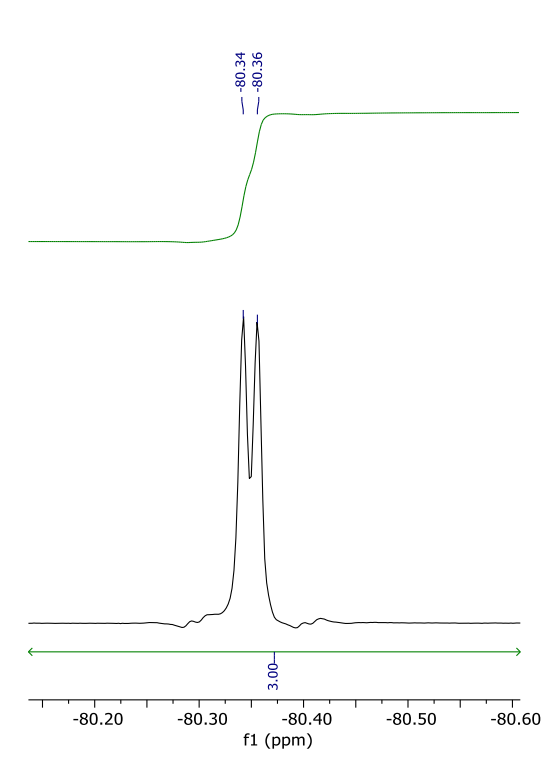

บับ

Yे

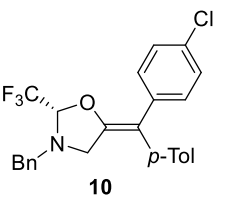

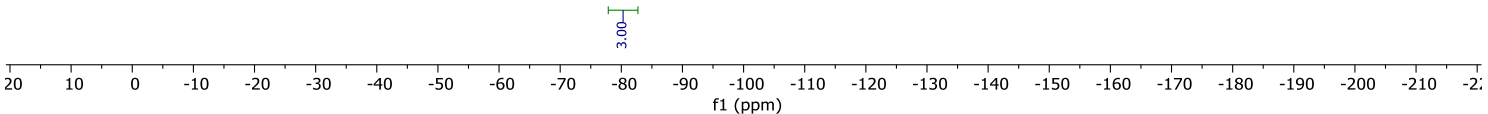




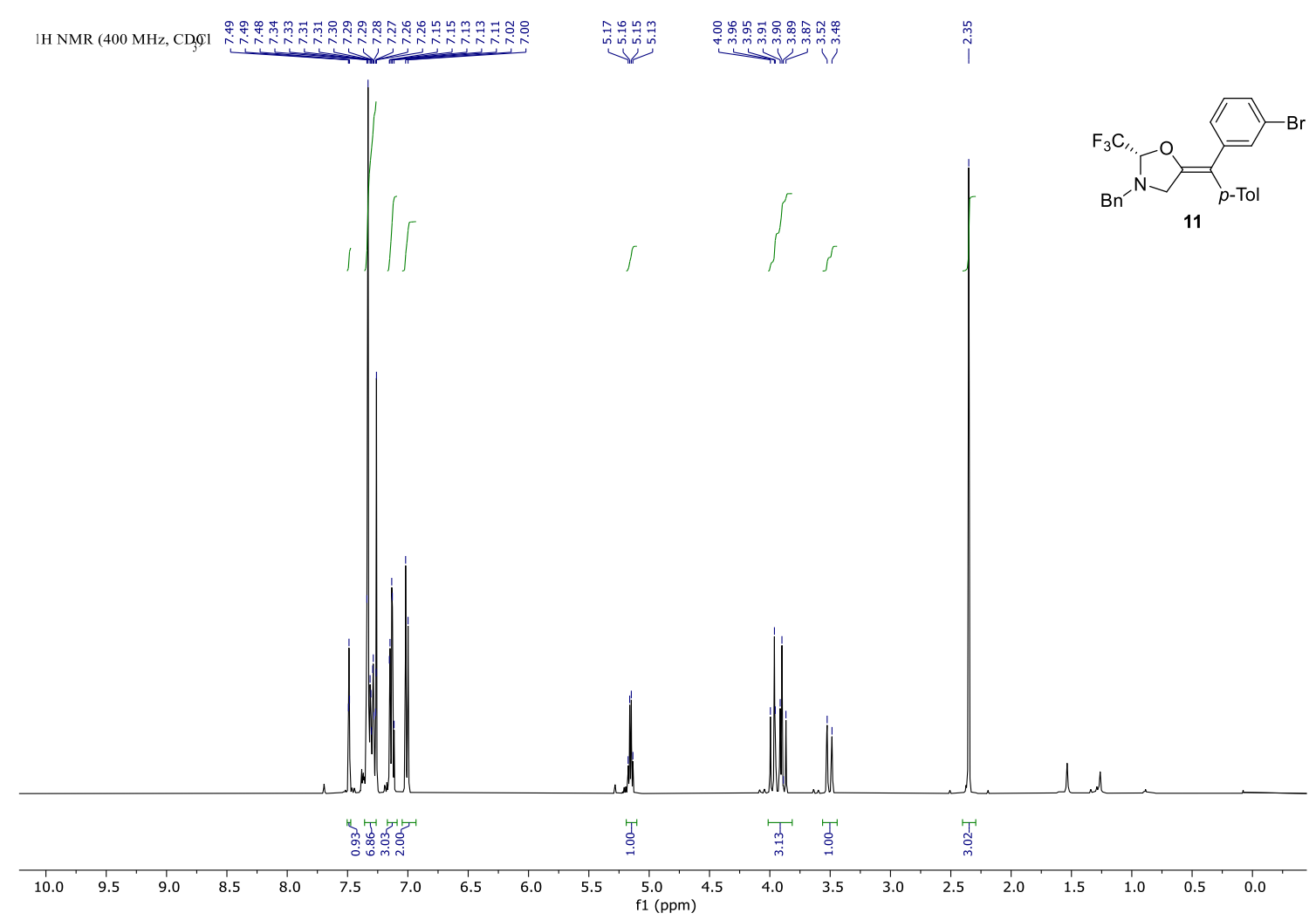

$13 \mathrm{C}$ NMR $(101 \mathrm{MHz}, \mathrm{CD}, \mathrm{Cl}$
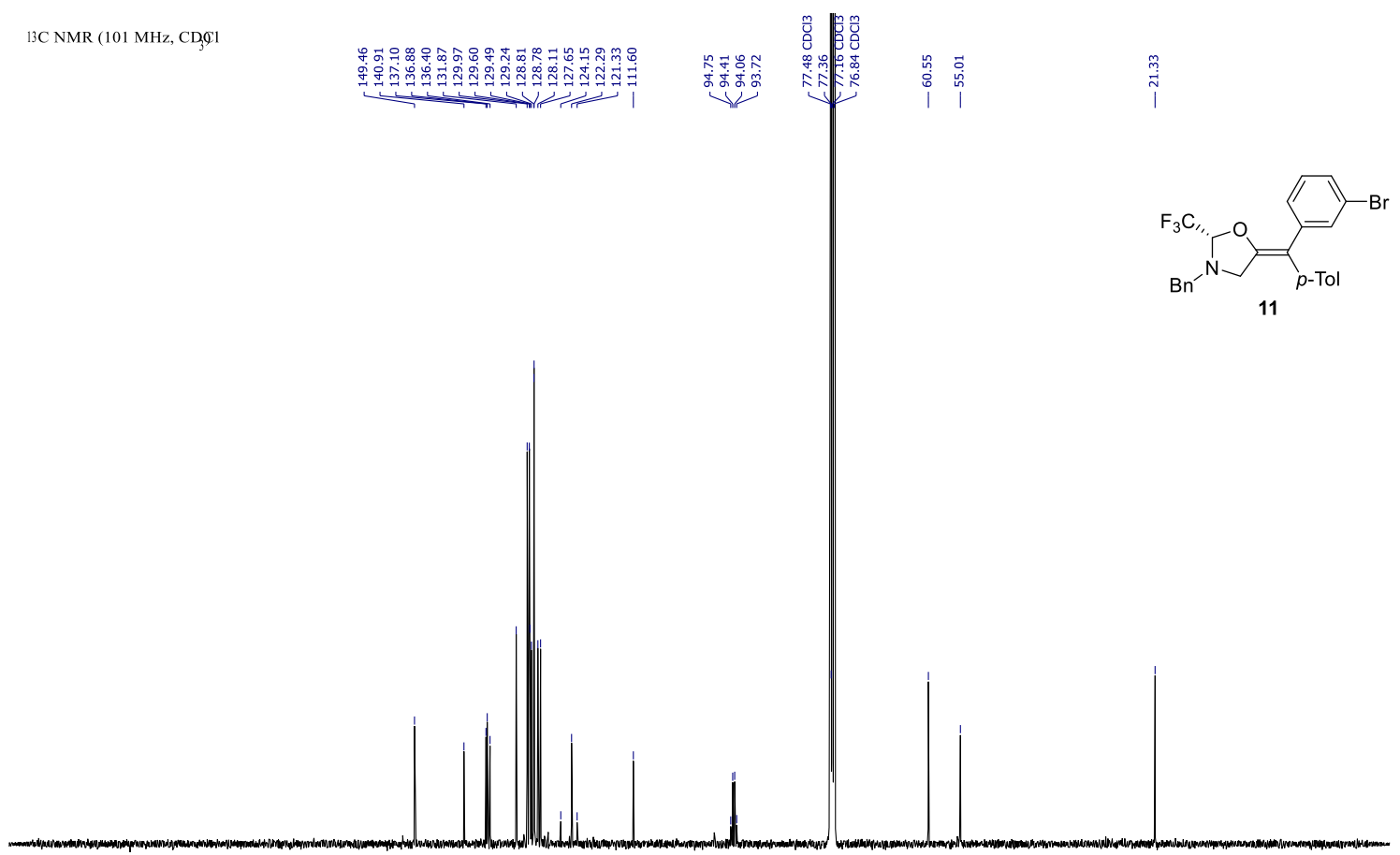

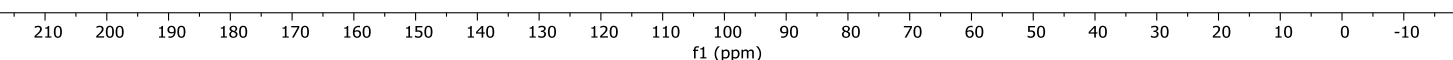



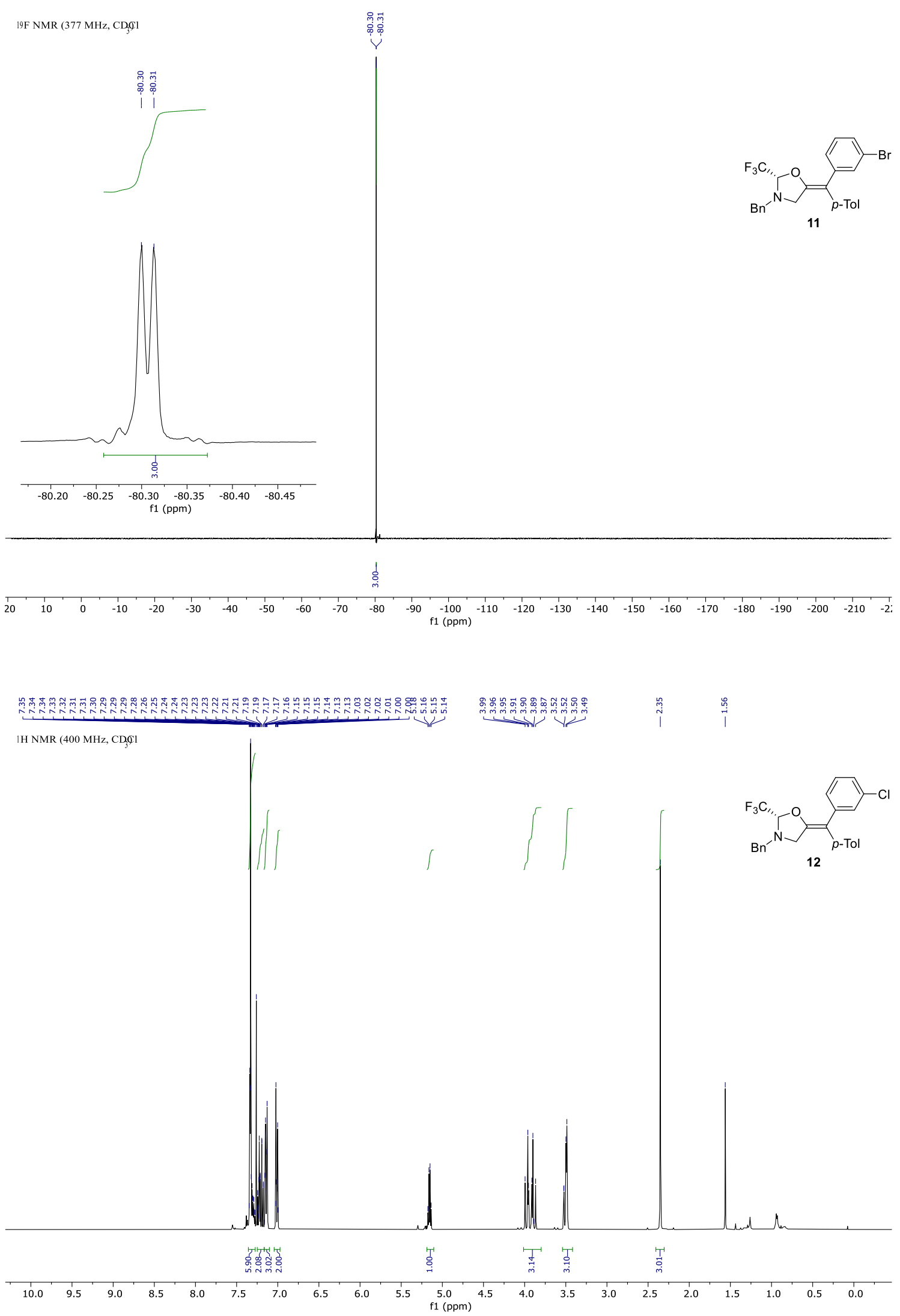

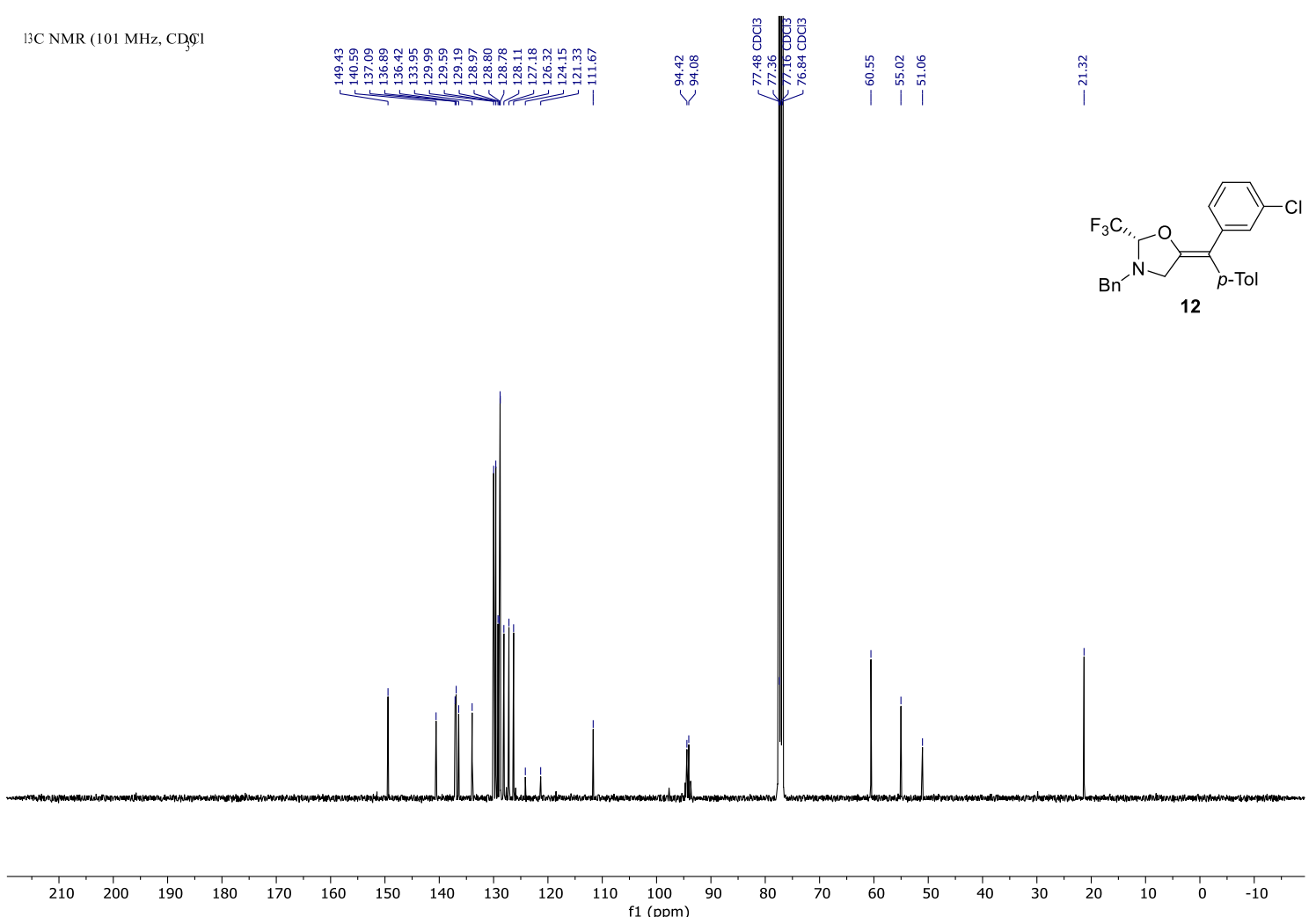

19F NMR (377 MHz, CD,91
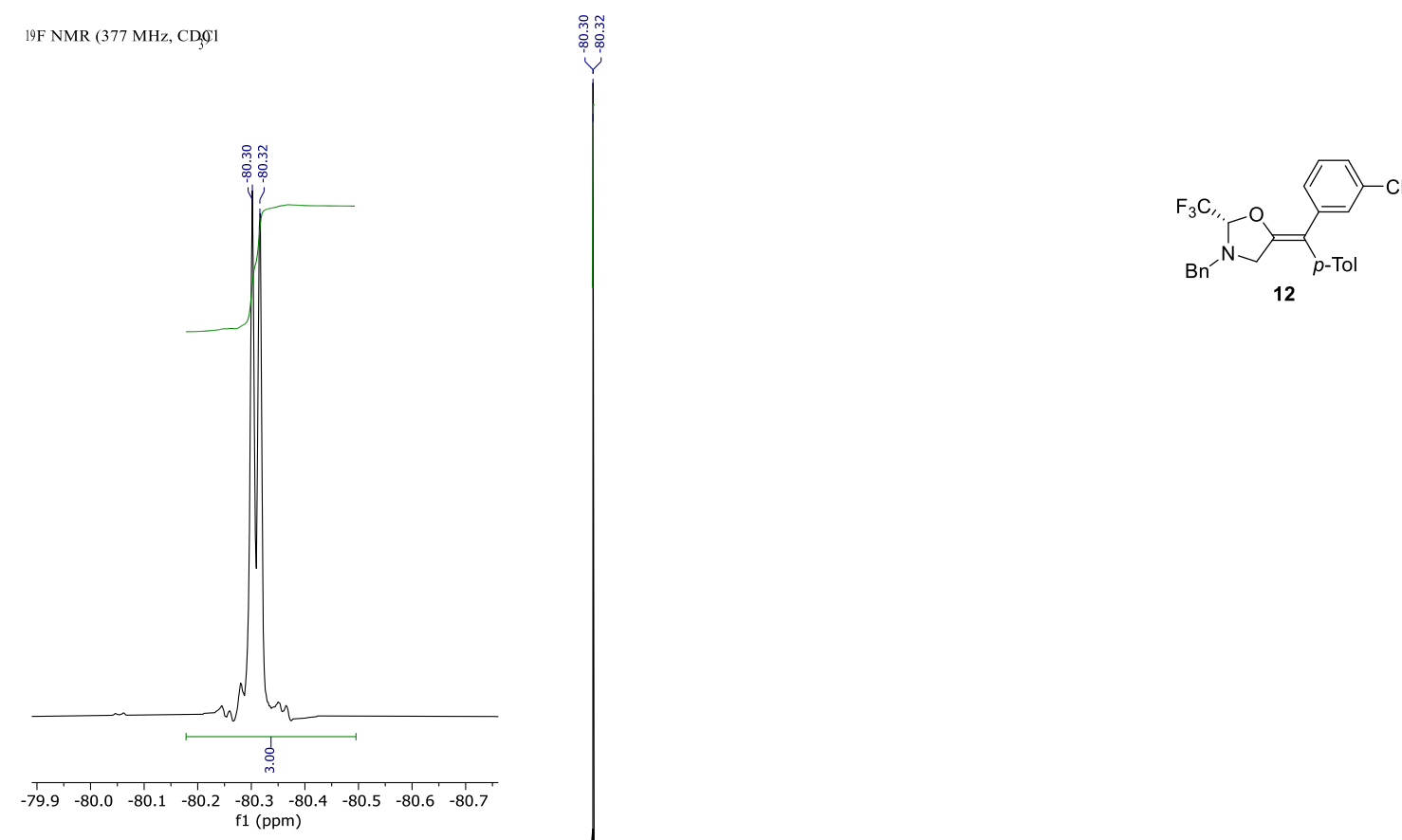

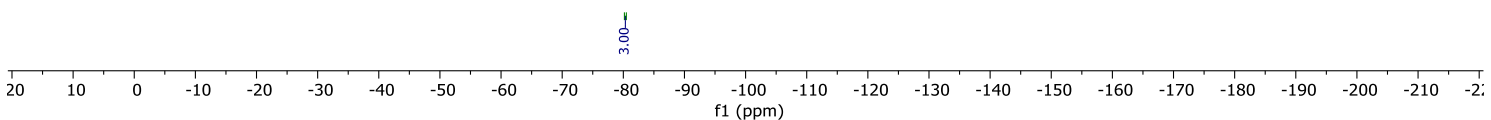




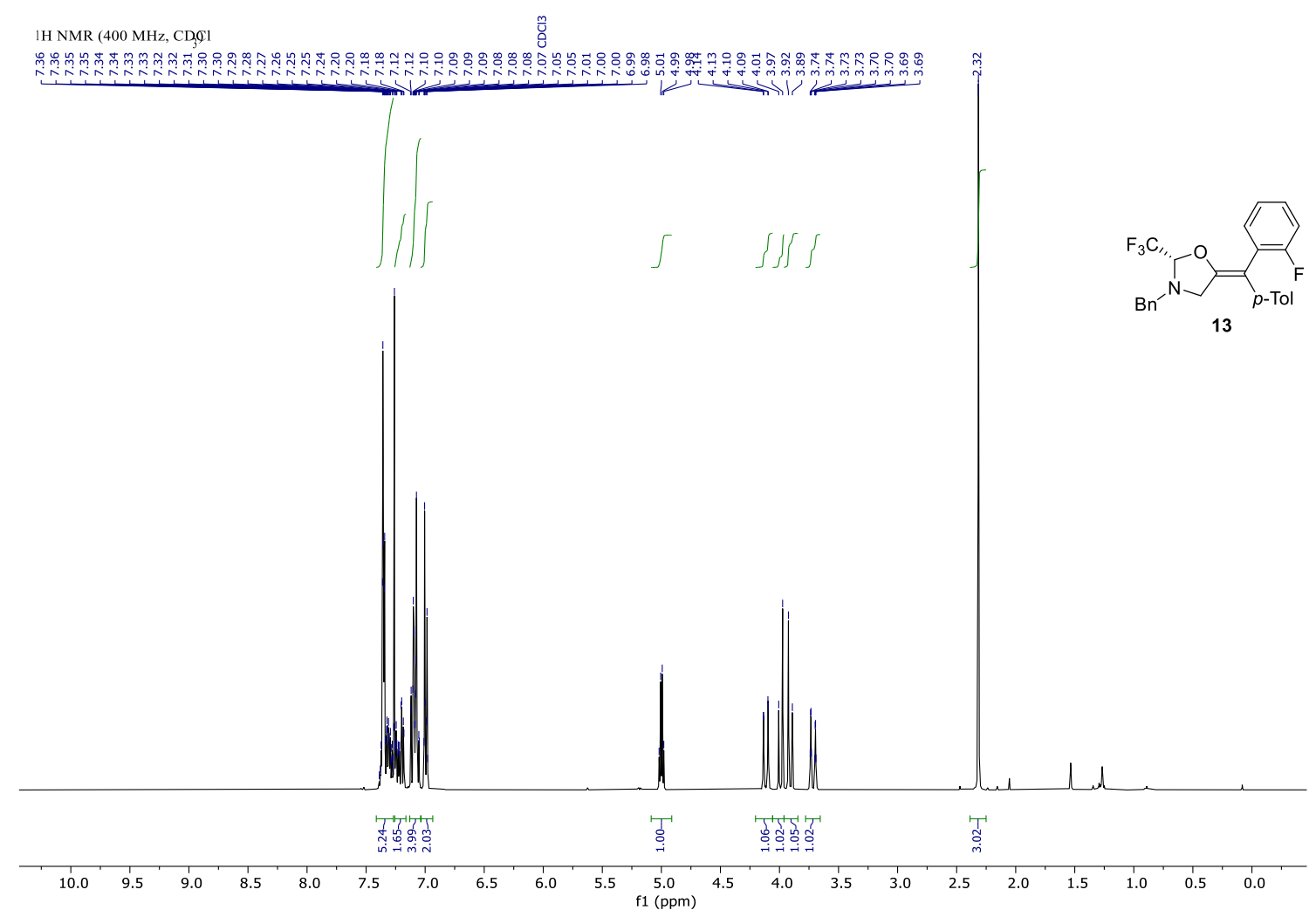

BC NMR (101 MHz, CDQ1
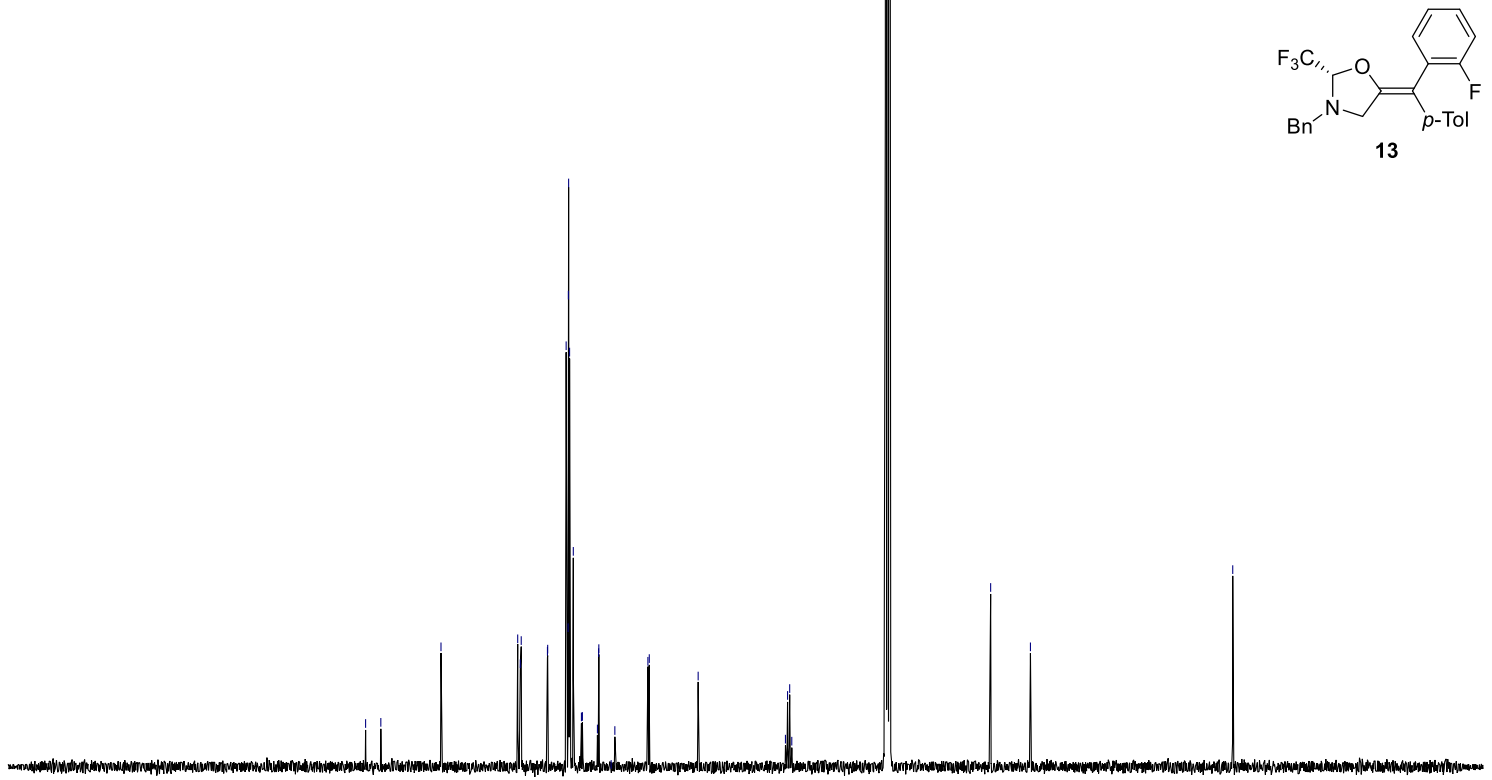

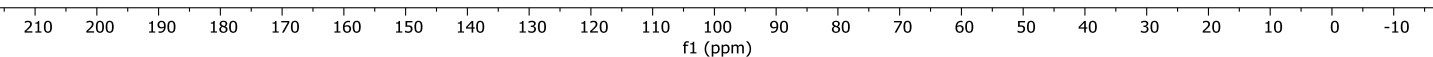




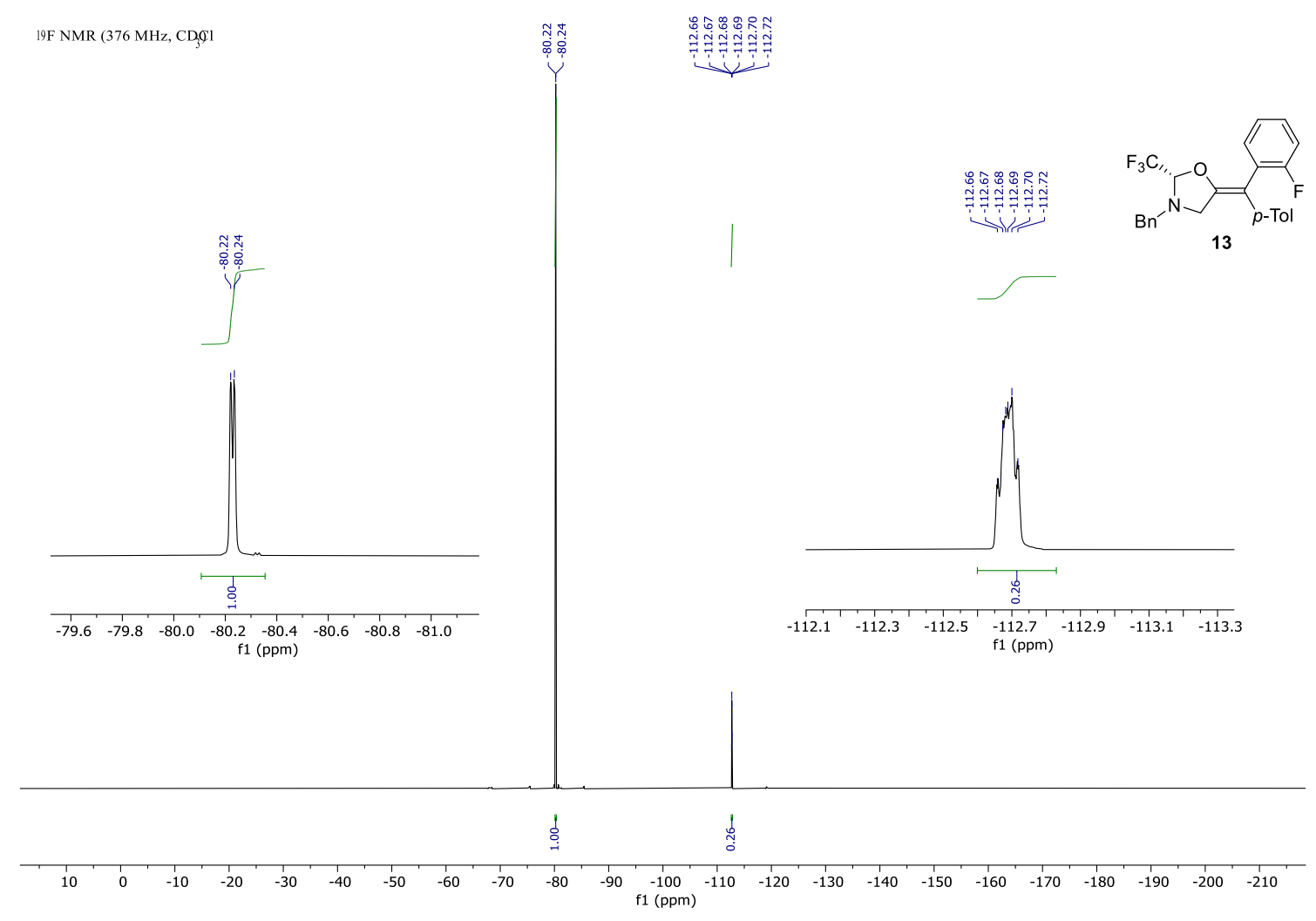

$1 \mathrm{H} \mathrm{NMR}(400 \mathrm{MHz}, \mathrm{CD}, 1 \underbrace{2}$

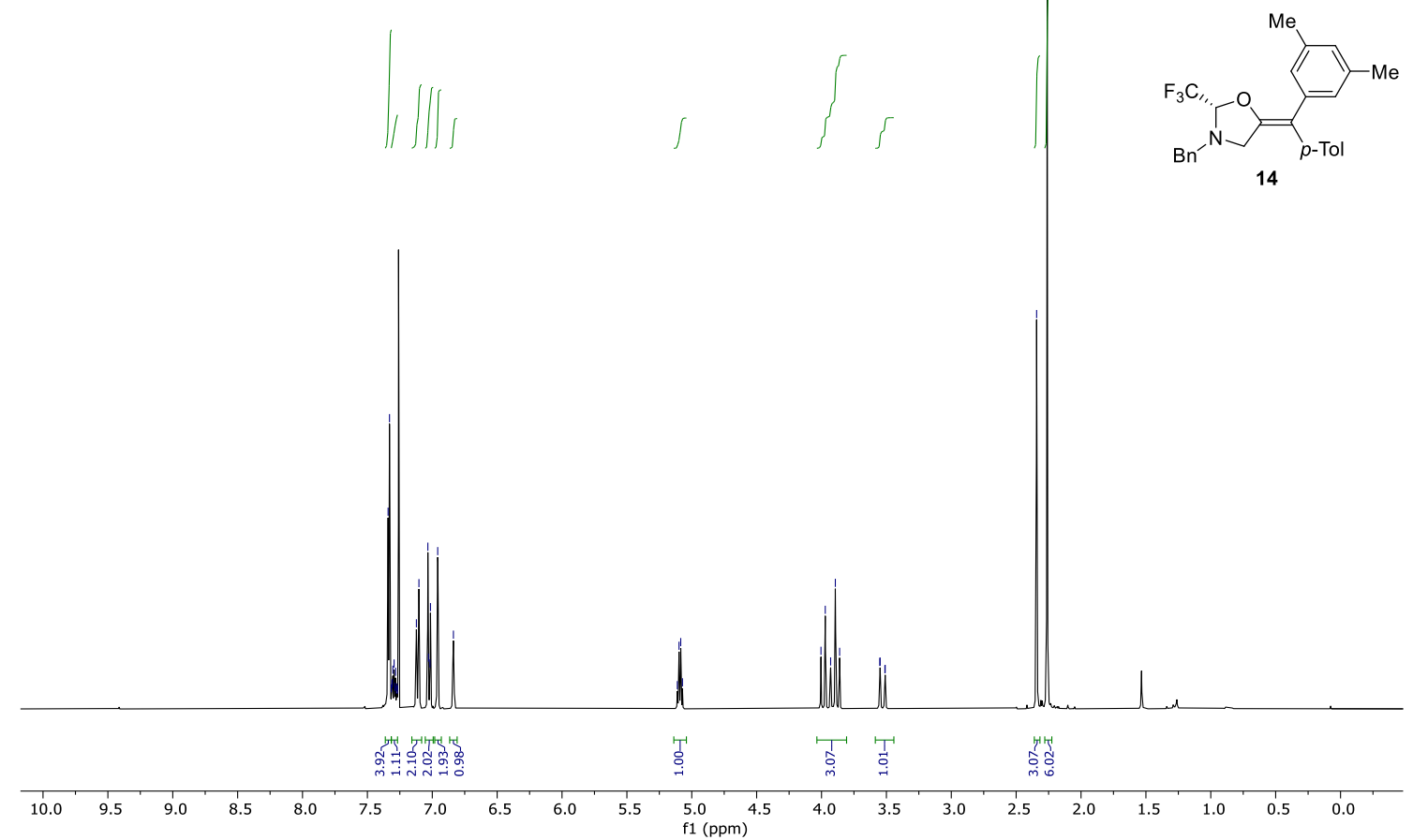



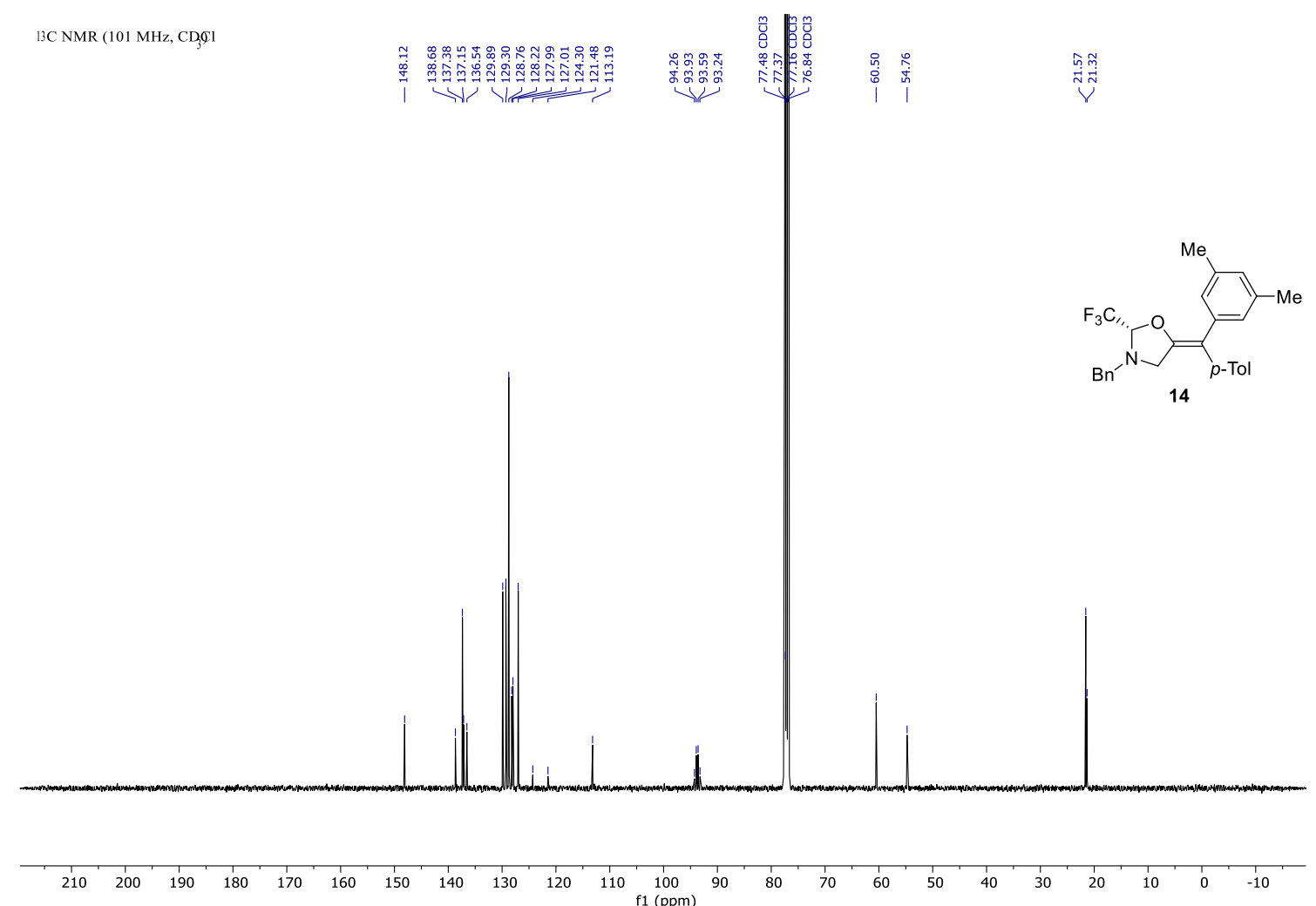

19F NMR (377 MHz, $\mathrm{CD}_{3} 91$
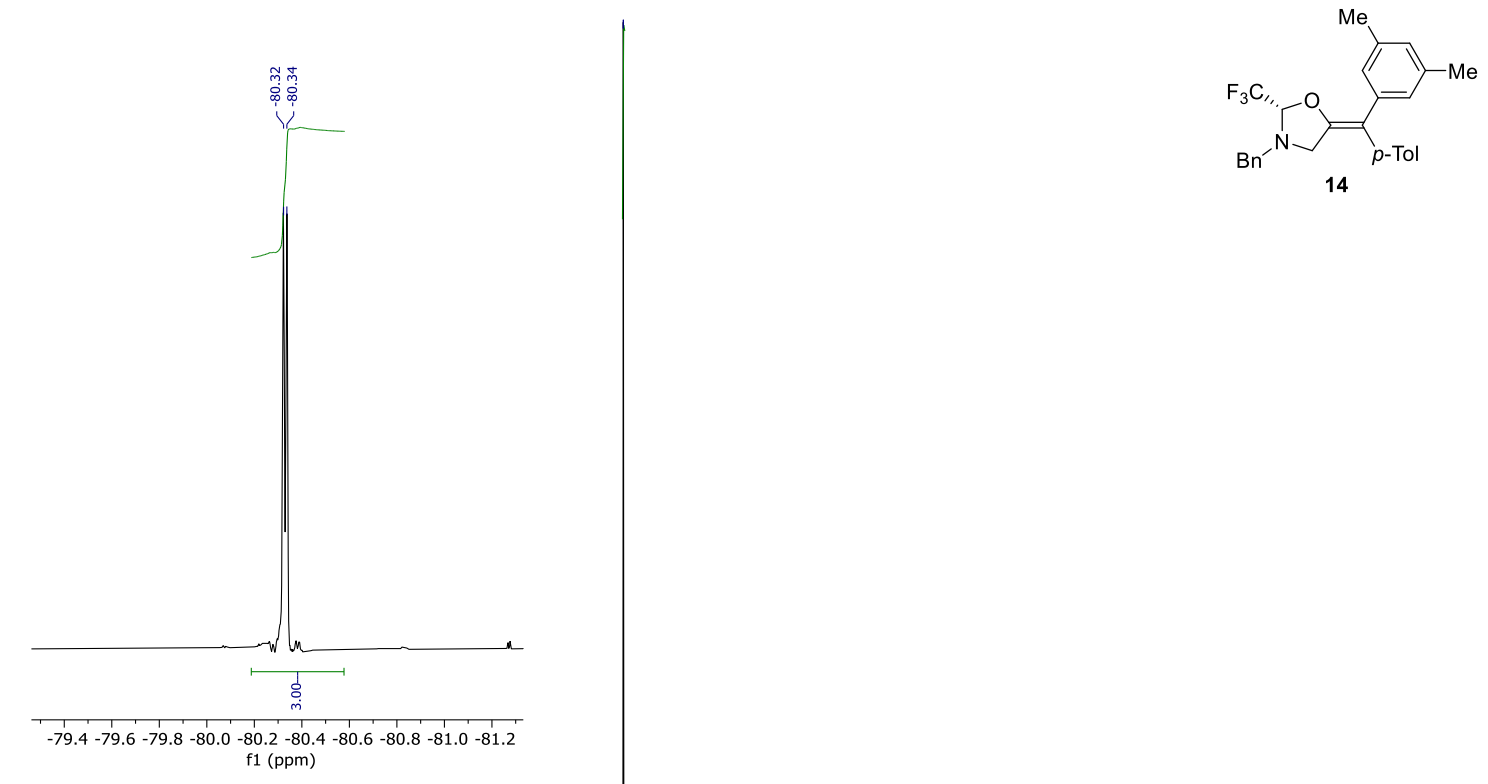

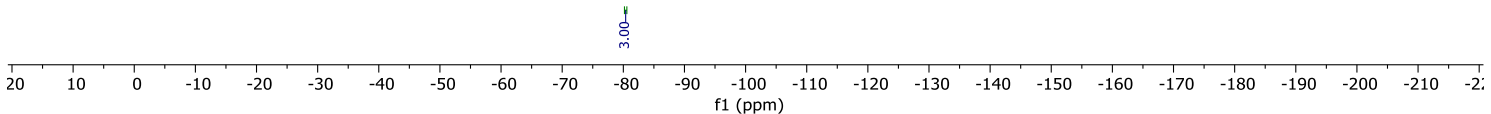




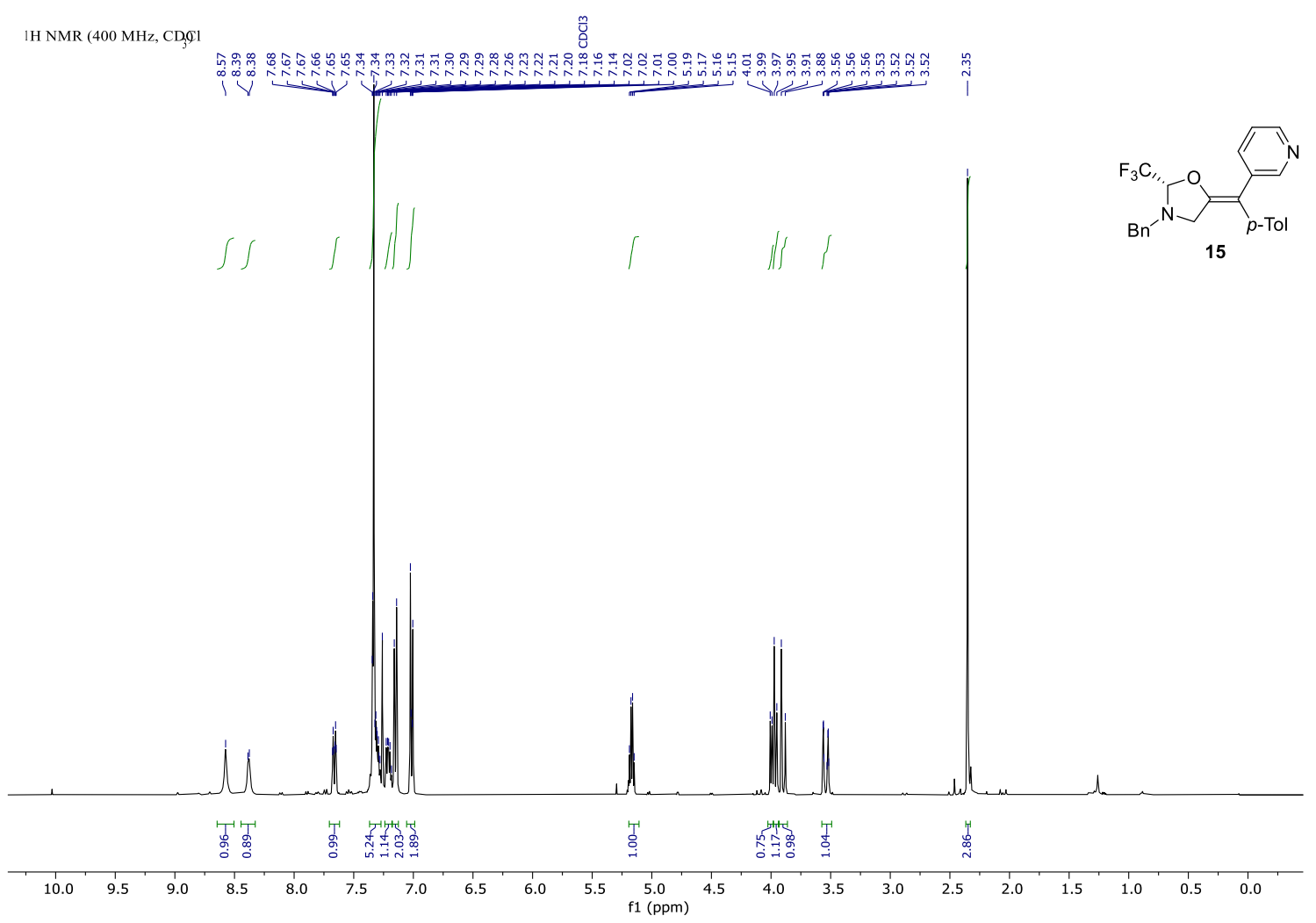

13C NMR (101 MHz, CD, 91

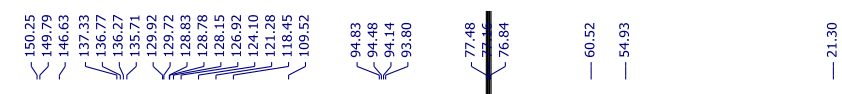

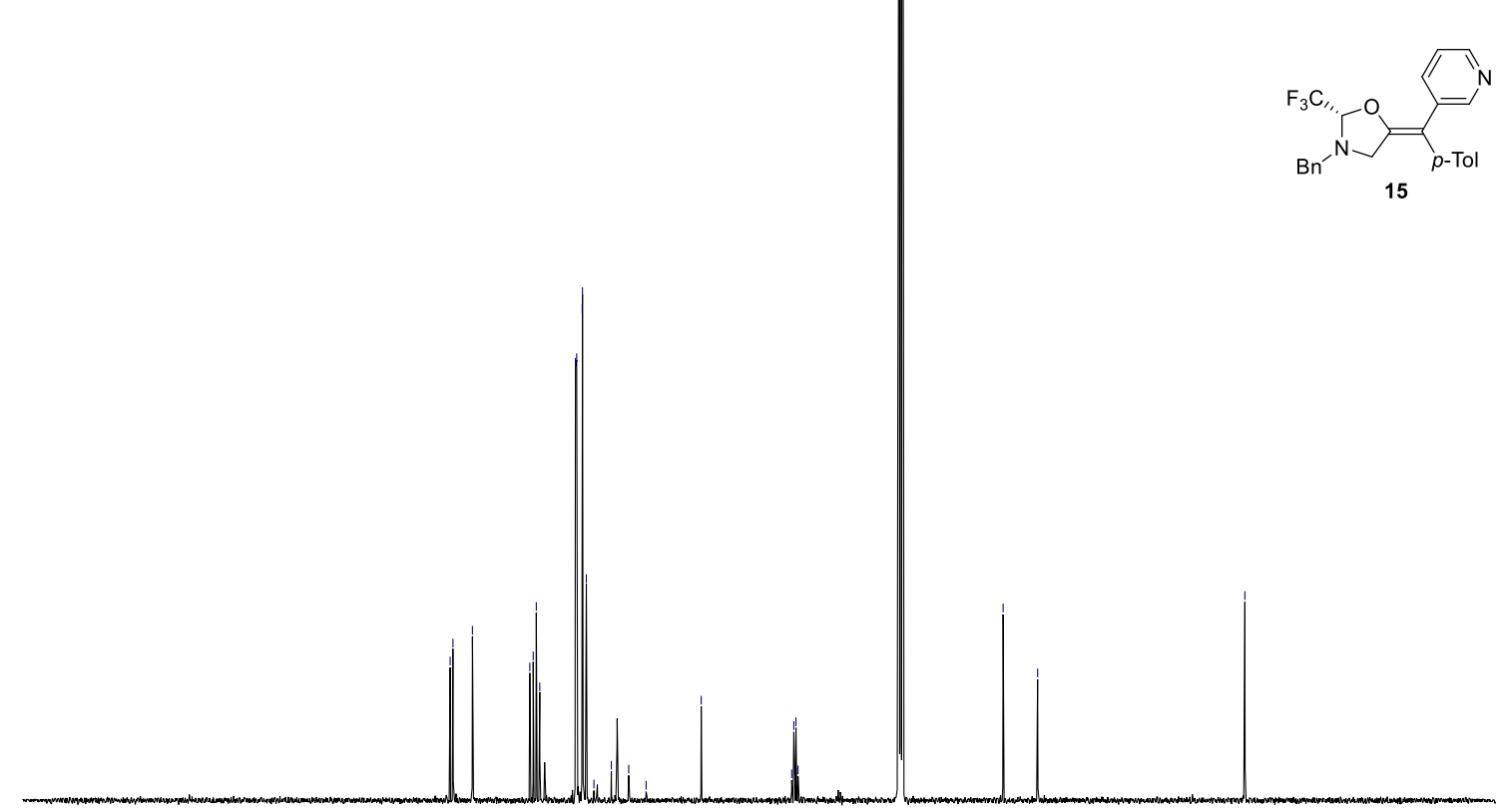

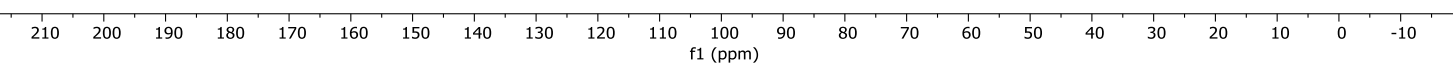




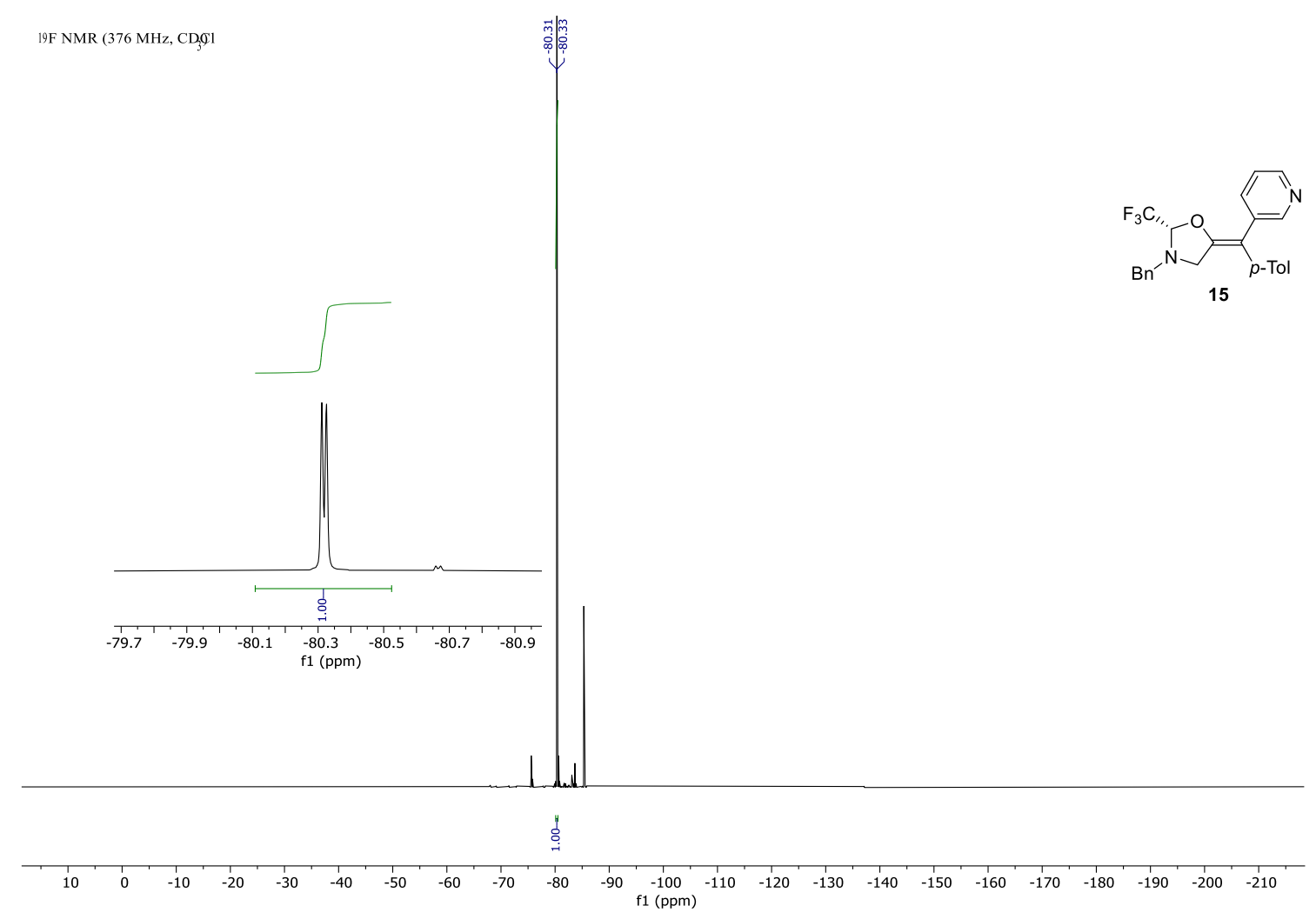

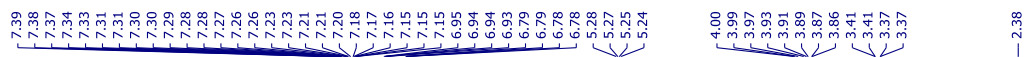

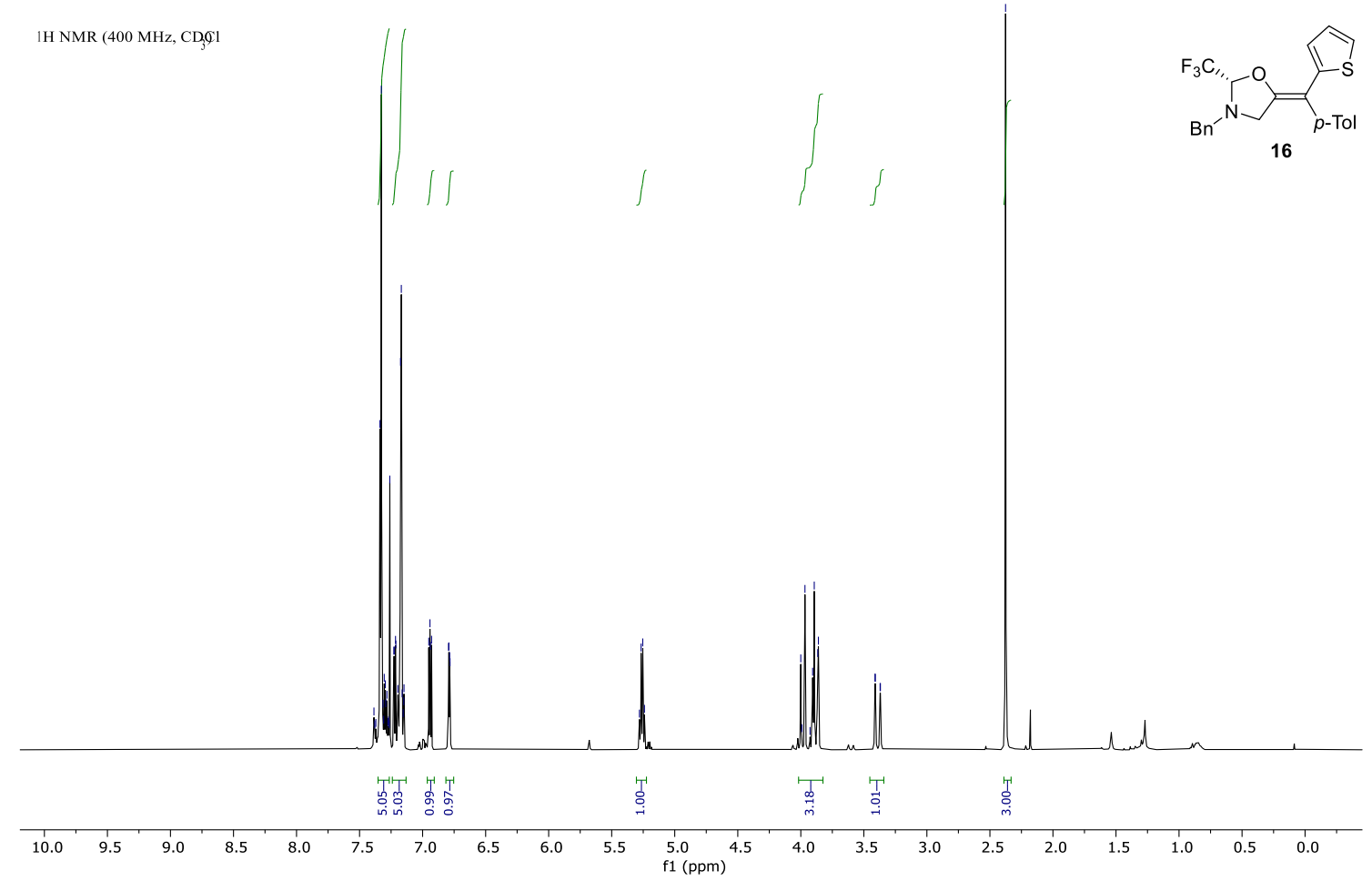



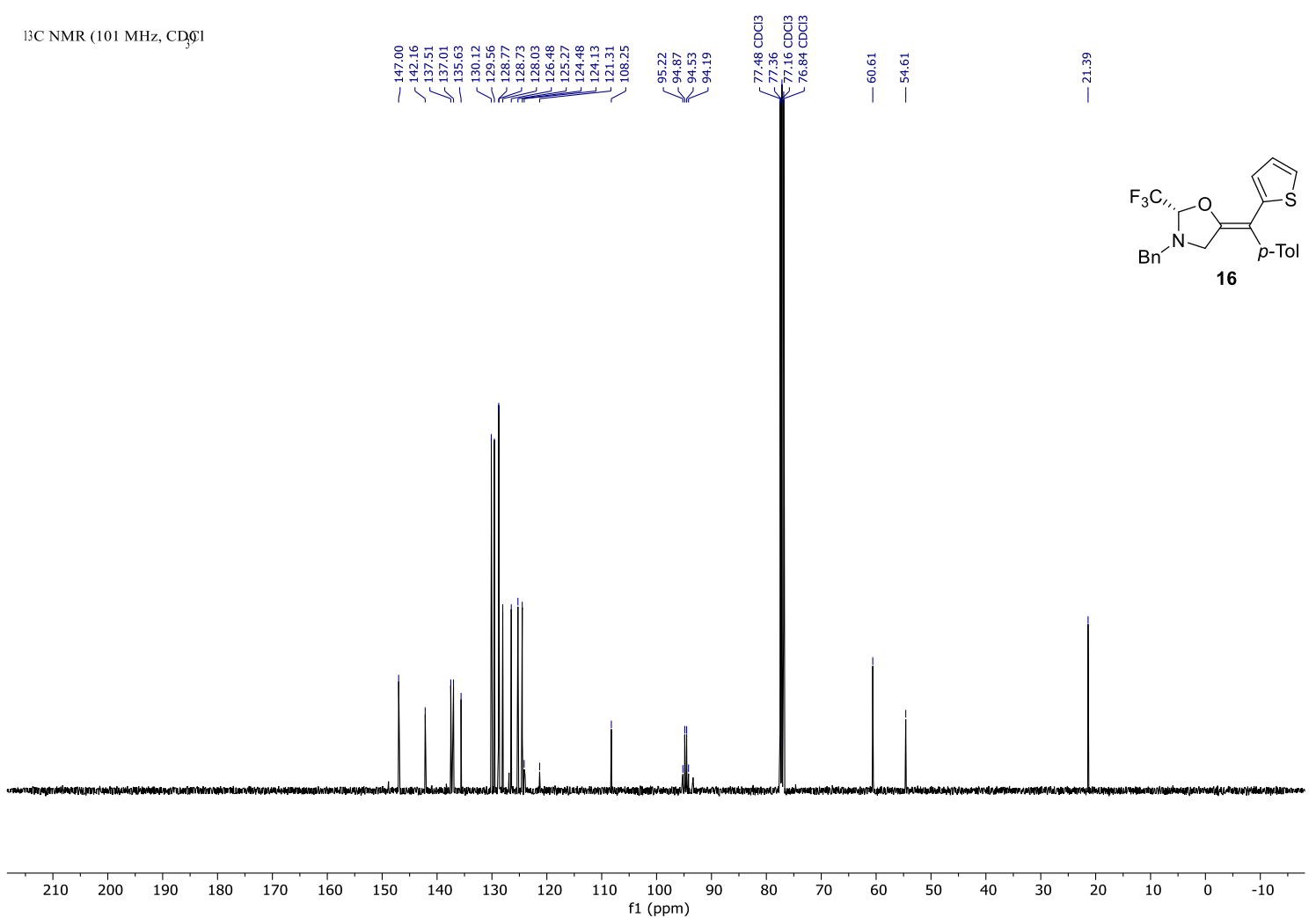

19F NMR (377 MHz, CD,91

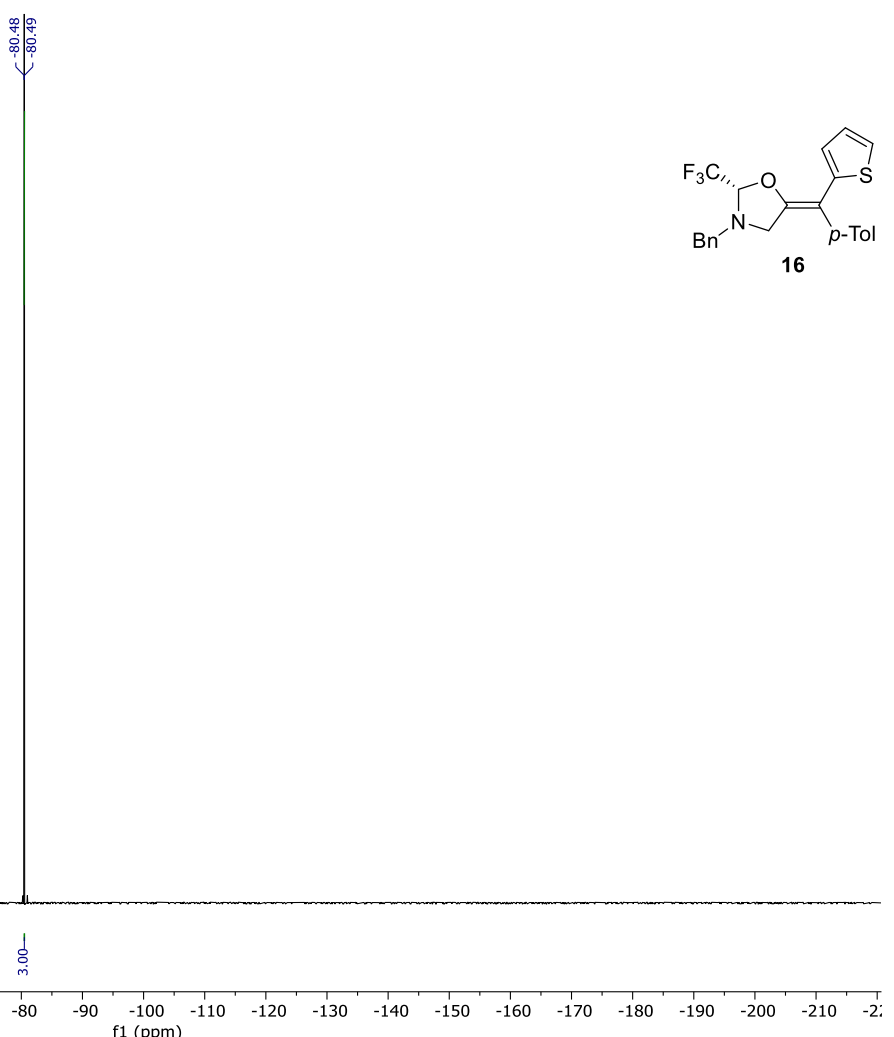

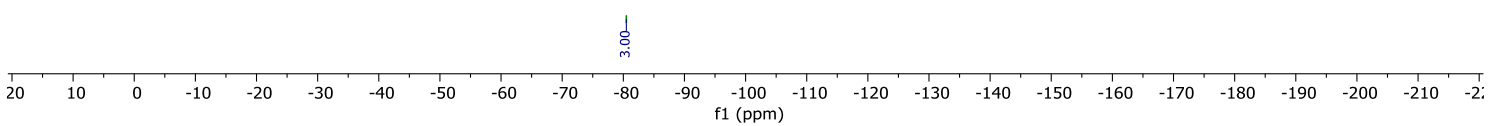




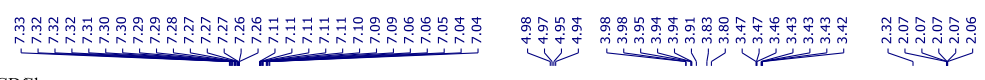

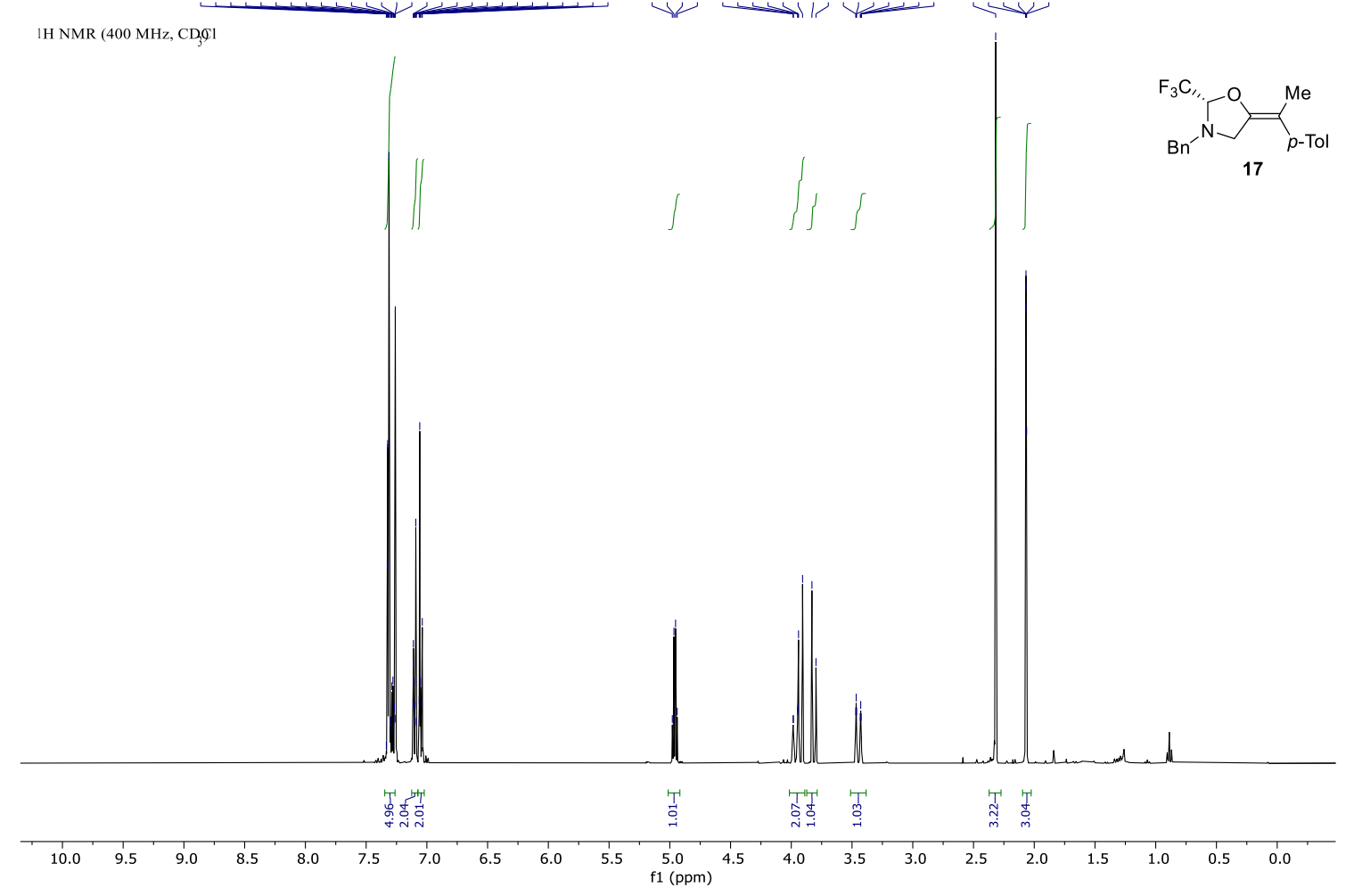

13C NMR (101 MHz, $\mathrm{CD}_{3} \mathrm{Cl}$

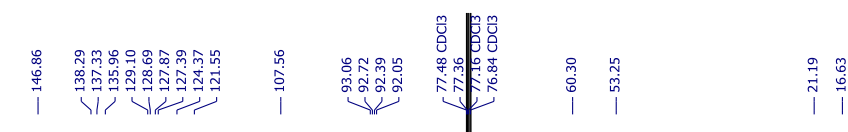

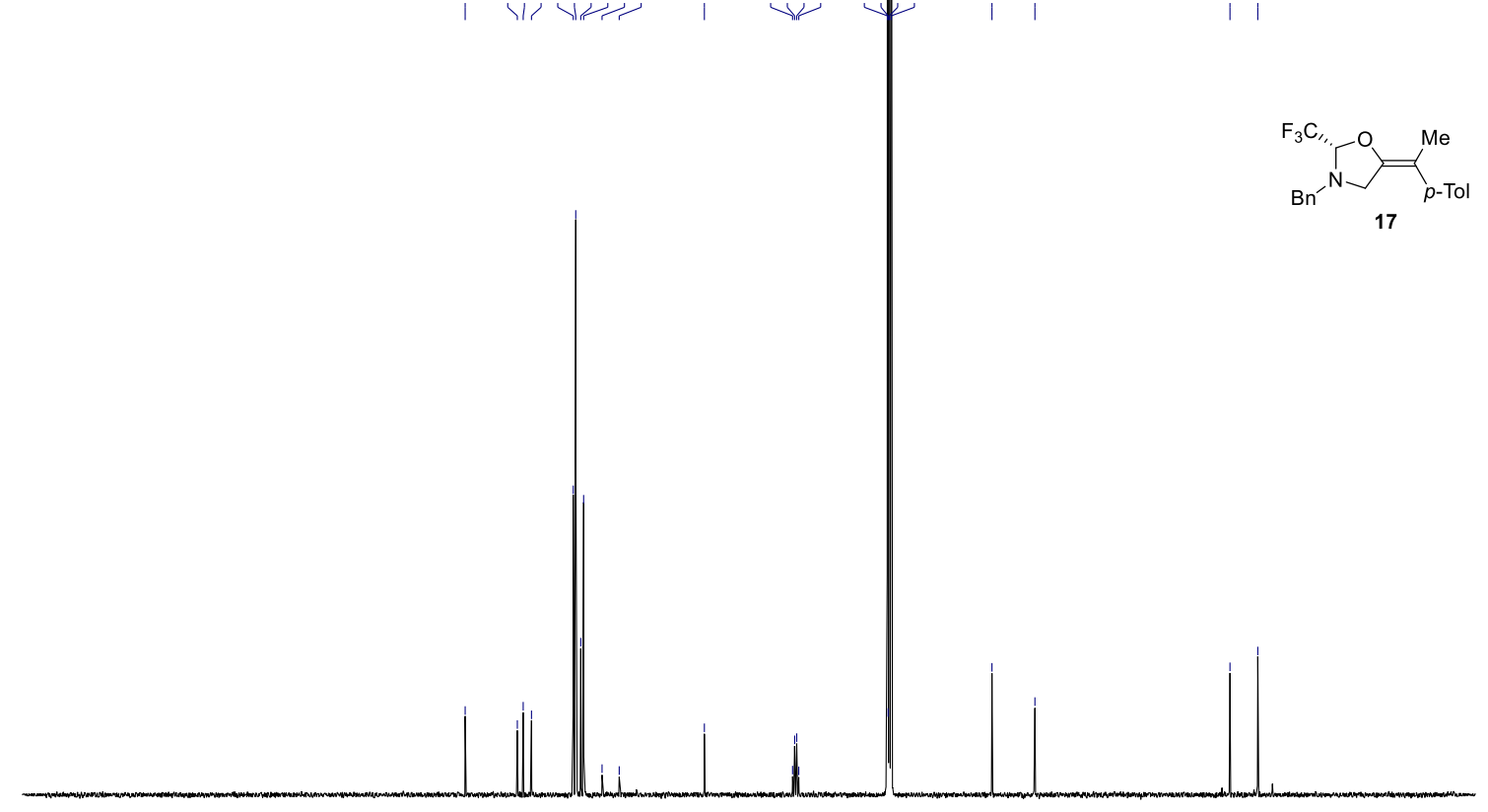

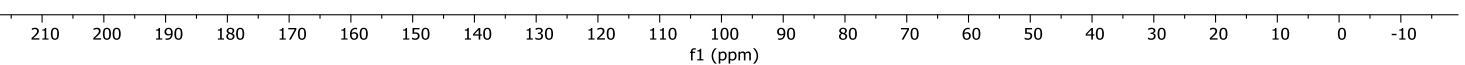



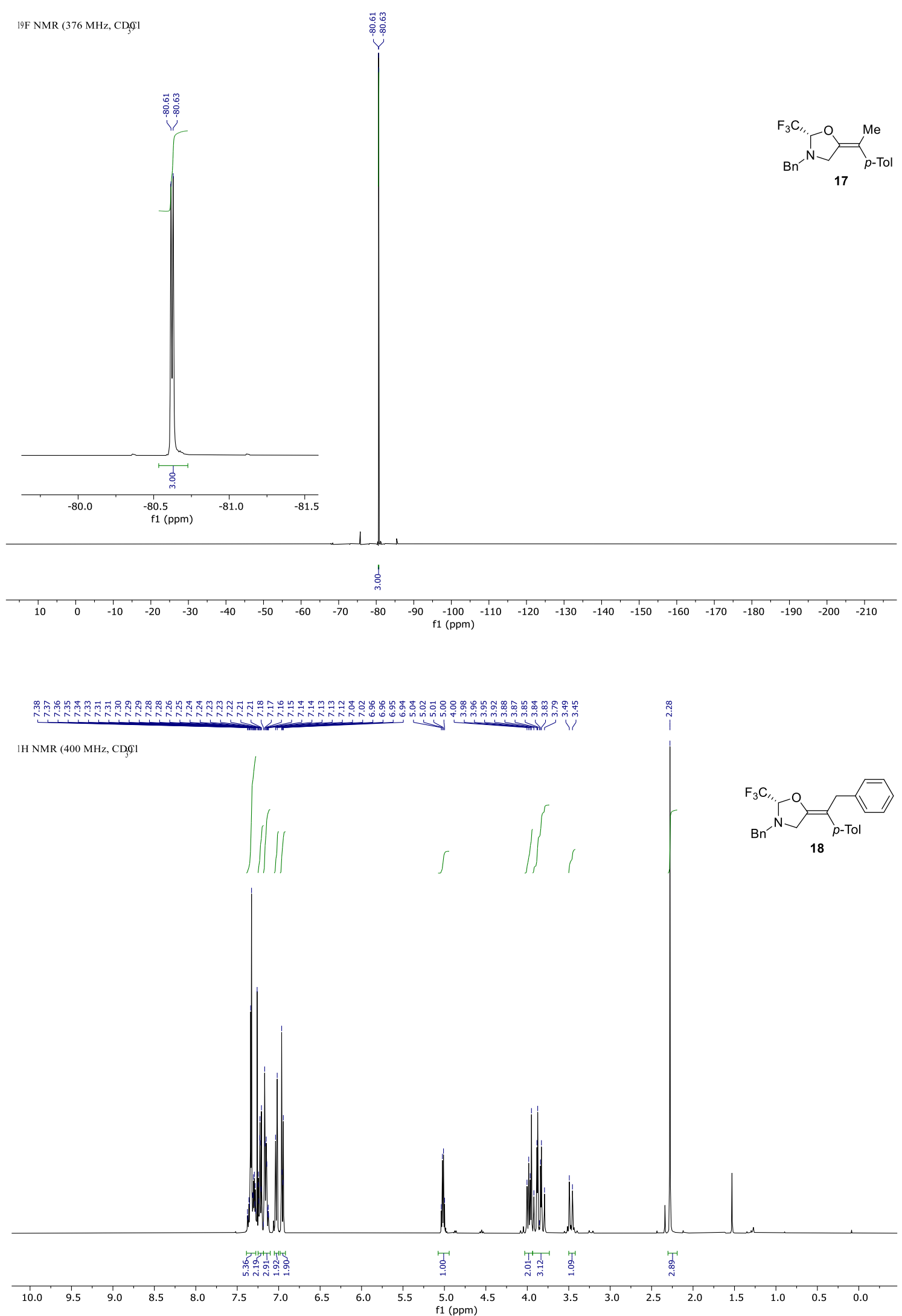


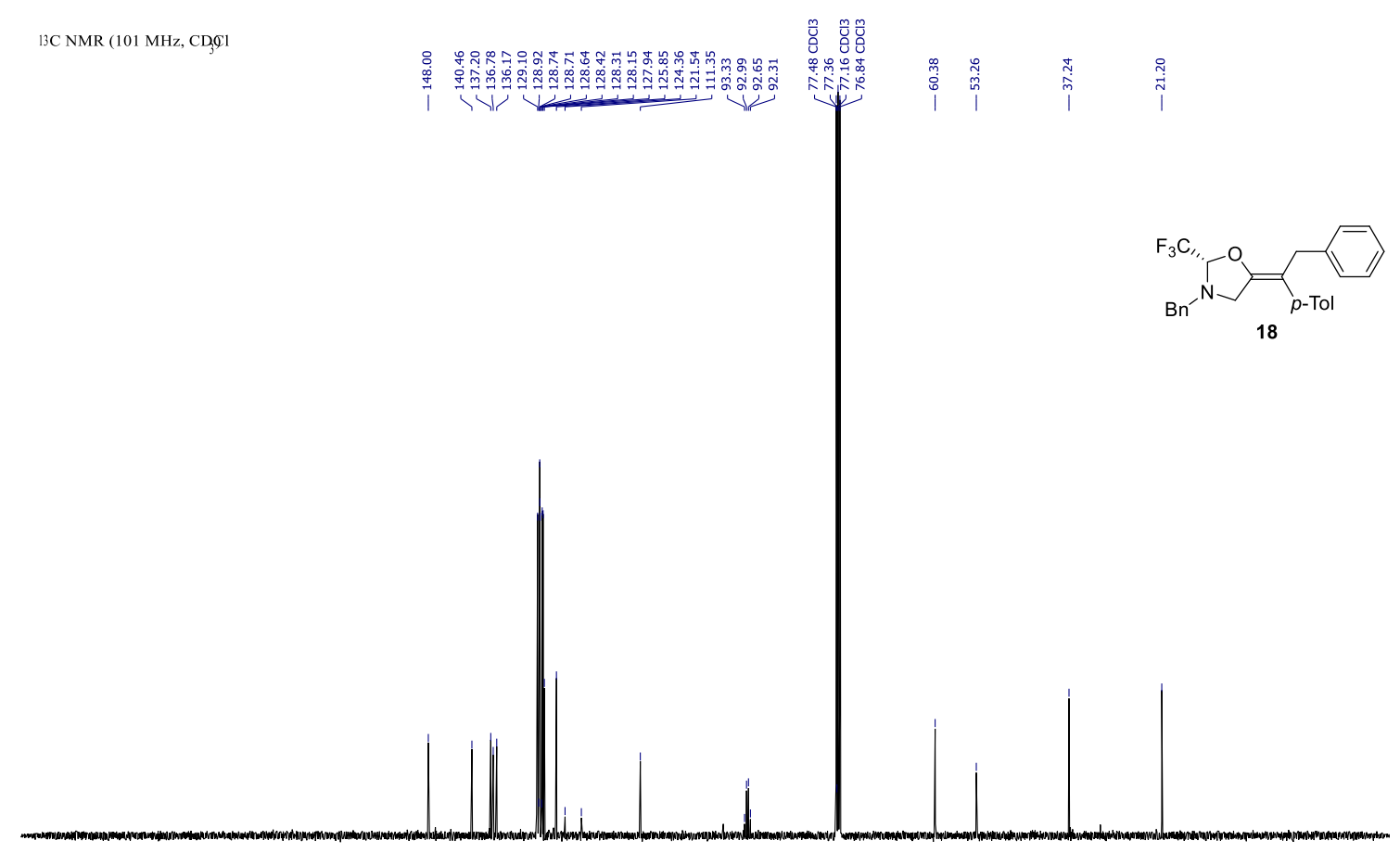

19F NMR (377 MHz, CD, 91
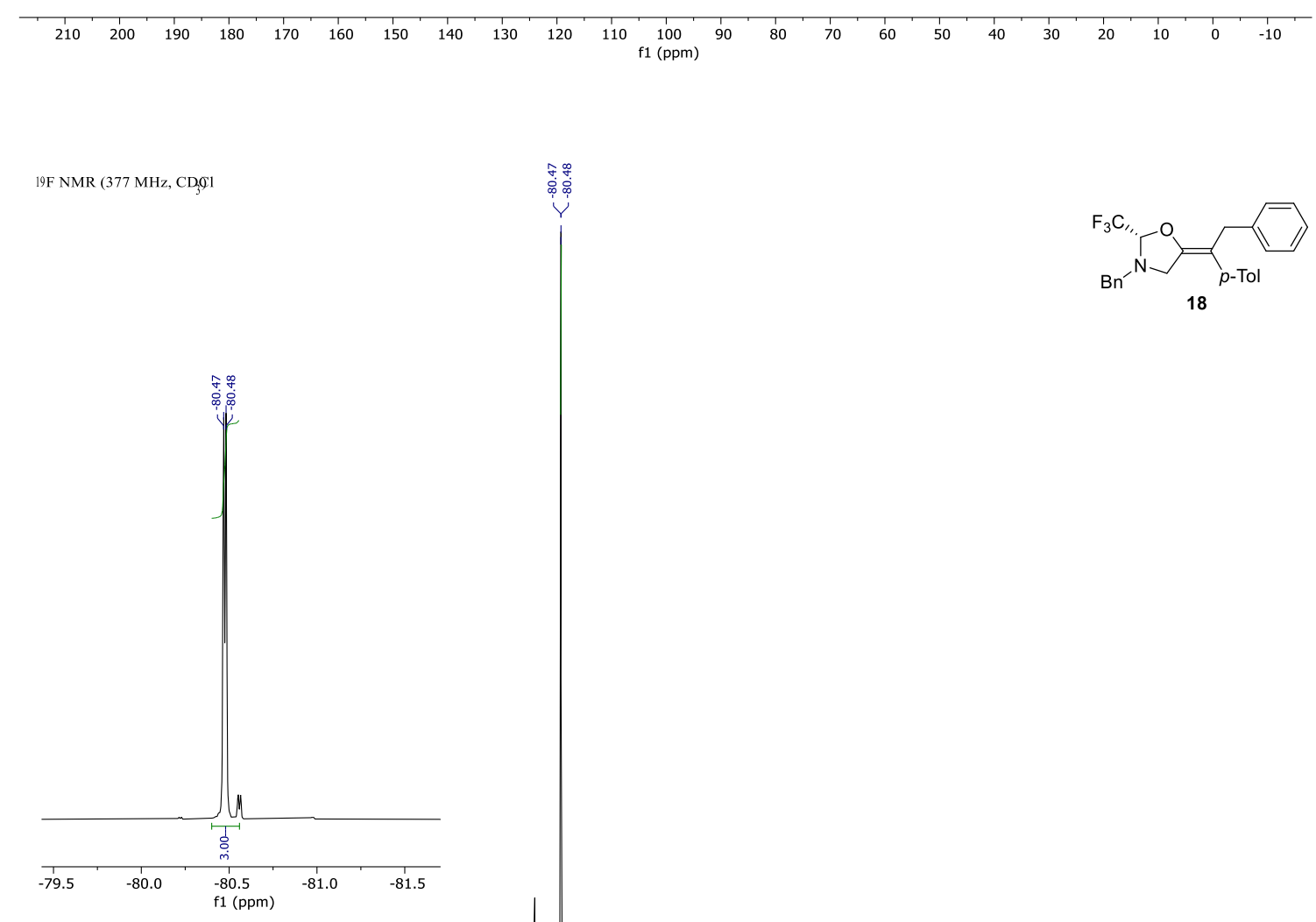

.

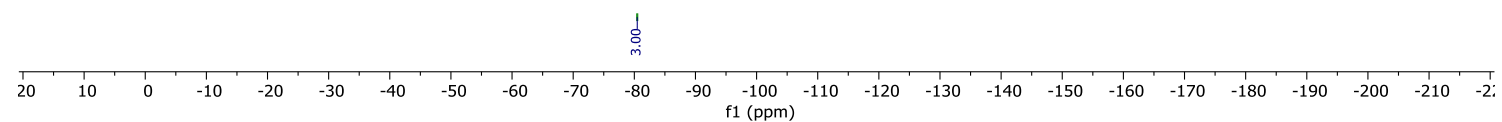



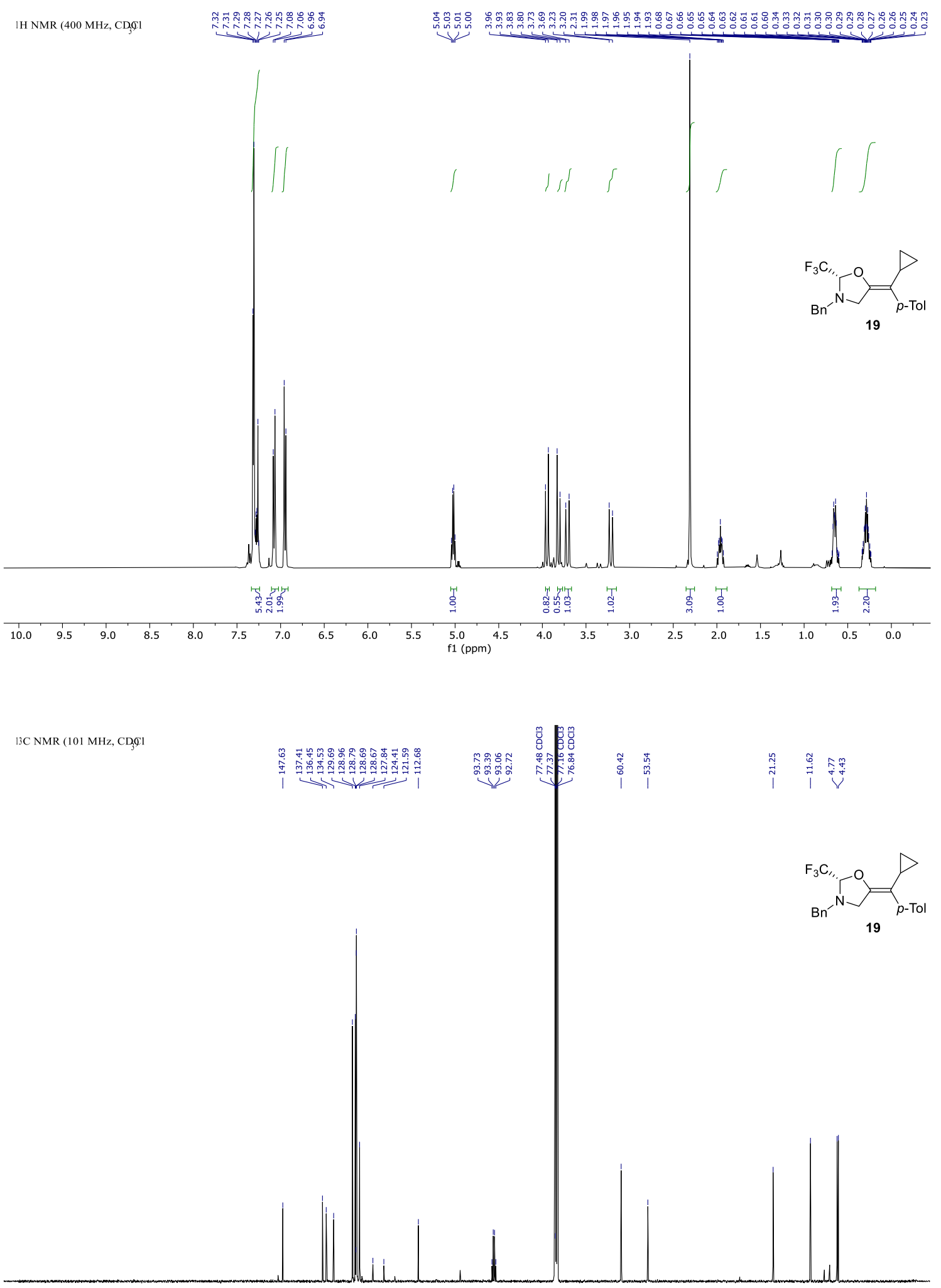

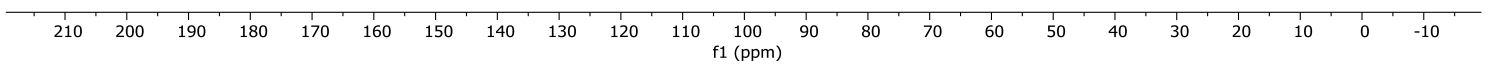


19F NMR (376 MHz, CD 91

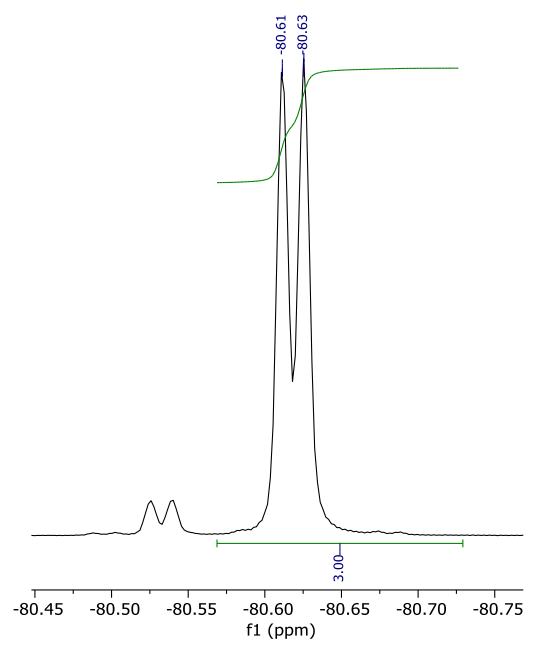

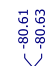

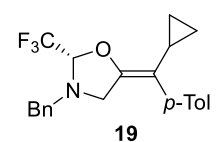

19

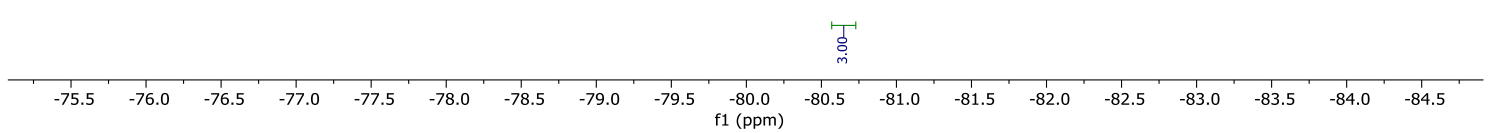

S81 

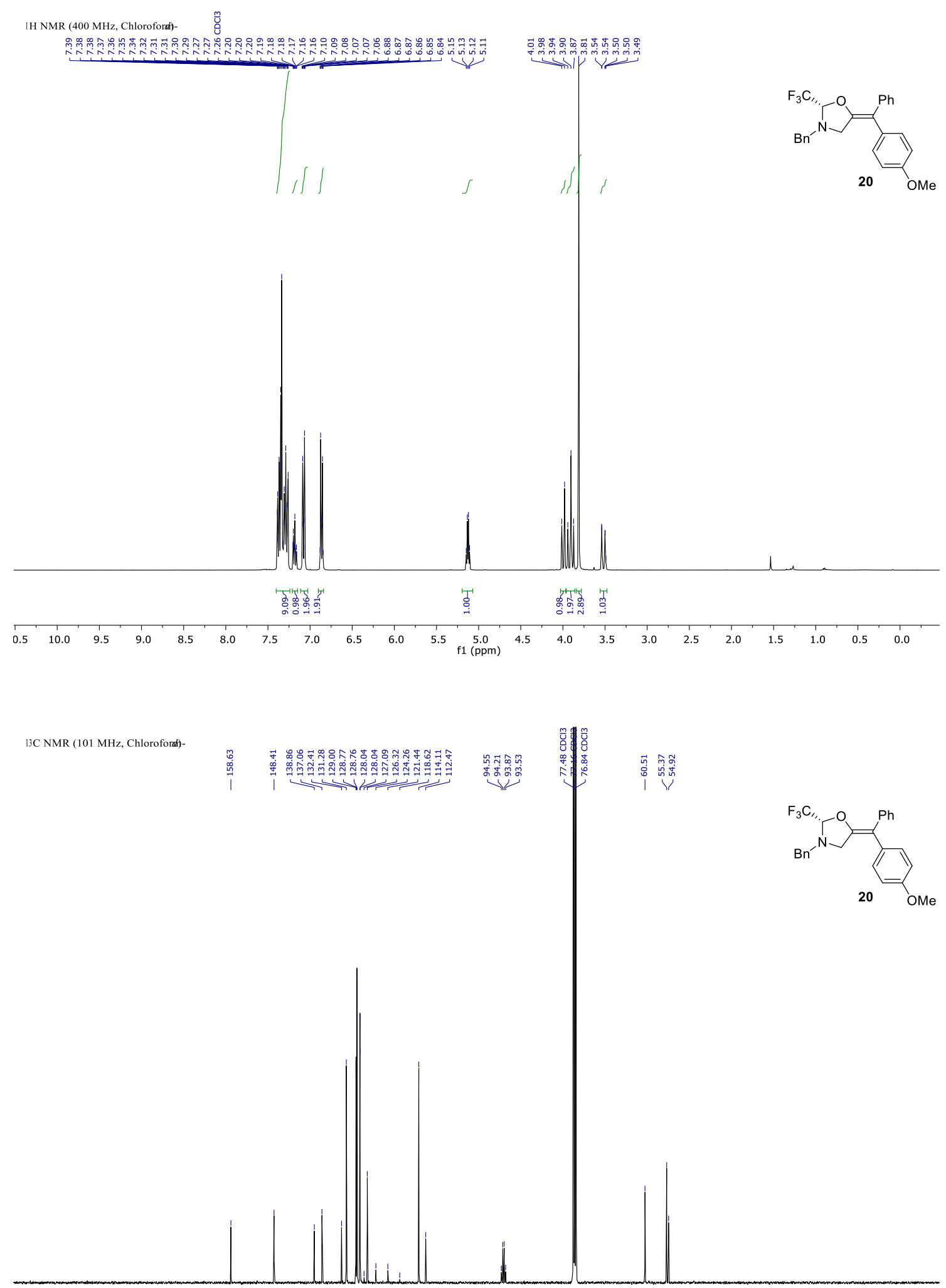

$\begin{array}{lllllllllllllllllllllllllllllll}10 & 200 & 190 & 180 & 170 & 160 & 150 & 140 & 130 & 120 & 110 & 100 & 90 & 80 & 70 & 60 & 50 & 40 & 30 & 20 & 10 & 0\end{array}$ 


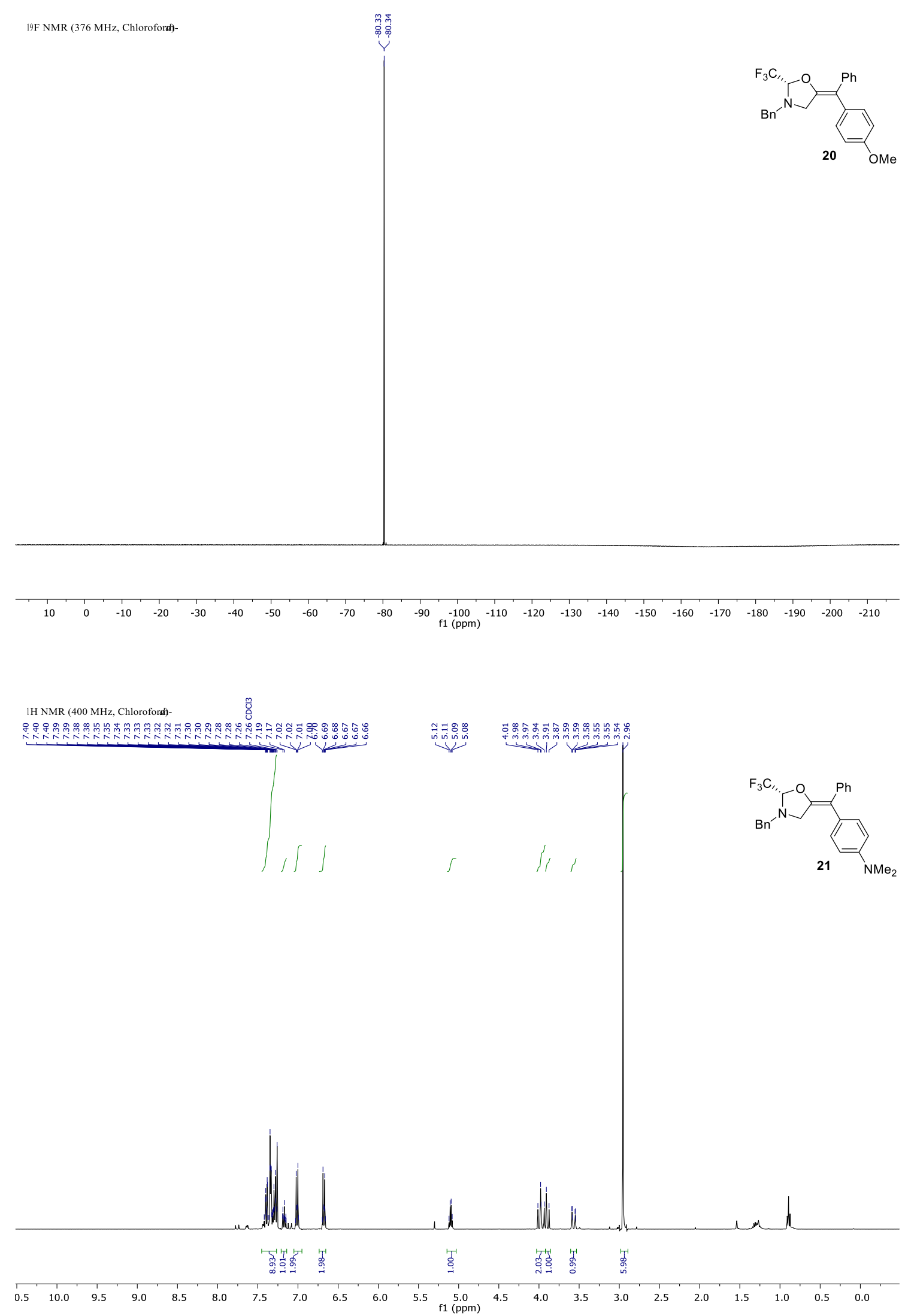




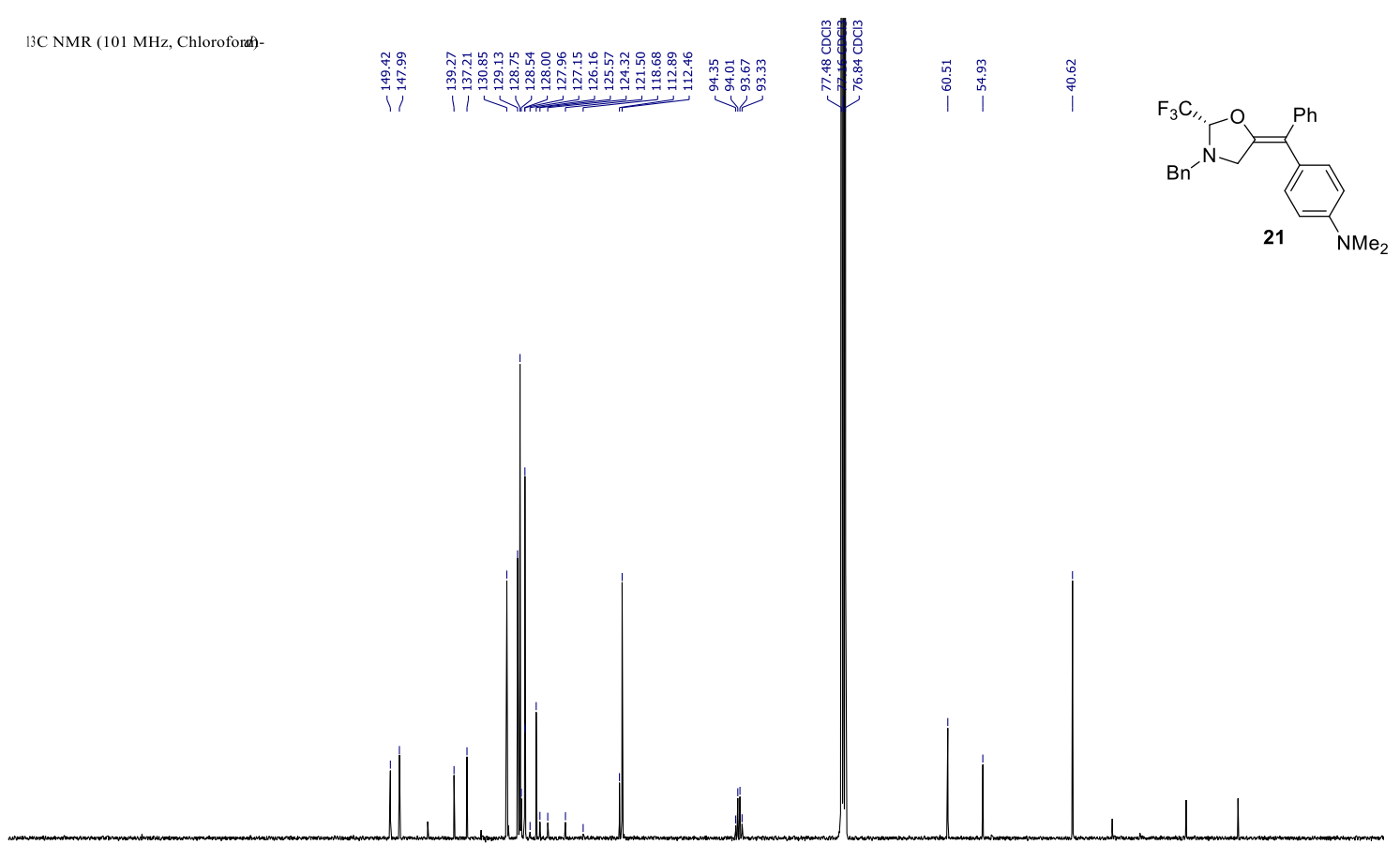

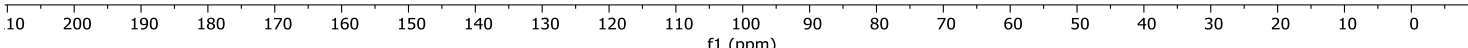
19F NMR (376 MHz, Chloroford-

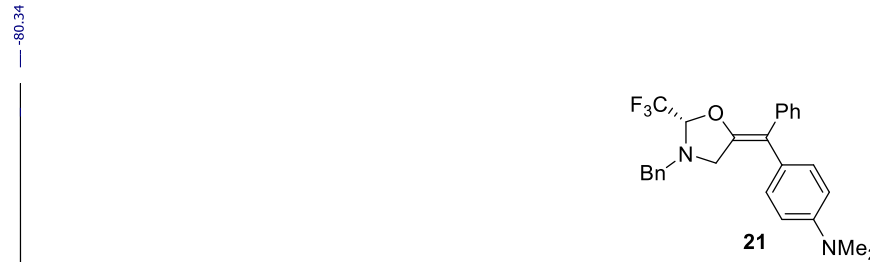

\begin{tabular}{|llllllllllllllllllllllllll}
1 & 0 & 0 & -10 & -20 & -30 & -40 & -50 & -60 & -70 & -80 & -90 & -100 & -110 & -120 & -130 & -140 & -150 & -160 & -170 & -180 & -190 & -200 & -210
\end{tabular} 

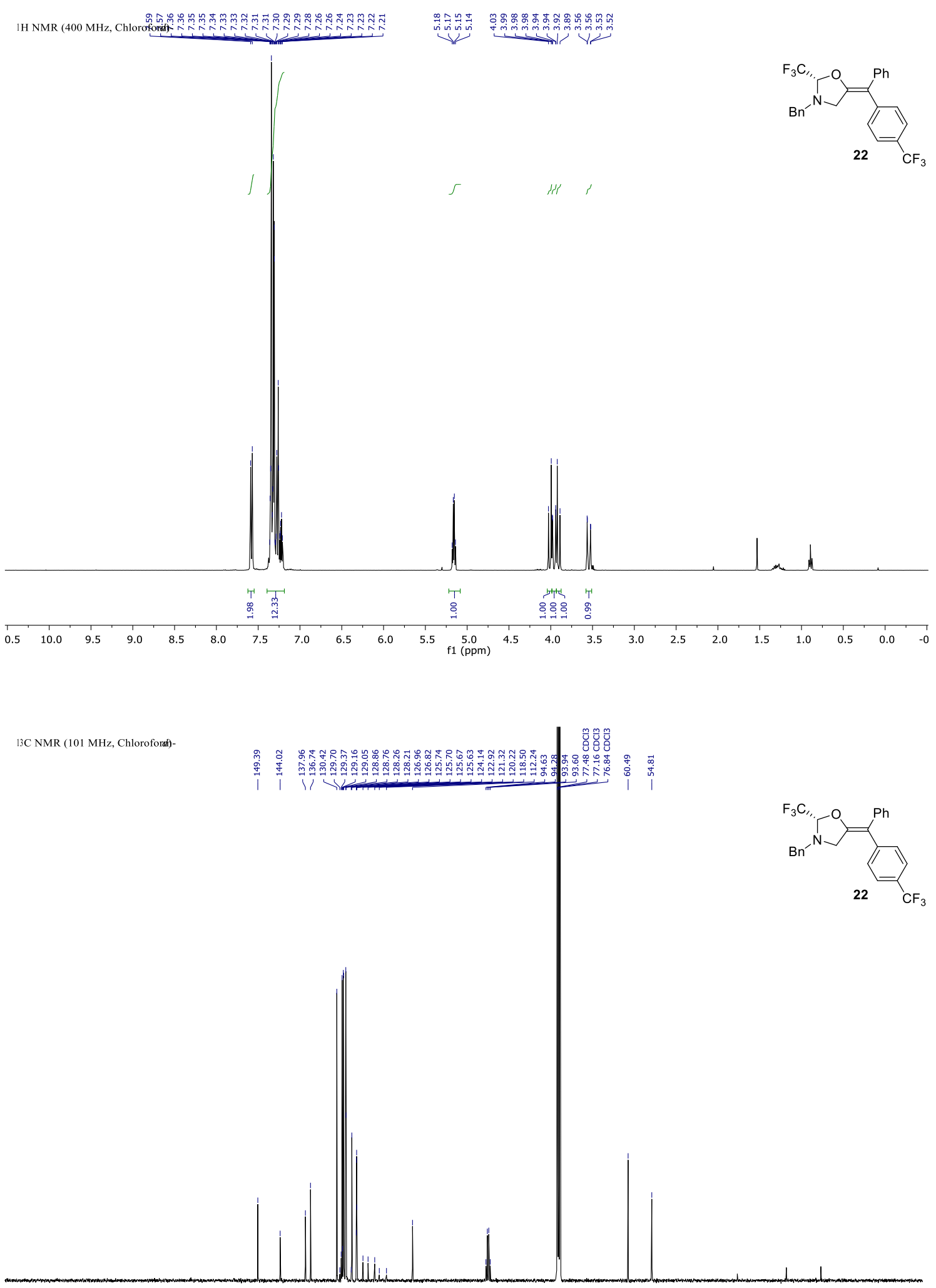

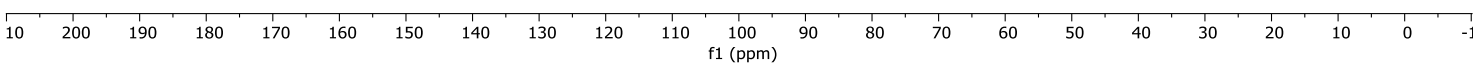



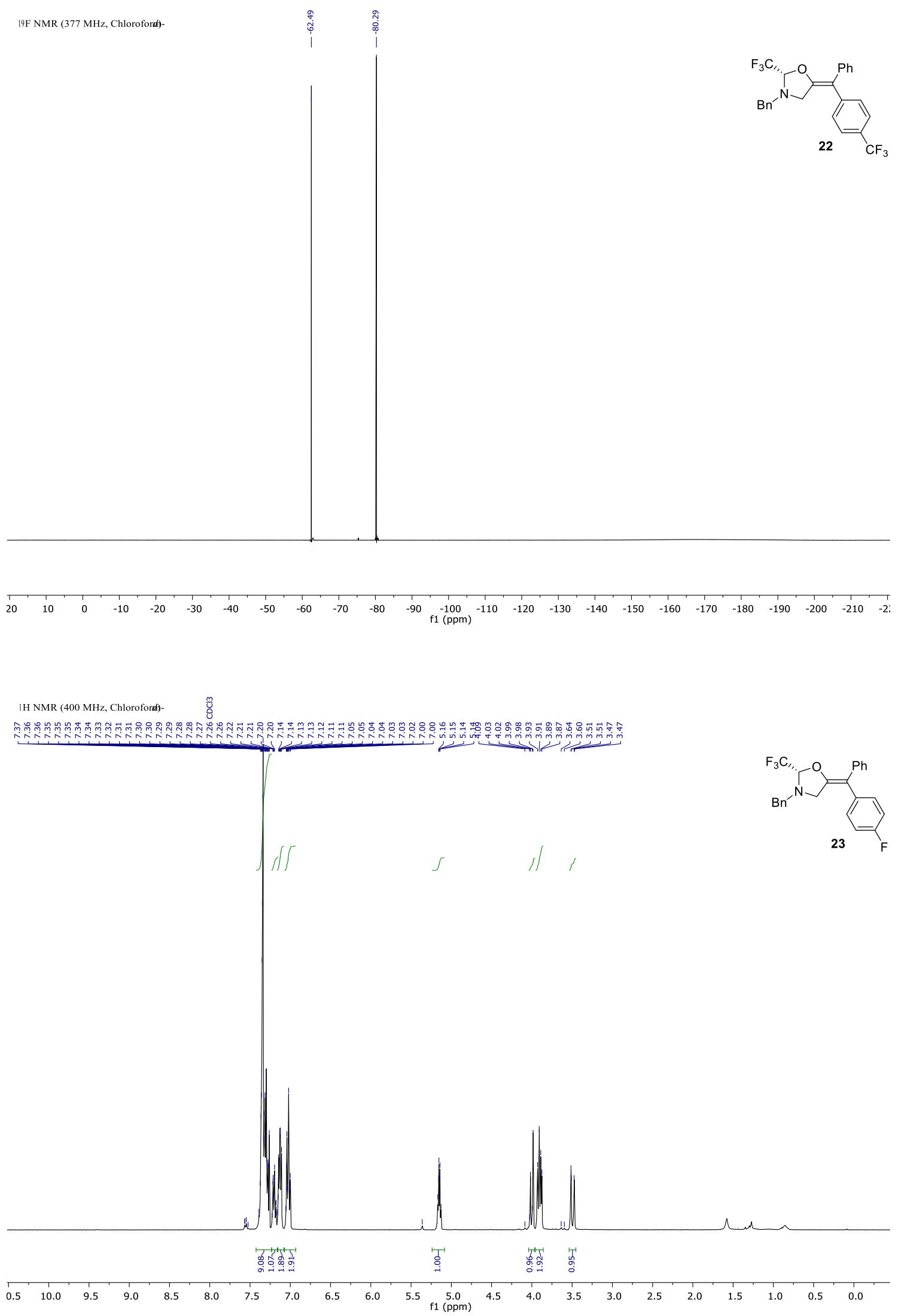

S86 


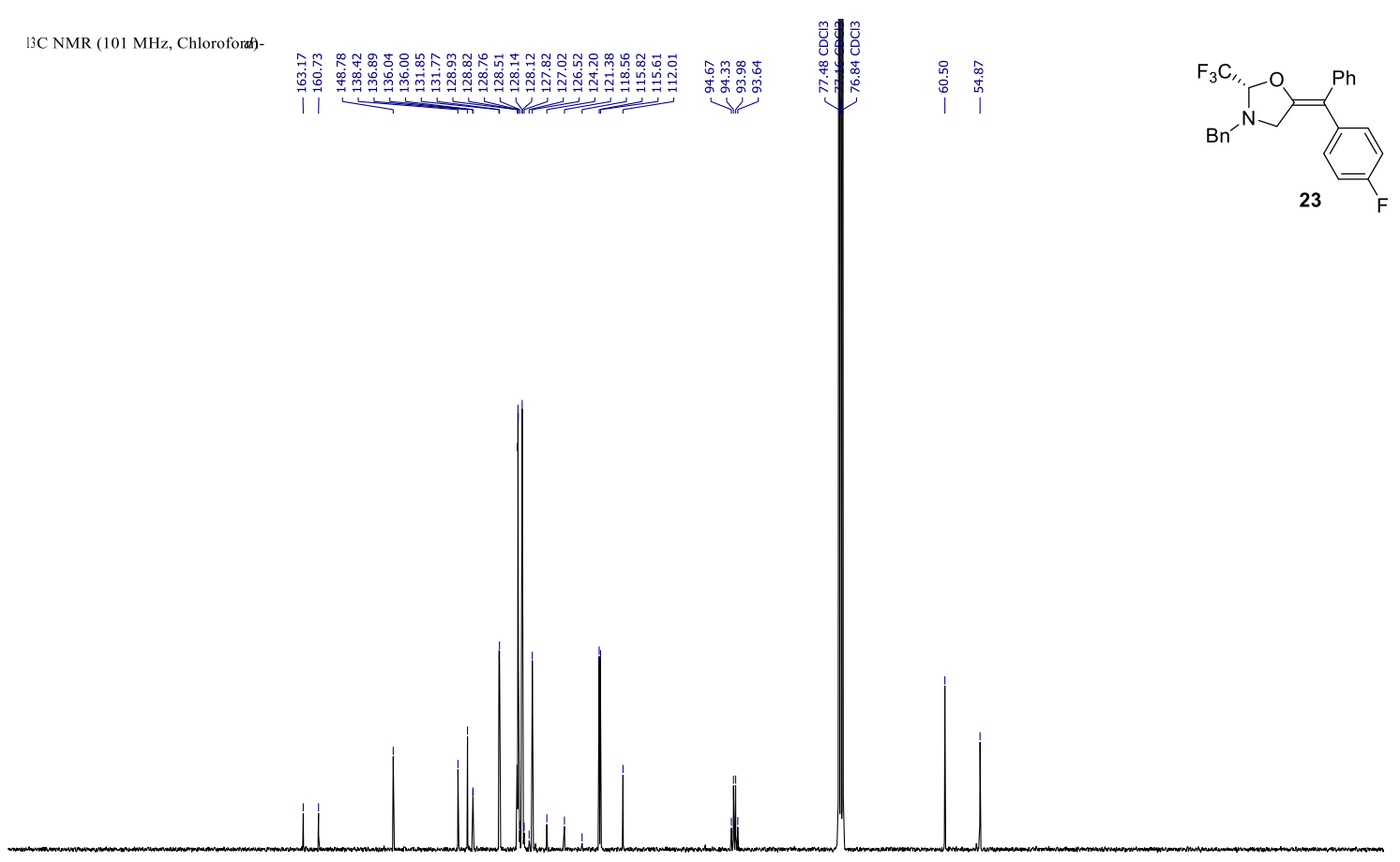

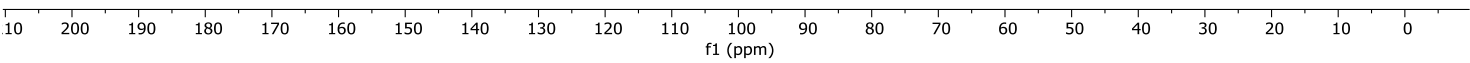

19F NMR (376 MHz, Chloroford)-

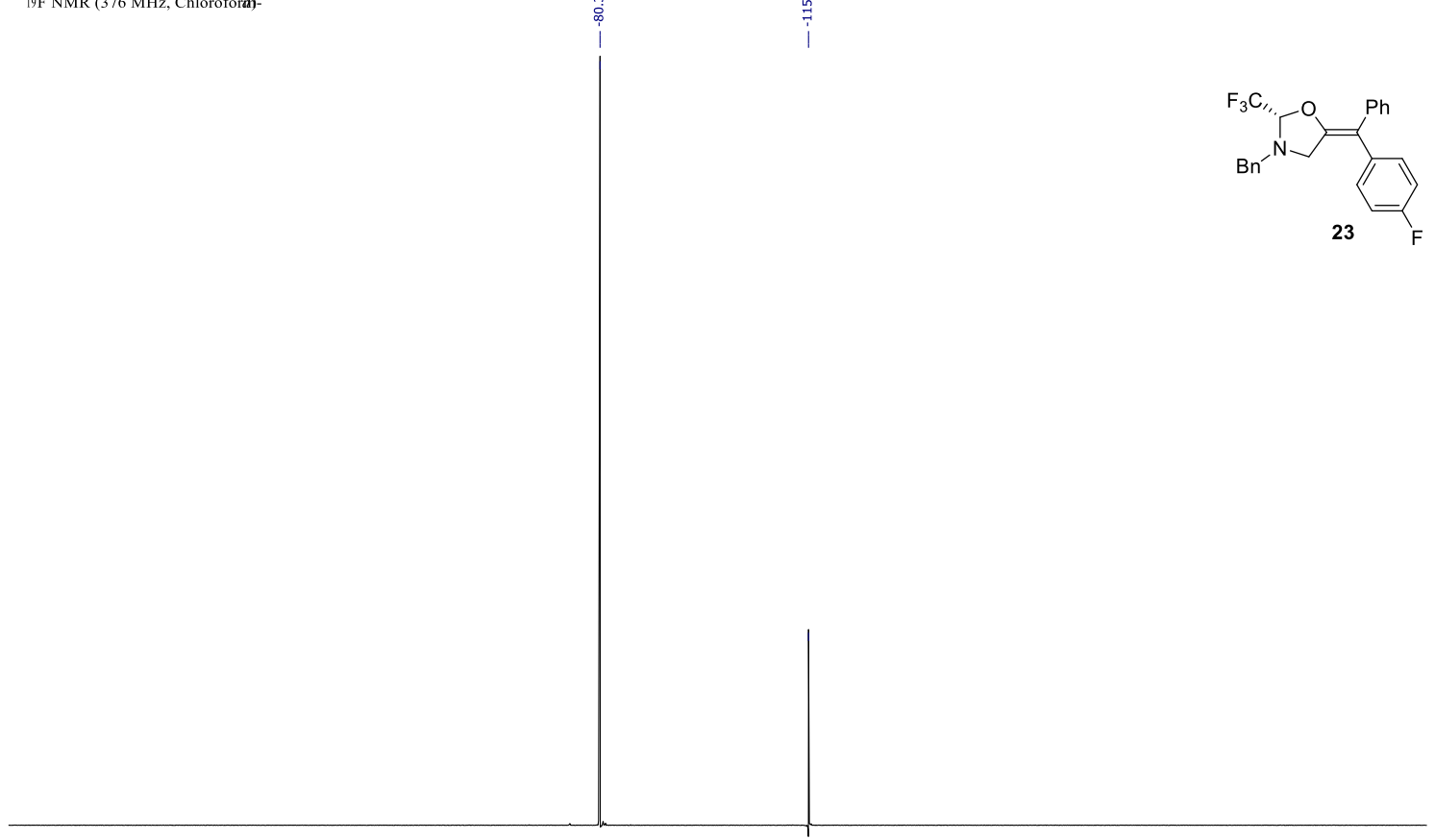

$\begin{array}{lllllllllllllllllllllllll}1 & 0 & 0 & -10 & -20 & -30 & -40 & -50 & -60 & -70 & -80 & -90 & -100 & -110 & -120 & -130 & -140 & -150 & -160 & -170 & -180 & -190 & -200 & -210\end{array}$ 

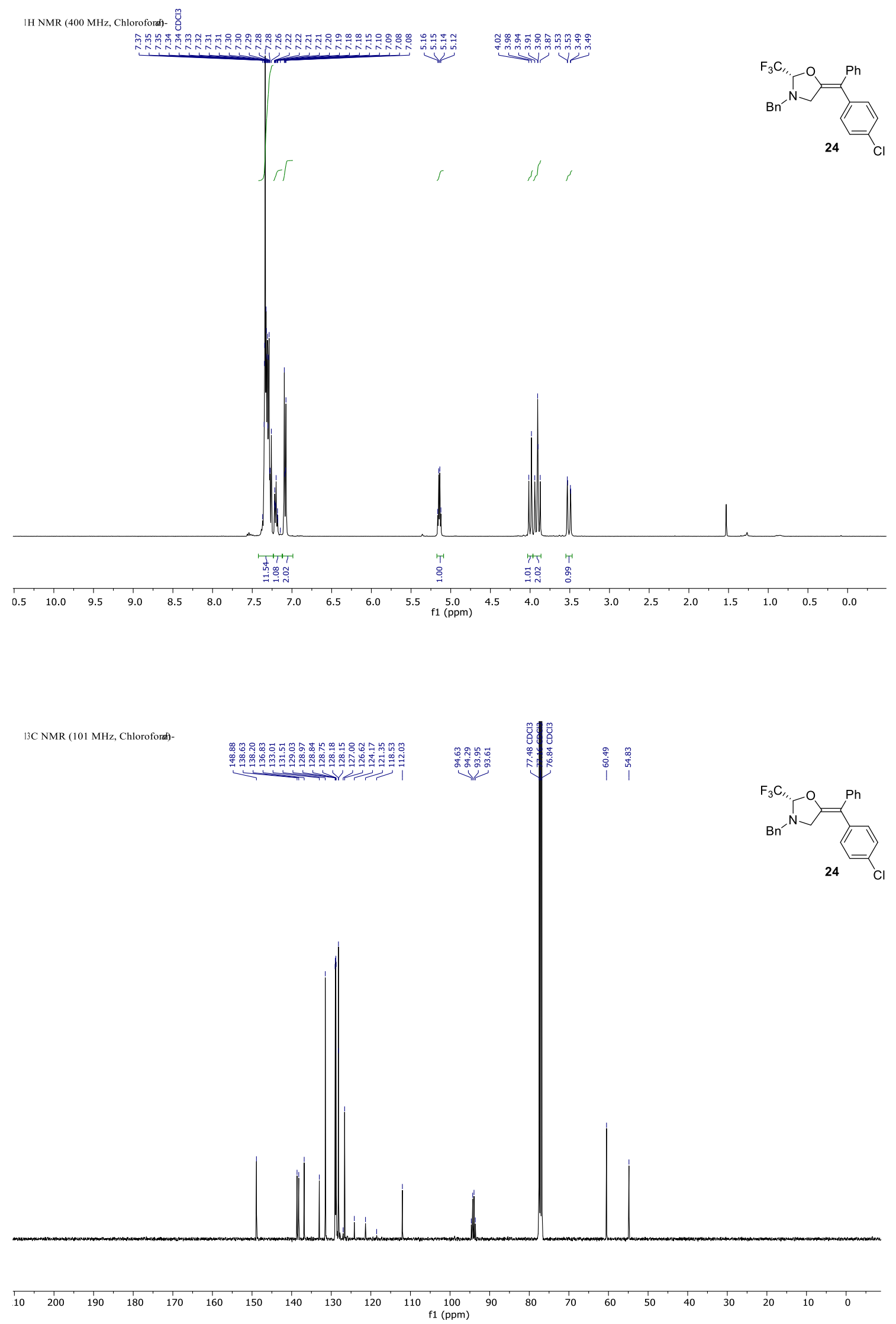

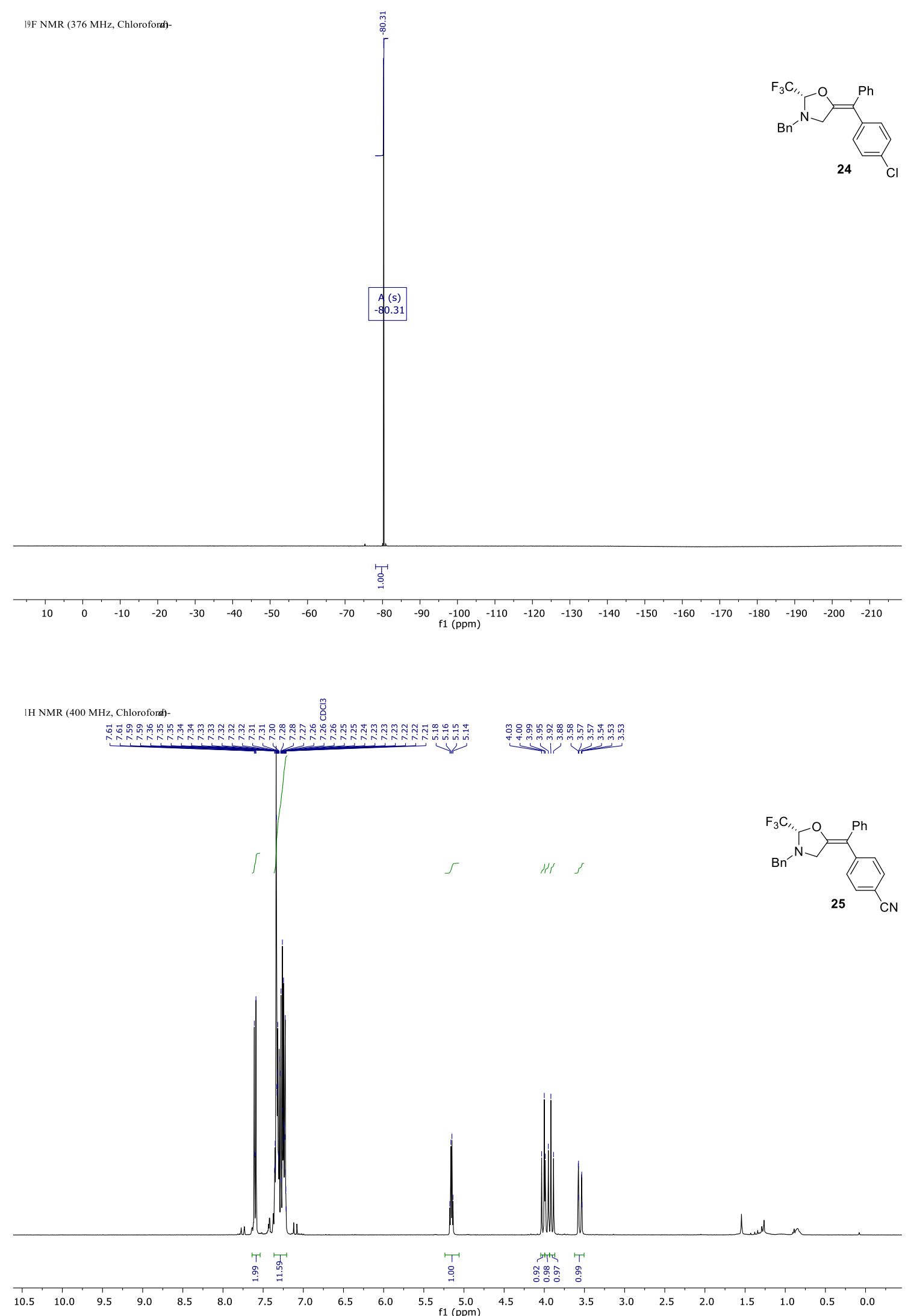


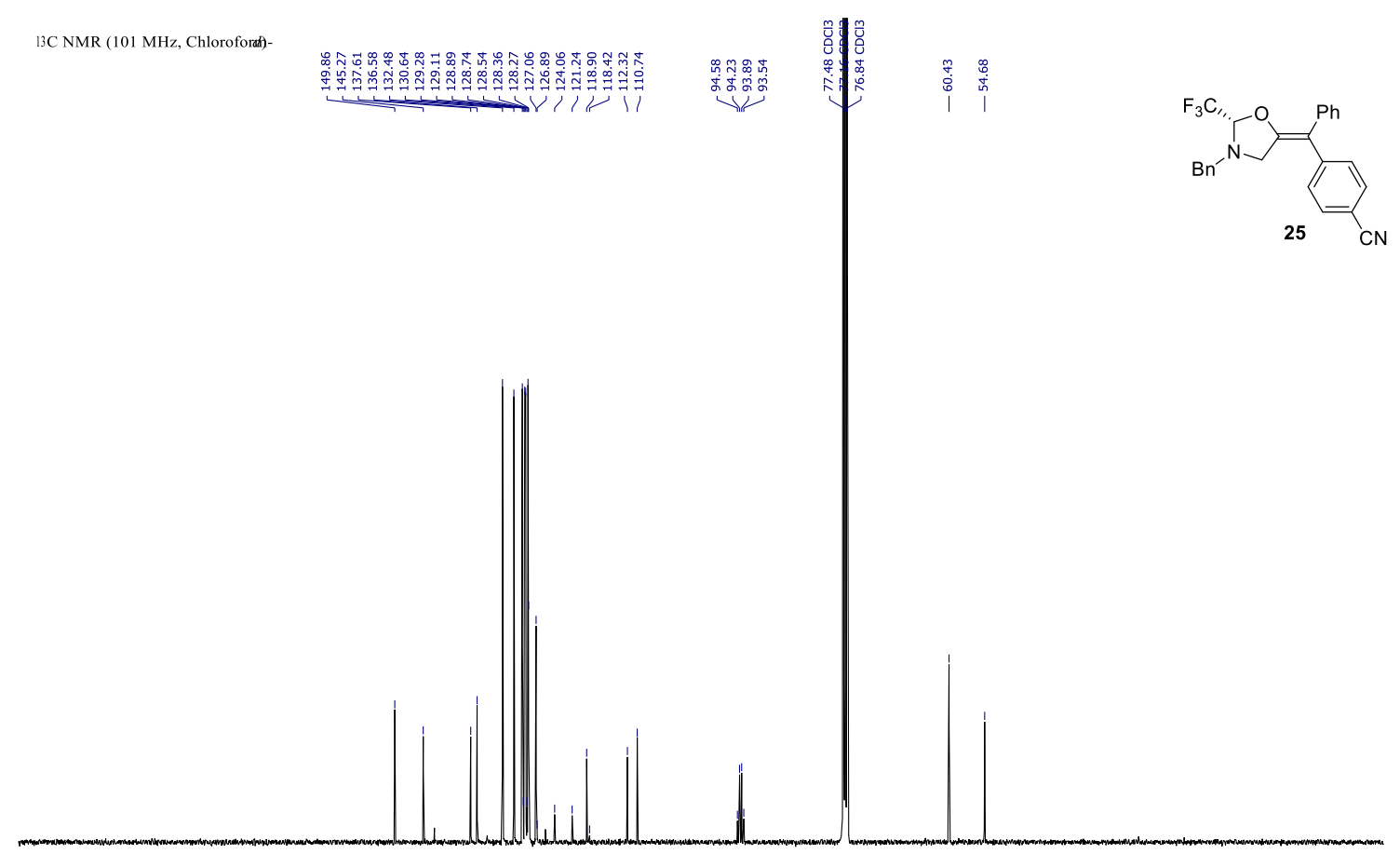

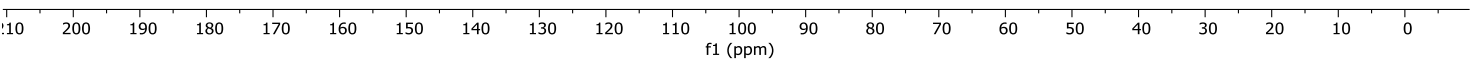

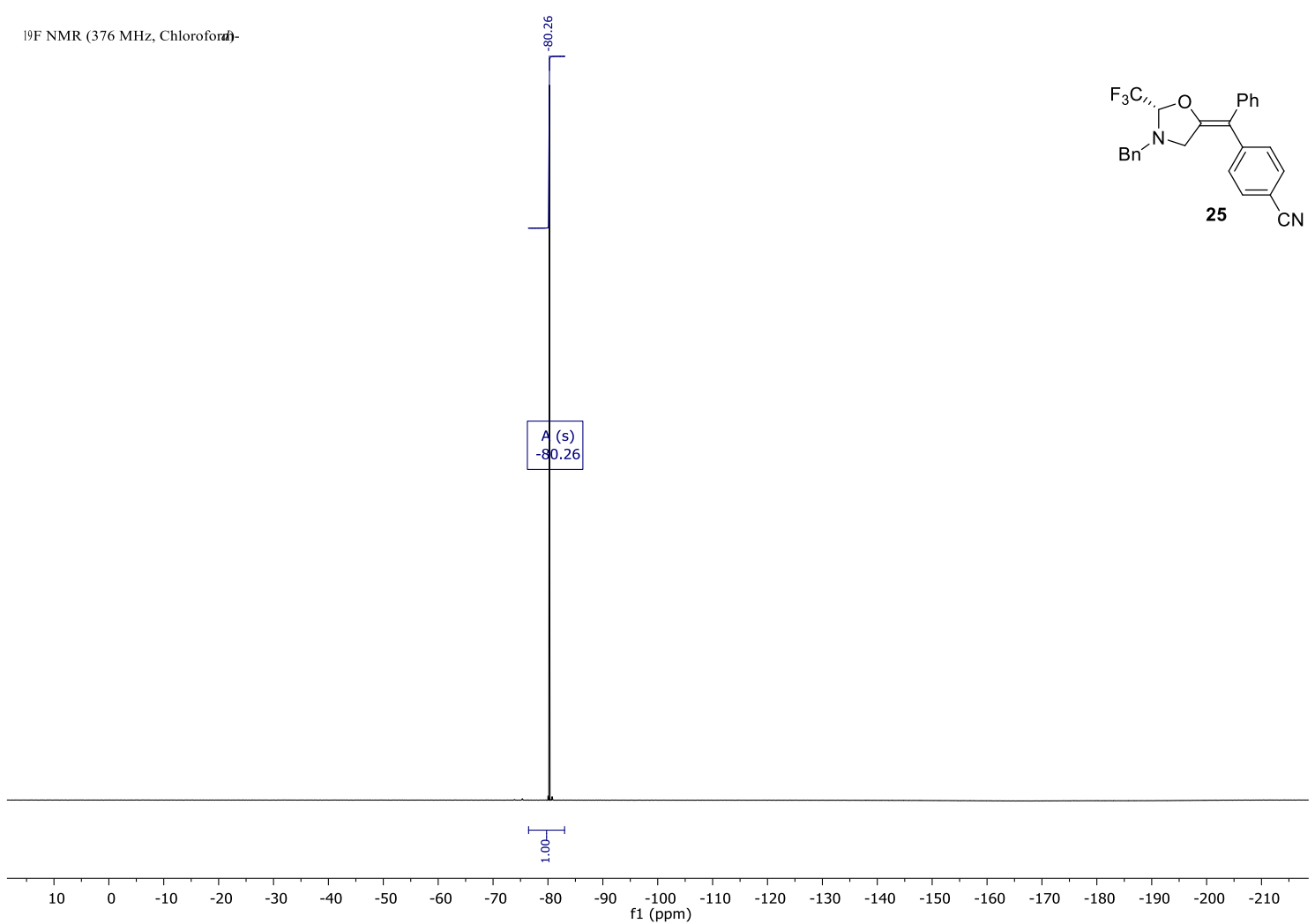




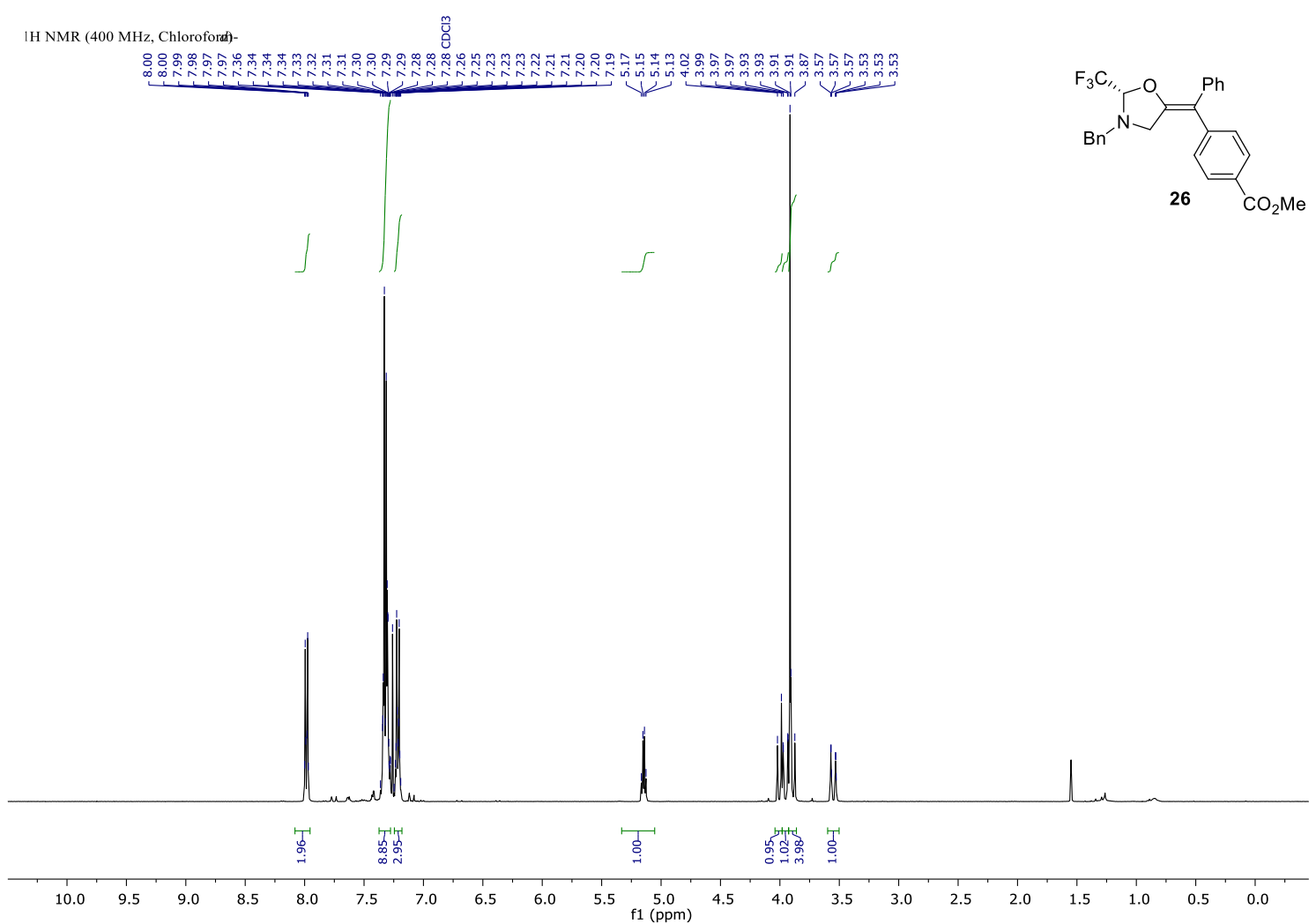

13C NMR (101 MHz, Chloroforal-
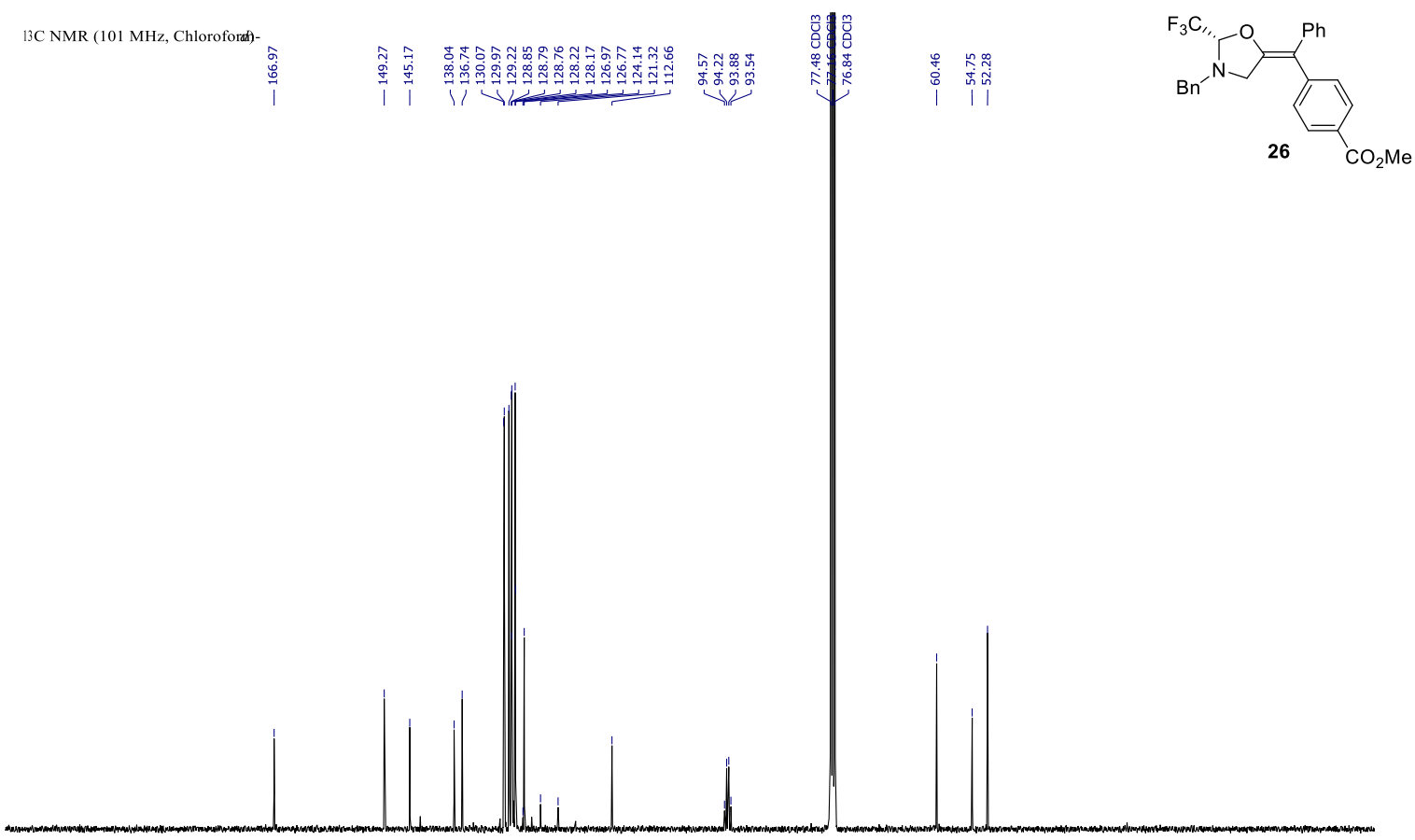

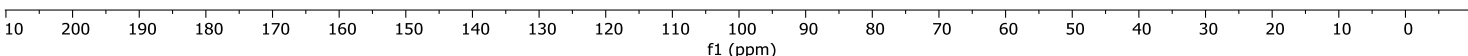




$$
\frac{1}{T_{1}}
$$




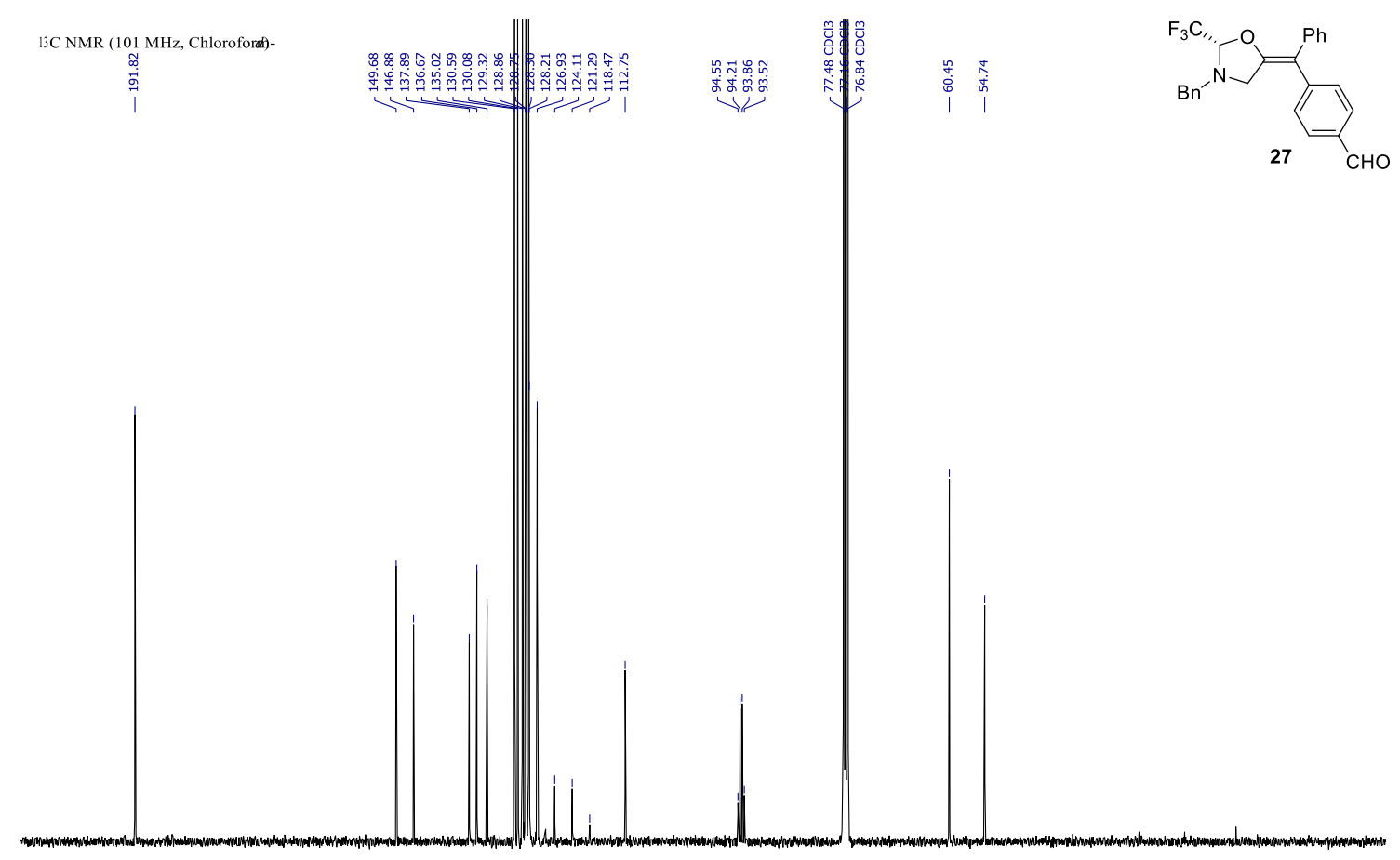

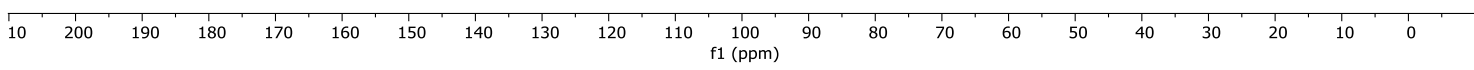

19F NMR (376 MHz, Chloroford)-

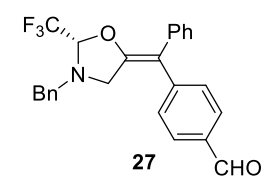

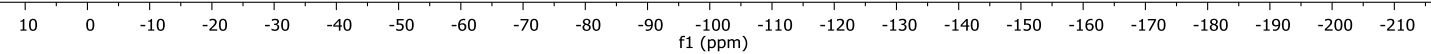



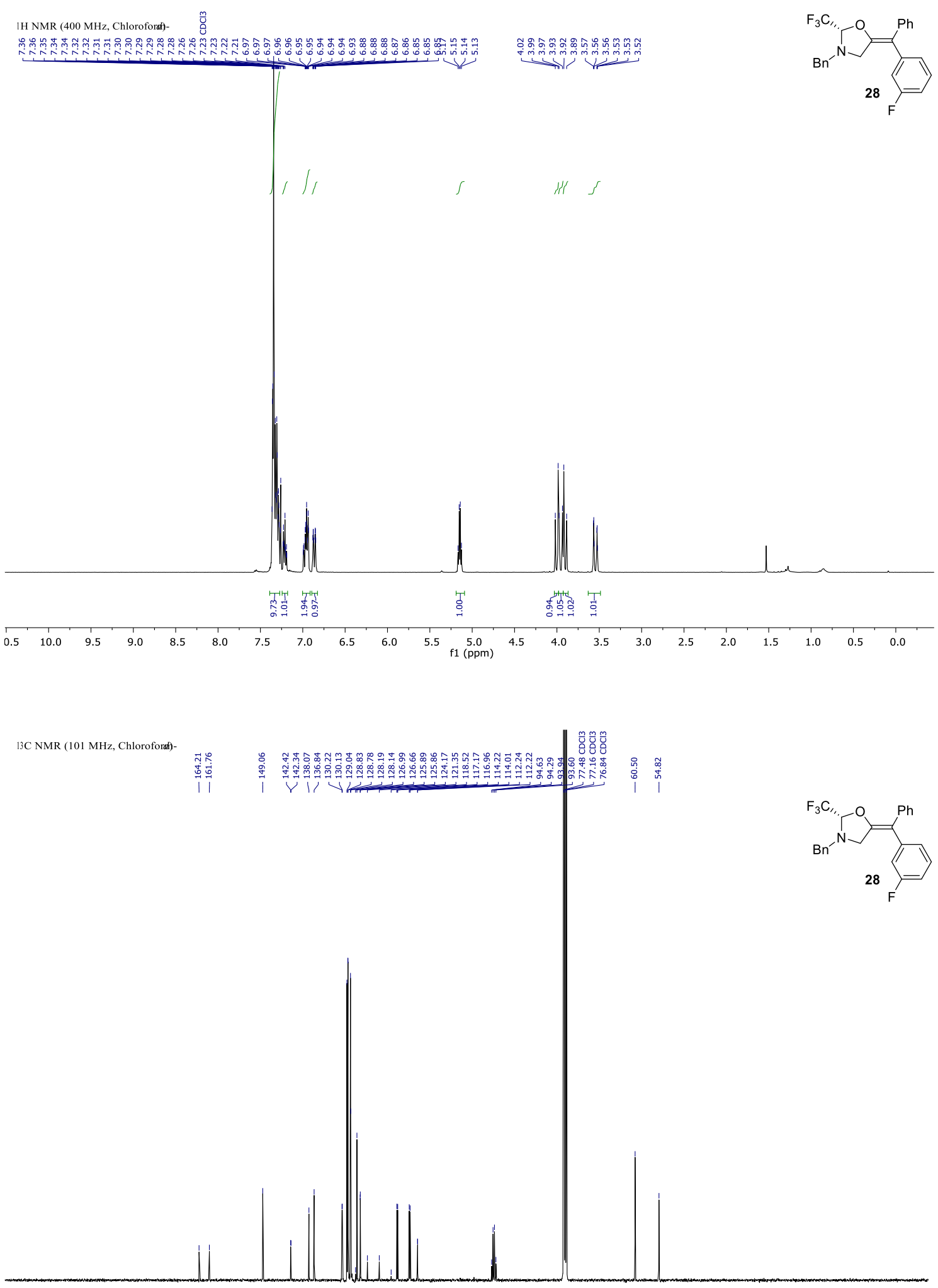

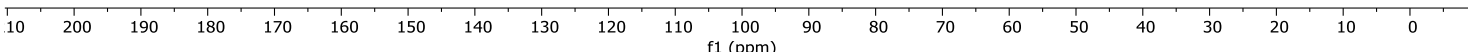




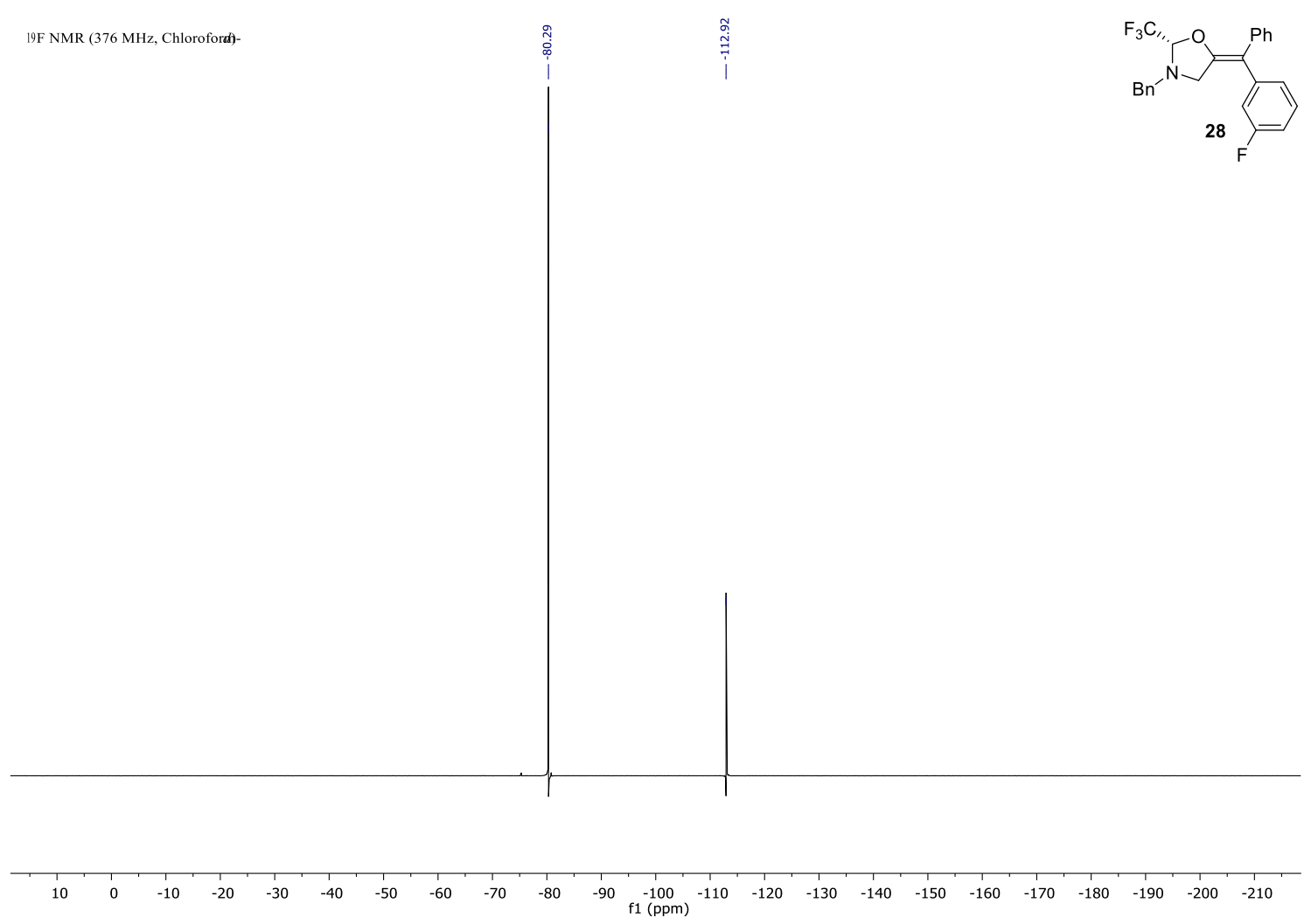

1H NMR (400 MHz, Chloroforad-

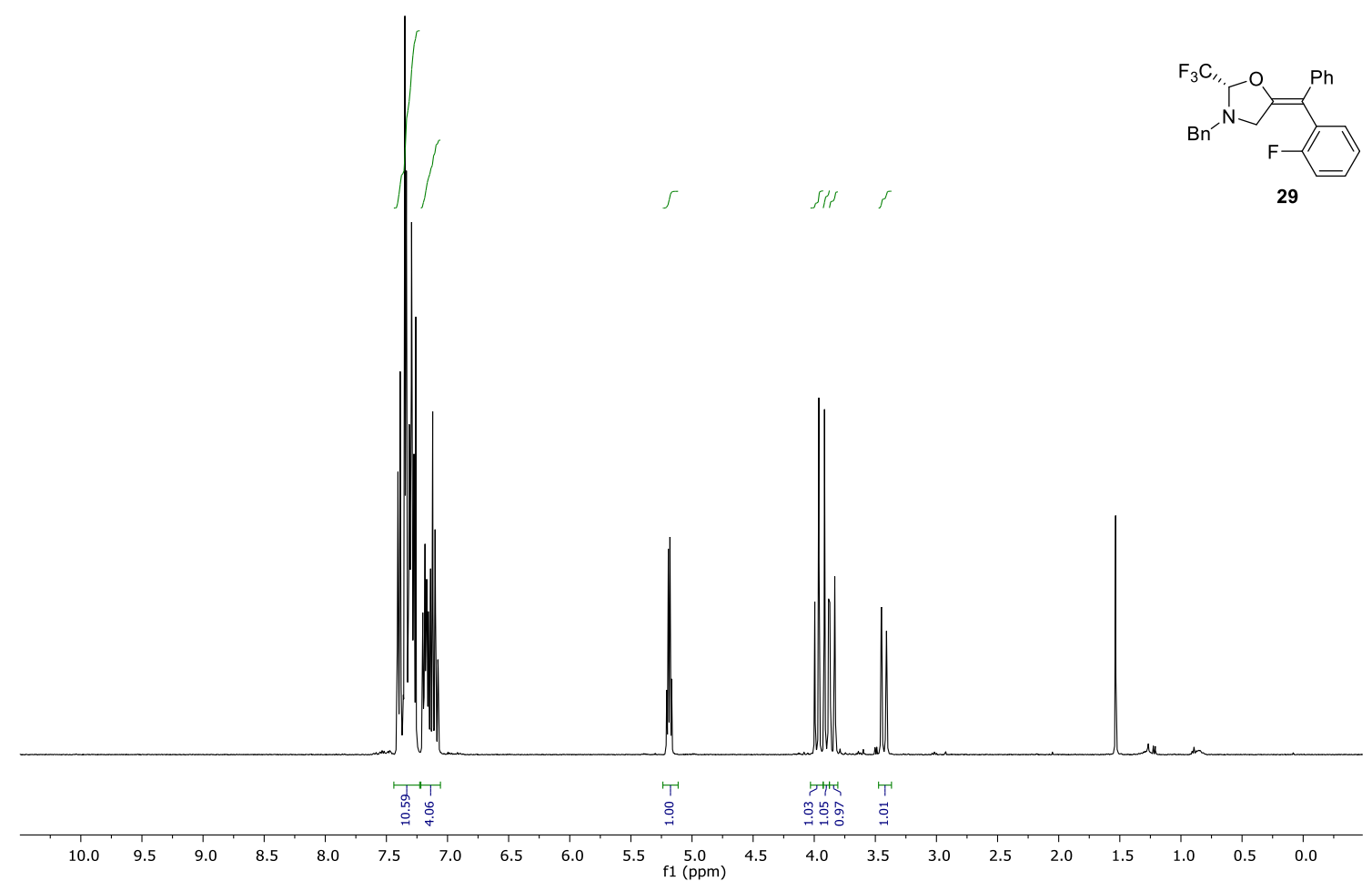



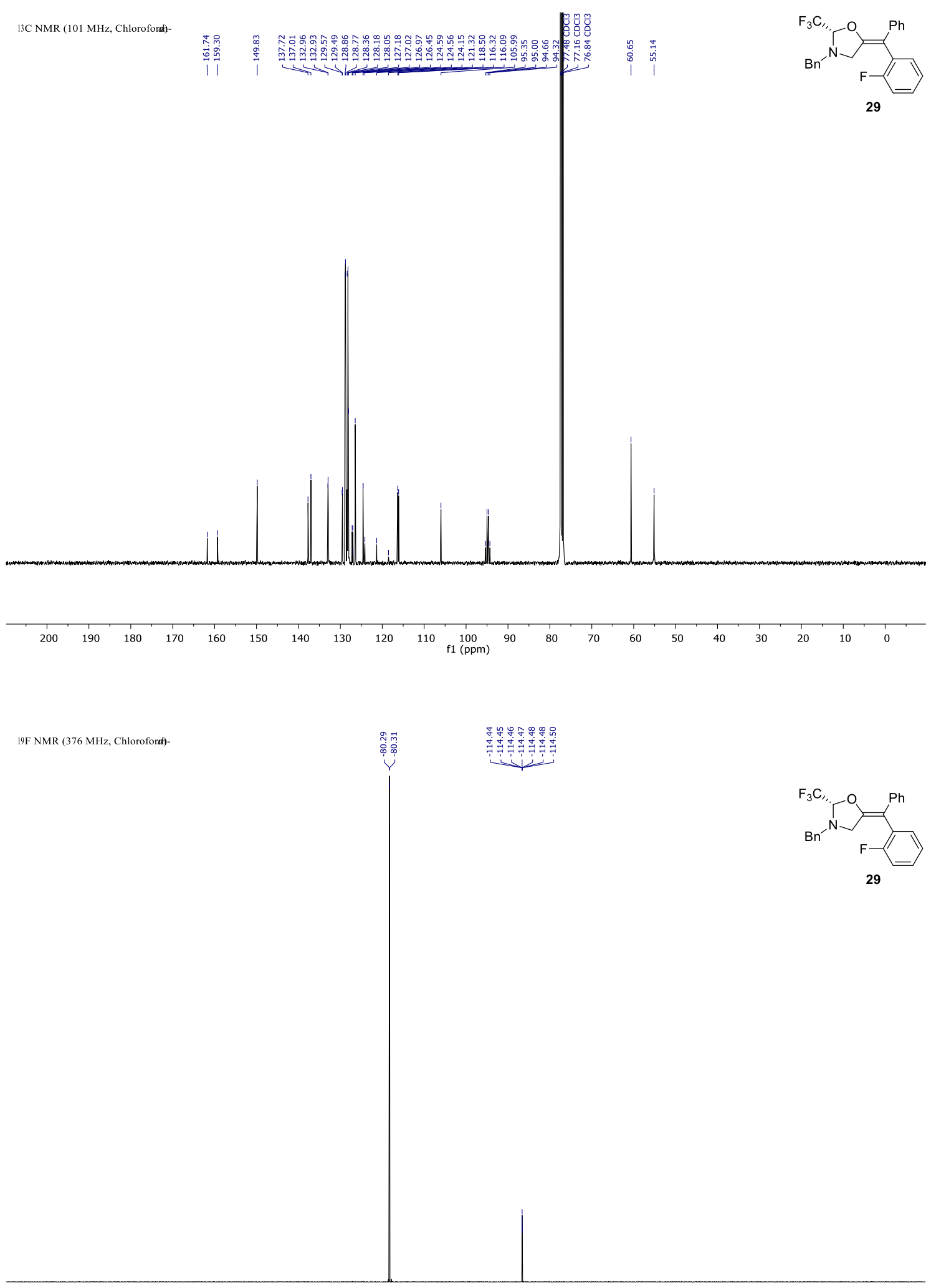

$\begin{array}{llllllllllllllllllllllllll}10 & 0 & -10 & -20 & -30 & -40 & -50 & -60 & -70 & -80 & -90 & -100 & -110 & -120 & -130 & -140 & -150 & -160 & -170 & -180 & -190 & -200 & -210\end{array}$ 

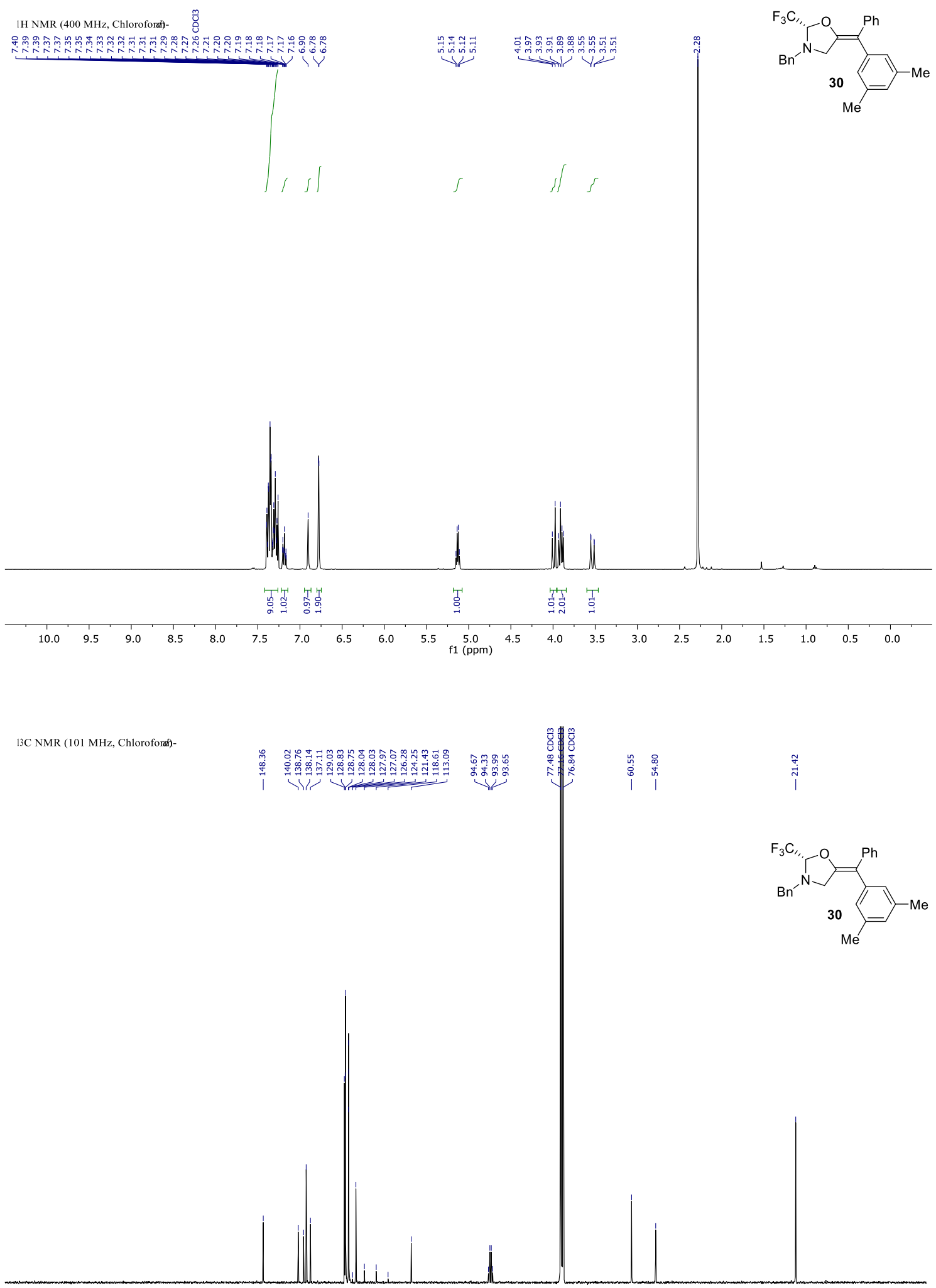

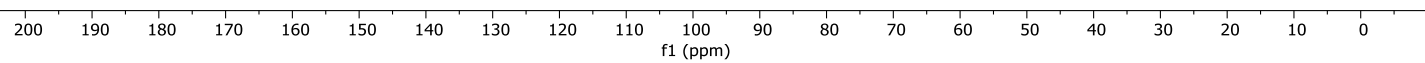




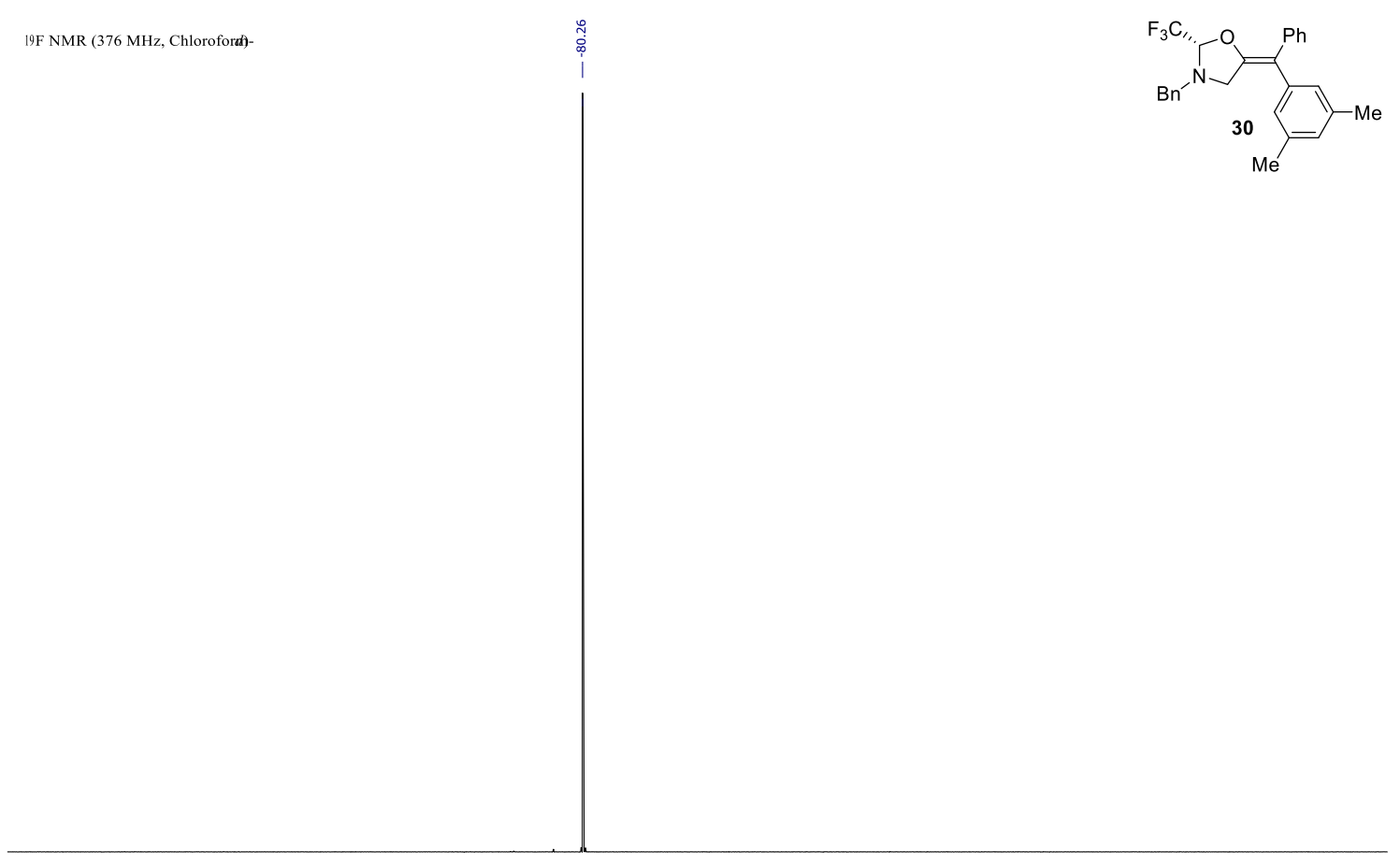

$\begin{array}{llllllllllllllllllllllll}1 & 0 & 0 & -10 & -20 & -30 & -40 & -50 & -60 & -70 & -80 & -90 & -100 & -110 & -120 & -130 & -140 & -150 & -160 & -170 & -180 & -190 & -200 & -210\end{array}$

1H NMR (400 MHz, Chloroforde-

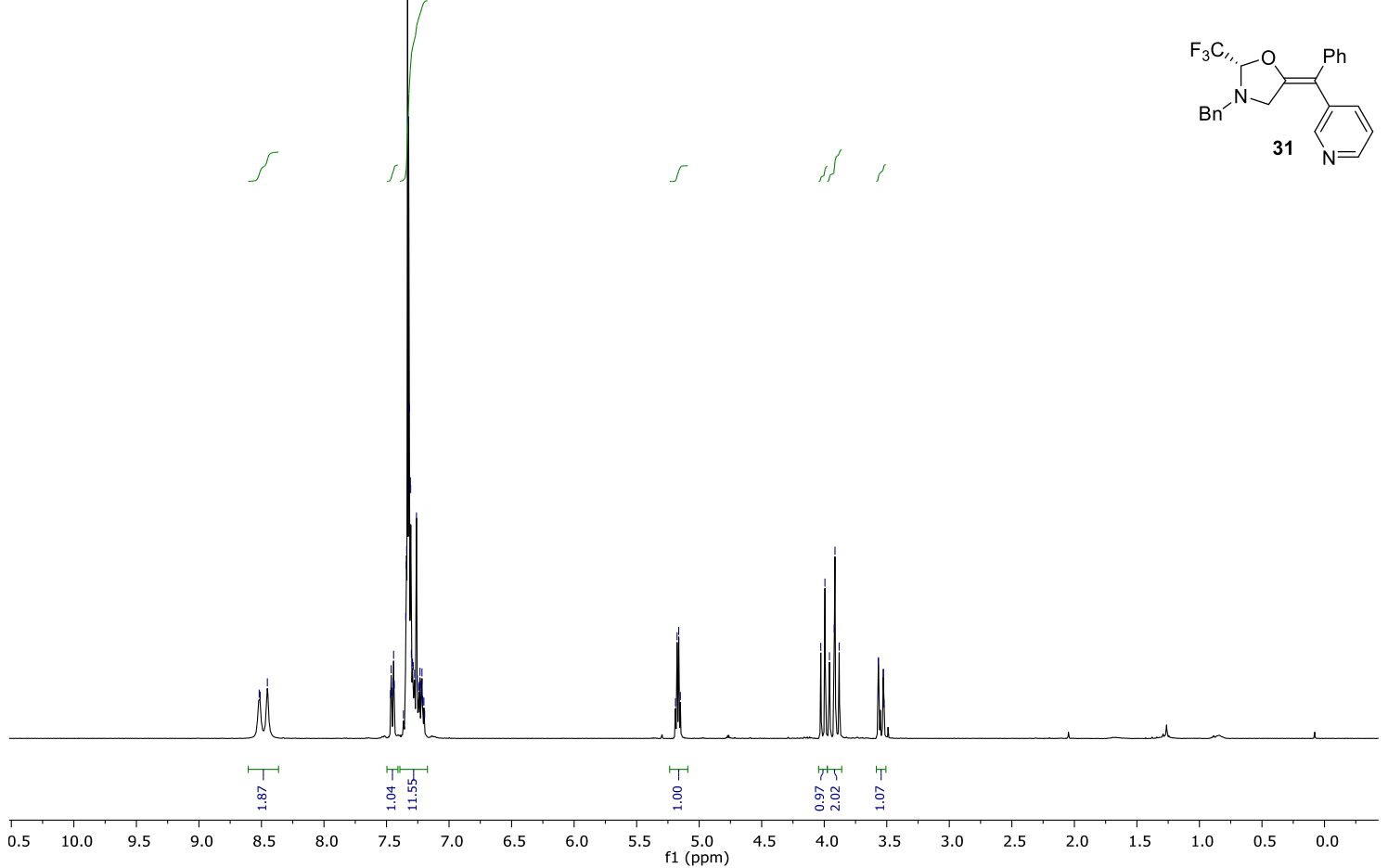




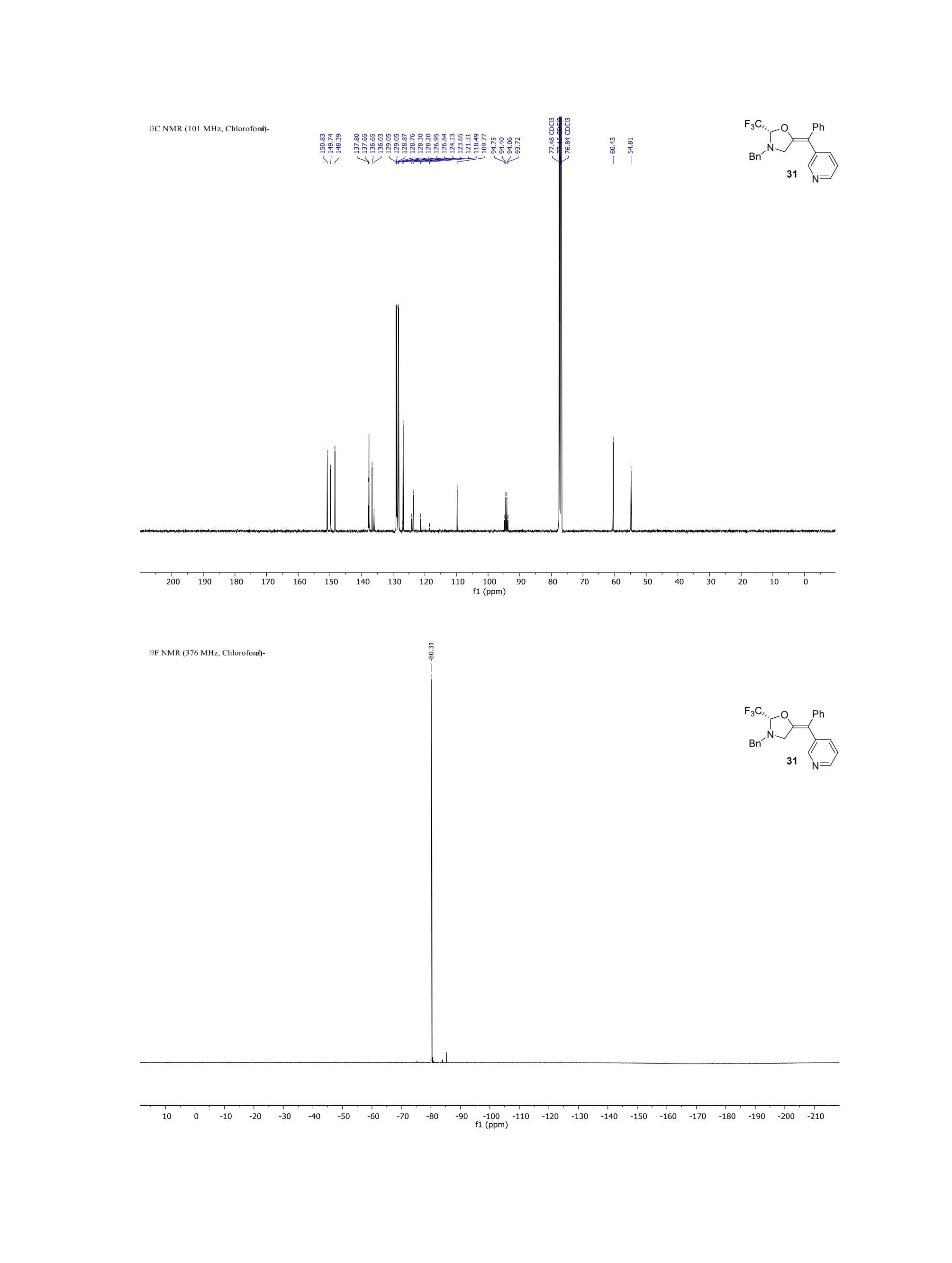



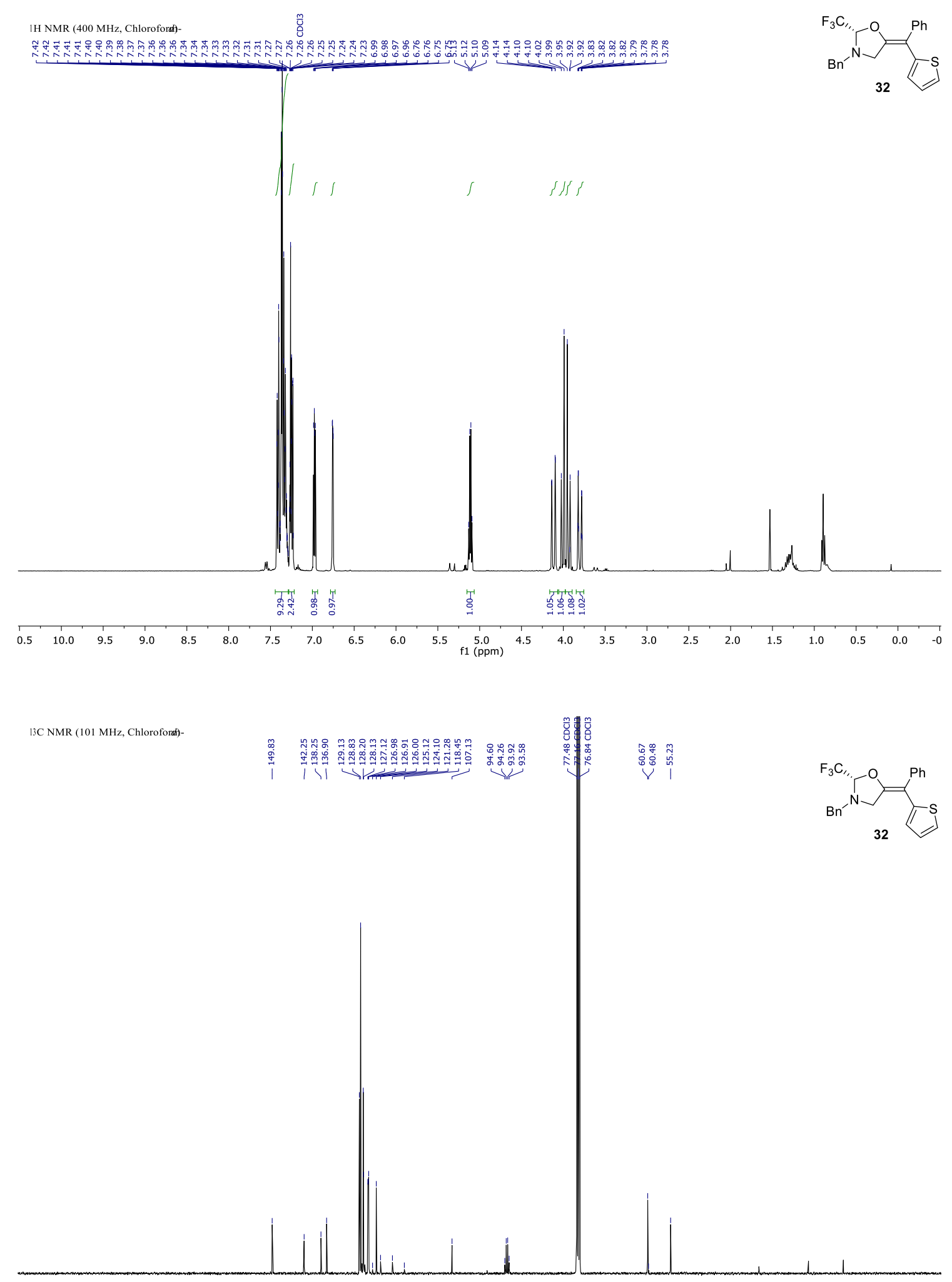

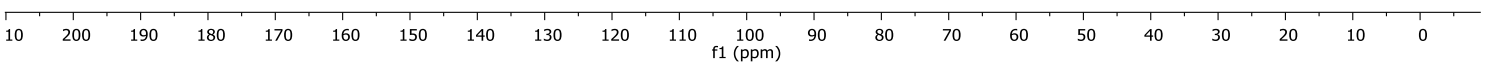



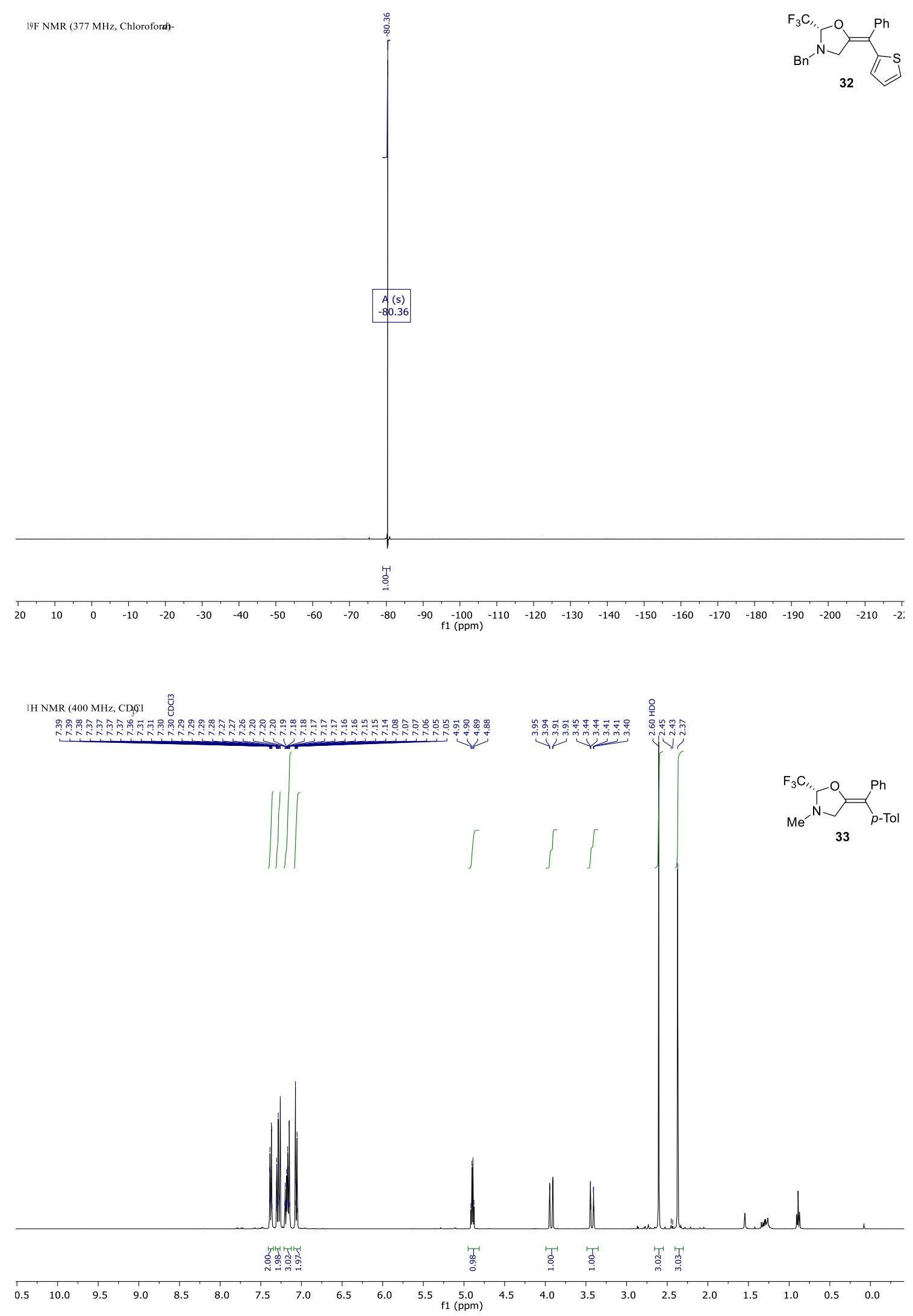


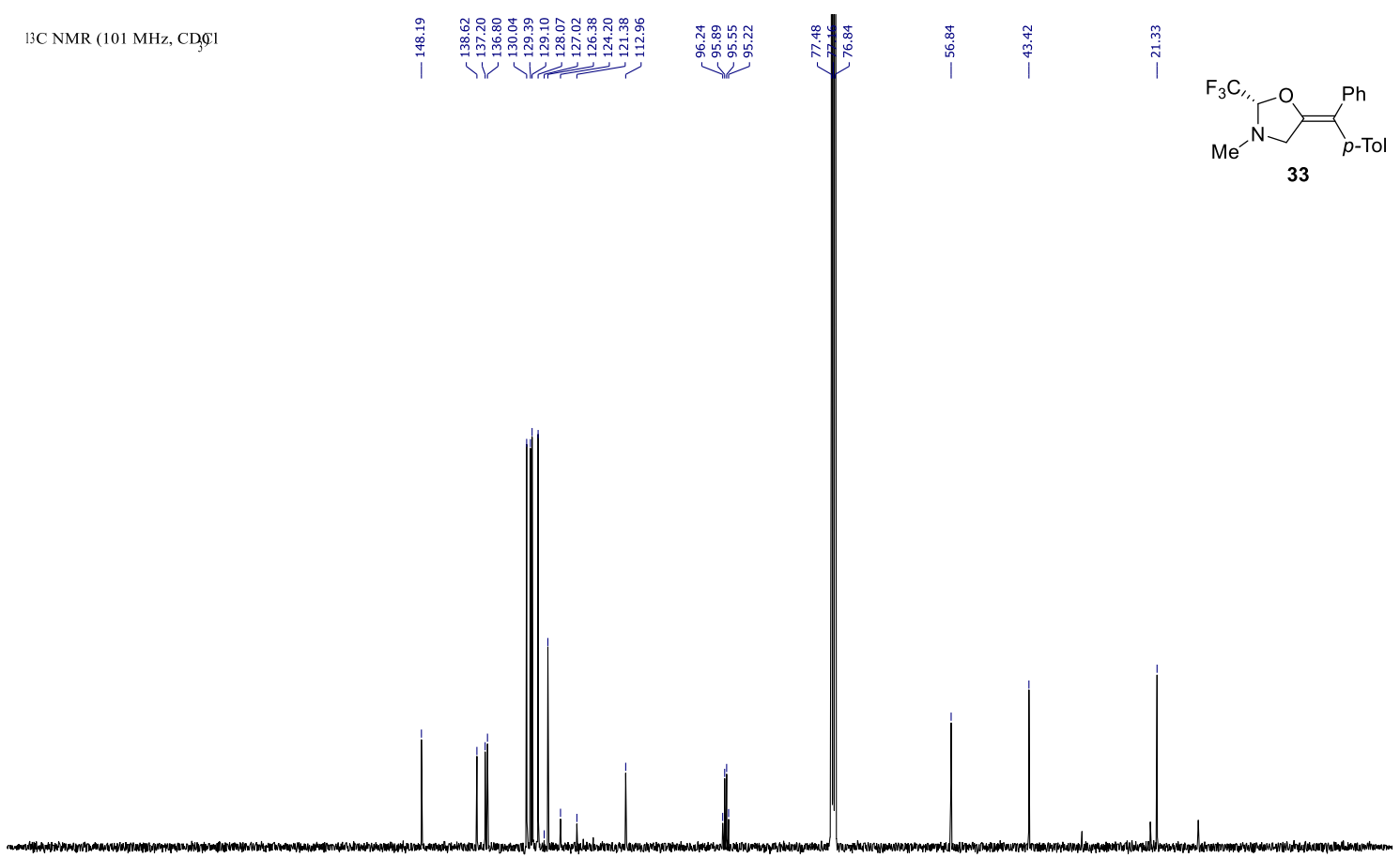

19F NMR (376 MHz, $\mathrm{CD}_{3} 91$
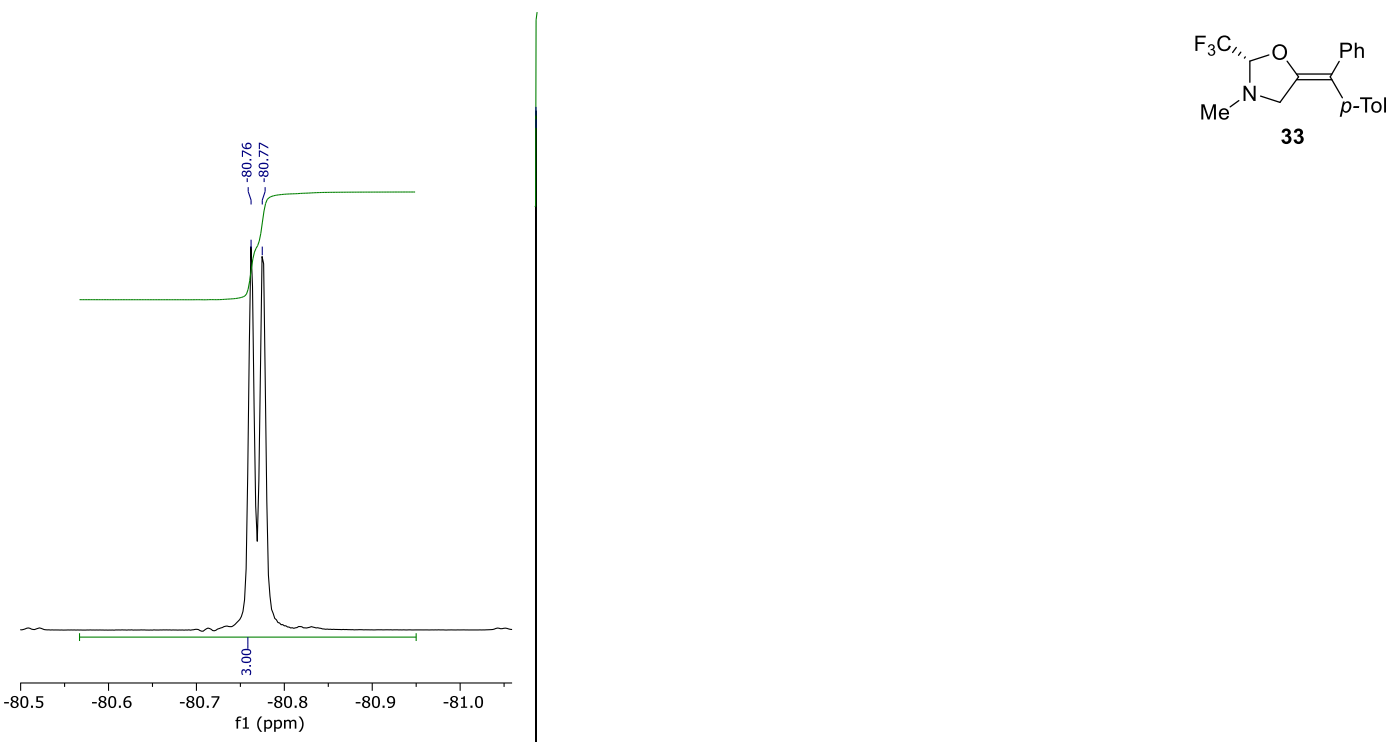

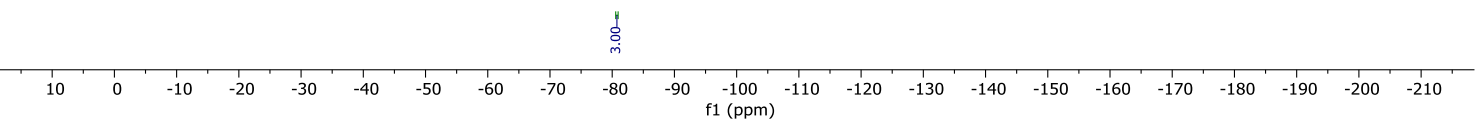



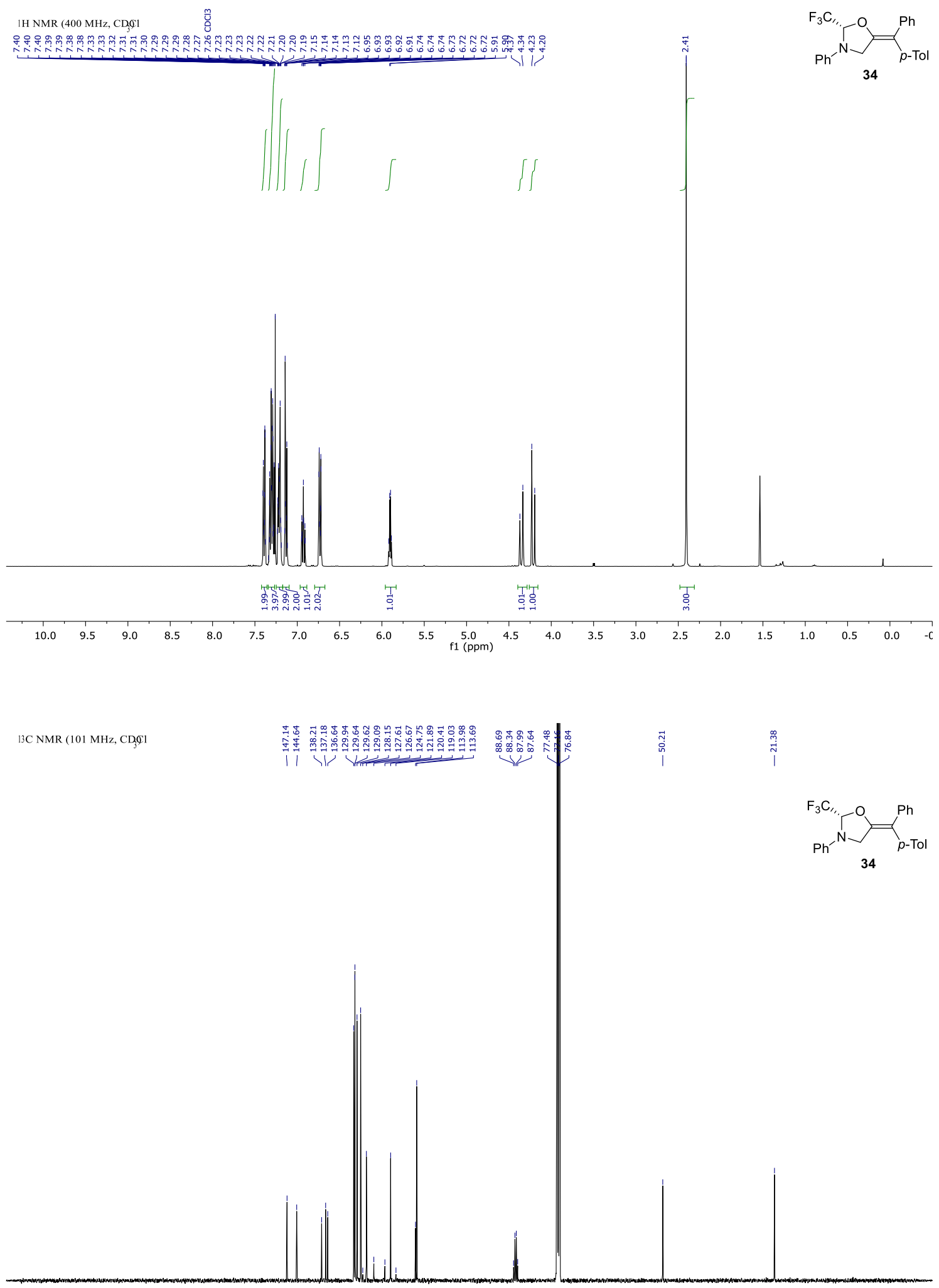

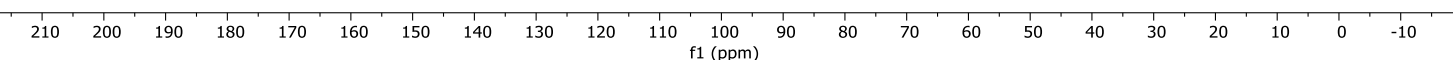


19F NMR (376 MHz, $\mathrm{CD}_{3}$ \%1

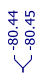

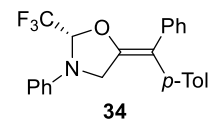

势竞
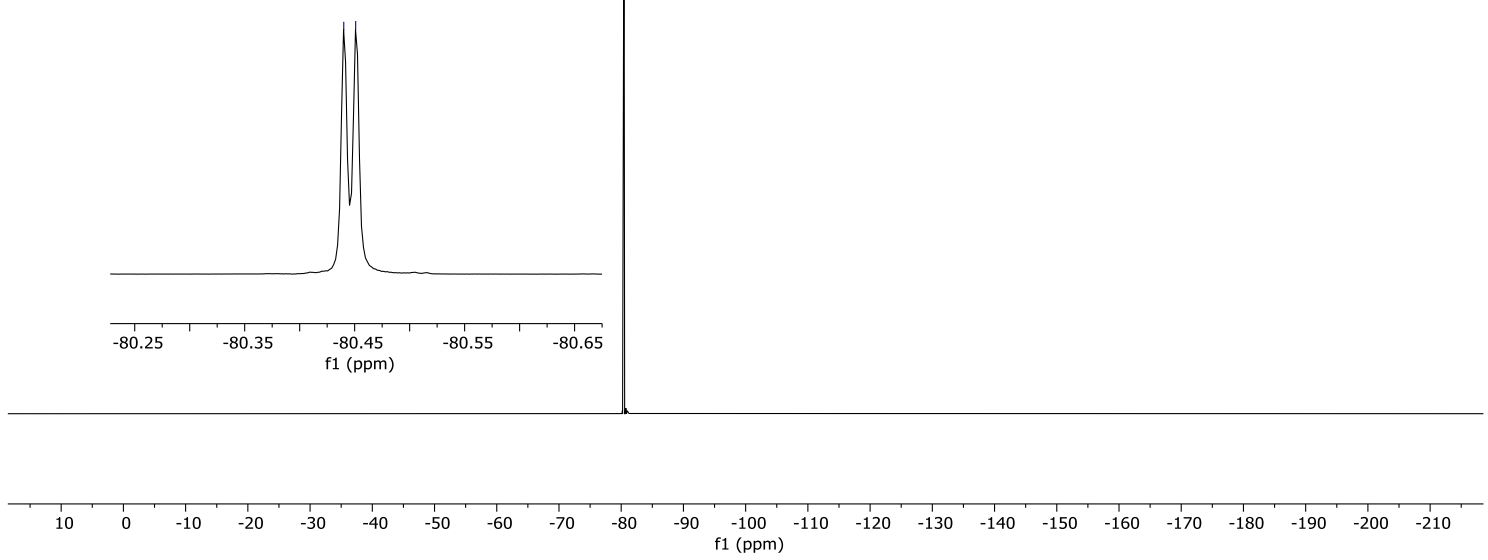

1H NMR (400 MHz, Chloroforda)-

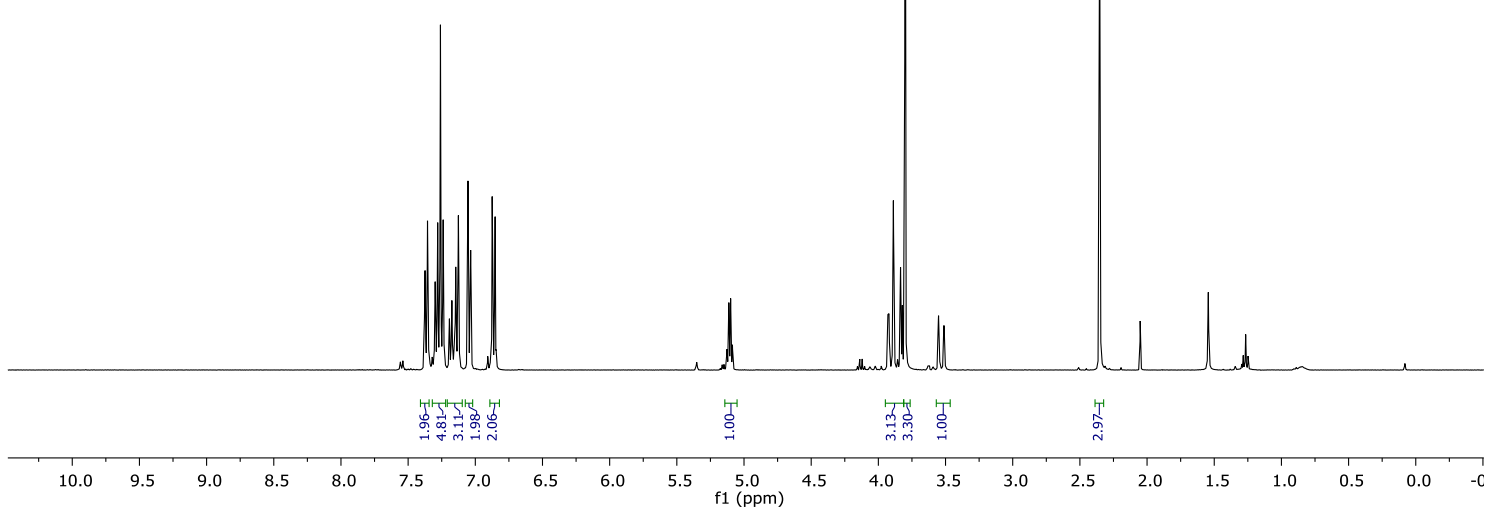

S104 


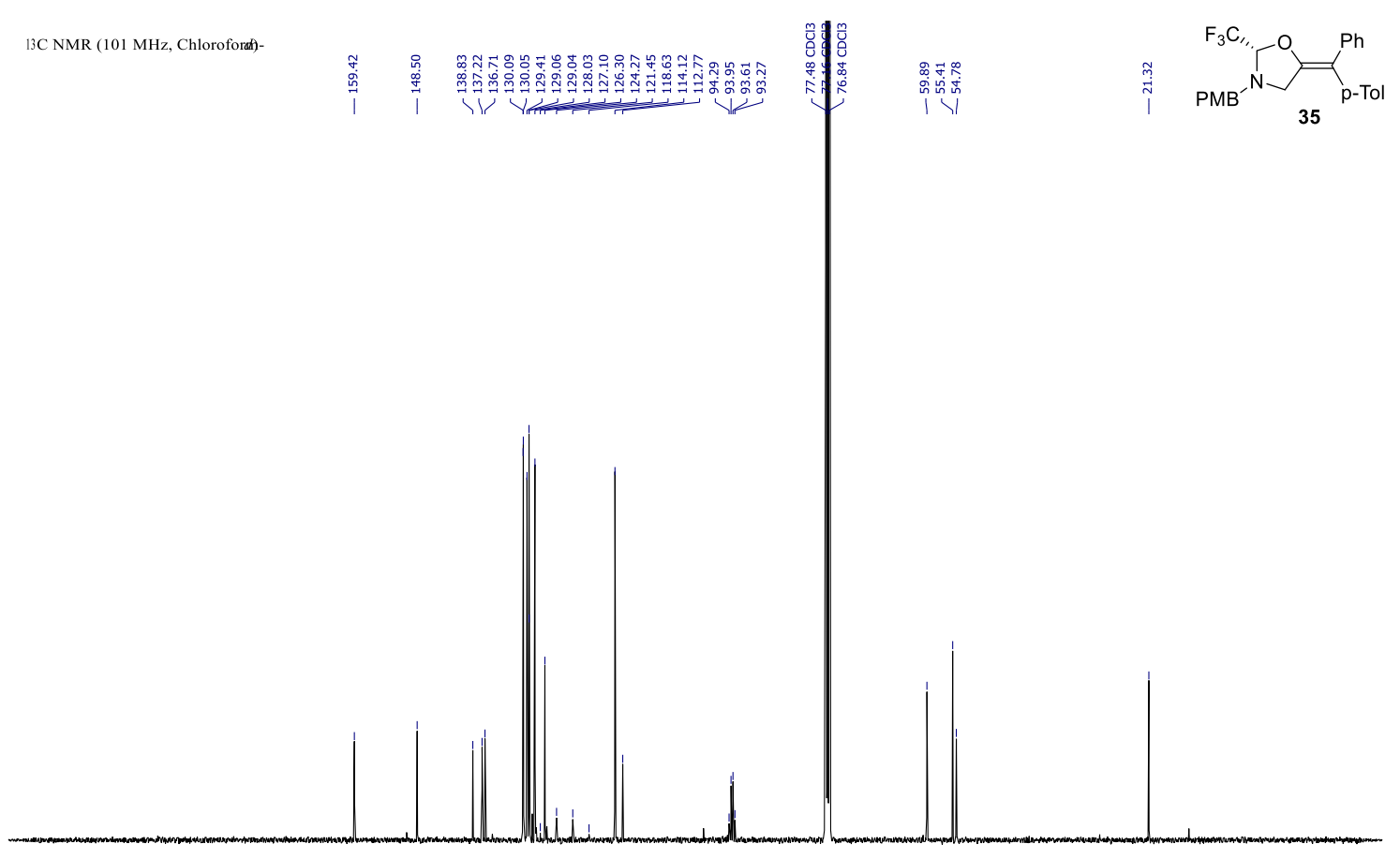

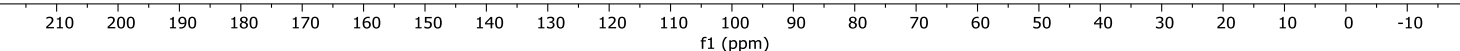

19F NMR (376 MHz, Chloroford)-

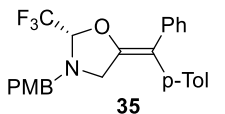

$\begin{array}{llllllllllllllllllllllll}10 & 0 & -10 & -20 & -30 & -40 & -50 & -60 & -70 & -80 & -90 & -100 & -110 & -120 & -130 & -140 & -150 & -160 & -170 & -180 & -190 & -200 & -210\end{array}$ 


\section{H.3. Asymmetric Hydrogenation Products}

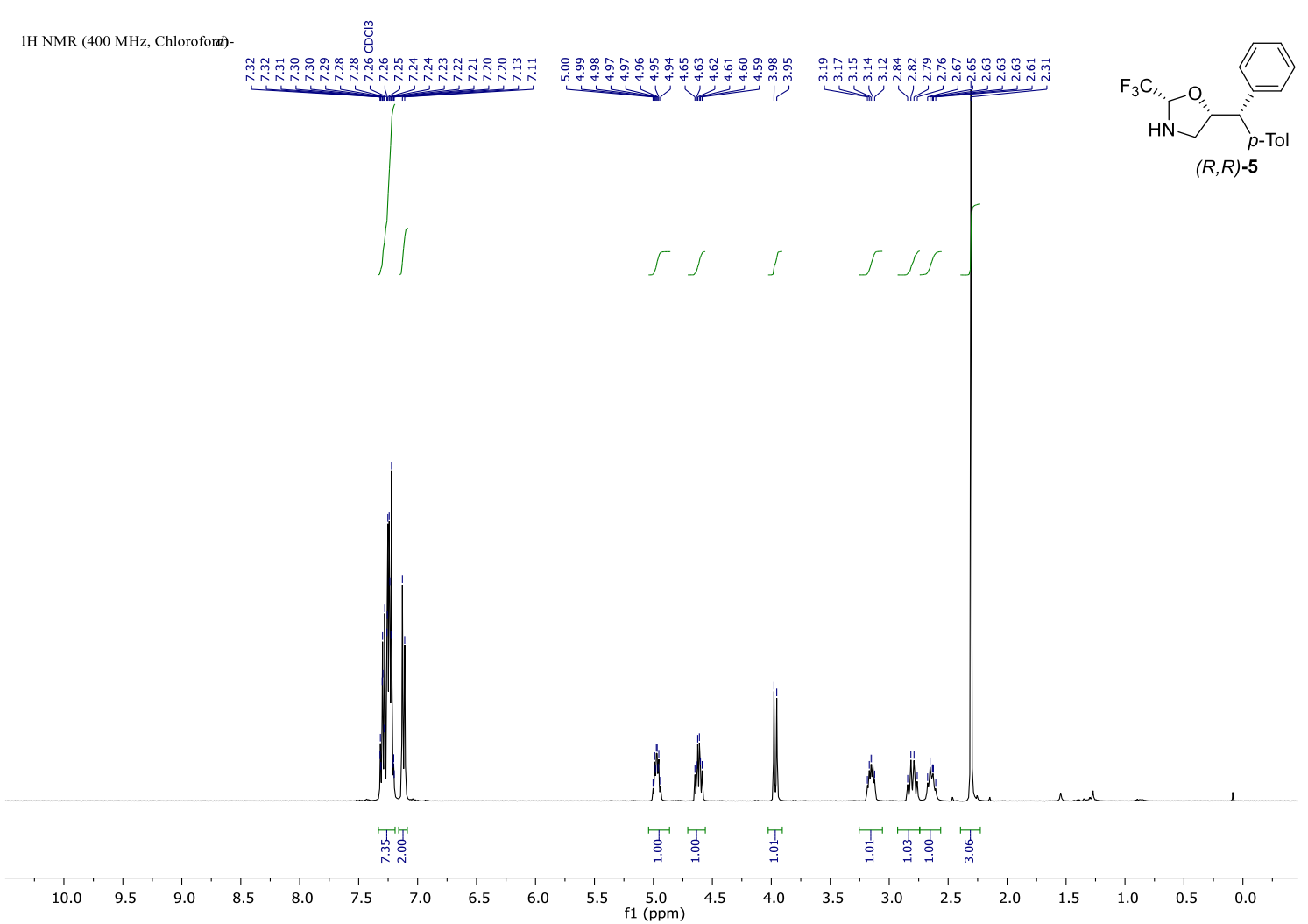

13C NMR (101 MHz, Chloroforat)-

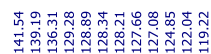

年

1114
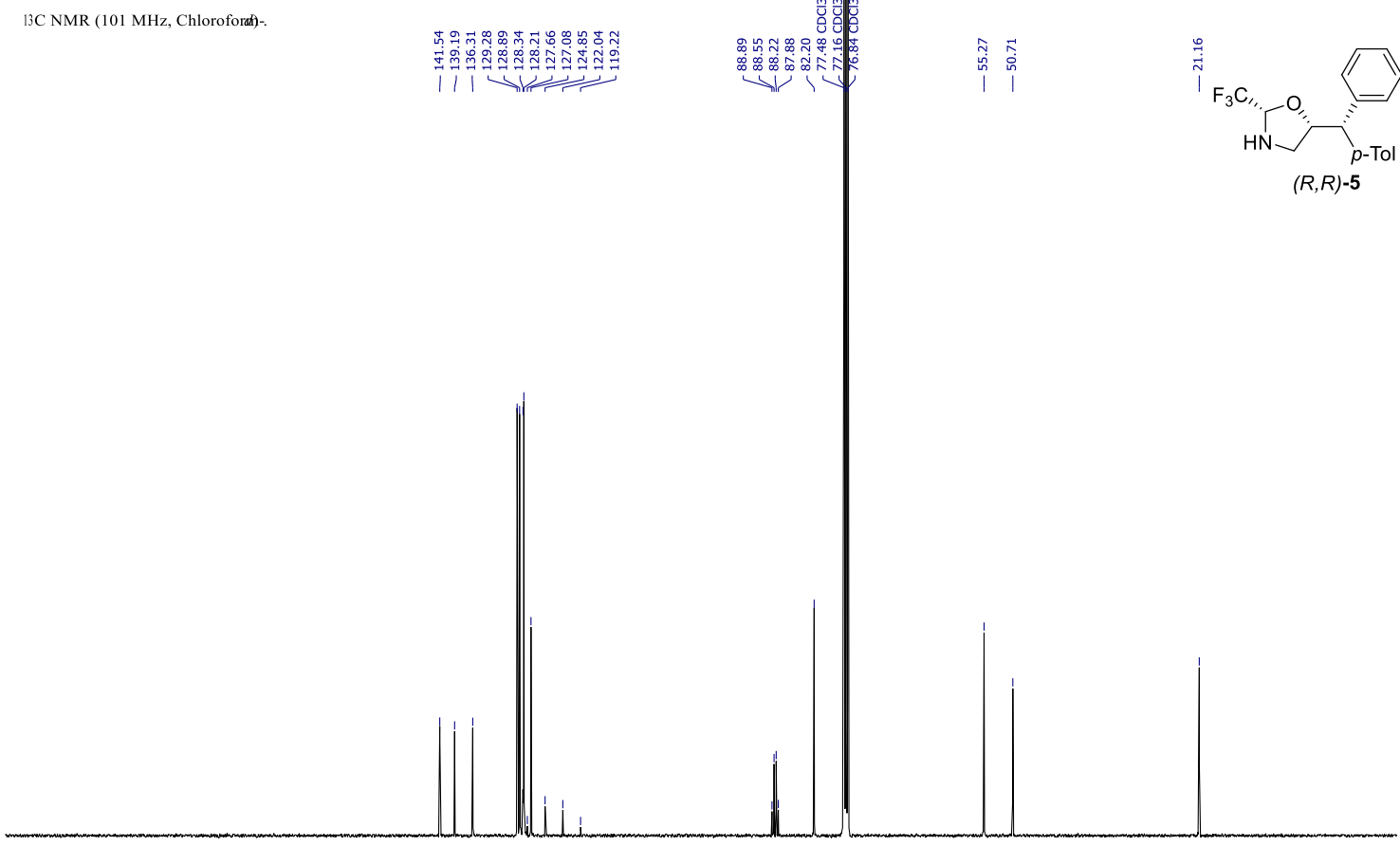

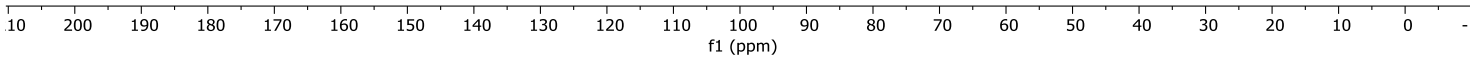




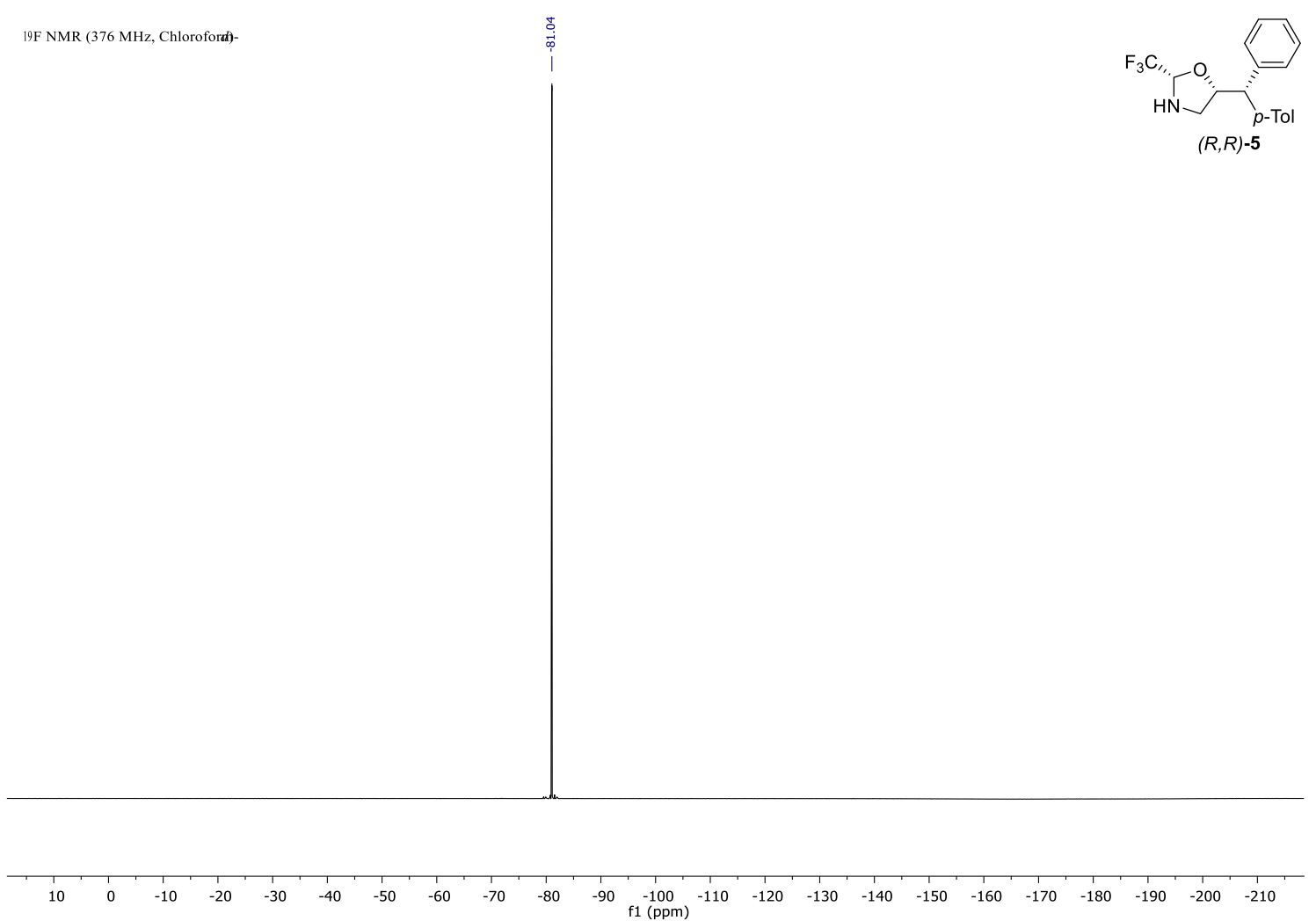

1H NMR (400 MHz, Chloroford-

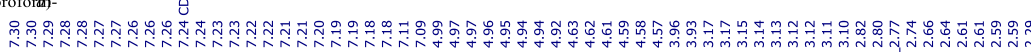
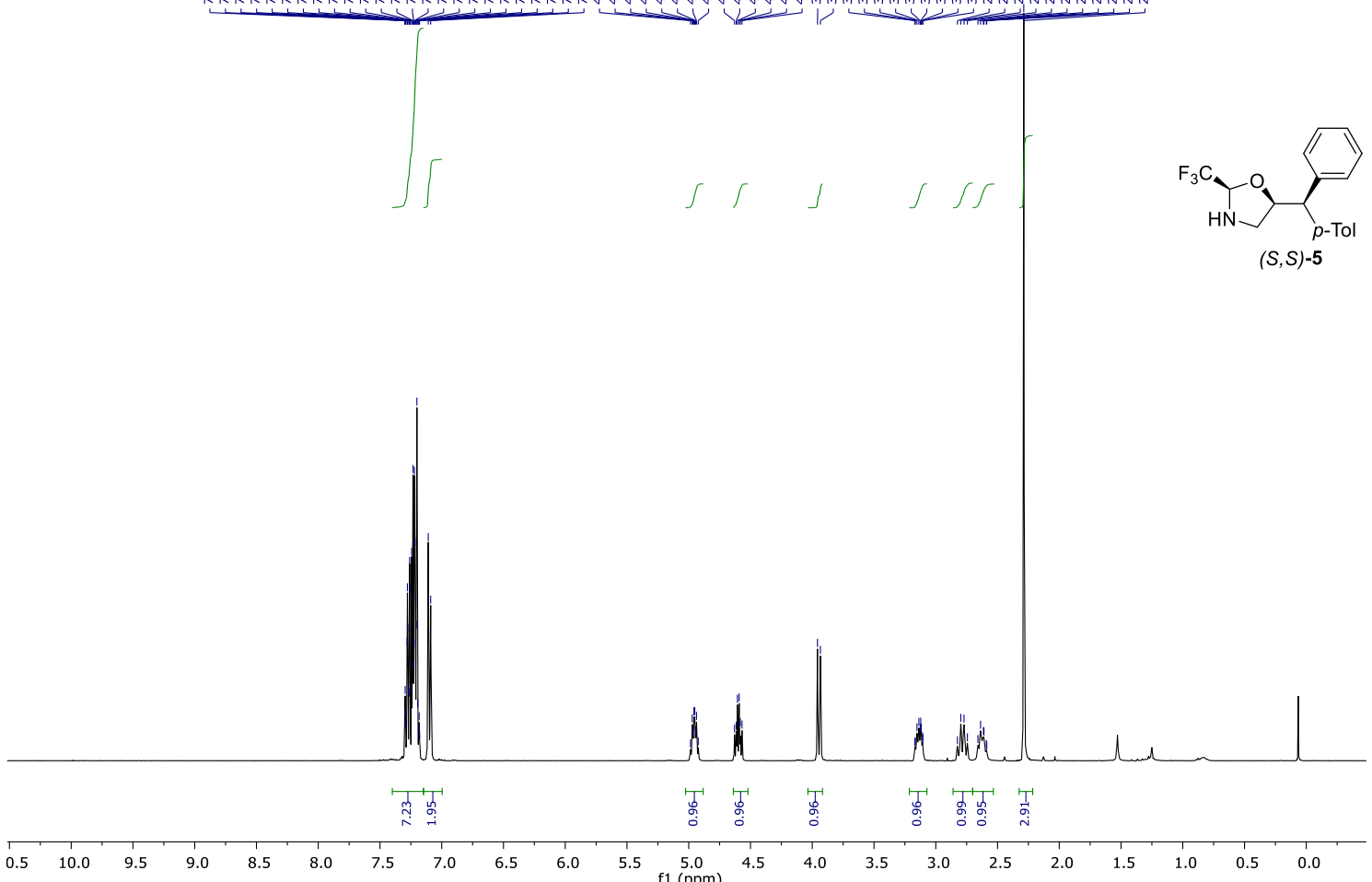


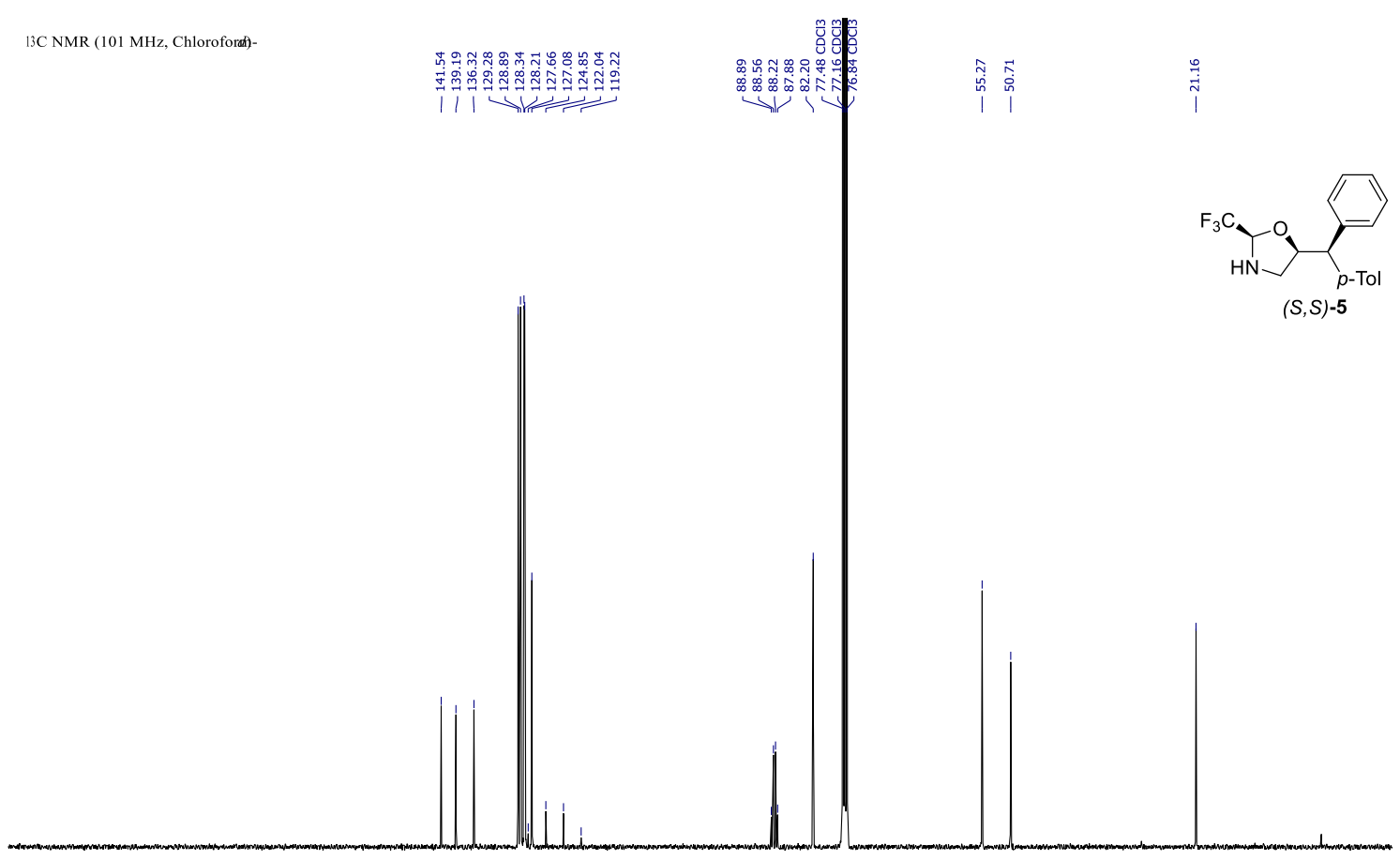

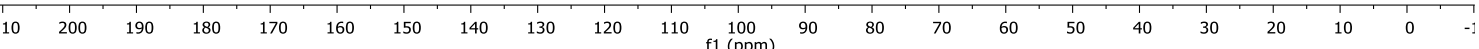

19F NMR (376 MHz, Chloroford)-

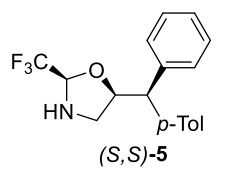

$\begin{array}{lllllllllllllllllllllllll}10 & 0 & -10 & -20 & -30 & -40 & -50 & -60 & -70 & -80 & -90 & -100 & -110 & -120 & -130 & -140 & -150 & -160 & -170 & -180 & -190 & -200 & -210\end{array}$ 


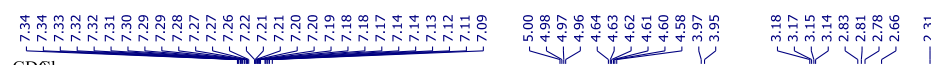

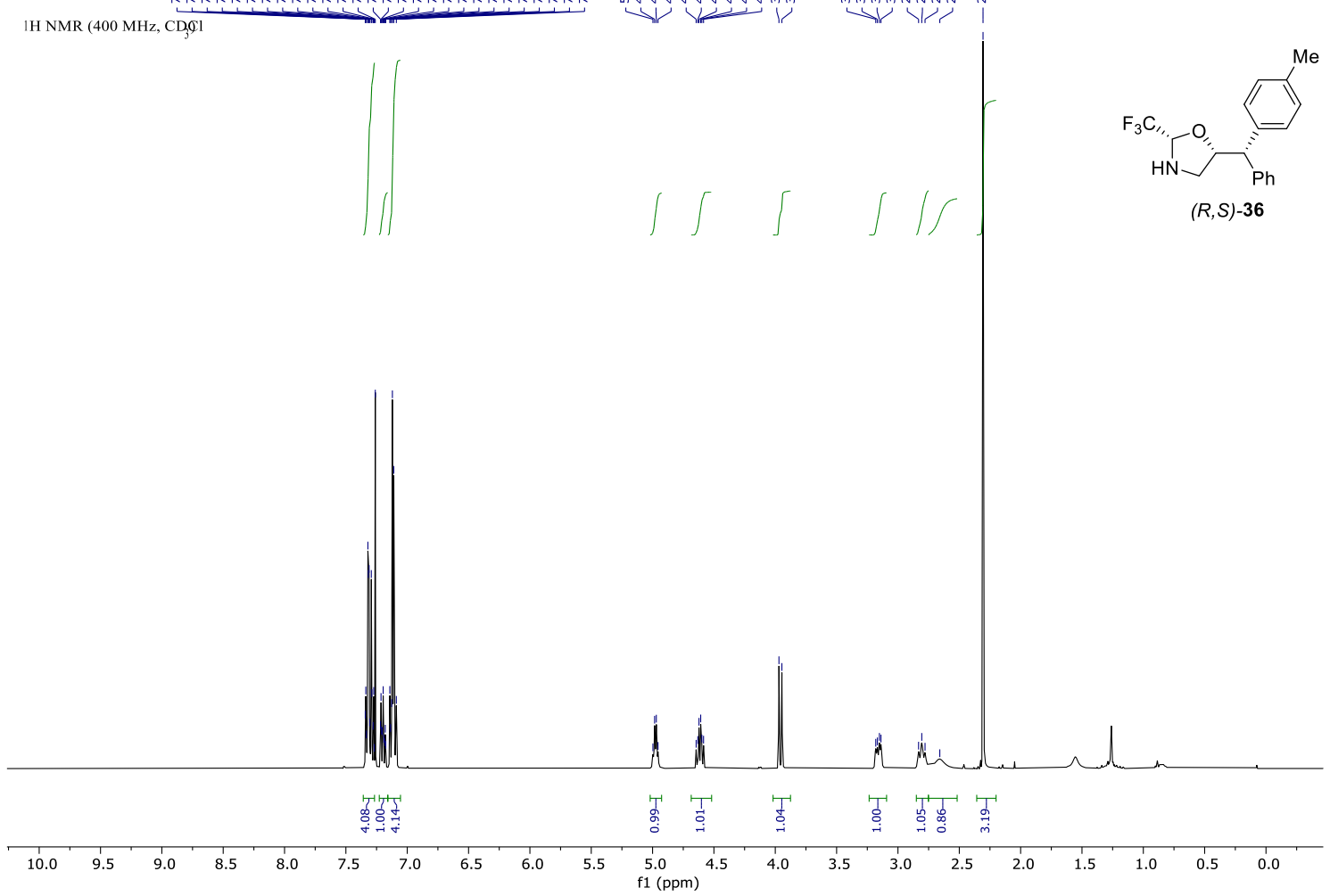

$13 \mathrm{C} \mathrm{NMR} \mathrm{(101} \mathrm{MHz,} \mathrm{CDQB}$

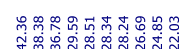

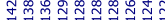

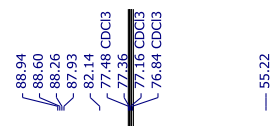

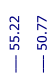
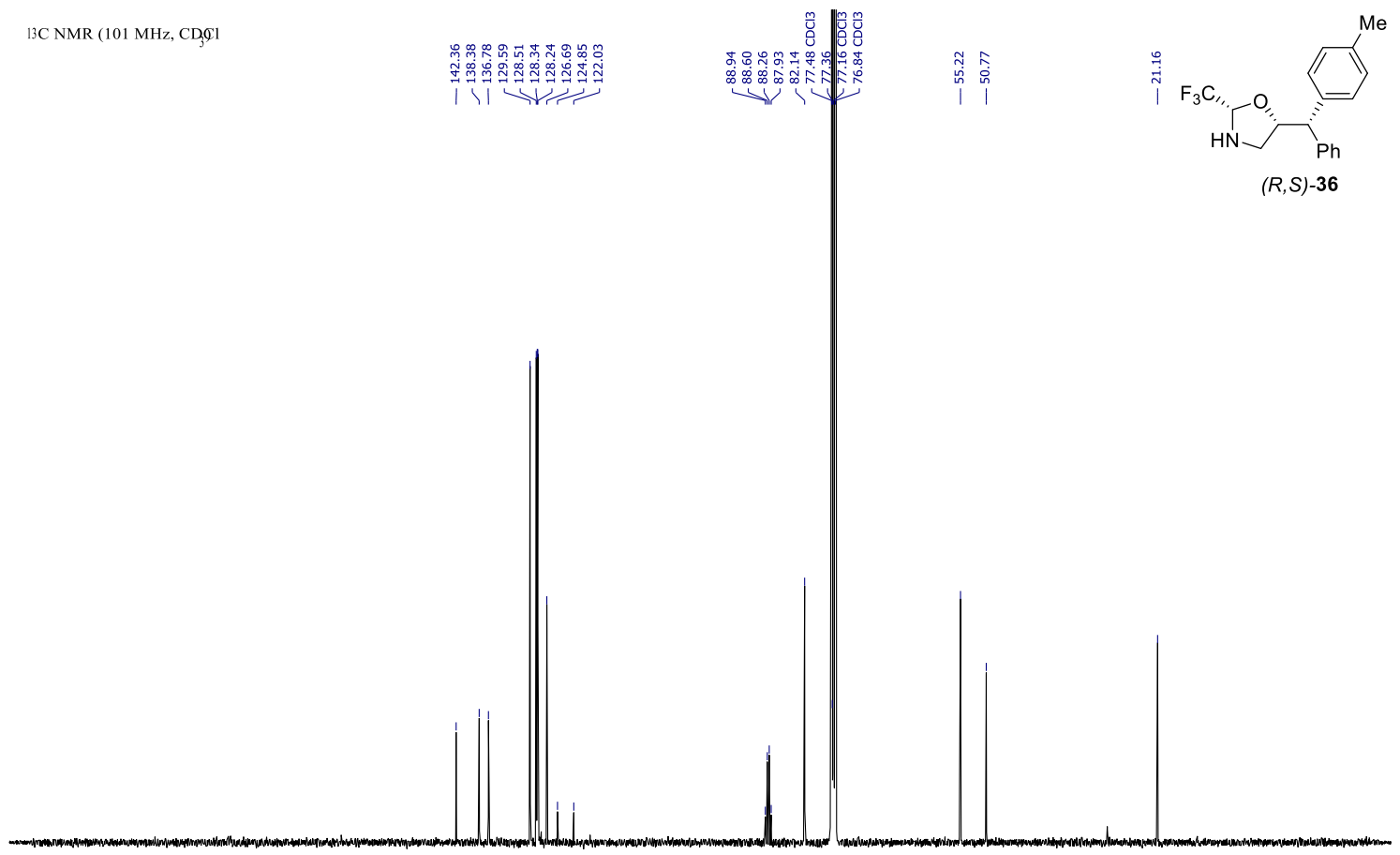

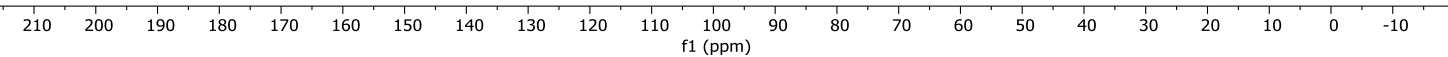



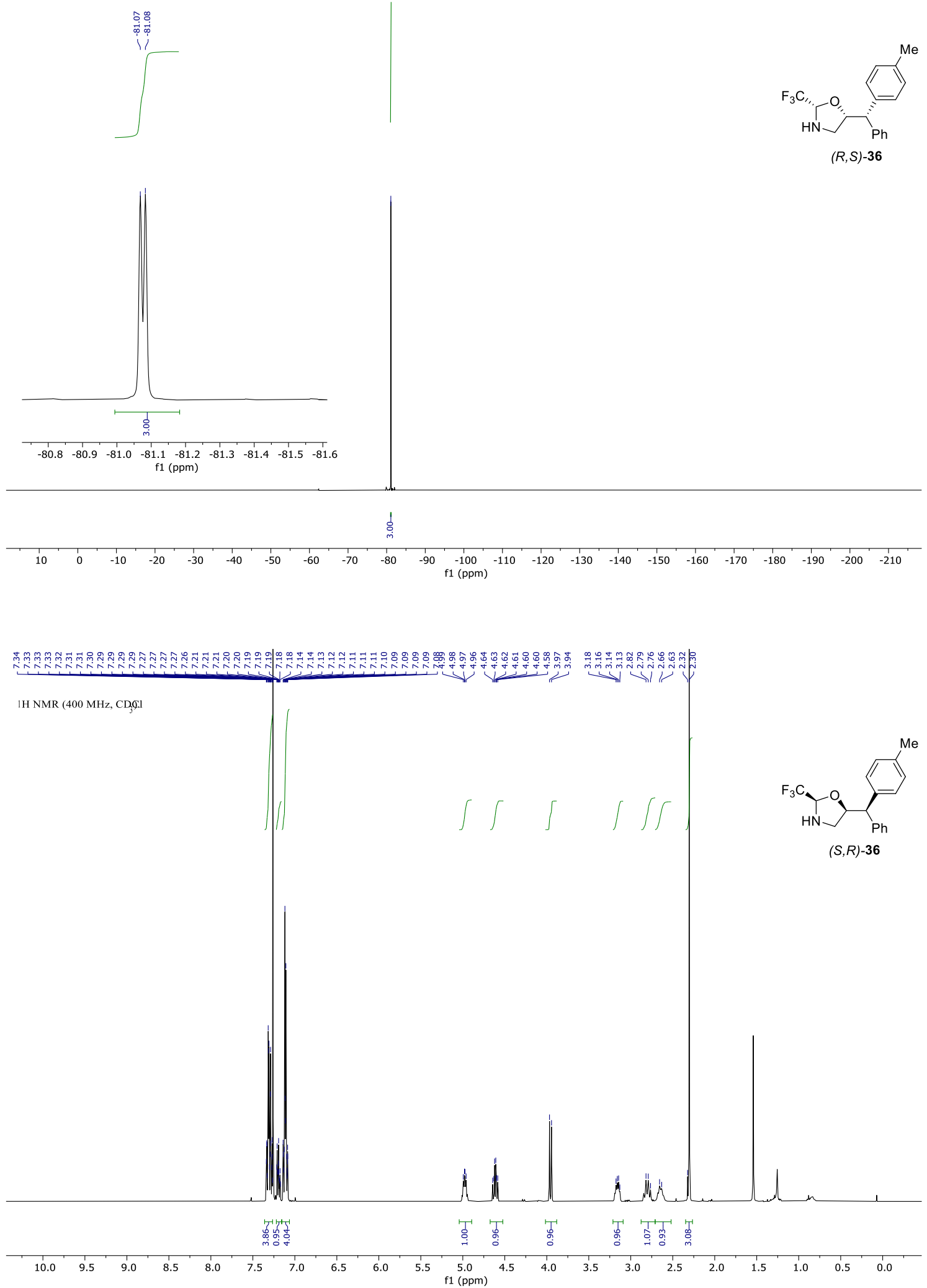

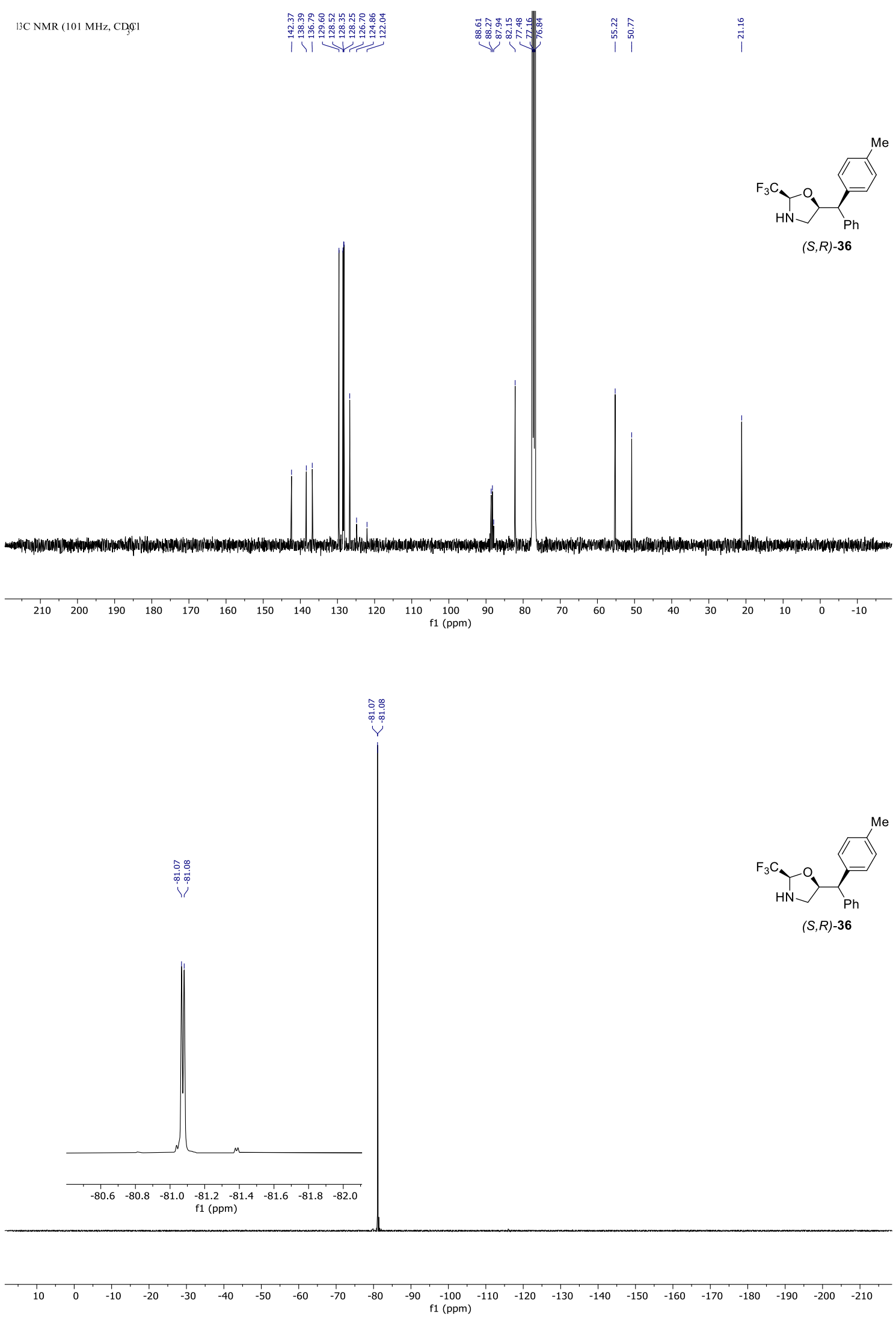


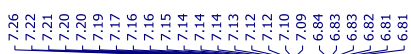

IH NMR (400 MHz, CDQ9l

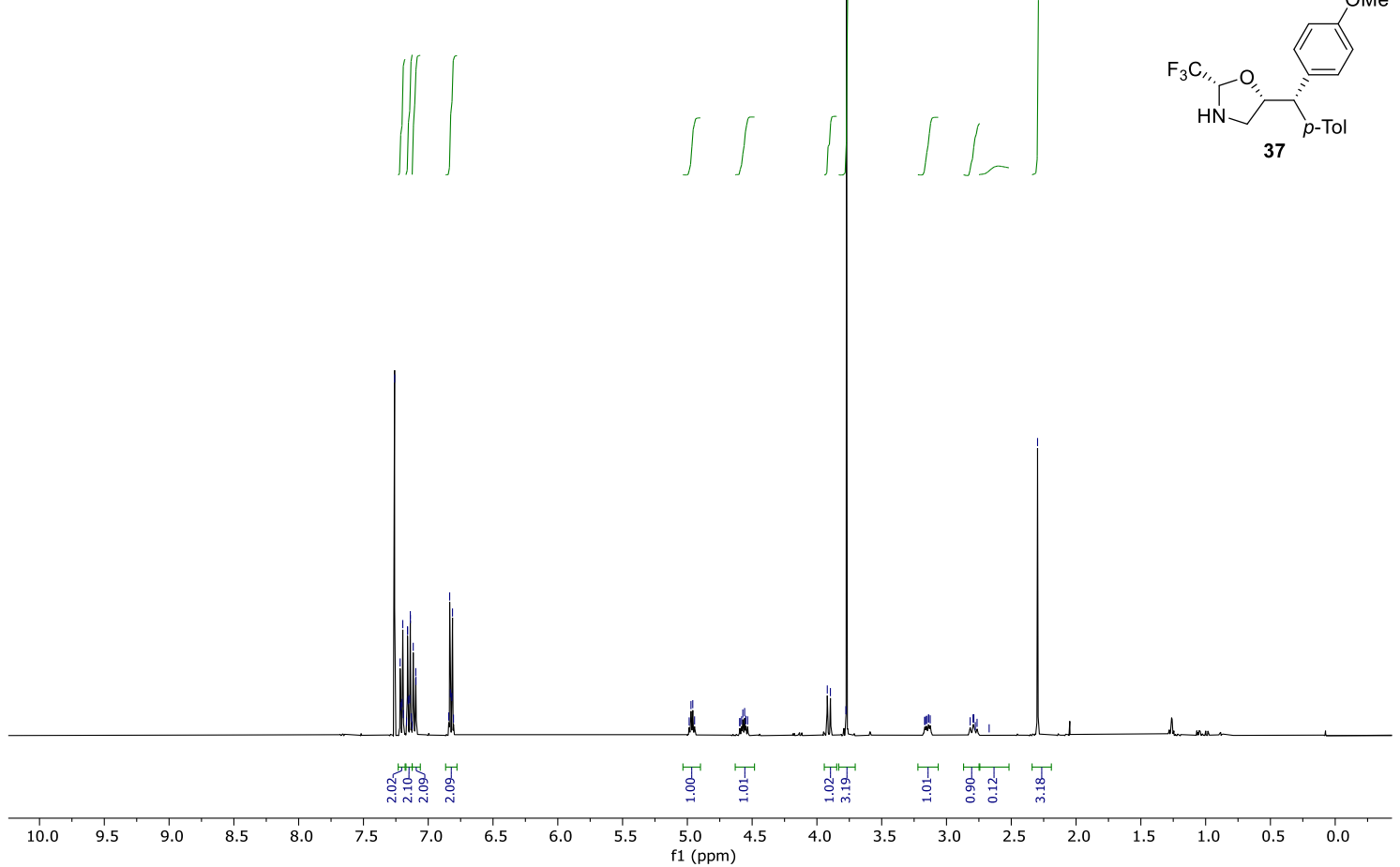

13. NMR (101 MHz, CD, 91
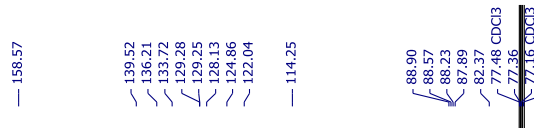

com

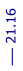

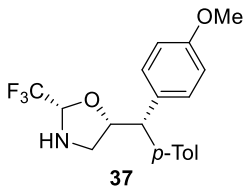

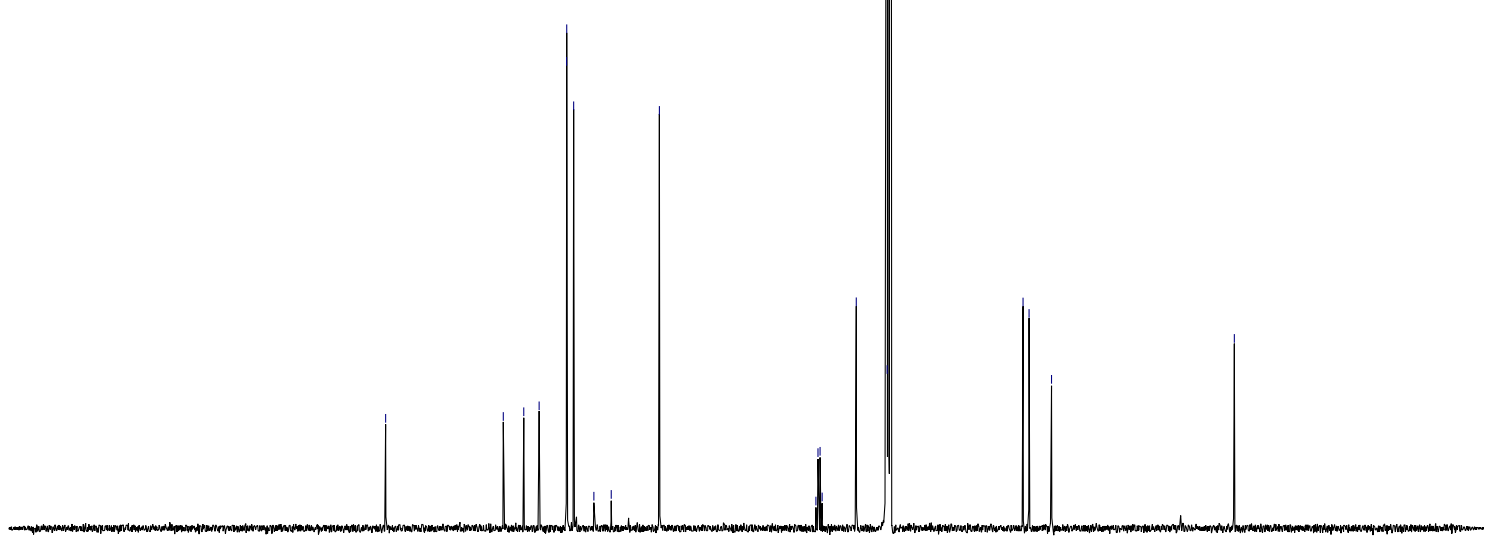

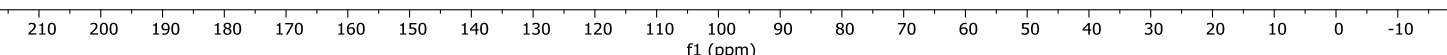



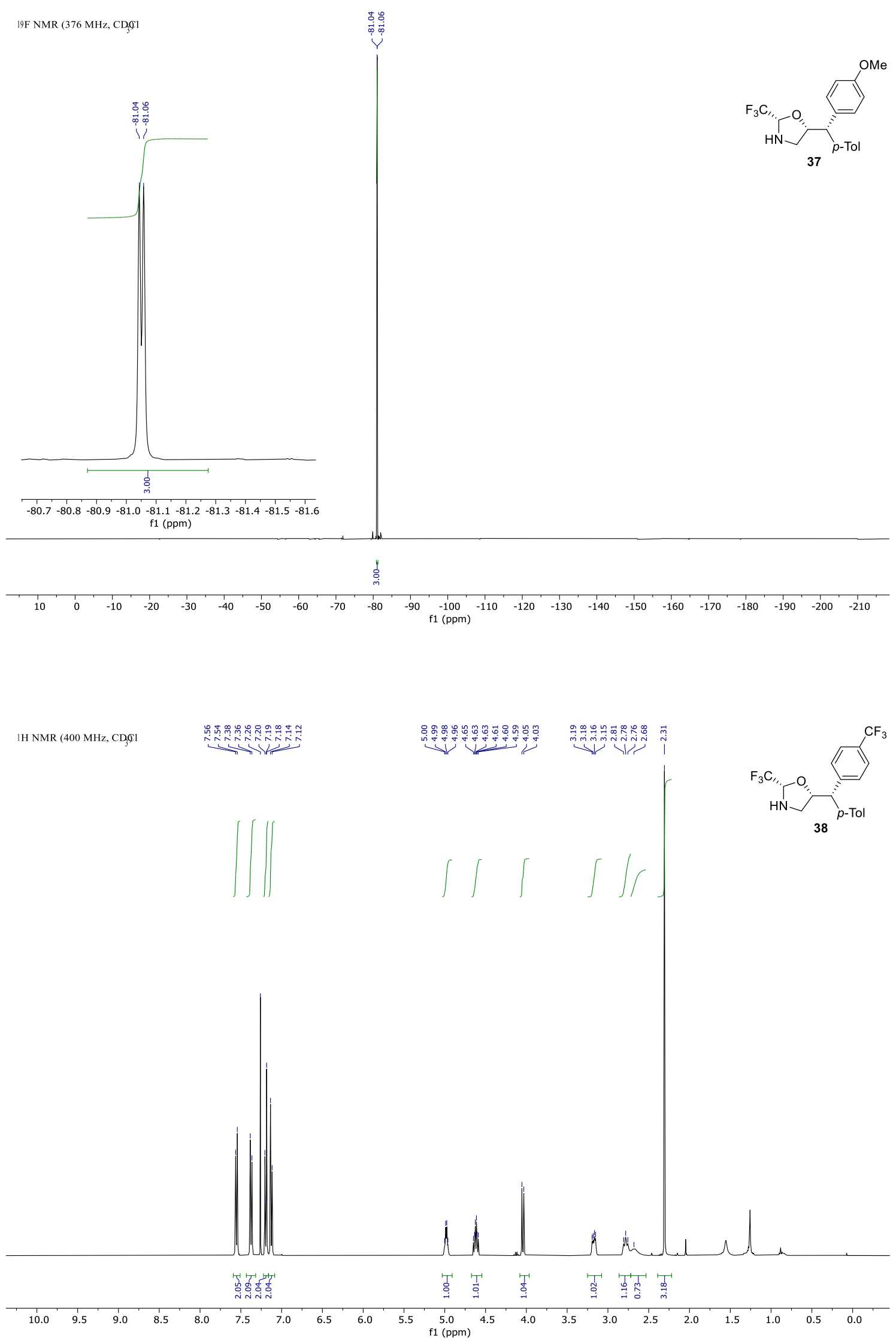


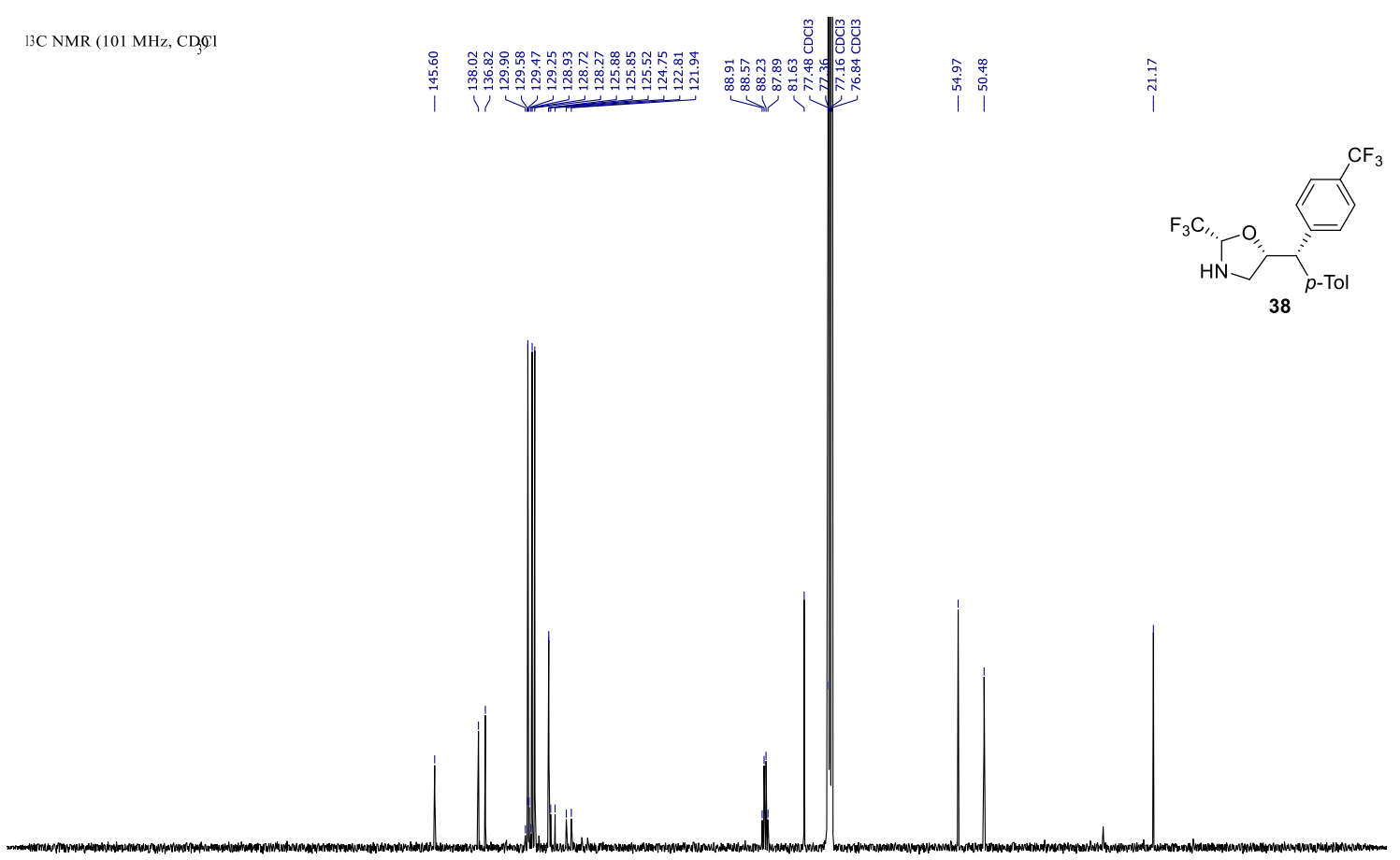

19F NMR (376 MHz, CD, 91
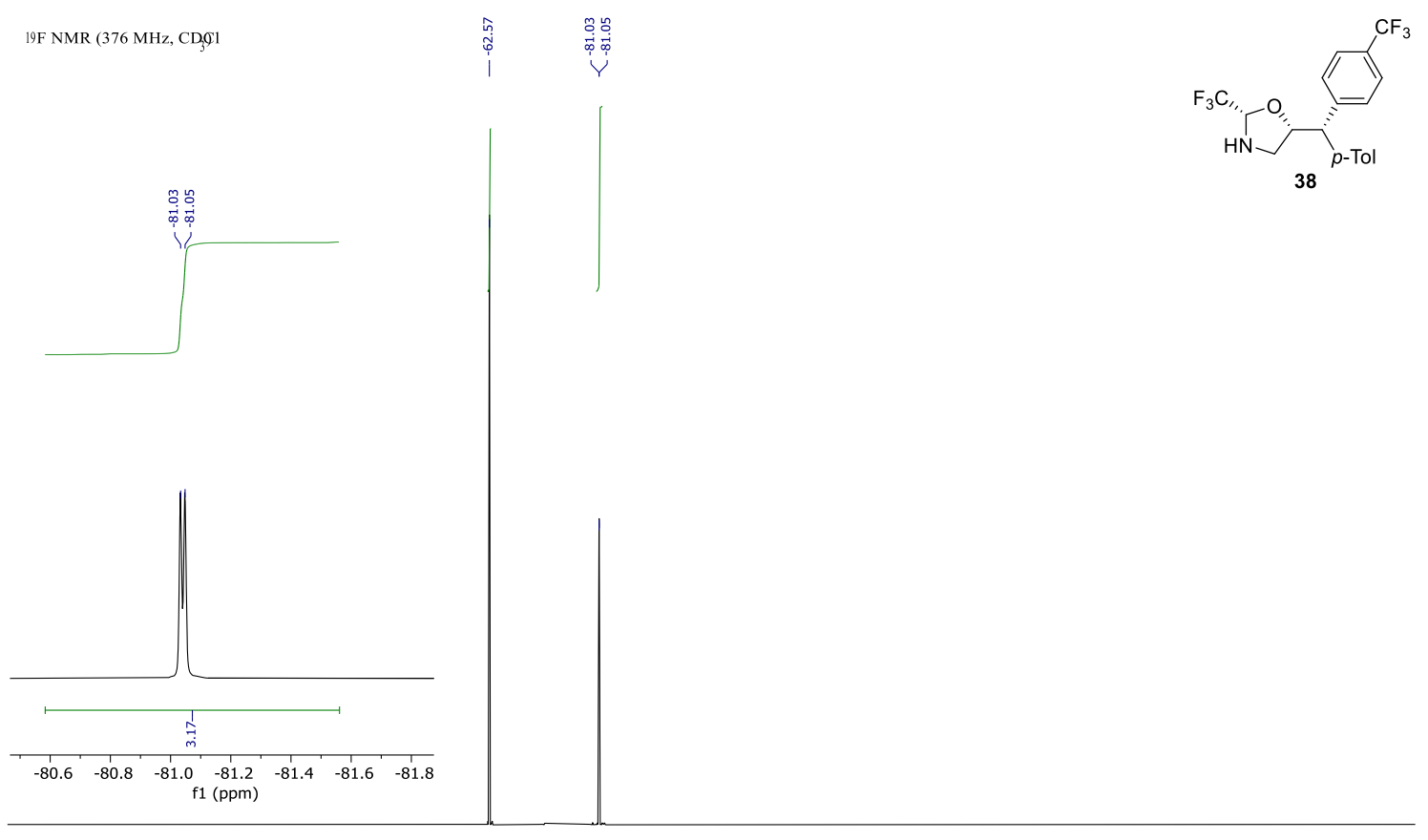

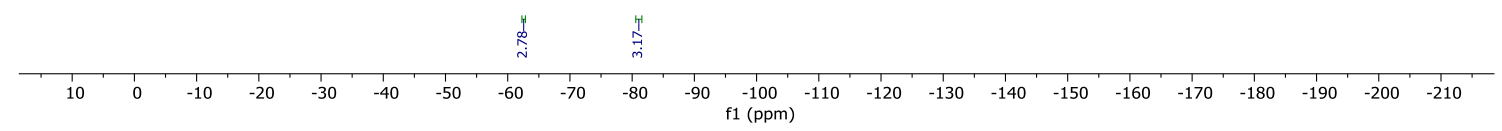



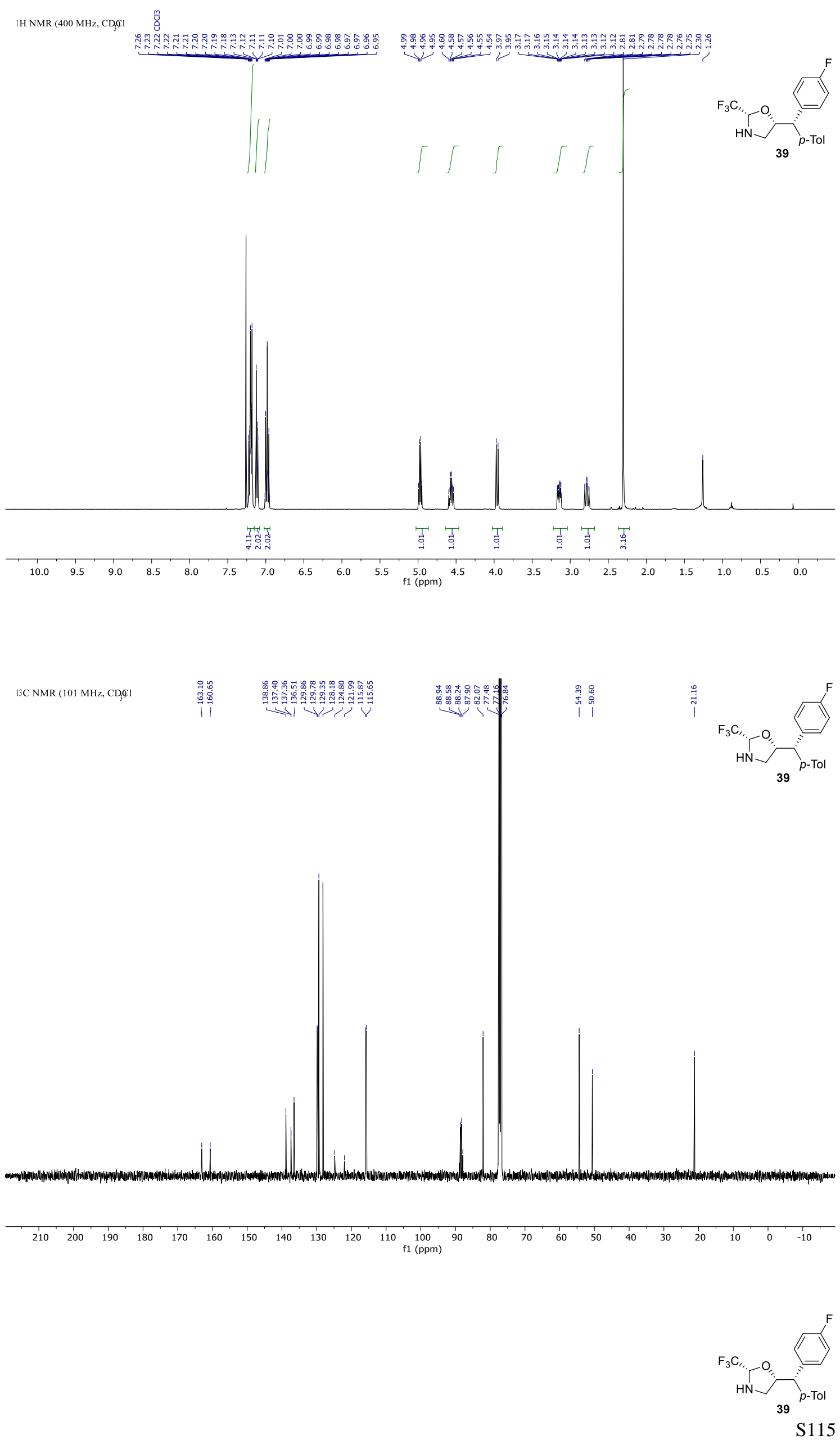


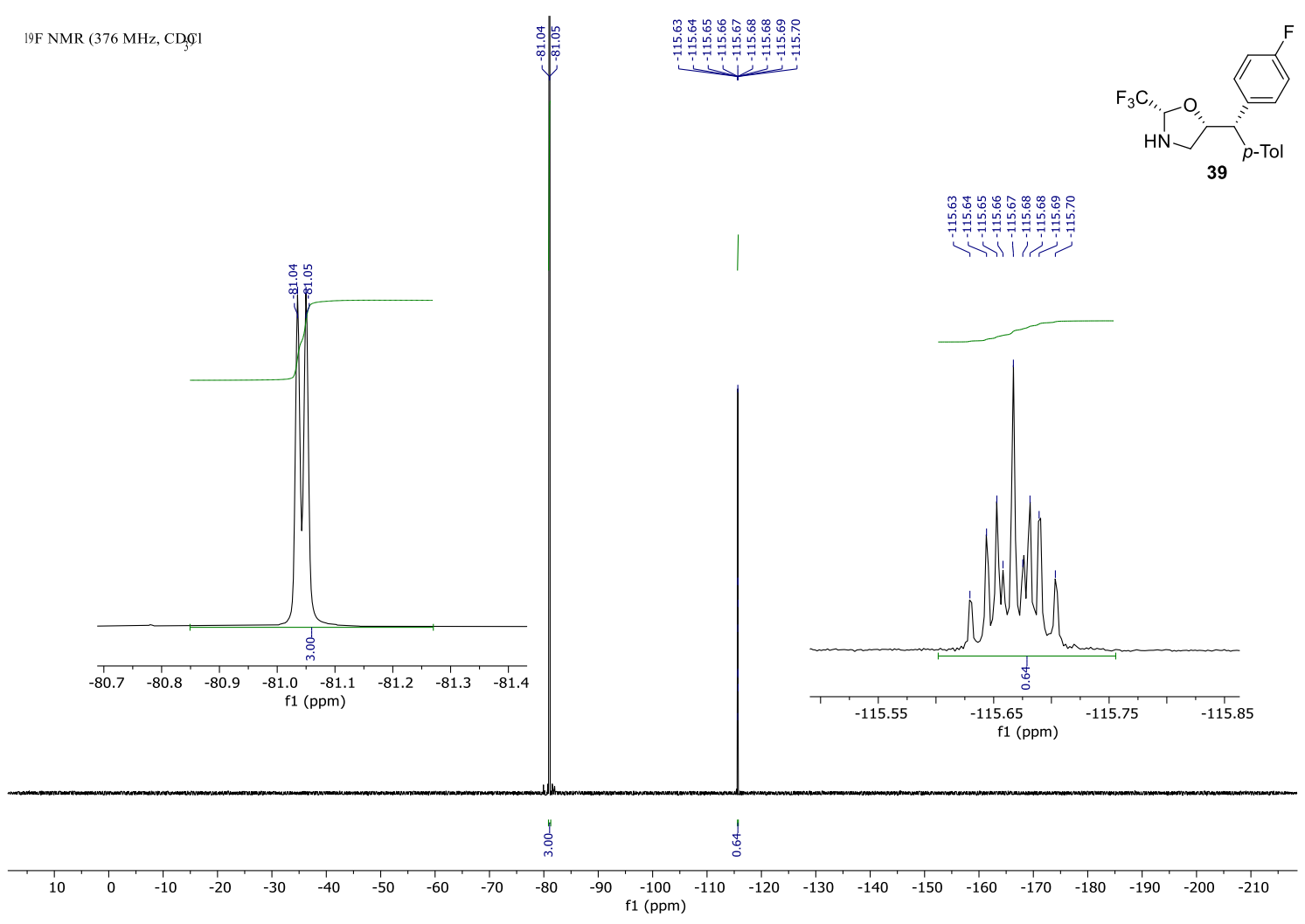

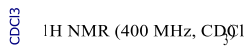

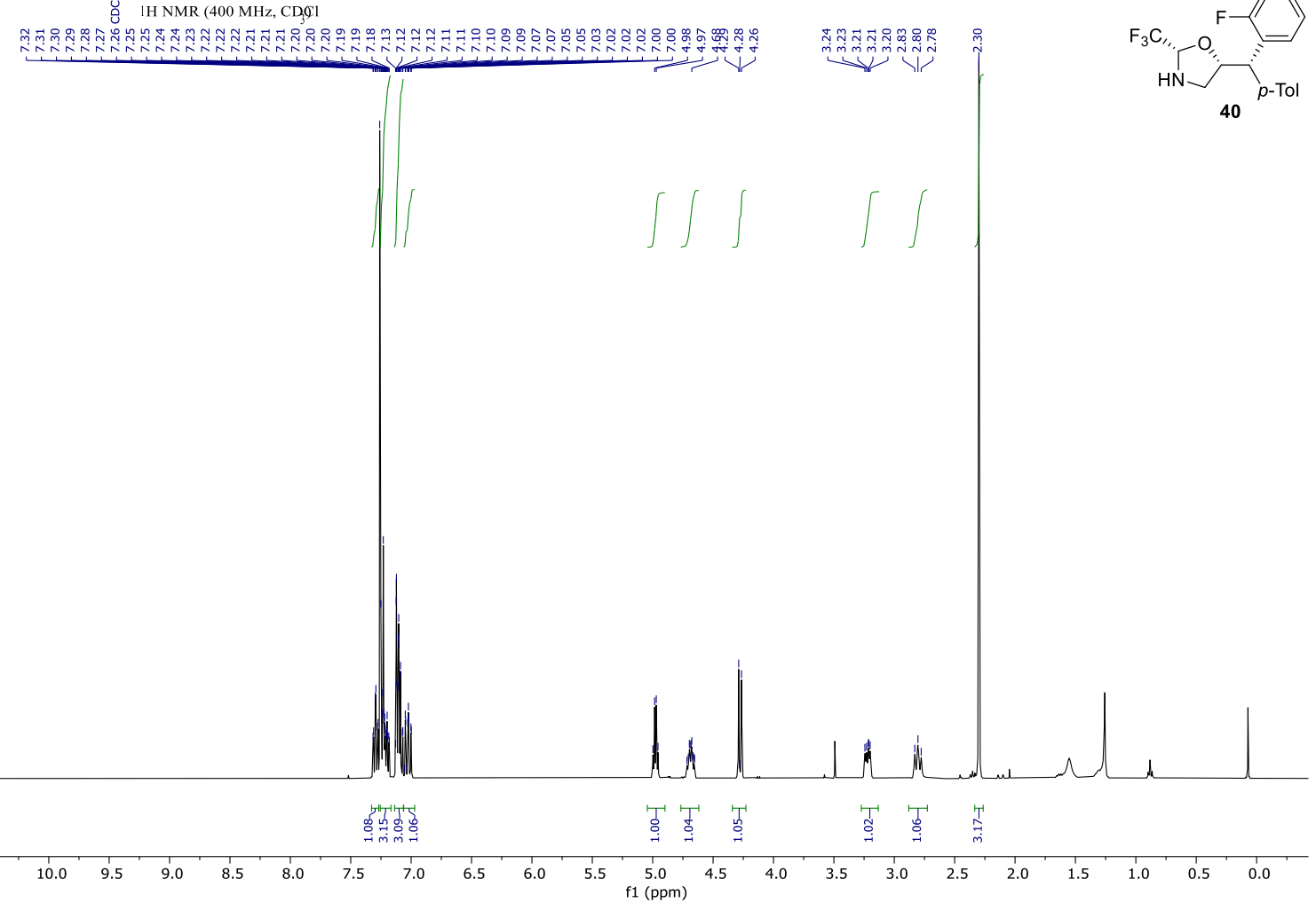



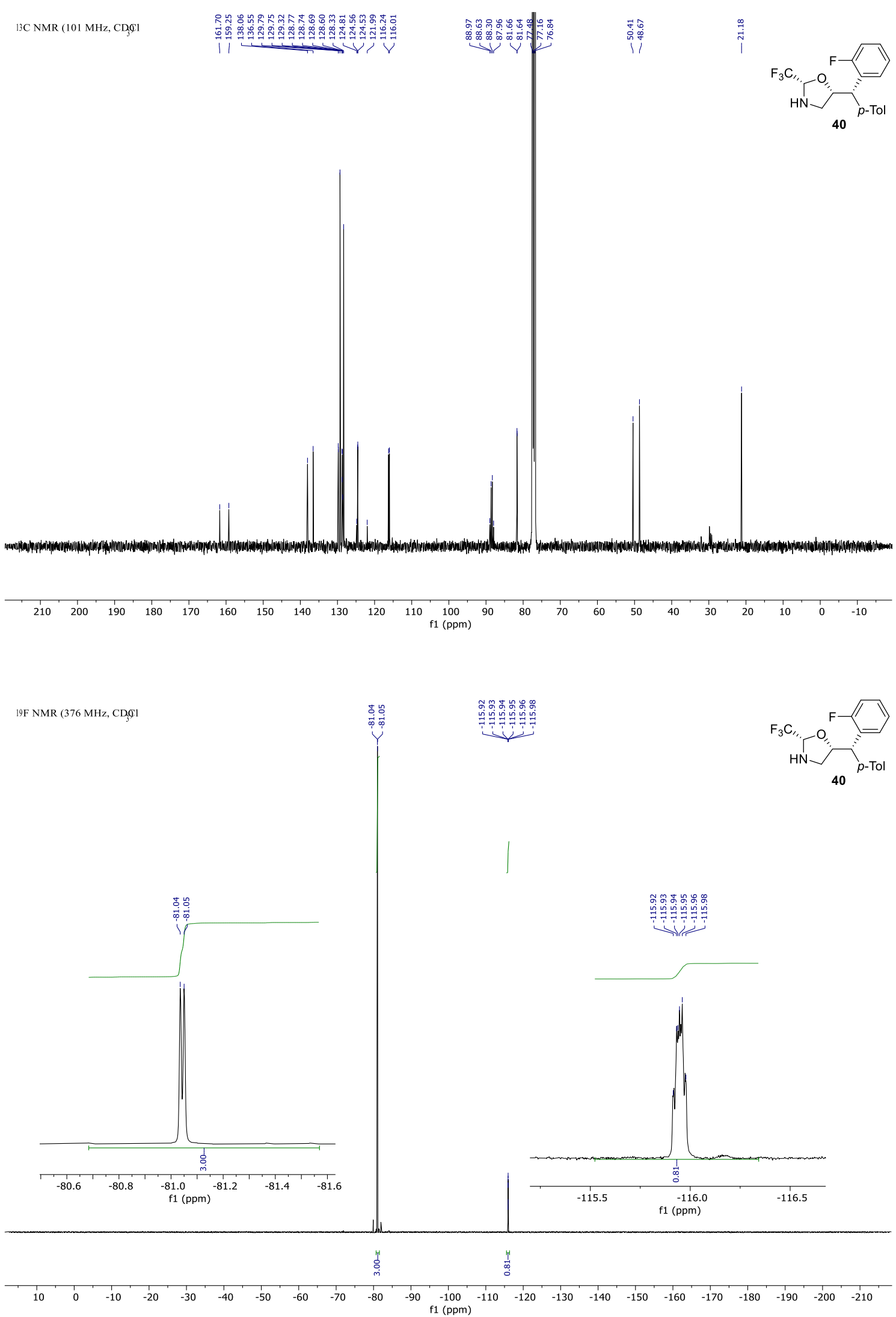

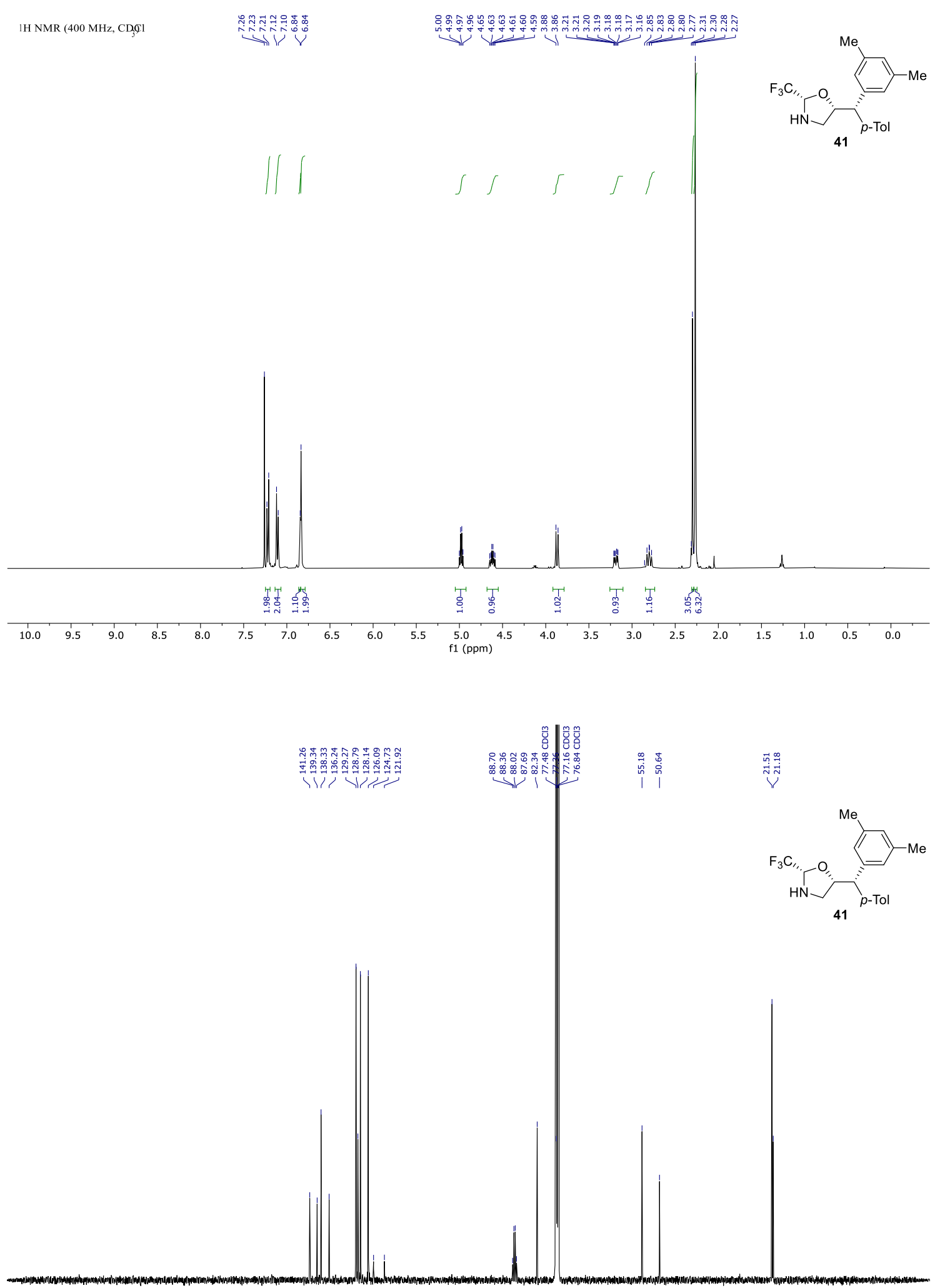

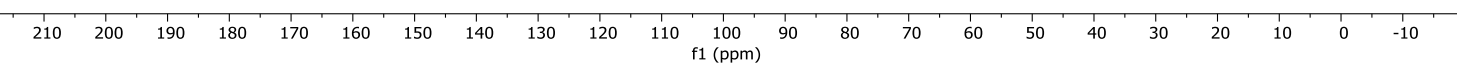



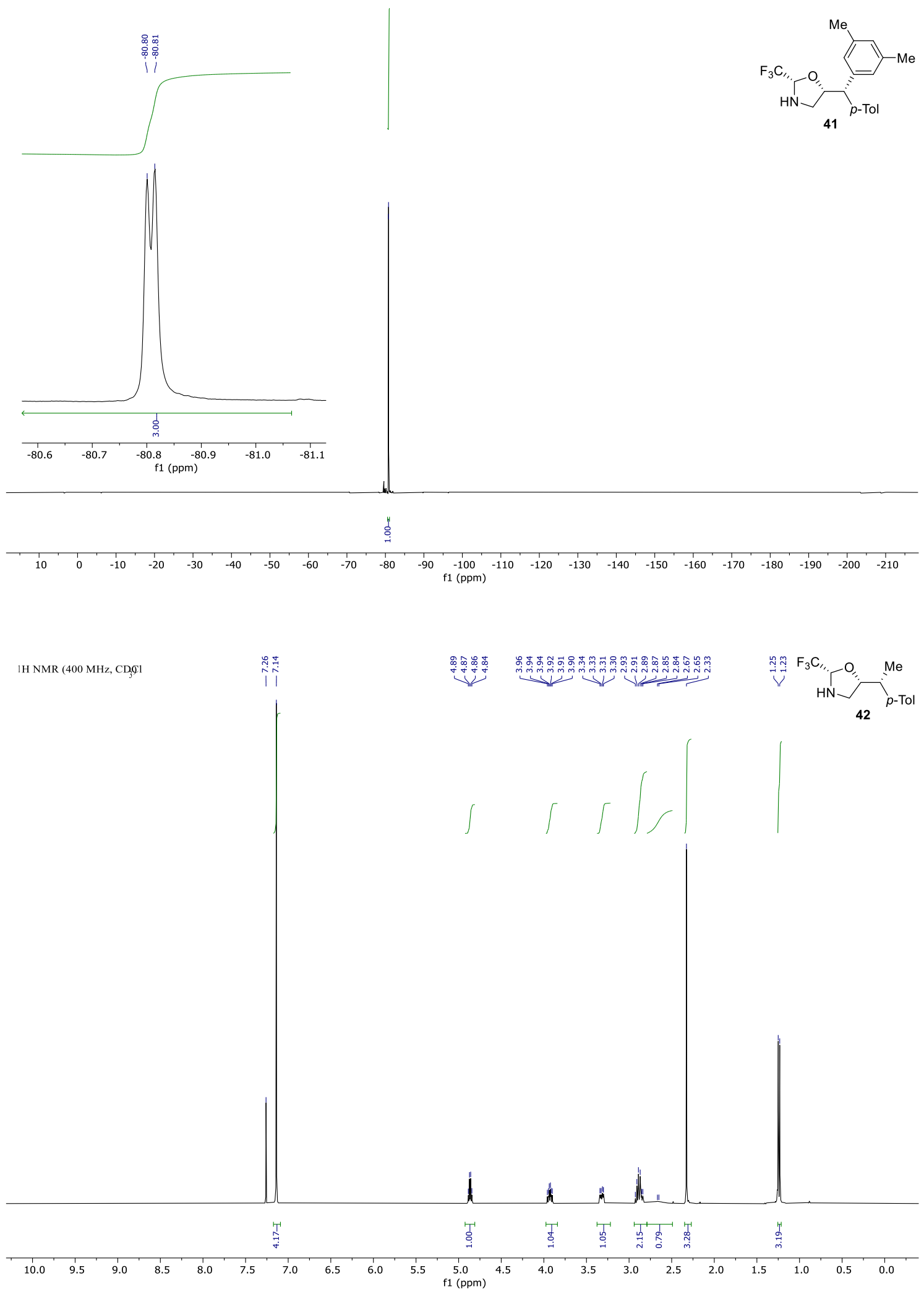


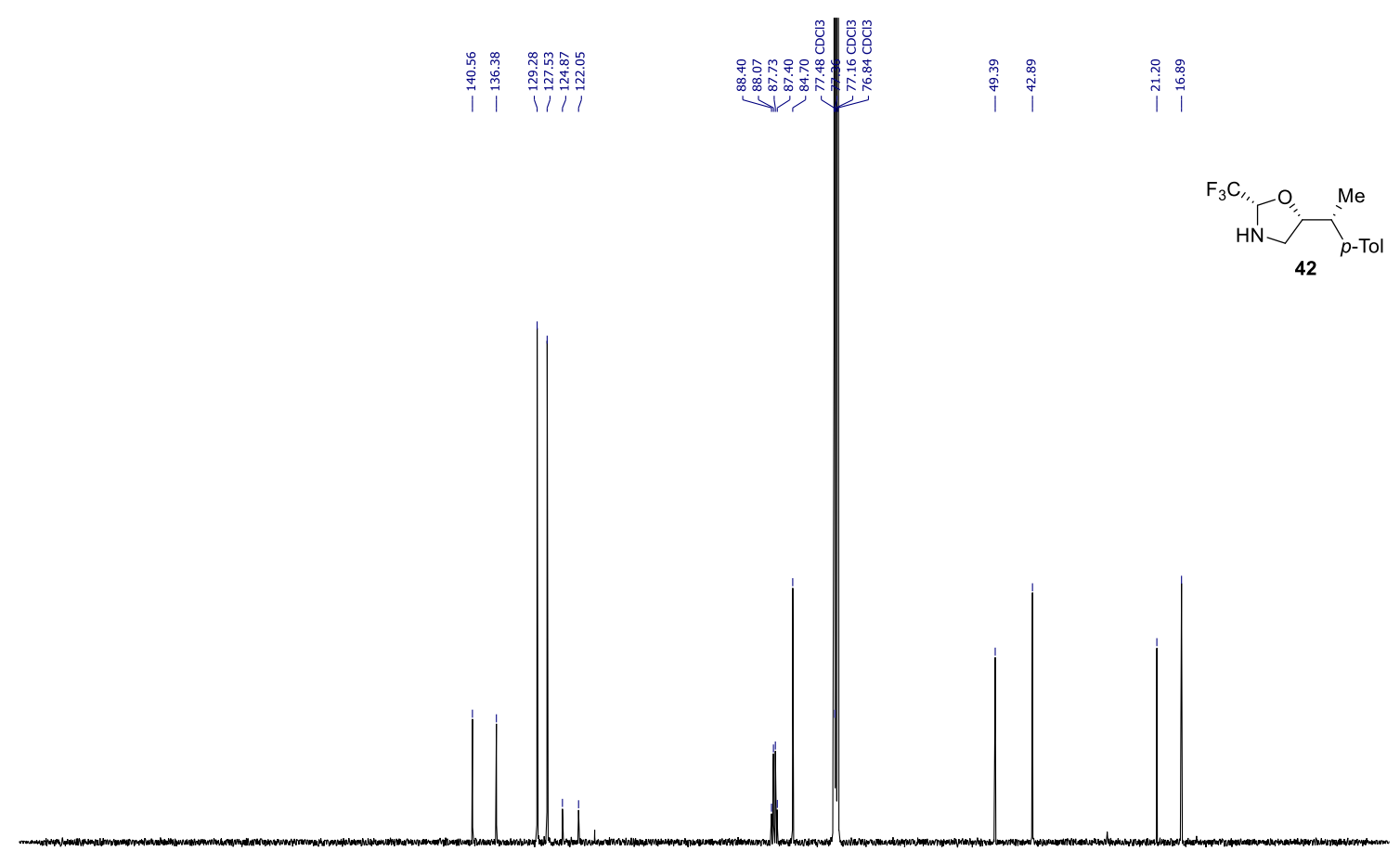

19F NMR $\left(377 \mathrm{MHz}, \mathrm{CD}_{3} 91\right.$

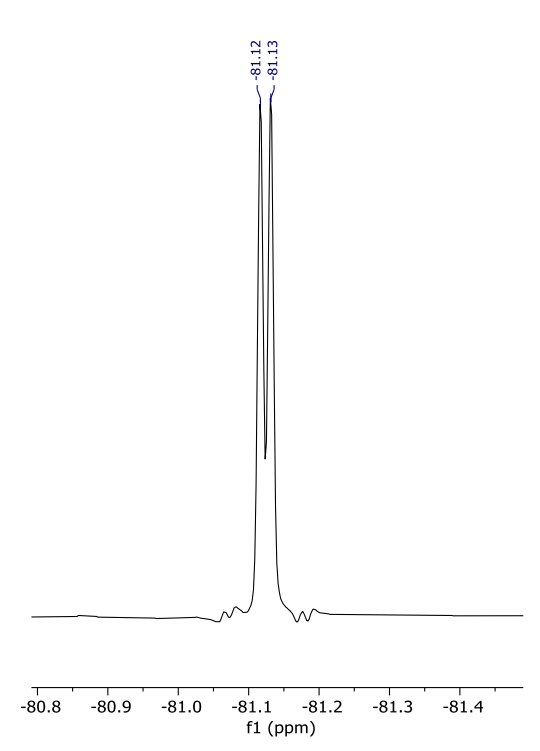




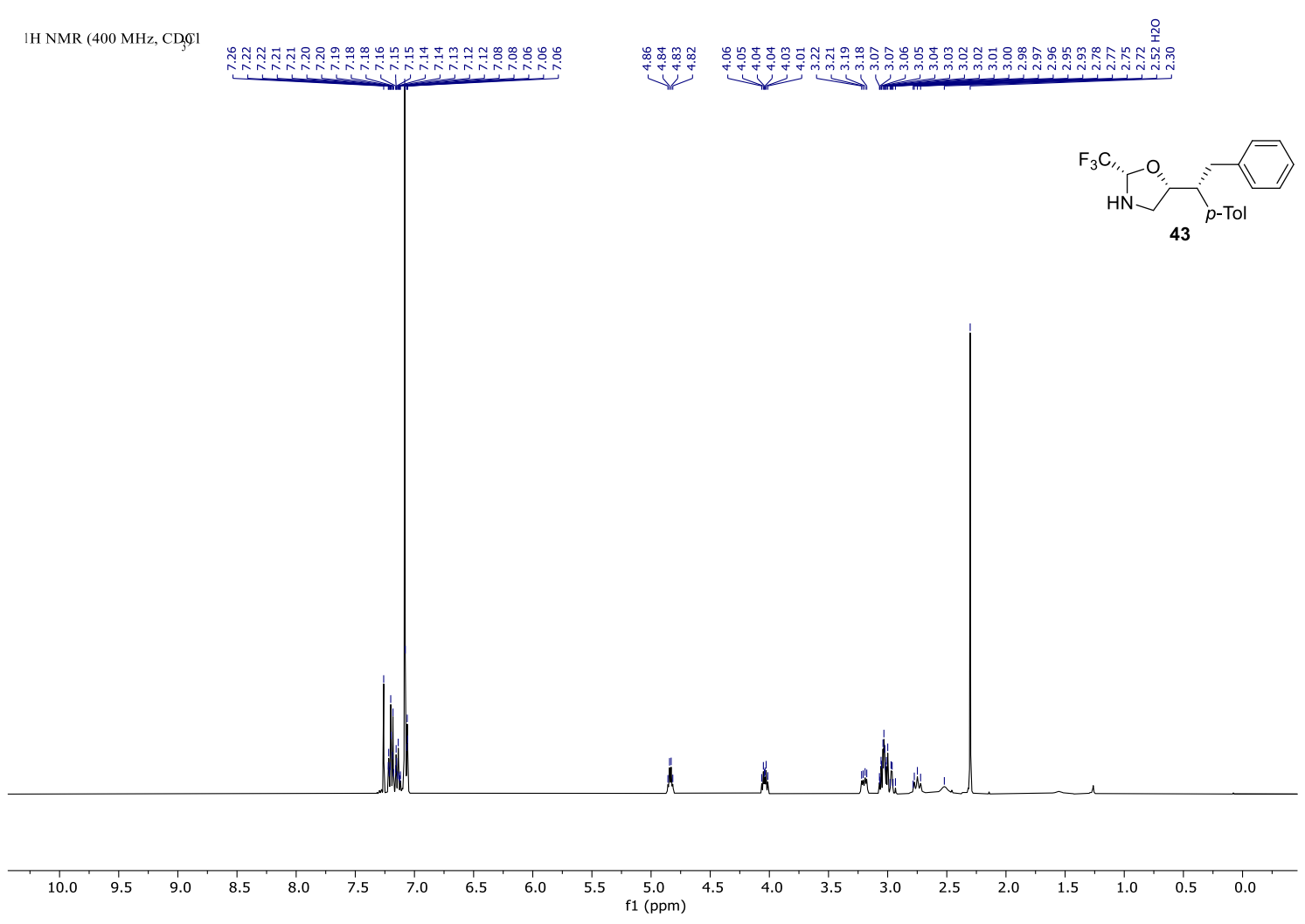

13C NMR (101 MHz, CDQ91 $m$
1
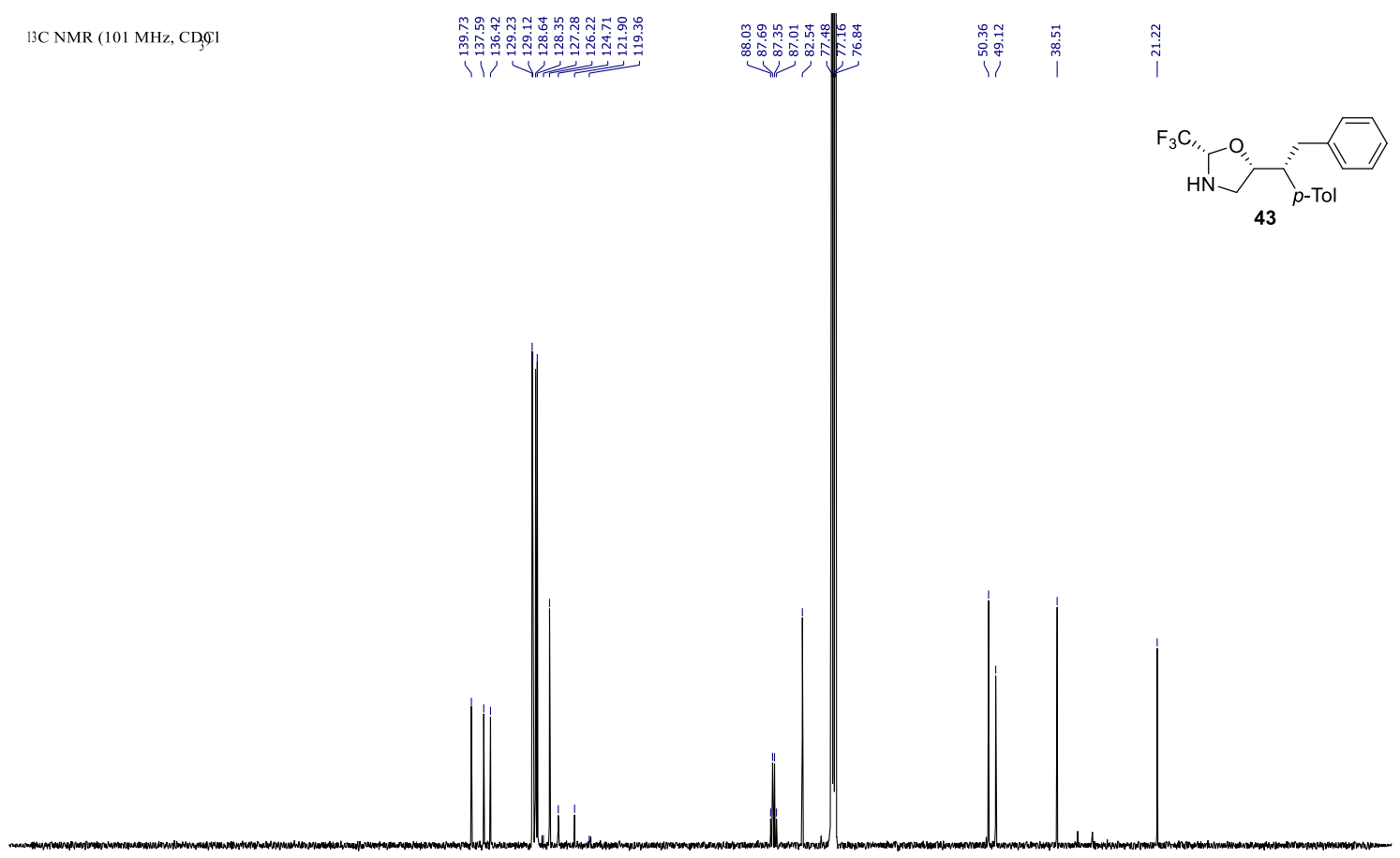

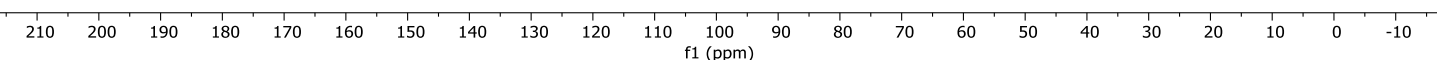


19F NMR $\left(376 \mathrm{MHz}, \mathrm{CD}_{3} \mathrm{gl}\right.$

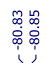

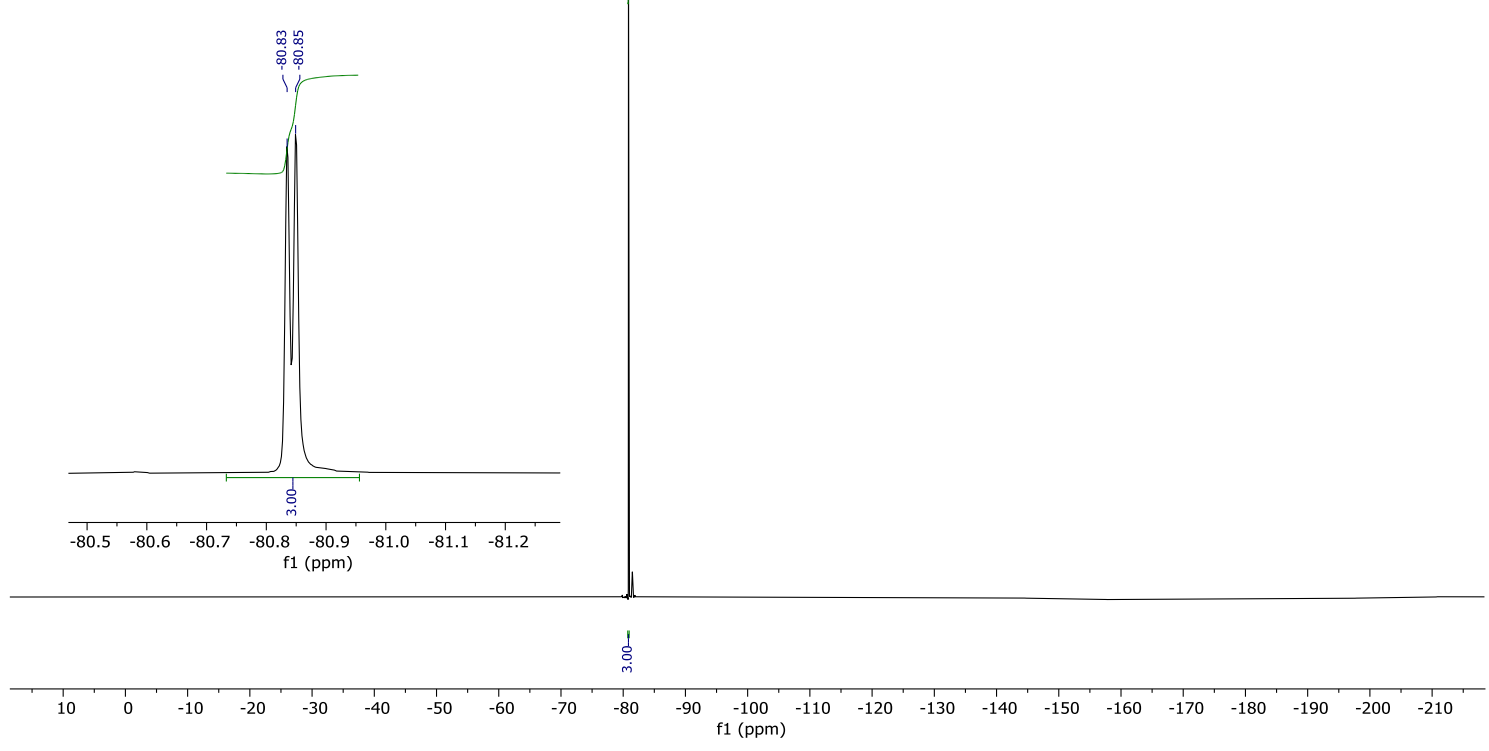

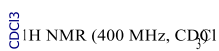

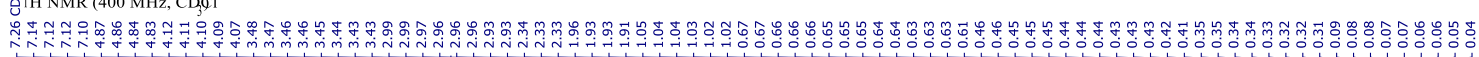

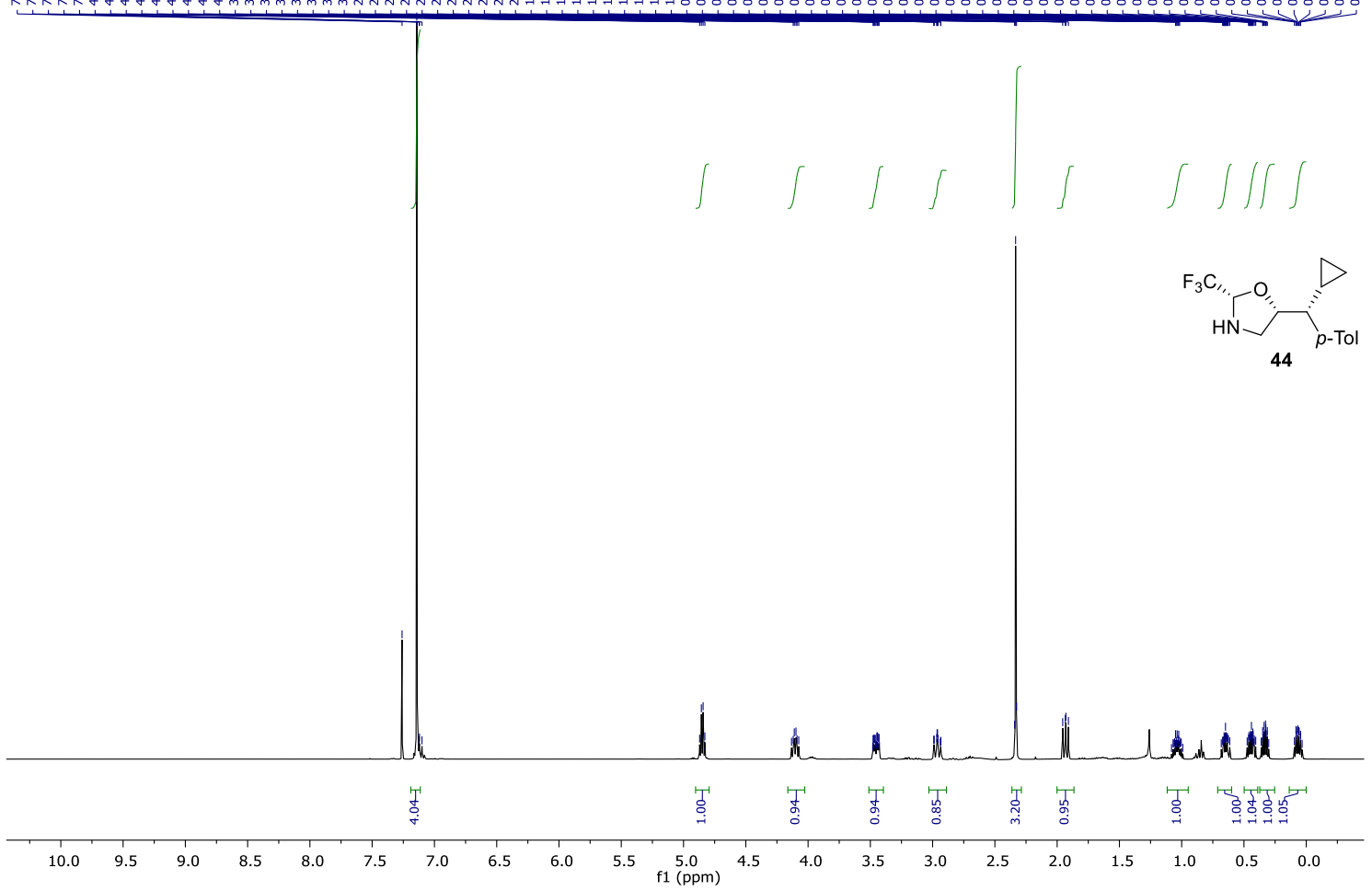

S122 


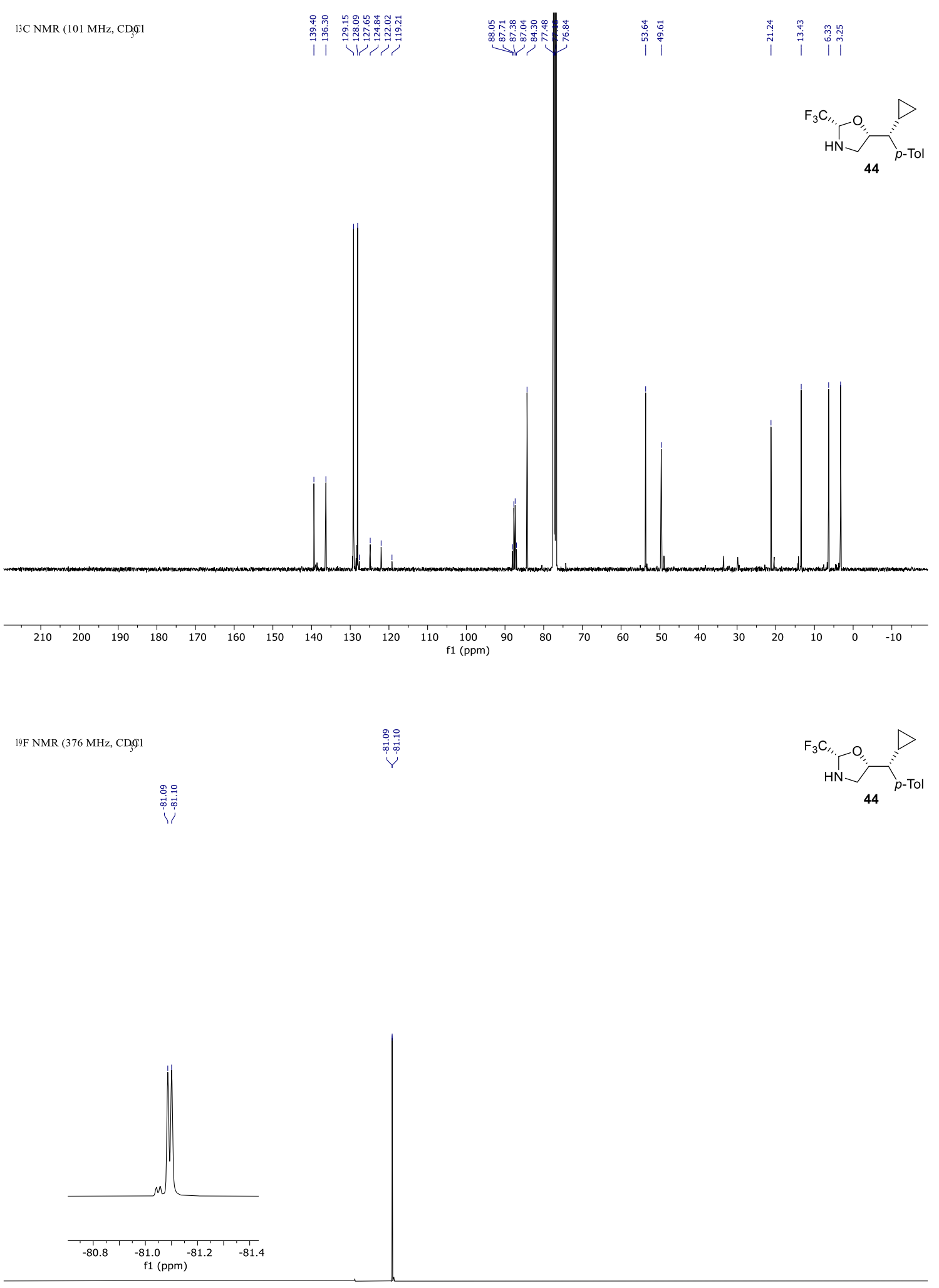

\begin{tabular}{rlllllllllllllllllllllllll}
\hline & 10 & 0 & -10 & -20 & -30 & -40 & -50 & -60 & -70 & -80 & -90 & -100 & -110 & -120 & -130 & -140 & -150 & -160 & -170 & -180 & -190 & -200 & -210 & 1
\end{tabular} 

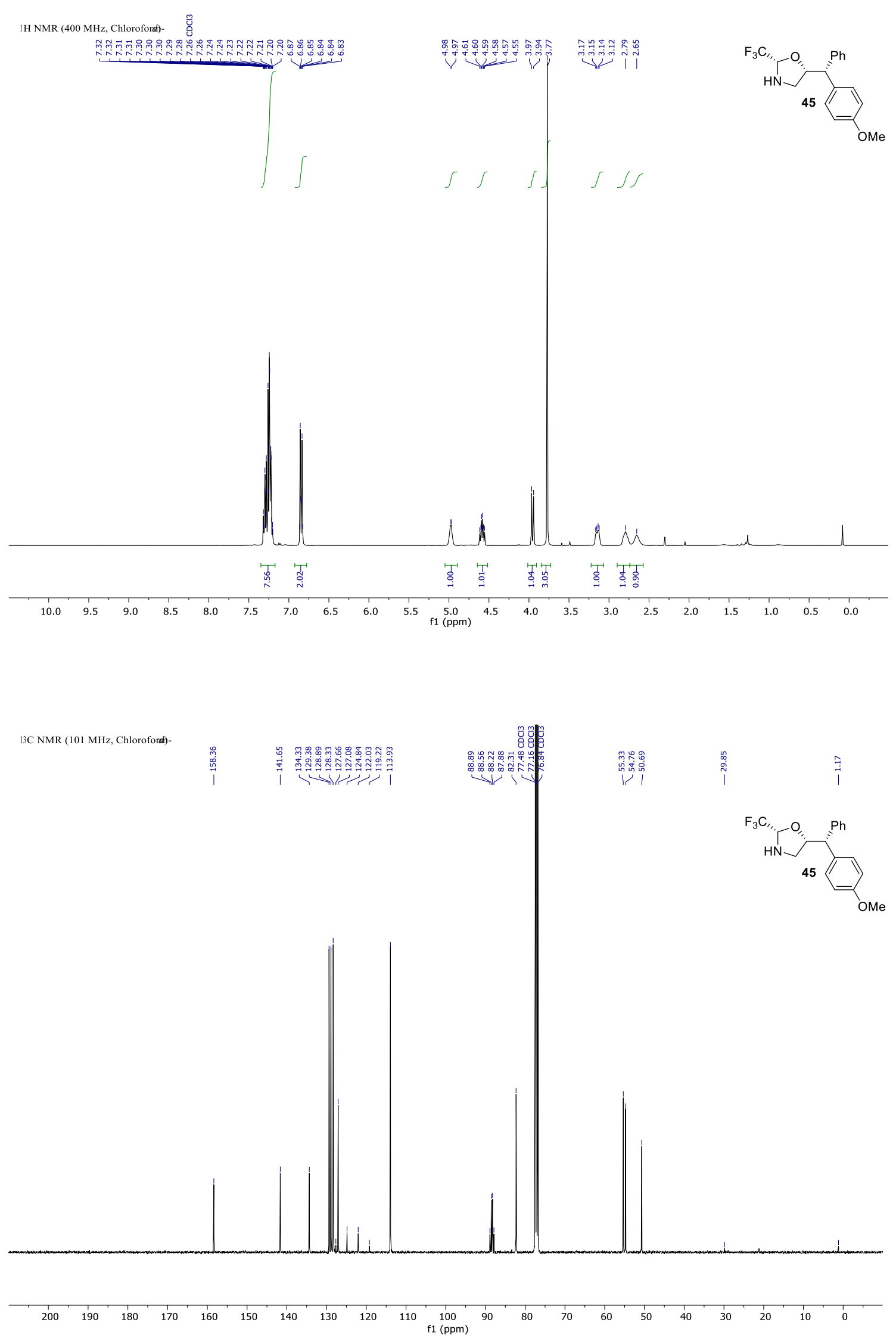

S124 


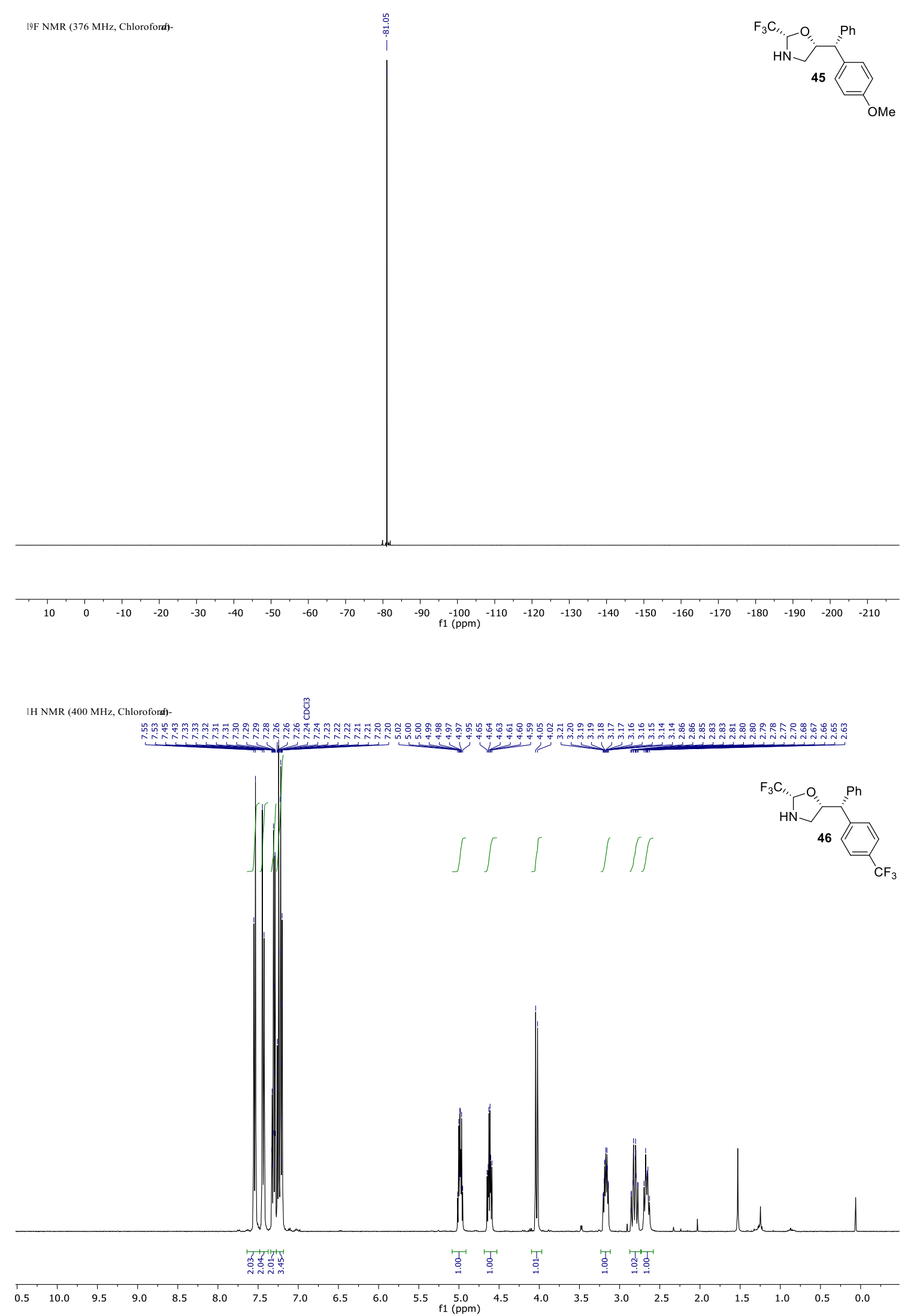


13C NMR (101 MHz, Chloroforde-
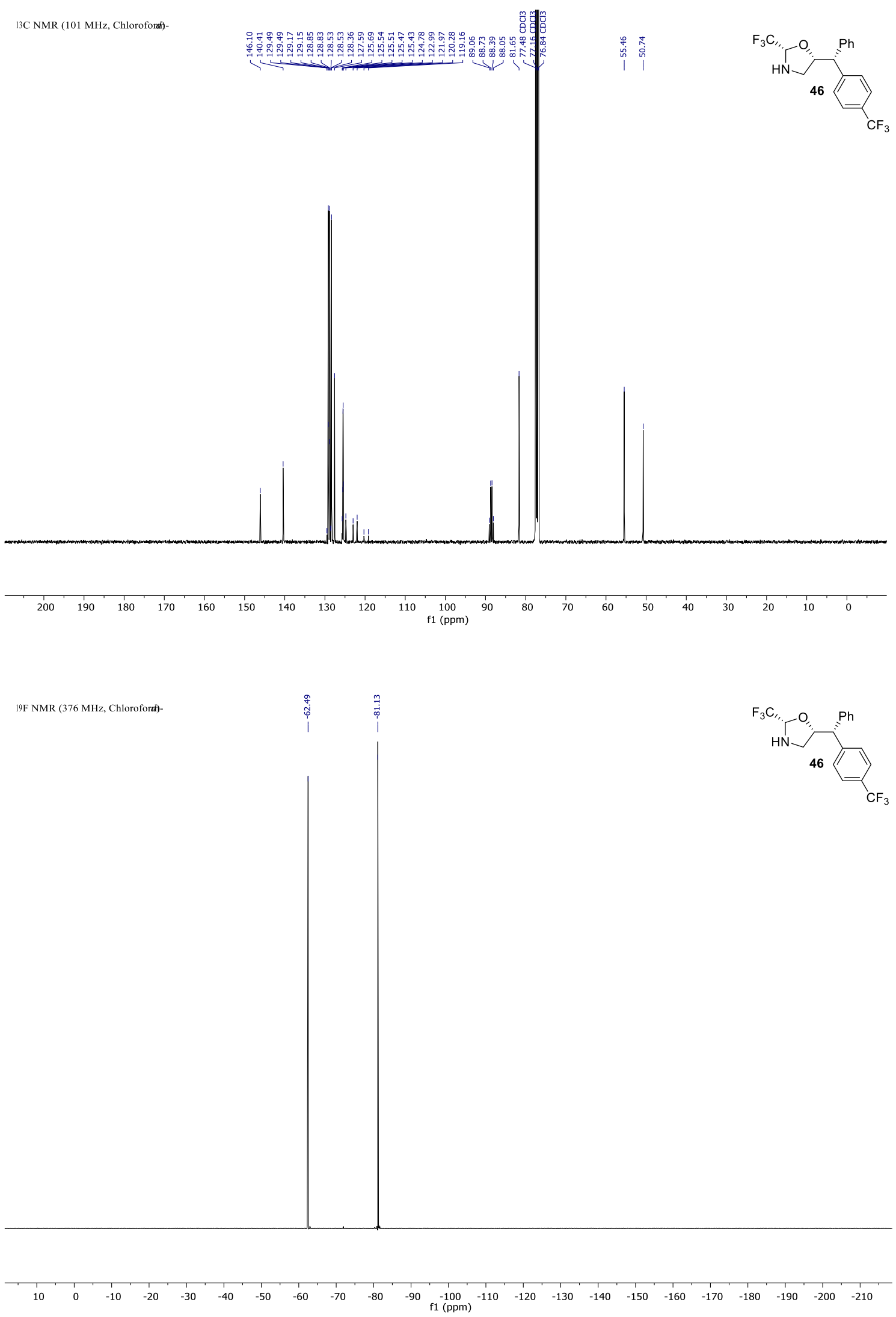

S126 


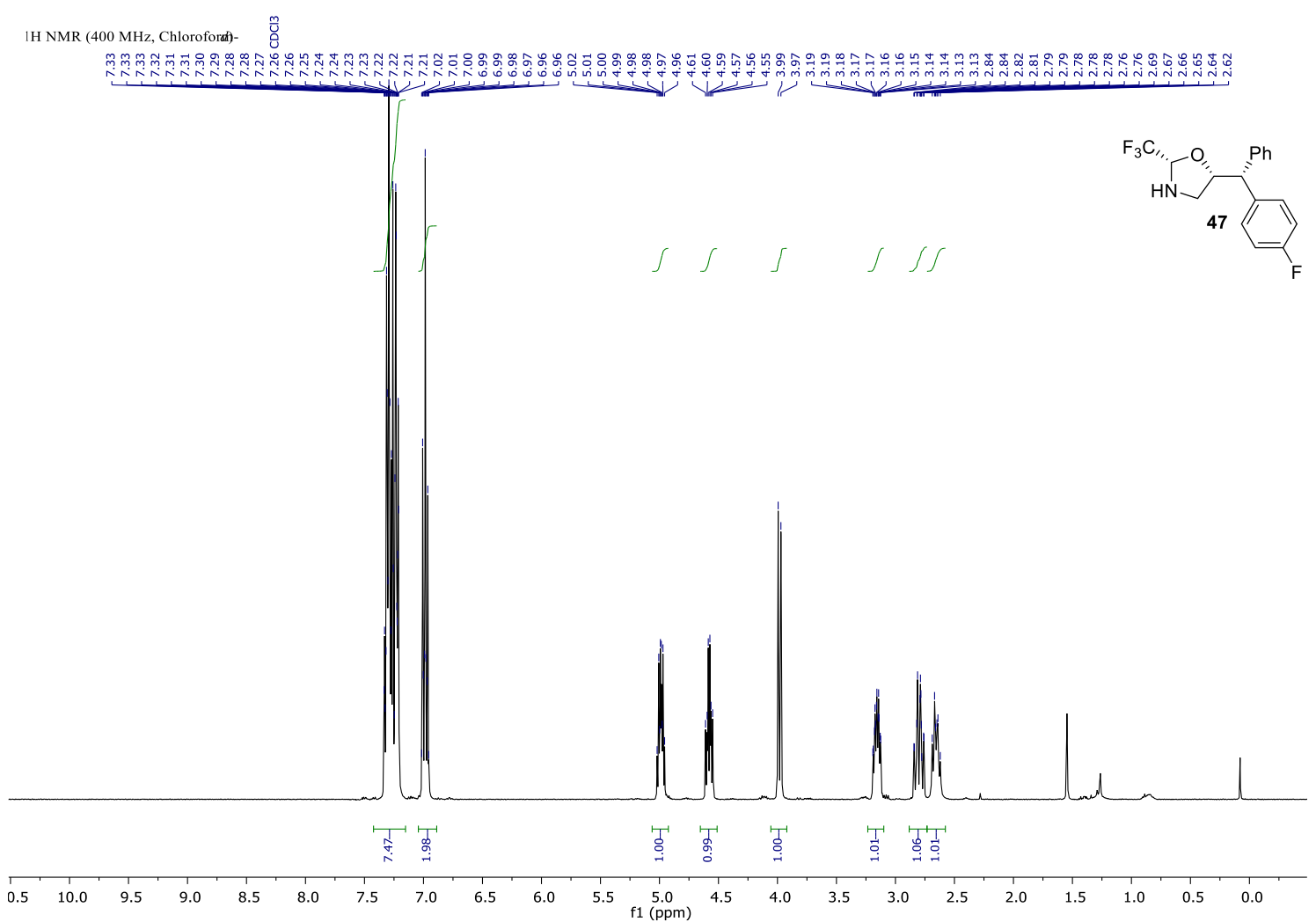

13C NMR (101 MHz, Chloroforat)-
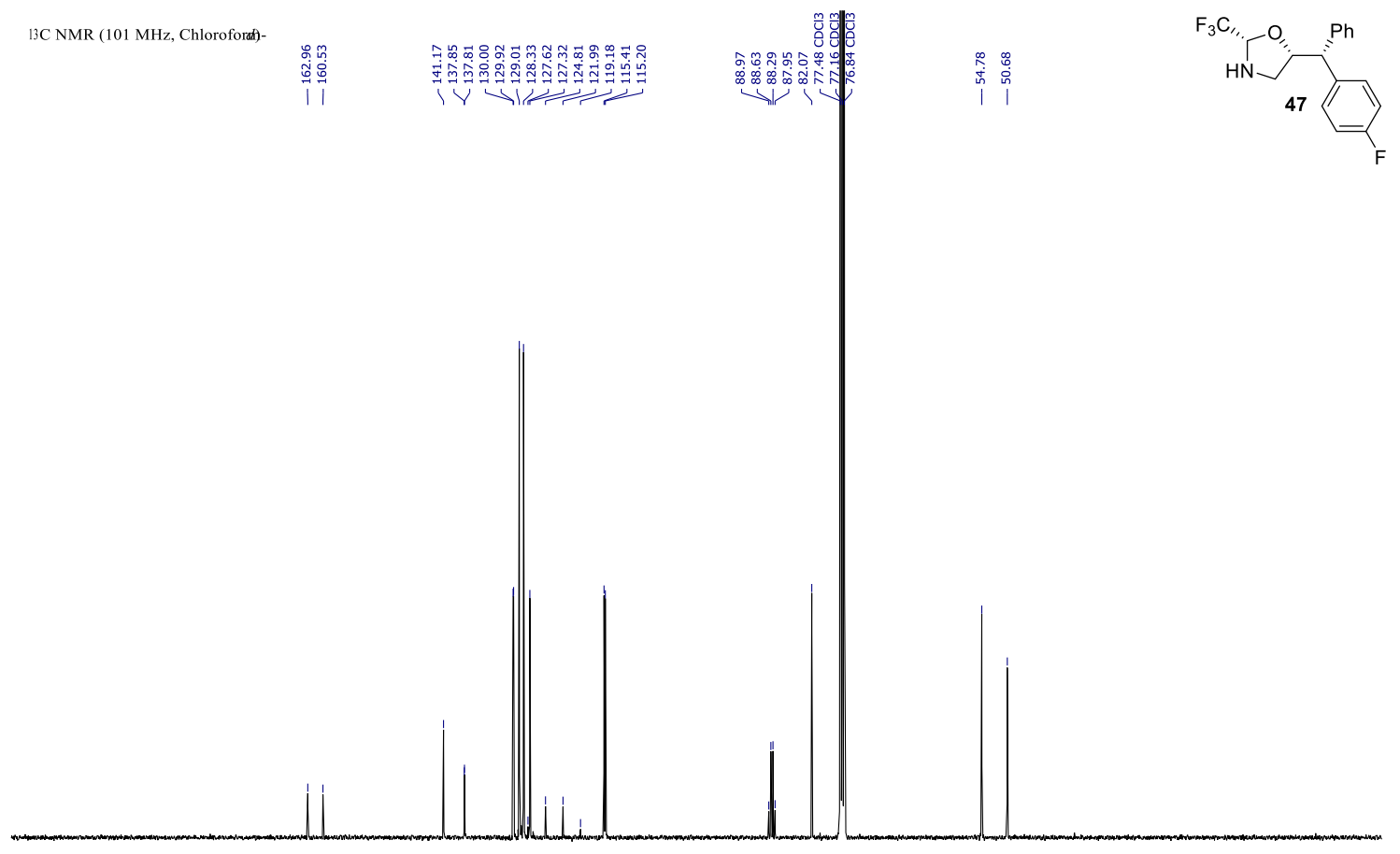

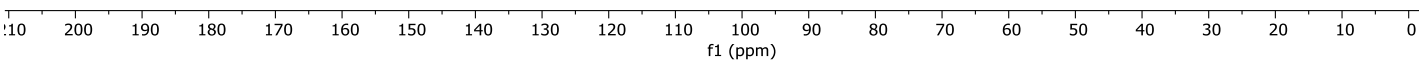




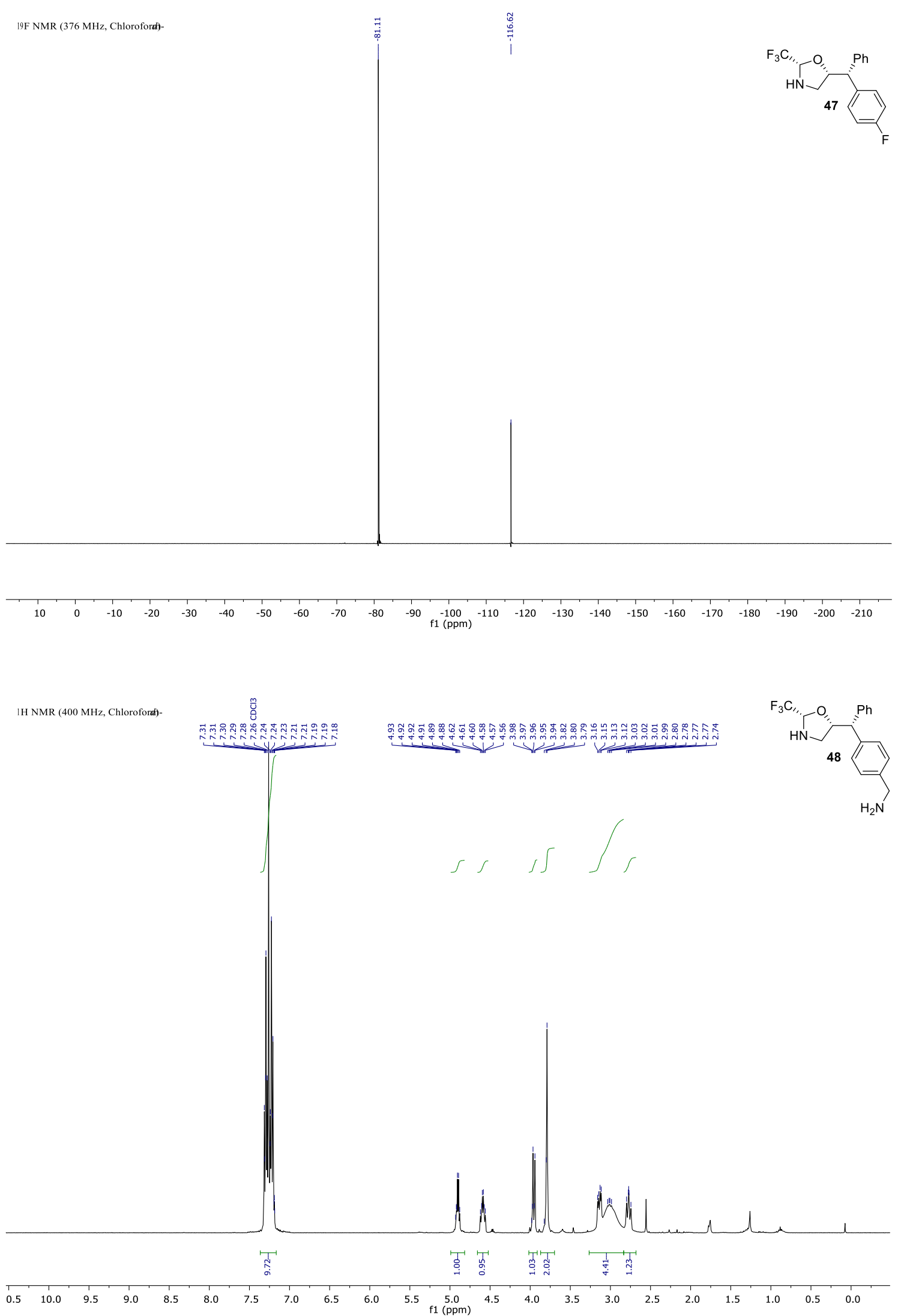




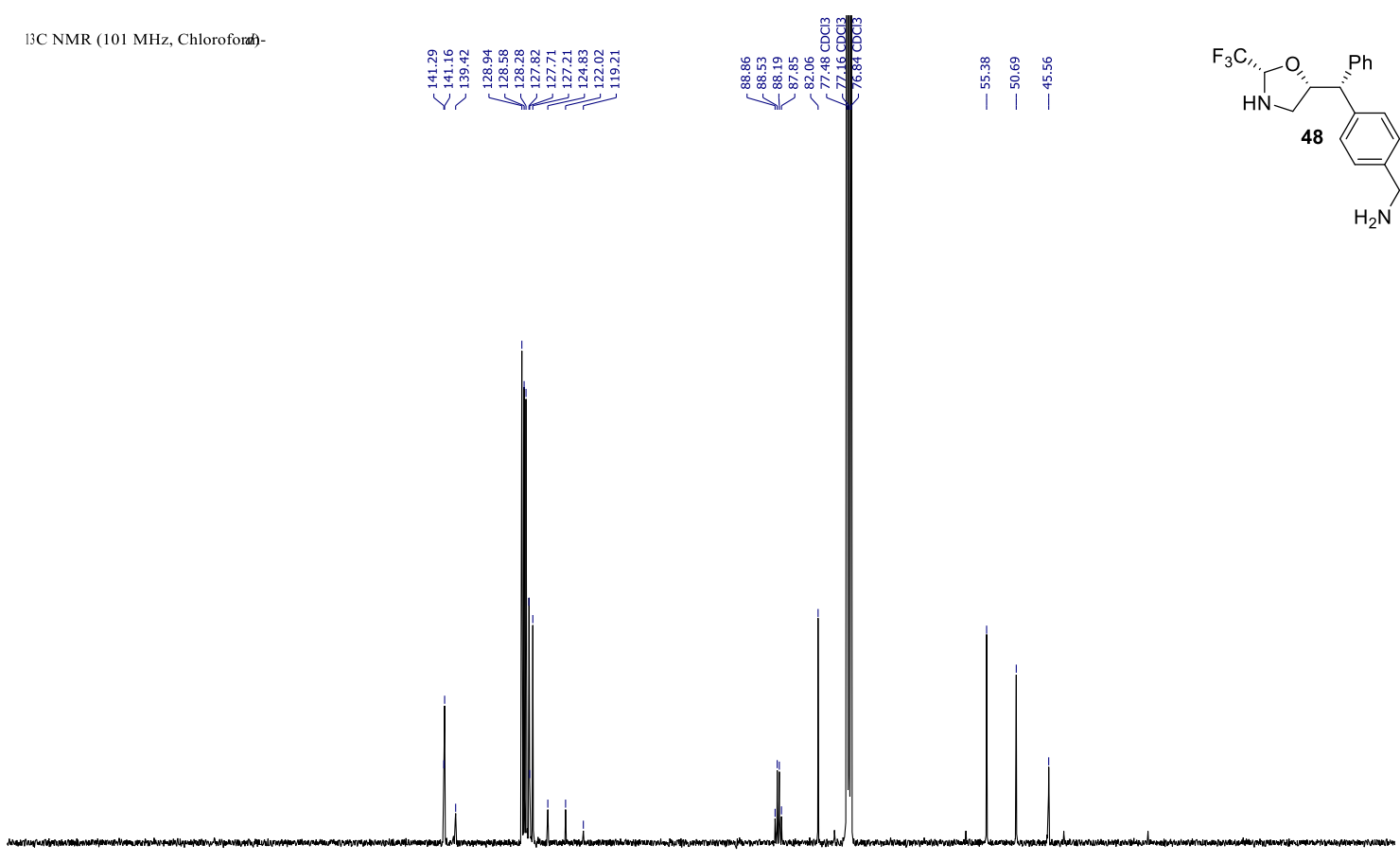

$\begin{array}{lllllllllllllllllllllllll}10 & 200 & 190 & 180 & 170 & 160 & 150 & 140 & 130 & 120 & 110 & 100 & 90 & 80 & 70 & 60 & 50 & 40 & 30 & 20 & 10 & 0\end{array}$

19F NMR (376 MHz, Chlorofordi)

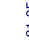

$\mathrm{F}_{3} \mathrm{C}_{1}$ (l)

$\begin{array}{lllllllllllllllllllllllllllll}10 & 0 & -10 & -20 & -30 & -40 & -50 & -60 & -70 & -80 & -90 & -100 & -110 & -120 & -130 & -140 & -150 & -160 & -170 & -180 & -190 & -200 & -210\end{array}$ 

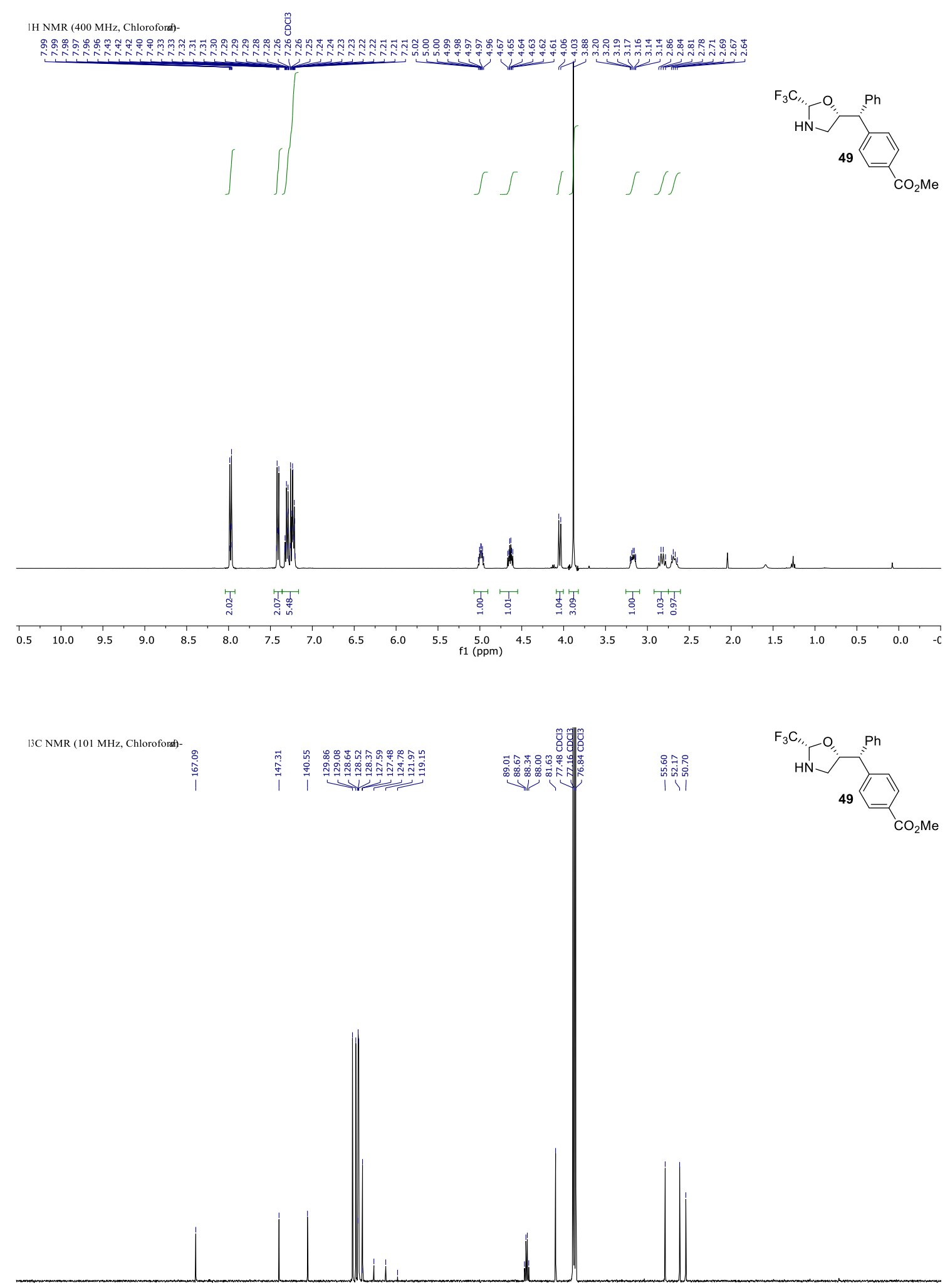

$\begin{array}{lllllllllllllllllllllllllll}200 & 190 & 180 & 170 & 160 & 150 & 140 & 130 & 120 & 110 & 100 & 90 & 80 & 70 & 60 & 50 & 40 & 30 & 20 & 10 & 0\end{array}$ 


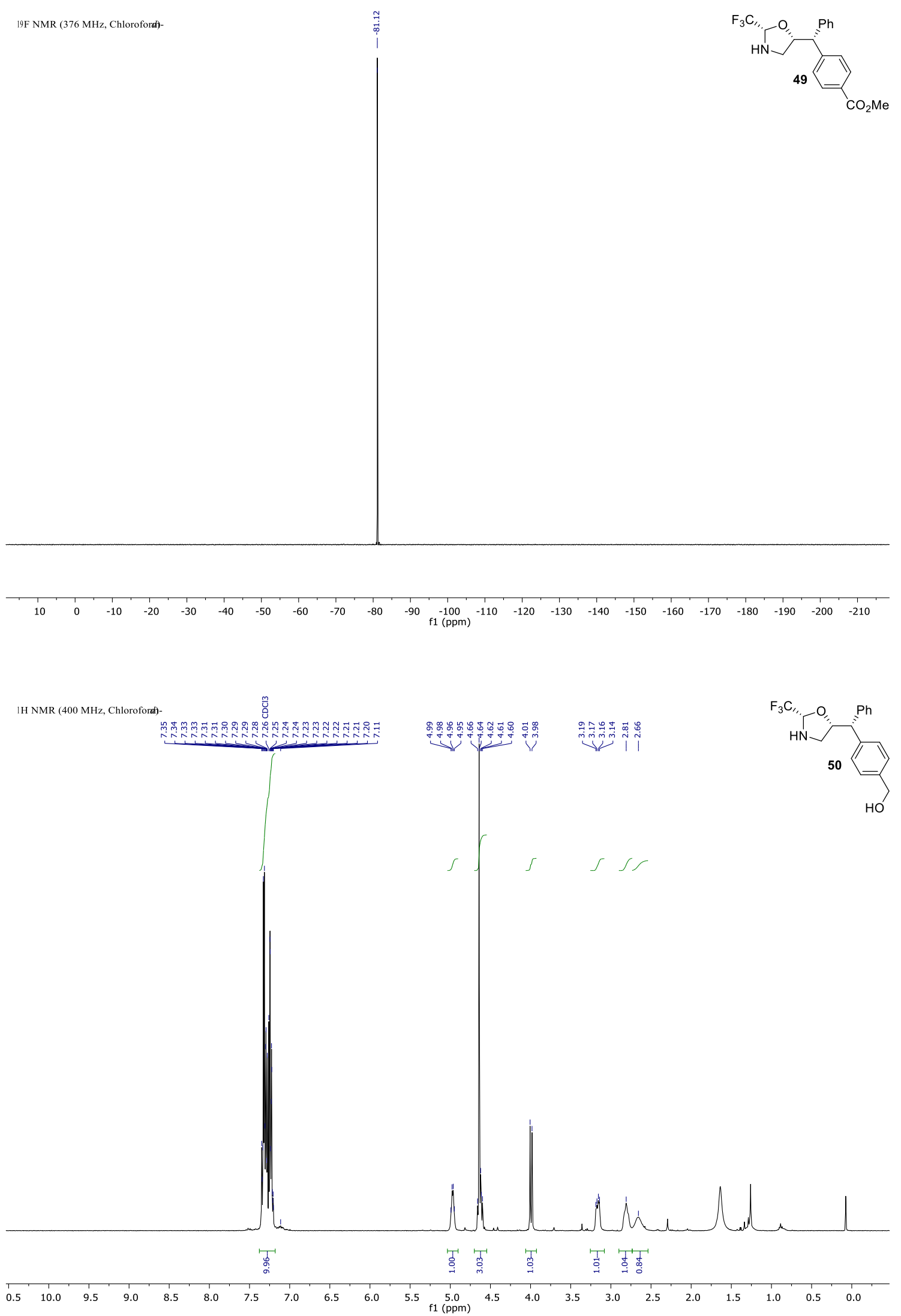



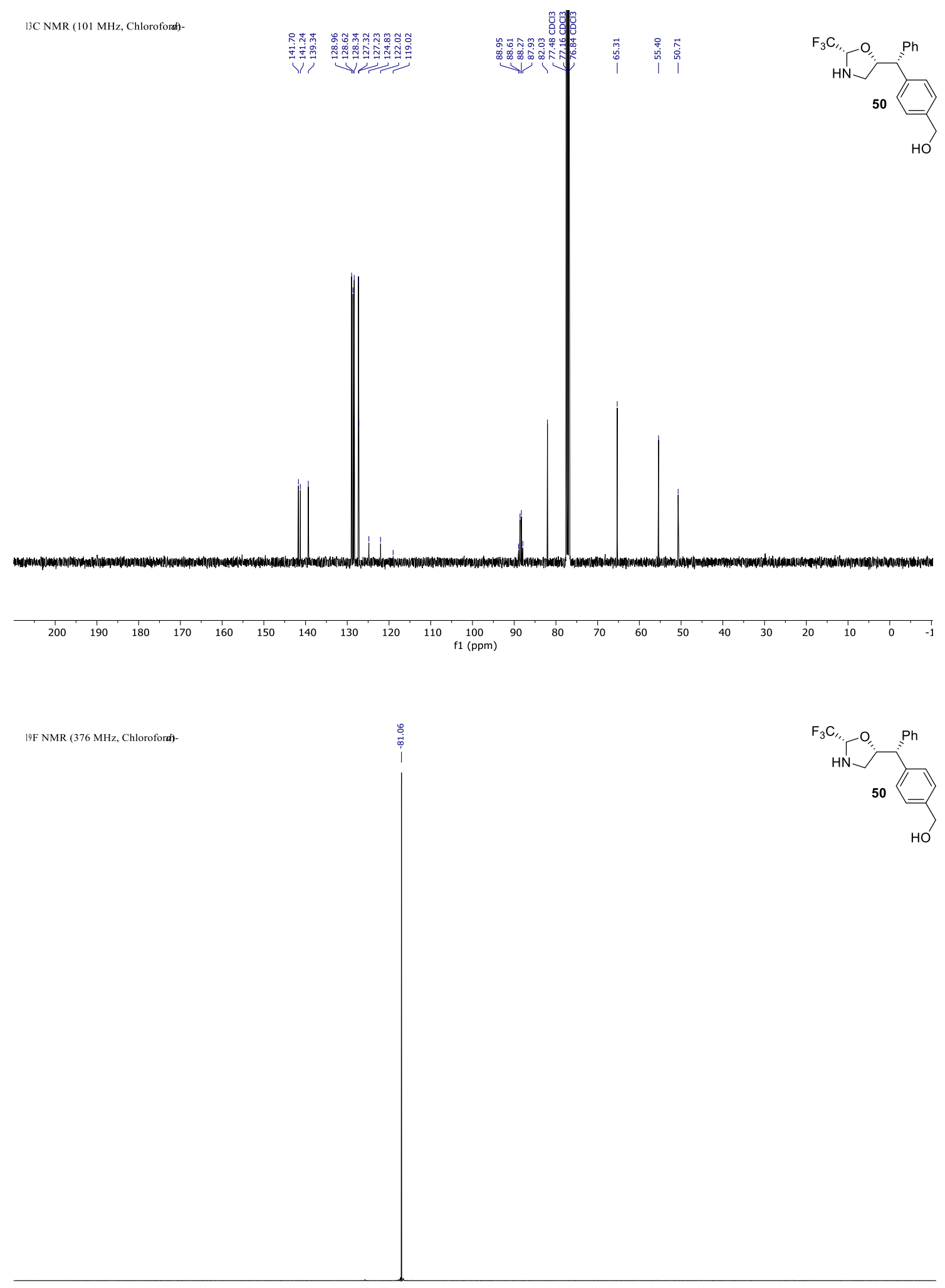

$\begin{array}{llllllllllllllllllllllll}10 & 0 & -10 & -20 & -30 & -40 & -50 & -60 & -70 & -80 & -90 & -100 & -110 & -120 & -130 & -140 & -150 & -160 & -170 & -180 & -190 & -200 & -210\end{array}$ 
$1 \mathrm{H} \mathrm{NMR}(400 \mathrm{MHz}$, Chloroforde)-

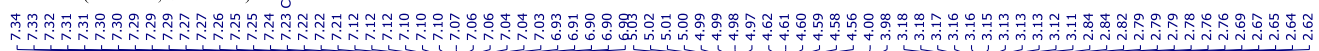

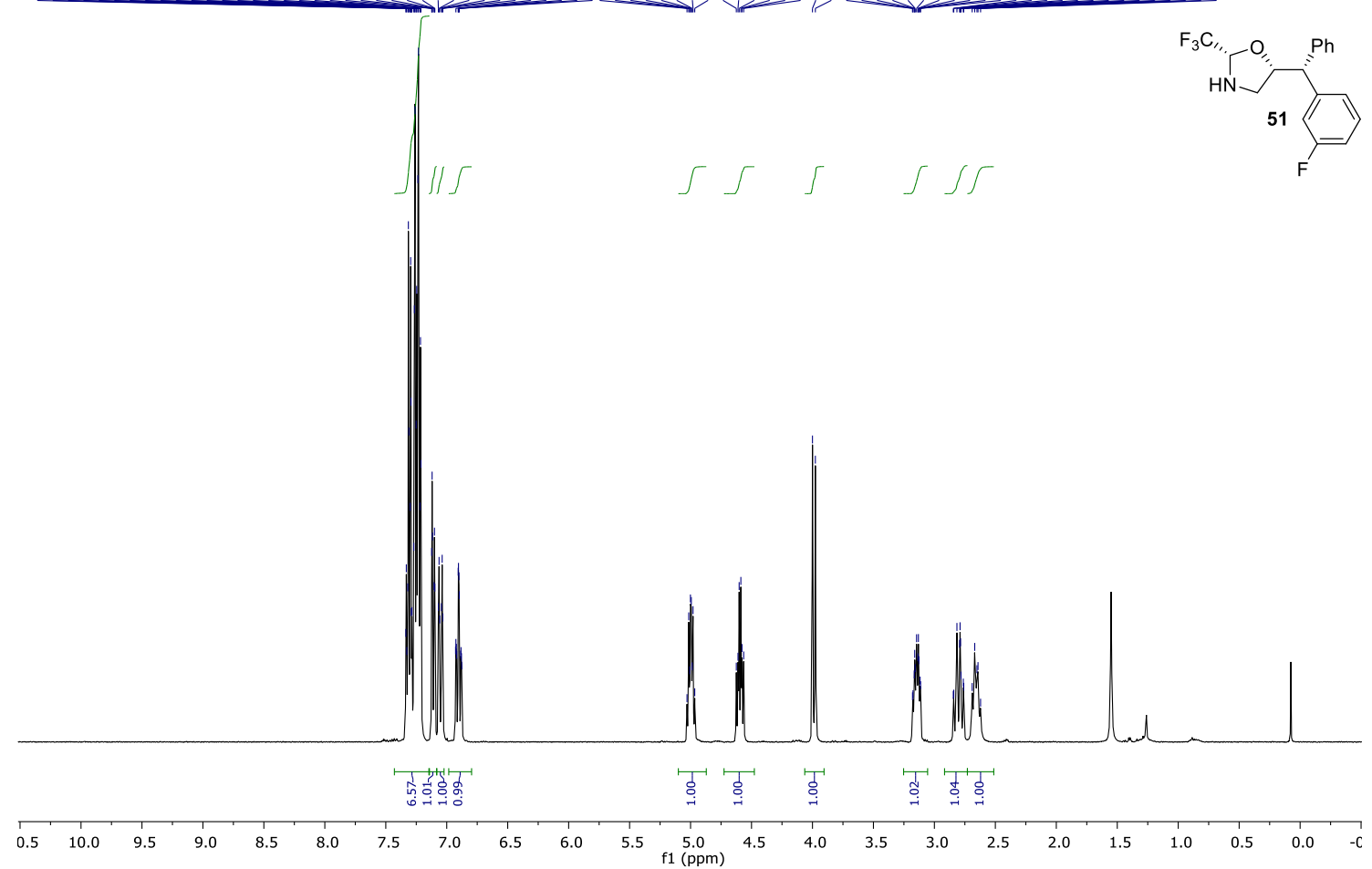

13C NMR (101 MHz, Chloroforat-
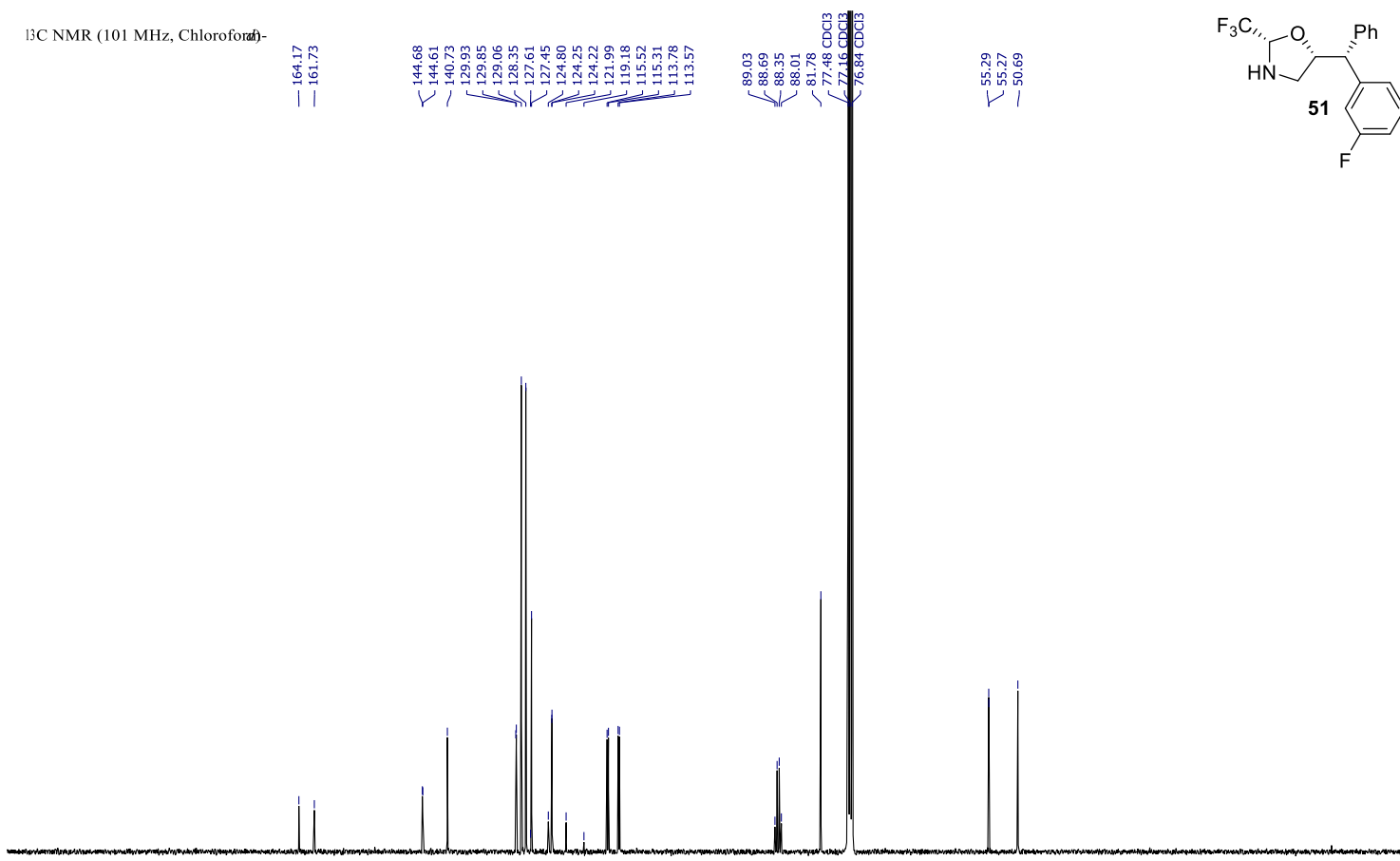

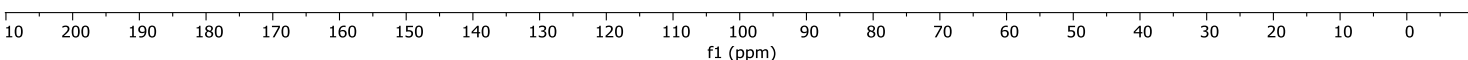




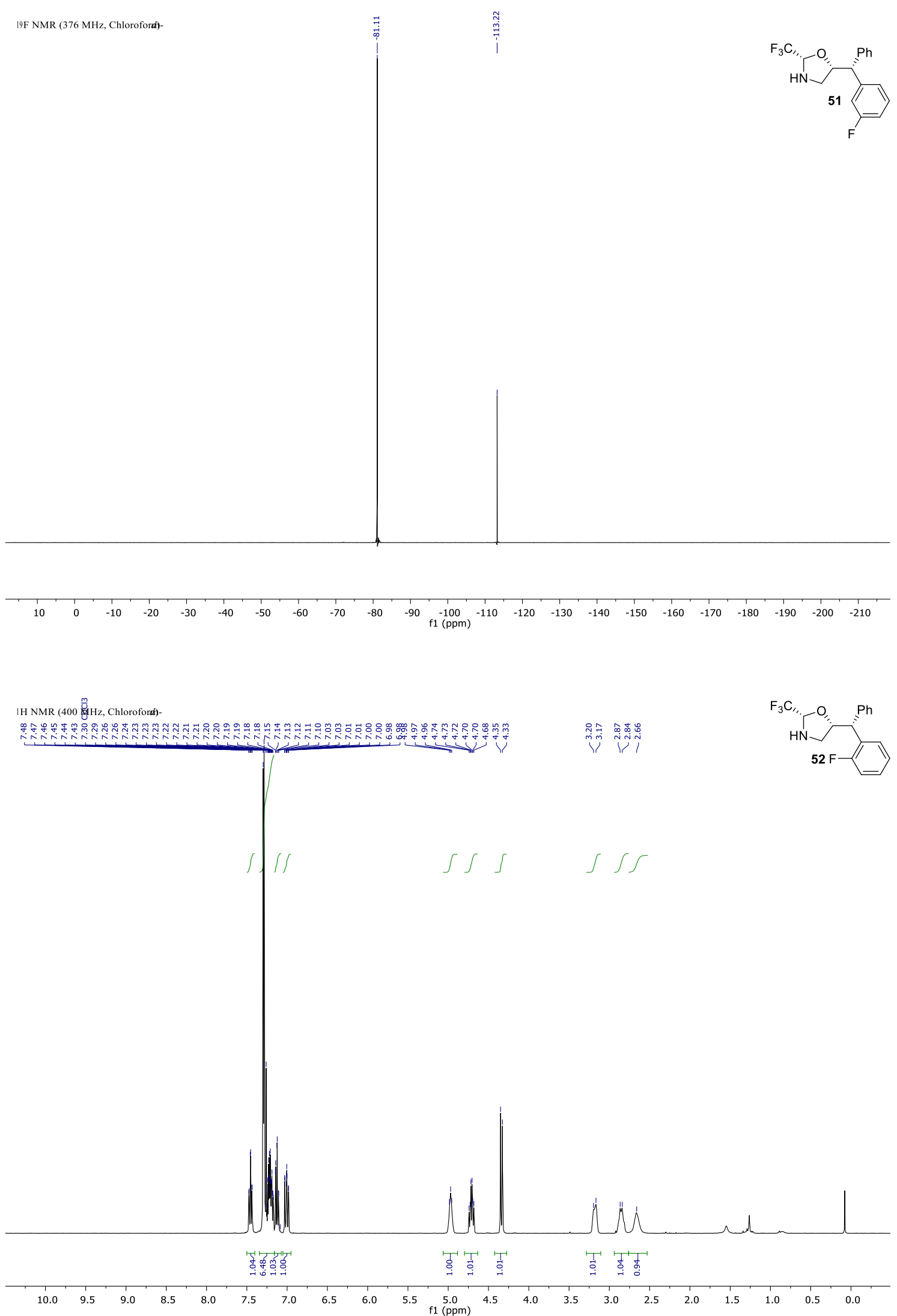



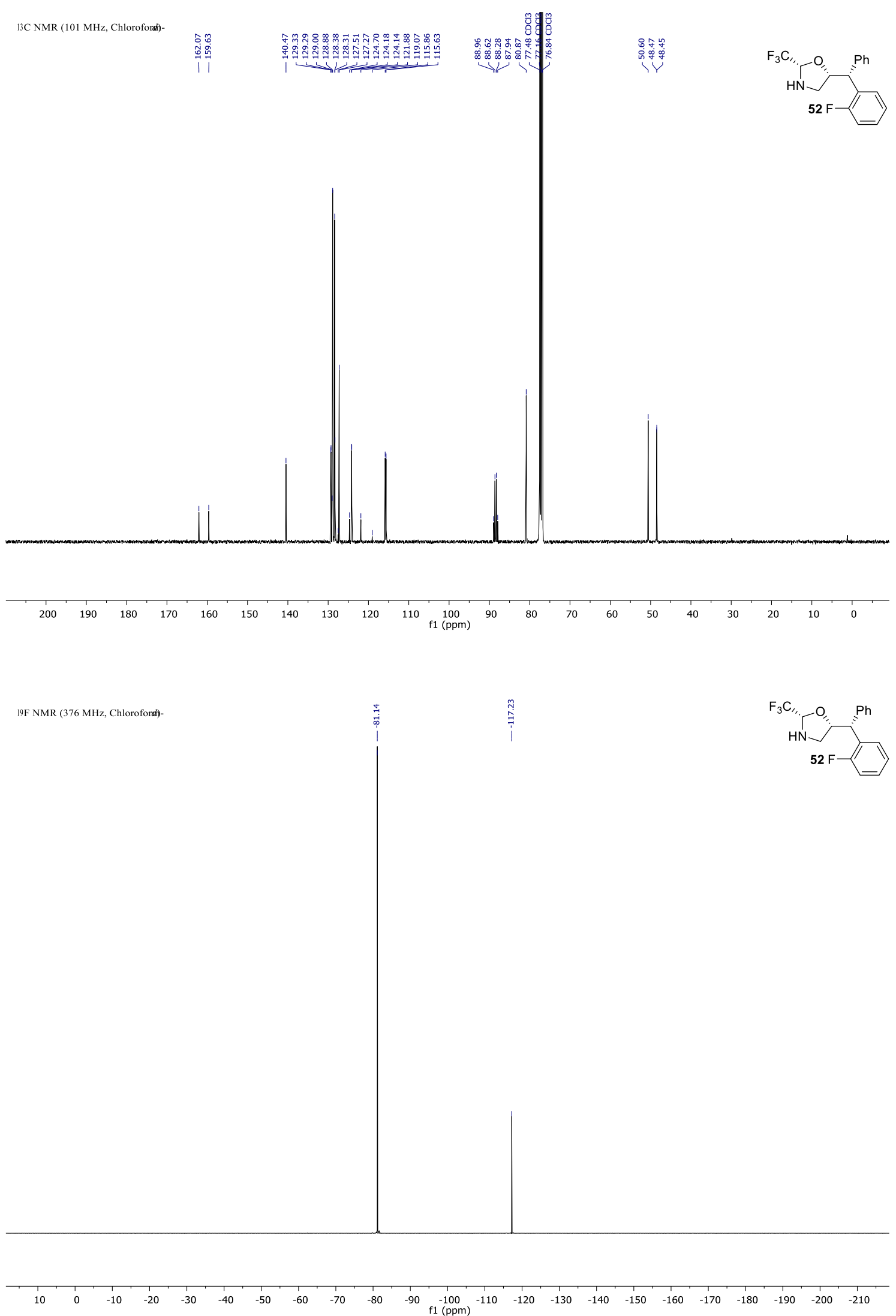

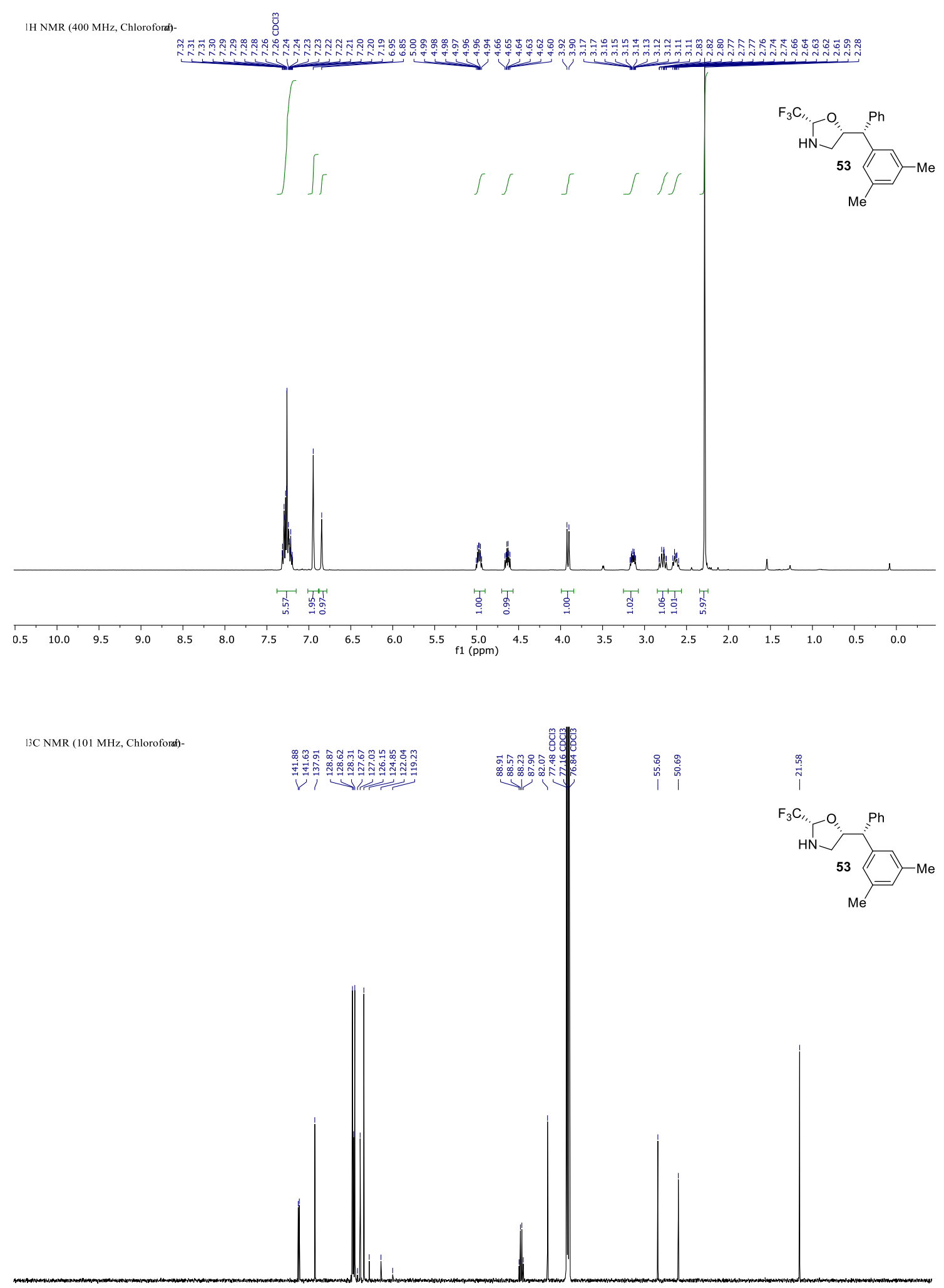

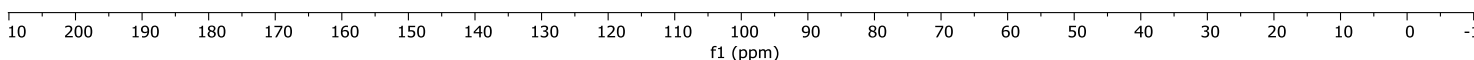




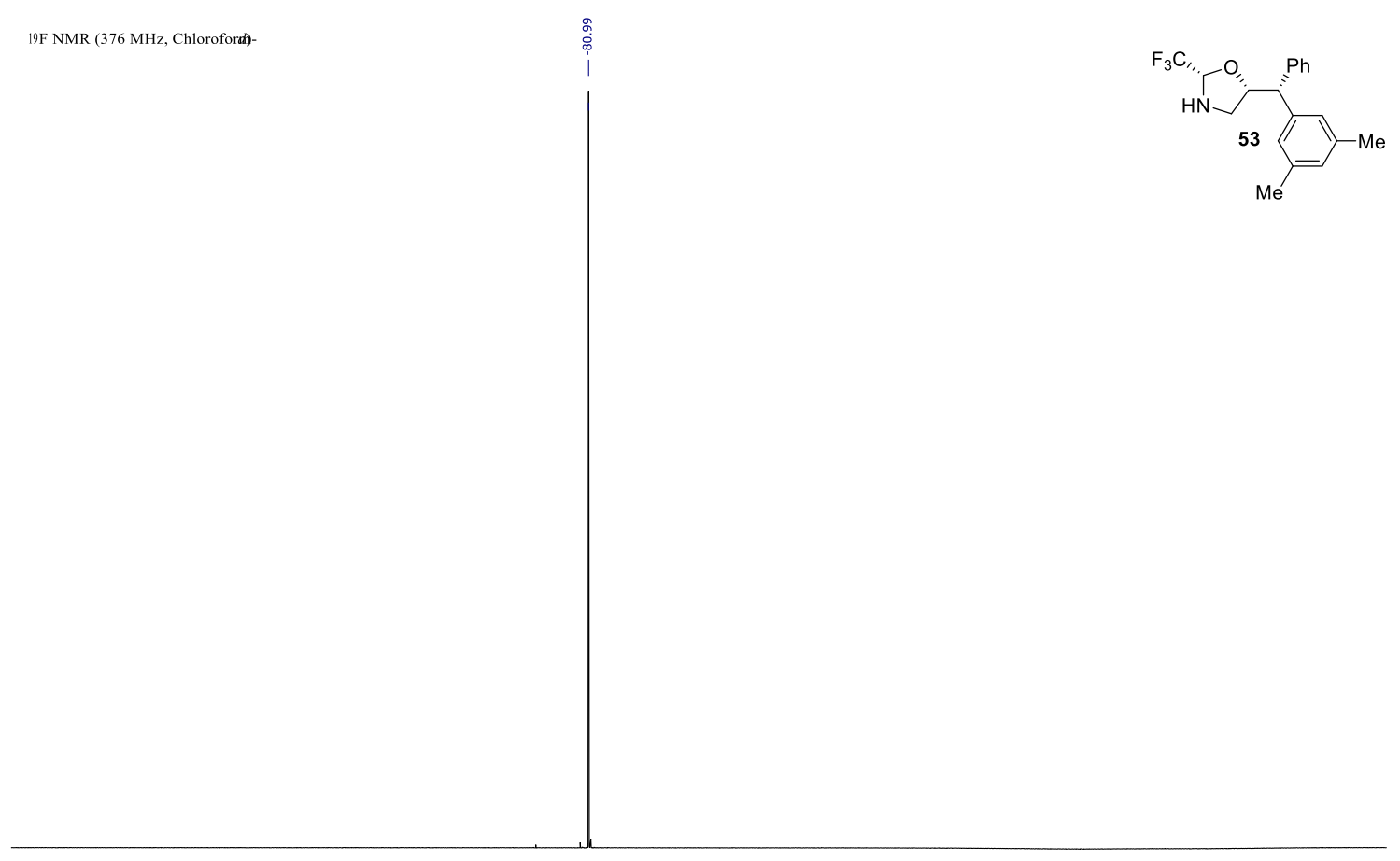

$\begin{array}{lllllllllllllllllllllll}10 & 0 & -10 & -20 & -30 & -40 & -50 & -60 & -70 & -80 & -90 & -100 & -110 & -120 & -130 & -140 & -150 & -160 & -170 & -180 & -190 & -200 & -210\end{array}$

$1 \mathrm{H} \mathrm{NMR} \mathrm{(400} \mathrm{MHz,} \mathrm{CD}_{3} \mathrm{Cl}$

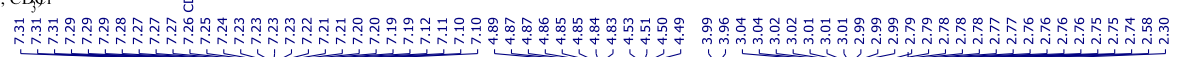

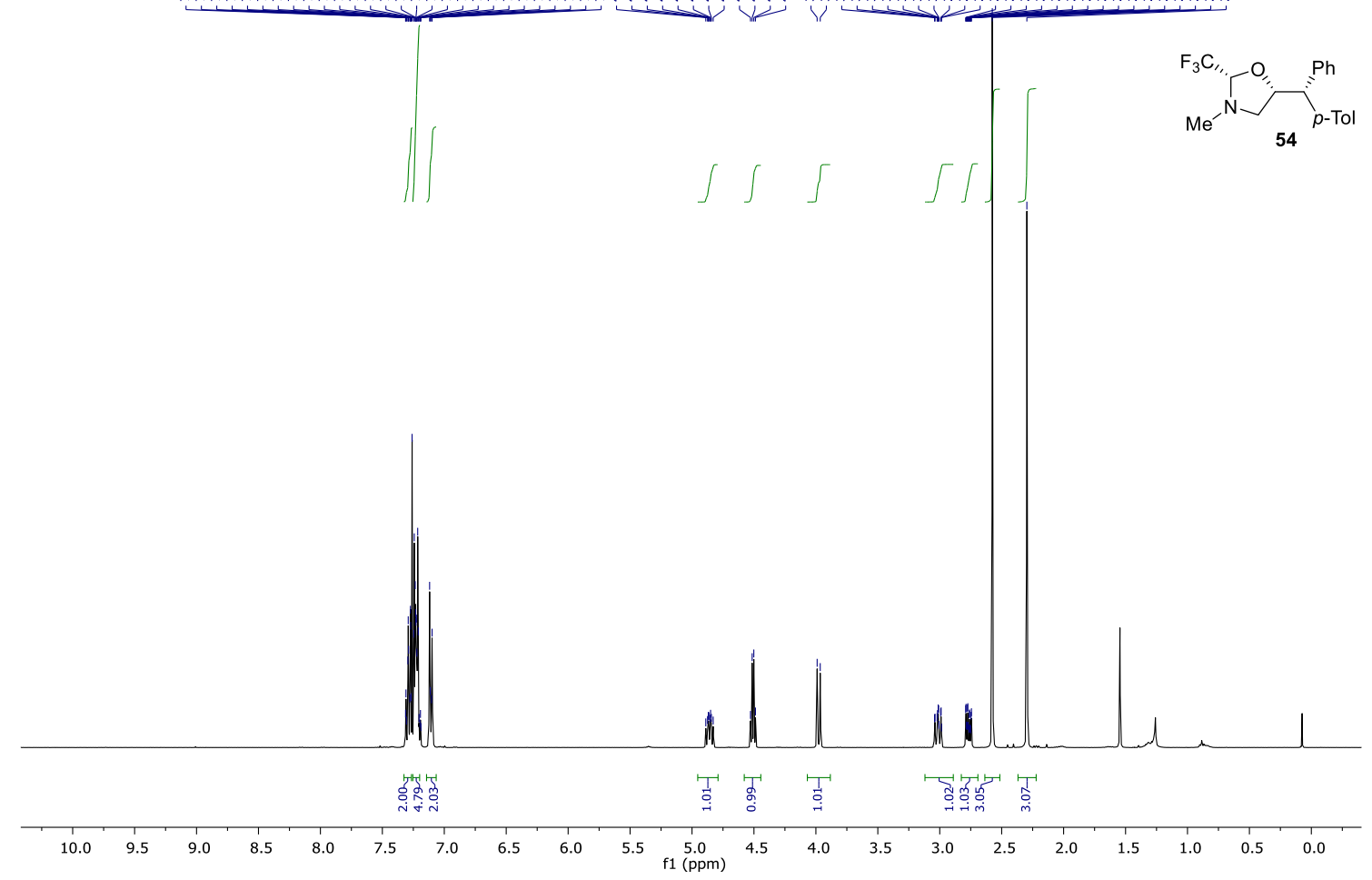



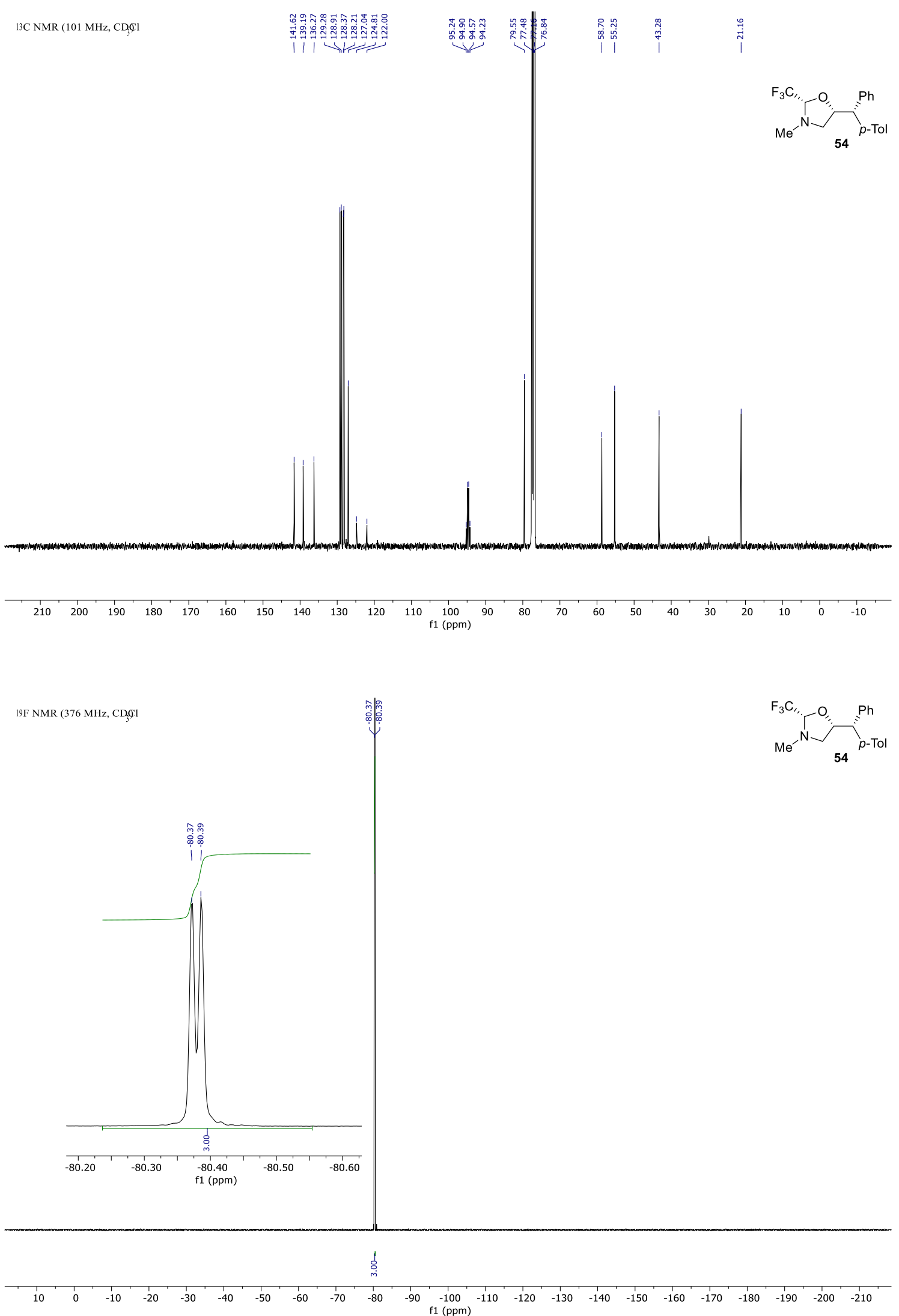


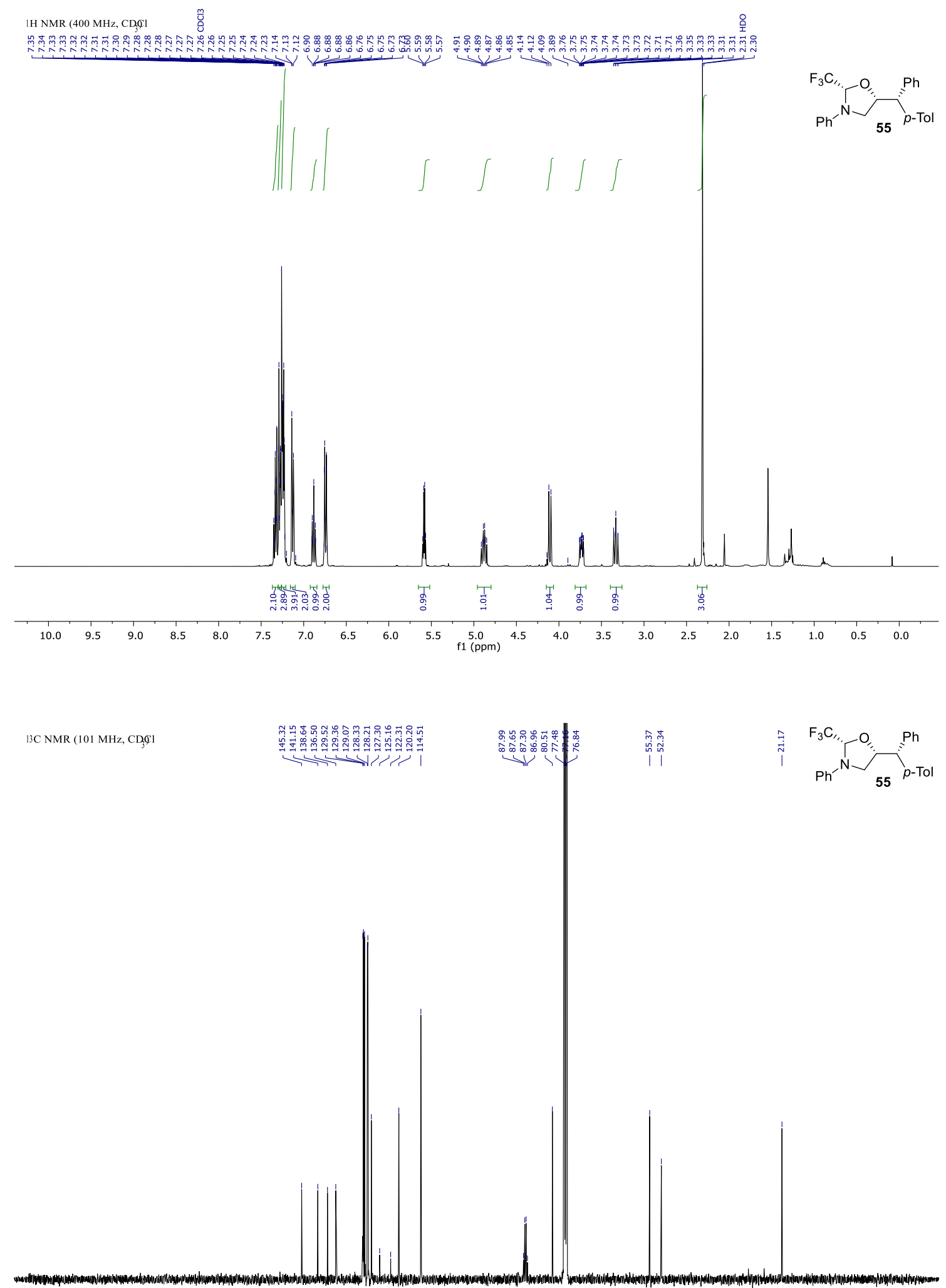

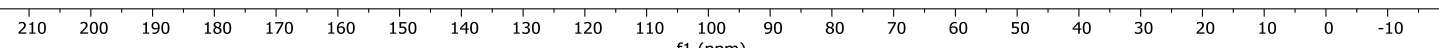
1 (ppm) 


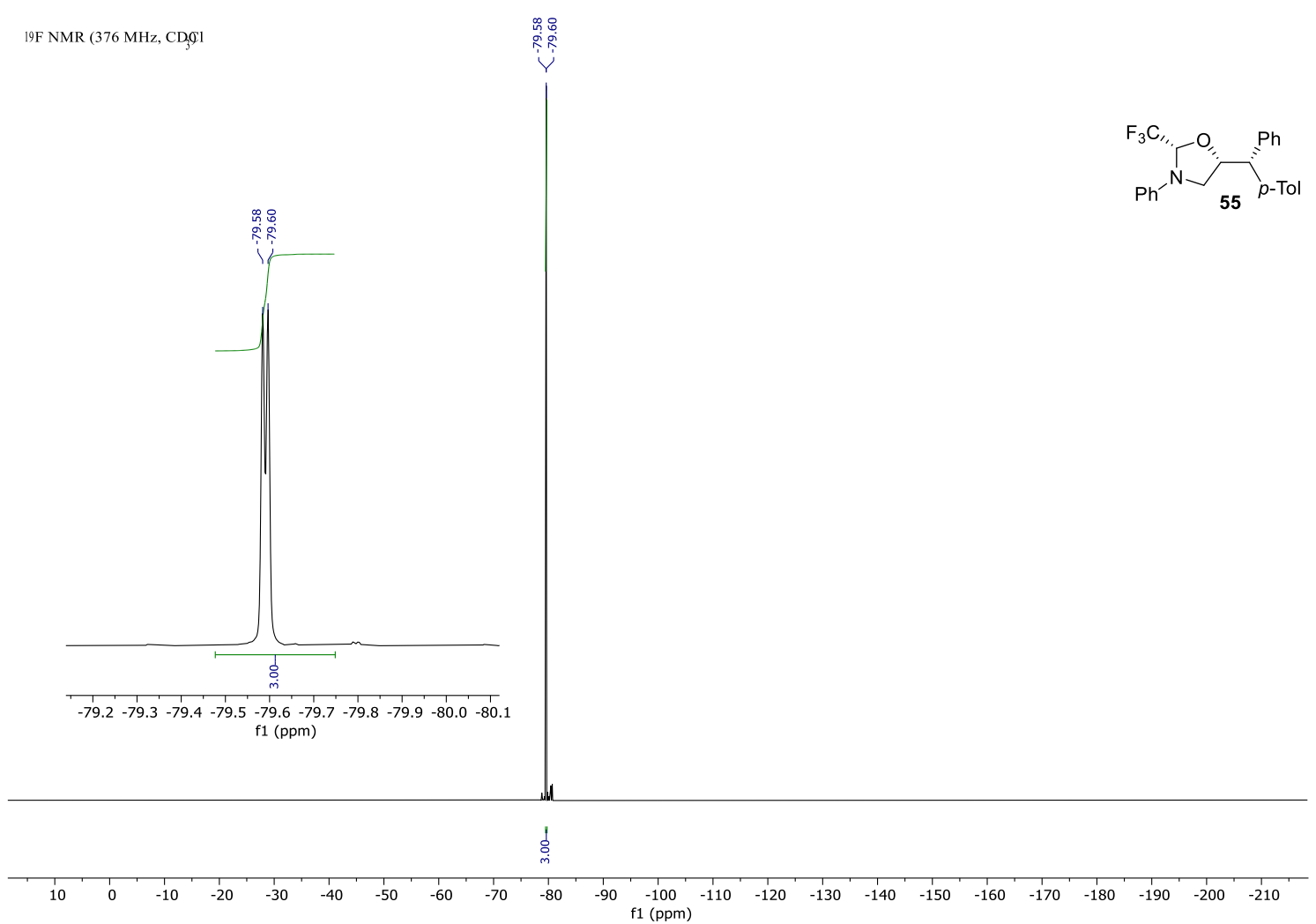



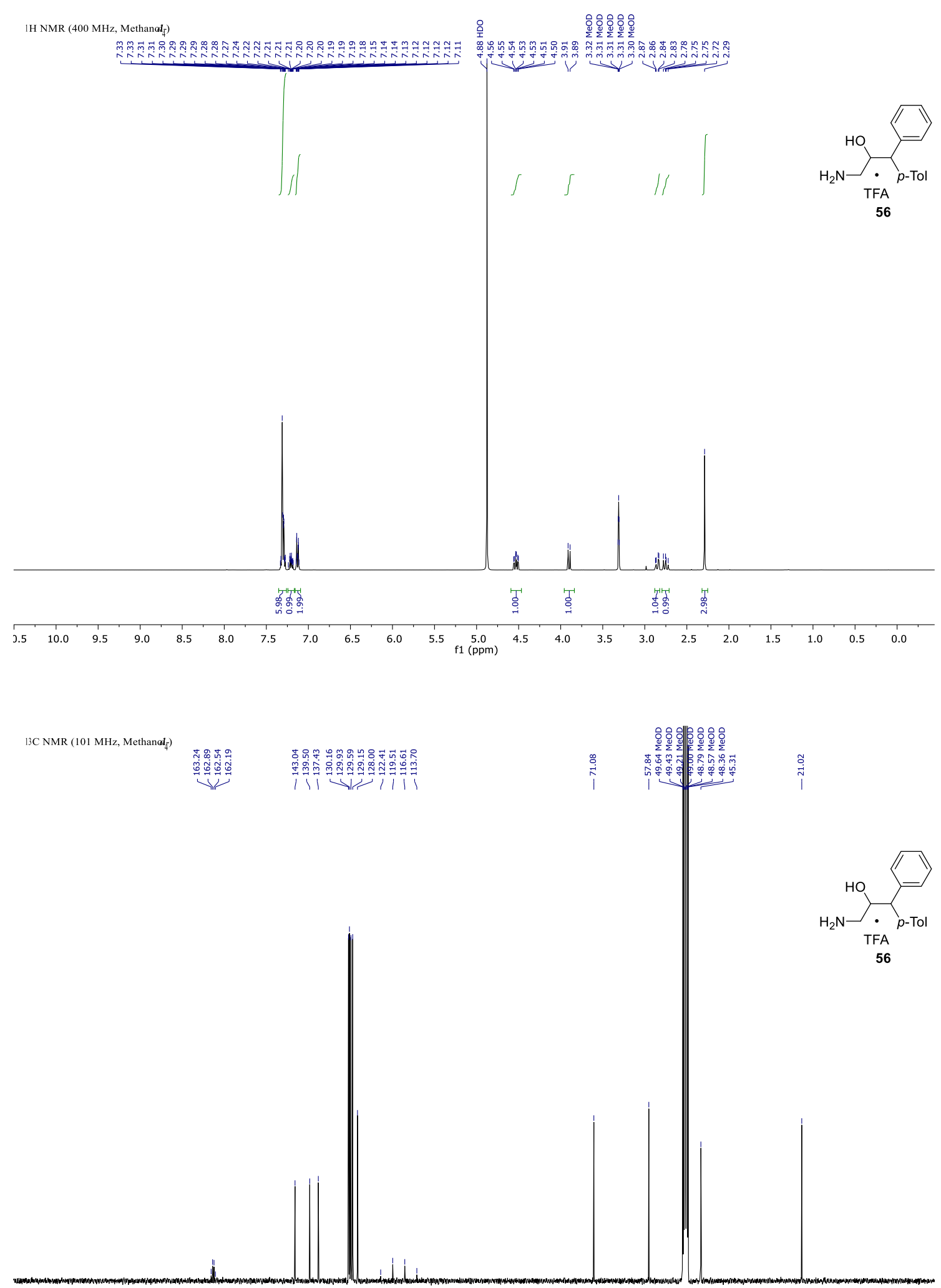

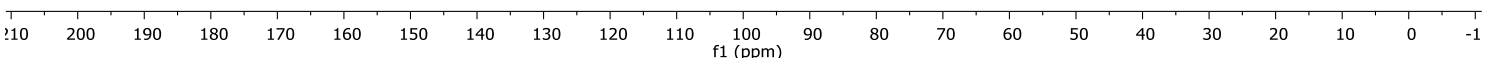




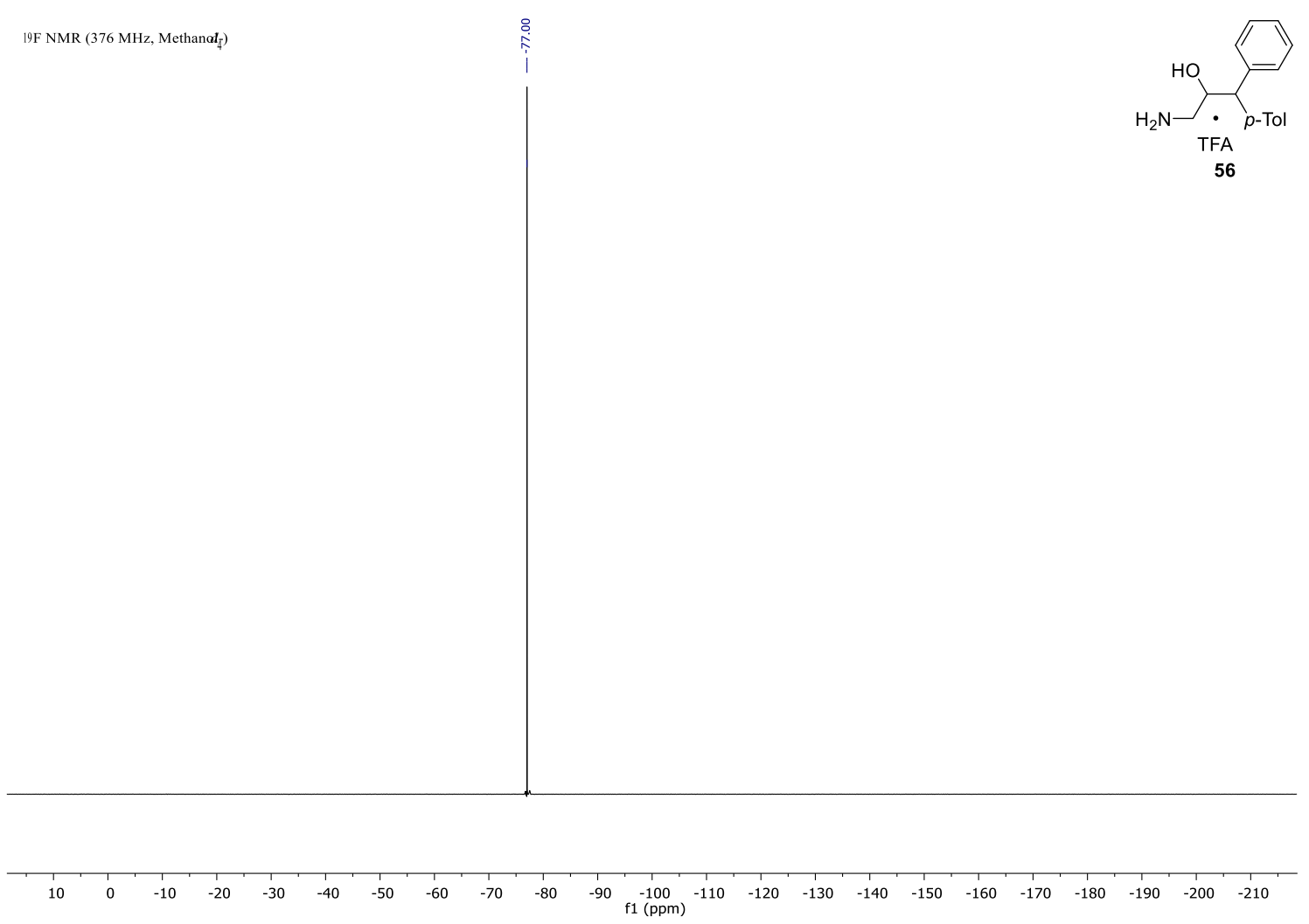




\section{HPLC Traces}

\section{I.1. Carboetherification Products}

Chiral HPLC Daicel Chiralpak IB N-5 column: 99:1 hexane/IPA, flow rate $1 \mathrm{~mL} / \mathrm{min}, \lambda=254 \mathrm{~nm}$

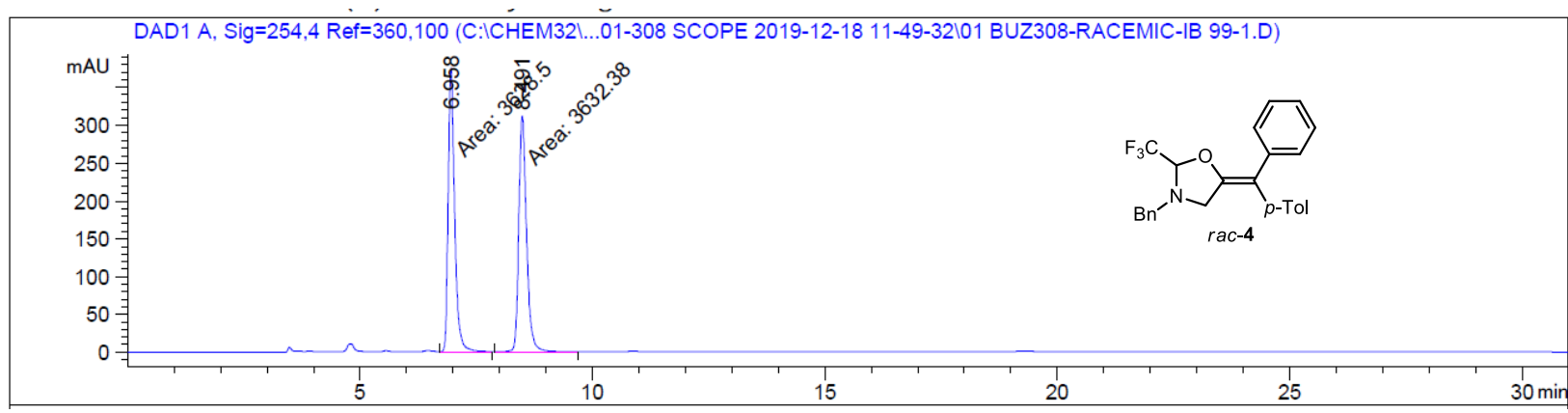

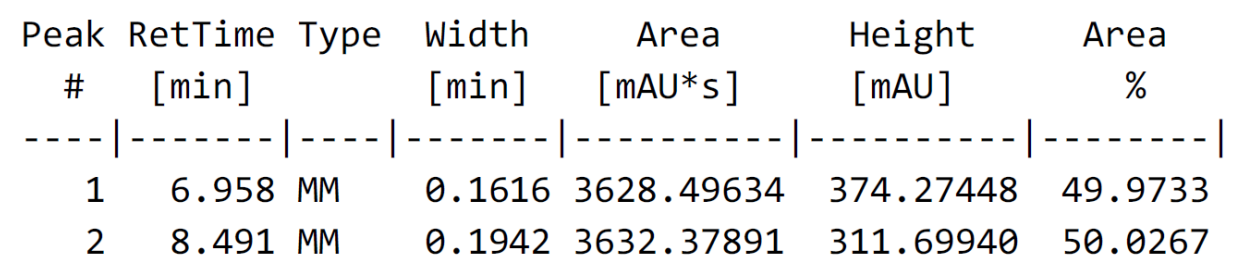

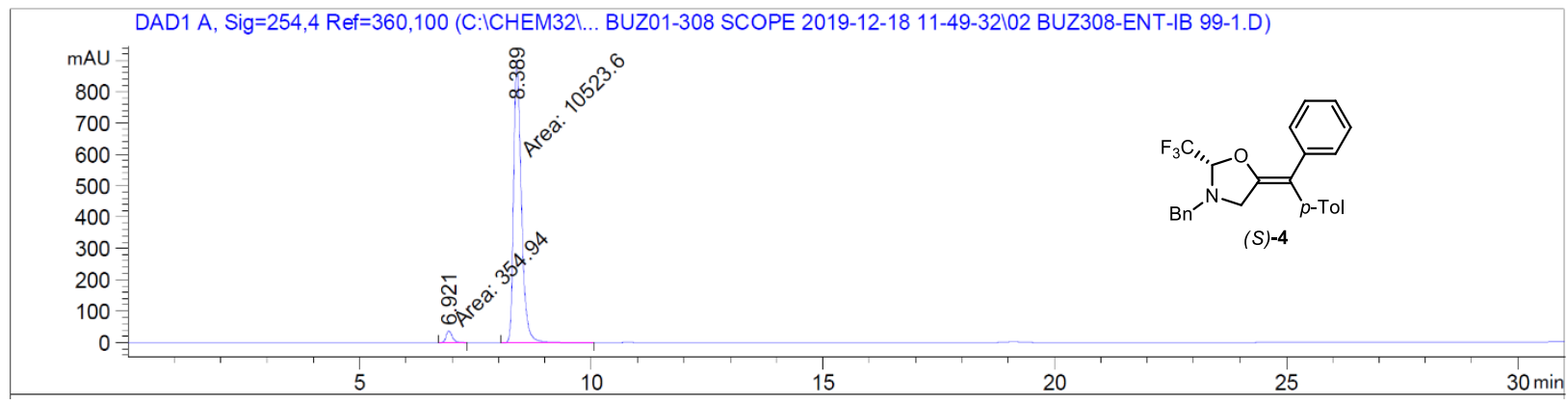

\begin{tabular}{|c|c|c|c|c|c|}
\hline $\begin{array}{c}\text { Peak } \\
\#\end{array}$ & $\begin{array}{l}\text { RetTime Type } \\
\text { [min] }\end{array}$ & $\begin{array}{l}\text { Width } \\
\text { [min] }\end{array}$ & $\begin{array}{c}\text { Area } \\
{\left[\mathrm{mAU}^{*} \mathrm{~s}\right]}\end{array}$ & $\begin{array}{l}\text { Height } \\
{[\mathrm{mAU}]}\end{array}$ & $\begin{array}{c}\text { Area } \\
\%\end{array}$ \\
\hline & & & & & \\
\hline 1 & 6. & 0.1 & 354.93954 & 37.28573 & 3.2628 \\
\hline 2 & $8.389 \mathrm{MM}$ & 19 & $1.05236 \mathrm{e} 4$ & 900.04584 & 96.7372 \\
\hline
\end{tabular}



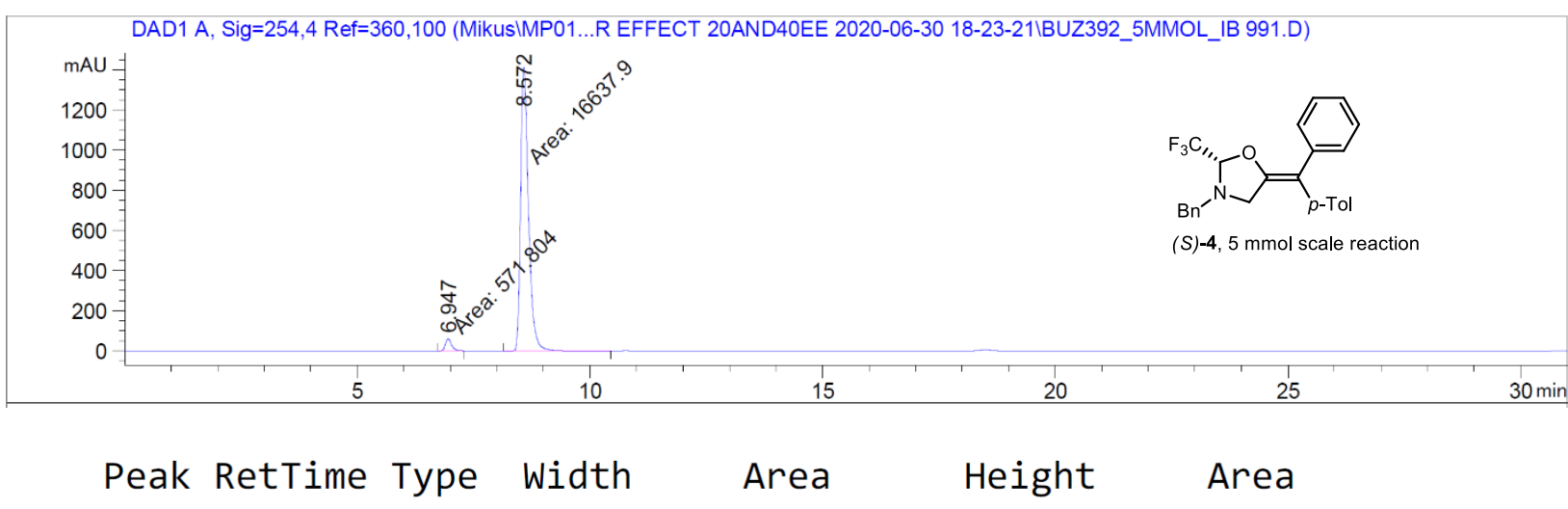

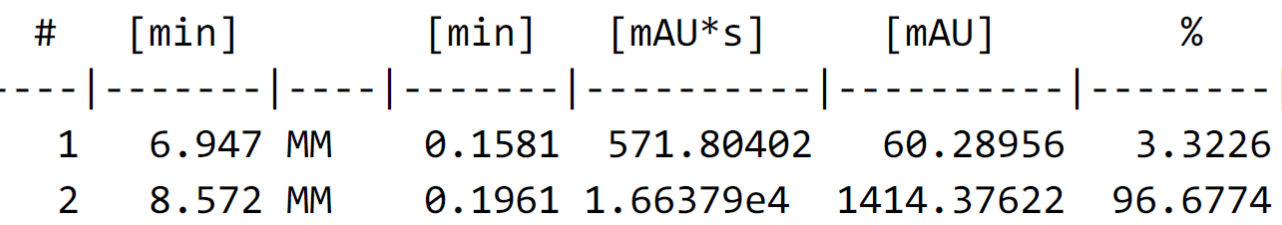

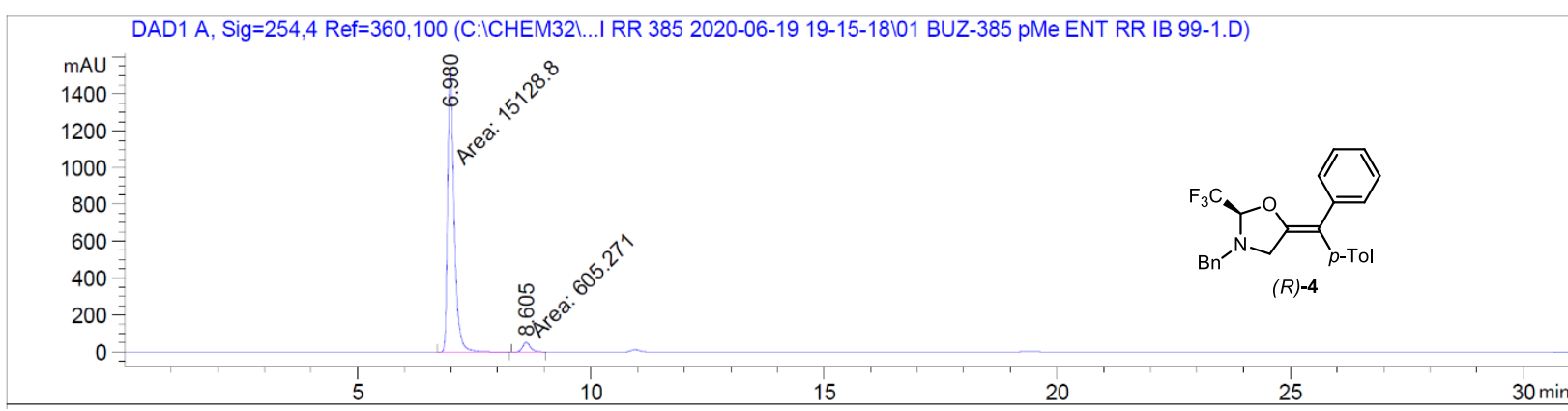

\begin{tabular}{|c|c|c|c|c|c|c|}
\hline $\begin{array}{c}\text { Peak } \\
\quad \#\end{array}$ & $\begin{array}{c}\text { RetTime } \\
\text { [min] }\end{array}$ & Type & $\begin{array}{l}\text { Width } \\
\text { [min] }\end{array}$ & $\begin{array}{c}\text { Area } \\
{\left[\mathrm{mAU}^{*} \mathrm{~s}\right]}\end{array}$ & $\begin{array}{l}\text { Height } \\
{[\mathrm{mAU}]}\end{array}$ & $\begin{array}{c}\text { Area } \\
\%\end{array}$ \\
\hline & 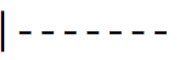 & & & . & |-- - & -- \\
\hline 1 & 6.5 & $M$ & & $1.51288 \mathrm{e} 4$ & 1543 & 96. \\
\hline 2 & 8.605 & M & 957 & 605.27081 & 55163 & 3.8469 \\
\hline
\end{tabular}


Chiral HPLC Daicel Chiralpak IB N-5 column: 99:1 hexane/IPA, flow rate $1 \mathrm{~mL} / \mathrm{min}, \lambda=254 \mathrm{~nm}$
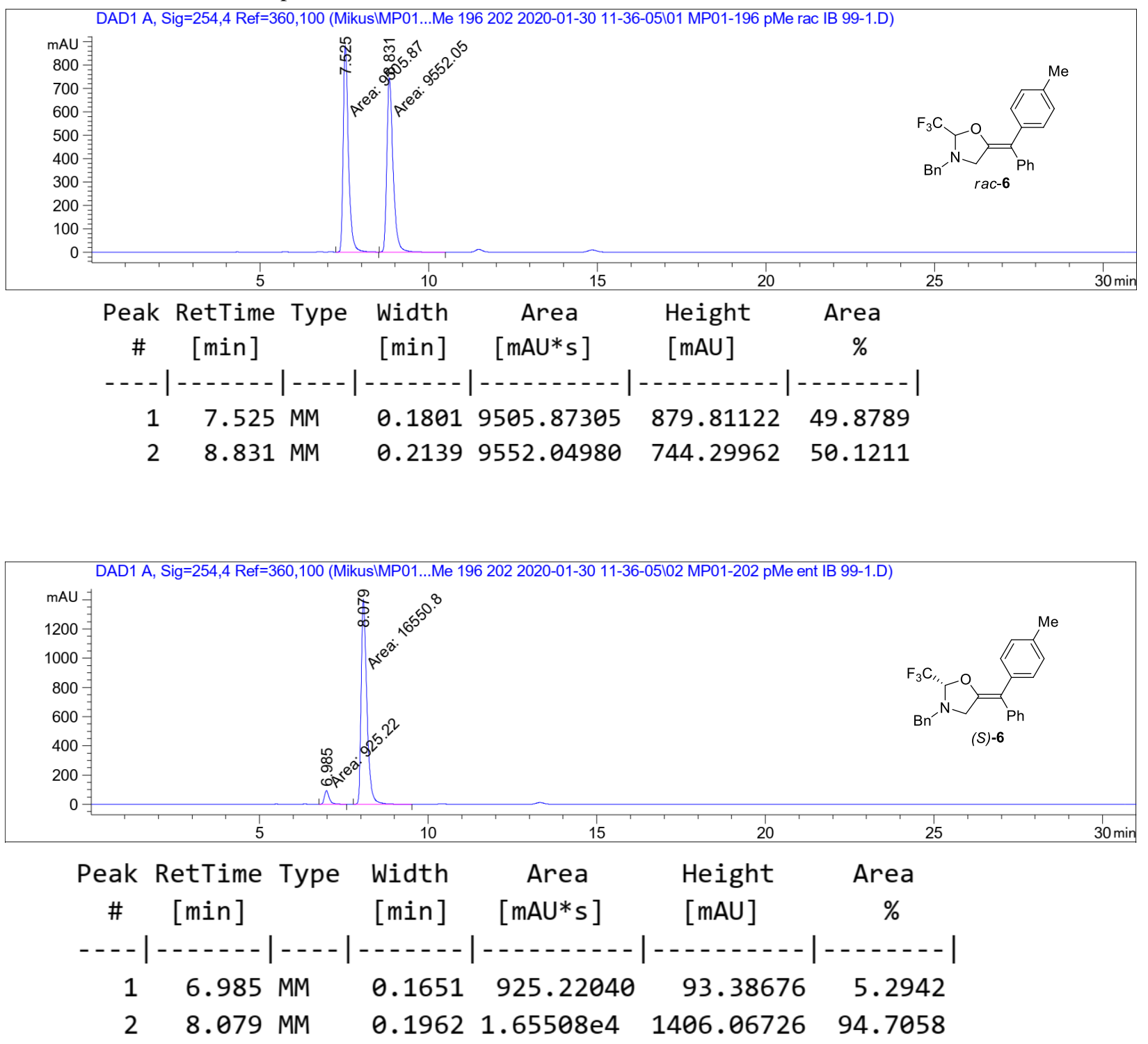


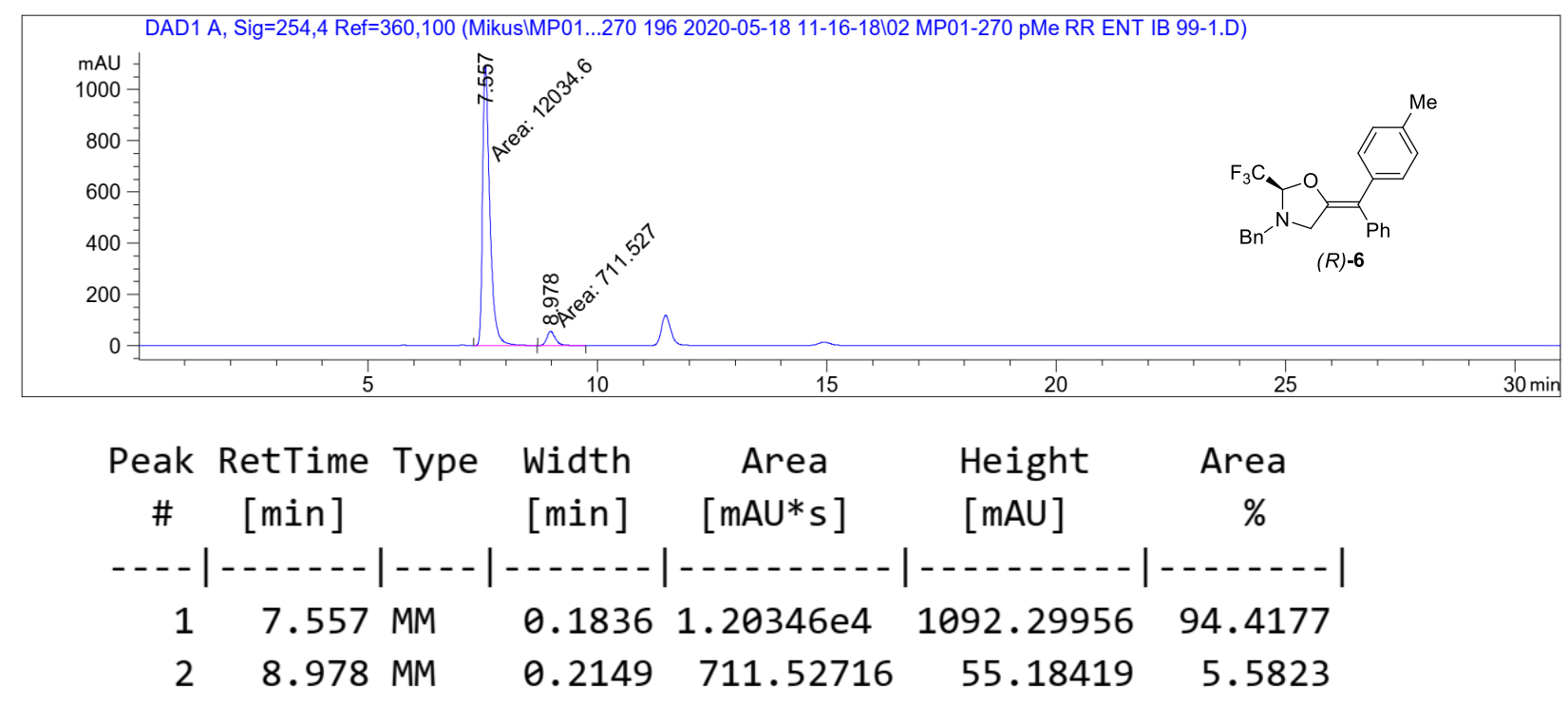


Chiral HPLC Daicel Chiralpak IB N-5 column: 99:1 hexane/IPA, flow rate $1 \mathrm{~mL} / \mathrm{min}, \lambda=254 \mathrm{~nm}$
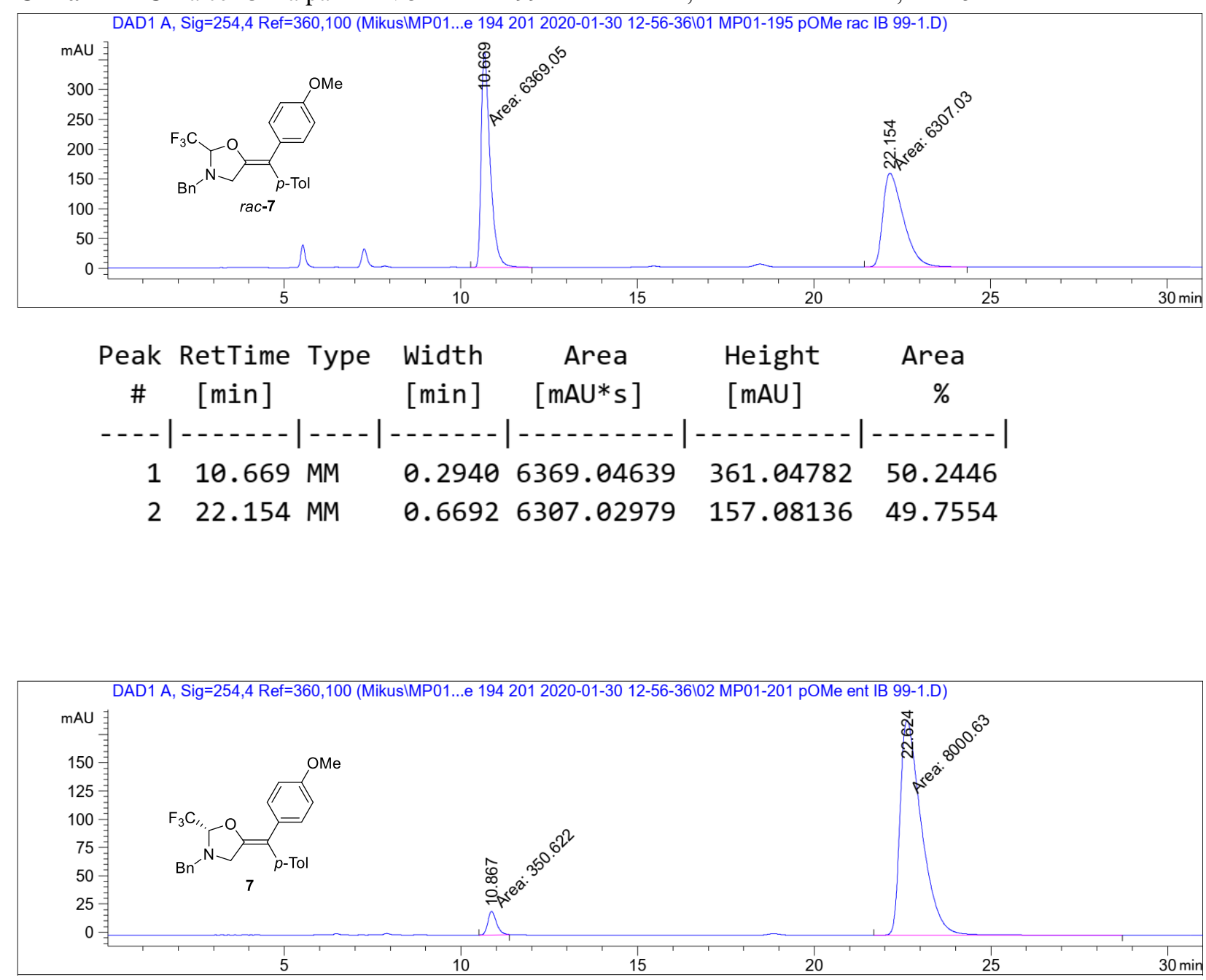

\begin{tabular}{cccccc}
$\begin{array}{c}\text { Peak RetTime Type } \\
\text { \# }\end{array}$ Width & $\begin{array}{c}\text { Area } \\
\text { [min] }\end{array}$ & $\begin{array}{c}\text { Height } \\
{[\mathrm{mAU} \text { s }]}\end{array}$ & \multicolumn{1}{c}{$\begin{array}{c}\text { Area } \\
{[\mathrm{mAU}]}\end{array}$} & $\%$ \\
\hline 1 & 10.867 MM & 0.2815 & 350.62244 & 20.76242 & 4.1984 \\
2 & 22.624 MM & 0.7010 & 8000.62646 & 190.21245 & 95.8016
\end{tabular}


Chiral HPLC Daicel Chiralpak IB N-5 column: 99:1 hexane/IPA, flow rate $1 \mathrm{~mL} / \mathrm{min}, \lambda=254 \mathrm{~nm}$
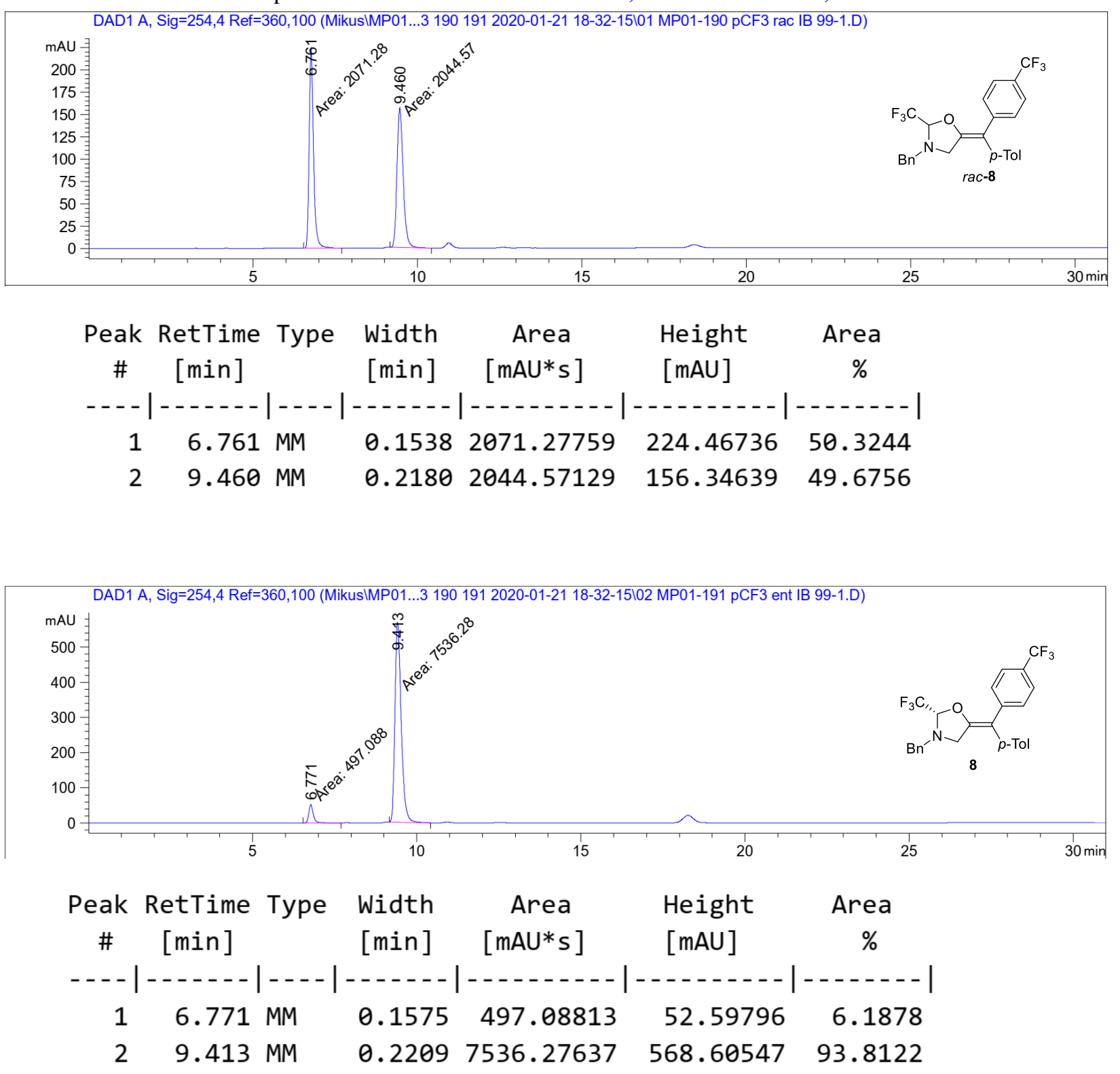
Chiral HPLC Daicel Chiralpak IB N-5 column: 99:1 hexane/IPA, flow rate $1 \mathrm{~mL} / \mathrm{min}, \lambda=254 \mathrm{~nm}$
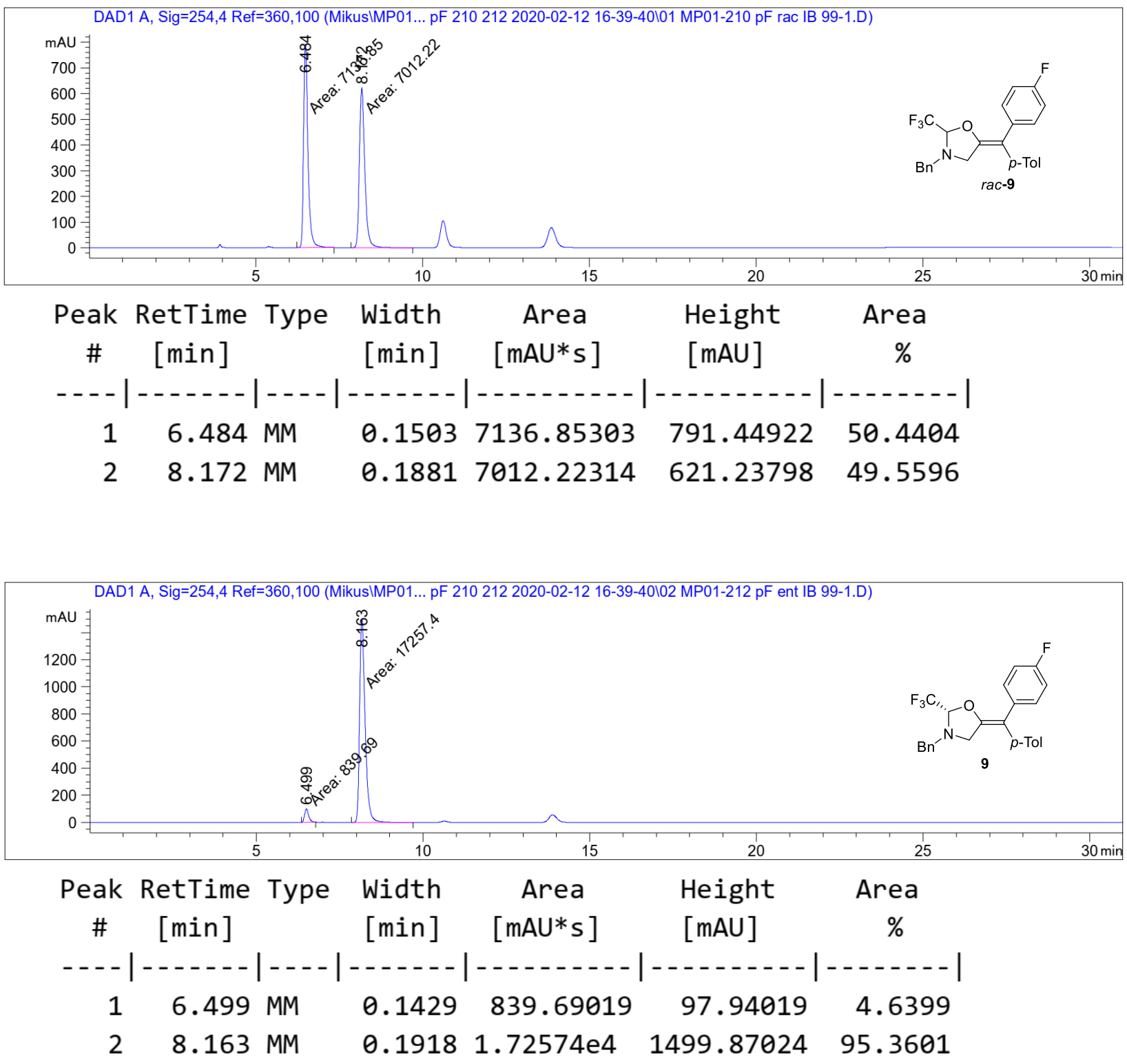
Chiral HPLC Daicel Chiralpak IB N-5 column: 99:1 hexane/IPA, flow rate $1 \mathrm{~mL} / \mathrm{min}, \lambda=254 \mathrm{~nm}$

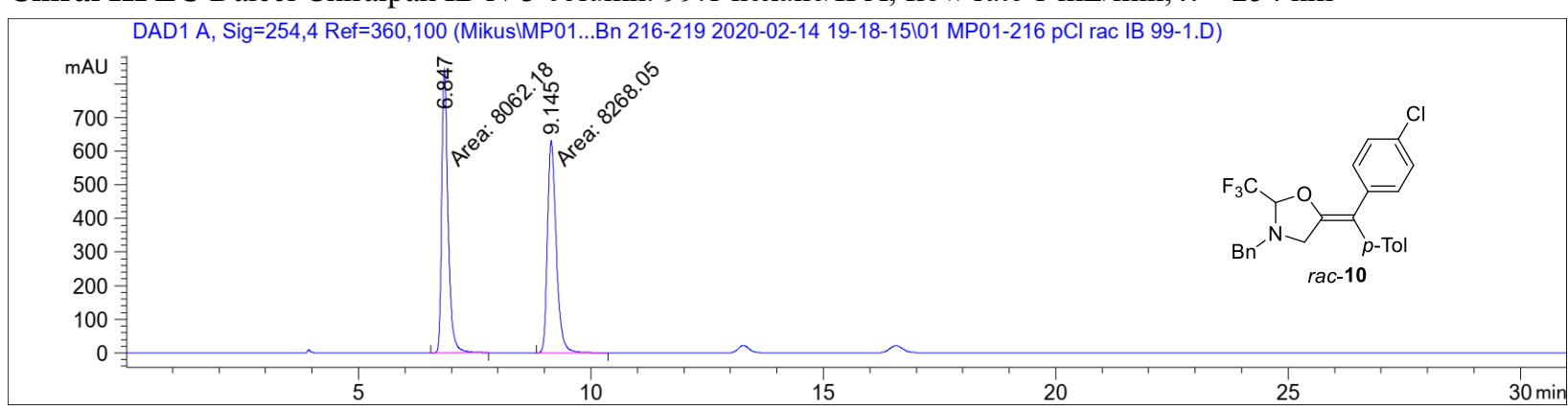

\begin{tabular}{|c|c|c|c|c|c|c|}
\hline $\begin{array}{l}\text { eak } \\
\#\end{array}$ & $\begin{array}{c}\text { RetTime } \\
\text { [min] }\end{array}$ & pe & $\begin{array}{l}\text { Width } \\
\text { [min] }\end{array}$ & $\begin{array}{c}\text { Area } \\
{\left[\mathrm{mAU}^{*} \mathrm{~s}\right]}\end{array}$ & $\begin{array}{l}\text { Height } \\
\text { [mAU] }\end{array}$ & $\begin{array}{c}\text { Area } \\
\quad \%\end{array}$ \\
\hline & & & & & & \\
\hline 1 & & & & 1 & 84 & 97 \\
\hline 0 & 9.145 & r & .2182 & 8268.05176 & 631.66949 & 50.6303 \\
\hline
\end{tabular}

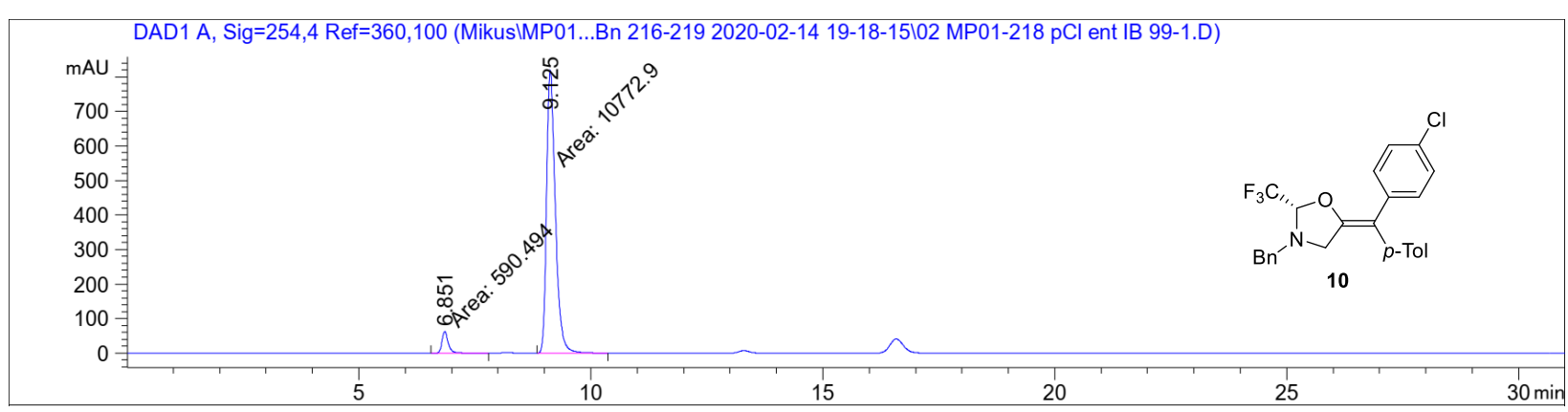

\begin{tabular}{|c|c|c|c|c|c|c|}
\hline $\begin{array}{l}\text { eak } \\
\text { \# }\end{array}$ & $\begin{array}{c}\text { RetTime } \\
\text { [min] }\end{array}$ & Type & $\begin{array}{l}\text { Width } \\
\text { [min] }\end{array}$ & $\begin{array}{c}\text { Area } \\
{\left[\mathrm{mAU}^{*} \mathrm{~s}\right]}\end{array}$ & $\begin{array}{l}\text { Height } \\
\text { [mAU] }\end{array}$ & $\begin{array}{c}\text { Area } \\
\%\end{array}$ \\
\hline & & & & & & \\
\hline 1 & & & .1 & 590. & 6822 & 965 \\
\hline 2 & 5 & & .2194 & $1.07729 \mathrm{e} 4$ & 18.30353 & 94.8035 \\
\hline
\end{tabular}


Chiral HPLC Daicel Chiralpak IB N-5 column: 99:1 hexane/IPA, flow rate $1 \mathrm{~mL} / \mathrm{min}, \lambda=254 \mathrm{~nm}$
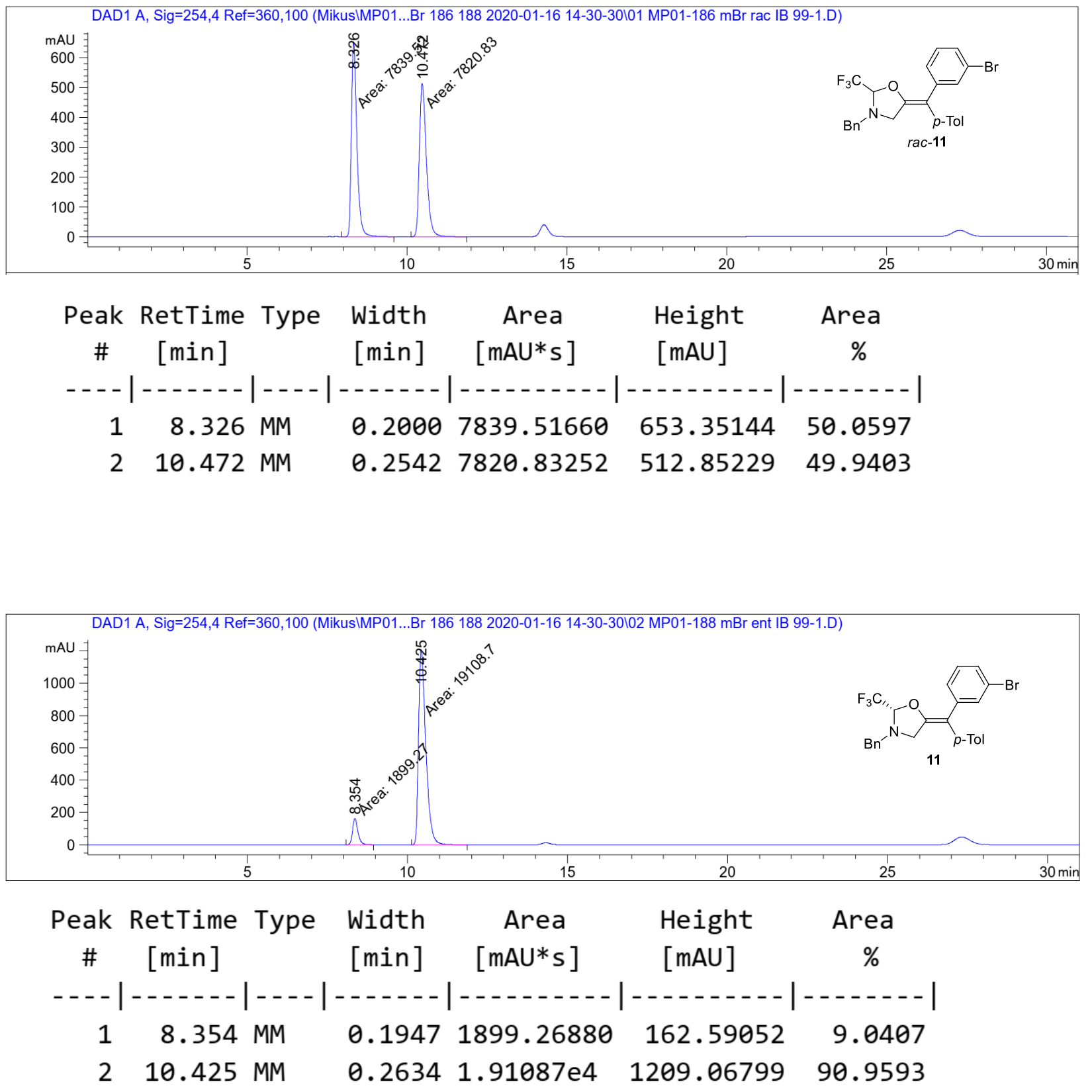
Chiral HPLC Daicel Chiralpak IB N-5 column: 99:1 hexane/IPA, flow rate $1 \mathrm{~mL} / \mathrm{min}, \lambda=254 \mathrm{~nm}$
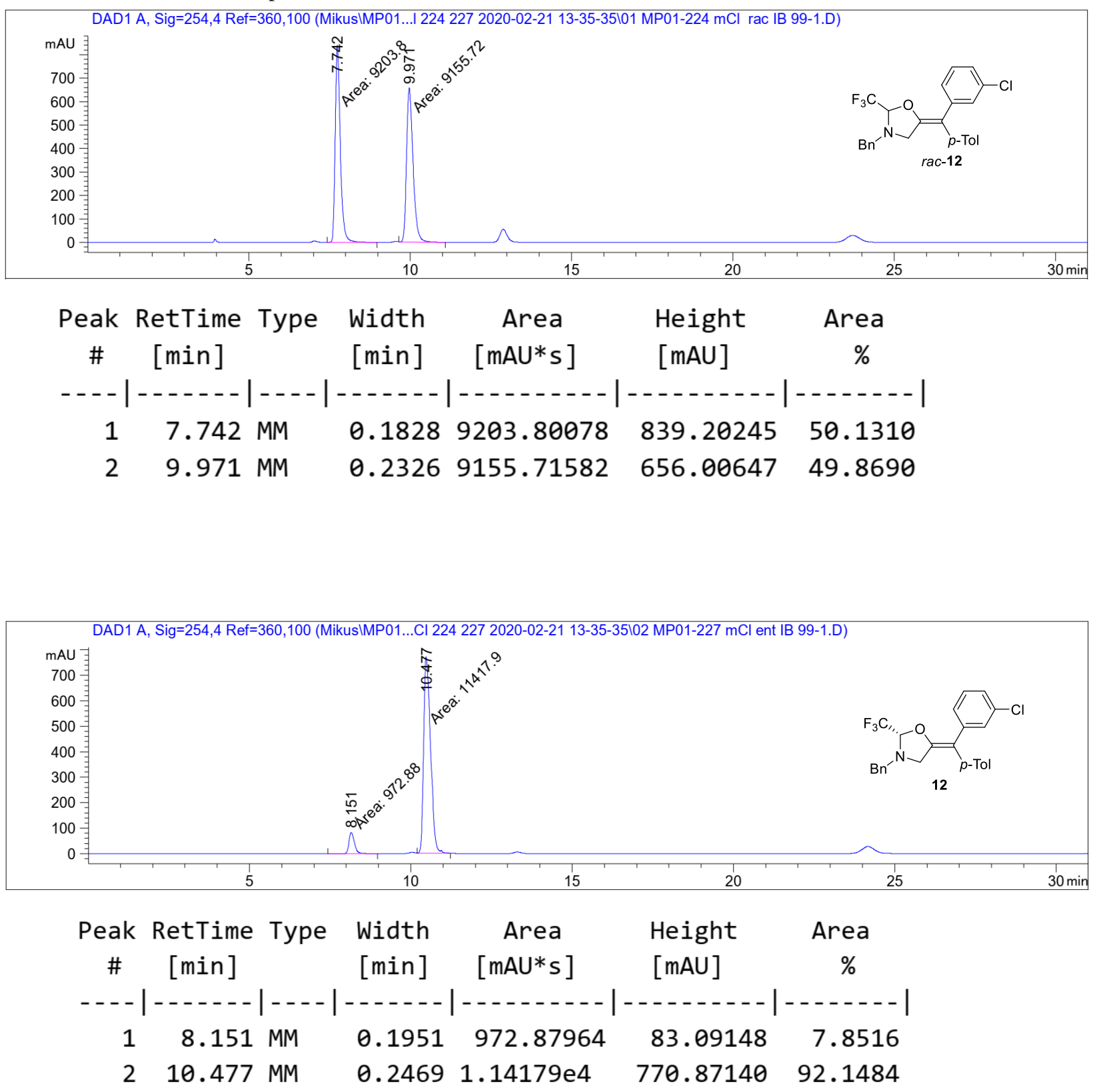
Chiral HPLC Daicel Chiralpak IB N-5 column: 99:1 hexane/IPA, flow rate $1 \mathrm{~mL} / \mathrm{min}, \lambda=254 \mathrm{~nm}$

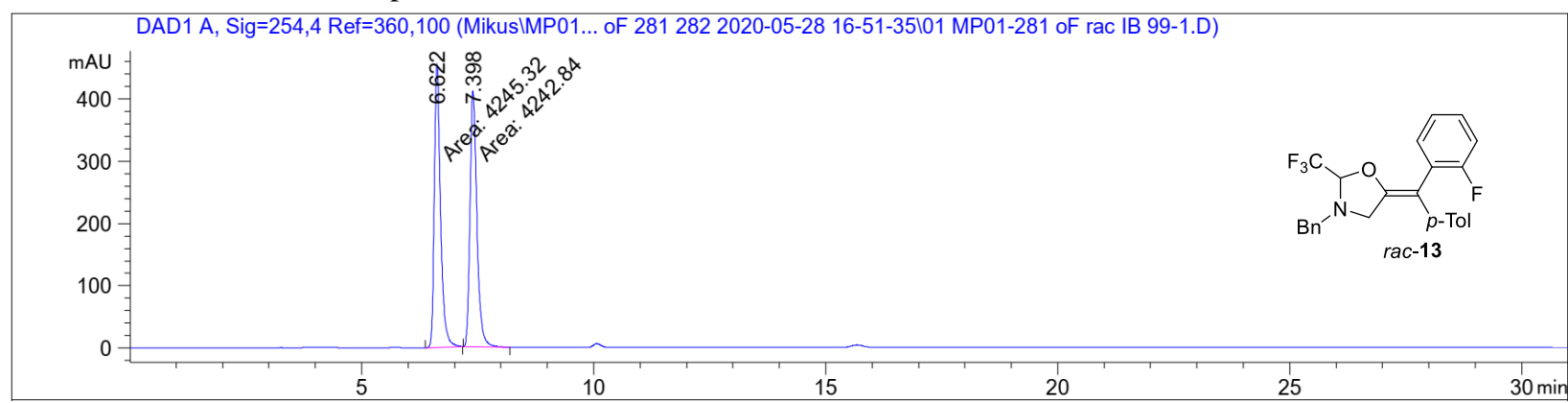

\begin{tabular}{|c|c|c|c|c|c|c|}
\hline $\begin{array}{c}\text { Peak } \\
\text { \# }\end{array}$ & $\begin{array}{c}\text { RetTime } \\
\text { [min] }\end{array}$ & Type & $\begin{array}{l}\text { Width } \\
\text { [min] }\end{array}$ & $\begin{array}{c}\text { Area } \\
{\left[\mathrm{mAU}^{*} \mathrm{~s}\right]}\end{array}$ & $\begin{array}{l}\text { ght } \\
\text { U] }\end{array}$ & $\begin{array}{c}\text { Area } \\
\%\end{array}$ \\
\hline & & & & & & \\
\hline 1 & & & a 1 & 424 & C & 46 \\
\hline & 8 & & .1721 & 4242.84326 & 411.00439 & 49.9854 \\
\hline
\end{tabular}

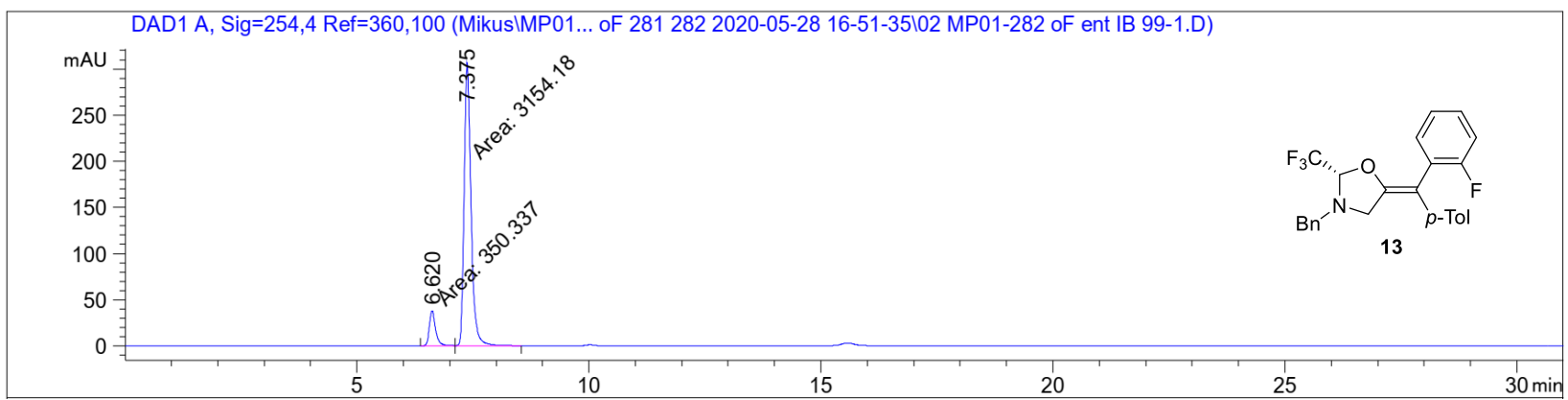

\begin{tabular}{cccccc}
$\begin{array}{c}\text { Peak RetTime Type } \\
\text { Width } \\
\text { [min] }\end{array}$ & $\begin{array}{c}\text { Area } \\
{[\mathrm{min}]}\end{array}$ & $\begin{array}{c}\text { Height } \\
{[\mathrm{mAU} \text { s }]}\end{array}$ & \multicolumn{1}{c}{$\begin{array}{c}\text { Area } \\
{[\mathrm{mAU}]}\end{array}$} & $\%$ \\
\hline 1 & 6.620 MM & 0.1539 & 350.33701 & 37.93580 & 9.9967 \\
2 & 7.375 MM & 0.1714 & 3154.18433 & 306.79001 & 90.0033
\end{tabular}


Chiral HPLC Daicel Chiralpak IB N-5 column: 99:1 hexane/IPA, flow rate $1 \mathrm{~mL} / \mathrm{min}, \lambda=254 \mathrm{~nm}$
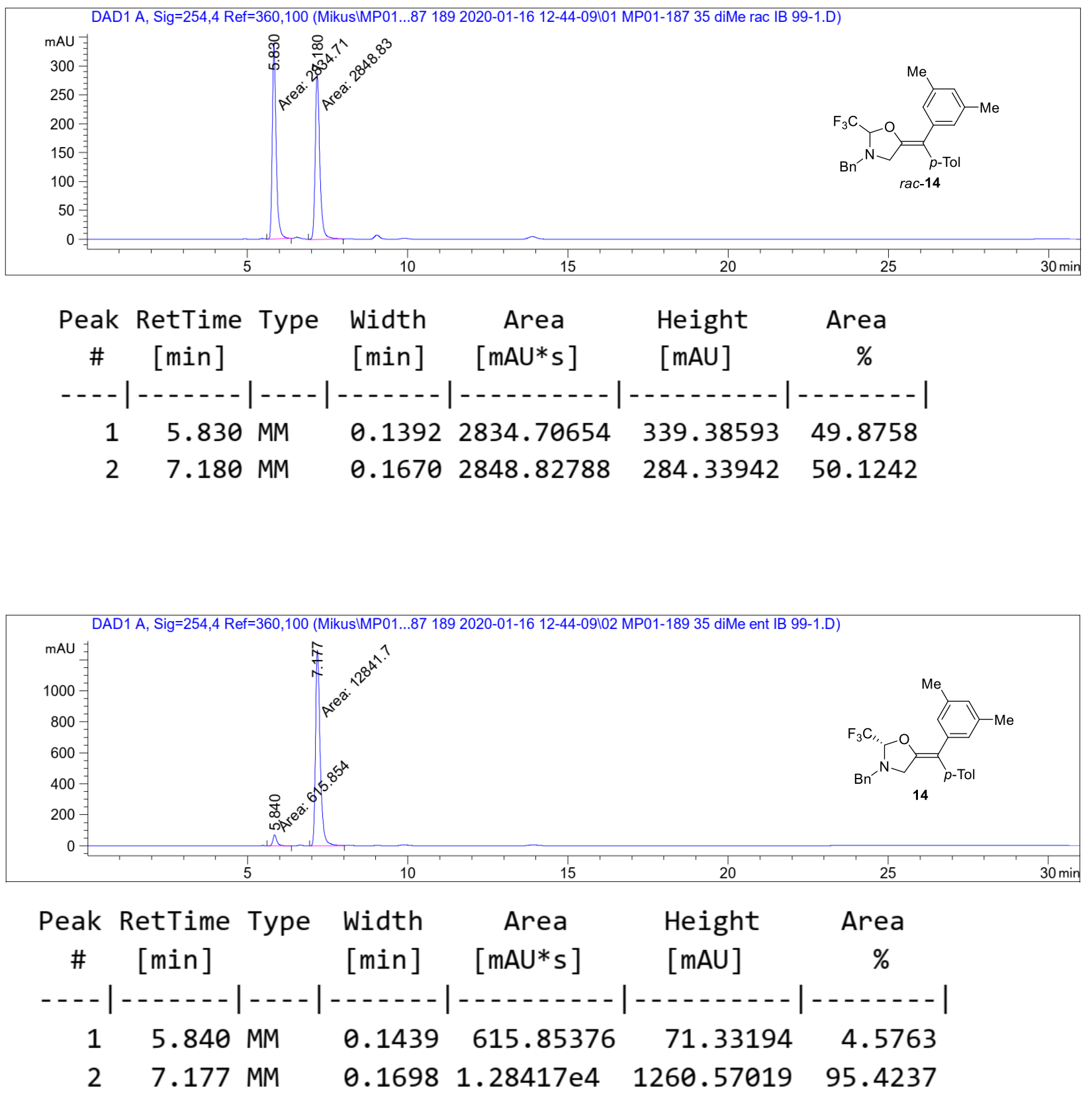
Chiral HPLC Daicel Chiralpak IB N-5 column: 90:10 hexane/IPA, flow rate $1 \mathrm{~mL} / \mathrm{min}, \lambda=254 \mathrm{~nm}$
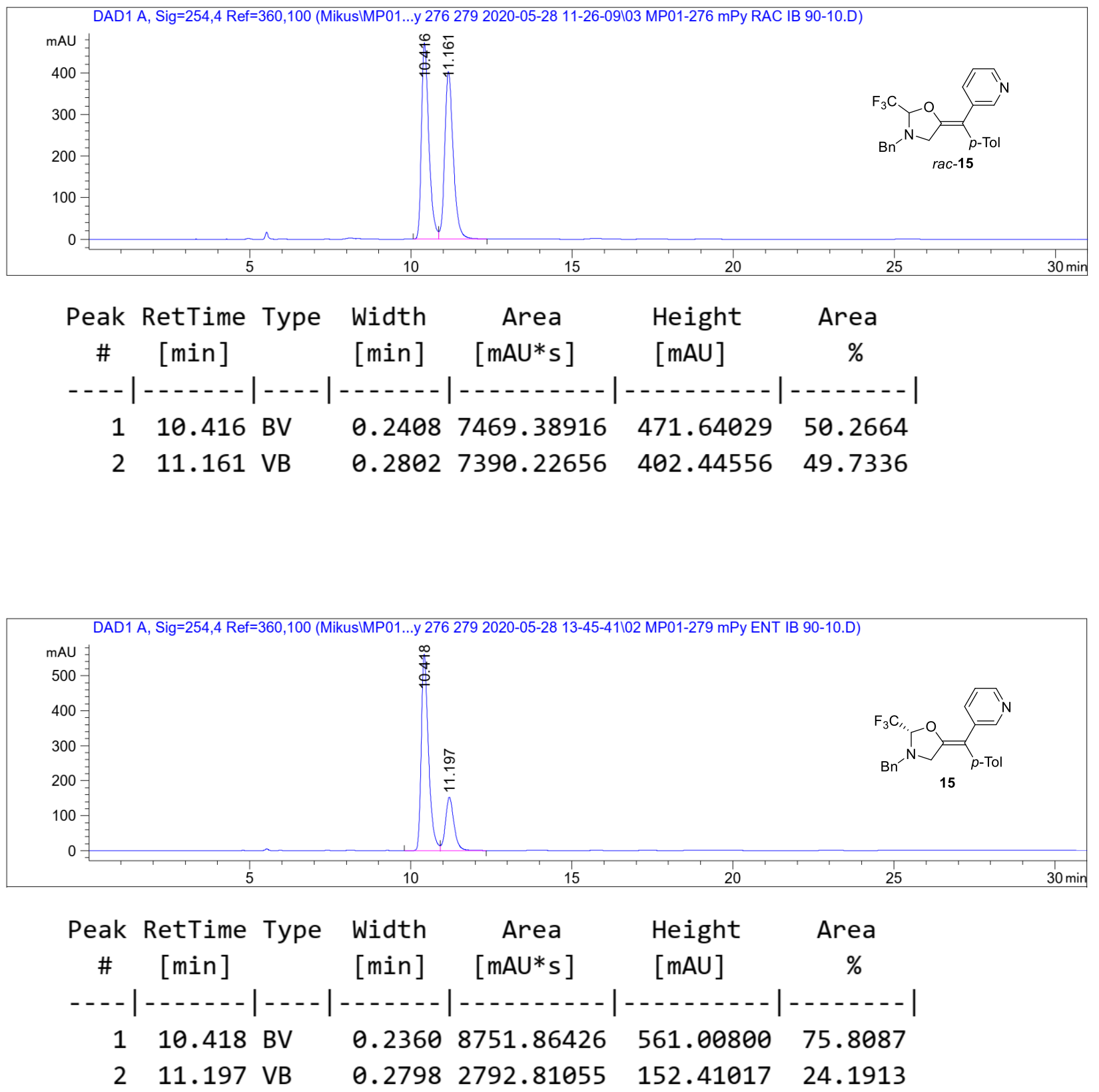
Chiral HPLC Daicel Chiralpak IB N-5 column: 99:1 hexane/IPA, flow rate $1 \mathrm{~mL} / \mathrm{min}, \lambda=254 \mathrm{~nm}$
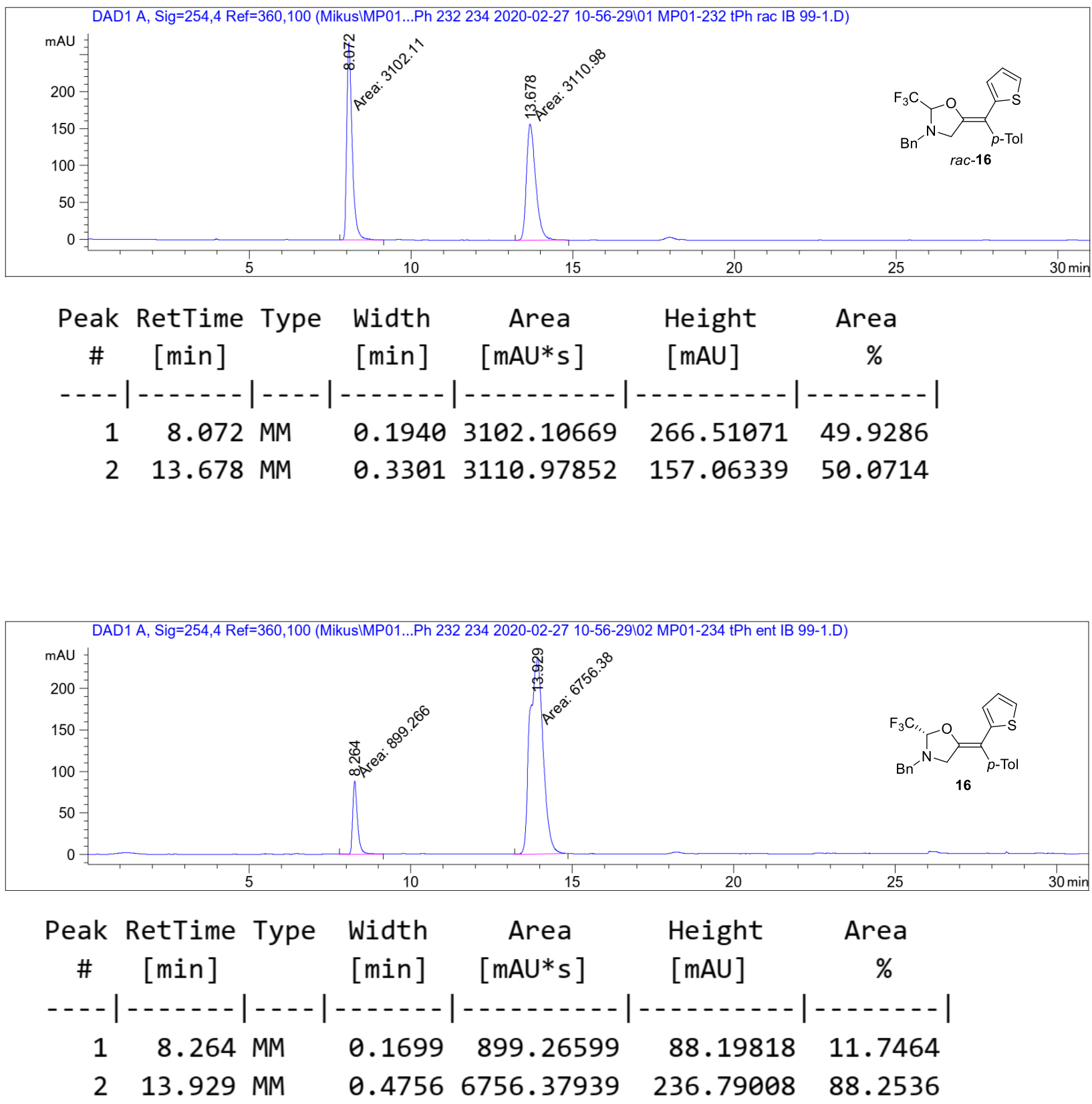
Chiral HPLC Daicel Chiralpak IB N-5 column: 99:1 hexane/IPA, flow rate $1 \mathrm{~mL} / \mathrm{min}, \lambda=254 \mathrm{~nm}$

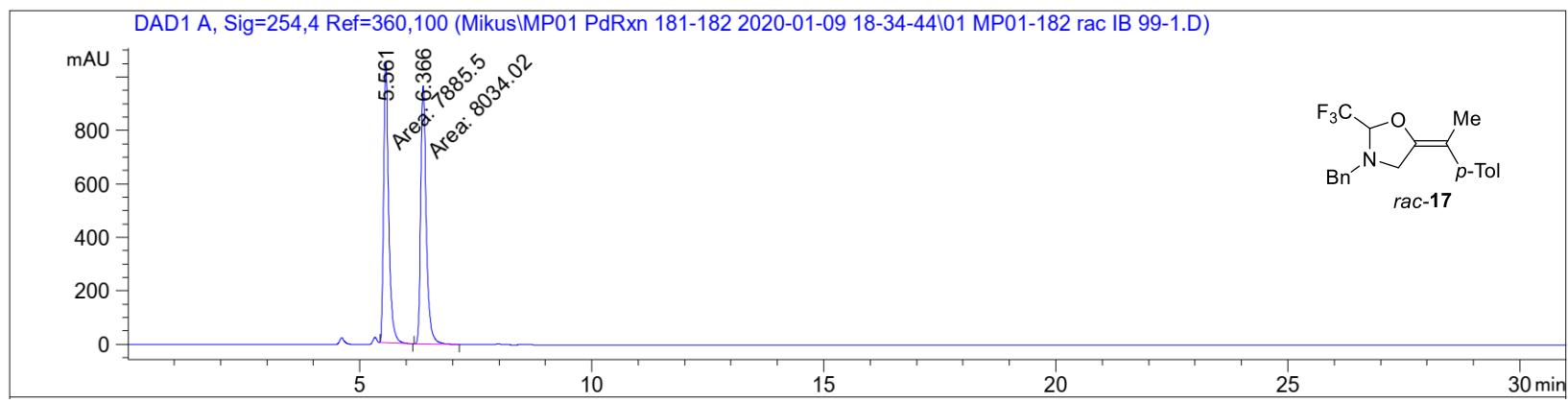

\begin{tabular}{|c|c|c|c|c|c|c|}
\hline $\begin{array}{c}\text { Peak } \\
\text { \# }\end{array}$ & $\begin{array}{c}\text { RetTime } \\
\text { [min] }\end{array}$ & Type & $\begin{array}{l}\text { Width } \\
\text { [min] }\end{array}$ & $\begin{array}{c}\text { Area } \\
{\left[\mathrm{mAU}^{*} \mathrm{~s}\right]}\end{array}$ & $\begin{array}{l}\text { Height } \\
{[\mathrm{mAU}]}\end{array}$ & $\begin{array}{c}\text { Area } \\
\%\end{array}$ \\
\hline & & & & & & \\
\hline+ & & & & 7885 & 460 & 335 \\
\hline ? & 6.3 & IM & 3 & 8034.02002 & 16638 & 50.4665 \\
\hline
\end{tabular}

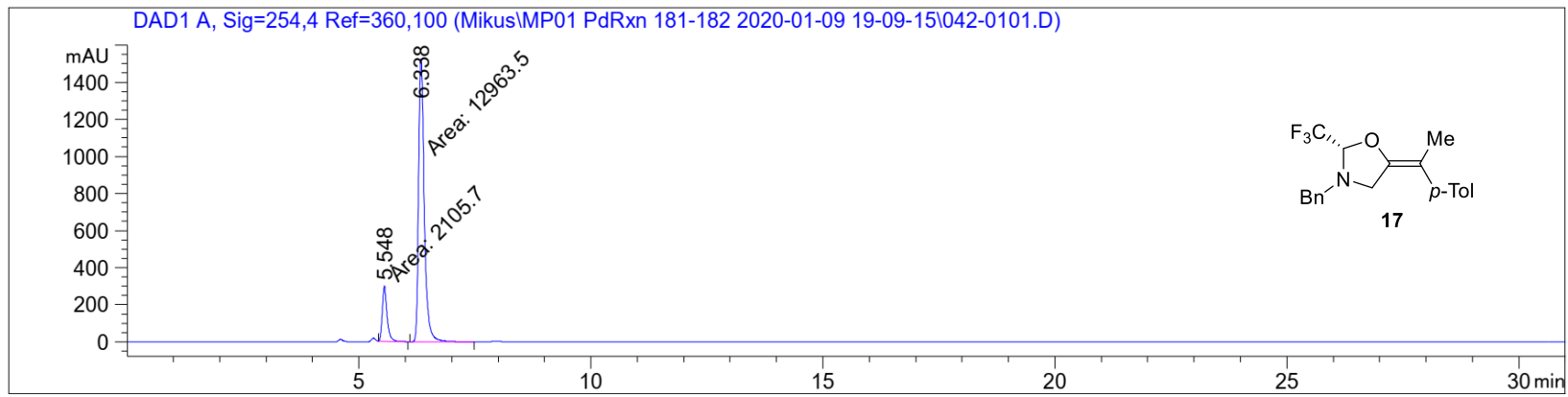

\begin{tabular}{|c|c|c|c|c|c|c|}
\hline eak & $\begin{array}{c}\text { RetTime } \\
\text { [min] }\end{array}$ & Type & $\begin{array}{l}\text { Width } \\
\text { [min] }\end{array}$ & $\begin{array}{c}\text { Area } \\
{\left[\mathrm{mAU}^{*} \mathrm{~s}\right]}\end{array}$ & $\begin{array}{l}\text { Height } \\
{[\mathrm{mAU}]}\end{array}$ & $\begin{array}{c}\text { Area } \\
\%\end{array}$ \\
\hline & & & & & & \\
\hline 1 & & & & 2105.70093 & 362 & 13 \\
\hline & . & 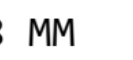 & 13 & $1.29635 \mathrm{e} 4$ & 1529.33142 & 86.026 \\
\hline
\end{tabular}


Chiral HPLC Daicel Chiralpak IB N-5 column: 99:1 hexane/IPA, flow rate $1 \mathrm{~mL} / \mathrm{min}, \lambda=254 \mathrm{~nm}$

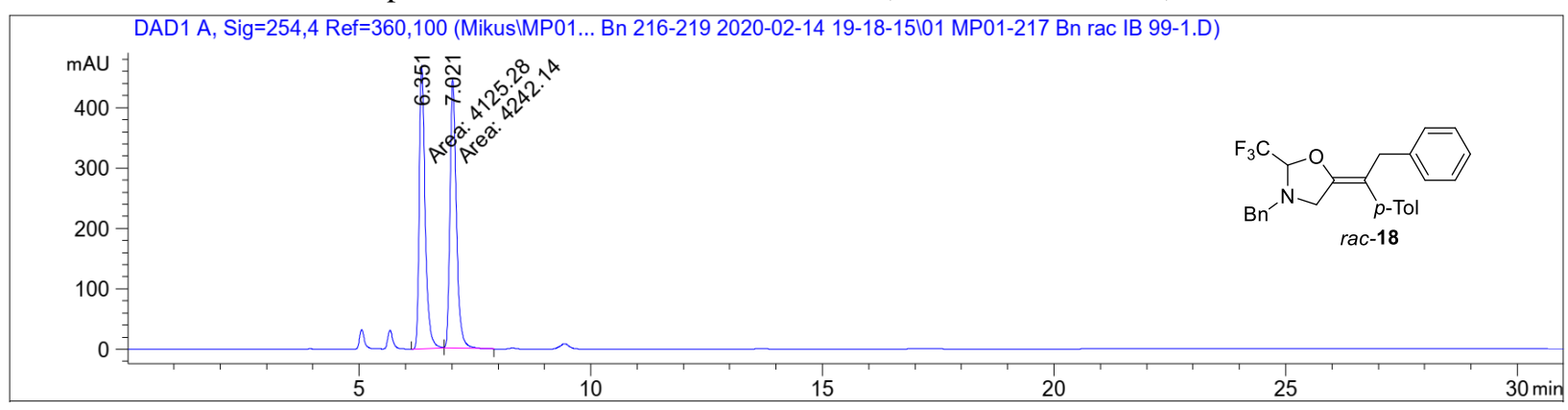

\begin{tabular}{|c|c|c|c|c|c|c|}
\hline $\begin{array}{l}\text { eak } \\
\#\end{array}$ & $\begin{array}{c}\text { RetTime } \\
\text { [min] }\end{array}$ & Гуре & $\begin{array}{l}\text { Width } \\
\text { [min] }\end{array}$ & $\begin{array}{c}\text { Area } \\
{\left[\mathrm{mAU}{ }^{*} \mathrm{~s}\right]}\end{array}$ & $\begin{array}{l}\text { Height } \\
\text { [mAU] }\end{array}$ & $\begin{array}{c}\text { Area } \\
\%\end{array}$ \\
\hline & & & & & & \\
\hline 1 & & & & 4125 . & 537 & 49.3017 \\
\hline & 7.021 & M & 1588 & 4242.14063 & 445.31125 & 50.6983 \\
\hline
\end{tabular}

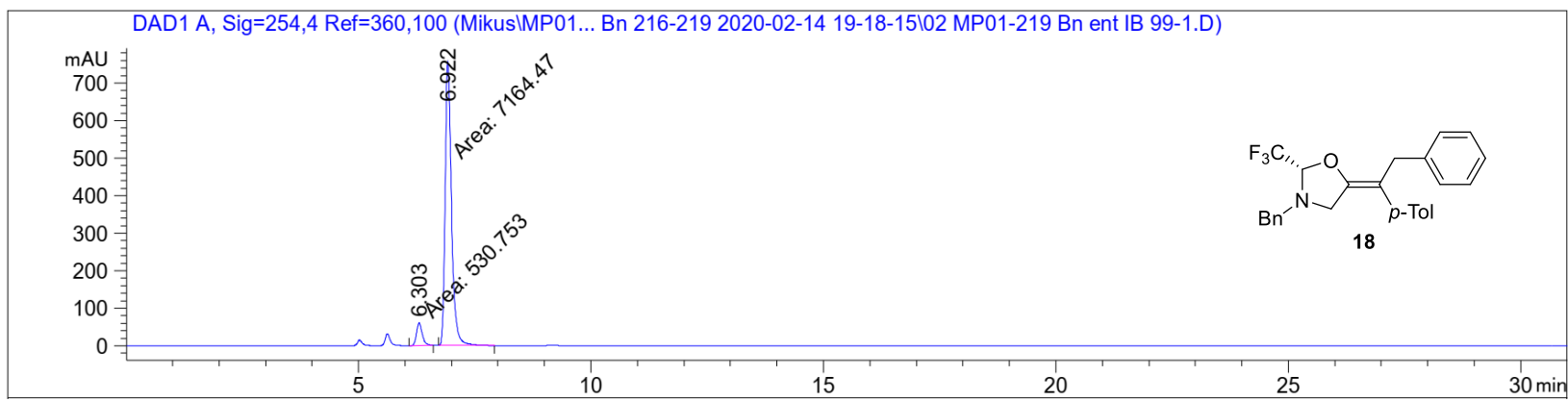

\begin{tabular}{|c|c|c|c|c|c|}
\hline $\begin{array}{c}\text { Peak } \\
\quad \#\end{array}$ & $\begin{array}{l}\text { RetTime Type } \\
\text { [min] }\end{array}$ & $\begin{array}{l}\text { Width } \\
\text { [min] }\end{array}$ & $\begin{array}{c}\text { Area } \\
{\left[\mathrm{mAU}^{*} \mathrm{~s}\right]}\end{array}$ & $\begin{array}{l}\text { Height } \\
{[\mathrm{mAU}]}\end{array}$ & $\begin{array}{c}\text { Area } \\
\quad \%\end{array}$ \\
\hline
\end{tabular}

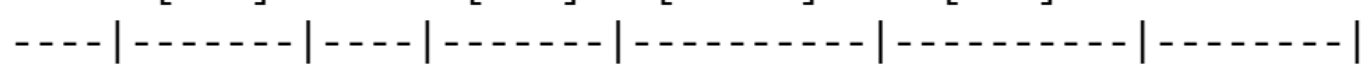

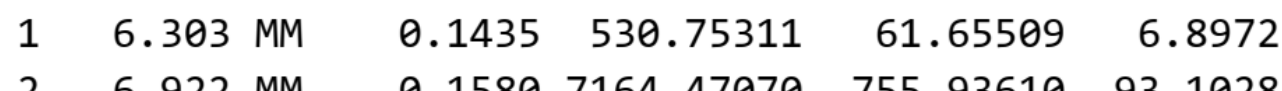

$\begin{array}{lllllll}2 & 6.922 \text { MM } & 0.1580 & 7164.47070 & 755.93610 & 93.1028\end{array}$ 
Chiral HPLC Daicel Chiralpak IB N-5 column: 99:1 hexane/IPA, flow rate $1 \mathrm{~mL} / \mathrm{min}, \lambda=254 \mathrm{~nm}$
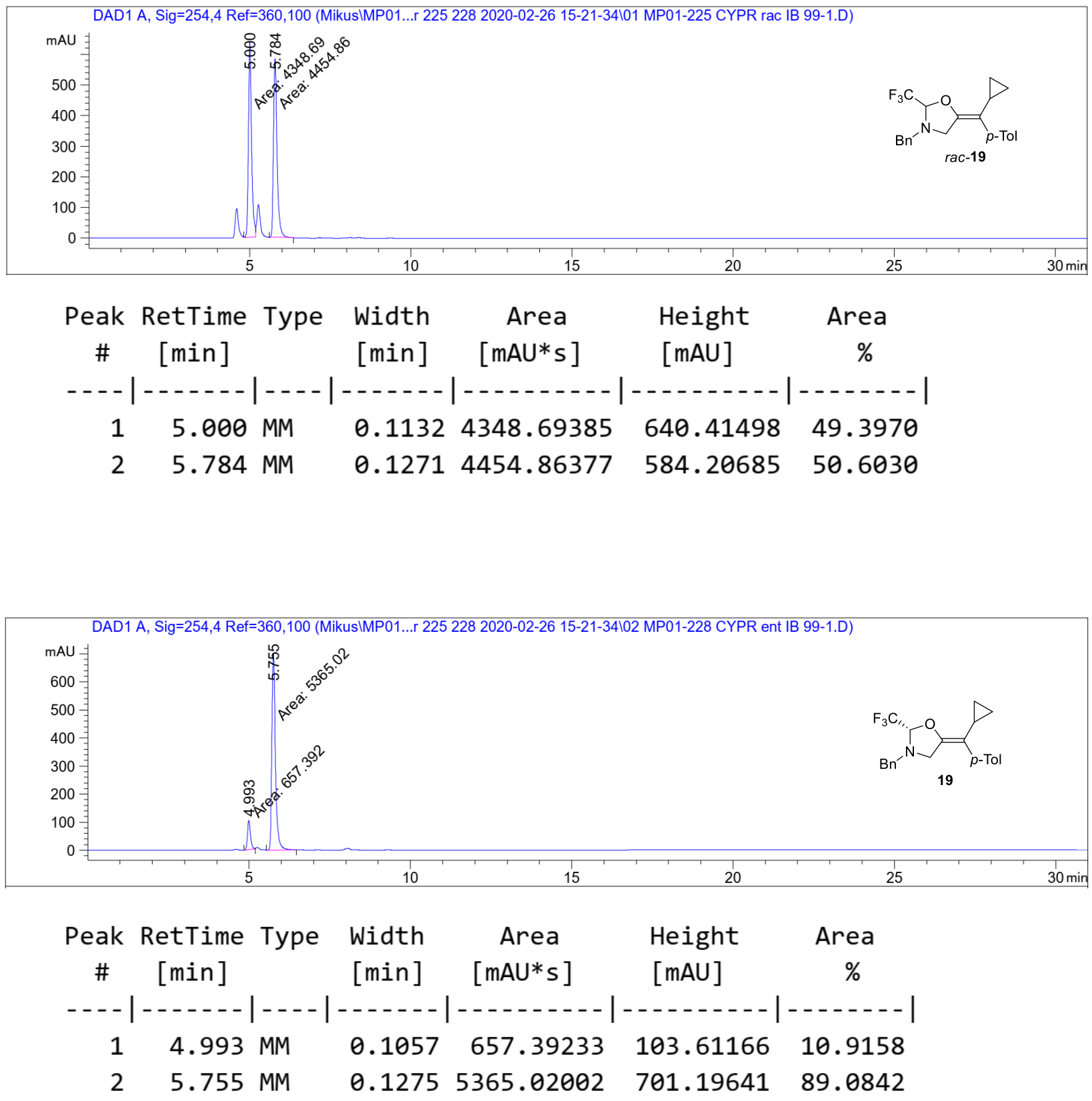
Chiral HPLC Daicel Chiralpak IB N-5 column: 99:1 hexane/IPA, flow rate $1 \mathrm{~mL} / \mathrm{min}, \lambda=254 \mathrm{~nm}$
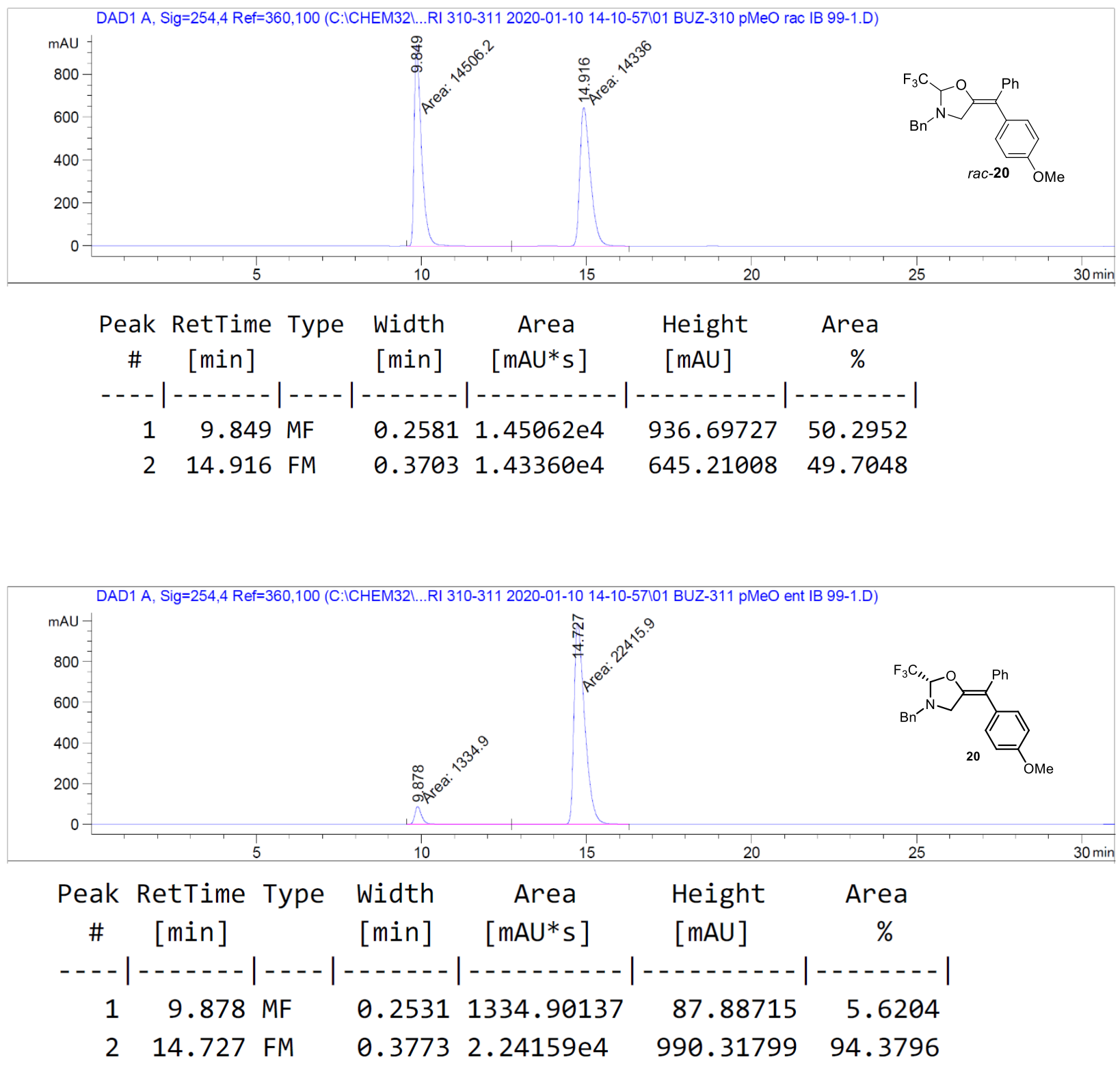
Chiral HPLC Daicel Chiralpak IB N-5 column: 99:1 hexane/IPA, flow rate $1 \mathrm{~mL} / \mathrm{min}, \lambda=254 \mathrm{~nm}$

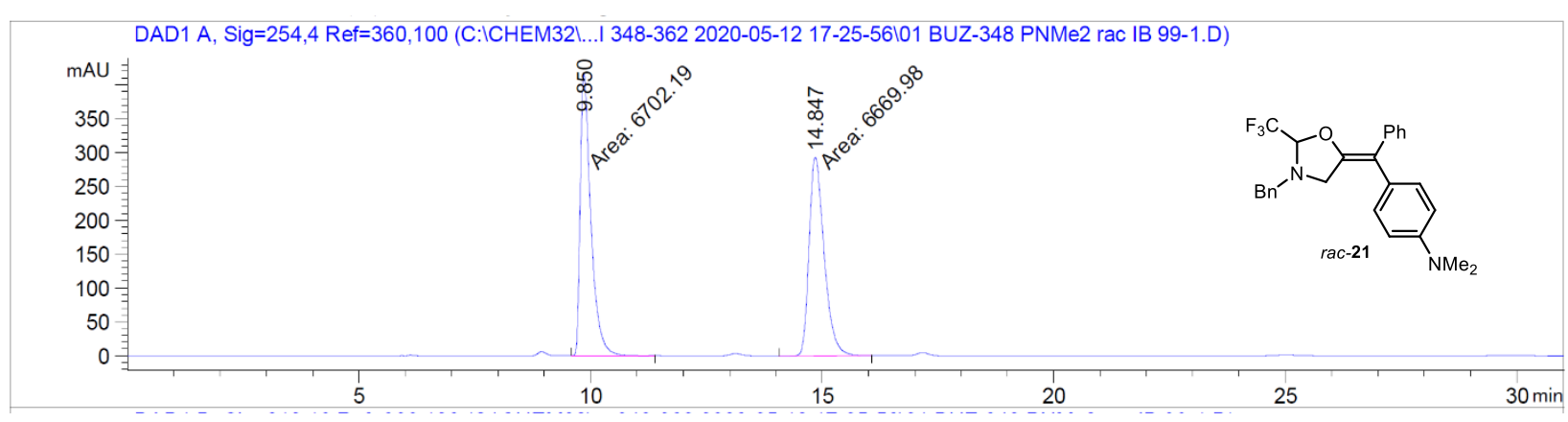

$\begin{array}{cccccc}\begin{array}{c}\text { Peak RetTime Type } \\ \text { \# }\end{array} & \text { Width } & \text { Area } & \text { Height } & \text { Area } \\ & {[\text { min }]} & {[\text { min }]} & {[\text { mAU*s }]} & {[\text { mAU] }} & \% \\ 1 & 9.850 \text { MM } & 0.2668 & 6702.18506 & 418.64359 & 50.1204 \\ 2 & 14.847 \text { MM } & 0.3783 & 6669.97803 & 293.84787 & 49.8796\end{array}$

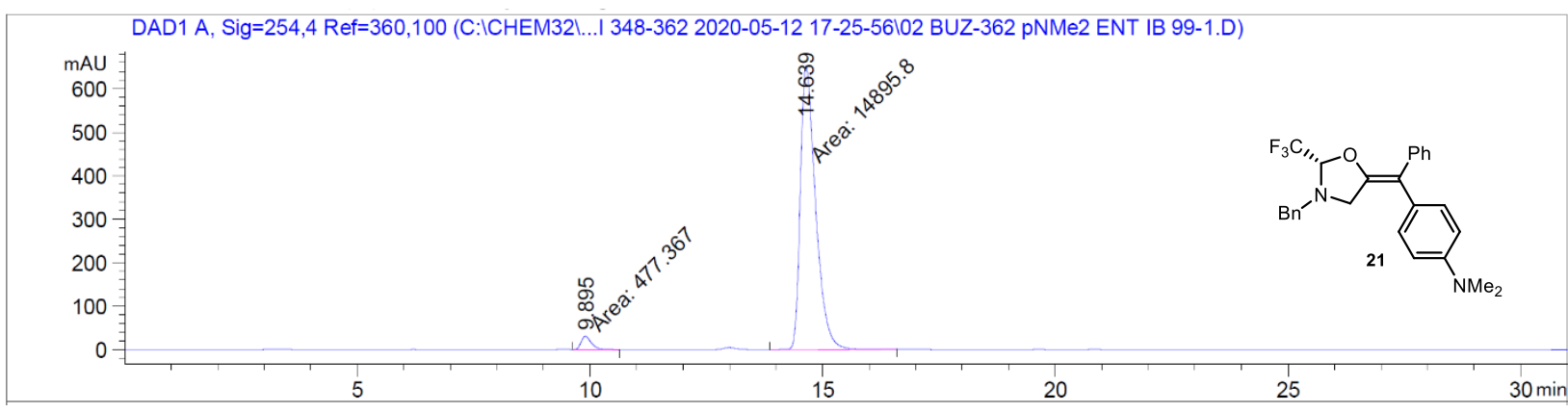

\begin{tabular}{|c|c|c|c|c|c|c|}
\hline $\begin{array}{c}\text { Peak } \\
\#\end{array}$ & $\begin{array}{c}\text { RetTime } \\
\text { [min] }\end{array}$ & Type & $\begin{array}{l}\text { Width } \\
\text { [min] }\end{array}$ & $\begin{array}{c}\text { Area } \\
{[\mathrm{mAU} * \mathrm{~s}]}\end{array}$ & $\begin{array}{l}\text { Height } \\
{[\mathrm{mAU}]}\end{array}$ & $\begin{array}{c}\text { Area } \\
\%\end{array}$ \\
\hline 1 & 9.895 & MM & 0.2570 & 477.36749 & 30.95416 & 3.1052 \\
\hline 2 & 14.639 & MM & 0.3806 & $1.48958 \mathrm{e} 4$ & 652.33496 & 96.8948 \\
\hline
\end{tabular}


Chiral HPLC Daicel Chiralpak IB N-5 column: 99:1 hexane/IPA, flow rate $1 \mathrm{~mL} / \mathrm{min}, \lambda=254 \mathrm{~nm}$
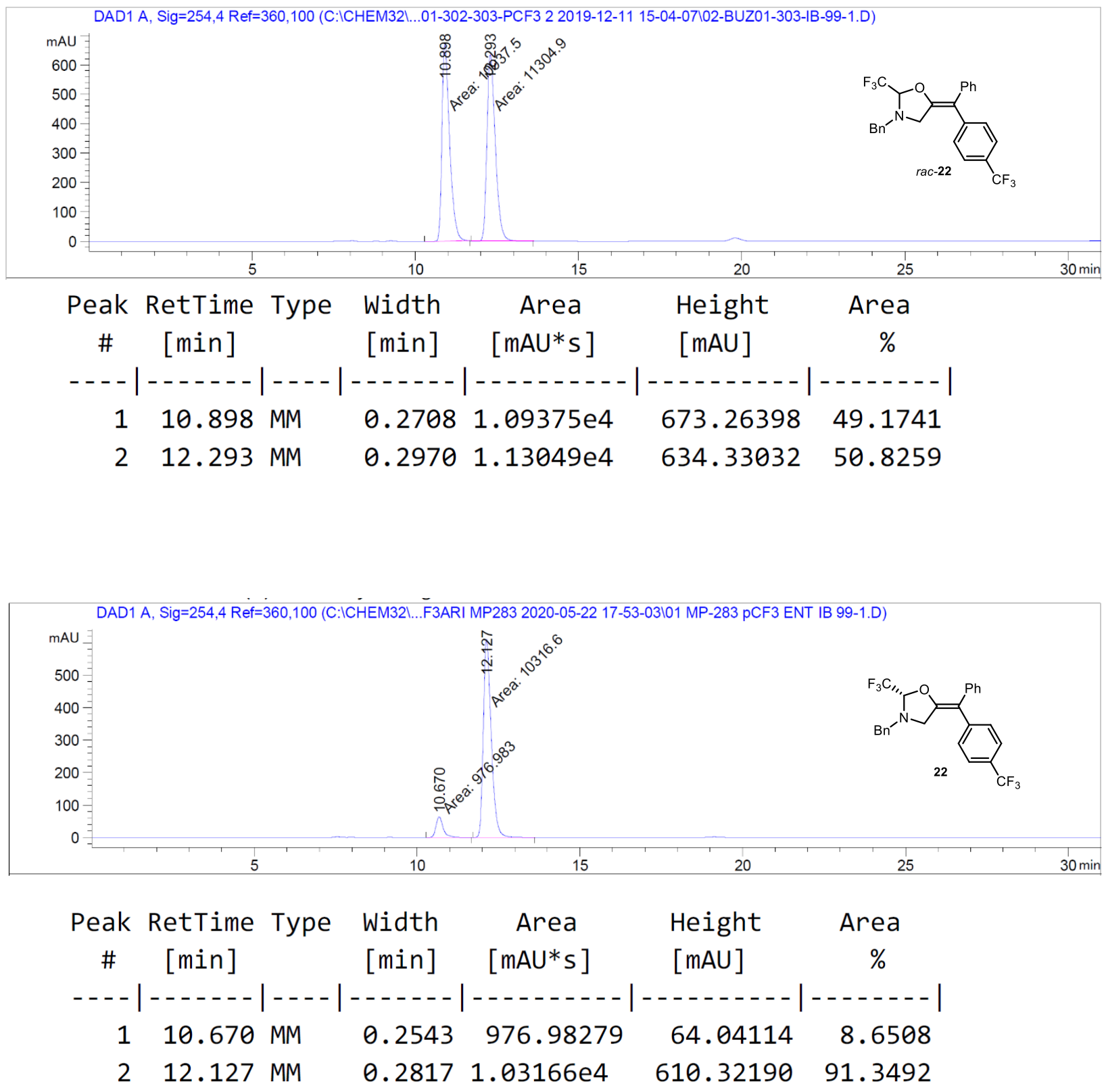
Chiral HPLC Daicel Chiralpak IB N-5 column: 99:1 hexane/IPA, flow rate $1 \mathrm{~mL} / \mathrm{min}, \lambda=254 \mathrm{~nm}$
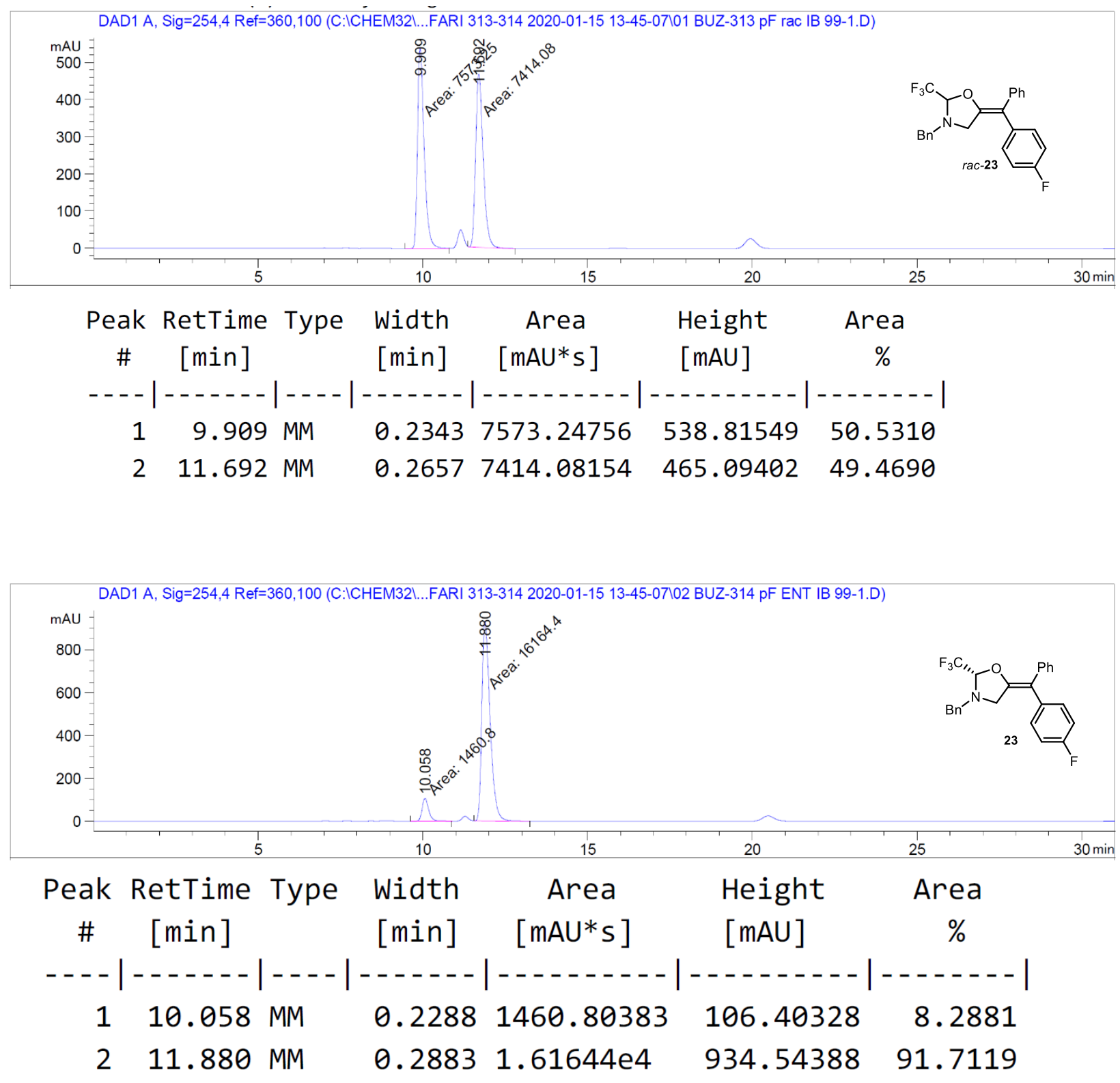
Chiral HPLC Daicel Chiralpak IB N-5 column: 99:1 hexane/IPA, flow rate $1 \mathrm{~mL} / \mathrm{min}, \lambda=254 \mathrm{~nm}$ DAD1 A, Sig=254,4 Ref=360,100 (C:ICHEM321...328 F1 2020-01-31 12-10-28101 BUZ01-327 pCIArl_rac IB 99-1.D)
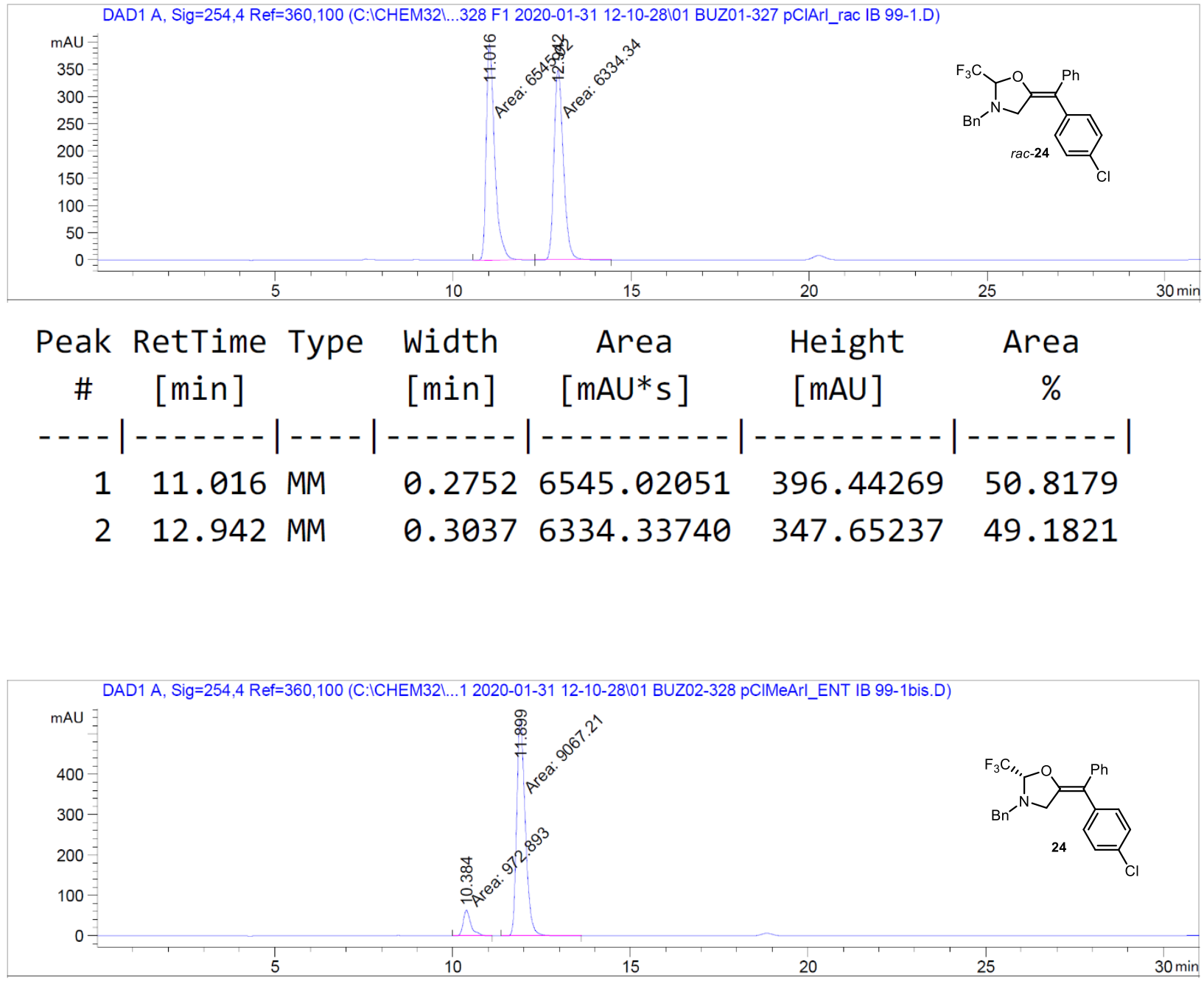

\begin{tabular}{|c|c|c|c|c|c|c|}
\hline \# & $\begin{array}{c}\text { RetTime } \\
\text { [min] }\end{array}$ & e & $\begin{array}{l}\text { Width } \\
\text { [min] }\end{array}$ & $\begin{array}{c}\text { Area } \\
{\left[\mathrm{mAU}^{*} \mathrm{~s}\right]}\end{array}$ & $\begin{array}{l}\text { Height } \\
{[\mathrm{mAU}]}\end{array}$ & $\begin{array}{c}\text { Area } \\
\%\end{array}$ \\
\hline & & & & $L_{2}$ & - & \\
\hline 1 & & & & 972 & 49 & \\
\hline 2 & & 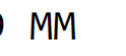 & & 9067. & 5524 & \\
\hline
\end{tabular}


Chiral HPLC Daicel Chiralpak IA column: 95:5 hexane/IPA, flow rate $1 \mathrm{~mL} / \mathrm{min}, \lambda=254 \mathrm{~nm}$

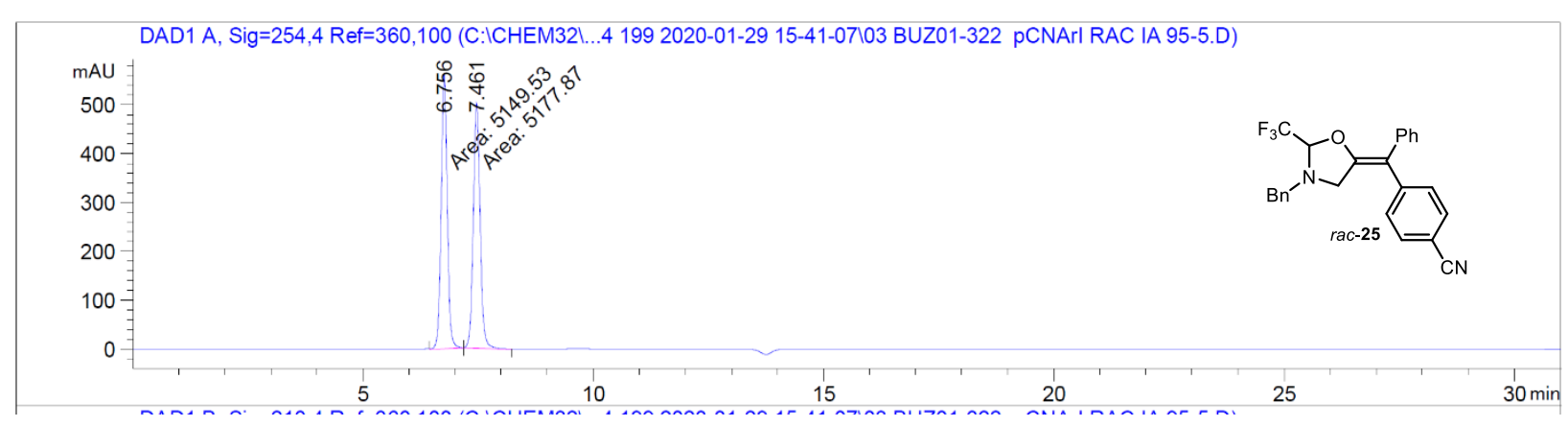

\begin{tabular}{|c|c|c|c|c|c|c|}
\hline $\begin{array}{c}\text { Peak } \\
\#\end{array}$ & $\begin{array}{c}\text { RetTime } \\
\text { [min] }\end{array}$ & Type & $\begin{array}{l}\text { Width } \\
\text { [min] }\end{array}$ & $\begin{array}{c}\text { Area } \\
{\left[\mathrm{mAU}^{*} \mathrm{~s}\right]}\end{array}$ & $\begin{array}{l}\text { Height } \\
{[\mathrm{mAU}]}\end{array}$ & $\begin{array}{c}\text { Area } \\
\%\end{array}$ \\
\hline & & & & & -- & -- \\
\hline 1 & & M & 27 & 5149.52881 & 830 & 628 \\
\hline 2 & 7.461 & MM & .1722 & 5177.86914 & 501.17307 & 50.1372 \\
\hline
\end{tabular}

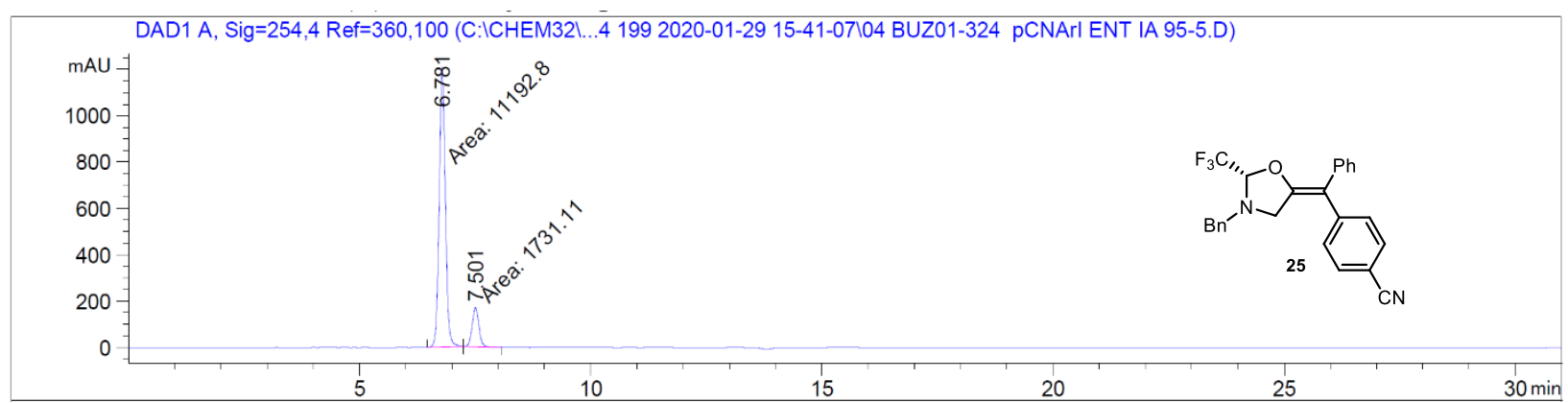

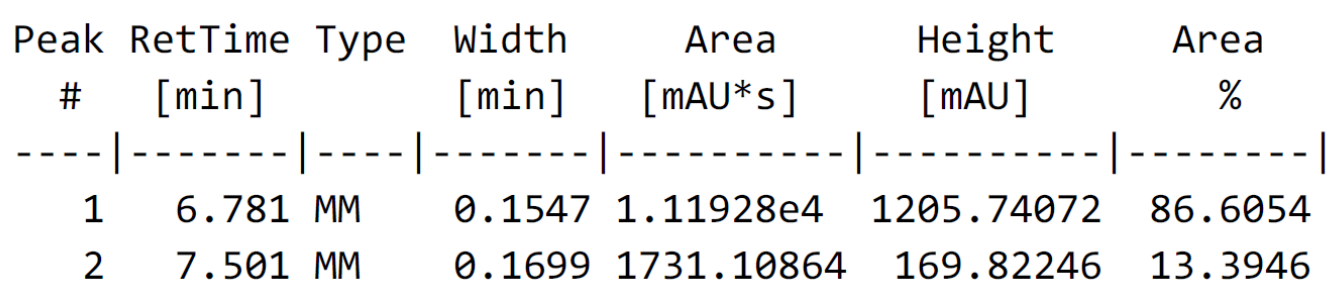


Chiral HPLC Daicel Chiralpak IA column: 95:5 hexane/IPA, flow rate $1 \mathrm{~mL} / \mathrm{min}, \lambda=254 \mathrm{~nm}$

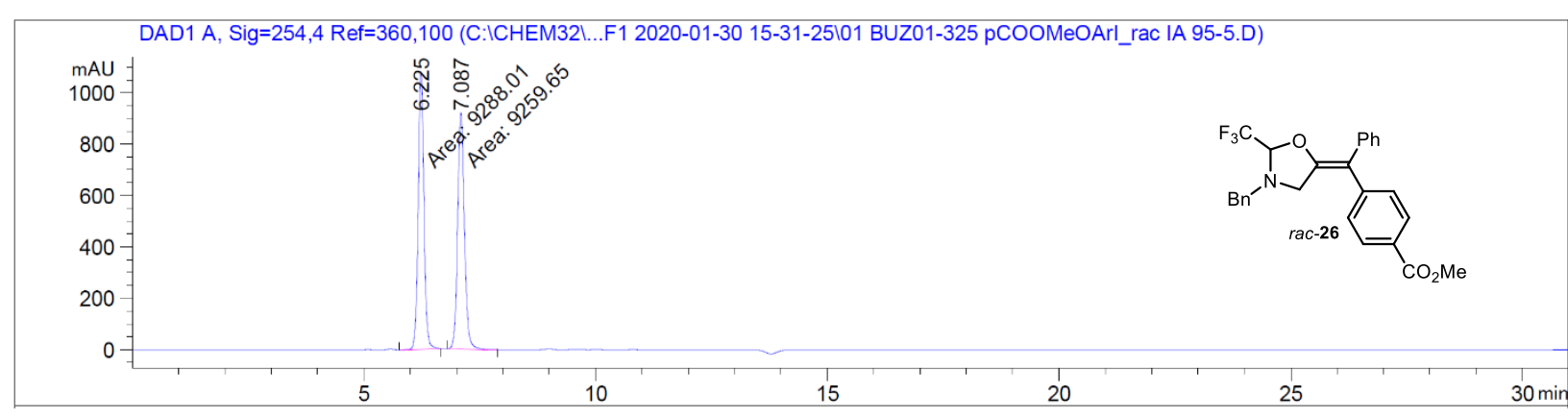

$\begin{array}{cccccc}\begin{array}{c}\text { Peak } \\ \text { \# }\end{array} & {[\mathrm{min}]} & \text { width } & \text { Area } & \text { Height } & \text { Area } \\ & {[\mathrm{min}]} & {\left[\mathrm{mAU}{ }^{*} \mathrm{~s}\right]} & {[\mathrm{mAU}]} & \% \\ 1 & 6.225 \mathrm{MM} & 0.1430 & 9288.00586 & 1082.22388 & 50.0764 \\ 2 & 7.087 \mathrm{MM} & 0.1676 & 9259.65234 & 920.65900 & 49.9236\end{array}$
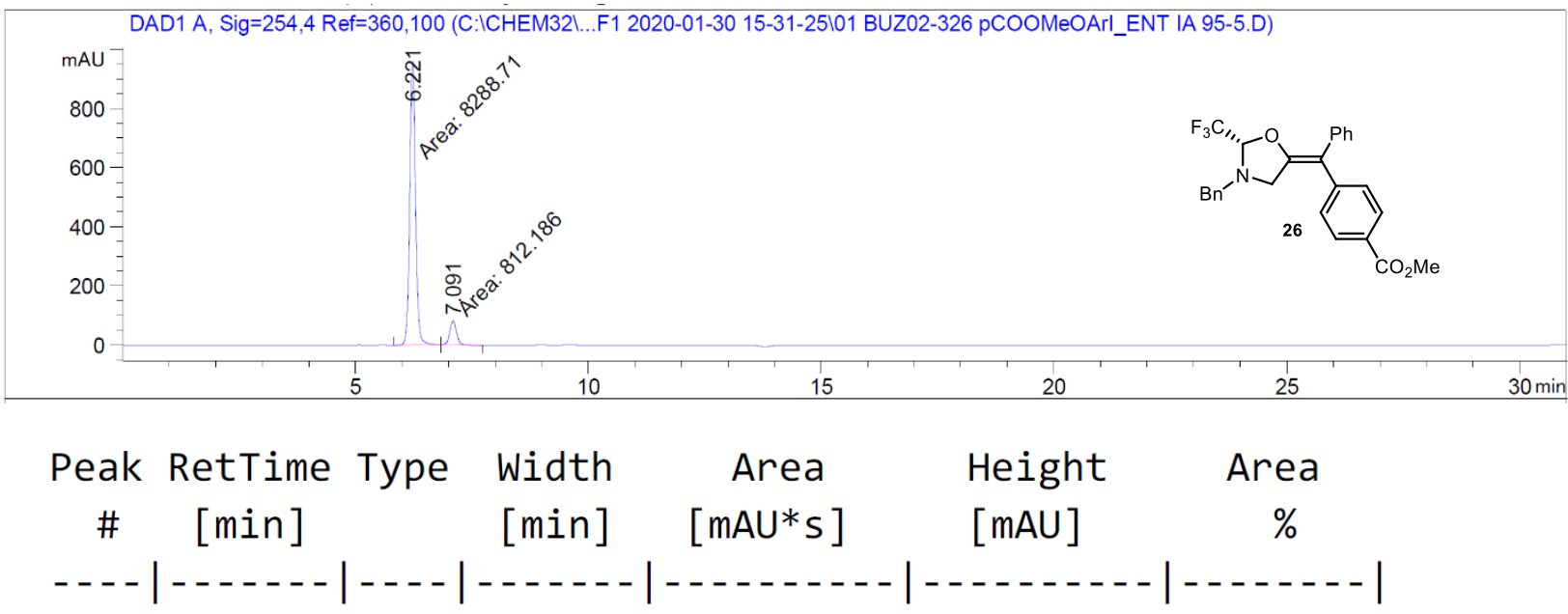
$16.221 \mathrm{MM}$
0.14438288 .71094
957.65491
91.0758
$27.091 \mathrm{MM}$
$0.1652 \quad 812.18579$
81.92288
8.9242 
Chiral HPLC Daicel Chiralpak IA column: 95:5 hexane/IPA, flow rate $1 \mathrm{~mL} / \mathrm{min}, \lambda=254 \mathrm{~nm}$
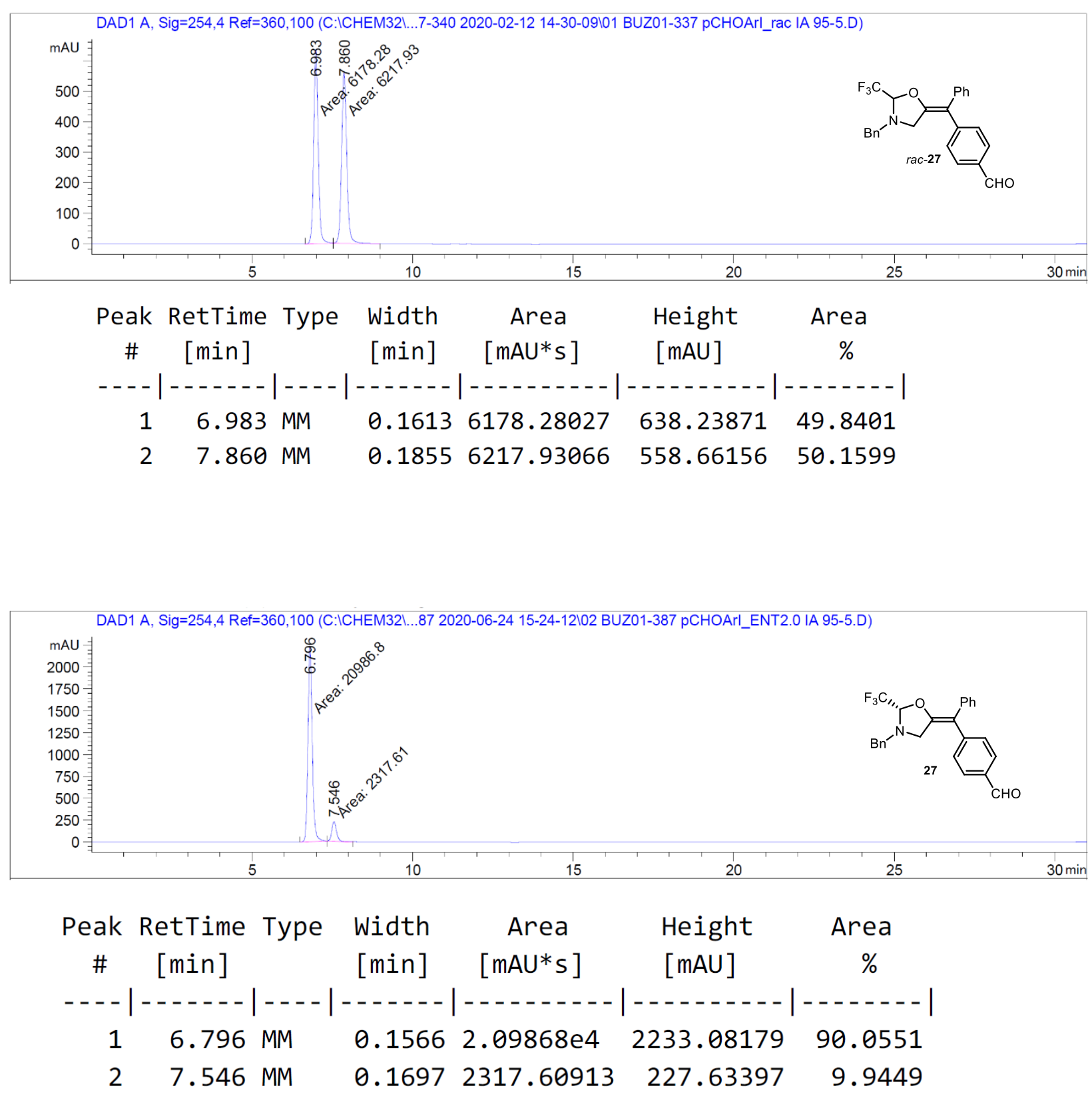
Chiral HPLC Daicel Chiralpak IB N-5 column: 99:1 hexane/IPA, flow rate $1 \mathrm{~mL} / \mathrm{min}, \lambda=254 \mathrm{~nm}$
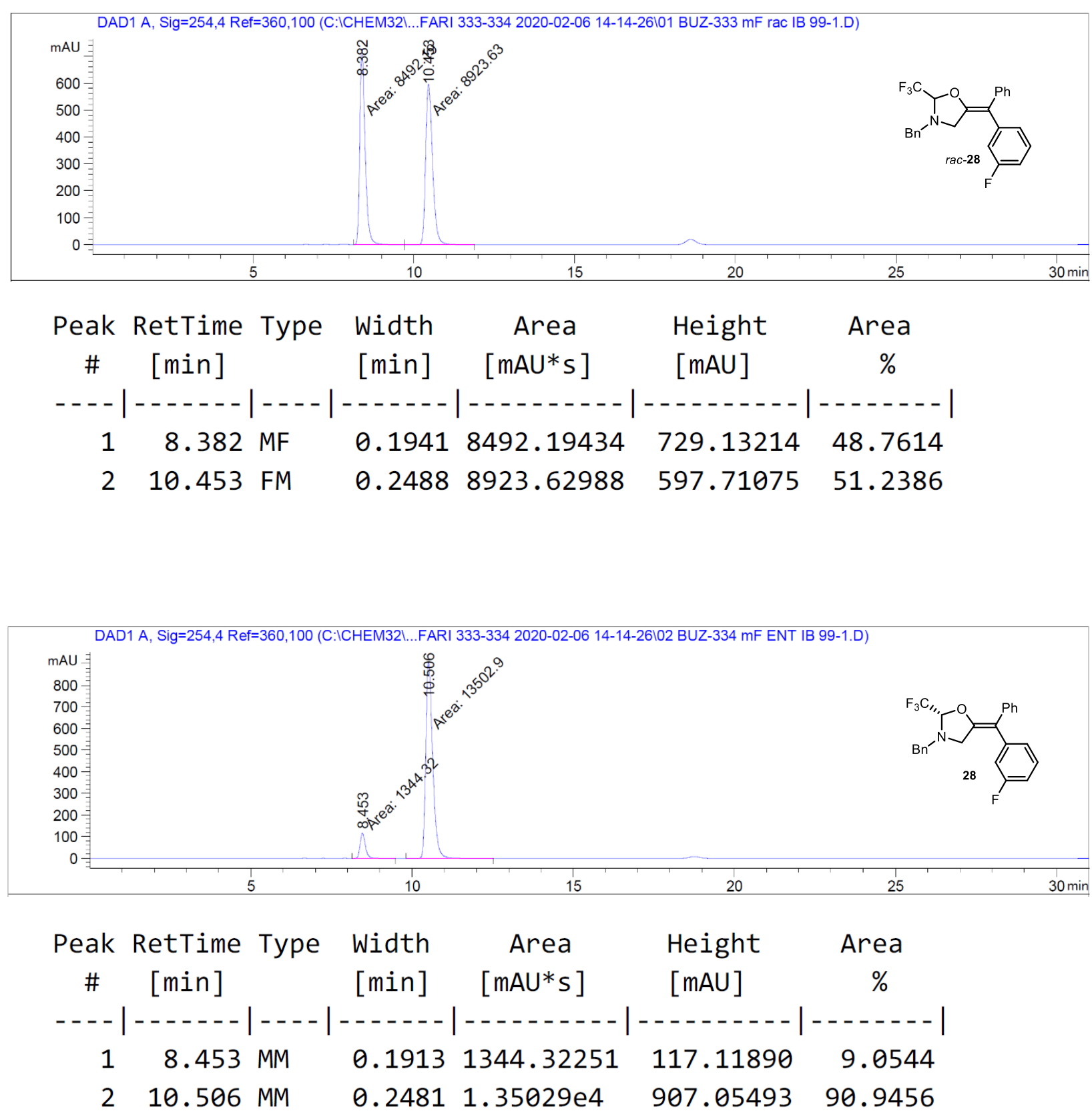
Chiral HPLC Daicel Chiralpak IB N-5 column: 99:1 hexane/IPA, flow rate $1 \mathrm{~mL} / \mathrm{min}, \lambda=254 \mathrm{~nm}$

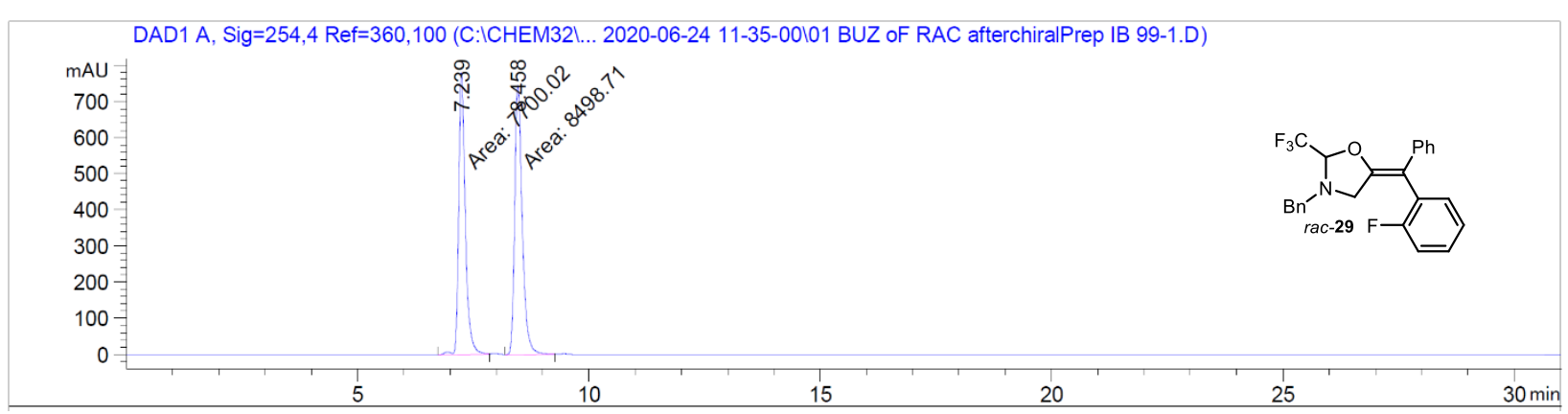

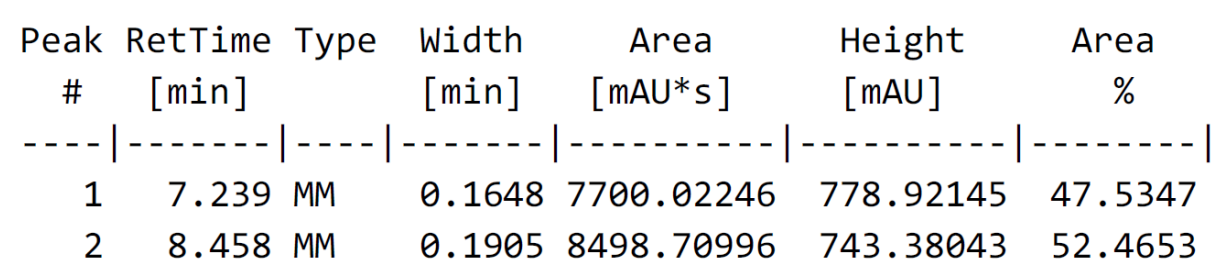

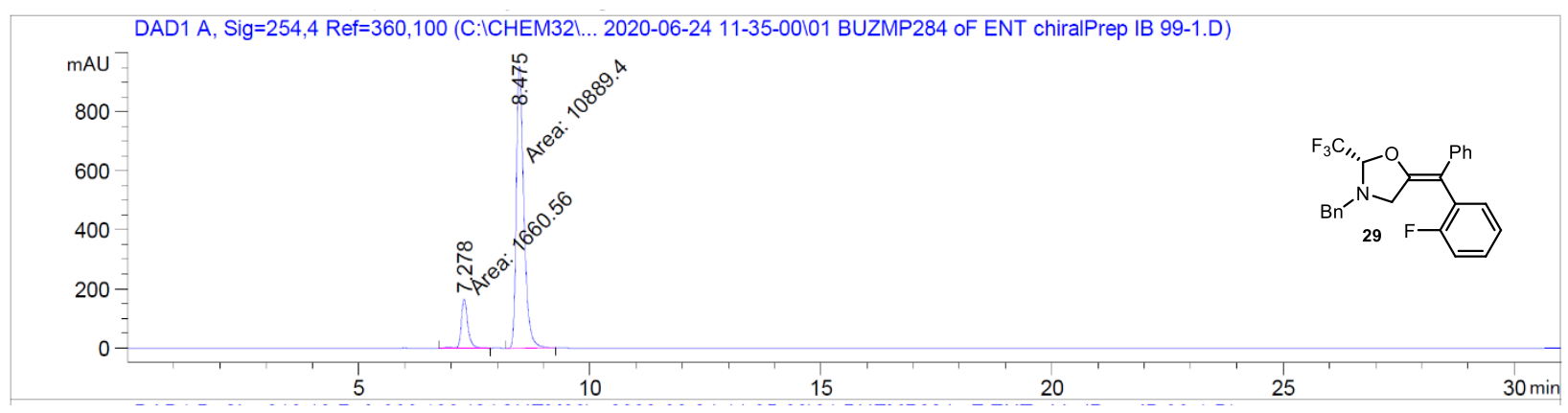

\begin{tabular}{|c|c|c|c|c|c|c|}
\hline $\begin{array}{c}\text { Peak } \\
\quad \#\end{array}$ & $\begin{array}{c}\text { RetTime } \\
\text { [min] }\end{array}$ & Type & $\begin{array}{l}\text { Width } \\
\text { [min] }\end{array}$ & $\begin{array}{c}\text { Area } \\
{\left[\mathrm{mAU}^{*} \mathrm{~s}\right]}\end{array}$ & $\begin{array}{l}\text { Height } \\
\text { [mAU] }\end{array}$ & $\begin{array}{c}\text { Area } \\
\%\end{array}$ \\
\hline & & & & & & \\
\hline 1 & & & & 1660.5 & 861 & 315 \\
\hline 2 & 8.475 & & 03 & $1.08894 \mathrm{e} 4$ & 953.67273 & 86 \\
\hline
\end{tabular}


Chiral HPLC Daicel Chiralpak IB N-5 column: 99:1 hexane/IPA, flow rate $1 \mathrm{~mL} / \mathrm{min}, \lambda=254 \mathrm{~nm}$

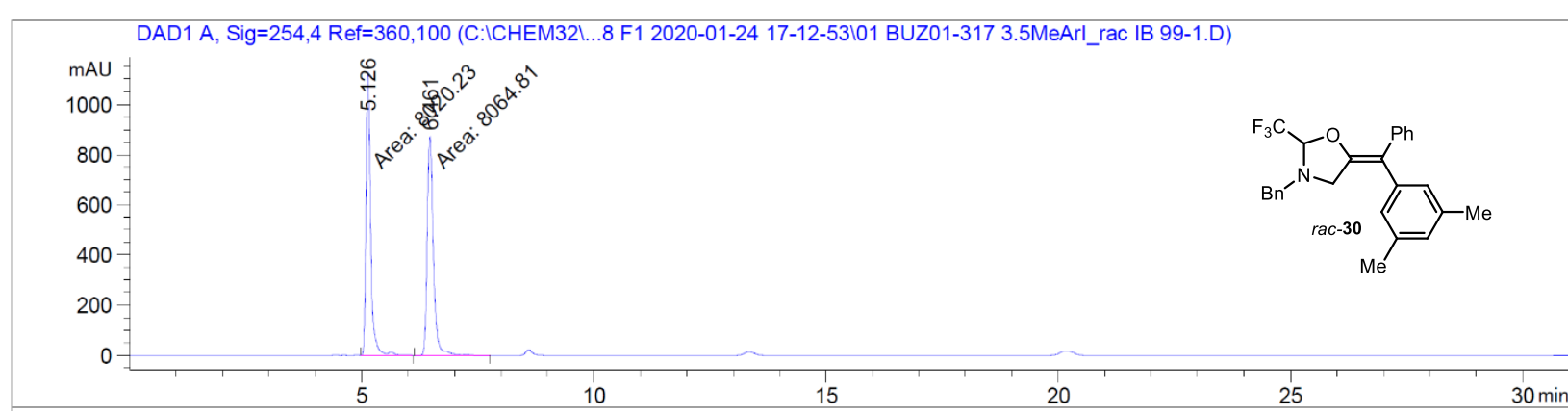

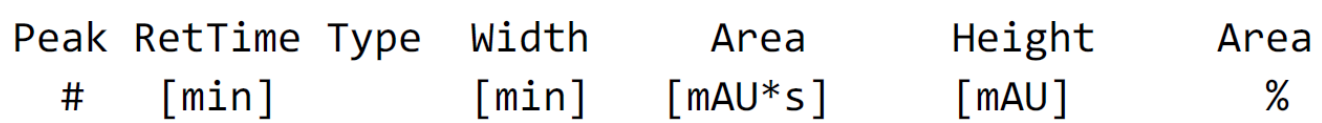

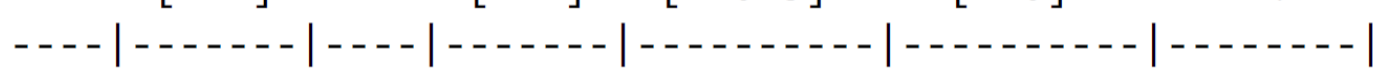

$\begin{array}{lllllll}1 & 5.126 & \text { MM } & 0.1181 & 8020.22705 & 1132.02124 & 49.8614\end{array}$

$\begin{array}{lllllll}2 & 6.461 & \text { MM } & 0.1543 & 8064.80762 & 871.38739 & 50.1386\end{array}$

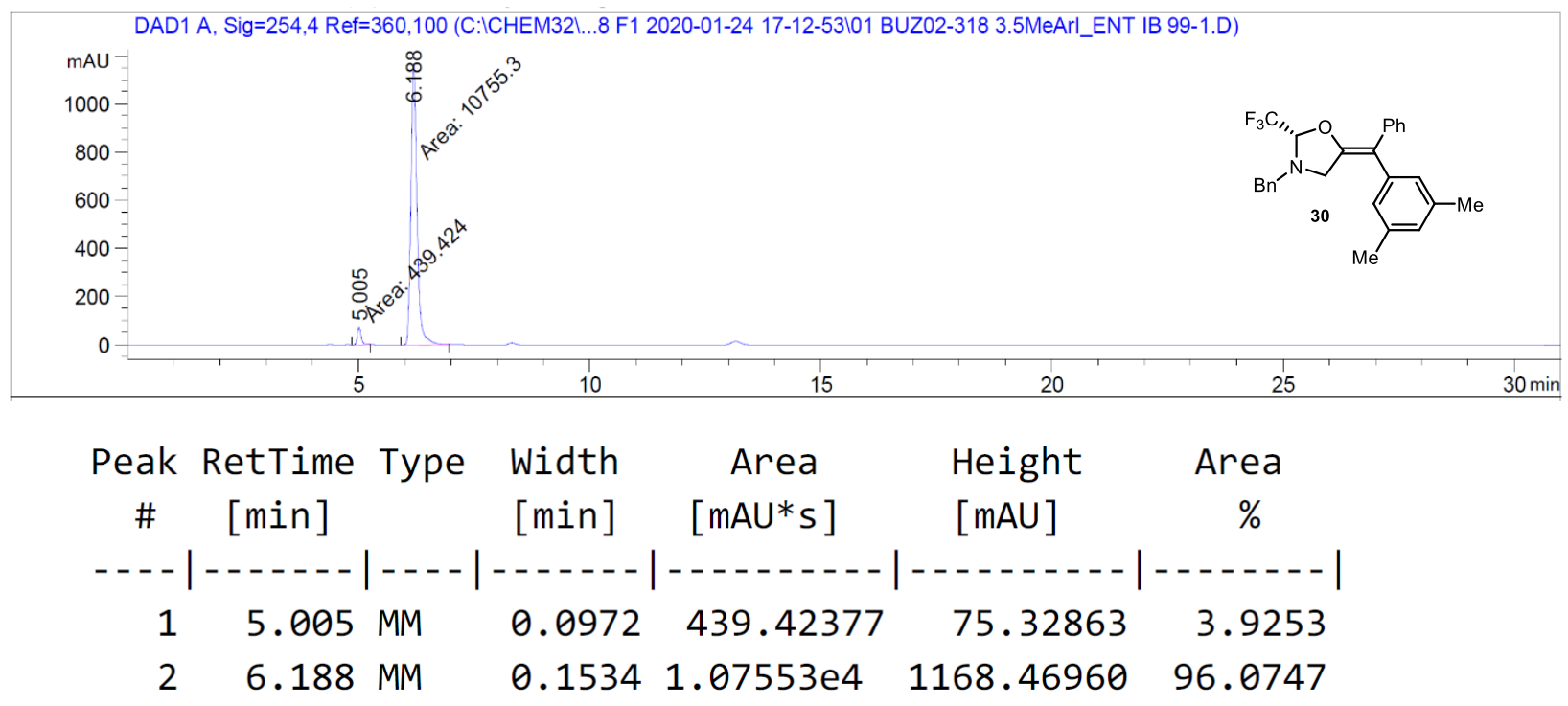


Chiral HPLC Daicel Chiralpak IB N-5 column: 90:10 hexane/IPA, flow rate $1 \mathrm{~mL} / \mathrm{min}, \lambda=254 \mathrm{~nm}$
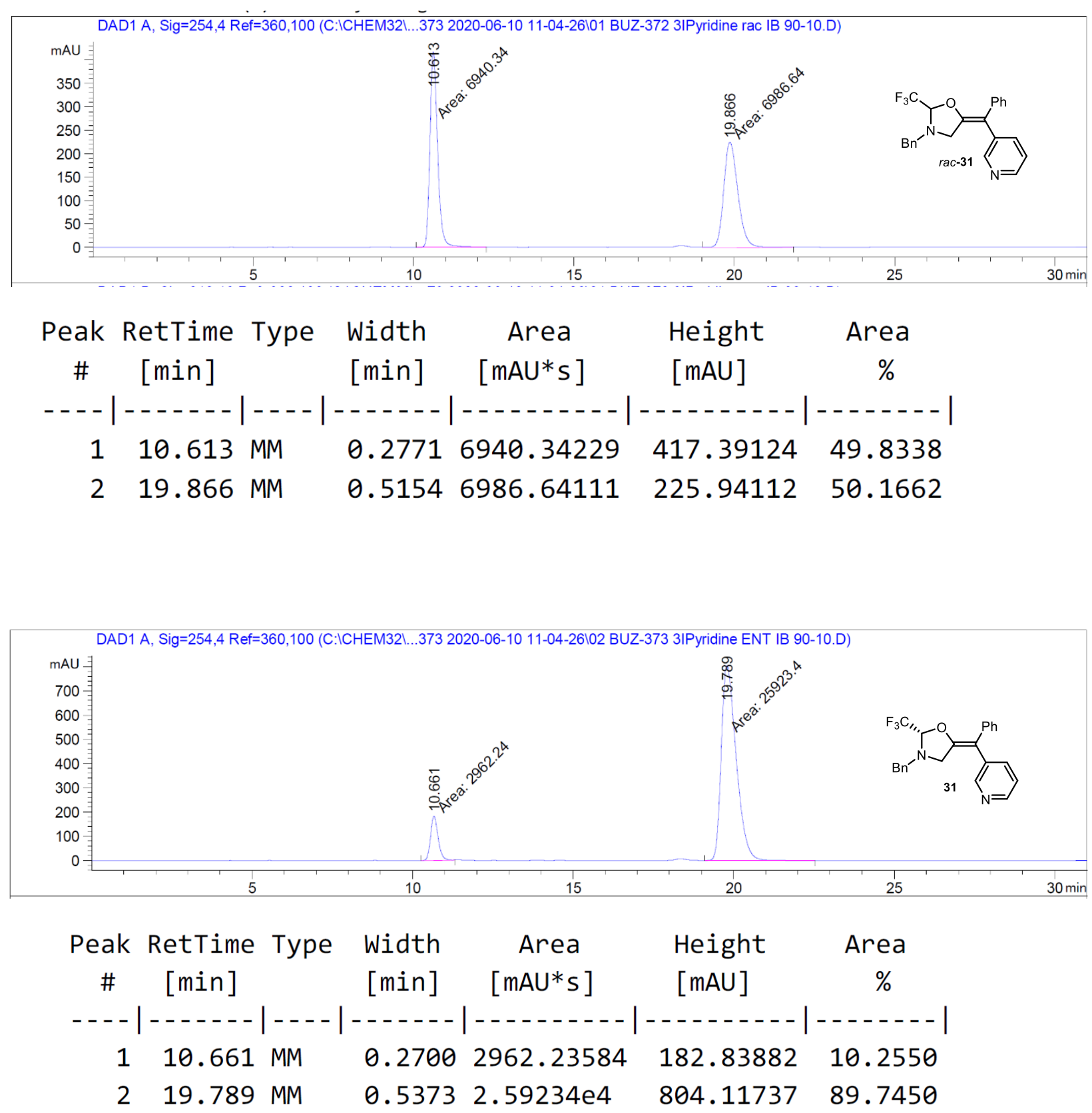
Chiral HPLC Daicel Chiralpak IB N-5 column: 99:1 hexane/IPA, flow rate $1 \mathrm{~mL} / \mathrm{min}, \lambda=254 \mathrm{~nm}$
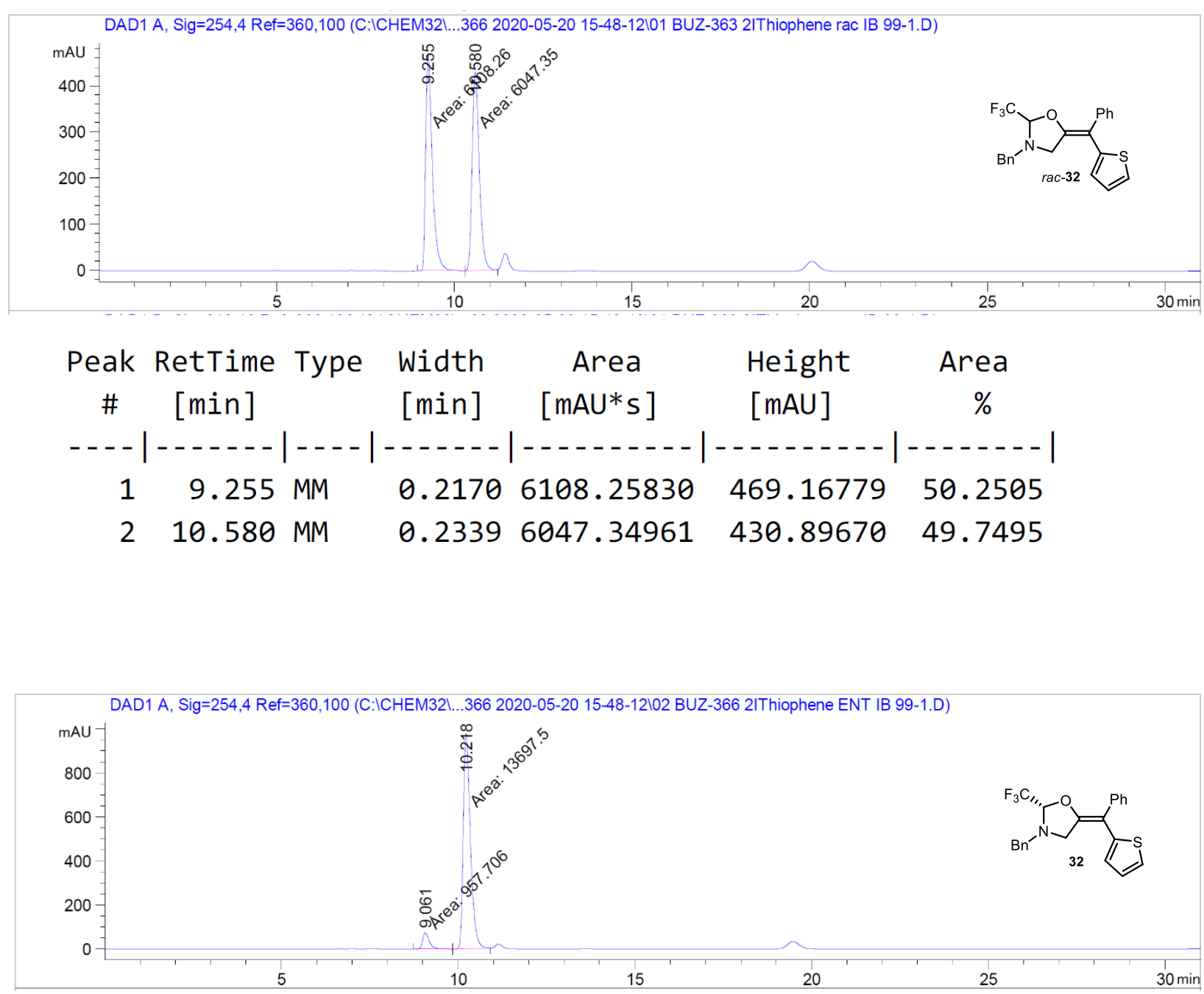

\begin{tabular}{|c|c|c|c|c|c|c|}
\hline $\begin{array}{c}\text { Peak } \\
\#\end{array}$ & $\begin{array}{c}\text { RetTime } \\
\text { [min] }\end{array}$ & Type & $\begin{array}{l}\text { Width } \\
\text { [min] }\end{array}$ & $\begin{array}{c}\text { Area } \\
{\left[\mathrm{mAU}^{*} \mathrm{~s}\right]}\end{array}$ & $\begin{array}{l}\text { Height } \\
{[\mathrm{mAU}]}\end{array}$ & $\begin{array}{c}\text { Area } \\
\%\end{array}$ \\
\hline-- & & & & ------- & & $------\mid$ \\
\hline 1 & 9.061 & MM & 0.2129 & 957.70569 & 74.95567 & 6.5349 \\
\hline 2 & 10.218 & MM & 0.2336 & $1.36975 \mathrm{e} 4$ & 977.10193 & 93.4651 \\
\hline
\end{tabular}


Chiral HPLC Daicel Chiralpak IA column: 99.75:0.25 hexane/IPA, flow rate $1 \mathrm{~mL} / \mathrm{min}, \lambda=254 \mathrm{~nm}$

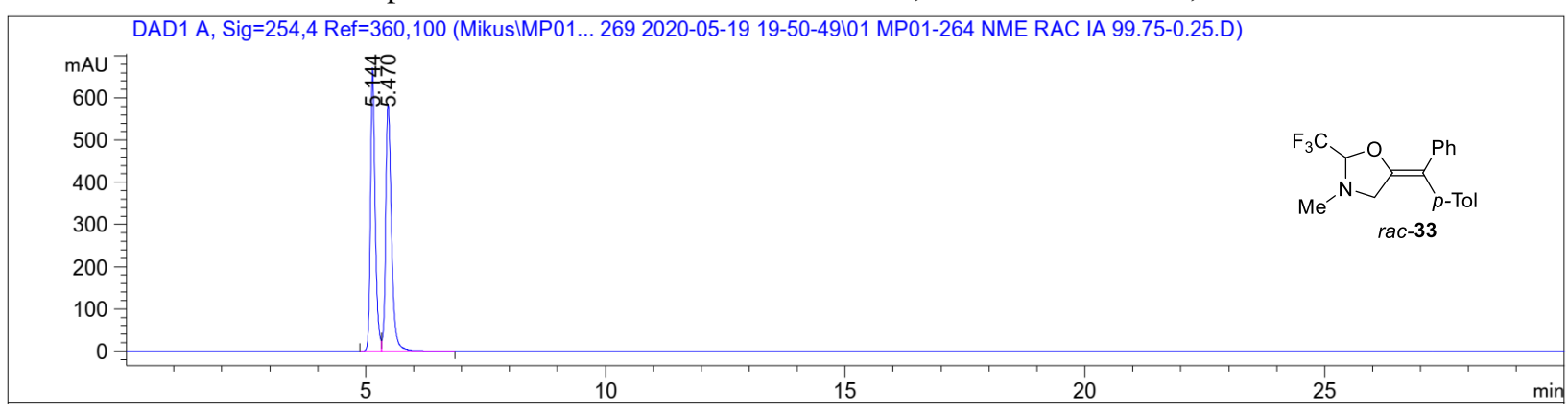

\begin{tabular}{|c|c|c|c|c|c|c|}
\hline $\begin{array}{c}\text { Peak } \\
\quad \#\end{array}$ & $\begin{array}{c}\text { RetTime } \\
\text { [min] }\end{array}$ & Type & $\begin{array}{l}\text { Width } \\
\text { [min] }\end{array}$ & $\begin{array}{c}\text { Area } \\
{\left[\mathrm{mAU}^{*} \mathrm{~s}\right]}\end{array}$ & $\begin{array}{l}\text { Height } \\
{[\mathrm{mAU}]}\end{array}$ & $\begin{array}{c}\text { Area } \\
\%\end{array}$ \\
\hline & & & & ------ & -- & -------- \\
\hline 1 & 5.144 & BV & 0.1056 & 4701.87695 & 672.19818 & 48.8437 \\
\hline 2 & 5.470 & VB & 0.1260 & 4924.50293 & 586.52747 & 51.1563 \\
\hline
\end{tabular}

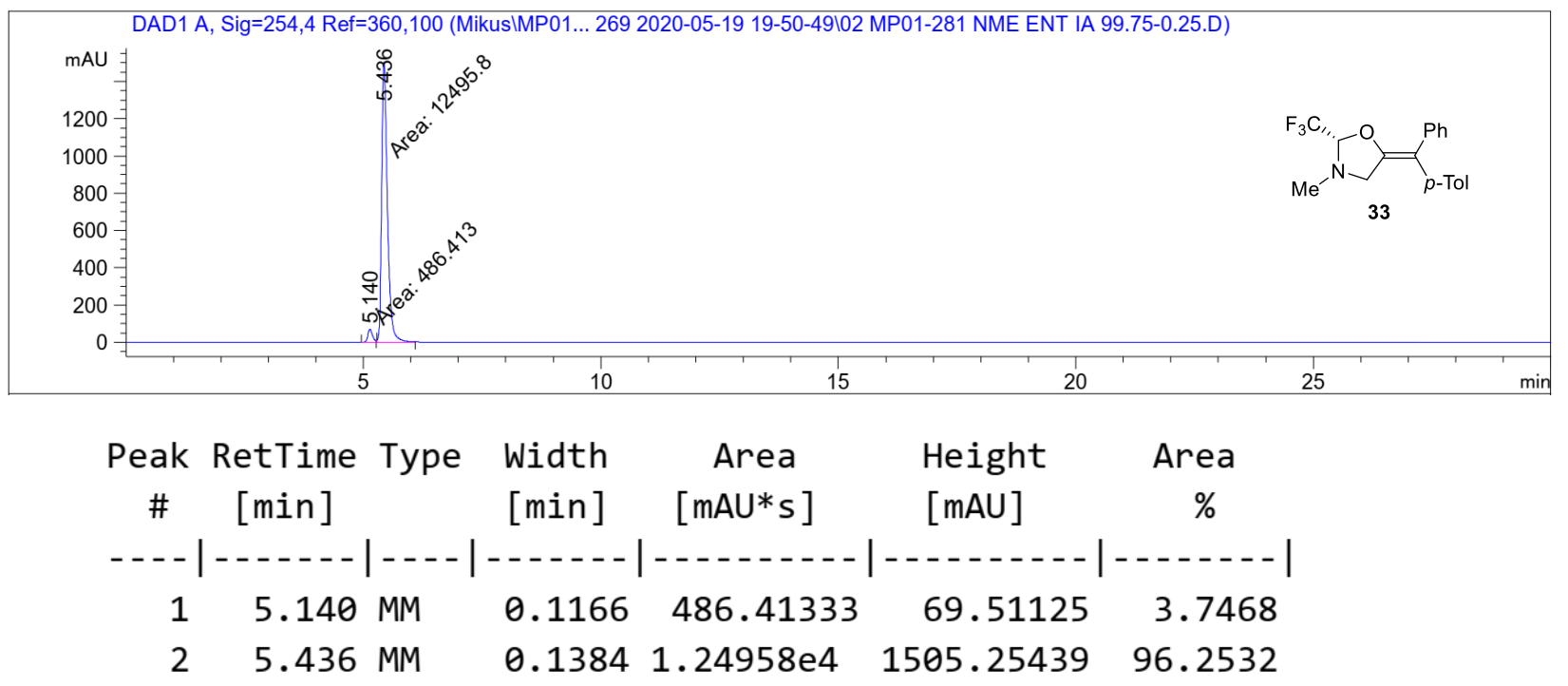


Chiral HPLC Daicel Chiralpak IB N-5 column: 99:1 hexane/IPA, flow rate $1 \mathrm{~mL} / \mathrm{min}, \lambda=254 \mathrm{~nm}$
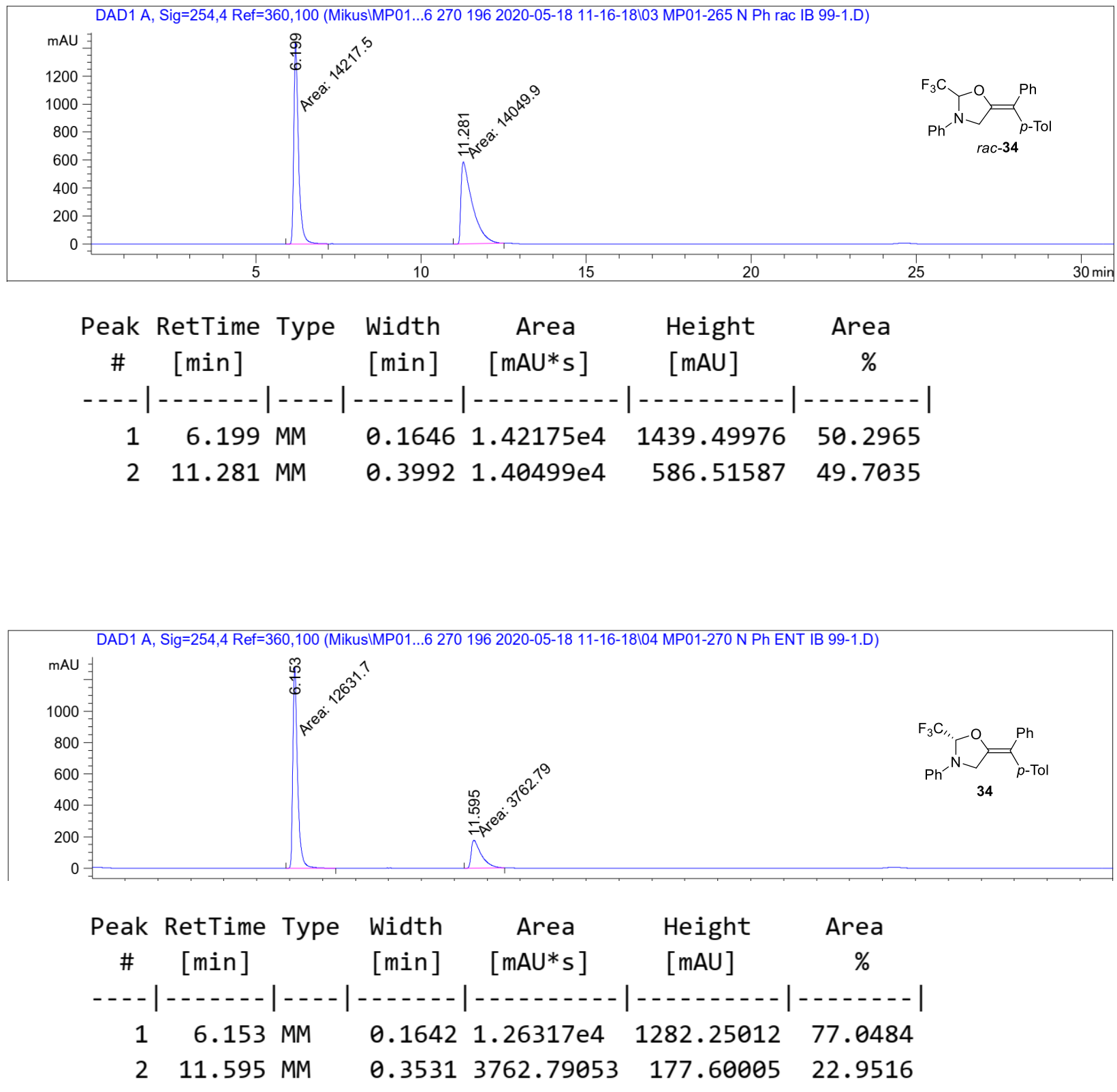
Chiral HPLC Daicel Chiralpak IB N-5 column: 99:1 hexane/IPA, flow rate $1 \mathrm{~mL} / \mathrm{min}, \lambda=254 \mathrm{~nm}$
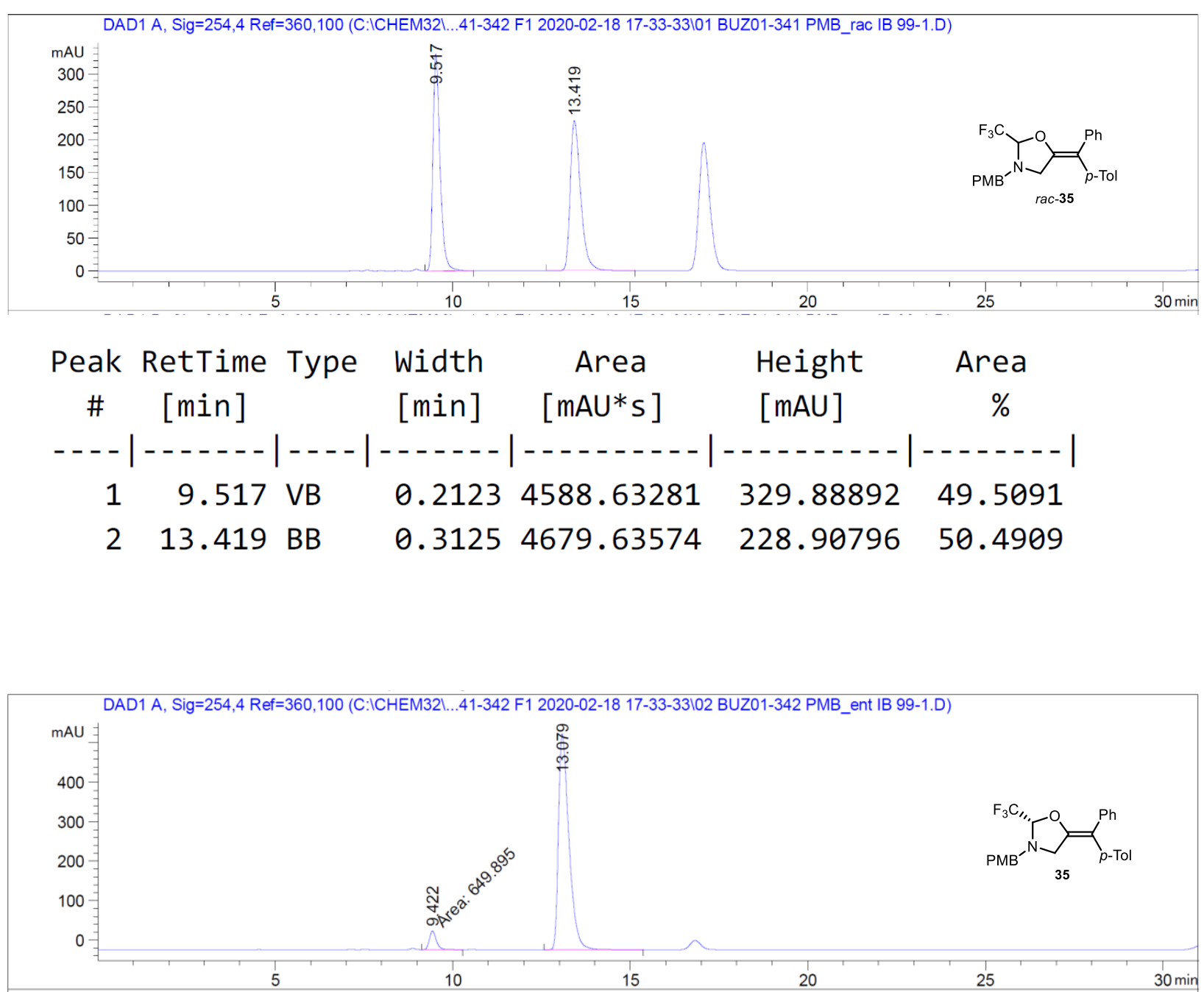

\begin{tabular}{|c|c|c|c|c|c|c|}
\hline $\begin{array}{l}\text { eak } \\
\#\end{array}$ & $\begin{array}{c}\text { RetTime } \\
\text { [min] }\end{array}$ & ype & $\begin{array}{l}\text { Width } \\
\text { [min] }\end{array}$ & $\begin{array}{c}\text { Area } \\
{\left[\mathrm{mAU}^{*} \mathrm{~s}\right]}\end{array}$ & $\begin{array}{l}\text { Height } \\
{[\mathrm{mAU}]}\end{array}$ & $\begin{array}{c}\text { Area } \\
\%\end{array}$ \\
\hline & & & & & . & \\
\hline 1 & & & & 64 & & \\
\hline 2 & 79 & & & $1.12374 \mathrm{e} 4$ & 6708 & 94.5329 \\
\hline
\end{tabular}


Chiral HPLC Daicel Chiralpak IA column: 95:5 hexane/IPA, flow rate $1 \mathrm{~mL} / \mathrm{min}, \lambda=210 \mathrm{~nm}$

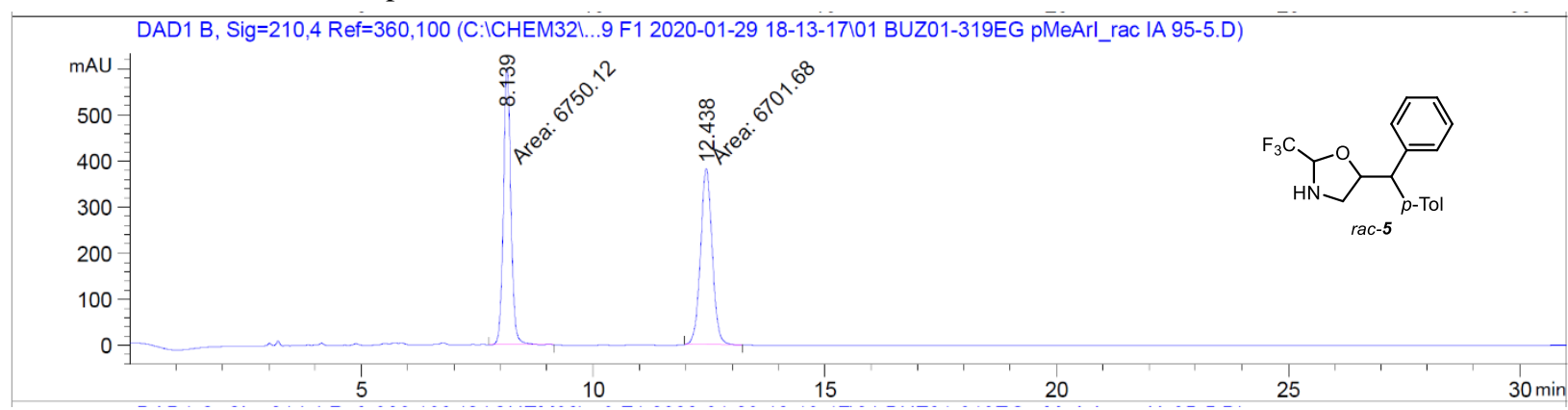

Peak RetTime Type Width Area Height Area

\begin{tabular}{cccccc}
$\#$ & {$[\mathrm{~min}]$} & {$[\mathrm{min}]$} & {$[\mathrm{mAU} * \mathrm{~s}]$} & {$[\mathrm{mAU}]$} & $\%$ \\
\hline 1 & $8.139 \mathrm{MM}$ & 0.1870 & 6750.12305 & 601.65063 & 50.1801 \\
2 & $12.438 \mathrm{MM}$ & 0.2923 & 6701.67676 & 382.18515 & 49.8199
\end{tabular}
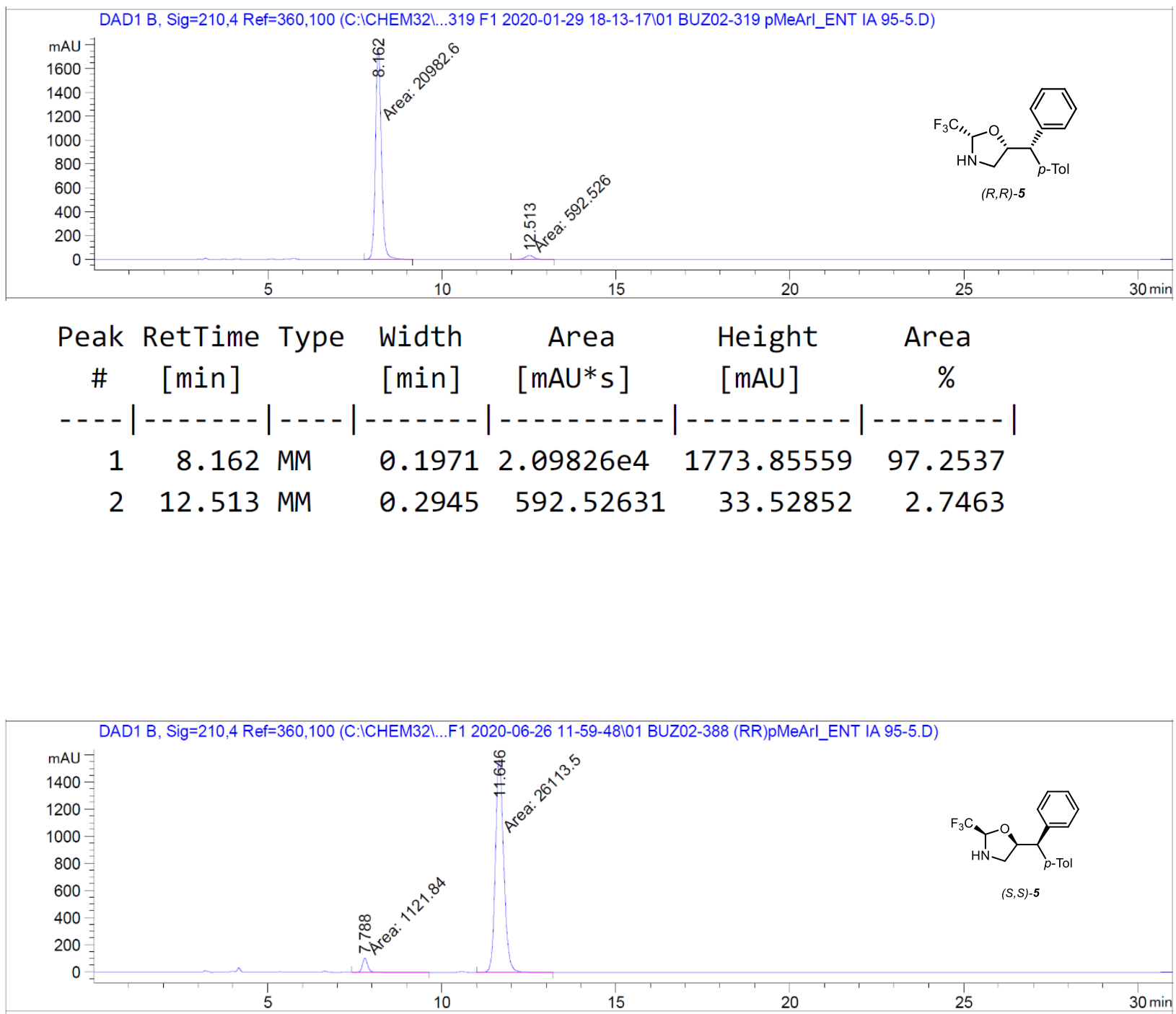
Peak RetTime Type Width Area Height Area

\# $[\mathrm{min}] \quad[\mathrm{min}] \quad[\mathrm{mAU} * \mathrm{~s}] \quad[\mathrm{mAU}] \quad \%$

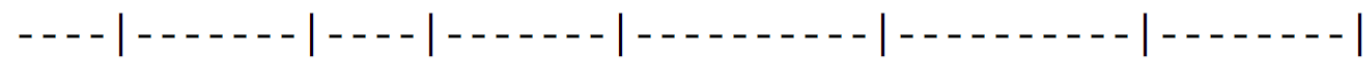

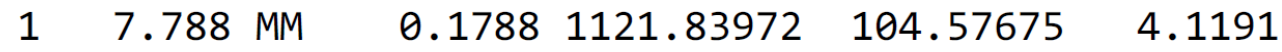

$\begin{array}{llllll}2 & 11.646 \text { MM } & 0.2773 & 2.61135 \mathrm{e} 4 & 1569.22839 & 95.8809\end{array}$

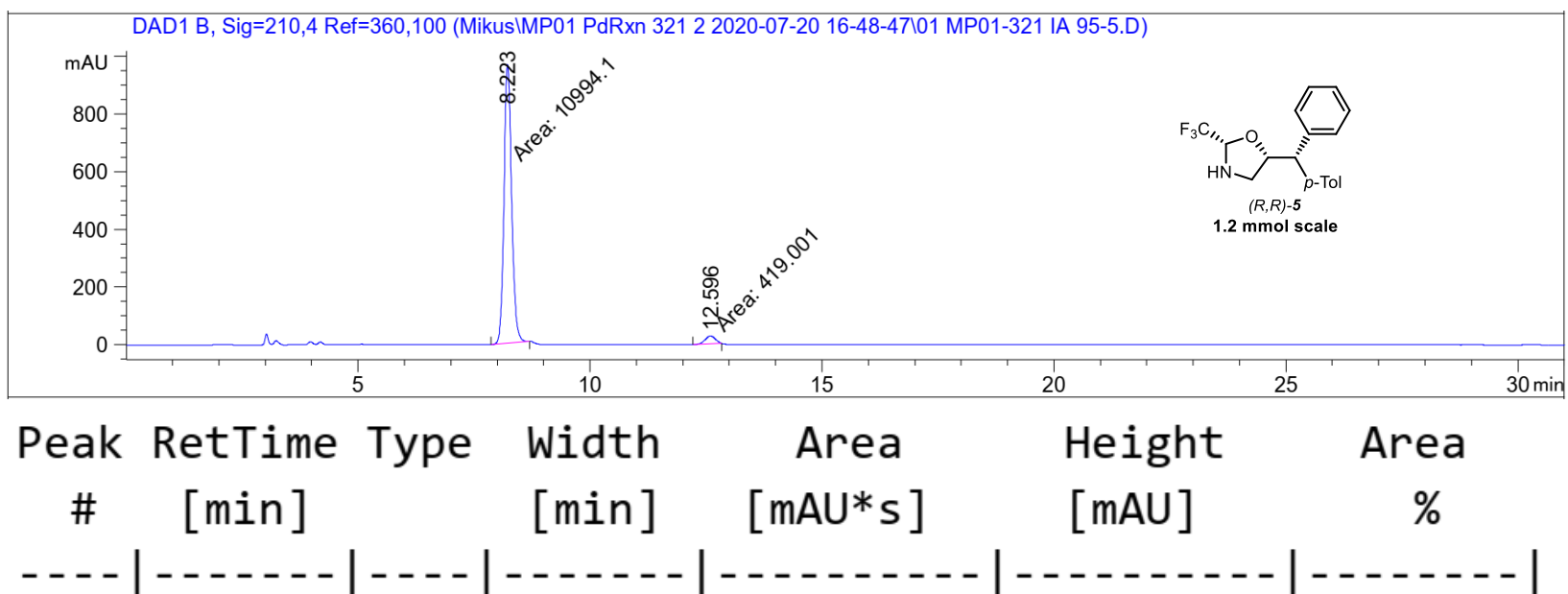

$1 \quad 8.223$ MM $\quad 0.1898 \quad 1.09941 \mathrm{e} 4 \quad 965.64703 \quad 96.3288$

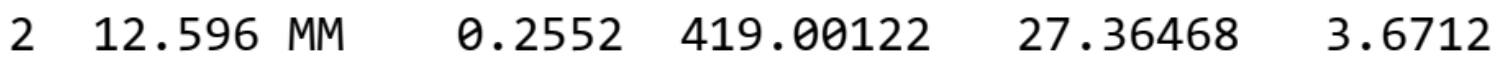


Chiral HPLC Daicel Chiralpak IA column: 95:5 hexane/IPA, flow rate $1 \mathrm{~mL} / \mathrm{min}, \lambda=210 \mathrm{~nm}$
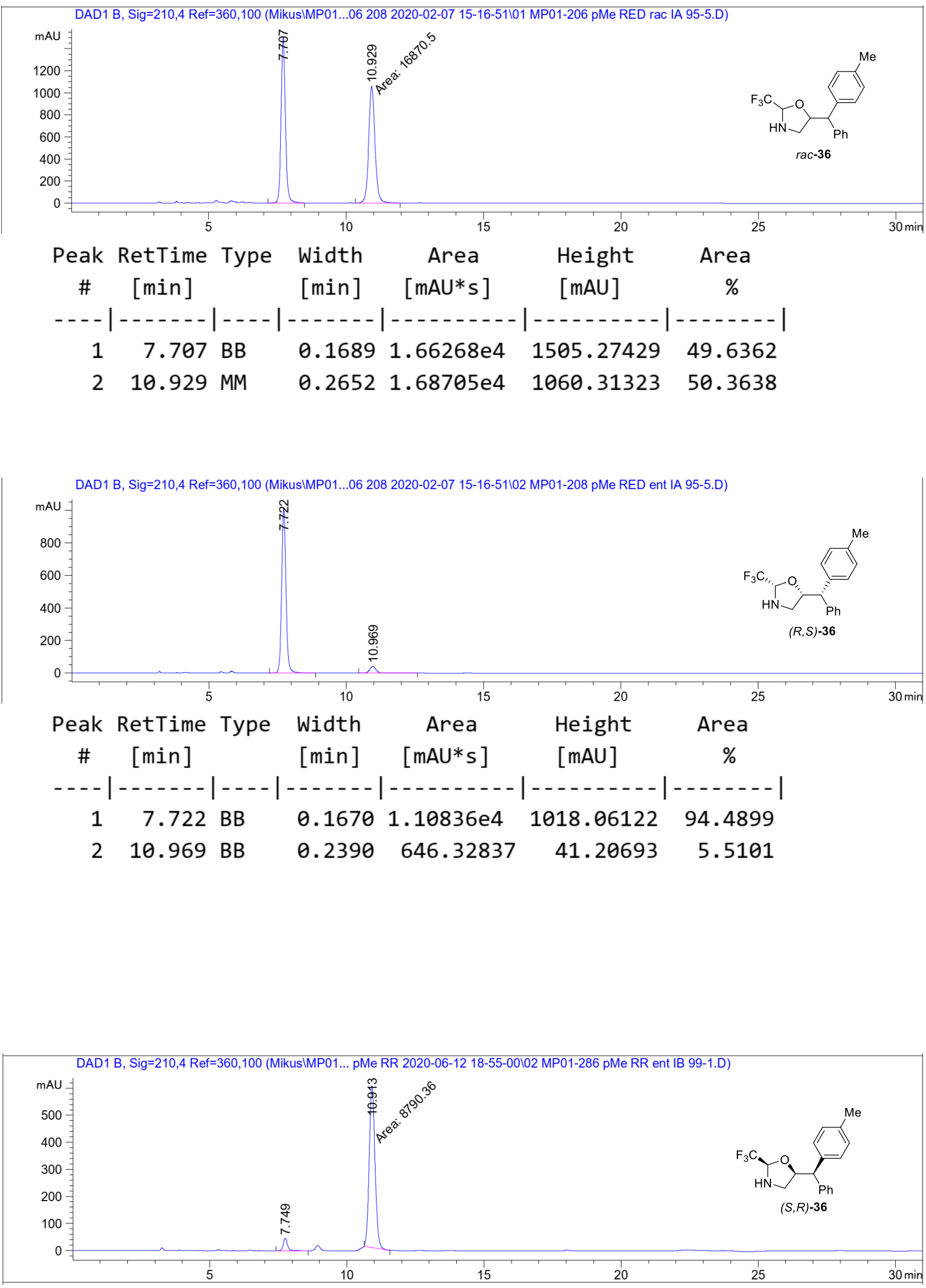


\begin{tabular}{|c|c|c|c|c|c|c|}
\hline $\begin{array}{c}\text { Peak } \\
\#\end{array}$ & $\begin{array}{c}\text { RetTime } \\
\text { [min] }\end{array}$ & Type & $\begin{array}{l}\text { Width } \\
\text { [min] }\end{array}$ & $\begin{array}{c}\text { Area } \\
{\left[\mathrm{mAU}^{*} \mathrm{~s}\right]}\end{array}$ & $\begin{array}{l}\text { Height } \\
{[\mathrm{mAU}]}\end{array}$ & $\begin{array}{c}\text { Area } \\
\%\end{array}$ \\
\hline & & & & & & \\
\hline 1 & & BB & 4 & 492.49951 & 45.44075 & 055 \\
\hline 2 & 10.913 & $\mathrm{MM}$ & 0.2449 & 8790.36035 & 598.13947 & 94.6945 \\
\hline
\end{tabular}




\section{I.2. Asymmetric Hydrogenation Products}

Chiral HPLC Daicel Chiralpak IA column: 95:5 hexane/IPA, flow rate $1 \mathrm{~mL} / \mathrm{min}, \lambda=210 \mathrm{~nm}$
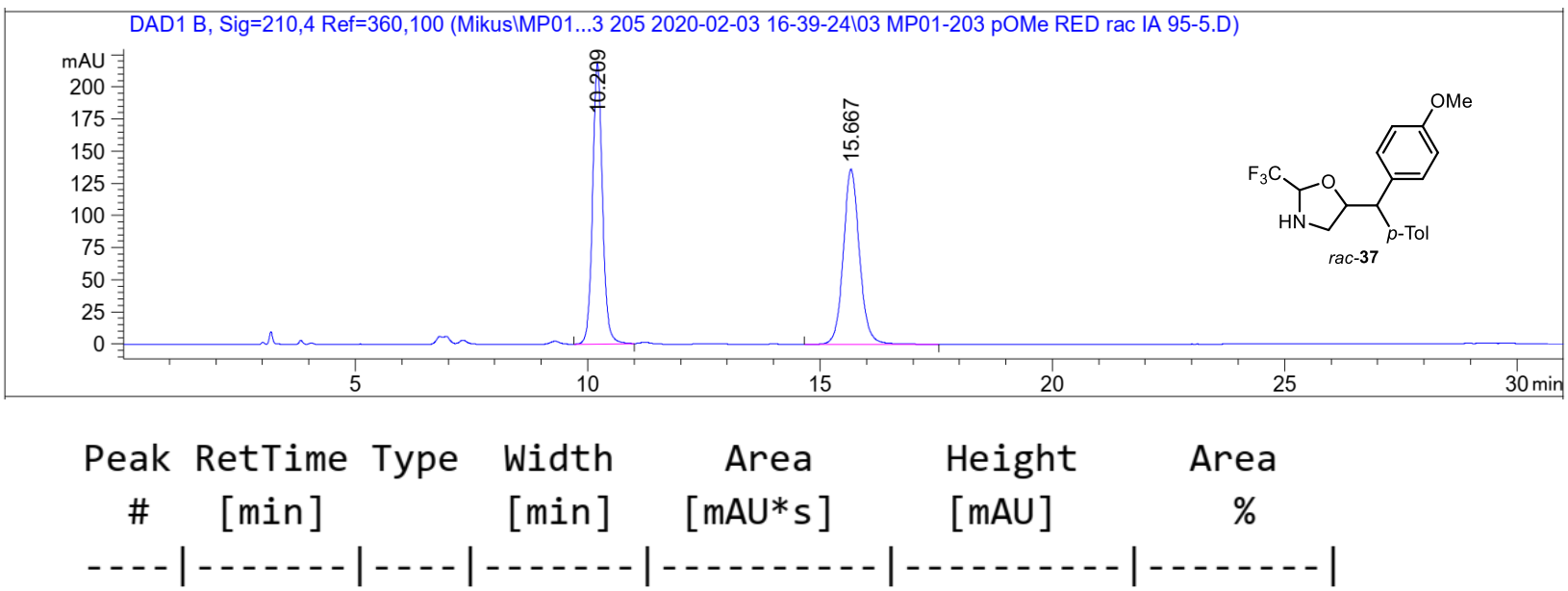
110.209 BB
0.22403224 .1108
218.68341
49.4854
$215.667 \mathrm{BB}$
$0.36793291 .16724 \quad 136.19072$
50.5146

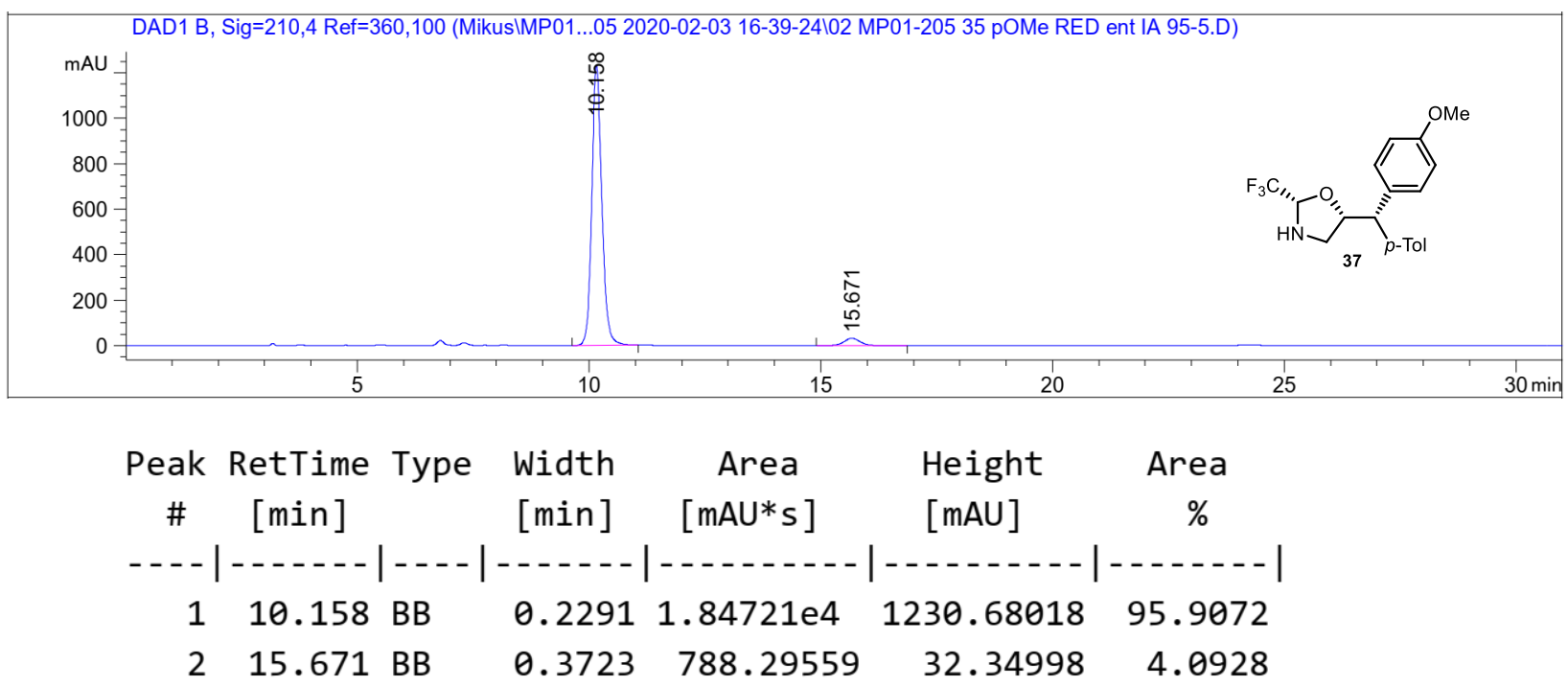


Chiral HPLC Daicel Chiralpak IA column: 95:5 hexane/IPA, flow rate $1 \mathrm{~mL} / \mathrm{min}, \lambda=210 \mathrm{~nm}$
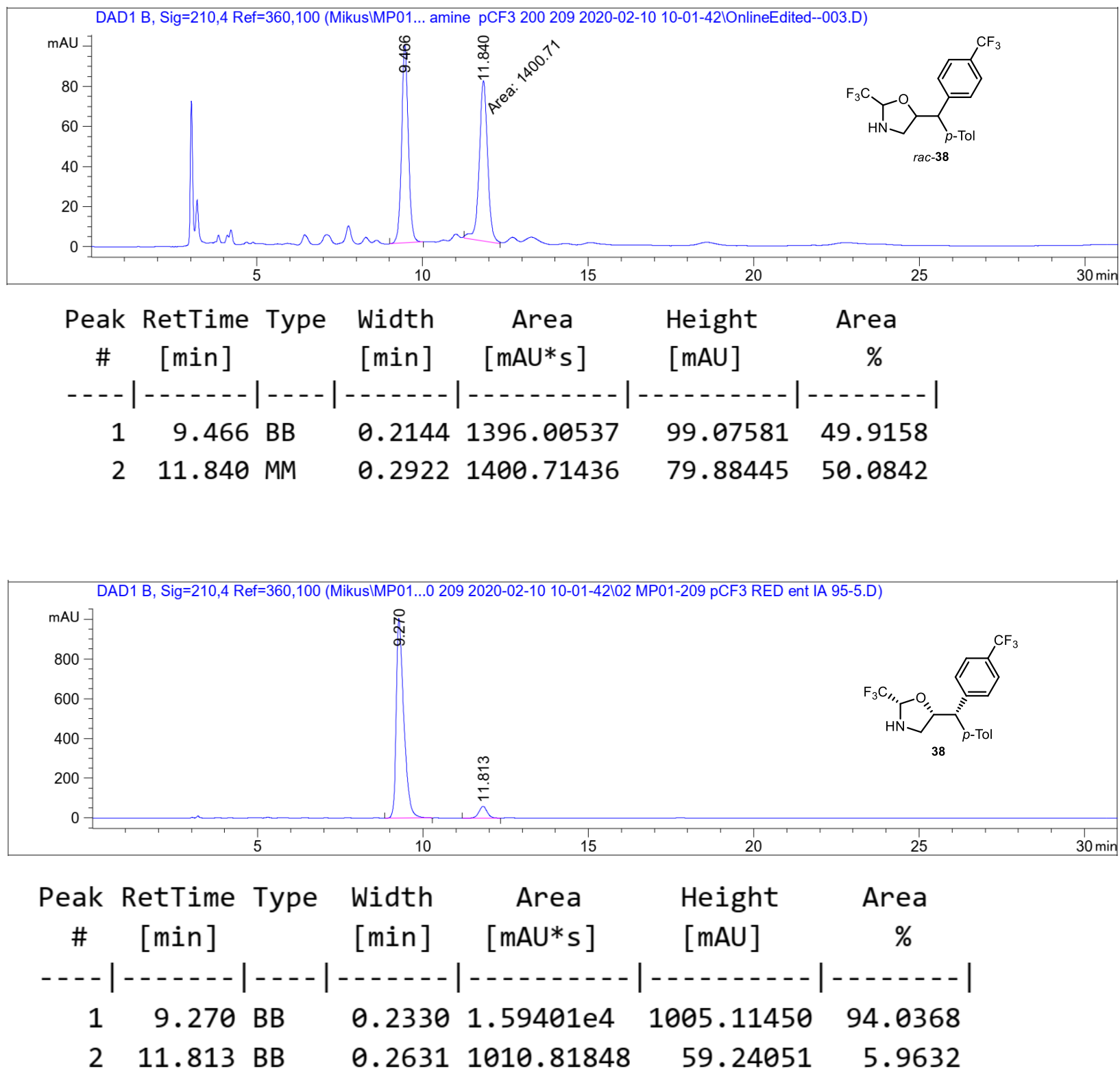
Chiral HPLC Daicel Chiralpak IA column: 95:5 hexane/IPA, flow rate $1 \mathrm{~mL} / \mathrm{min}, \lambda=210 \mathrm{~nm}$
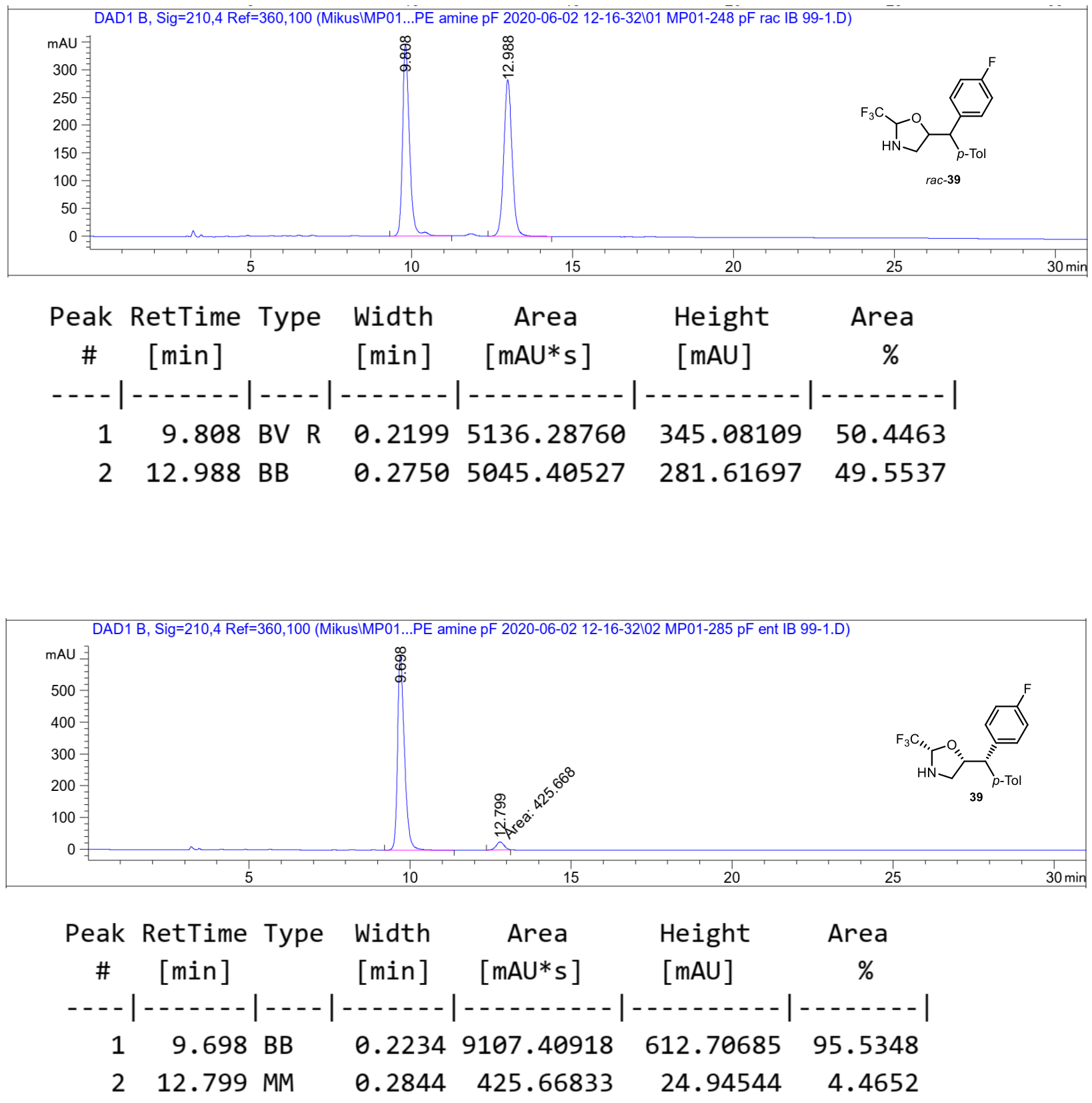
Chiral HPLC Daicel Chiralpak IA column: 95:5 hexane/IPA, flow rate $1 \mathrm{~mL} / \mathrm{min}, \lambda=230 \mathrm{~nm}$
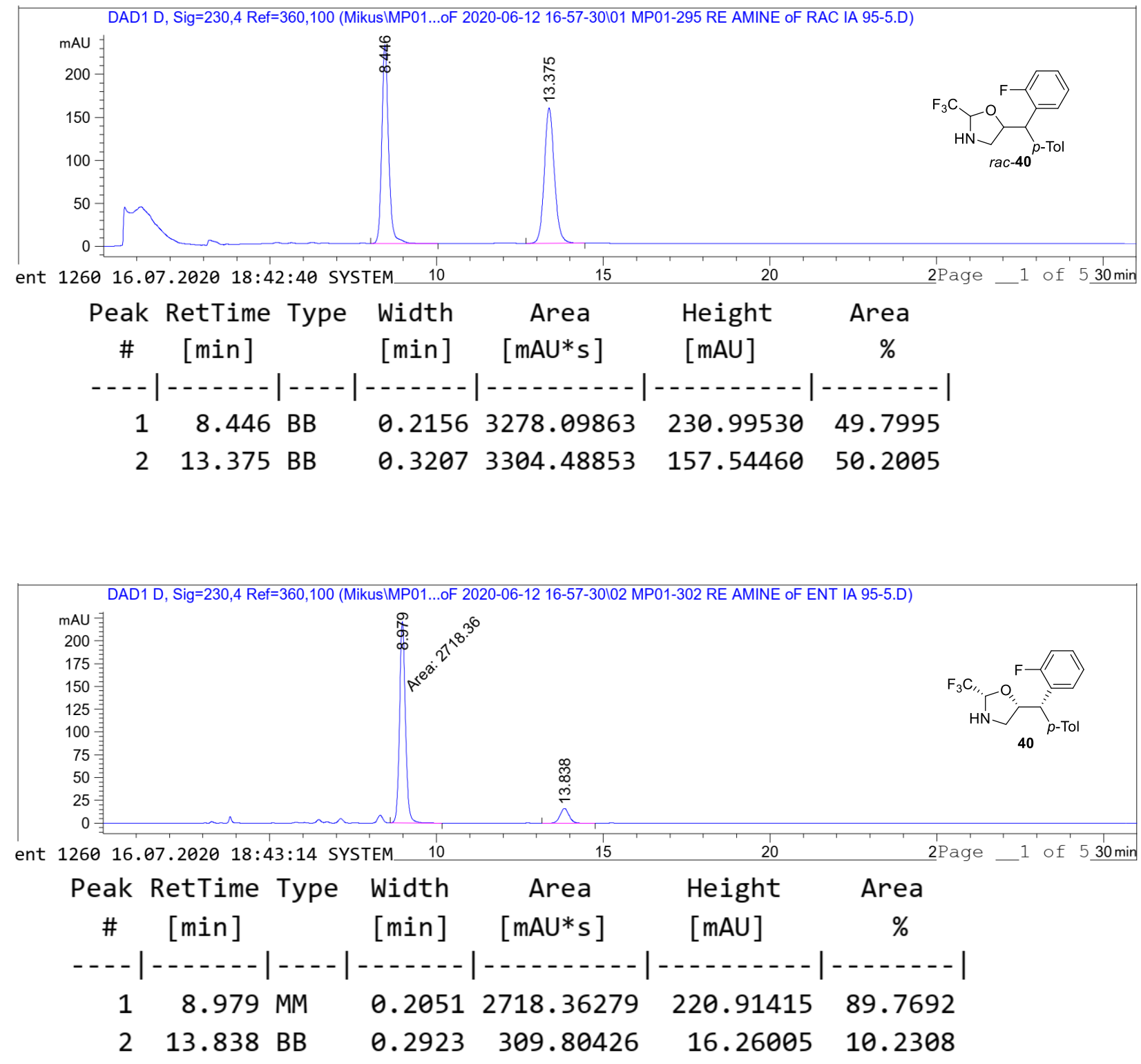
Chiral HPLC Daicel Chiralpak IA column: 95:5 hexane/IPA, flow rate $1 \mathrm{~mL} / \mathrm{min}, \lambda=230 \mathrm{~nm}$ DAD1 D, Sig=230,4 Ref=360,100 (MikusIMP01...99 2020-01-30 16-44-20101 MP01-194 35 diMe RED rac IA 95-5.D)

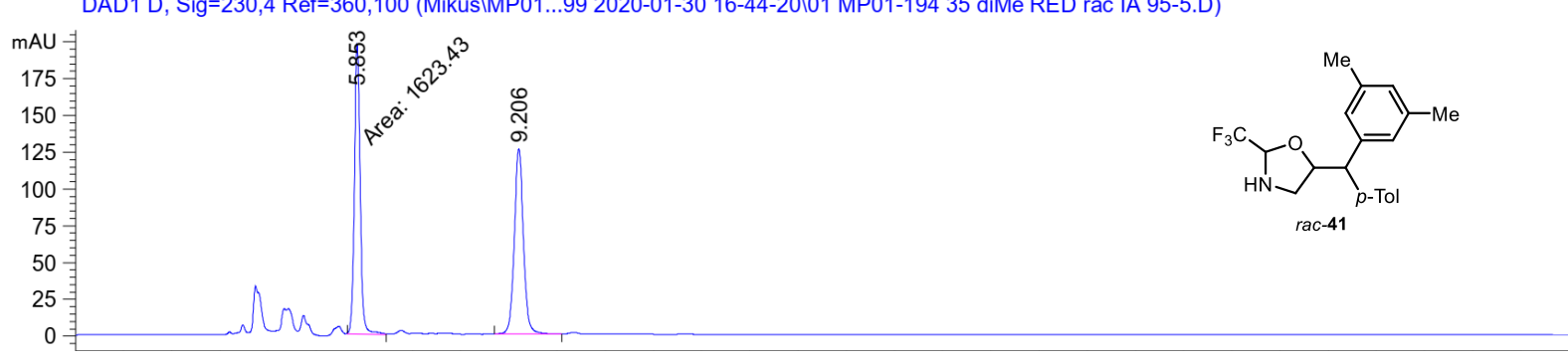

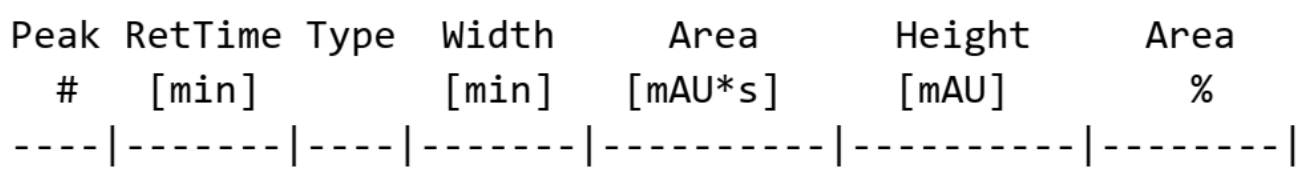
$15.853 \mathrm{MM}$
$0.13741623 .43127 \quad 196.94261 \quad 49.7401$
$29.206 \mathrm{BB}$
0.20011640 .39392
125.81128
50.2599

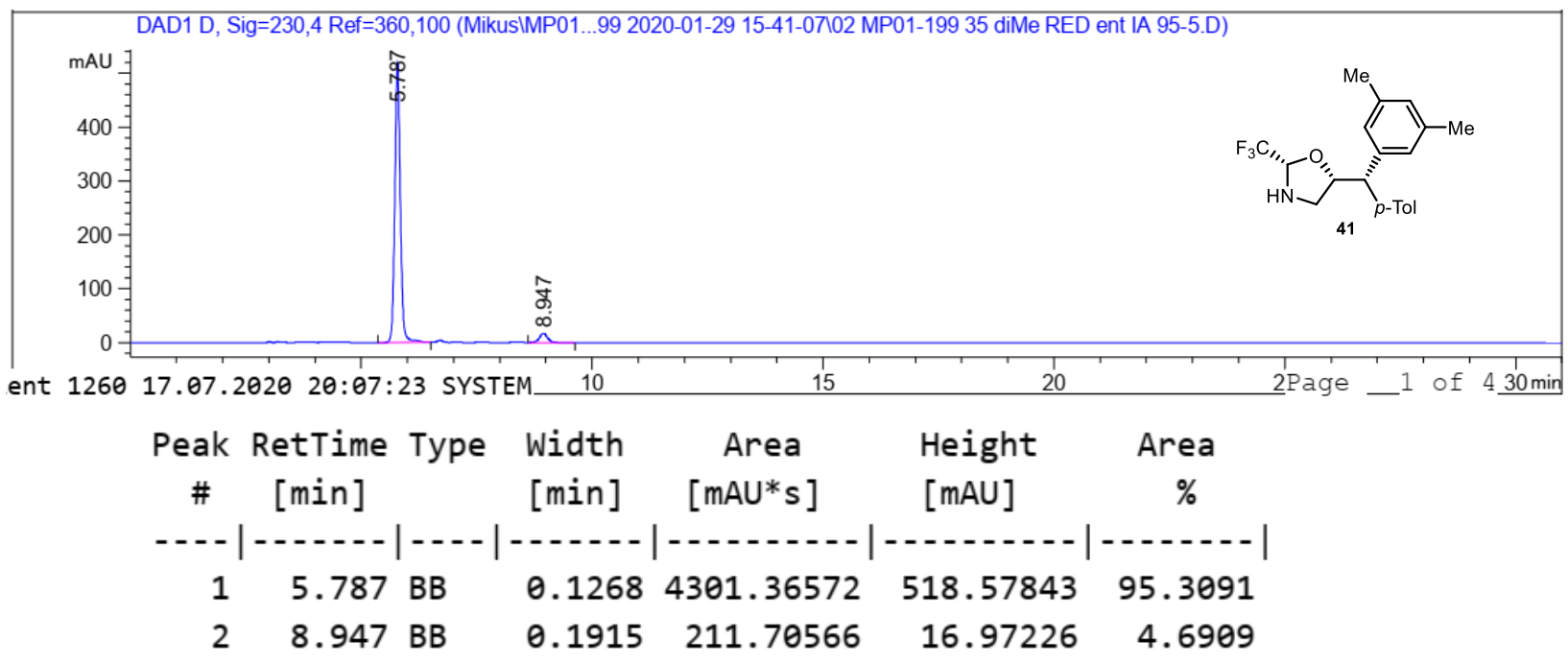


Chiral HPLC Daicel Chiralpak IA column: 95:5 hexane/IPA, flow rate $1 \mathrm{~mL} / \mathrm{min}, \lambda=210 \mathrm{~nm}$
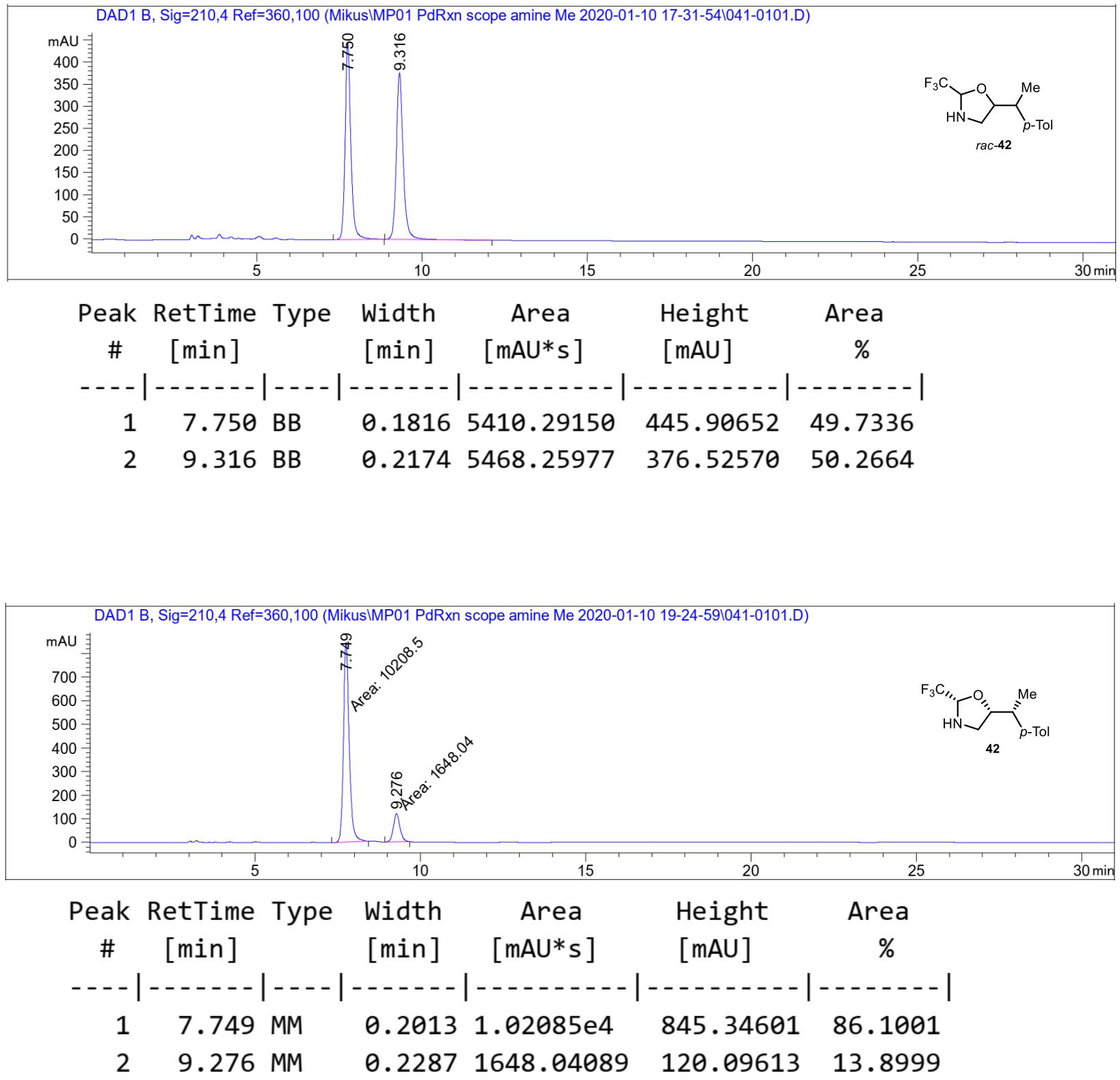
Chiral HPLC Daicel Chiralpak IA column: 95:5 hexane/IPA, flow rate $1 \mathrm{~mL} / \mathrm{min}, \lambda=210 \mathrm{~nm}$
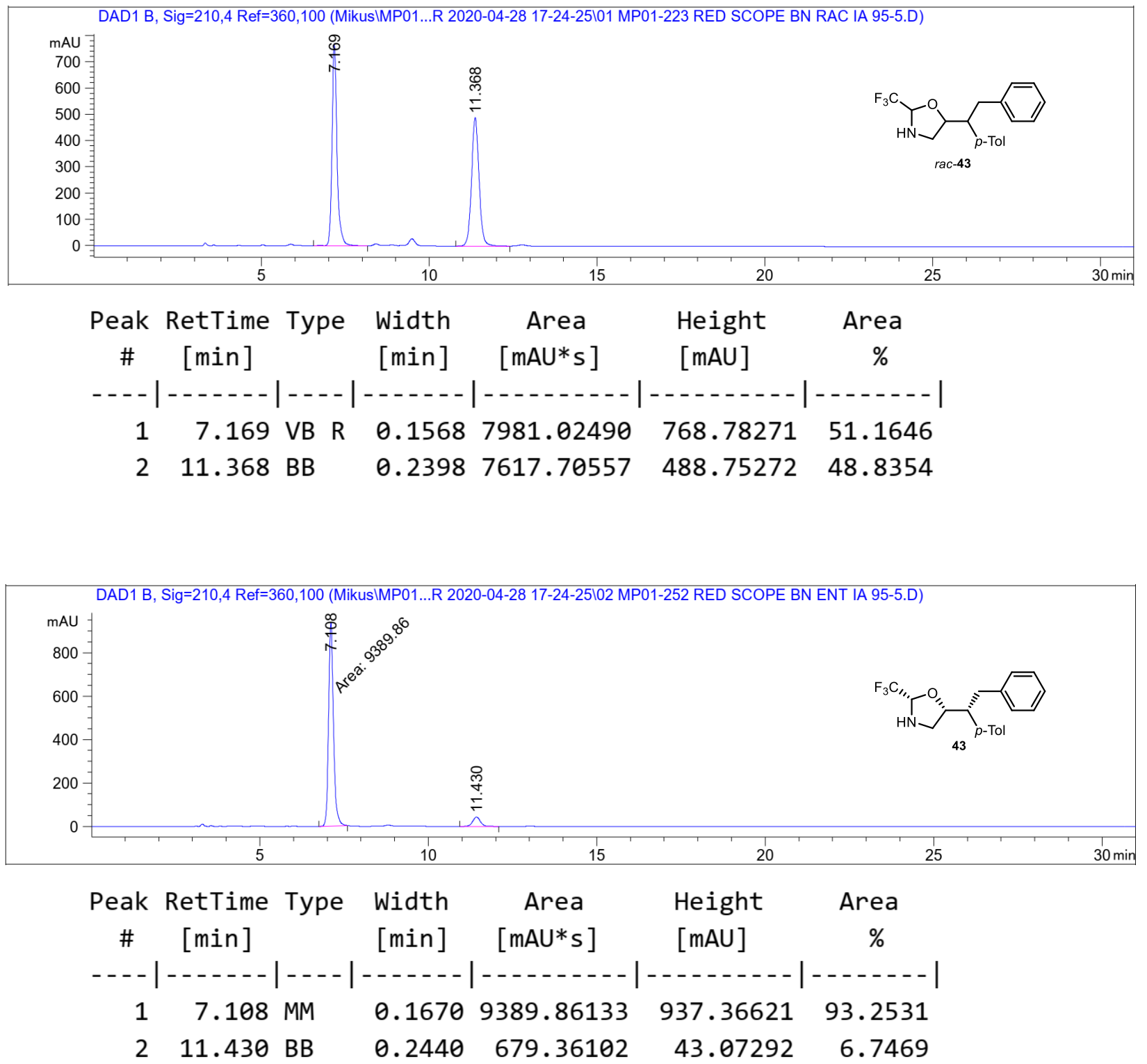
Chiral HPLC Daicel Chiralpak IA column: 95:5 hexane/IPA, flow rate $1 \mathrm{~mL} / \mathrm{min}, \lambda=210 \mathrm{~nm}$
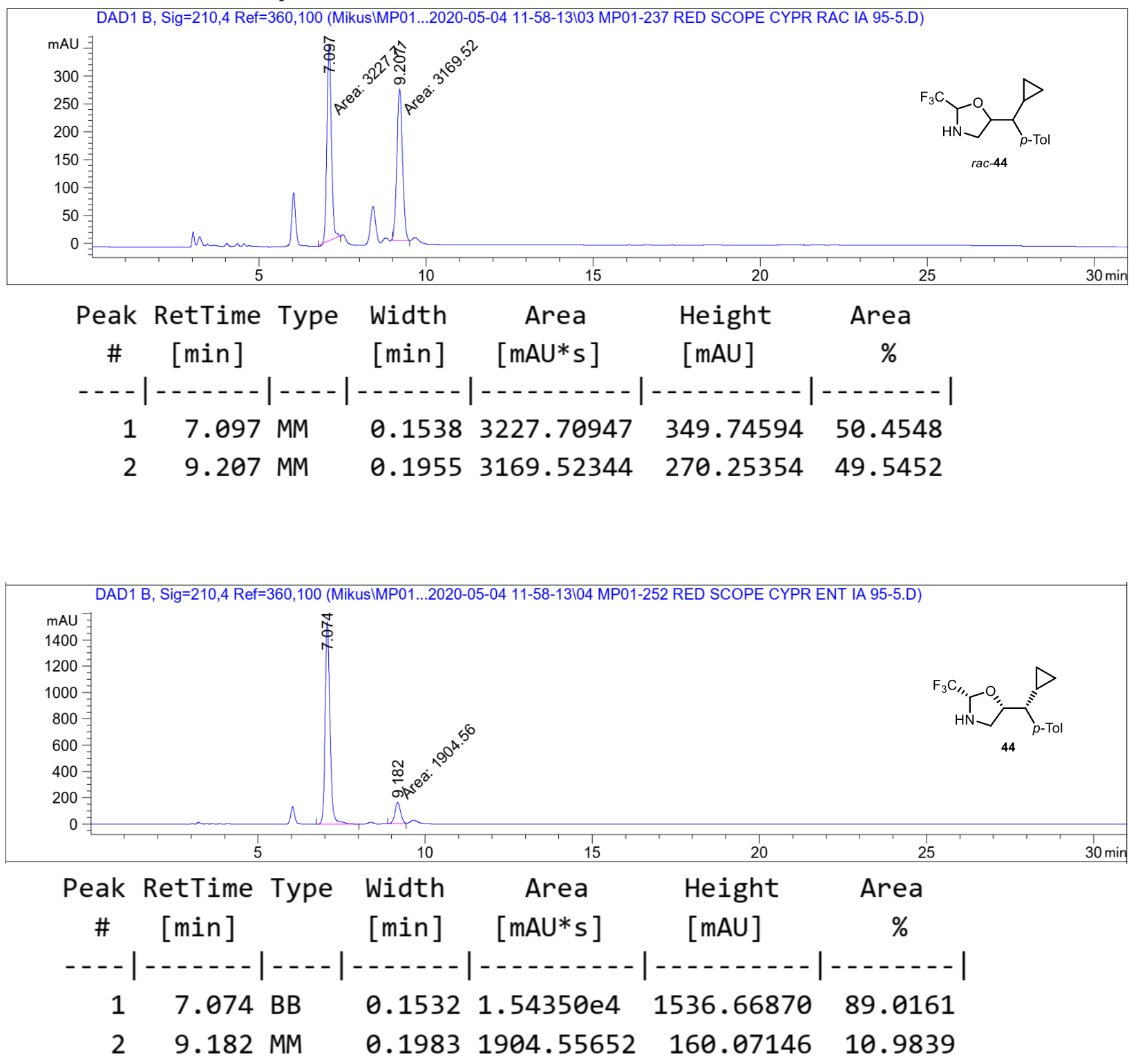
Chiral HPLC Daicel Chiralpak IA column: 95:5 hexane/IPA, flow rate $1 \mathrm{~mL} / \mathrm{min}, \lambda=210 \mathrm{~nm}$
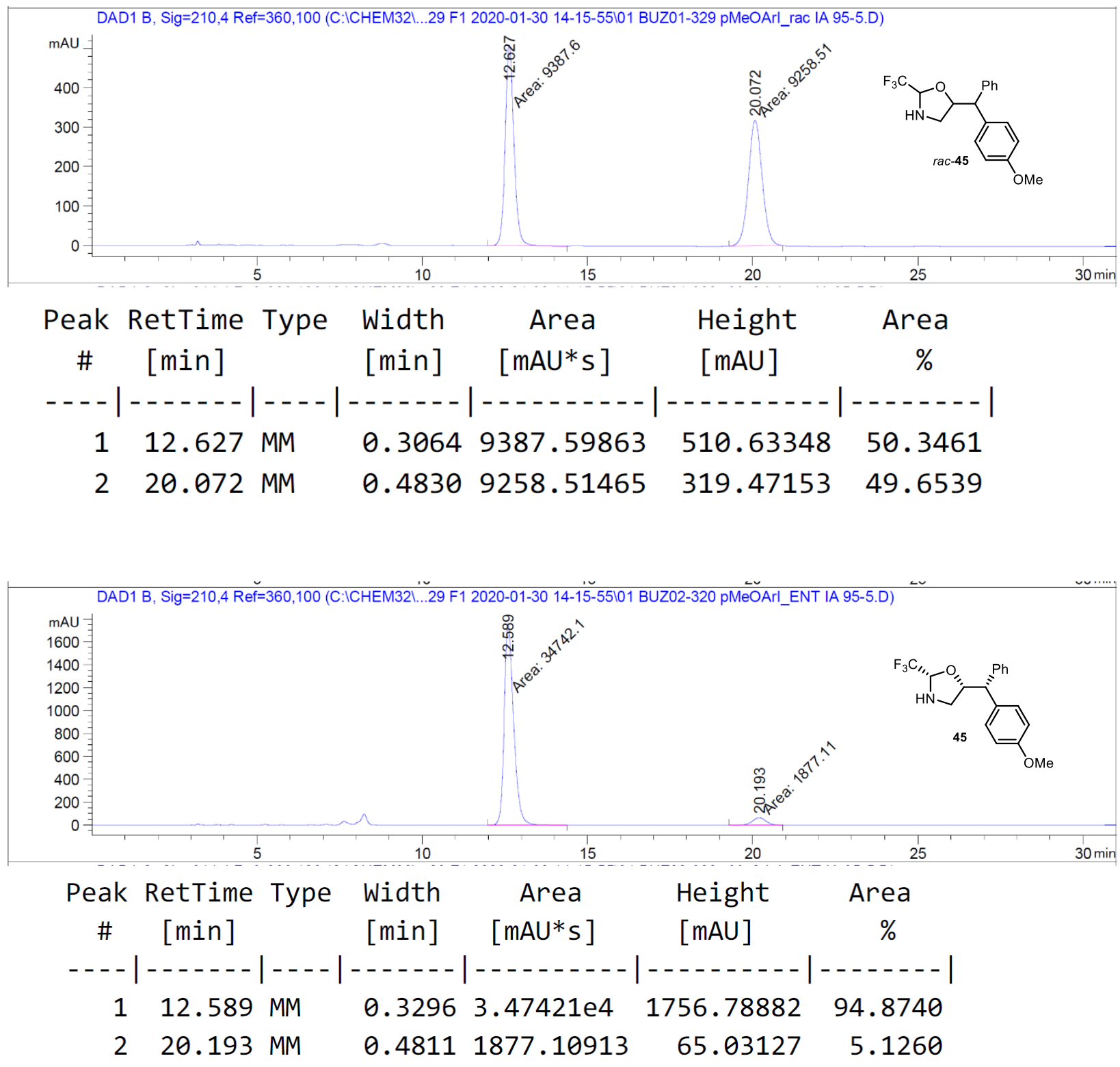
Chiral HPLC Daicel Chiralpak IA column: 95:5 hexane/IPA, flow rate $1 \mathrm{~mL} / \mathrm{min}, \lambda=210 \mathrm{~nm}$
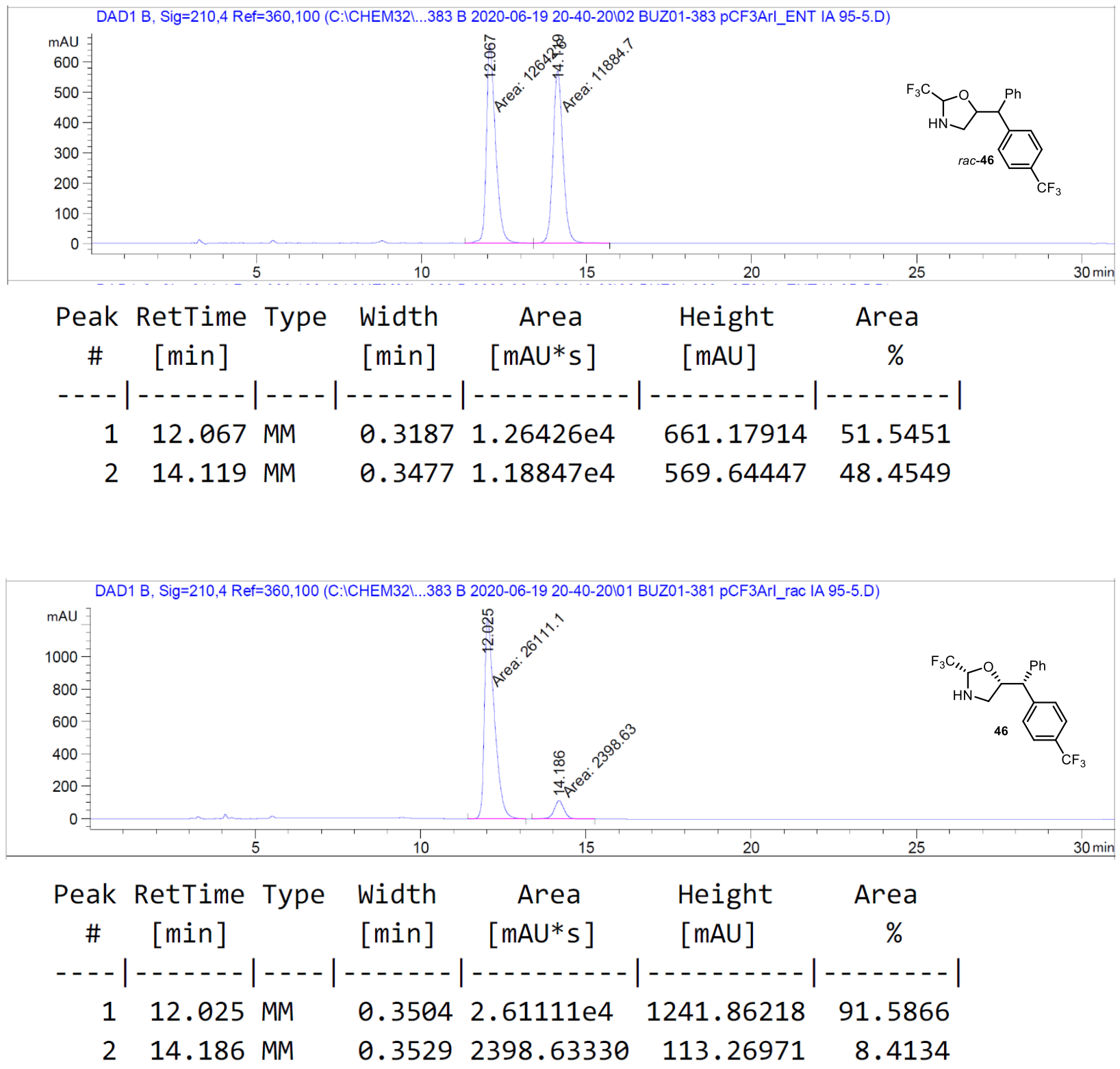
Chiral HPLC Daicel Chiralpak IA column: 95:5 hexane/IPA, flow rate $1 \mathrm{~mL} / \mathrm{min}, \lambda=210 \mathrm{~nm}$
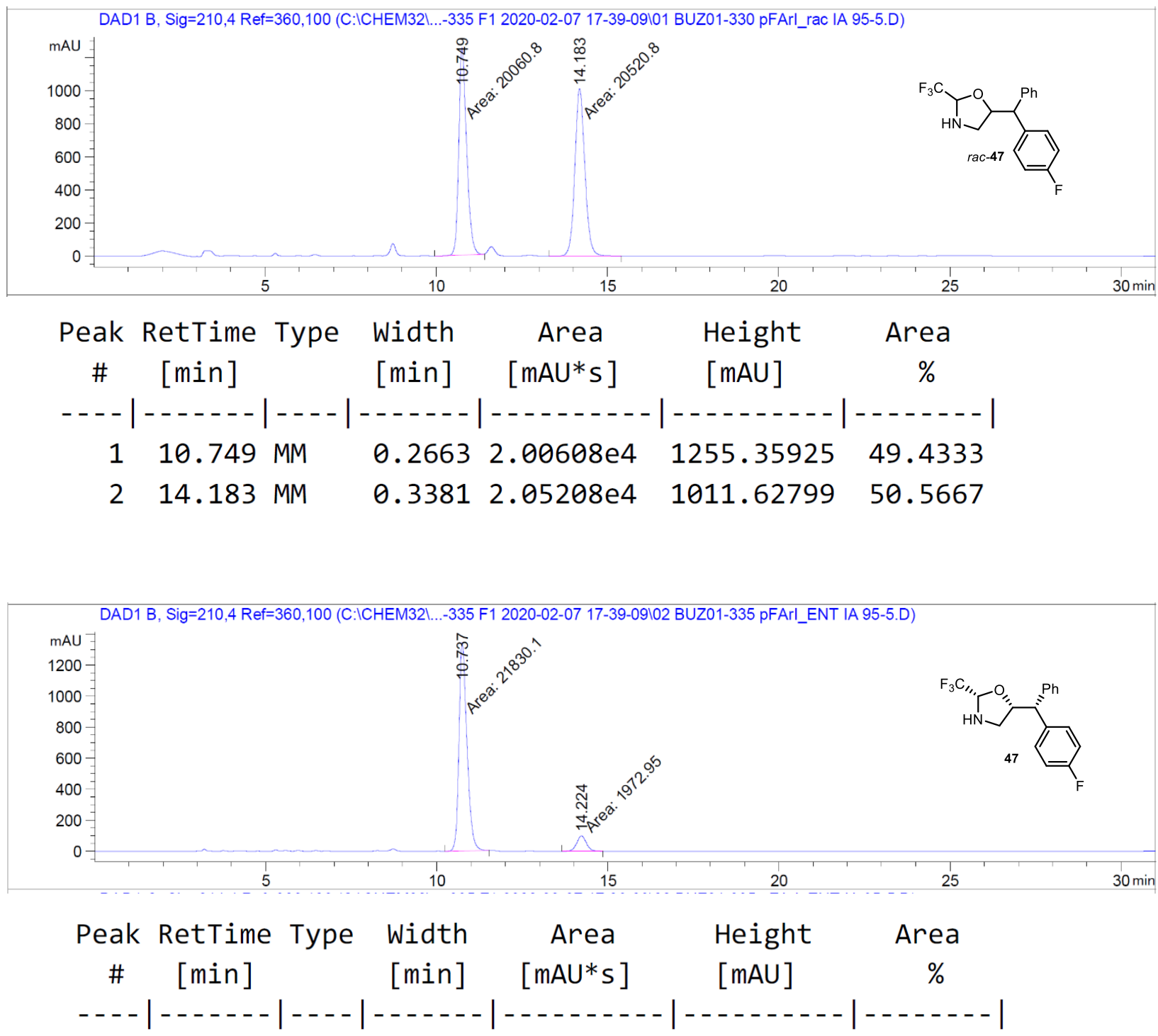
$110.737 \mathrm{MM}$
$0.2706 \quad 2.18301 \mathrm{e} 4 \quad 1344.68372 \quad 91.7114$
$214.224 \mathrm{MM}$
$0.33141972 .94580 \quad 99.23210$
8.2886 
Chiral HPLC Daicel Chiralpak IC column: 85:15 hexane/IPA, flow rate $1 \mathrm{~mL} / \mathrm{min}, \lambda=210 \mathrm{~nm}$
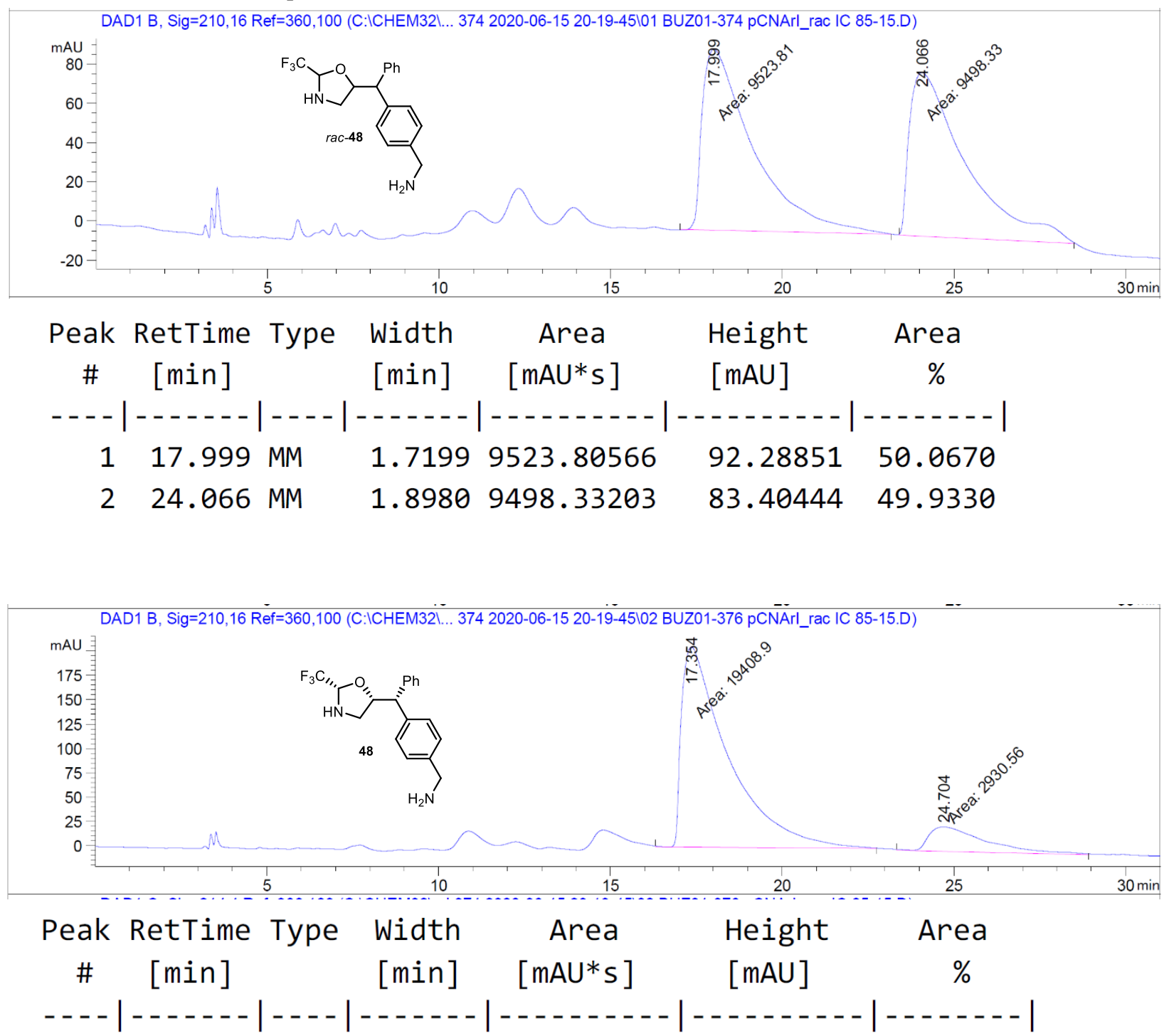

$\begin{array}{lllllll}1 & 17.354 \mathrm{MM} & 1.5701 & 1.94089 \mathrm{e} 4 & 206.02518 & 86.8817\end{array}$

$\begin{array}{llllll}2 & 24.704 \text { MM } & 1.9329 & 2930.55688 & 25.26850 & 13.1183\end{array}$ 
Chiral HPLC Daicel Chiralpak IA column: 90:10 hexane/IPA, flow rate $1 \mathrm{~mL} / \mathrm{min}, \lambda=210 \mathrm{~nm}$
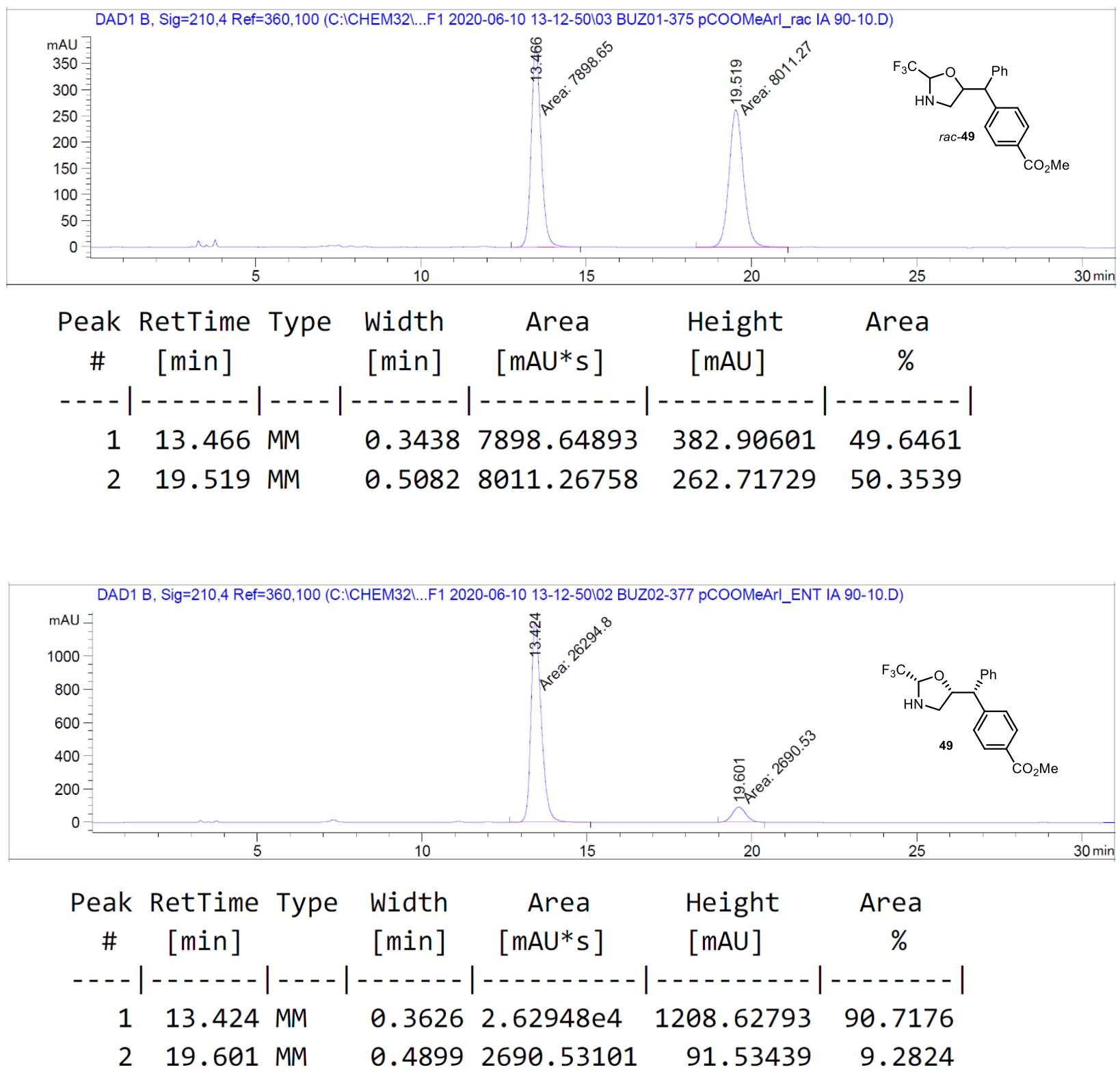
Chiral HPLC Daicel Chiralpak IA column: 80:20 hexane/IPA, flow rate $1 \mathrm{~mL} / \mathrm{min}, \lambda=210 \mathrm{~nm}$
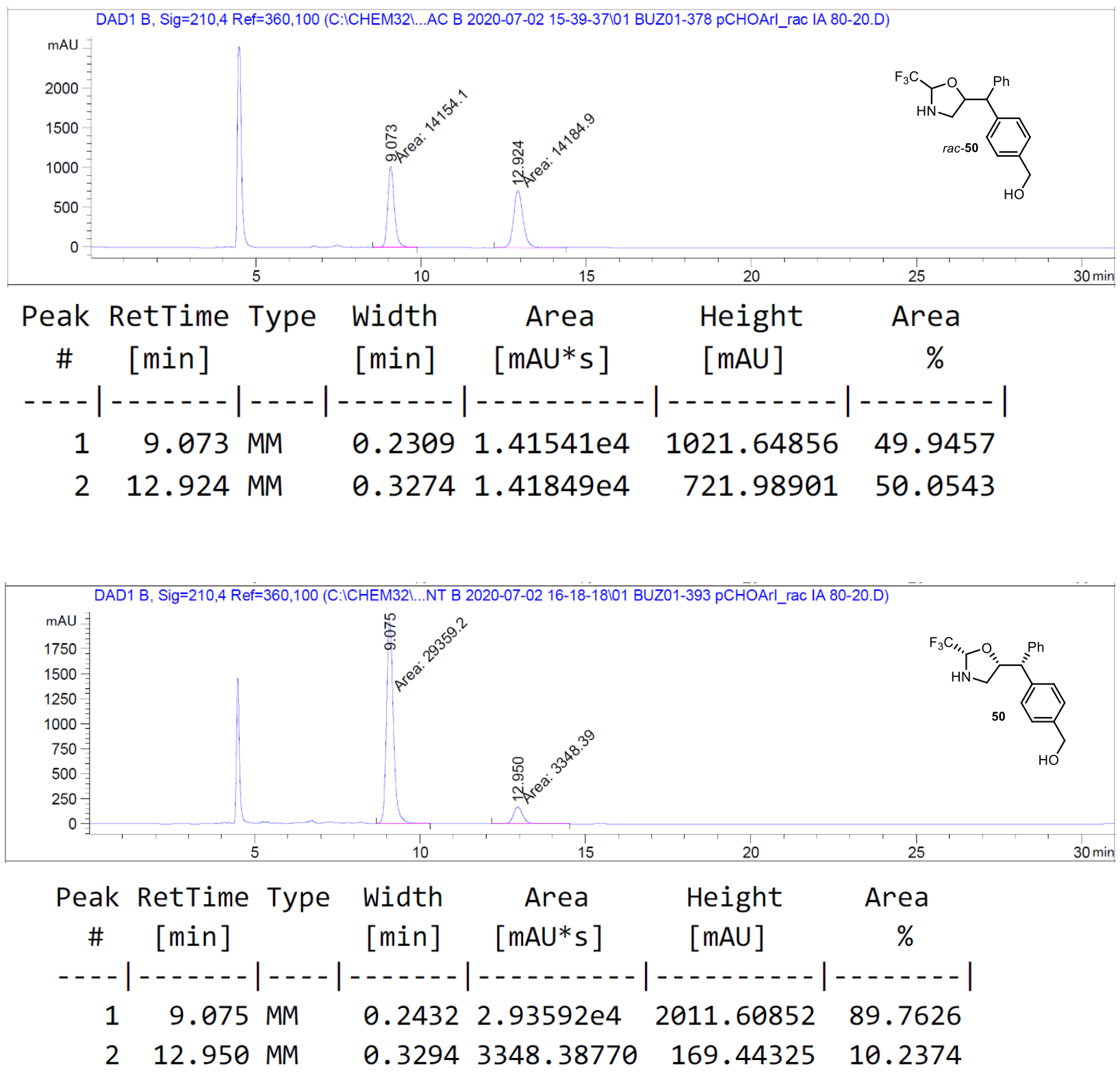
Chiral HPLC Daicel Chiralpak IA column: 95:5 hexane/IPA, flow rate $1 \mathrm{~mL} / \mathrm{min}, \lambda=210 \mathrm{~nm}$
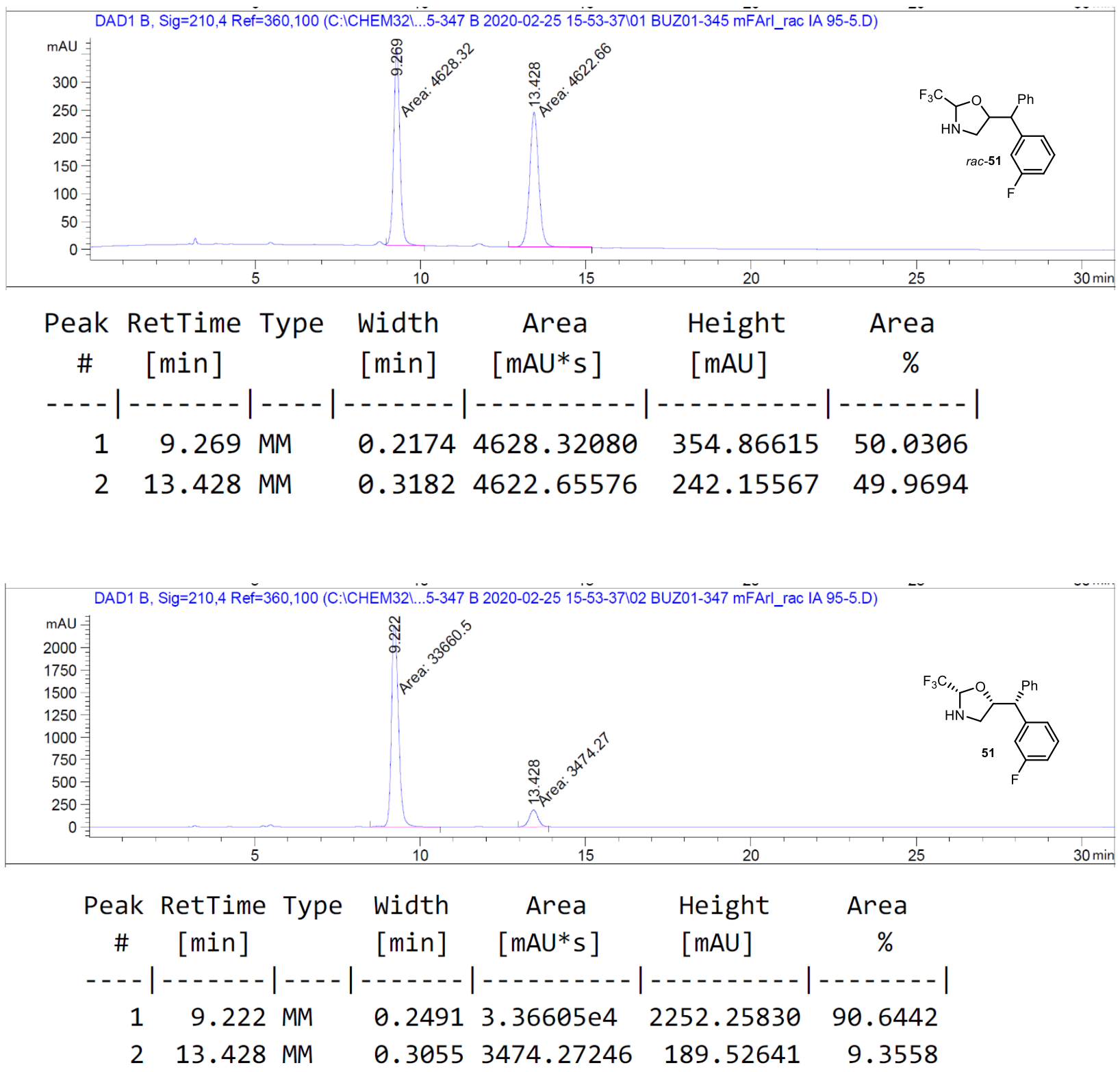
Chiral HPLC Daicel Chiralpak IA column: 95:5 hexane/IPA, flow rate $1 \mathrm{~mL} / \mathrm{min}, \lambda=254 \mathrm{~nm}$
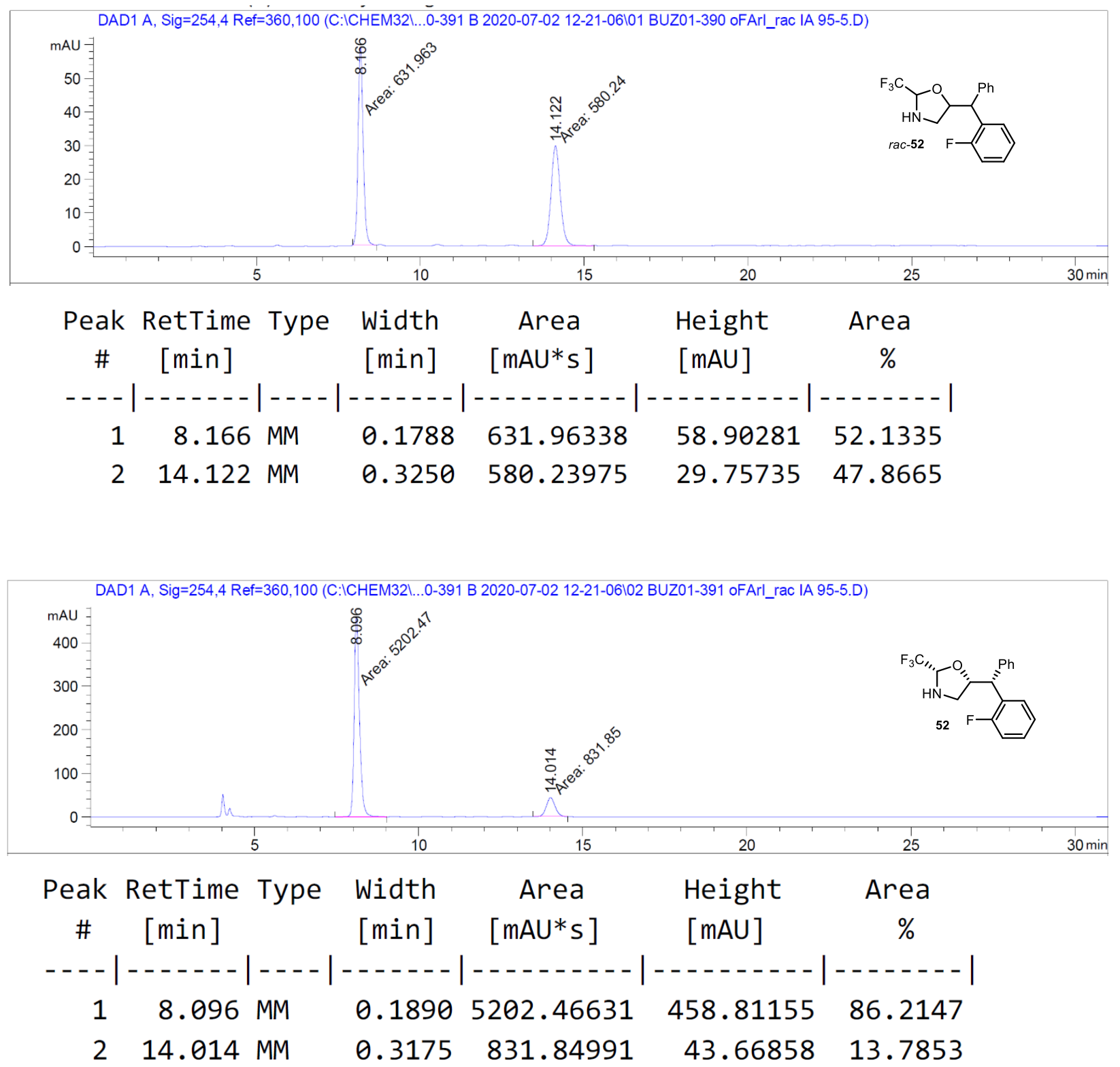
Chiral HPLC Daicel Chiralpak IA column: 95:5 hexane/IPA, flow rate $1 \mathrm{~mL} / \mathrm{min}, \lambda=210 \mathrm{~nm}$
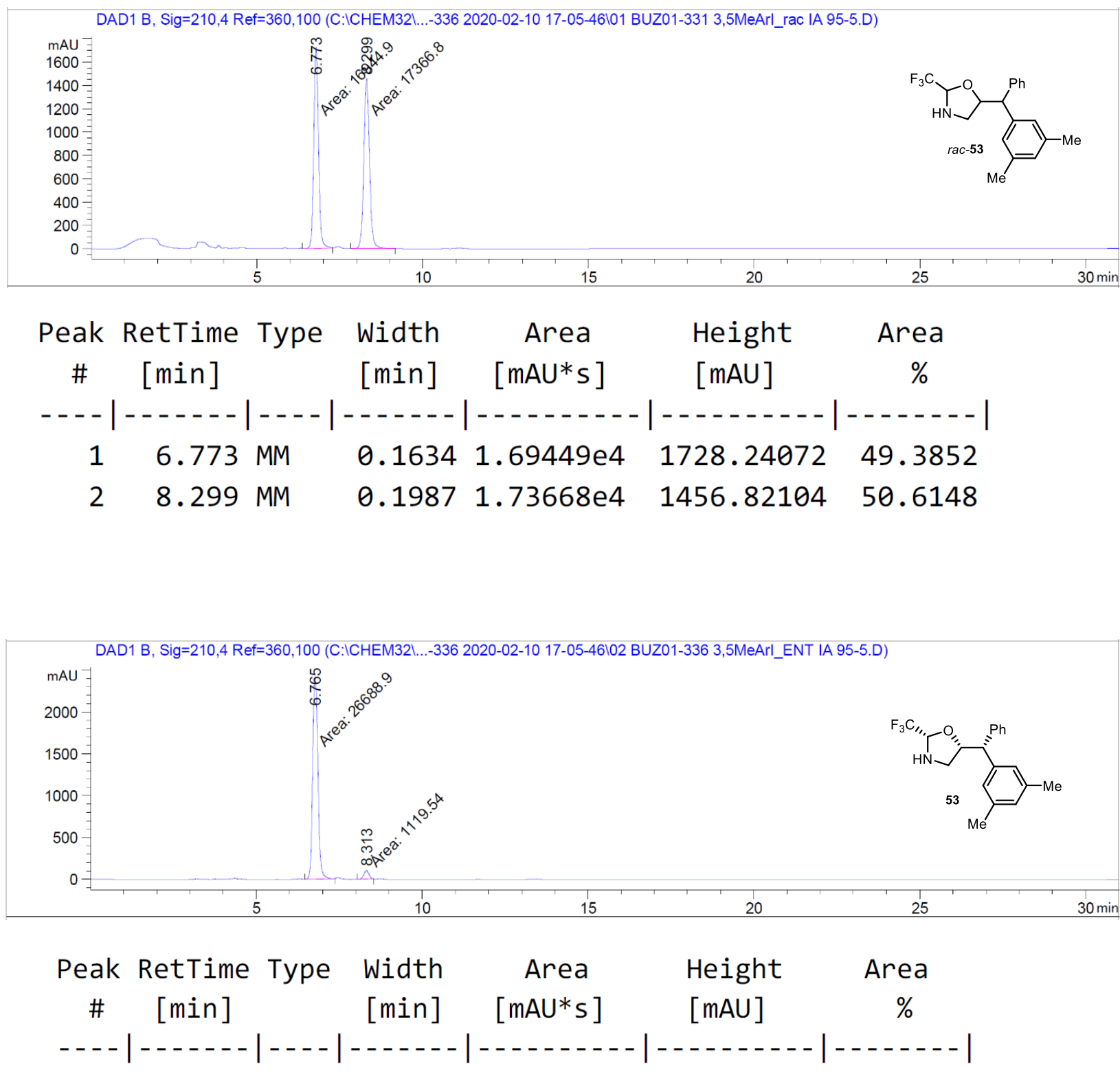

$\begin{array}{lllllll}1 & 6.765 & \mathrm{MM} & 0.1844 & 2.66889 \mathrm{e} 4 & 2411.76831 & 95.9741\end{array}$

$\begin{array}{lllllll}2 & 8.313 \text { MM } & 0.1797 & 1119.54456 & 103.83485 & 4.0259\end{array}$ 
Chiral HPLC Daicel Chiralpak IB N-5 column: 99:1 hexane/IPA, flow rate $1 \mathrm{~mL} / \mathrm{min}, \lambda=210 \mathrm{~nm}$
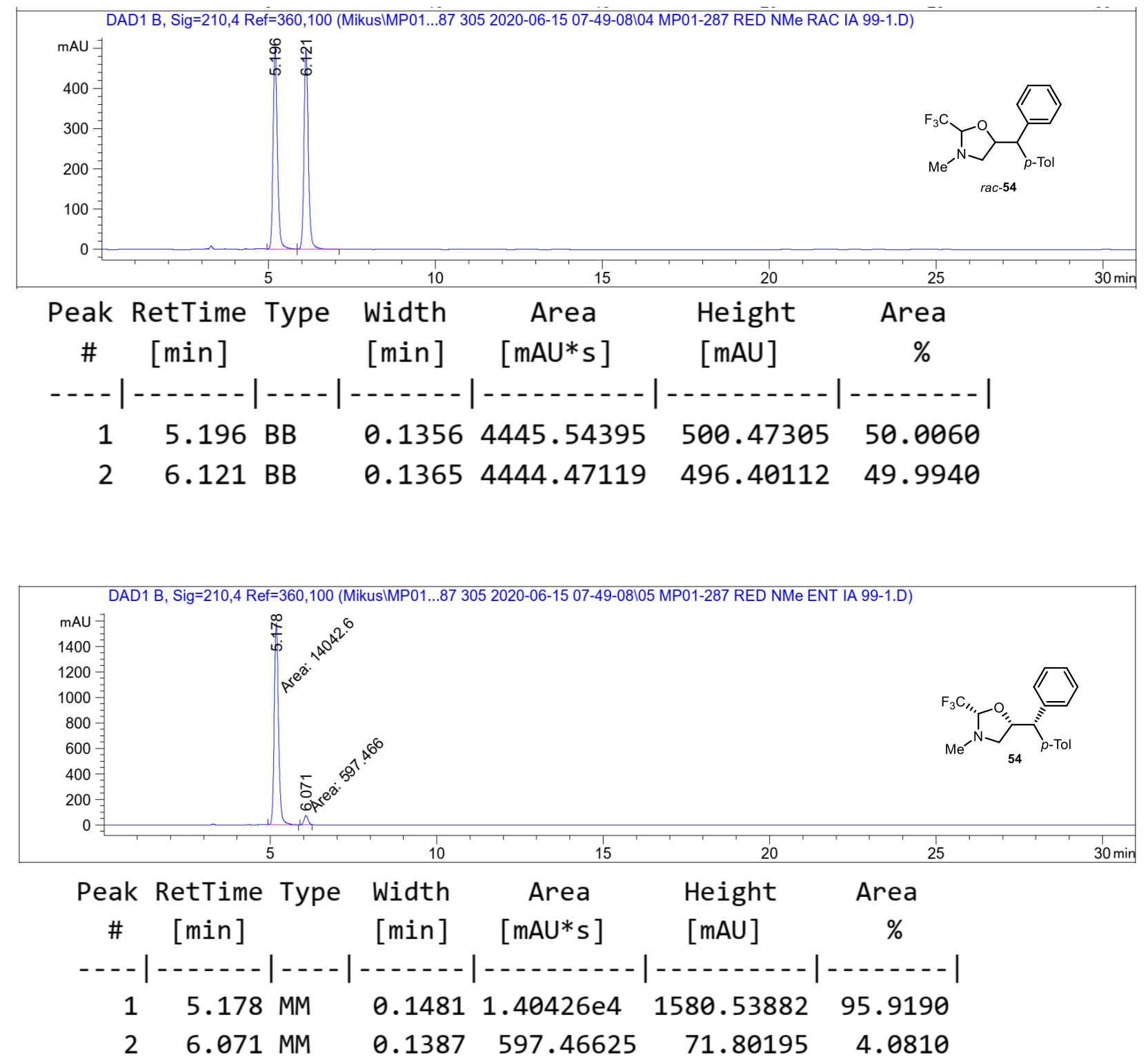
Chiral HPLC Daicel Chiralpak IB N-5 column: 99:1 hexane/IPA, flow rate $1 \mathrm{~mL} / \mathrm{min}, \lambda=210 \mathrm{~nm}$
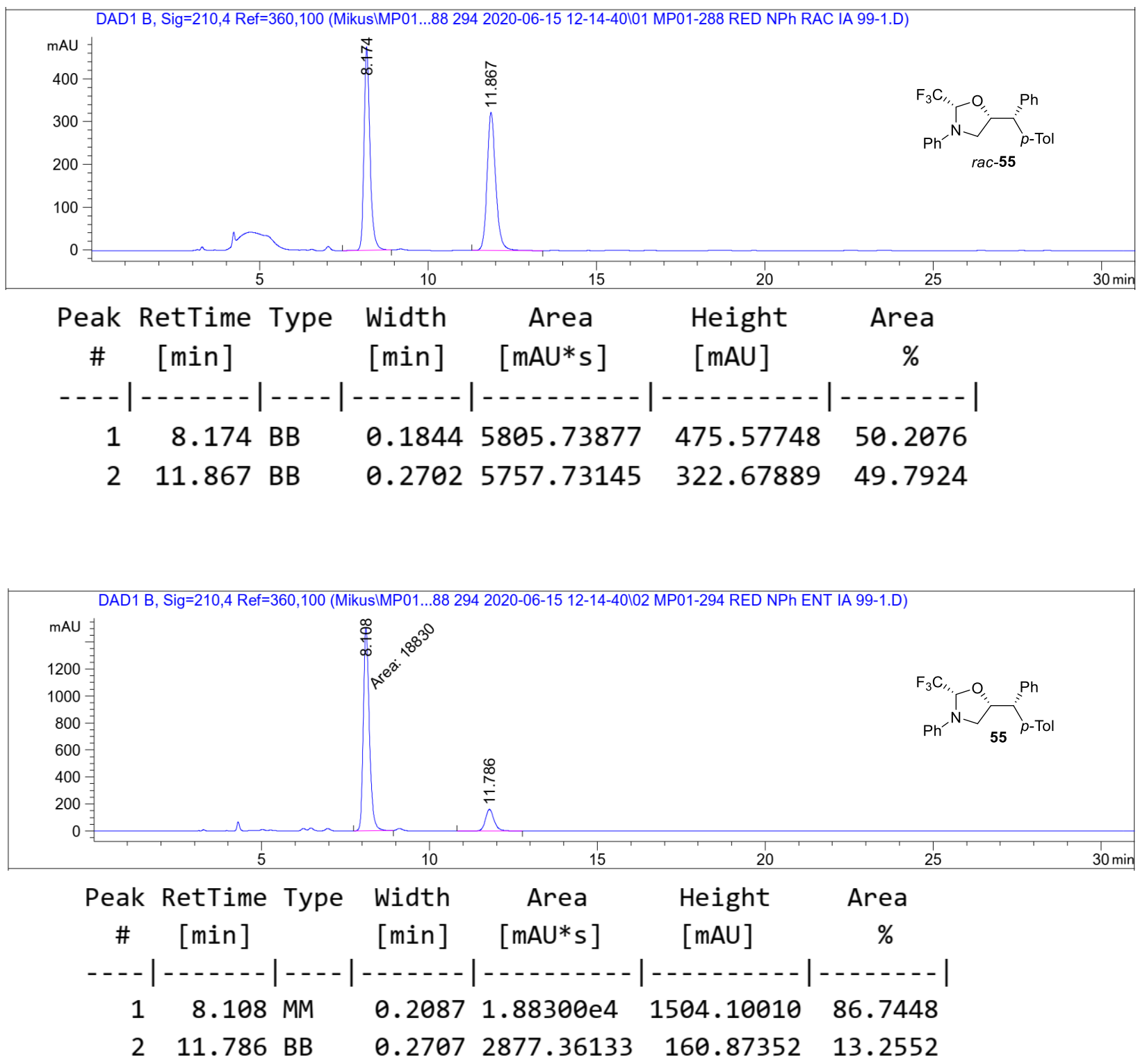
Chiral HPLC Daicel Chiralpak IB N-5 column: 99:1 hexane/IPA, flow rate $1 \mathrm{~mL} / \mathrm{min}, \lambda=210 \mathrm{~nm}$

(Recovered from the reduction)

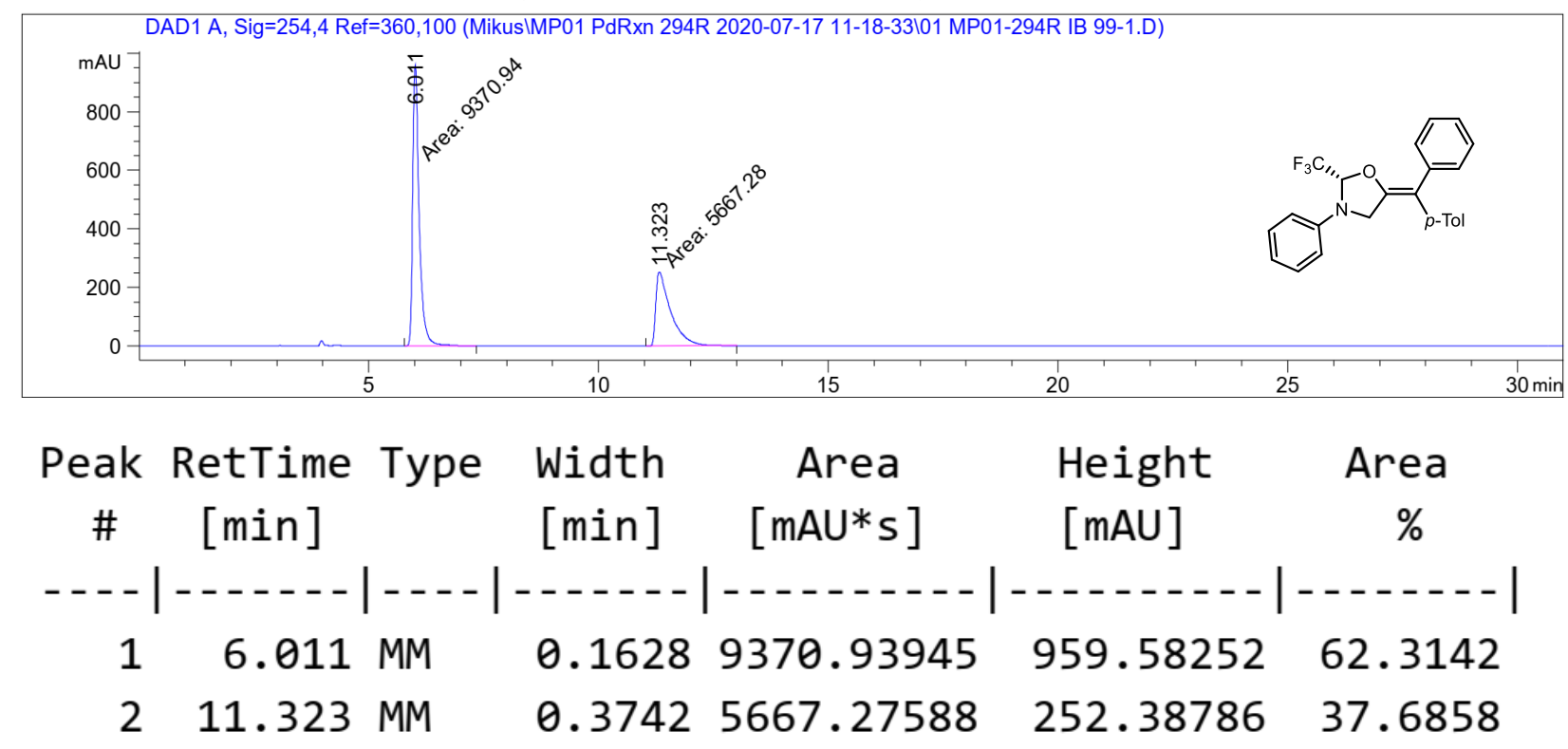


Chiral HPLC Daicel Chiralpak IA column: 80:20 hexane/IPA, flow rate $1 \mathrm{~mL} / \mathrm{min}, \lambda=210 \mathrm{nms}$

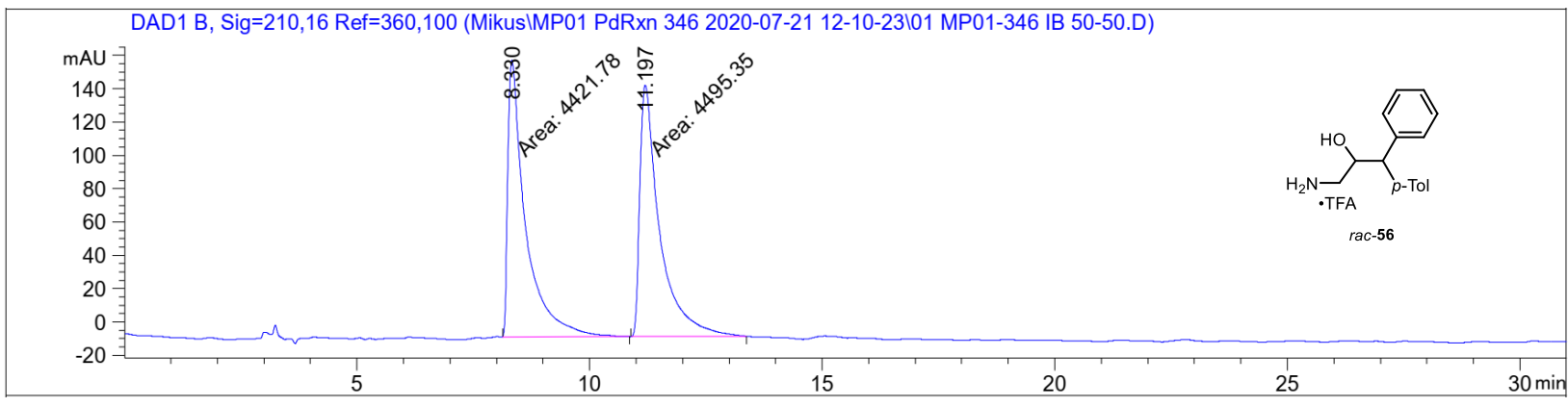

Peak RetTime Type Width Area Height Area

\# $[\mathrm{min}] \quad[\mathrm{min}] \quad[\mathrm{mAU} * \mathrm{~s}] \quad[\mathrm{mAU}] \quad \%$

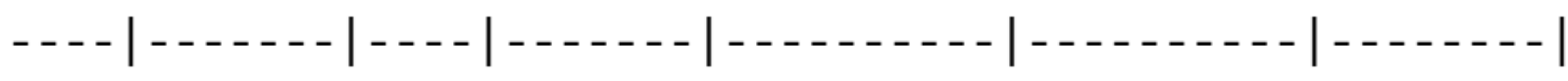

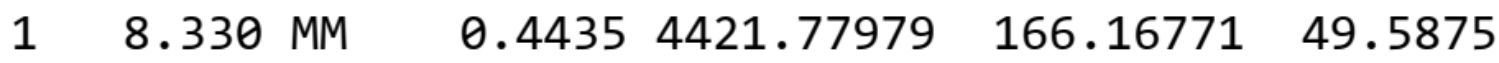

$\begin{array}{lllllll}2 & 11.197 & \text { MM } & 0.4967 & 4495.35107 & 150.85443 & 50.4125\end{array}$

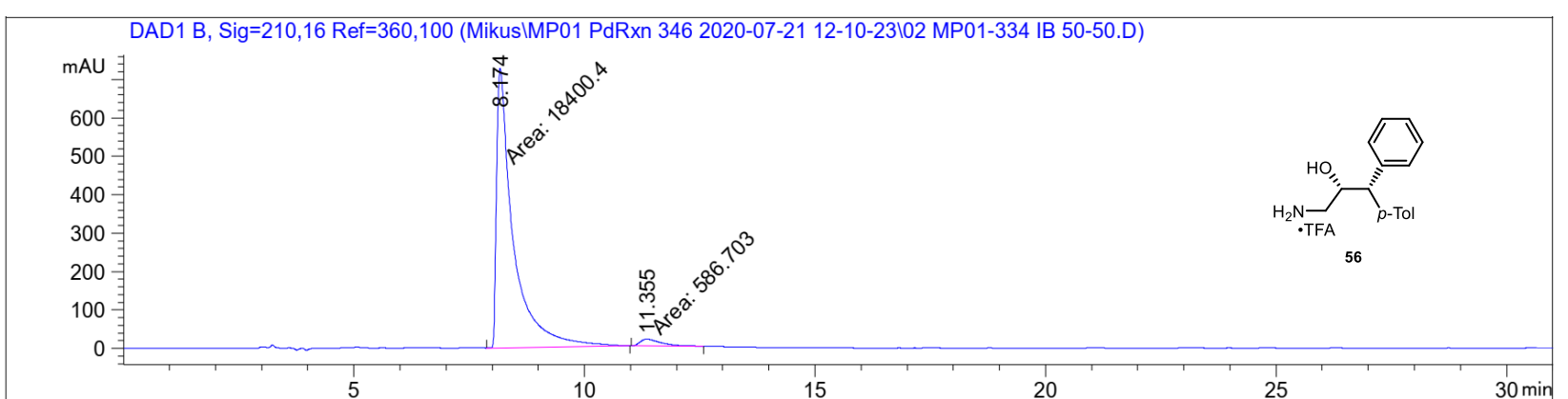

Peak RetTime Type Width Area Height Area

$\begin{array}{lllll}\# & {[\mathrm{~min}]} & {[\mathrm{min}]} & {[\mathrm{mAU} * \mathrm{~s}]} & \text { [mAU] }\end{array}$

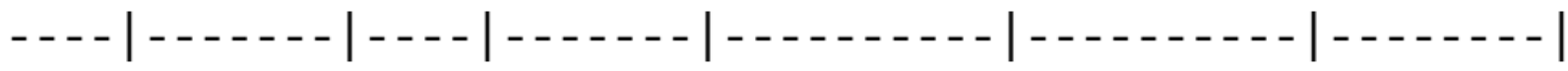

$\begin{array}{lllllll}1 & 8.174 \text { MM } & 0.4213 & 1.84004 \mathrm{e} 4 & 727.84509 & 96.9100\end{array}$

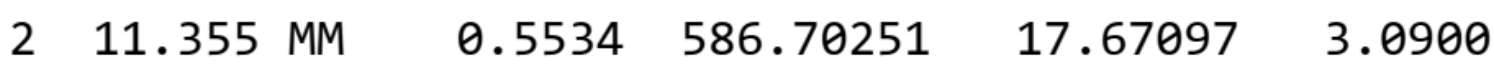

